ST)

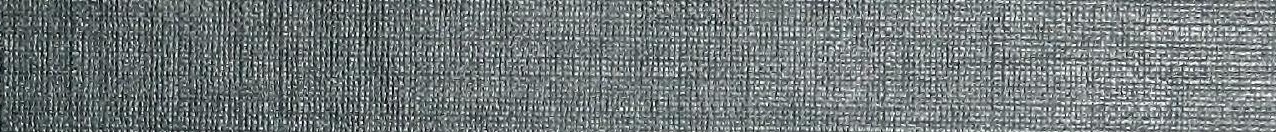

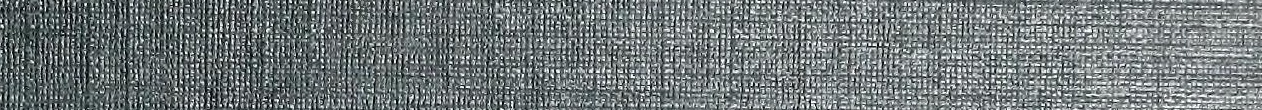

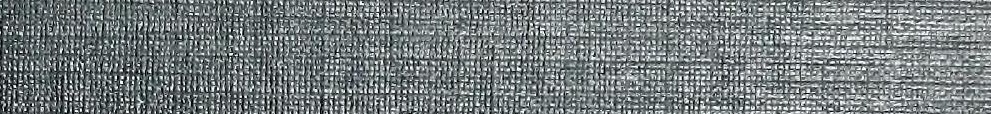

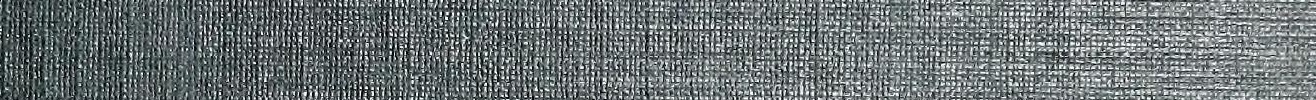
1. \begin{tabular}{|lll}
3 \\
3
\end{tabular} 1.4.4. (1)

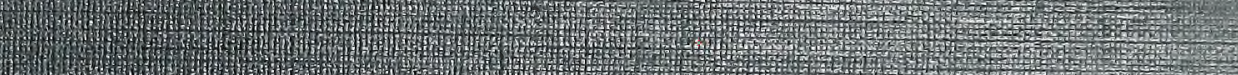
-4.

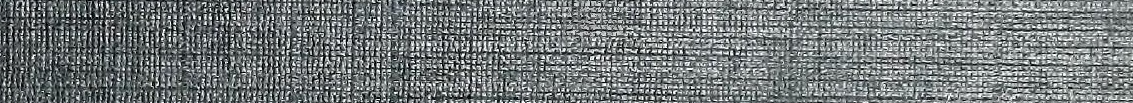
(1)

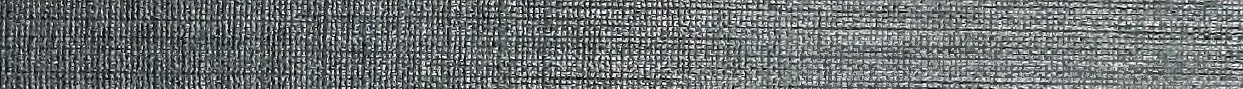

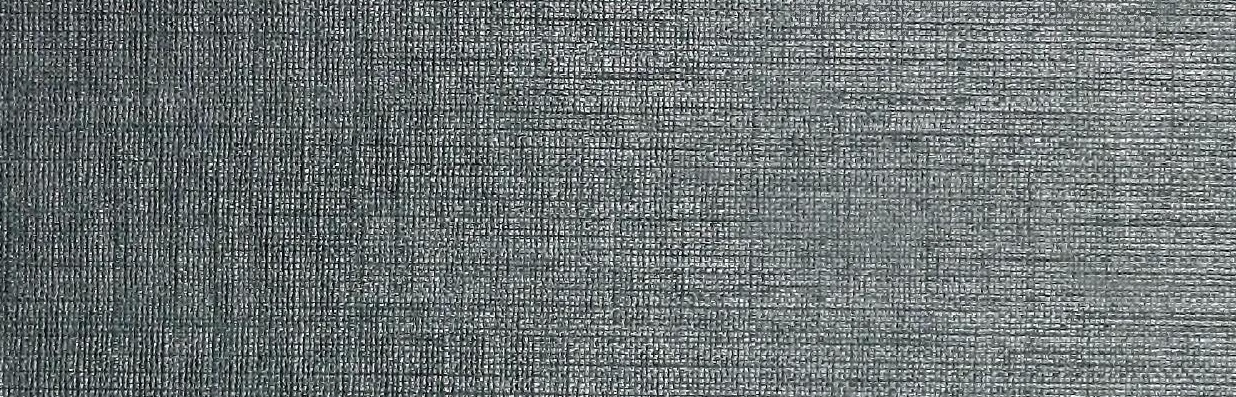
1.

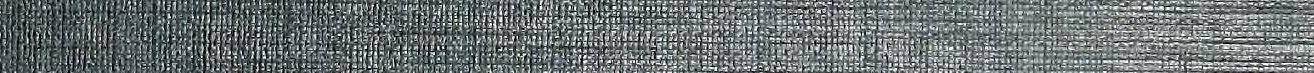
4.

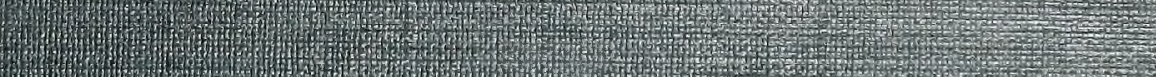
2.7.7. W(1)

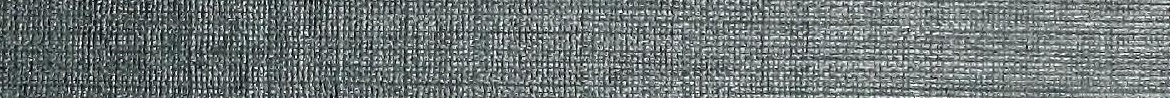
th 3. (2) 1.

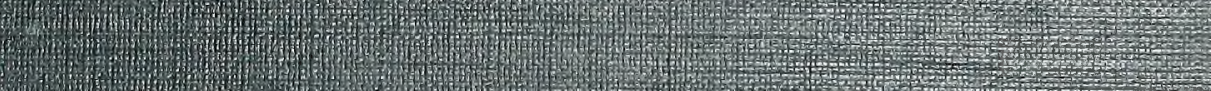

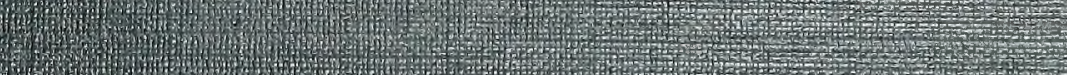
4.

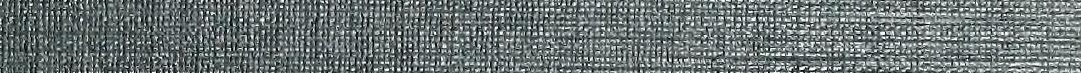

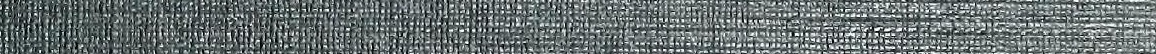
1.6. 1.7. 


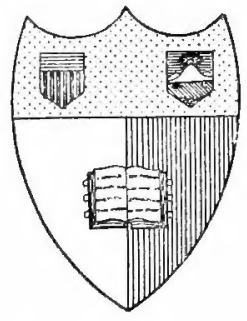

\section{Aveu 蚏ark \\ State Tollege of Agritulture}

At Gornell Zlniuersity

Jthara, Av. ㅋ.

\section{Titbrary}




\section{QK 484. Cornell University Library}

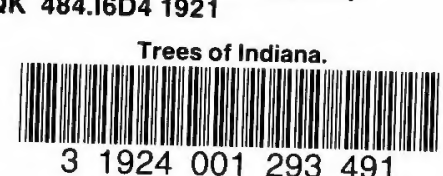




\section{Cornell University Library}

The original of this book is in the Cornell University Library.

There are no known copyright restrictions in the United States on the use of the text. 


\section{TREES \\ OF \\ I N D I A N A}

(First Revised Edition)

BY

CHAS. C. DEAM

APRIL, 1921 

THE

\section{Department of Conservation STATE OF INDIANA}

W. A. GUTHRIE, Chairman.

STANLEY COULTER.

JOHN W. HOLTZMAN.

E. M. WILSON, Secretary. 



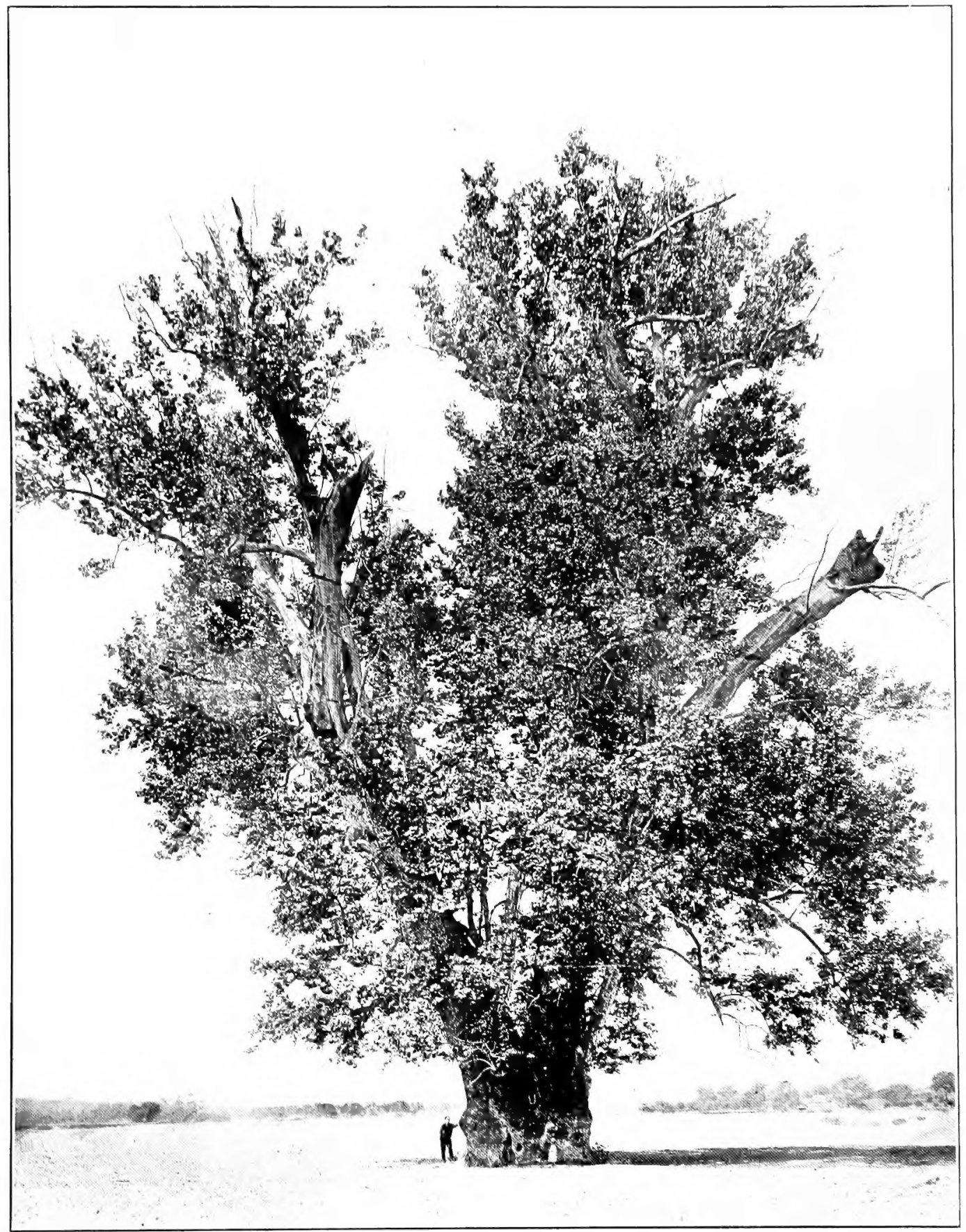

STCAMORE NEAR WORTHINGTON, INI,. THE LARGSAT BROAT-IEAVED TREE IN THE

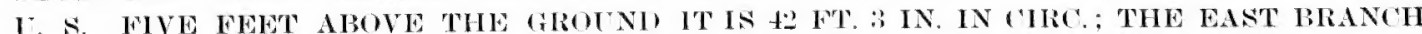
IN 27 FT. 3 IN. IN CIRC. ANI THE WEST BRANOH IS 23 FT. 2 IN. IN CIRC. SEE JOLR. HEREITT, VOL, $6: 407: 1915$. 



\section{Preface}

The first cdition of Deam's "Trees of Indiana" was published in 1911. By limiting the distribution, the edition of 10,000 lasted about three years. The demand for a book of this kind was so great that a second edition of 1,000 copies was published in March 1919. This edition was exhausted within five days after its publication was announced, and thousands of requests for it could not be filled. These came from all classes of people, but the greatest demand was from the school teachers of the State.

Since forestry is an integral part of agriculture which is now taught in our public schools, and since a book on the trees of the State is in demand, the Conservation Commission has authorized a revised edition of "The Trees of Indiana." What was formerly Bulletin No. 3 of the Division of Forestry is now published as Publication No. 13 of the Department. The reader's attention is called to a new departure in illustrations, which were made from photographic reproductions of specimens in Mr. Deam's herbarium. The photographs were taken by Mr. Harry F. Dietz of the Division of Entomology. It is believed that it will be gratefully received by the public and will stimulate an interest in forestry that should achieve practical results.

RICHARD LIEBER,

Director, The Department of Conservation. 



\section{Table of Contents.}

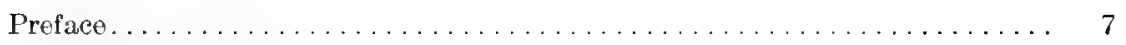

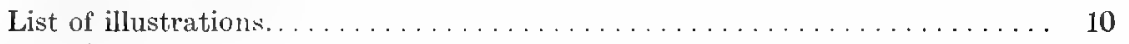

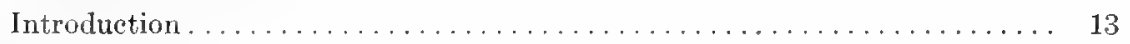

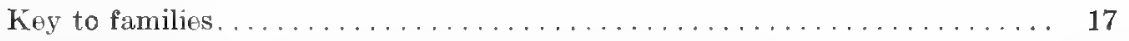

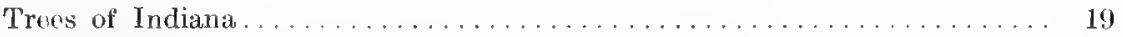

Excluded Species................................... 290

Measurements of some large trees that grow in Indiana............. 297

Specific gravity of Indiana woods . . . . . . . . . . . . . . . . . . 299

Index . . . . . . . . . . . . . . . . . . . . . . . . . . . . 305 


\section{Illustrations.}

1. Frontispiece; Sycamore, largest hardmood tree in U.S......... 5

2. Pinus Strobus (White Pine) .................... 21

3. Pinus Banksiana (Gray or Jack Pine) ................ 23

4. Pinus virginiana (Serub Pine) ..................... 24

5. Larix laricina (Tamarack) ...................... 27

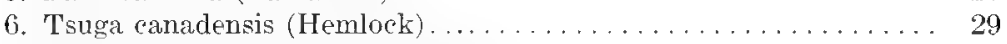

7. Taxodium distichum (Cypress) ................... 31

8. Thuja occidentalis (Arbor-Vita $) \ldots \ldots \ldots \ldots \ldots \ldots \ldots \ldots \ldots \ldots$

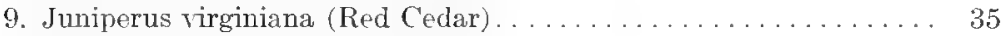

10. Salix nigra (Black Willow).................... 37

11. Salix amygdaloides (Peach-leaved Willow).............. 39

12. Salix alba (White Willow) .................... 41

13. Salix fragilis (Crack Willow) . . . . . . . . . . . . . . . 42

14. Salix discolor (Pussy Willow) . . . . . . . . . . . . . . . . . 44

15. Populus alba (Silver-leaf Poplar) . . . . . . . . . . . . . 46

16. Populus heterophylla (Swamp Cottonwood) ............. 48

17. Populus deltoides (Cottonrood).................... 49

18. Populus grandidentata (Large-toothed Aspen) ........... 5 I

19. Populus tremuloides (Quaking Aspen)................ 53

20. Juglans cinerea (Butternut) .................... 55

21. Juglans nigra (Black Walnut) ................... 57

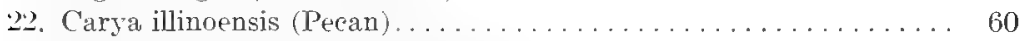

23. Carya cordiformis (Pignut Hickory) .................. 62

24. Carya ovata (Shellhark Hickory) ....................... 64

25. Carya laciniosa (Big Shellhark Hickory) .............. 67

26. Carya alba (White Hickory) .... . . . . . . . . . . . . 69

27. Carya glabra (Black Hickory) ................... 71

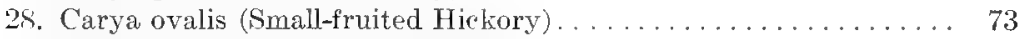

29. Carya Buckleyi var. arkansana................... 77

30. Carpinus caroliniana (Water Beech) . . . . . . . . . . . . . 79

31. Ostrya virginiana (Ironwood) ...................... 81

32. Betula lutea (Yellow Birch) . . . . . . . . . . . . . . 83

33. Betula populifolia (Gray or White Birch) ............... 86

34. Betula papyrifera (Paper or Canoe Birch).............. 87

35. Betula nígra (Black or Red Birch) ................ 89

36. Alnus incana (Speckled Alder). . . . . . . . . . . . . . . . . 91

37. Alnus rugosa (Smooth Alder) . ................... 93

38. Fagus grandifolia (Beech) . . . . . . . . . . . . . . . 95

39. Castanea dentata (Chestnut) . . . . . . . . . . . . . . . . 97

40. Quercus alba (White Oak) ........................ 102

41. Quereus bicolor (Swamp White Oak) ................. 105

42. Quercus Muhlenhergii (Chinquapin Oak) ............... 106

43. Quercus Michauxii (Cow or Basket Oak) .............. 108 
44. Quorcus Prinus (Chestunut ()ak) . . . . . . . . . . . . . 111

45. Quereus stellata (Post ()ak) . . . . . . . . . . . . . . 113

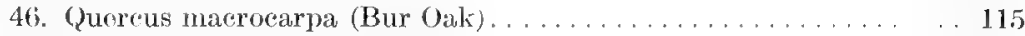

47. Quereus lyrata (Ovoreup Oak) . . . . . . . . . . . . . 118

48. Quorcus imbricaria (Shinglo Oak) ................... 120

49. (Quercus rubra $(\operatorname{Red}$ Oak) . . . . . . . . . . . . . . . . . . 122

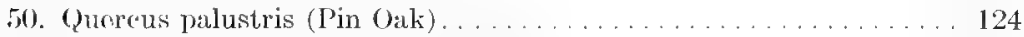

51. Quoreus Schnorkii (Schneck's Red Oak).................. 125

52. Quoreus ellipsoidalis (Hill's Oak) ................... 128

5i3. Quereus velutina (Blark Oak) ...................... 129

54. Quercus coccinea (Scarlot Oak) ..................... 1332

55. Qucreus falcata (Spanish Oak) .................... 134

56. Quoreus marilandica (Black Jack ()ak) .............. $1: 36$

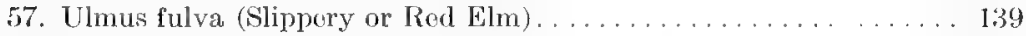

58; Ulmus amerieana (White Elm) ................... 141

59. Ulmus Thomasi (Hickory or Rock Elm) .............. I 433

60. Ulmus alata (Winged $\mathrm{Elm}$ ) . . . . . . . . . . . . . . . . . 144

61. Celtis oecidontalis (IIackberry) .................. 147

62. Coltis pumila var. Deamii (Dwarf Hackborry) .... . . . . . . 149

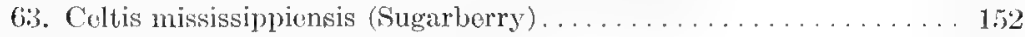

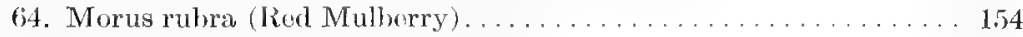

65. Marlura pomifora (Osage Orange).................. 156

66. Magnolia acuminata (Cucumber Tree) . . . . . . . . . . . 158

67. Liriodendron Tulipfora (Tulip Treo or Yellow Poplar)......... 160

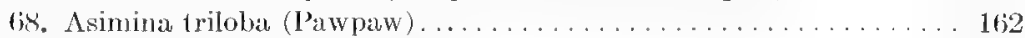

69. Sassafras officinale (Sassal'ras) ...................... 164

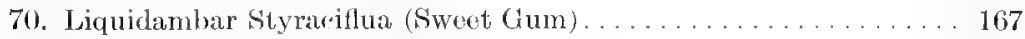

71. Platanus oecidentalis (Syramore) .................... 169

72. Malus glaueeseens (Ameriean Crab Apple) ................ 173

73. Malus laneifolia (Narrow-leaved Crab Apple) . . . . . . . . . 175

74. Malus ionensis (Western Crab Apple) ................. 176

75. Amelanchior eanadensis (Juneberry or Service Berry) . . . . . . 178

76. Amelanchier lavis (Smooth Juneberry or Service Berry)........ 179

77. Cratongus Crus-galli (Cockspur Thorn) ................ 183

7s. Cratiogus cuneiformis (Marshall's Thorn) ............... 184

79. Cra1ngus punctata (Large-fruited Thorn) ............. 186

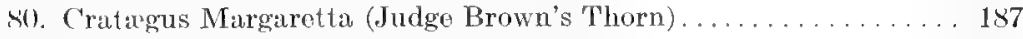

81. Cratxgus collina (Chapman's Hill Thorn) . . . . . . . . . . . 1 s9

12. Cratxgus suceulenta (Long-spined Thorn) .............. 190

33. Cratogus neofluvialis (Now IRiver Thorn) . . . . . . . . . . . 192

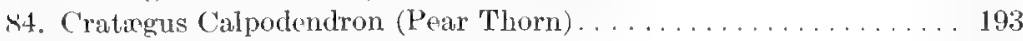

s5. Cratixgus chrysocarpa (Round-leaved Thorn) . . . . . . . . . . . 195

s6. Cratxgus viridis (Southorn Thorn) . . . . . . . . . . . . . . 196

87. Cratrgus nitida (Shining Thorn) . . . . . . . . . . . . . . . . 198

88. Crategus macrosporma (Variable Thorn) . . . . . . . . . . . . 199

89. Crabugus basilica (Edson's Thorn) . . . . . . . . . . . . . 201

90. Cratregus Jesupi (Jesup's Thorn) . . . . . . . . . . . . 202

91. Cratrgus rugosa (Frotz's Thorn) . . . . . . . . . . . . . . 204

92. Cratrogus filipes (Miss Berkwith's Thorn) . . . . . . . . . . . 205

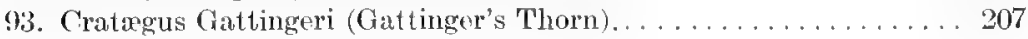


PLATE: NCMBER PA(iE

94. Cratsegus pruinosa (Waxy-fruited Thorn)............... 204

9.). Crategus eoccinoides (Eggert's Thorn)... . . . . . . . . . 210

96. Cratagus coceinea (Scarlet Thorn) . . . . . . . . . . . . 211

97. Crategus mollis (Red-fruited or Downy Thorn) . . . . . . . . . 213

95. Crategus Phenopyrum (Washington's Thorn) ............ .21.

99. Prunus americana (Wild Red Plum) . . . . . . . . . . . . . . .217

100. Prunus americana var. lanata (Woolly-leaf Plum) . . . . . . . . . 219

101. Prumus nigra (Canada Plum) . . . . . . . . . . . . . . . . . .20)

102. Prunus hortulana (Wild Goose Plum) . . . . . . . . . . . . . . .2.2

10:3. Prunus pennsylvanica (Wild Red Cherry) . . . . . . . . . . . . 244

104. Prunus serotina (Wild Black Cherry) . . . . . . . . . . . . . . . 2;)

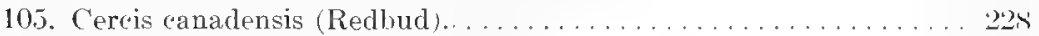

106. Gleditsia triacanthos (Honey Locust) . . . . . . . . . . . . . . 229

107. Gleditsia aquatica (Water Honey Loeust) . . . . . . . . . . . . 2:31

108. Gymnoclađus dioica (Coffeenut Tree) . . . . . . . . . . . . . . 234

109. Rohinia Pseudo-Acacia (Black Locust) . . . . . . . . . . . . . . 236

110. Ailanthus altissima (Ailanthus or Tree of Heaven) .......... 234

111. Acer Negundo (Box Elder) . . . . . . . . . . . . . . . . 241

112. Acer saccharinum (Silver Maple) ... . . . . . . . . . . . 24;

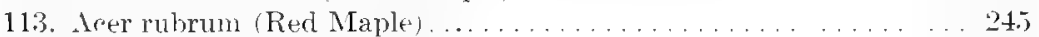

114. Acer nigrum (Blark Maple) . ...................... 247

115. Acer saccharum (Sugar Maple) . . . . . . . . . . . . . . . . . 249

116. Aesfulus glahra (Buckeye) . . . . . . . . . . . . . . . . . . . .

117. Aesculus ortandra (Sweet Burlieye) . . . . . . . . . . . . . . . 254

118. Tilia glahra (Linn or Basswood) . . . . . . . . . . . . . 256

119. Tilia heterophylla (White Basswood) . . . . . . . . . . . 258

120. Nyssa sylvatica (Black Gum)... . . . . . . . . . . . . . . . . 260

121. Cornus florida (Dogwood) . . . . . . . . . . . . . . . . 262

122. Oxydendrum arboreum (Sour Wood or Sorrel Tree) ........... 264

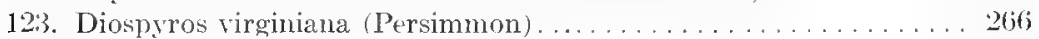

124. Fraxinus merirana (White Ash) . . . . . . . . . . . . . 269

125. Fraxinus hiltmoreana (Biltmore Ash) . . . . . . . . . . . 271

126. Fraxinus lancelata (Green Ash) ................. 273

127. Fraxinus pennsylvaniea (Red Ash) . . . . . . . . . . . 275

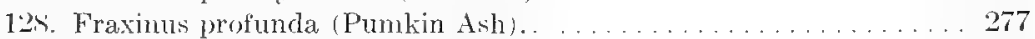

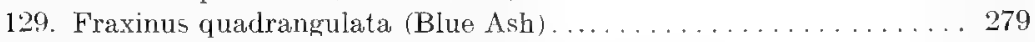

130. Fraxinus nigra (Blark Ash) . . . . . . . . . . . . . . 281

1:31. Adelia aruminata (Pond Brush or Crooked Brush) . . . . . . . . . 28.3

1:32. Catalpa hignonioides (Catalpa) ................. 285

133. Catalpa speriosa (Hardy Catalpa) . . . . . . . . . . . . . . 286

134. Vihurnum prunifolium (Blark Haw) . . . . . . . . . . . . . . . . $2 \$ 9$

13.). County Map of Indiana. . . . . . . . . . . . . . . . . 301

13t;. Map showing rertain arras of forest distribution. . . . . . . . 302

137. English and Metrir Sralts compared . . . . . . . . . . . . . 303 


\title{
Trees of Indiana
}

\author{
INTROD $U(T I O N$
}

The present edition has been entirely rewritten. While the general plan of the first edition has been followed, some changes have been marle.

The number of trees included has been wholly arbitrary. All woody plants of the State which generally attain a maximum diameter of 10 c'm. (4 inches) at breast high are regarded as tree forms. Alnus rugosa which so closely lesembles Alnus incana, is an exception, and a description of it is given to aid in the identification of our tree form of Almus. Also several species of Cratægus are included which commonly do not attain tree size. The species of all Cratagus begin to flower and fruit many years before they attain their maximum size. The genus is much in need of study, and the smaller forms are included to stimulate a study of the genus, and in order that the larger forms may be more easily and certainly identified.

The number of introduced trees has been limited to those that more or less freely escape at least in some parts of the State. The one exception is Catalpa bignonioides, which is given to help separate it from our native eatalpa, both of which are now commonly planted.

Botanic Deseription. - The botanic descriptions have been made from specimens collected in Indiana. In most instances the material has been quite ample, and collected from all parts of the State. Technical terms have been avoided, and only when precision and accuracy were necessary have a few been used which ean be found in any sehool dictionary. The length of the description varies in proportion to the importance and interest of the species and the number of characters necessury to separate it from other forms. The characters used are those which are the most conspicuous, and are generally with the specimen at hand. In most instances mature leaves are at hand, and these are most fully described. When leaves are discussed, only mature and normal leaves are considered. The descriptions are not drawn to include the leaf forms, and sizes of coppice shoots or seedlings. Meisurements of simple leaves do not include the petiole unless montioned. 
When the term twig is used, it means the growth of the year. Branchlets and branches mean all growth except the present year. By seasons are meant the calendar seasons.

The size of trees is designated as small, medium and large. These terms are defined as follows: Small trees are those that attain a diameter of $2 \mathrm{dm}$; medium-sized trees are those whose maximum diameter is between $2 \mathrm{dm}$. and $6 \mathrm{dm}$.; large-sized trees are those which are commonly more than $6 \mathrm{dm}$. in diameter. Diameter measurements are at $14 \mathrm{dm}$. (11/2) feet above the ground, or breast high.

The common names given are those most generally used in our area. Where common names are rarely applied to our forms, the common conmercial or botanical common name is given. In some instances where a tree is known by several names, one or more of which are often applied to a related species, the liberty has been taken to select a common name which should be restricted to the one species.

Botanical names are usually pronounced according to the English method of pronouncing Latin. The accented syllables have been marked as follows: the grave $(\backslash)$ accent to indicate the long English sound of the vowel and the acute (/) accent to show the short or otherwise modified sound.

Measurements have been given in the metric system, and in some instances the English equivalent has also been given.

The nomenclature attempted is that of the International Code. The sequence of families is that of Gray's Manual, 7th Edition.

Distribution.- The general distribution of the species is first given, which is followed by the distribution in Indiana. The general distribution has been obtained by frecly consulting all the local floras and general works on botany. The Indiana distribution has been obtained for the greater part from specimens represented in the writer's herbarium and from notes in doing field work during the past 24 years. Since the first edition of the "Trees of Indiana" was published the writer has traveled over 27,000 miles in Indiana, via auto, making a special study of the flora of the State, and has visited every county and has traversed practically every township in the State. In discussing numbers in distribution it was decided to use terms already in common use, but to assign a definite meaning to each as follows: Very common means more than 25 trees to the acre; common, $5-25$ trees to the acre; frequent $1-5$ trees to the acre; infrequent, 1 trec to $2-10$ acres; rare, 1 tree to every 11-100 acres; very rare, 1 tree to more than 100 acres; local when the distribution is cireumseribed or in spots.

Where a species has the limit of its range in our area, its distribution is sometimes given at length for scientific reasons. It should be remembered that some of the older records of distribution were made by 
geologists or inexperienced botanists, and when such records are questioned it is done with a spirit of scientific accuracy. Some of our early authors did not distinguish between cultivated and native trees, which involves the distribution of certain species.

The hubitat of many species is discussed; which suggests forestal, horticultural and ornamental possibilities. Then too, the habitat of a tree, holps to identify it. When associated trees are given, those are cnumerated which are characteristic of the species throughout its range in our area and they are arranged in the order of their abundance.

A county map of the State is included which will assist in fincling the range of each species. A forestal area map is also added to visualize certain habitats of the State.

The range and distribution of the species in the State has been given considerable attention to encourage investigation along this line.

Remarks.-Under this title the conomic uses of the trees and their products have been given. In addition horticultural and unclassified information is included.

Illustrations. - All of the illustrations except two are photographic reproductions of specimens in the writer's herbarium. The two drawings were used in the first edition.

About 20 of the photographs were made by Paul Ulman, and the remainder by Harry F. Dietz, who has laboriously tried to obtain good reproductions from the material at hand.

Explanation of Map of Certain Forestal Areas.-In describing the distribution of ecrtain species of trees within the State, it was found convenient to speak of certain forestal areas which are here described, and are illustrated by a map which may be found at the end of the text.

Lake Region:-The southernmostlakes in Indiana are those located in the southwestern part of Wells County; Lake Galacia about five miles northeast of Fairmount in Grant County; Lake Cicott in Cass County; and Kate's Pond about 11/2 miles northwest of Independence in Warren County. Roughly estimated, all of Indiana north of a line connecting these lakes might be considered the lake area of the State. Prairie Area:- While the interior of Indiana has quite a few small areas called prairies, the real western prairic did not extend far into the State. The dividing line is very irregular, and several elongated lobes cxtended farther east than indicated by the map. The larger areas east of the line were the extensive prairie area of the Kankake Valley; the northern part of Pulaski County; and parts of White and Tippecanoe Counties. "Knob" Area:-This is the hilliest part of the State and is located in the south-central part. It is contained in the unglaciated portion of the state, and includes the "knobs" of the Knolstone, Chester and Mansfield sandstone areas of Indiana. In 
this area are included the scrub pine and chestnut oak, with one exception; sorrel tree and the chestnut, with two possible exceptions. The Flats:- This is a level stretch of country, here and there deeply eroded. Being level, and the soil a fine compact clay, the drainage is poor which suggested the local name "flats." The Lower Wabash Valley:-This is part of Knox, Gibson and Posey Counties which is usually inundated each year by the Wabash River.

Acknowledgments. - The character and qualities of the wood have for the greater part been taken from the works of Britton and Brown, Hough, and Sargent, to whom indebtedness is acknowledged.

The Salicaceae, except the genus Populus was written by C. R. Ball, of the Bureau of Plant Industry, Washington, D. C. The Malaceae was contributed by W. W. Eggleston, also of the Bureau of Plant Industry, Washington, D. C. These authors were asked to make their part conform to the general plan of the book. Mr. Ball and Mr. Egglest on are recognized authorities on the respective parts they have written and users of this book will appreciate the value of having these difficult parts written by our best authorities. The author wishes to gratefully acknowledge this great favor.

The most grateful acknowledgement is given to Prof. Stanley Coulter, Dean, School Science, Purdue University, who has read all of the manuscript and made valuable suggestions, corrections and criticisms.

I wish to acknowledge the assistance of Stella M. Deam, my wife, in field and clerical work.

I wish to thank the Department of Conservation for the opportunity of doing this work. 


\section{Key to the Families.}

PAGE

Leaves linear or scale-like................... Prnace

Leaves not as above.

A. Leaves compound.

Leaves palmately compound.................Aesculace. . . . . 2.51

Leaves pinnately compound.

Leaves without an odd leaflet at the end........ CaESALPINACE

Leaves with an odd leaflet at the end.

Leaves alternate.

Leaflets toothed all around............JGLANDACE.

Leaflets entire, or with 1-4 teeth near the base.

Trees with thorns, leaflets entire, generally

less than $4 \mathrm{~cm}$. (1 $1 \frac{1}{2}$ inches) long......FABACE. . . . . . . 233

Trees without thorns, leaflets entire or with

1-4 teeth near the base, generally longer

than $4 \mathrm{~cm}$. (1 $1 \frac{2}{2}$ inches)........... Shmarubace. .... 237

Leaves opposite.

Leaflets $3-5$, fruit in pairs. . . . . . . . . . . ACERACE IE....... 239

Leaflets 5-11, fruit single.............. Oteace无...... 267

A. Leaves simple.

Leaves opposite or whorled.

Petioles more than $4 \mathrm{~cm}$. (1/2 inches) long.

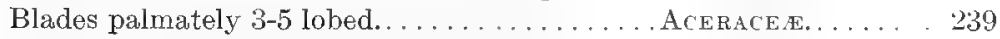

Blades entire or with 1 or 2 lateral lobes...... Bignoniace. .....284

Petioles less than $4 \mathrm{~cm}$. (1/2/2 inches) long.

Flowers 4-parted, stone of fruit round ....... CORAACE

Flowers 5-parted, stone of fruit flattened...... CAPRIfoliace $\ldots . .2 S S$

Leaves alternate.

B. Leaves entire.

Trees with thorns and a milky sap..........MACLURA IN

MIORACEA..... 1.5

Trees without thorns, sap not milky.

Leaves 3-5 nerved at the base.

Leaves 3 -nerved at the base.......... Celtis in

UlMace....... 146

Leaves 5 -nerved at the base.......... Cercis IN

Caesalpinace.e. . 227

Leaves with 1 primary nerve.

Leaves usually more than $1.5 \mathrm{dm}$. (6 inches)

long, flowers solitary.

Flowers appearing before or with the leaves.Anonaces..... 161

Flowers appearing after the leaves.........Magnolace. ... 1.i. 
Leaves less than $1.5 \mathrm{dm}$. (6 inches) long, flowers in clusters.

Bark and leaves aromatis.

Bark and leaves not aromatic.

Fruit dry, an acorn.

LaURaCe. . . . . . . 163

.............. QuERCUS IMBRICARIA

in Fagace

Fruit fleshy.

Fruit with one seed, stone eylindrical. Nyssa iN

Cornacea.... 259

Fruit with more than one seed, rarely one, seeds flat.......... EBENACE $\ldots$. . . . 26. 265

B. Leaves finely serrate, coarsely toothed or lobed.

C. Leaves with one primary vein.

Bark and leaves aromatic.

LAURACEA......, 163

Bark and leaves not aromatic.

Staminate and pistillate flowers and fruit in catkins.

Scales of winter buds 2 , ovary many-seeded, seeds with a tuft of hairs at the summit... SALIX IN

Salicace $2 \ldots . .34$

Seales of winter buds more than 2, ovary 1setded, seeds without a tuft of hairs at the

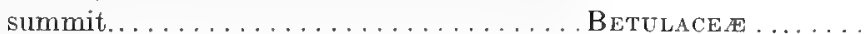

Staminate and pistillate flowers and fruit not in catkins.

Fruit dry.

Fruit a samara..................... Ulmus In Ulmace 137

Fruit not a samara.

Bark smooth; fruit spiny........... FAGACE....... 92

Bark furrowed; fruit a smooth capsule... ERTCACERE....... 263

Fruit fleshy.

Flowers more than $8 \mathrm{~mm}$. ( $1 / 3$ inch) broad,

fruit edible, apple-like.

Trees mostly with thorns, fruit with remnant of calyx at apex of fruit, normally

with more than 1 seed............MALACE $\ldots \ldots \ldots 171$

Trees without thorns, fruit with no remnant of ealyx at the apex, fruit a 1seeded edible drupe. ..............Amygdalace $2 \ldots . .216$

Flowers less than $8 \mathrm{~mm}$. ( $1 / 3$ inch) across,

fruil a non-edible drupe........... Connace $2 \ldots . . .259$

C. Leaves with more than 1 primary vein.

Staminate and pistillate flowers in catkins.

Fruit dry

PoptuUs IN

Salicace无....

Fruit fleshy. Morus IN

Morace $A \ldots \ldots, 151$

Staminate and pistillate flowers not in catkins.

Pistillate and staminate flowers separate.

Leaves 3-nerved at the base, fruit a 1-seeded

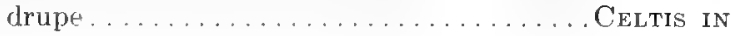

Ulmace $\pi \ldots \ldots 146$ 
Leaves 5-nerved at the base, fruit a head of rarpels or achenes.

Bark fissured, not peeling off in flakes, leaves aromatic............................ 166

Bark peeling off in flakes, leaves not aromatic. Platanace. . . . . 168 Pistillate and staminate flowers in one.

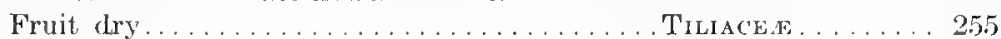

Fruit fleshy. ..................MALACEA. ..... 171

\section{PINÀCea E. The Pine Family.}

Trees and shrubs with a resinous sap, which yields rosin, tar, turpentine and essential oils. The leaves are linear or scale-like, alternate, whorled or clustered; flowers naked, appearing in the spring; fruit a cone or sometimes berry-like. A large family of trees and shrubs, containing over 200 species, found in many parts of the world, and of great economic importance. In Indiana only nine species are native, and the distribution of seven of these speeies has always been very limited.

Leaves linear, in clusters of $2,3,5$ or more than 5 .

Leaves in bundles of $2-5 \ldots \ldots \ldots \ldots \ldots \ldots \ldots \ldots \ldots$ Pinus.

Leaves in bundles of more than $5 \ldots \ldots \ldots \ldots \ldots \ldots$ Larix.

Leaves linear and solitary, or scale-like.

Leaves all linear.

Leaves obtuse....................... 3 Tsuga.

Leaves sharp-pointed.

Leaves green on both sirles, alternate..........4 Taxodium.

Leaves glaucous beneath, opposite or whorled . . . . . . 6 Juniperu

Leaves all scale-like, or some of the branches with linear sharp-pointed leaves.

Leaves all scale-like, fruit a cone of $8-12$ imbricated scales. 5 Thuja.

Leaves srale-like or some linear and sharp-pointed, fruit herry-like. ..................... 6 Juniperus.

\section{PİNUS. The Pines.}

Evergreen trees with needle-shaped leaves in bundles of $2-5$ or 7 ; flowers appearing in the spring, the staminate clustered at the base of the season's shoots, the pistillate on the side or near the end of the shoots; fruit a wooly cone which matures at the end of the second season, or more rarely at the end of the third season; scales of the cone variously thickened; seeds in pairs at the base of the scales.

There are about 70 species of pines of which three are native to Indiana. Commercially the pines are classed as soft and hard. In our area the soft pines are represented by the white pine, while the graty and Jersey pines are classed as hard pines. 
Leaves 5 in a bundle, 6-12 $\mathrm{cm}$. long

1 P. Strobus

Leav's $2-3$ in a bundle.

Scales of cones unarmed, leares usually $2-4 \mathrm{~cm}$. long.....

Seales of cones tipped with a short spine, leaves usually over 4 cm. long.

2 P. Banksiana.

$3 \mathrm{P}$. virginiana.

1. Pinus Stròbus Linnæus. White Pine. Plate 2. Bark greenish and smooth on young trees, becoming reddish or gray and furrowed on old trees; young twigs scurvy-pubescent, soon smooth and light brown; leaves normally 5 in a bundle, sometimes more, 6-12 cm. long, 3-sided, sharp-pointed, bluish-green, maturing and falling at end of second season; cones ripening at end of second season, usually 10-20 cm. long; wood light, soft, not strong, works easily, takes a good polish, and warps little.

Distribution.-- Newfoundland to Manitoba, south to Iowa, Kintucky and along the Alleghany Momtains to northern Georgia. The mass distribution of this species is to the north of our area, and in Indiana it is loca? and found in small numbers. It is a common tree on some of the dunes bordering Lake Michigan, and is found locally throughout the area hordering Lake Michigan. Its distribution in this part of the State has not been studied, but it is believed that in Lake and Porter Counties it is not at present found far from the Lake. Blatchley" reports "a thicket of this species about a peat bog on the Havward farm one mile east of Merrillville in Lake County." The writer has seen it as a frequent tree in a black oak woods about four miles southwest of Michigan City, also quite a number of large trees seven miles northeast of Michigan (ity in a swampy woods, associated with white elm, black ash, soft maple, etc.

Nieuwland ${ }^{2}$ reports a single tree found in a tamarack swamp 25 miles ("ist of Michigan City near Lydick in St. Joseph County. The next appearance of this species is to the south in Warren C'ounty on the outcrops of sandstone along Big Pine, Little Pine, Rock and Kickapoo creeks. It is found more or less on bluffs of these creeks. It was the most abundant along Big. Pine Creck, and followed up the creek for a distance of about ten miles, or midway between Rainsville and Indian Village. To the south it is next found in Fountain County on the outrops of sandstone along Big shawnee and Bear Crecks. Franklin Watts who owns the "Bear Creek Canyon" just south of Fountain says he remembers the area before any cutting was done along the creek. He says that the white pine was a common tree along the creek for a distance of half a mile and that a few scattered trees were found as far as 40 rods from the creek. He stated that the largest trees were

Ind. Geol. Rept. $2293: 18 ! 98$

2. Amer. Mid. Nat. 3:70:1913. 
Plate 2.

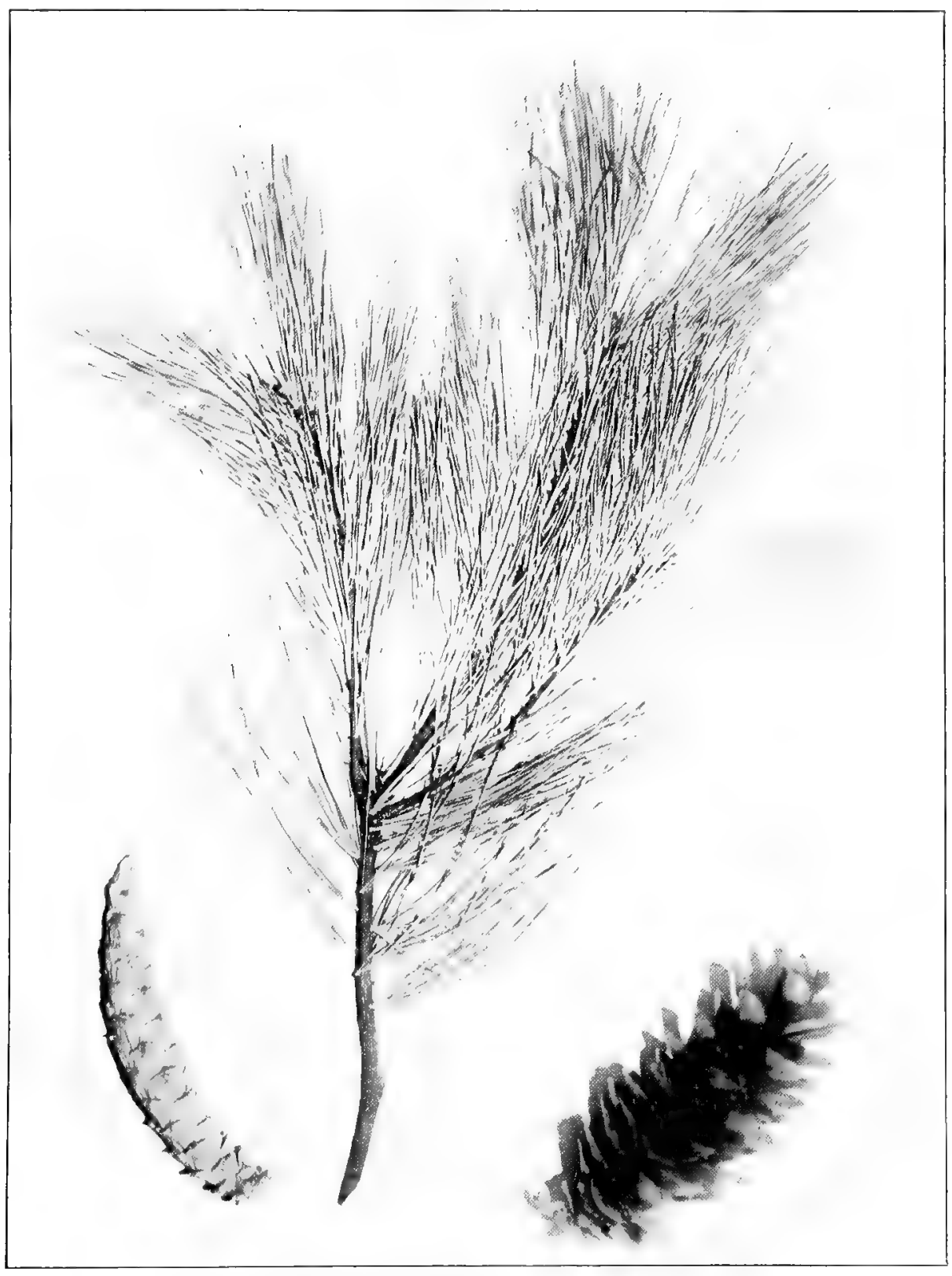

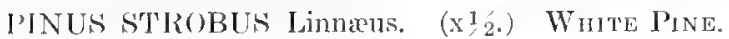


about 30 inches in diameter and as high as the highest of the surrounding trees. Moving southward it is next found on a ridge of sandstone in Montgomery County on the south side of Sugar Creek about a mile east of the shades. Here it is elosely associated with hemlock which is absent in all of the stations to the north. Coulter ${ }^{1}$ reports a colony in the "knobs" of the northeast corner of Floyd County. This species was also reported from Clark County by Baird and Taylor. The writer has made inquiry and diligently searched for this species in this county but failed to locate it. In the vicinity of Borden where the Jersey pine grows, millmen distinguish two kinds of pines. Investigation showed that both are Jersey pine. The one with resinous exudations along the trunk is one kind, and trunks without exudation is the other. Since Baird and Taylor include cultivated trees in their list of the plants of Clark County, it is proposed to drop this reference.

Remarks. - White pine on account of the excellent qualities of its wood is in great demand, and has always ranked as one of our leading timber trees. In fact it was so highly prized that practically all of the original stand of this species has been eut.

The tree adapts itself to many habitats, hence has been used extensively for forestry purposes both in America and Europe. In fact it was the most used tree in forestry until about ten years ago when the white pine blister rust was discovered in America. This disease is now found in practically all of the states where this species forms dense stands. However, Federal and State authorities are trying to stamp out the disease. In Indiana it is a species well worth a trial for forestry purposes, especially in windbreaks where other species are used.

2. Pinus Banksiàna Lambert. Gray Pine. JACK Pine. Plate 3. A small tree $10-15 \mathrm{~m}$. high with reddish-brown bark, broken into short flakes; shoots of season yellow-green, turning reddish-brown, smooth; leaves dlark green, in twos, $2-5 \mathrm{~cm}$. long, divergen $₹$, curved or twisted, rigid, sharp-pointed, persisting for two or three years; cones sessile, sharp-pointed, oblique at the base, $3-5 \mathrm{~cm}$. long, usually pointing in the direction of the branch; wood light, soft and weak.

Distribution.- The most northern of all of our pines. Nova Scotia to northern New York, northern Illinois, Minnesota and northward. In Indiana it is found only on and among the sand dunes in the immediate vicinity of Lake Michigan, and in no instance has it been seen more than three miles from the Lake. Found sparingly in Lake, Porter and Laporte Counties. It is the most abundant in the vicinity of Dune Park. 
Plate 3.

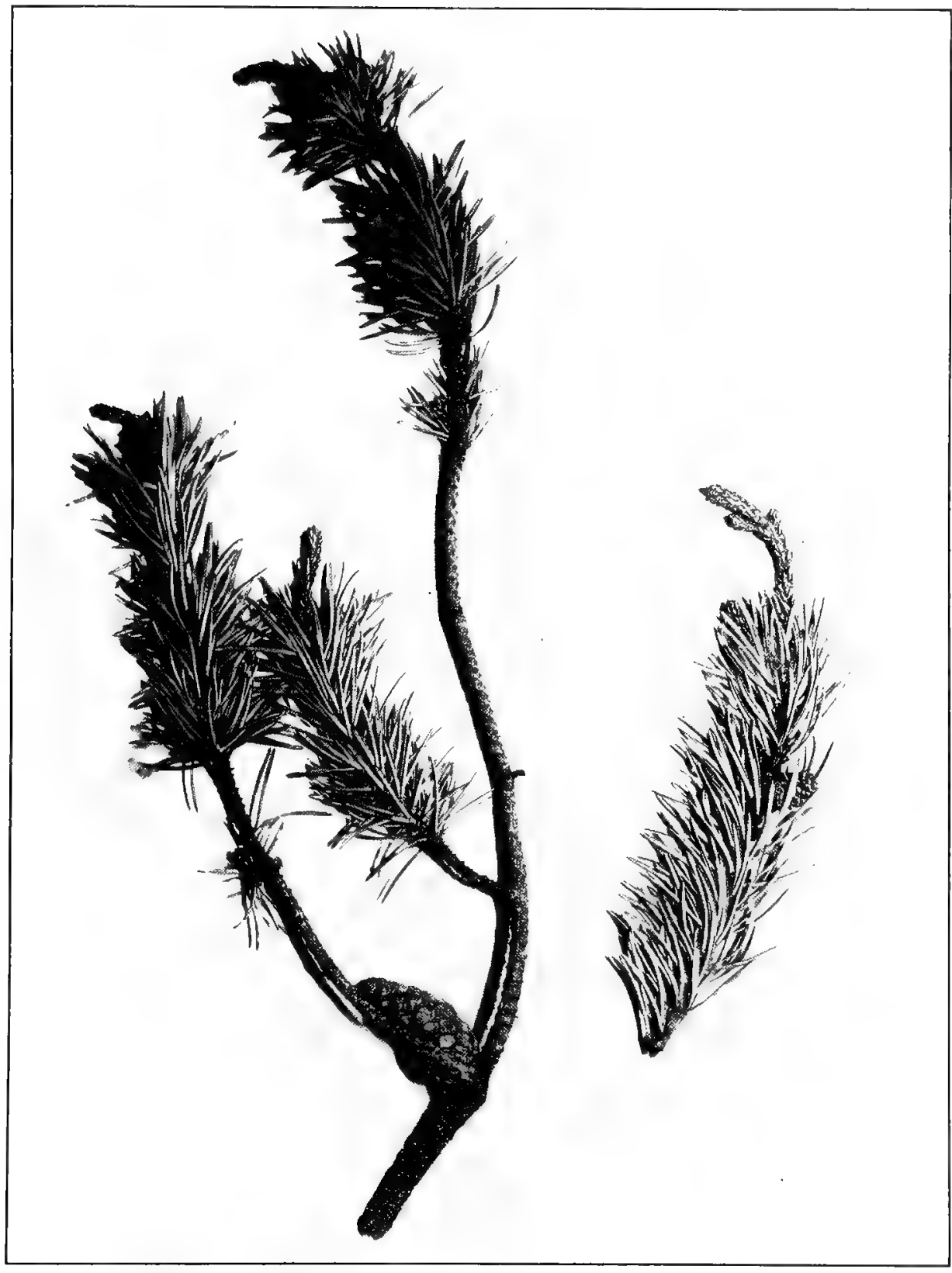

PINUS BANKSIANA Lambert. Gray or JACK Pine. ( $x 1 / 2)$, 
Plate $t$.

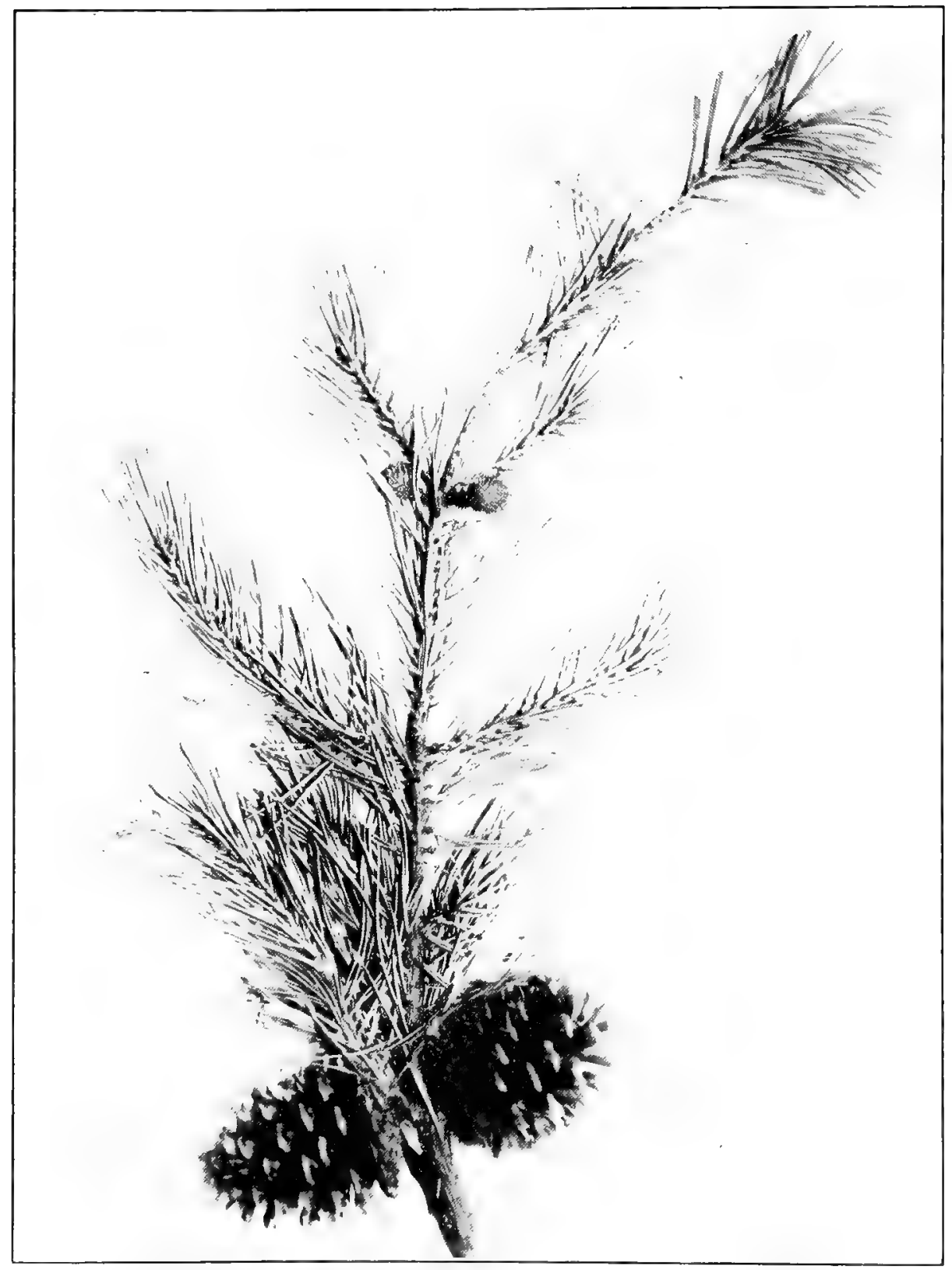

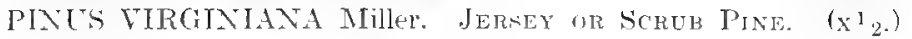


3. Pinus virginiàna Miller. Jersey Pine. Scrub Pine. Plate 4. Bark dark-brown with rather shallow fissures, the ridges broken, somewhat scaly; shoots green, light brown or purplish with a bloom, becoming a gray-brown; leaves in bundles of two, rarely three, twisted, usually about 4-5 cm. long, deciduous during the third or fourth year; cones sessile or nearly so, narrowly conic when closed, 4-7 cm. long, opening in the autumn of the second season; scales armed with a curved spine 2-4 mm. long; wood light, soft, weak, brittle and slightly resinous.

Distribution.-Long Island to South Carolina, Alabama and north to Indiana and Licking County, Ohio. The distribution in Indiana is quite limited, and has never been understood by authors who variously give it as found throughout the southern part of Indiana. It is confined to the knob area of Floyd, Clark and Scott Counties, and the southeastern part of Washington County. In the original forest it is confined to the tops of the knobs where it is associated with Quercus Prinus (Gray's Man. 7th Edition). It propagates easily from selfsown seed, hence is soon found on the lower slopes of cut-over lands, and soon occupies fallow fields. It is now found in the open woods several miles east of the knobs in the preceding counties, but pioneers of this section say it was not a constituent of the original forests but has come in since the original forests were heavily cut over. It is believed that it crowned the knobs over our area from 5-10 miles wide extending through the counties named and extending northward about 25 miles. This species is found in the open woods on a few hills on the Millport Ridge in the northern part of Washington County, and it appears as if native, but investigation showed that it had spread from a tree on the site of a pioneer's cabin. It is also found as a frequent escape on the wooded bluff of Raccoon Creek in the southern part of Owen County, and appears as native here. It is associated on the bluff and slope with hemlock. Chas. Green, a man of sixty years, who owns the place says the trees were seeded by a tree planted in his father's yard nearby. His father also planted a white pine in his yard, and it is to be noted while the Jersey Pine has freely escaped the white pine has not, although the habitat seems favorable.

Remarks.--In its native habitat on the exposed summits of the "knobs" it is usually a small tree about $3 \mathrm{dm}$. in diameter and $10 \mathrm{~m}$. high. When it finds lodgement on the lower slopes and coves it may attain a diameter of $7 \mathrm{dm}$. and a height of $25 \mathrm{~m}$. This tree is really entitled to be called "old field pine" on account of its ability to establish itself on them.

From the ease with which this species propagates itself from seed it scems worthy a trial for forestry purposes in the "knob" area of the 
State. Howerer, all attempts to grow this species from seedlings at the Forest Reserve have failed.

\section{LÀrix. The Larches.}

Larix laricina (Du Roi) Koch. Tamarack. Plate No. 5. Tall spire-like trees, usually $2-3 \mathrm{dm}$. in diameter, rarely as large as $5 \mathrm{clm}$. in diameter; bark gray or reddish-brown, scaly; twigs slender, smooth, light brown, becoming a dark gray brown; leaves scattered along the shoots of the season, in fascicles on the older branches, usually 20-50 in a bundle; filiform, 1-2.5 $\mathrm{cm}$. long, obtuse at apex, triangular in cross-section, all falling off late in autumn; staminate flowers borne on the short leafless branches, the pistillate appear with the leaves on the branches of the previous season; cones borne on short, stout branchlets, normally erect or inclined to be so, $10-20 \mathrm{~mm}$. long, purplish brown while growing, turning to a light brown at maturity, persisting on the tree for about a year; wood hard, heavy, light brown, variable in strength.

Distribution.-Labrador, Newfoundland south to southern New York, West Yirginia, northern Ohio and Indiana, Wisconsin, Minnesot a and northward. In Indiana it is confined to the northern part of the State, and has not been reported south of the northern part of Cass County. The most southern station in the eastern part of the State is about Lake Everett in the northwest part of Allen County. It is found on low borders of lakes, in swamps and in bogs. In all of its stations in Indiana it is found growing near the water level in great depths of or ganic matter more or less decomposed or in beds of peat, which contain little or practically no soil. Where it is found, it usually forms a pure stand.

Remarks.--Formerly the tamarack was a common tree in its area. Recently many of the tamarack swamps have been drained. This with heavy cutting has reduced the supply of tamarack in Indiana to an insignificant amount. The tamarack is popularly classed as white and yellow-the yellow being considered the better of the two. In our area it is used principally for poles and posts. There is a diversity of opinion as to the durability of tamarack in contact with the soll. The most authentic information places the life of fence posts at about ten years.

3. TSÜGA. The HemLocks.

Tsuga canadénsis (Linnæus) Carière. Hemlock. Plate 6. Tall trees, 3-7 dm. in diameter, with redclish-brown or grayish bark, deeply furrowed; shoots very slender and hairy, becoming smooth in a 
PLATE 5.

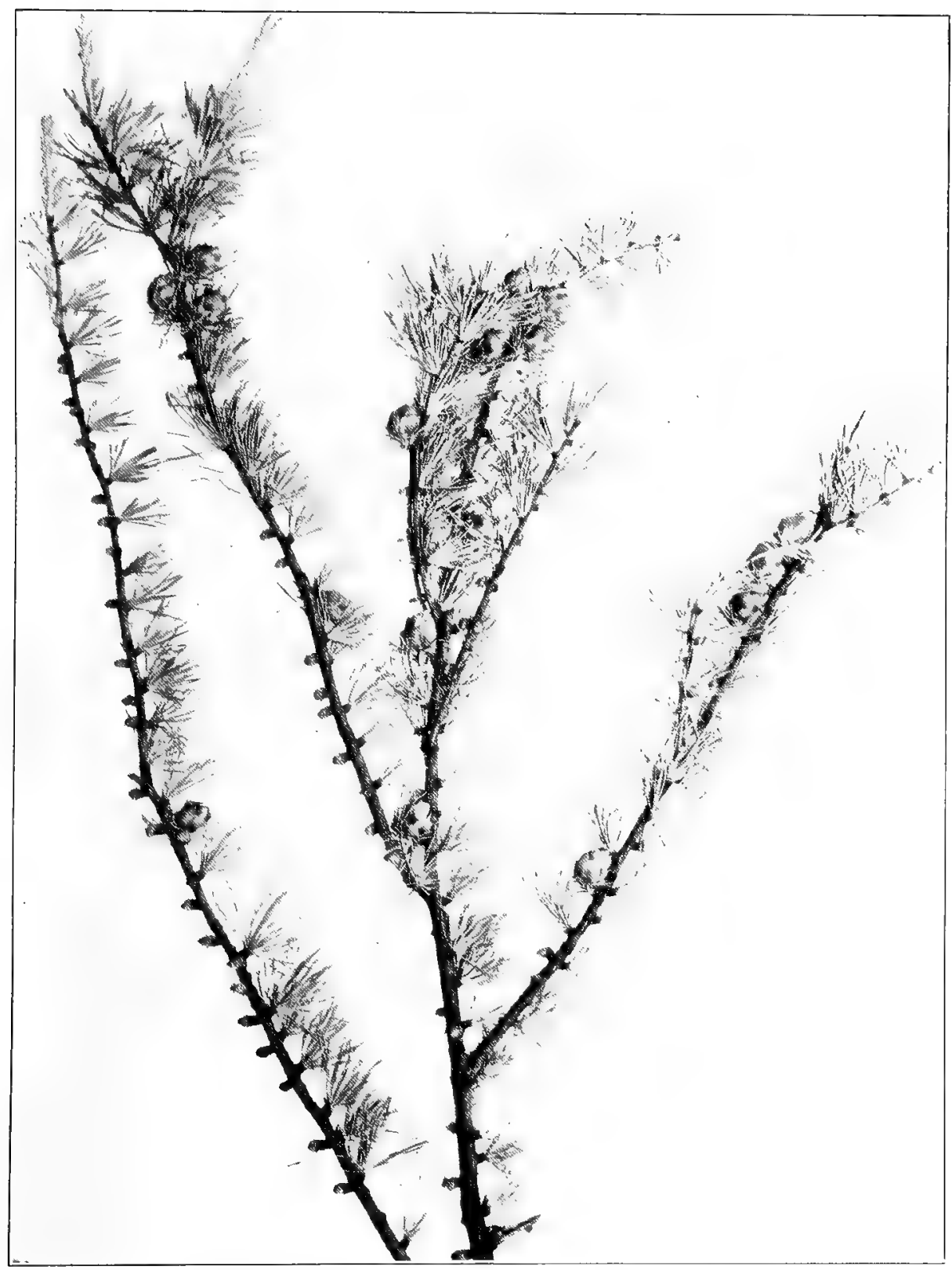

LARIX LARICINA (Du Roi) Koch. Tamarack. ( $x$ 1.) 
few years; leaves apparently 2-ranked, persisting for about three years, linear, short petioled, 6-13 mm. long, usually about $10 \mathrm{~mm}$. long, usually flat, obtuse or notched at apex, bright green and shiny above, bluish-white beneath; staminate flowers appear early in the spring from buds in the axils of the leaves of the previous season, the pistillate terminal, erect, oblong; cones almost sessile and pendulous, borne on the end of last year's branch, maturing the first season, ovoid, 1.5-2.5 cm. long; wood light, soft, brittle, not durable, difficult to work, splintery but holds a nail well.

Distribution.- Nova Scotia south to Delaware, west to Minnesota and southeastward through Indiana and eastern Kentucky, thence southward on the mountains to northern Alabana. In Indiana it is not found ${ }^{1}$ north of Brown County. It is found in limited numbers at the following places: on a bluff of Bean Blossom Creek in Brown County; on a steep wooded slope on the south side of a small creek about one and a half miles north of Borden in Clark County, and also reported on the bank of silver Creek between Clark and Floyd Counties; a few trees on the top and sides of the eliffs about one mile cast of Taswell in Crawford County; a few trees on the bluff of Guthrie Creek in Jackson County; a few trees along the north fork of the Muscatatuck River between Vernon and North Vernon in Jennings County; a few trees on the south bank of Back Creek near Leesville in Lawrence County; frequent on the banks of Sugar Creek near the "Shades" in Montgomery County; a few trees on the bank of Raccoon Creck in the southern part of Owen County; frequent on the bank of Sugar Creek in Turkey Run State Park in Parke County; a few trees on the banks of Raccoon and Walnut Creeks in Putnam County. Also reported by Breler as found on a bluff of White River in Morgan County.

In all of its stations it is found on sandst one bluffs on the south side of streams, giving it a north or northwest exposure. In a few of the stations there are no small trees, but in Montgomery County along Sugar Creek it is reproducing well.

Remarks.-Hemlock is of no economic importance in Indiana. The bark is much used in tanning. Hemlock is frequently used for a hedge plant, also as a specimen tree in parks, etc.

\section{TAXòdiuM. The Bald Cypress.}

Taxodium dístichum (Linnæus) L. C. Richard. Cypress. Plate 7. Large tall straight trees, up to $18 \mathrm{dm}$. in diameter and $45 \mathrm{~m}$. high, usually with a buttressed base which is frequently hollow. In wet situations it develops stceple-shaped projections from the roots to

ي⿻ere discussion under thies balsamea on page 290

a Prore. Ind. Hort. Sioc. 18:12:53:18:13. 
Plate 0.

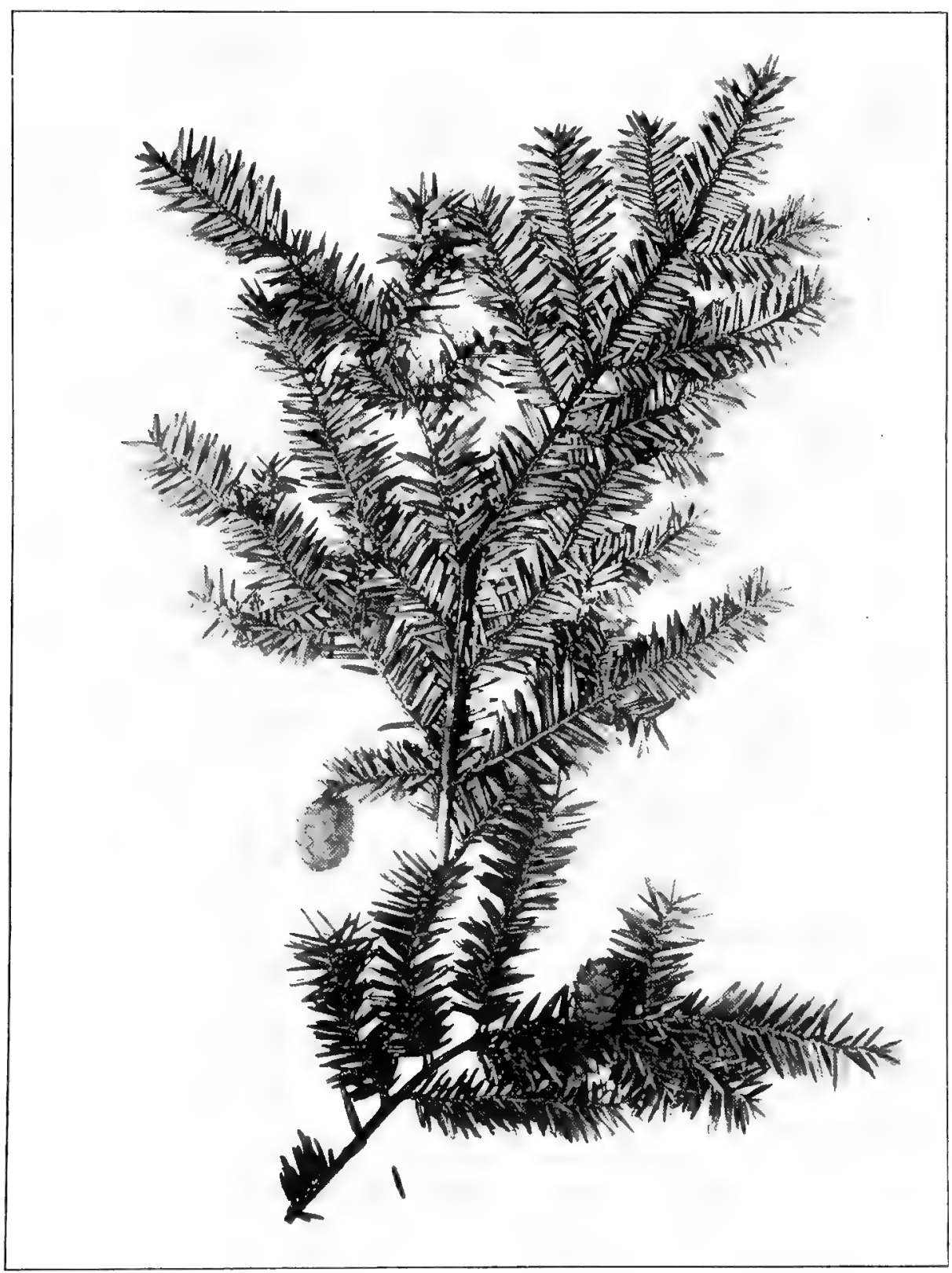

TSUGA CANADENSIS (Linnæus) Carrière. HemLock ( $\mathrm{x}$ 1/2.) 
above the water level, known as "knees"; bark gray or reddish-brown, separating from the trunk in long thin narrow strips; shoots light green, smooth, turning reddish-brown the first year, then a darker brown; leaves spirally arranged, appearing as if 2-ranked on vegetative shoots, linear, 5-15 mm. long, sessile, acute, yellowish-green, turning brown in the fall and dropping off; staminate flowers numerous, borne on long terminal panicles, pistillate flowers solitary in the axils of the leaves; fruit a cone, globose, about $2.5 \mathrm{~cm}$. in diameter, the surface with some wrinkles made by the edges of the closely fitting scales; wood light, soft and straight-grained, lather weak, does not warp or shrink much and reputed to be very durable when exposed to soil or weather.

Distribution.-Along the Atlantic coast from Delaware to Florida and along the Gulf west to Texas and north along the Mississippi Valley to Indiana. In Indiana it has a peculiar and limited distribution. The mass distribution was just north and west of Decker in Knox County. Collett" estimates that 20,000 acres were "covered with a fine forest of cypress". Wright ${ }^{2}$ maps the other places in the southern part of Knox C'ounty where the cypress was known to have occurred. At present the only cypress in Knox County is in the extreme southwest part of the county, and is known as Little Cypress swamp. Here it is associated with such trees as white elm and Schneck's oak. It is believed that it extended only a few miles north of the Deshee River. Going southward it has not been seen in Gibson County, and is first noted in Posey County along the Wabash River in a cypress pond about 12 miles southwest of Mt. Vernon. Then again in Posey County along the Ohio River on the shores of Hovey Lake, and in a slough about 3 miles east of Mt. Vernon. It occurred in a few spots in Vanderburg County along the Ohio River southwest of Evansville. It again appears in limited numbers along Cypress Creek a few miles east of Newburg in Warrick County, which is its eastern ${ }^{3}$ known limit.

The cypress in all of its stations is found only in places that are for the greater part of the year under water.

Remarks. - The original stand of cypress in Indiana has practically all been cut, and the swamps drained and now under cultivation. In the slough east of Mt. Vernon for several years, thousands of seedlings of the year have been noted, but for some reason they do not survive a second year. The present indications are that the cypress will be extinct in Indiana before many years because practically no small trees ('an be found.

This species is highly recommended by some nurserymen for orna-

IInd. Geol. Surv, Rept, 5:338:1874.

3Bairt \& Taylor's reference to this species is regardod as a cultivated tree or as an error Manual Public Schools of Clark County. Ind. 1878-9, page 62. 
Plate T.

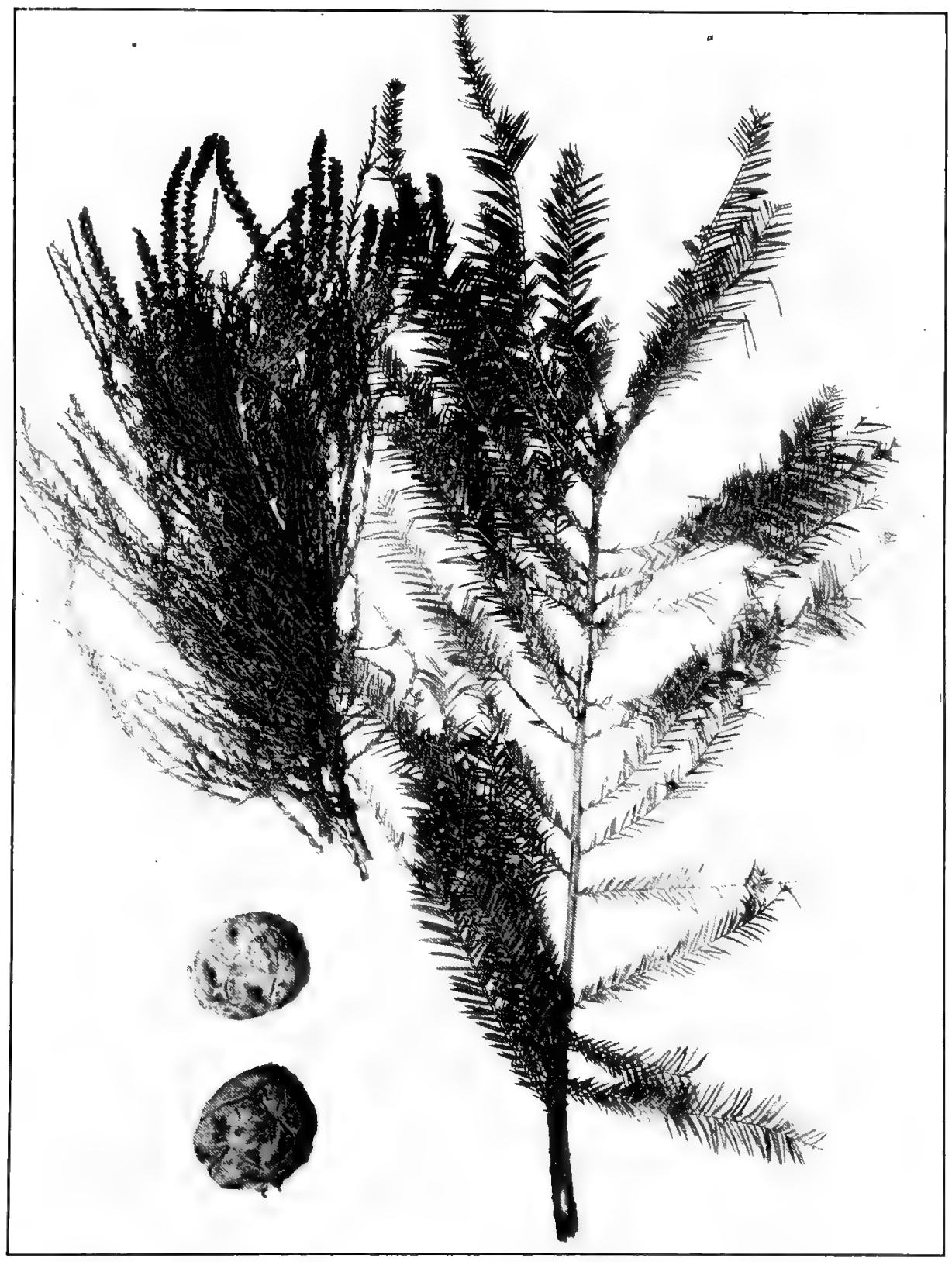

TAXODIUM DISTICHUM (Linnæus) L. C. Richard, Cypress. (x 1/2.) 
mental planting. It proves hardy in the southern part of the state. It is a fint growing tree, adapted to a wet soil, but will succeed in drier situations.

\section{THÙJA. Arbor-vitae.}

Thuja occidentàlis Linnæus. Arbor-vitae. Plate 8. Small evergreen trees with a conical crown, bark on old trees reddish-brown or dark gray, shreddy; branchlets compressed, reddish-brown; leaves all closely appressed, in alternate pairs, scale-like, about"3 $\mathrm{mm}$. long on young branchlets, on old branches somewhat longer together with a spine 2-3 $\mathrm{mm}$. long; flowers appear early in the spring from the ends of the branches; cones mature the first season, about $1 \mathrm{~cm}$. long and .5 ('m. in diameter; wood soft, brittle, weak and durable.

Distribution. - New Brunswick to Manitoba, south to Minnesota and New Jersey thence southward along the Alleghanies to North Carolina and Tennessee. In Indiana it is found native ${ }^{1}$ only in Lake and Porter Counties. In Lake County a few isolated specimens have been found in several places near Lake Michigan. In Porter County it is known only in a large tamarack swamp north of the Mineral Springs stop on the Traction line, and about a mile from Lake Michigan. Here about 100 trees are found scattered over an area of less than two acres. The largest specimen measures $70 \mathrm{~cm}$. in circumference. This species is doomed to early extinction in our area. No doubt it already has vanished from Lake County, and it is probable that the colony north of Mineral Springs is the last of the species in Indiana.

Remarks. - While only found in a swamp in Indiana, this species aclapts itself to all kinds of soils and exposures. It transplants readily and is used for ornamental purposes, and for windbreaks. Dwarf forms are frequently planted for hedges. The wood is used principally for poles and posts, and is commercially known as white cedar.

\section{JUNIPERUS. THE JUnipers.}

Evergreen shrubs or trees, leaves opposite or whorled, sessile, scalelike or short-linear; fruit berry-like; seeds 1-3.

Juniperus virginiàna Linnæus. RED CedAr. Plate 9. A small tree, usually $1-2 \mathrm{dm}$. and rarely up to $5 \mathrm{dm}$. in diameter; bark shreddy; branches usually more or less ascending which gives the tree a narrow conic appearance; shoots green, soon turning light to reddishbrown and on older branches gray or dark brown; leaves 4-ranked, scalelike and 1.5-2 $\mathrm{mm}$. long, or subulate, decurrent at base and $3-10 \mathrm{~mm}$. long on vigorous branches or very small trees; flowers terminal; fruit

, Hamilton County by Wilson, no doubt from a cultivated tree. 
Plate $\$$.

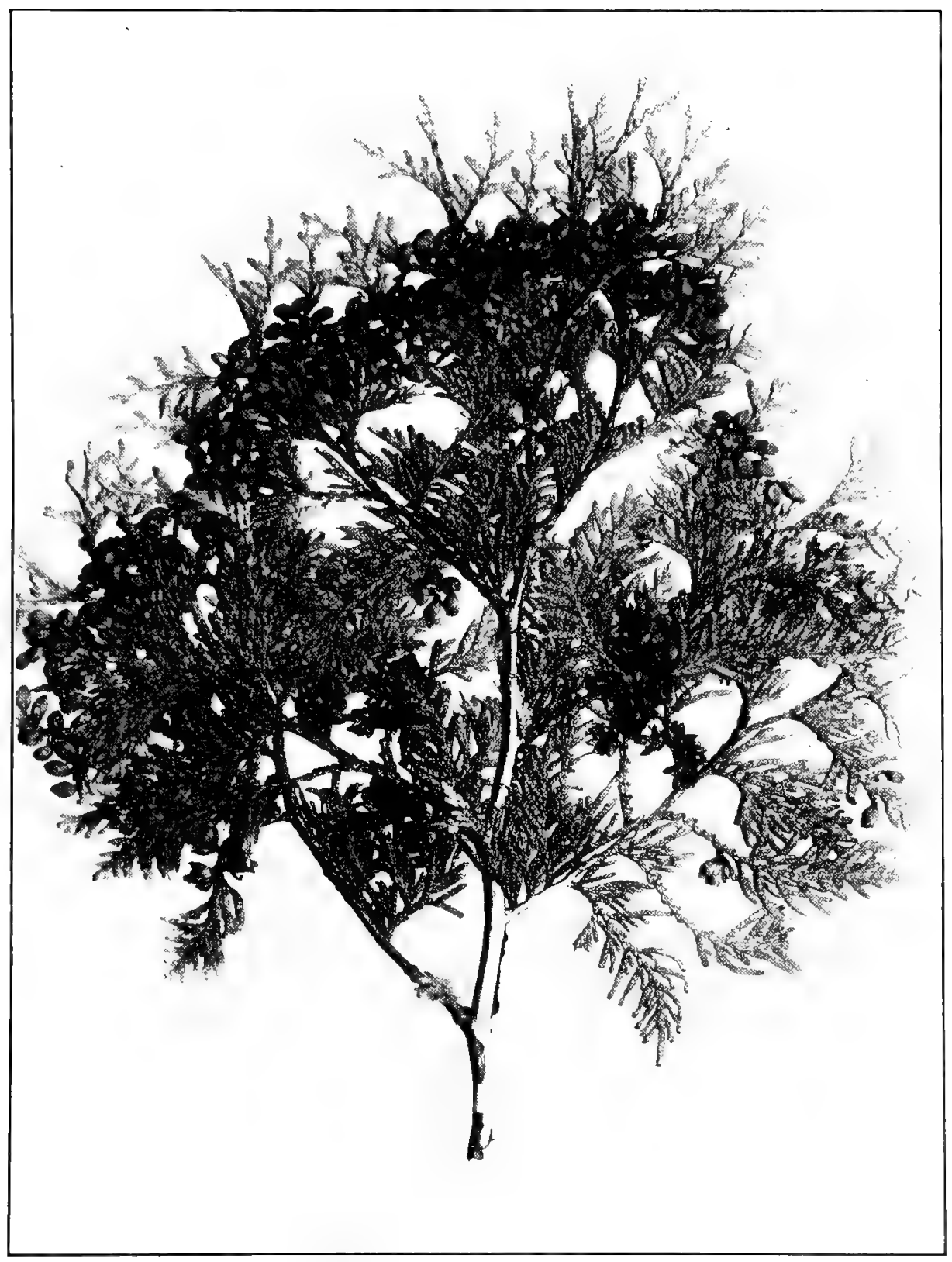

THUJA OCCIDENTALIS Linnæus. ARbor-vite. ( $x, 12$. 
ripening the first season, berry-like, globose but longer than wide, with a bloom and a very resinous pulp about the seeds which are usually 1 or 2; wood light, brittle, close-grained, durable and fragrant.

Distribution.- Nova Scotia south to Florida, west to Texas and north to South Dakota. It is found in all parts of Indiana, although sparingly in the northern part, especially where streams with bluffs are absent. No doubt this species in the original forests was confined principally to the bluffs of streams and rocky ravines. Since the forests have been cut, it is now found growing along fences, in open dry woods, and in southern Indiana it is a common tree in old abandoned fields, and in waste places.

Remarks.--Red cedar has had many uses, and the large trees have been practically all harvested. It is now used principally for poles, posts, cross-ties, cigar boxes and lead pencils. It is the best wood known for lead pencils. The odor is so objectionable to insects that a market has been made for chests of this wood in which to store clothing and furs.

\section{SALICĀCEAE. 1 The Willow Family.}

Trees or shrubs with bitter bark; simple alternate leaves; flowers in catkins, which fall off as a whole, the staminate after flowering, the pistillate after ripening and scattering of the seeds, the staminate and pistillate on different plants (dicecious); flower scales single, below each flower; fruit a lanceolate or ovate-lanceolate capsule opening lengthwise into 2 recurving carpels or valves; seeds numerous, minute, oblong, bearing a tuft of hairs at the base. Genera 2, Salix, the willows, and Populus, the aspens and poplars, or cottonwoods, separated by the following characters, those applying only to Indiana trees species in parentheses:

Buds covered by a single scale; (leaf-blades mostly enlongated, more than twice as long as wide); flower seales entire or rarely shallowly toothed at apex; stamens mostly 2 or 3-8 or $10 \ldots \ldots \ldots \ldots \ldots \ldots \ldots \ldots \ldots \ldots \ldots \ldots \ldots$ Salix.

Buds covered by numerous scales; (leaf-blades mostly cordateovate, less than twire as long as broad); flower scales deeply cut or lacerate; stamens more than $10 \ldots \ldots .2$ Populus.

\section{SÀLIX. THE WILLOWs.}

Trees or shrubs (occasionally herbaceous) with usually clustered teims, twigs round; leaf-blades lanceolate and long-acuminate or slleptic-lanceolate and short pointed in all Indiana tree species, finely

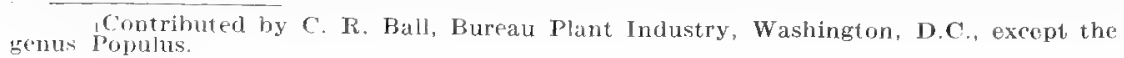


Plate \%.

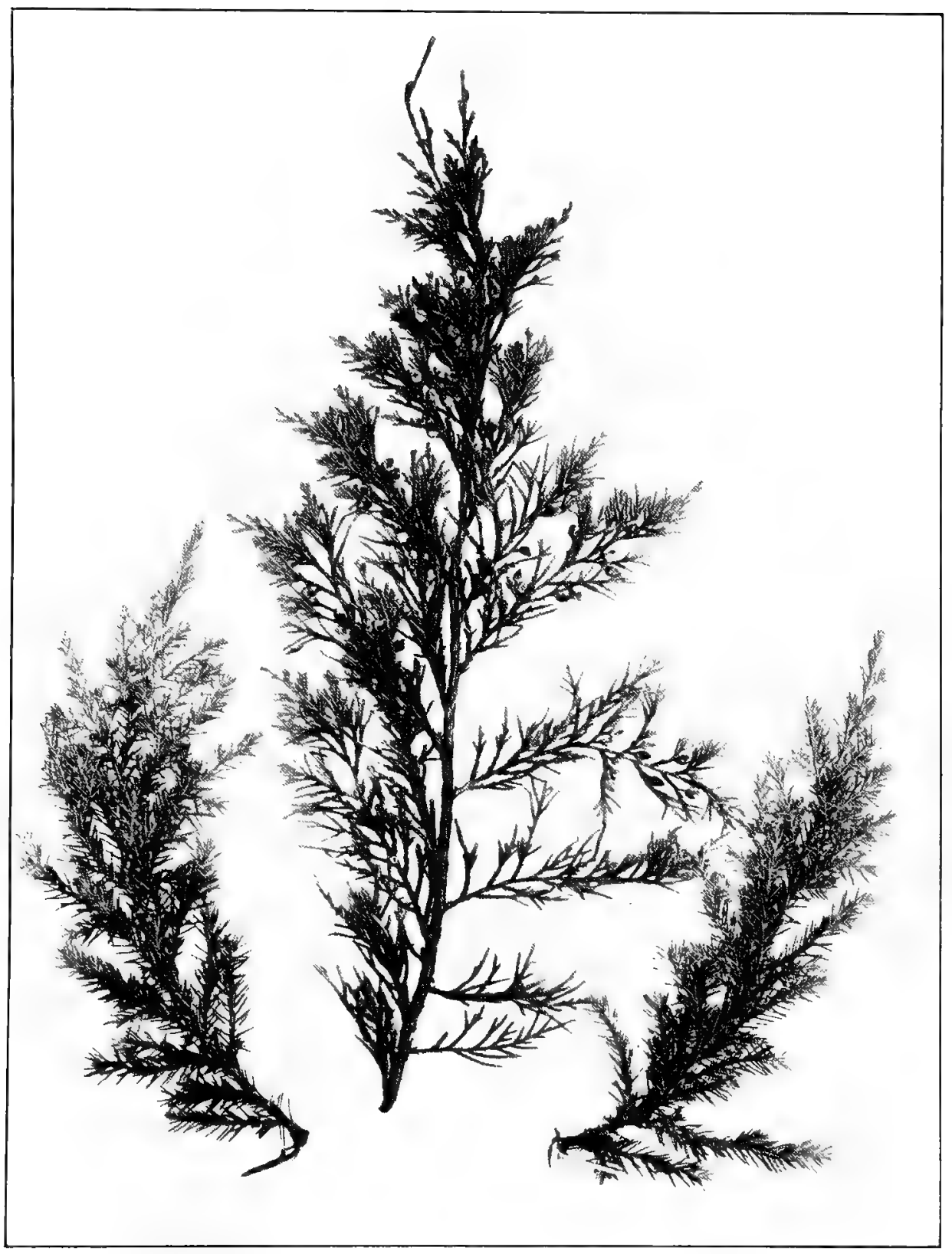

JUNIPERUS VIRGINIANA Linnæus, RED CEDAR. ( $x$ l. 2.) 
toothed or nearly entire; catkins appearing before (precocious), with (cotaneous), or after the leaves (serotinous); each pistillate flower with a little gland at the base of the pedicel on the inside.

A large genus of several hundred species varying from tiny shrubby or subherbaceous plants scarcely an inch in height to $0.5 \mathrm{~m}$. (2 feet) or more in diameter, in alluvial lowlands; occurring under Indiana conditions from cold bogs and river banks to dry sand dunes. Willows are used for many purposes, among them ornament, shade, hedges, posts, poles, mattresses, revetments to protect levees, baskets, fishweirs, whistles, ete, while the wood is used for charcoal, which is especially prized for gunpowder making, and the bark is used for tanning and furnishes salicin, which is used in medicine as a substitute for quinine and as a tonic and febrifuge.

Small to large trees; leaves narrowly to broadly lanceolate, mostly long pointed, finely and rather closely toothed; flowers appearing with the leaves; capsules not hairy. Native trees; leaves green on hoth sides (No. 1) or white (glaucous) beneath (No. 2), and then with very long points and long slender twisted petioles which are never glandular; stamens $3-5-7$ or more.

Twigs dark green, spreading; leaves narrowly lanceolate, green on both sides; petioles short............. 1 S. nigra.

Twigs yellowish, somewhat drooping; leaves broadly lanceolate, glaucous beneath; petioles long, twisted. 2 S. amygdaloides.

European trees, eultivated for ornament and use; leaves always glaucous beneath; stamens always 2 .

Teeth on edge of leaf 8-10 to each cm. (20-25 to the inch); petioles usually glandular; capsules almost sessile... $3 \mathrm{~s}$. alba.

Teeth on edge of leaf $6-8$ per $\mathrm{cm}$. (15-20 to the inch); petioles usually glandular; pedicels $0.5-1 \mathrm{~mm}$. long...... $4 \mathrm{~s}$. fragilis.

Shruhs or rarely small trees; leaves elliptical or oblanceolate, short pointed; margin entire or coarsely wavy or shallowtoothed; flowers before the leaves; stamens 2; capsules long, hairy.

Twigs and leaves not hairy; leaves thin...........4 S. discolor.

Twigs and sometimes the lower suface of the leaves densely hairy, leaves thicker.

5 S. discolor eriocephala.

1. Salix nigra Marshall. Willow. Black Willow. Plate 10. Shrub or tree 5-20 m. (17-65 feet) high, dark green in mass color; bark of trunk thick, rough, flaky, dark brown to nearly black; twigs brittle at base, the younger pubescent and green, becoming glabrous and darker with age; buds ovate, small, 2-3 $\mathrm{mm}$. (1/8 inch) long; petioles $3-6$ or $8 \mathrm{~mm}$. ( $1 / \mathrm{s}^{-3 / 8}$ inch) long; stipules small, ovate to roundish; leaf blades narrowly lanceolate, acute or rounded at base, long-acuminate at the apex, 6-11 cm. (2 1/4-4 1/4 inches) long, 7-12 
Plate 10.

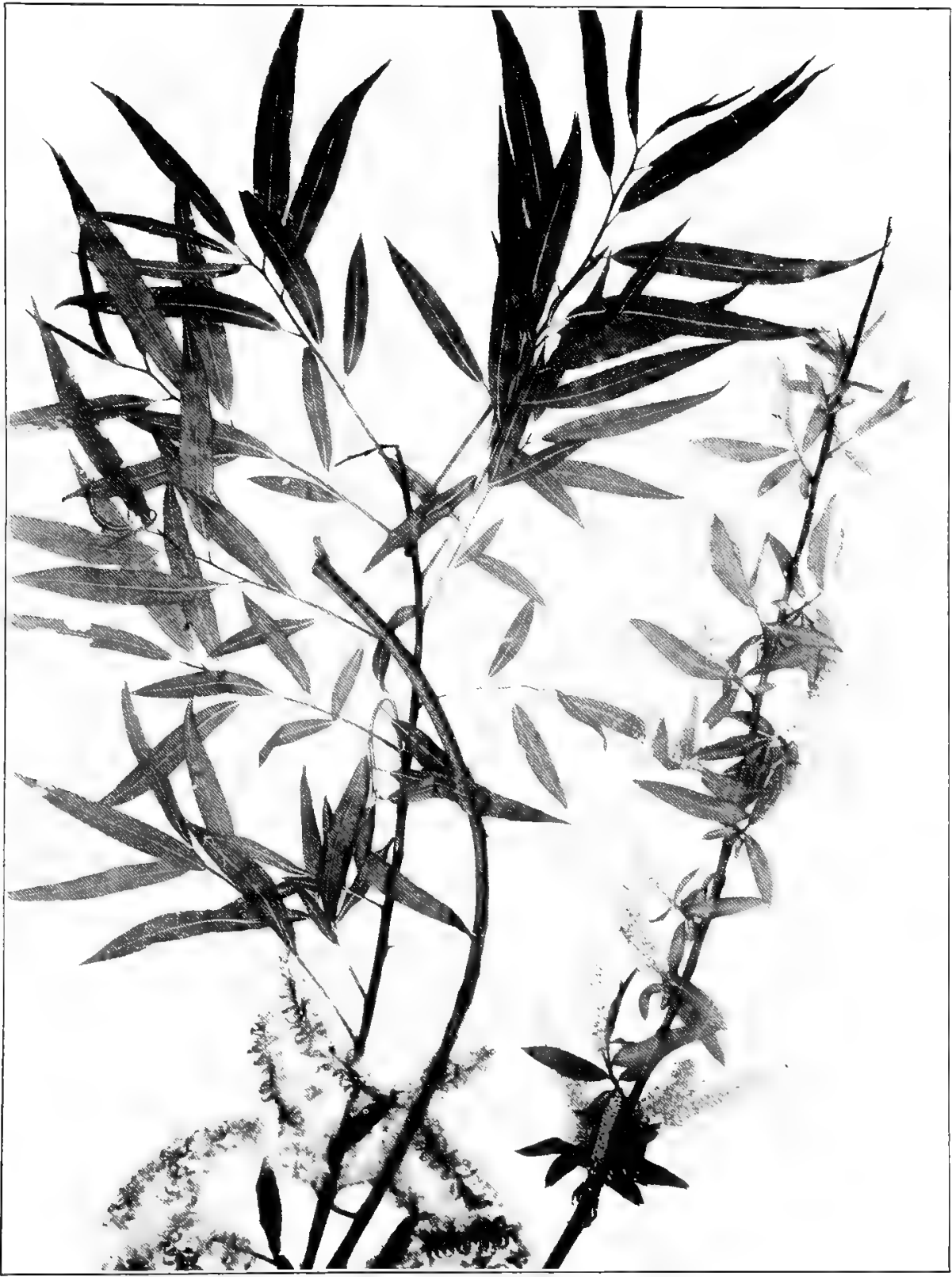

SALIX NiGRA Marshall. Black Willow, (x I.2.) 
mn. ( ${ }_{4}^{-1 / 2}$ inch) wide, often falcate (scythe-shaped), the so-called variety falcata), finely serrate, green on both sides, shining above, paler and dull beneath, glabrous or sometimes pubescent beneath on midib and larger veins; flowers appearing with the leaves in late April in the souther'n part of the State and well into May in the northern part; catkins slender, $2-5$ or $6 \mathrm{~cm}$. (4/5-2 or $2 \frac{1}{2}$ inches) long, the staminate hright yellow; capsules $3-5 \mathrm{~mm}$. (1.s inch) long, ovoid or ovoid-lanceolate, on pedicels $1-2 \mathrm{~mm}$. (1/16 inch) long.

Distribution.-New Brunswick and New England, westward to the eastern part of the Great Plains area fiom North Dakota to Texas, and, in some forms, westwand across that State and into Mexico. It is interesting that this species, the first willow published in America, in the first book on American Botany ever published in this country, should be abundantly and widely distributed in the United States.

Specimens have been seen from the following counties in Indiana:Allen (Deam); Bartholomew (Deam); Clark (Deam); Crawford (Deam); Dearborn (Deam); Dubois (Dean); Decatur (Deam); Floyd (Deam); Fulton (Deam); Harrison (Deam); Hendricks (Deam); Henry (Deam); Jackson (Deam); Jay (Deam); Jennings (Deam); Knox (Deam); Kosciusko (Deam); Lagrange (Deam); Marion (Mrs. Chas. (. Deam); Marshall (Deam); Miami (Deam); Morgan (Deam); Noble (Deam); Ohio (Deam); Parke (Deam); Perry (Deam); Porter (Deanı); Posey (Deam); Pulaski (Deam); Ripley (Deam); Steuben (Deam; Sullivan (Deam); Tippecanoe (Deam); Vermillion (Deam); Wabash (Deam); Warrick (Deam); White (Deam).

Economic Uses. - The black willow is used very extensively along the lower reaches of the Mississippi Ruver in making matresses which protect the levees from washing. In 1912, it was estimated that 150,000 cords were used annually.

2. Salix amygdaloides Andersson. Willow. Peach-leaved WilLow. Plate 11 . Trees 3-12 m. (10-40 feet) high, yellowish-green in mass color; bark of trunk fissured, dark brown or reddish-brown; twigs longer and less brittle than those of Salix nigra, yellowish to reddishbrown, usually somewhat drooping, giving a "weeping" effect, which, with the color, makes the species easily recognizable from a distance; buds ovoid, about $3 \mathrm{~mm}$. (1/8 inch) long, colored as the twigs; petioles long, slender, twisted, $5-15$ or $20 \mathrm{~mm}$. (1/4-4/5 inch) long; leaves lanceolate to broadly lanceolate or ovate-lanceolate, rounded or somewhat acute at hase, long-pointed at apex, closely serrulate, $5-12 \mathrm{~cm}$. (2-5 inches) long, $1.5-3 \mathrm{~cm}$. (3/5-11/4 inches) wide, yellowish-green above, glaucous beneath, glabrous; flowers appear from late April throughout May, usually later than those of Salix nigra; catkins slender, 3-5 cm. 
Plate 11.

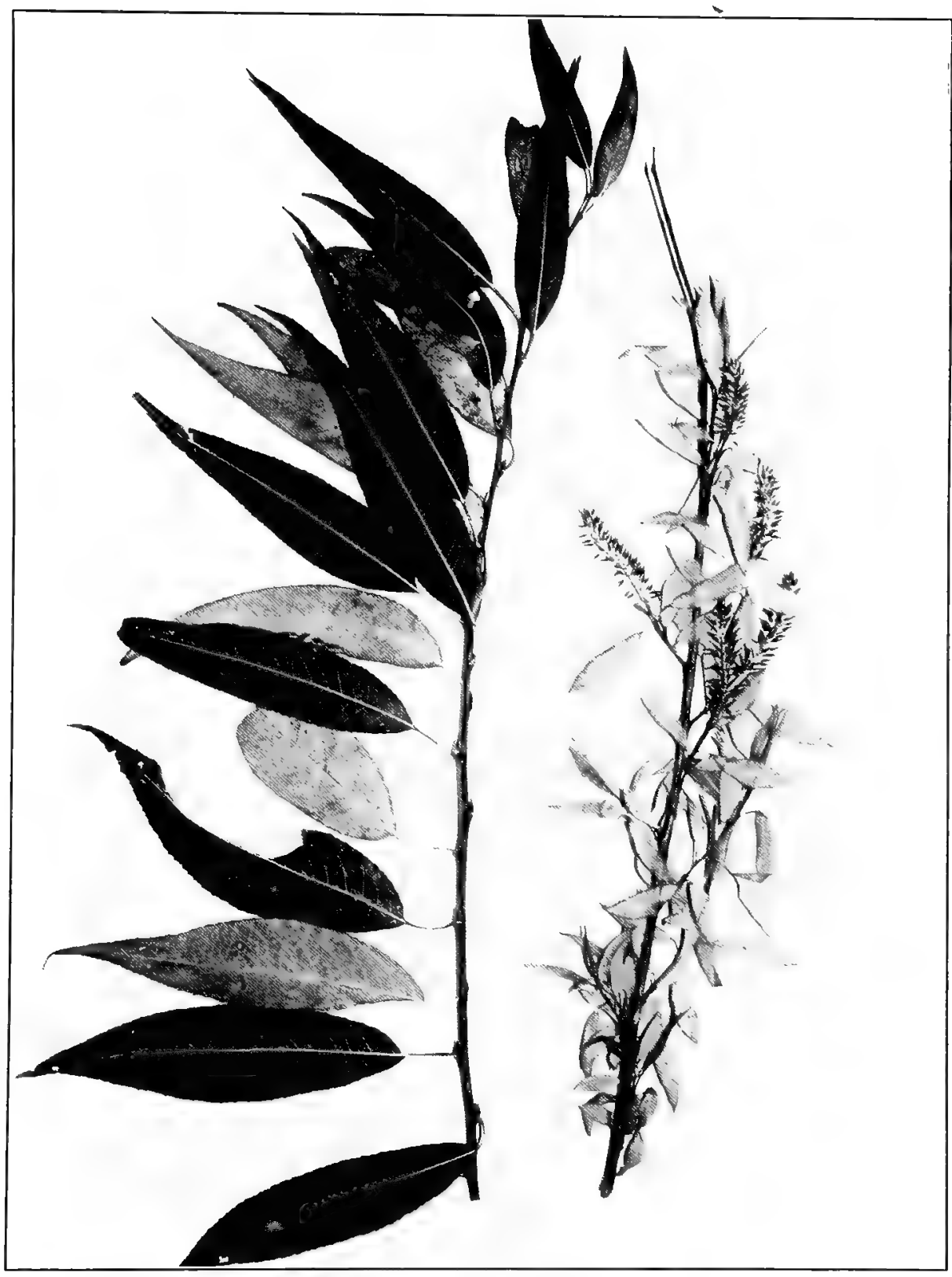

SAliX anigdaloides Andersson. Peach-leaved Willow. ( $\mathrm{x}$, 12 . 
(1-2 inches) long, the fertile becoming $4-8 \mathrm{~cm}$. ( $1 \frac{1}{2}-3$ inches) long in fruit; capsules lanceolate, $4-5 \mathrm{~mm}$. (1/6 inch) long; pedicels slender, $2 \mathrm{~mm}$. (1/12 inch) long.

Distribution.-From Western Quebec and Central New York, west to the Cascade Mountains in British Columbia, Washington and Oregon, south to Colorado and northwest Texas. In Indiana fairly common in the northern third, rale in the central third, and lacking in the southern portion of the state.

Specimens have been seen from Indiana from the following counties: Elkhart (Deam); Fulton (Deam); Henry (Deam); Jasper (Deam); Kosciusko (Deam); Lake (Deam), (Lmbach); Laporte (Deam); Marion (Mrs. Chas. C. Deam); Iarshall (Deam); Pulaski (Deam); Steuben (Dean); Wolls (Deam); White (Deam).

3. Salix álba Limnæus. Willow. White Willow. Plate 12. Trees with 1-5 spreading stems, 5-20 m. (17-65 feet) high; bark rough, coarsely ridged, gray to brownish; twigs brittle at base, green or yellowish, glabrous; buds $5-6 \mathrm{~mm}$. (1/ 1 inch) long; petioles $5-10 \mathrm{~mm}$. (1/5$2 / 5$ inch) long, seldom glandular; leaves lanceolate, $5-12 \mathrm{~cm}$. (2-5 inches) long, $1-2.5 \mathrm{~cm} .(2 / 5-1 \mathrm{inch})$ wide, acuminate at apex, usually acute at base, leaves bright green above, glaucous beneath, thinly to densely silky on both sicles when young, often permanently silky beneath, margins with about $9-10$ teeth per $\mathrm{cm}$. (2/5 inch), usually glandular; flowers with the leaves, in April and May; catkins slender, cylindrical, 3-6 cm. (11/4-21/2 inches) long; scales pale yellow; capsules ovoid-conical, $3-5 \mathrm{~mm}$. (1/1 inch) long, almost sescile. The common form usually is referred to variety vitellina (Linnæus) Koch, with orange twigs and more glabratc leaves.

Distribution. - A native of Europe which has been frequently planted and sometimes escapes.

Sperimens have been seen from Indlana trom the following counties: Gibson (Schneck); Hamilton (Mrs. Chas. C. Deam); Harrison (Deam); Switzerland (Deam); Warren (Dcam); Wells (Deam).

4. Salix frágilis Linnæus. Willow. Crack Willow. Plate 13. Tree very similar to Salix alba; twigs very brittle at the base (hence the name), green to reddish; petioles $7-15 \mathrm{~mm}$. (1, / $-5 / 8$ inch) long, glandular just below the base of the leaf; leaves lanceolate, acuminate, 7-15 cm. (3-6 inches) long, $2-3.5 \mathrm{~cm} .(4 / 5-11 / 2$ inches) wide, coarsely serrate with 5-6 tecth to each $\mathrm{cm}$. (2/5 inch) of margin, dark green and shining above, paler to glaucous beneath, rarely green, glabrous on both sides; catkins appearing with the leaves in late April and during May, 4-8 cm. (1 1/2-3 inches) long; capsules slenderly conical, $4-5 \mathrm{~mm}$. (1/5 inch) long, on perlicels $0.5-1 \mathrm{~mm}$. (1/16 inch) long. 
Plate 12.

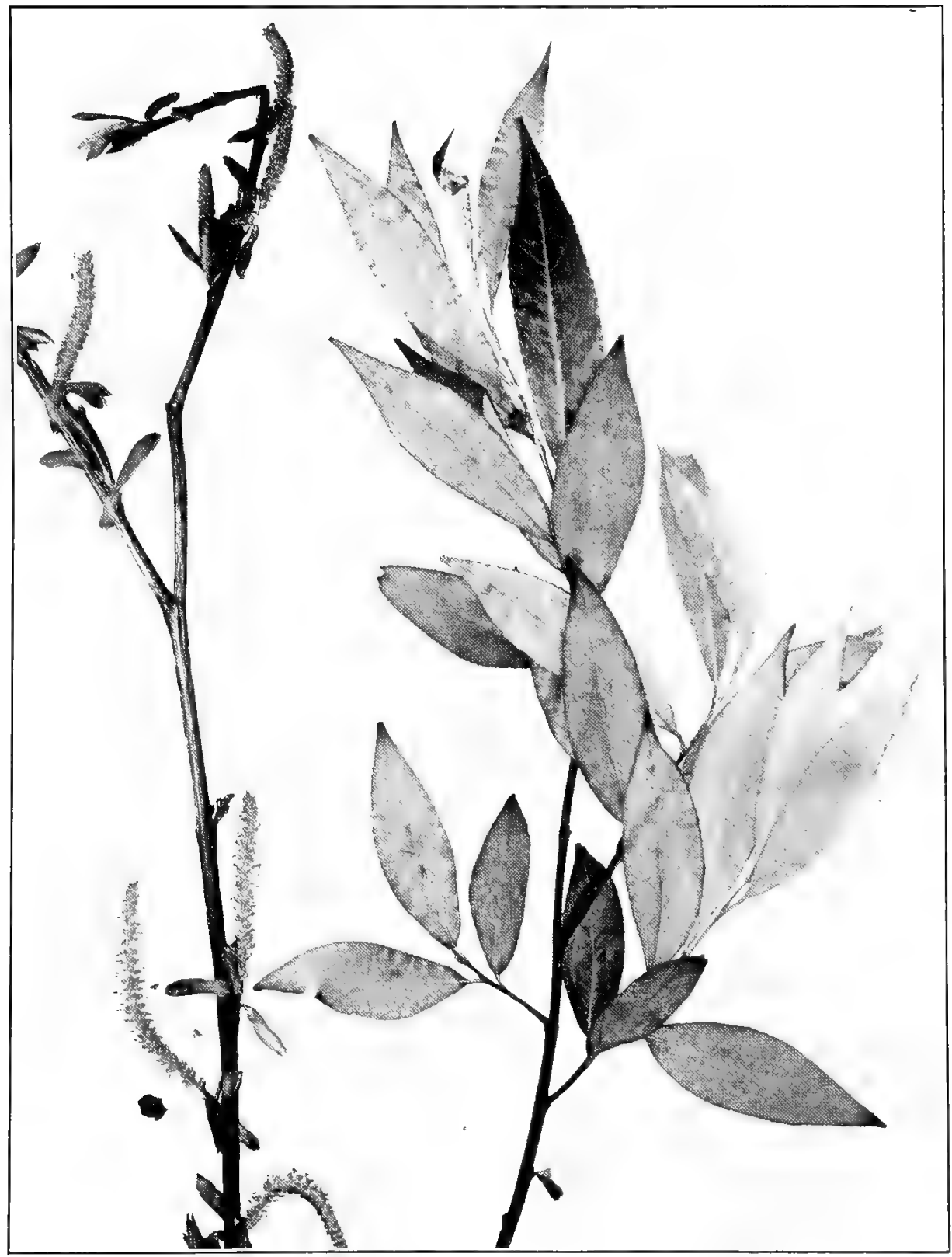

SALIX ALBA Linnæus. White Willow. (x 1 ’.) 
Plate 13.

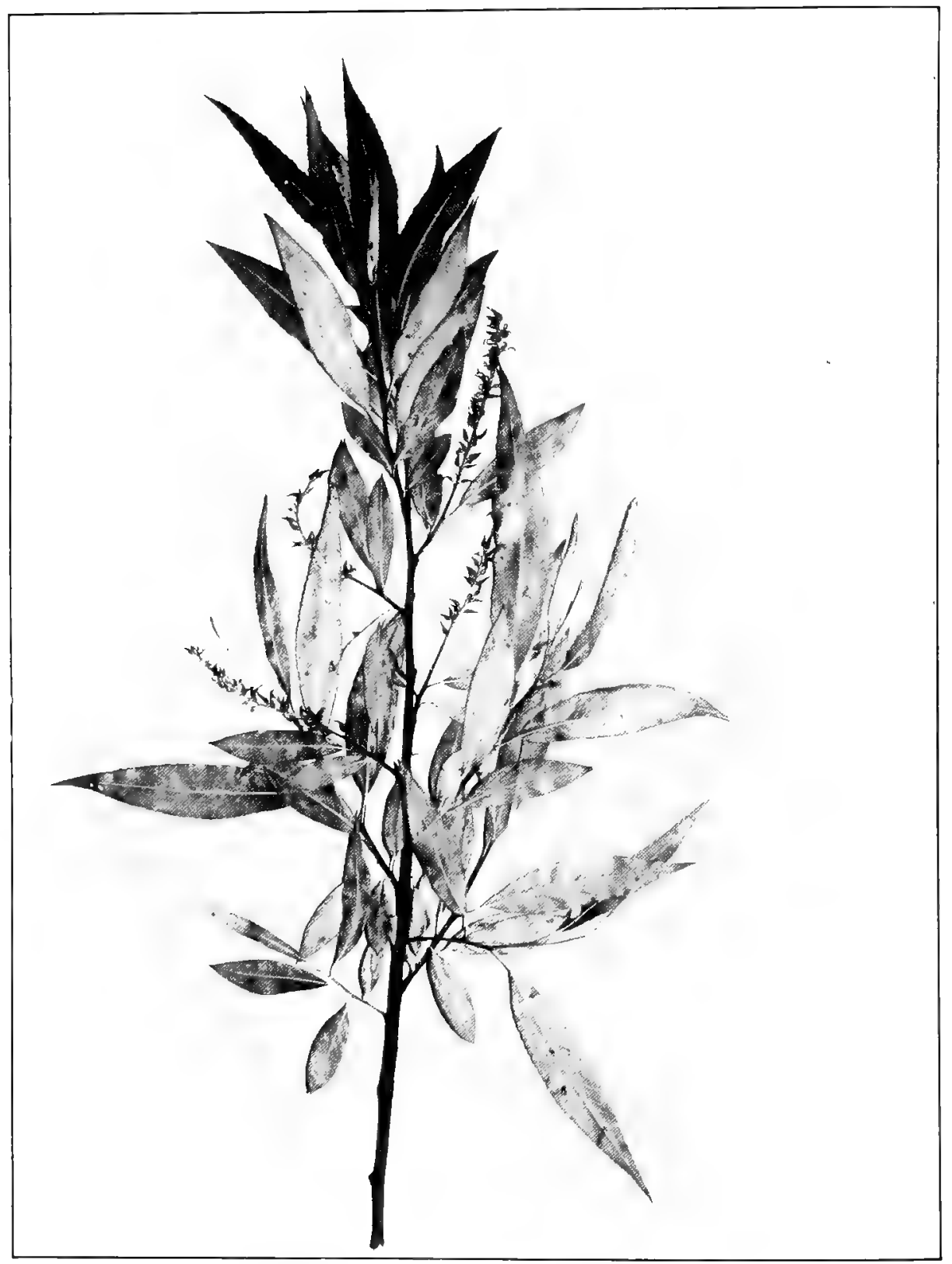

SALIX FRAGILIS Linnæus. Crack Willow. ( $x^{1}$ 2.) 
Distribution.-A native of Europe. It has been frequently planted and often escapes.

Specimens have been seen from the following Indiana counties: Benton (Deam); Clark (Deam); Laporte (Deam); Switzerland (Deam); Union (Deam); Wells (Deam).

Economic Uses.- This species and the white willow are introduced from Europe and extensively grown for the production of charcoal to use in powder making.

5. Salix díscolor Muhlenberg. Pussy Willow. Swamp Willow. Glaucous Willow. Plate 14 . Shrub or small tree, $2-4$ or occasionally 7-5 m. (7-15 or 25 feet) high; bark thin, usually smooth, reddish brown; twigs stoutish, reddish-purple to dark brown, often pubescent (see the variety); buds large, $5-10 \mathrm{~mm}$. (1/5-2/5 inch) long, colored as the twigs; stipules large, mostly roundish, entire or toothed; leaves shortlanceolate to elliptic or elliptic-oblanceolate, acute or short-acuminate at the apex, rounded or acute at the base, $5-10 \mathrm{~cm}$. (2-4 inches) long, $2-3.5 \mathrm{~cm}$. (4/5-1 1/2 inches) wide, nearly entire to coarsely wavy-toothed on the margins, dark shining green above, densely glaucous and occasionally somewhat pubescent beneath, especially on midrib and primaries; flowers appear in late March or in April before the leaves; catkins sessile, on old wood, stout, dense, the staminate very beautiful (pussies), without leaf-bracts at base, $2-5 \mathrm{~cm}$. (1-2 inches) long, the pistillate becoming $3-8 \mathrm{~cm}$. (1//2-3 inches) long in fruit; scales ellipticoblanceolate, densely clothed with long shining hairs; capsules conicrostrate, $7-10$ or $12 \mathrm{~mm}$. (1/4-1/2 inch) long, densely gray-woolly; pedicels $1.5-3 \mathrm{~mm}$. (1/16-1/8 inch) long.

Distribution.- Nova Scotia south to Delaware and west to the eastern edge of the Great Plains area. Fairly well distributed over the entixe State of Indiana. Specimens have been seen from the following counties: Allen (Deam); Dearborn (Deam); Decatur (Deam); Elkhart (Deam); Fulton (Deam); Gibson (Schneck); Hancock (Mrs. Chas. C. Deam); Henry (Deam); Jackson (Deam); Jay (Deam); Jefferson (Deam); Jennings (Deam); Knox (Deam); Lake (Deam); Marion (Mrs. Chas. C. Deam); Marshall (Deam); Newton (Deam); Porter (Deam); Randolph (Deam); Ripley (Deam); Shelby (Mrs. Chas. C. Deam); Sullivan (Deam); Tippecanoe (Deam); Wabash (Deam); Warren (Deam); Wayne (Deam); Wells (Deam); White (Deam).

5a. Salix discolor variety eriocéphala (Michaux) Andersson. Differs from the species chiefly in rather densely pubescent twigs and buds; thicker and more lanceolate leaves, usually more or less pubescent beneath; and the sometimes more densely pubescent catkins.

Distribution.- Range of the species but less common. Specimens have been seen from the following Indiana counties: Cass (Deam); 
Plate 14.

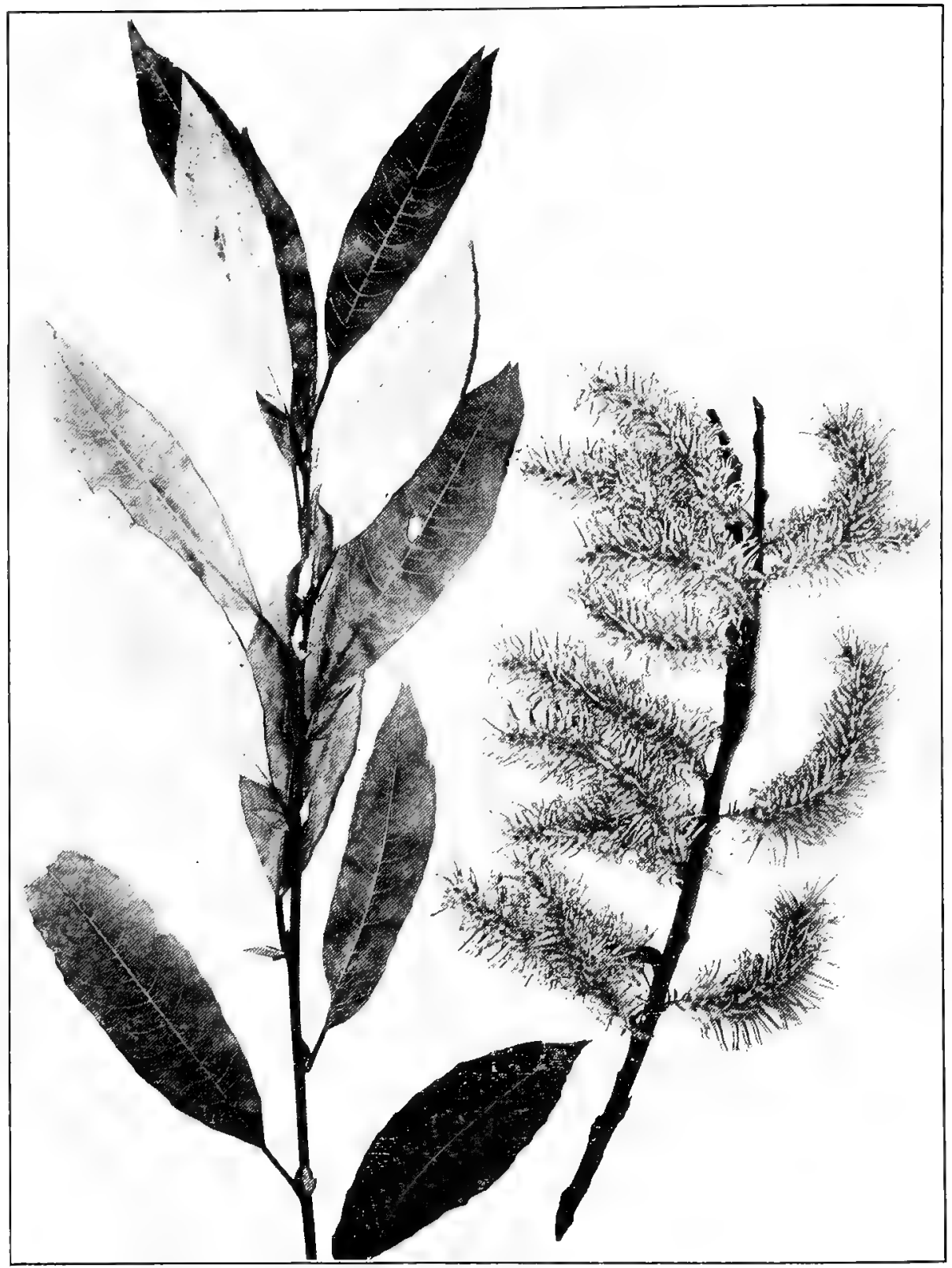

SALIX DISCOLOR Mublenberg. Pussy Willow. (x 1/2.) 
Decatur (Deam); Fulton (Deam); Gibson (Schneck); Jackson (Deam); Jay (Deam); Knox (Deam); Laporte (Deam); Pulaski (Deam); Sullivan (Deam); Warren (Deam); Wayne (Deam).

\section{Pópulus. The poplars.}

Rapidly growing trees; buds usually large, scaly and more or less resinous; leaves alternate, broad, toothed or sometimes lobed; flowers appearing before the leaves on large pendulous catkins; anthers red or purple.

In the following key mature leaves from trees are considered:

Petioles round or channeled, searcely or not at all flattened laterally.

Leaves chalky-white tomentose beneath, some of them more or less lobed, blades $6-10 \mathrm{~cm}$. long........ 1 P. alba.

Leaves pubescent or whitish tomentose while young, never lobed, blades $10-17 \mathrm{~cm}$. long............. $2 \mathrm{P}$. heterophylla.

Petioles strongly flattened laterally especially near the blade.

Winter buds more than $8 \mathrm{~mm}$. in length, stamens more than 20 , capsules more than $3 \mathrm{~mm}$. in diameter, leaves broadly deltoid, majority more than $8 \mathrm{~cm}$. wide. 3 P. deltoides

Winter buds less than $8 \mathrm{~mm}$. in length, stamens fewer than 20 , capsules less than $3 \mathrm{~mm}$. in diameter, leaves roundish ovate, majority less than $8 \mathrm{~cm}$. wide.

Winter buds more or less pubeseent, dull; leaves generally with less than 12 teeth to a side............ 4 P. grandidentata. Winter buds smooth or rarely somewhat pubescent, glossy; leaves with more than 12 teeth to a side.....5 P. tremuloides.

1. Populus álba Linnæus. Silver-leaf Poplar. Plate 15. Shorttrunked trees with a round top, up to a meter or more in diameter; bark on young trees smooth, greenish-white or gray, becoming furrowed on old trees, gray or dark brown; shoots white tomentose, becoming smooth in age; leaves ovate or triangular, 3-5 lobed or irregularly toothed, hairy on both surfaces on expanding, becoming dark green and glabrous above, remaining white tomentose beneath; stamens about 8; wood light, soft and weak.

Distribution.--Introduced from Europe and escaped in all parts of the State.

Remarks. - This tree has long been under cultivation, and several horticultural forms have been introduced. It is falling into disuse on account of its habit of sending up root shoots. It adaptsitself to all kinds of soil, grows rapidly, transplants easily, stands pruning well and has few insect or fungous enemies. 
Plate 15.

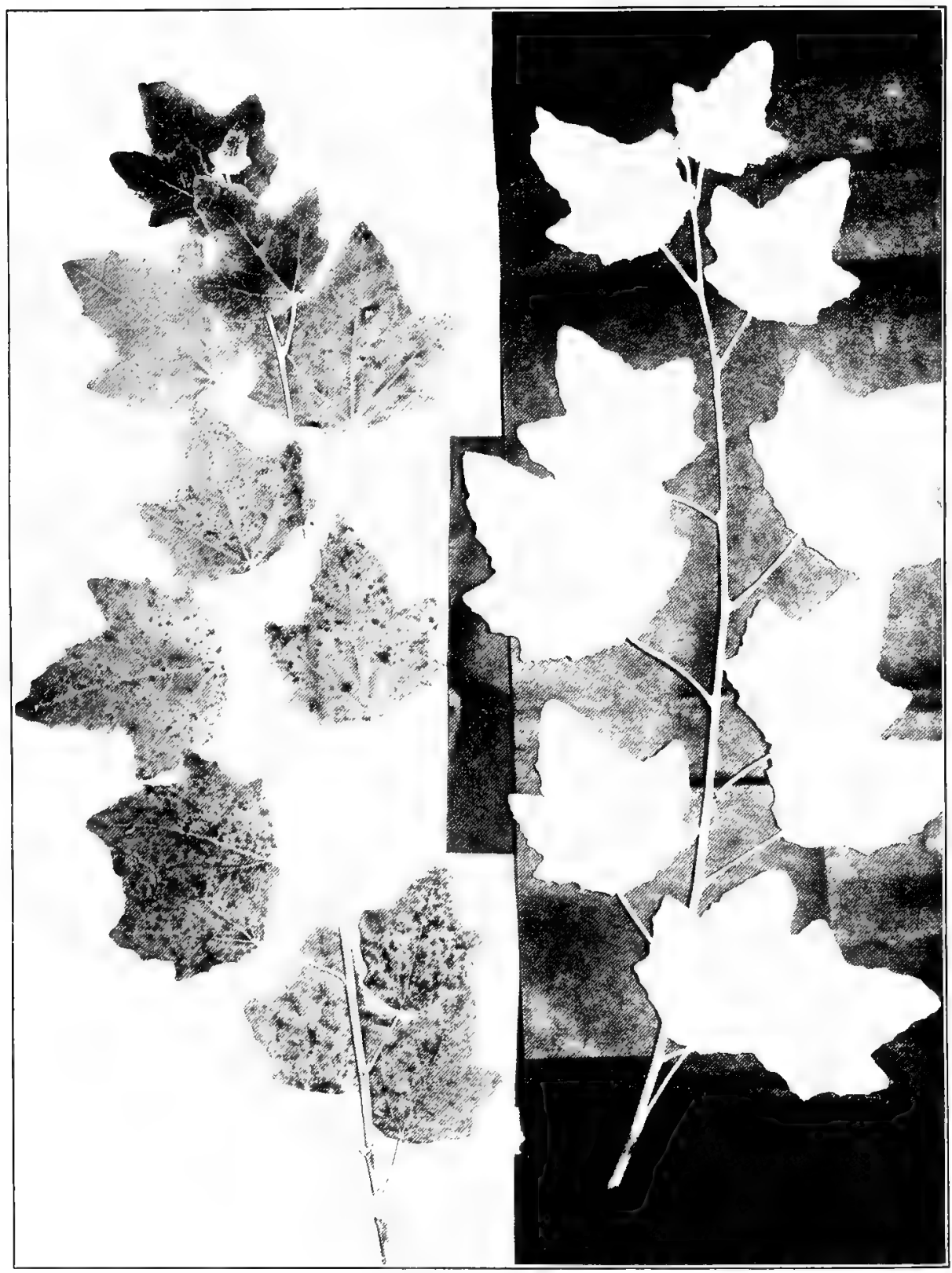

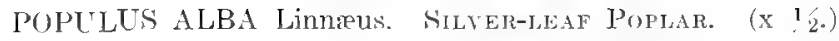


2. Populus heterophylla Linnæus. SWAMP COTTONWOOD. Swamp Poplar. Plate 16 . Tall trees up to $5-8 \mathrm{dm}$. in diameter; bark of old trees very thick, broken into long ridges which are separated by deep furrows, reddish-brown but generally weathered to ash-color; shoots densely woolly at first, becoming glabrous before the second season; leaves broadly-ovate with petioles $2-10 \mathrm{~cm}$. long, more or less woolly on both surfaces on unfolding, becoming glabrous above and remaining woolly beneath, at least on the larger veins, rarely becoming entirely glabrous, usually cordate at the base, blunt at apex, margins rather regularly crenate-serrate; flowers in April; capsules ripening in June, about $6 \mathrm{~mm}$. in diameter, on stalks $5-10 \mathrm{~mm}$. long; wood same as the next species.

Distribution.-Along the Atlantic Coast from Connecticut to Florida and along the Gulf to Louisiana, and northward along the Mississippi Valley to Michigan. It is found in many parts of Indiana. In the northern counties it is found in "gumbo" soils in swamps. It is a common tree in the river swamps of the lower Wabash Valley where it reaches its greatest size. There are no records for the extreme southeastern part of the State, although it has been found in swamps in Harrison and Clark Counties and is found in many counties of Ohio.

Remarks. - The pith of the shoots of this species is orange which easily distinguishes it from all other species of the genus which have a white pith. This species in all of its range is closely associated with the common cottonwood, and millmen make no distinction in the price or qualities of the timber.

3. Populus deltoides Marshall. Cottonwood. Carolina PopLAR. (Populus balsamifera var. virginiana (Castiglioni) Sargent). Plate 17. One of the largest trees of the Indiana forests; bark of very old trees very thick, broken into ridges up to $1 \mathrm{dm}$. or more in thickness, separated by deep furrows, reddish-brown, weathering to a gray; leaves hairy on both surfaces as they unfold, soon glabrous except on the margins which are more or less ciliate, broadly-deltoid, usually 7-12 $\mathrm{cm}$. long, and about as wide, base more or less truncate or cordate, or somewhat wedge-shaped, with rather short acuminate tips, crenateserrate; capsules ovate, about $6 \mathrm{~mm}$. in diameter, on stalks $1-2 \mathrm{~mm}$. long; wood light, soft, weak, sap wood white, heartwood small and brown; warps badly on drying.

Distribution.-Quebec to Florida and west to the Rocky Mountains. Throughout Indiana in low ground along streams, in swamps and about lakes. On account of its habit of growing only in low ground it is infrequent in the hill country of southern Indiana.

Remarks. - The cottonwood is adapted to a moist soil, propagates easily, grows rapidly and is one of the best trees for forestry purposes 
Plate 16.

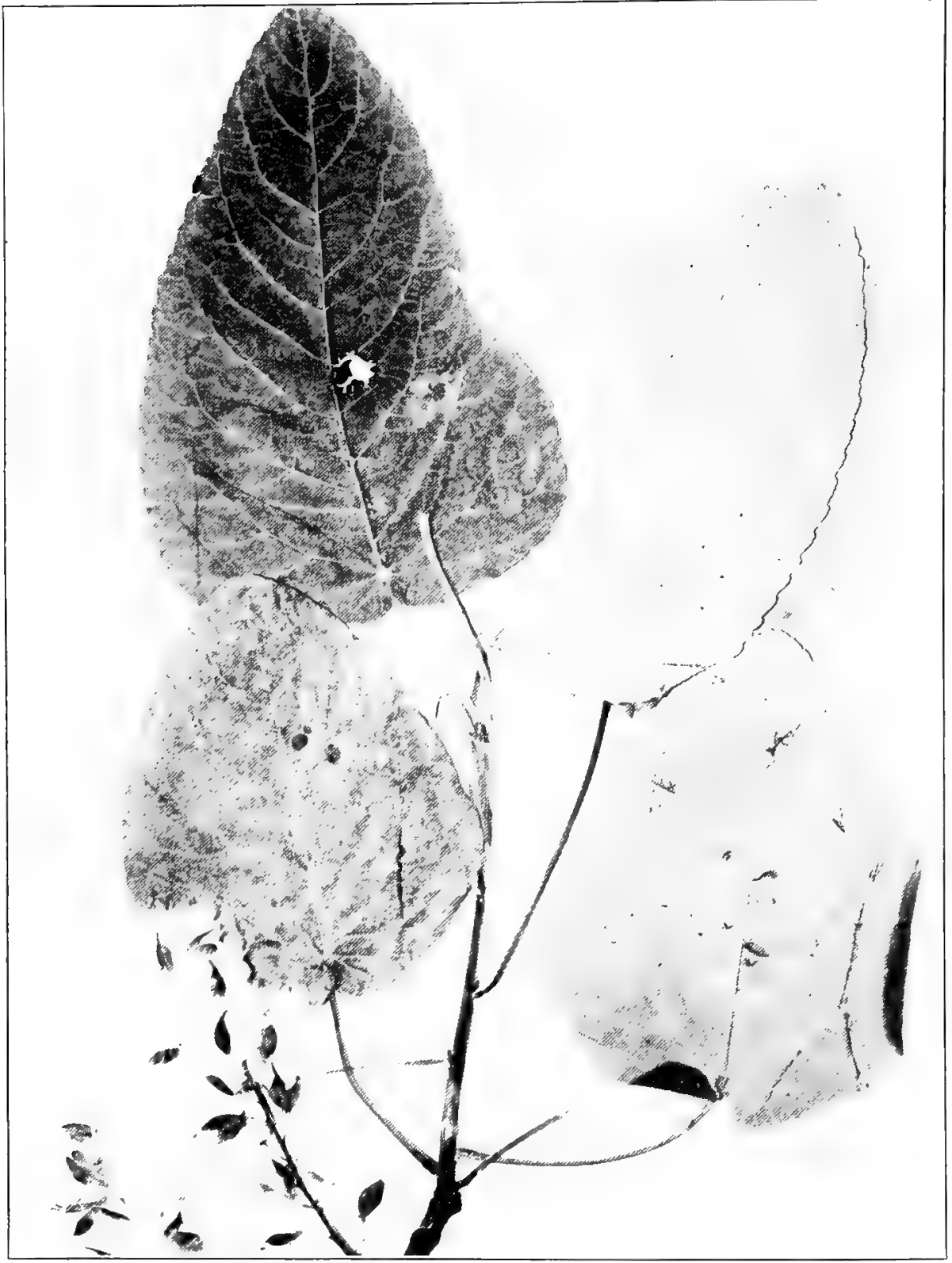

POPULUS HETEROPHYLIA Linnuæs. Swamp CotTonwood. (x $1_{2}$.) 
Plate 17.

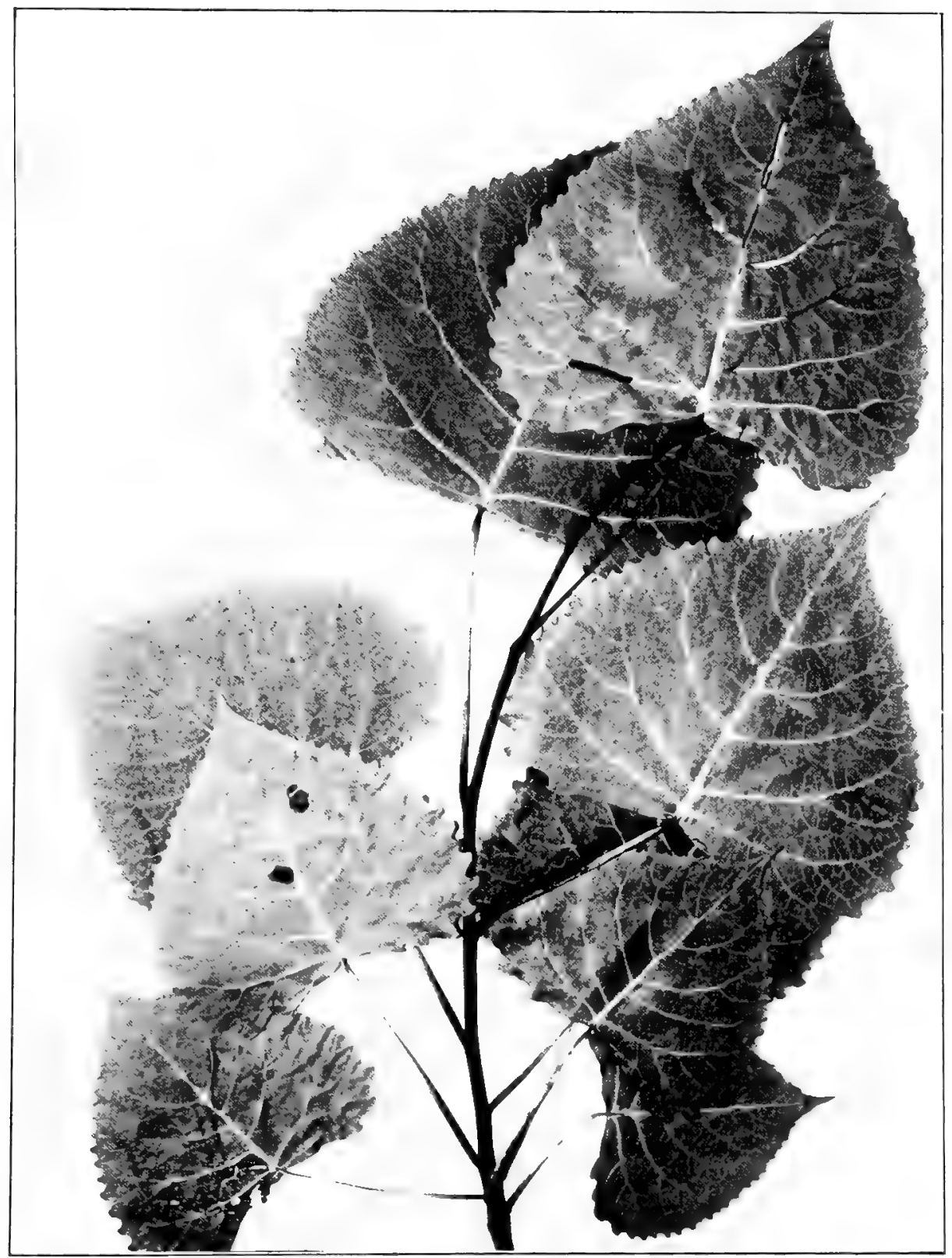

POPULUS DELTOIDES Marshall. CotTonwood. $\left(x, \frac{1}{2}\right.$. $)$ 
for planting overflow lands, and for planting where a quick shade is desired or for temporary windbreaks.

The leaves of this tree are quite variable and several forms have been described. The Carolina poplar of nurserymen has an upright habit of growth and was formerly much planted as a shade tree. Its undesirable qualities have condemned it, and most cities now prohibit its planting.

Cottonwood has many uses, and was formerly a very important timber tree, but the supply has so diminished that large trees have become quite scarce. The thick bark was much used by the boys of the pioneers for whittling out toys, ete.

4. Populus grandidentàta Michaux. Large-toothed Aspen. Plate 18. A small or medium-sized tree, 1-4 dm. in diameter; bark smooth, grayish-green or whitish, becoming furrowed and dark brown on the trunks of old trees that grow in the northern part of the State, especially when growing in aswampy habitat. In the southern part of the state where the tree usually grows on the top of hills, the bark does not darken so much, frequently remaining a light to dark gray until maturity. Shoots more or less woolly at first, becoming glabrous, reddish-brown; leaves on sprouts and very young trees very velvety beneath, slightly hairy above, ovate in outline, cordate at base and with blades up to 20 cm. in length; leaves on older trees a yellow gieen, glabrous, ovate, blades usually 6-10 $\mathrm{cm}$. long, coarsely and unevenly toothed, the base slightly rounded, rarely truncate or slightly cordate, the apex pointed or rounded; petioles strongly flattened laterally; stamens 6-12; capsule about $5 \mathrm{~mm}$. long on a stalk about $1 \mathrm{~mm}$. long; wood soft, light and not strong.

Distribution.- Nova Seotia west to northern Minnesota and south to the Ohio River, and along the Alleghany Mountains to South Carolina. Found throughout Indiana, except we have no authentic records for Gibson ${ }^{1}$ and Pose $y^{2}$ Counties. In the northern part of Indiana it is found in great colonies about lakes, etc. or rarely a few trees on the crests of gravel and sand ridges. In southern Indiana it is found in the "knob" area in small colonies on the tops of the ridges associated with scrub pine and chestnut oak and is rarely found in low ground in this part of the State.

Remarks.- This species is too rare to be of much economic importance. It could be most profitably used for excelsior and pulp wood.

${ }_{1}$ Coulter's record for Gibson County by Schneck is regarded as an error because schneck himself does not report it, and there was no specimen in the Schneck herbarium. error.

¿ Deam's record in Rept. Ind. St. Board Forestry 1911:124:1912 was a manuscript 
Plate 18.

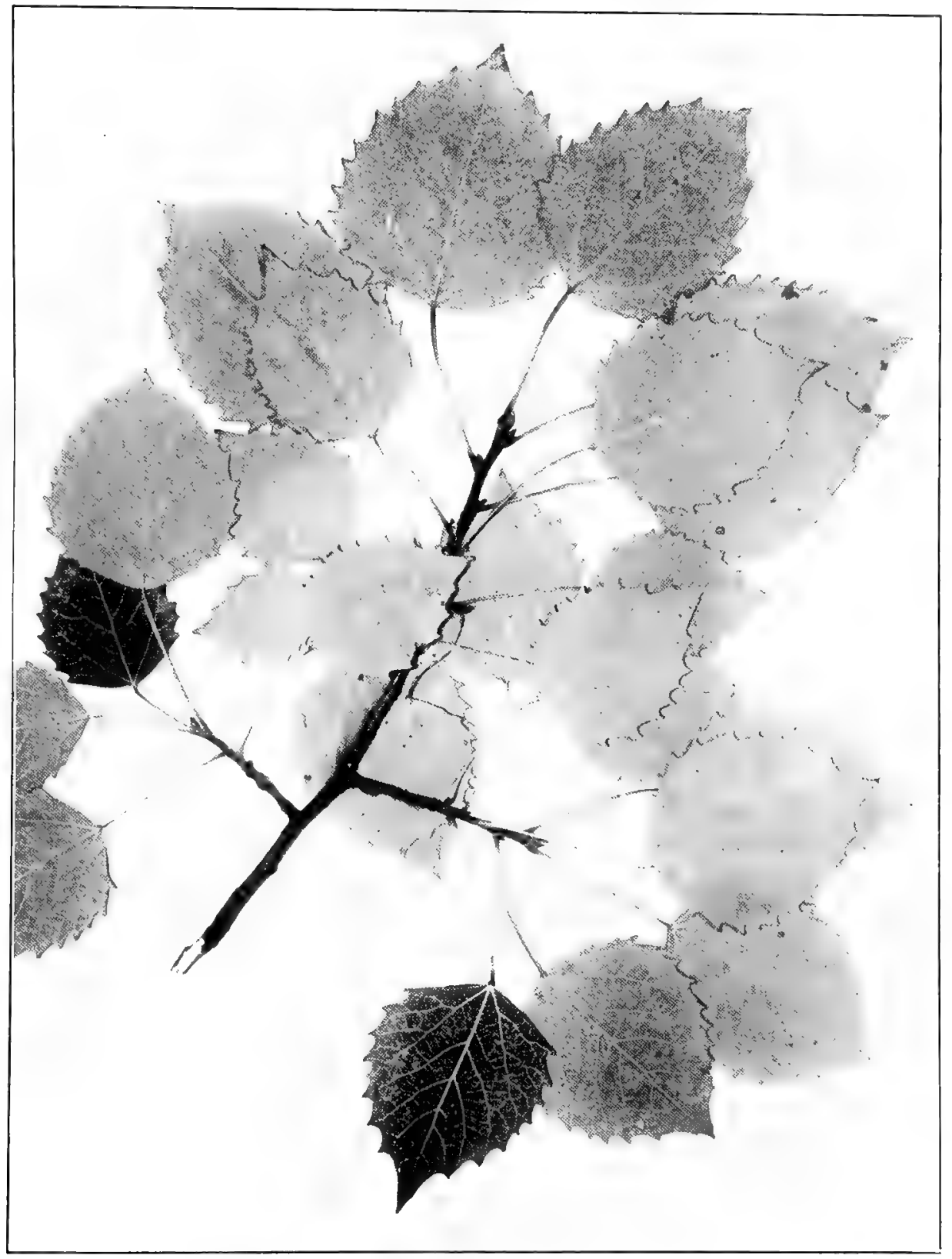

Populus Grandidentata Michaux. Large-toothed Aspen. (x 1/2.) 
5. Populus tremuloides Michaux. Quaking Aspen. Plate 19. A straight narrow tree up to $3 \mathrm{dm}$. in diameter, usually about $1-5 \mathrm{dm}$. in diameter; bark usually smooth, greenish-white or gray, on older trees hecoming rough or fissured, and turning darker; shoots glabrous or with a few hairs, turning reddish-brown the first season, later to a gray; leaves of sprouts and very small trees usually ovate with a cordate base and two or three times as large as leaves of older trees; mature leaves on older trees variable, glabrous, the prevailing type has a bluish-green leaf which is widely ovate or nearly orbicular, 3-7 'm. long, tiuncate or slightly rounded at the base, usually abruptly short-pointed at apex, finely and regularly serrate, the unusual type of leaf is thinner, yellow-green, ovate, 23 as wide as long, rounded or wedge-shaped at base, gradually tapering to a point at the apex, otherwise as the prevailing form; stamens $6-12$; capsules about $6 \mathrm{~mm}$. long, on stalks about $1 \mathrm{~mm}$. long; wood light, soft and weak.

Distribution.- One of the most widely distributed of North American trees. It ranges from Labrador sout h to Pennsylvania, thence southwest to northern Mexico, and then north to northern Alaska. It is found at sea level and at elevations of 10,000 feet. There are records of its occurrence in all parts of Indiana. In all of its Indiana stations it grows only in low ground about lakes, swamps, ponds, low places between sand dunes, and along streams. In many places in the lake region it is found in almost pure stands over small areas.

Remarks.-In Indiana this species is not of sufficent size and abundance to be of much economic importance.

\section{JUGLandä́eae. The Walnut Family.}

Trees with large, aromatic, odd pinnate leaves; flowers appearing after the leaves unfold, the staminate in catkins, the pistillate solitary or in clusters; fruit a nut in a fleshy or hard fibrous shell; kernel edible or astringent.

Pith of twigs ehambered; staminate cathins thick, sessile or short stalked; stamens $8-40$, glabrous; nuts with a network of rough projestions..................... 1 Juglans.

Pith of twigs not chambored; staminate eatkins slender, longstalkerl; stamens 3-10, hairy; nuts more or less angled but smooth 2 Carya.

\section{JÜGLANS. Tine WaLntTs.}

Trees with furrowed bark; pulp surrounding nut continuous, without lines of dehiscence on the surface. 
Plate 19.

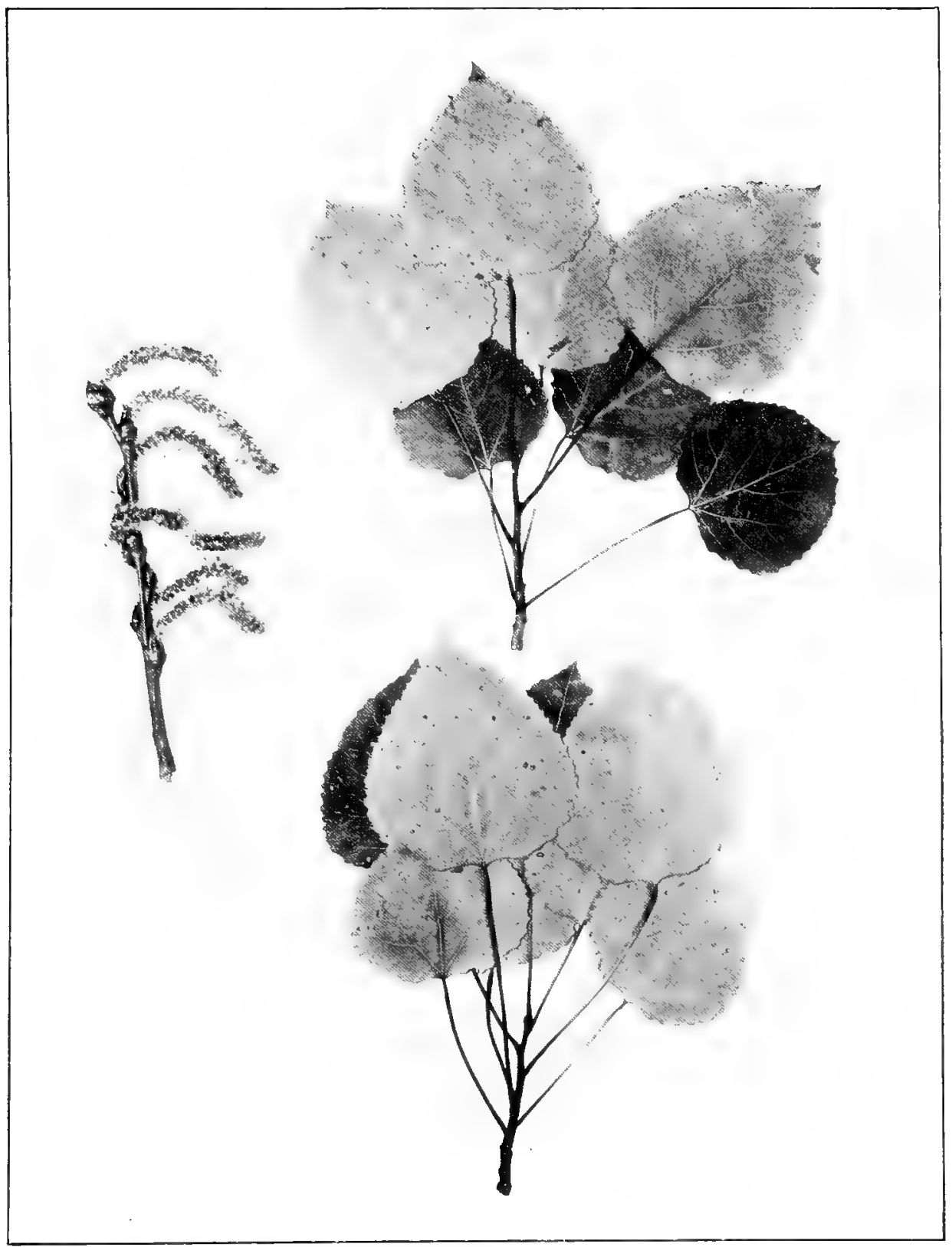

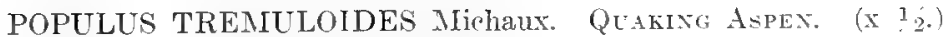


Bark gray, ridges smooth; upper part of leaf-sear of last year's twigs with a mat of hairs; pith dark-brown; fruit oblong, husk clammy ........................................ 1 J. cinerea.

Bark dark brown, ridges rough; upper part of leaf-scar of last orbicular to slightly elongate, husk not clammy....... 2 J. nigra.

1. Juglans cinèrea Linnæus. Butternut. Plate 20. A medium sized tree, usually less than $6 \mathrm{dm}$. in diameter; leaf-sears with upper margin convex or rarely notched; leaves 3-6 dm. in length; leatlets $7-19$, the middle pairs the longest, clammy, almost sessile, oblong-lanceolate, 6-12 cm. long, fine serrate, rounded at base and acuminate at apex; flowers in May or June; fruit ripens in October, 4-8 cm. long with 4 prominent longitudinal ridges; kemel sweet and very oily; wood light, soft, not strong, coarse-grained but takes a good polish.

Distribution. - Valley of the St. Lawrence River south to the Gulf States and west to Nebraska. Found in all parts of Indiana, although very sparmgly in some counties. It is an infrequent tree in our range, and in only a few localities is it frequent or common. It is found along streams and in ravines, and in two instances it has been noted in old tamarack marshes. It prefers a well drained gravelly soil, and is rarely if ever found in a compact soil.

Thrifty trees of any size in the woodland are now rarely seen. The tops of the larger trees are usually found in a more or less dying condition. Benedict and Elrod as early as 1892 make the following observation in a catalogue of the plants of Case and Wabash Counties: "A few scrubby, half dead trees were seen, the last of their race. It seems unable to adapt itself to new conditions, and is rapidly dying out."

Remarks.- This tree is often called the white walnut to distingush it from the black walnut from which it is easily separated. It is too rare in Indiana to be of economic importance, except that trees growing in the open are spared for the nut crop. Trees growing in the open develop a short trunk with a wide spreading top and are apparently much healthier than when grown under forest conditions. The bark of the root is used in medicine as a hepatic stimulant.

2. Juglans nigra Linnæus. WaLnut. Plate 21 . One of the largest and most valuable trees of the Indiana forest. Leaf-scars with the upper margin notched; leaves 3-7 $\mathrm{dm}$. long, mature leaves glabrous above and pubescent beneath, leaflets, usually 11-23, almost sessile, o vate-lanceolate, $4-10 \mathrm{~cm}$. long, finely serrate, long-pointed at apex;

IInd. Geol. Rept, 17:2633:1892. 
Plate: 20.

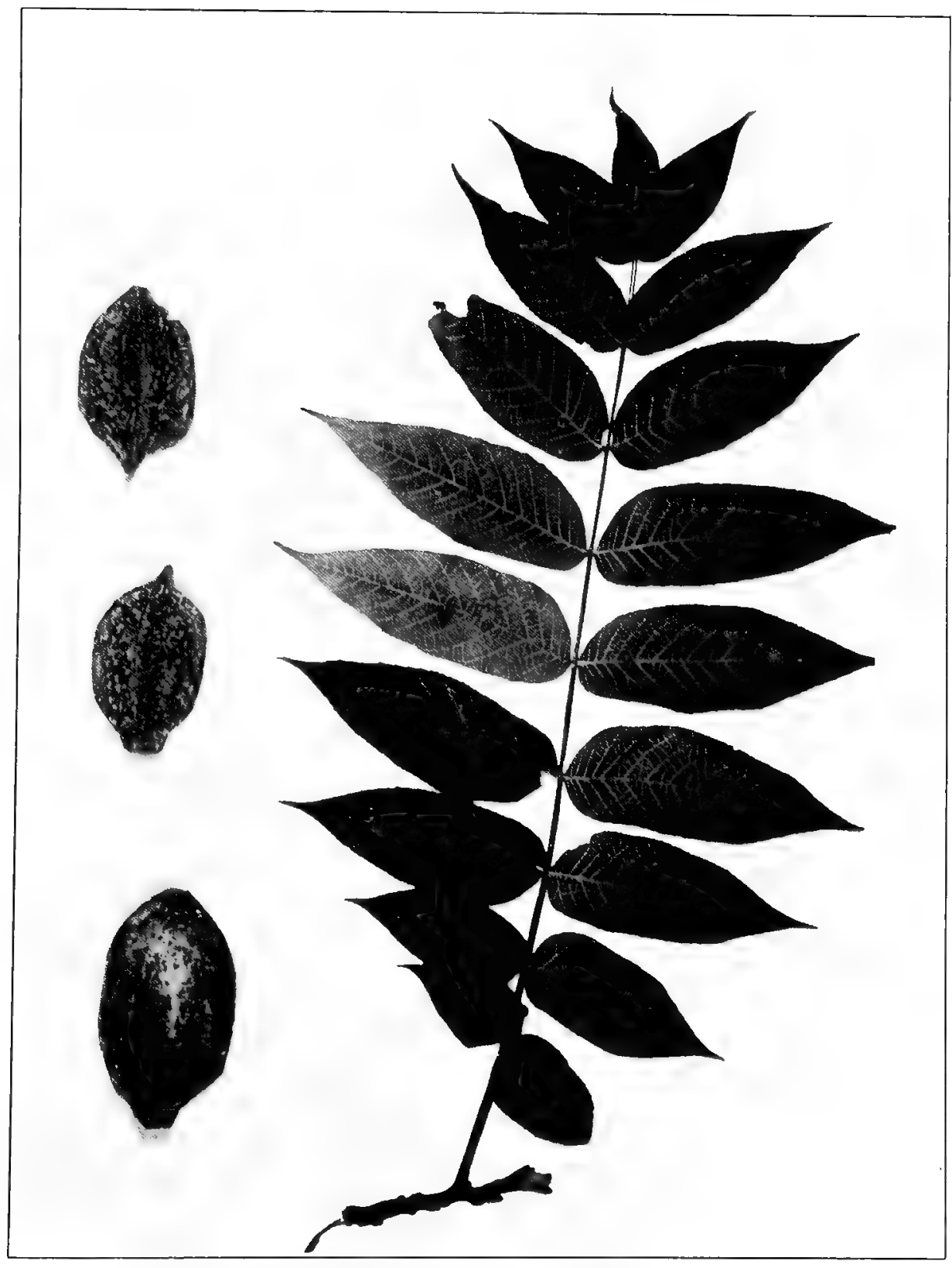

JUGLANS CINEREA Linniells, BrTterNTT. ( $x$ 1/2.) 
flowers in May or June; fruit ripens the firt year, in September and October, globose to oblong, $5-8 \mathrm{~cm}$. In diameter; nut variable, from subglobose to ovoid or elliptical, more ar less rounded or pointed at the cuds, 1.5-3.5 cm. through the widest cliameter; kennel edible; wood heary, hard, stıong, rather coarse, heart wood dark brown, durable, works easily and takes a high polish.

Distribulion.- Ontario south to the Culf States and west to Texas and Nebraska. It was more or less frequent to common in all parts of Indiana in well drained rich soils.

Remarks.- This tree is frequently called black walnut. On aceount of the many excellent qualities of the wood, the walnut has been a choice timber tree from pioneer days to the present. It served the pioneer for rails, and in his buildings for sleepers, rafters, interior finish, fumiture, otc. It soon sprung into commercial importance, and has heen used for almost everything for which wood is used. Indiana and ()hio have furnished the greatest amount of walnut. The supply of lumber from old forest-grown trees has become so scarce that it is sought in old buildings, ral fences, old st umps and old furnit ure has been worked over. That the demand for walnut timber will not cease is assured; this should encourage land owners to grow this tree. It is adapted to a moist, rich, deep soil and will do well in such a habitat in all parts of the sitate. Where such land is set aside for forestry purposes, no better tree could be used for planting. Since the tree develops a long tap root which makes it difficult to transplant, it is recommended that the nuts be stratified in the fall, and the germinated nuts be planted in April or May. The foliage of the walnut is often attacked by the "tent caterpillar" which can be easily destroyed by burning about sun down when the larva collect in a bunch on or near the trunk of the tree. Since the nut of the walnut is of consiclerable commercial value, it is recommended that the walnut be planted along fences, about orchards and as one of the species in windbreaks.

\section{CìR YA. The Hickories.}

Trees with hard, tight or scaly bark; leaflets alternate, odd-pinnate, glandular-dotted beneath; leaflets serrate, usually unequal at the base, the lateral sessile or nearly so, the terminal short-stalked, the Jowest pair the smallest, upper pair and terminal the largest, bruised leaflets characteristically aromatic; staminate flowers in slender catkins, anthers hairy; pistillate flowers in small clusters; fruit a bony nut contained in a wooly husk which separates more or less completely from the nut into four parts. 

There are now recognized ${ }^{1}$ fifteen species and several varicties of hickory, all of which grow in the United States east of the Rocky Mountains. Hickory grows in no other place in the world, except one speries in northern Mexico. The wood of the different species of hickory is not of equal commercial value, but the wood of the commercial species heads the list of Indiana woods for strength, toughness and resiliency.

The individuals of the several species vary much in respect to their bark, size and pubescence of the twigs, number and size of the leaflets, size and shape of the nuts. No attempt will be made to deal with all of the extreme forms, and only those reported by Heimlich ${ }^{2}$ and Sargent ${ }^{3}$ will be discussed.

Bud srales 4-6, valvate (in pairs), leaflets generally eurved barkward.

Leaflets 9-17, generally about 13 ; nut elongated, cireular in (ross-sertion; bernel sweet................ 1 C. illinoensis.

Leaflets 5-9, generally 5-7; nut ahout as broad as long, compressed in cross-section; kernel bitter......2 C. cordiformis.

Bud scales more than 6 , imbrirated (not in pairs); leaflets not curved harkward.

Branchlets usually stout; terminal buds large, 7-25 $\mathrm{mm}$. long; the year's growth usually more or less hairy; dry husks $4-10 \mathrm{~mm}$. thick.

Prevailing number of leaflets $5 \ldots \ldots \ldots \ldots \ldots \ldots . \ldots \ldots$ C. ovata.

Prevailing number of leaflets more than 5 .

Trees of low ground; bark of young trees tight and light, of older trees scaly, separating into long thin plates; branchlets usually light orange color; nuts usually large, compressed, 3-6 em. long,

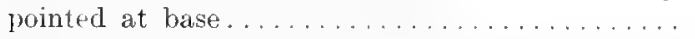

4 C. laciniosa.

Trees of high ground; bark of young trees tight and dark, of older trees tight and deeply furrowed, the thick ridges broken into short lengths which on very old trees loosen at the base; hranchlets reddish-hrown; nuts usually ahout half as large as the preceding and usually with a rounded base... 5 C. alba.

Brauchlets usually slender; terminal buds small, 5-12 mm. long; the year's growth usually glabrous, rarely hairy; dried husk 1-2.5 mm. thick.

Branchlets and leaves not covered when they first appear with rusty-hrown pubeseence.

${ }_{1}$ Sargent in Bot. Gaz. Tol. 64: $58: 1918$

${ }_{2}$ Heimlich in Proc. Ind. Acad. Sci. 1917:437:439:1918 credits most of my records jointly with Prof. G. N. Hoffer. This is an error. On my invitation Prof. Hoffer accompanied me nine days in the field doing mycological work. While he gave me valuable assistance in collecting during these days, his assistance and responsibility stopped there and he never asked or expected to be considered joint author. Again on our trip we collected only in Daviess, Gibson. Fountain, Knox. Lawrence, Martin, Pike and Sullivan Counties. 3 Sargent 1, c. 
Prevailing number of leaflets 5 ; fruit usually smooth and tapering at base to a short stem (fig-like); shell of nut thick, kernel sweet and astringent..........6 C. glabra.

Prevailing number of leaflets generally 7 ; fruit usually granular, rarely tapering at the base to a short stem (fig-like); shell of nut thin, kernel sweet without astringeney.

Branchlets and leaves densely covered when they first

appear with rusty-brown pubescence.

7 C. ovalis.

8 C. Buckleyi.

1. Carya illinoénsis (Wangenheim) K. Koch. Pecan. Plate 22. Very tall slender trees up to $15 \mathrm{dm}$. in diameter; bark tight, sometimes becoming scaly on very old trees, fissured, ridges narrow, ashy-brown tinged with red; twigs at first hairy, becoming smooth or nearly so and reddish-brown by the end of the season; leaves $3-5 \mathrm{dm}$. long; leaflets 9-17, ovate to oblong-lanceolate, somewhat curved backward, 7-15 $\mathrm{cm}$. long, taper-pointed, hairy when they unfold, becoming at maturity smooth or nearly so, dark green above, and a yellow-green beneath; clusters of staminate catkins sessile; fruit single or in small clusters, oblong 3.5-6 cm. long, the winged sutures extending to the base, the husk splitting to below the middle; nut ovoid-oblong, reddish-brown; wood heavy, hard and not strong.

Distribution.-In the Mississippi Valley from Indiana and Iowa south to Texas. In Indiana it was a native of the southwest part of the State. It was a common tree in the river bottoms of Point Township of Posey County, and in the bottoms of the southwest part of Gibson County. It was found more or less frequently in the bottoms of the Wabash Valley, as far north as to within four miles of Covington where the author collected specimens in 1918. It followed the bottoms of the Ohio River east at least as far as Clark County. Michaux ${ }^{1}$ gives it as rare in the vicinity of Louisville. Victor Lyons of Jeffersonville says that it was a native to the east part of Survey 29 of the Illinois Grant, and one tree in the north-west corner of No. 32; and there were nine trees 9-10 dm. in diameter in Floyd County on "Loop Island". A large tree grew in the bottoms near Bethlehem in Clark County, which is said to have been a native.

Young ${ }^{2}$ says that there are two trees in Jefferson County, one planted, the other probably native. Coulter" says "there are several trees in the river bottoms."

There are several trees on the Elisha Golay farm about one mile east of Vevay which are in rows, which show that they were planted. The largest has a trunk $2.2 \mathrm{~m}$. long and a circumference of $31 \mathrm{dm}$.

André Michaux's Travels 1793-1796.

2Flora of Jefferson County. Ind. Geol. Surv. Rept. 2:283:1871.

${ }^{3}$ Flora of Jefferson County. Ind. Geol. Surv. Rept. 6:265:1875. 
Plate 20?

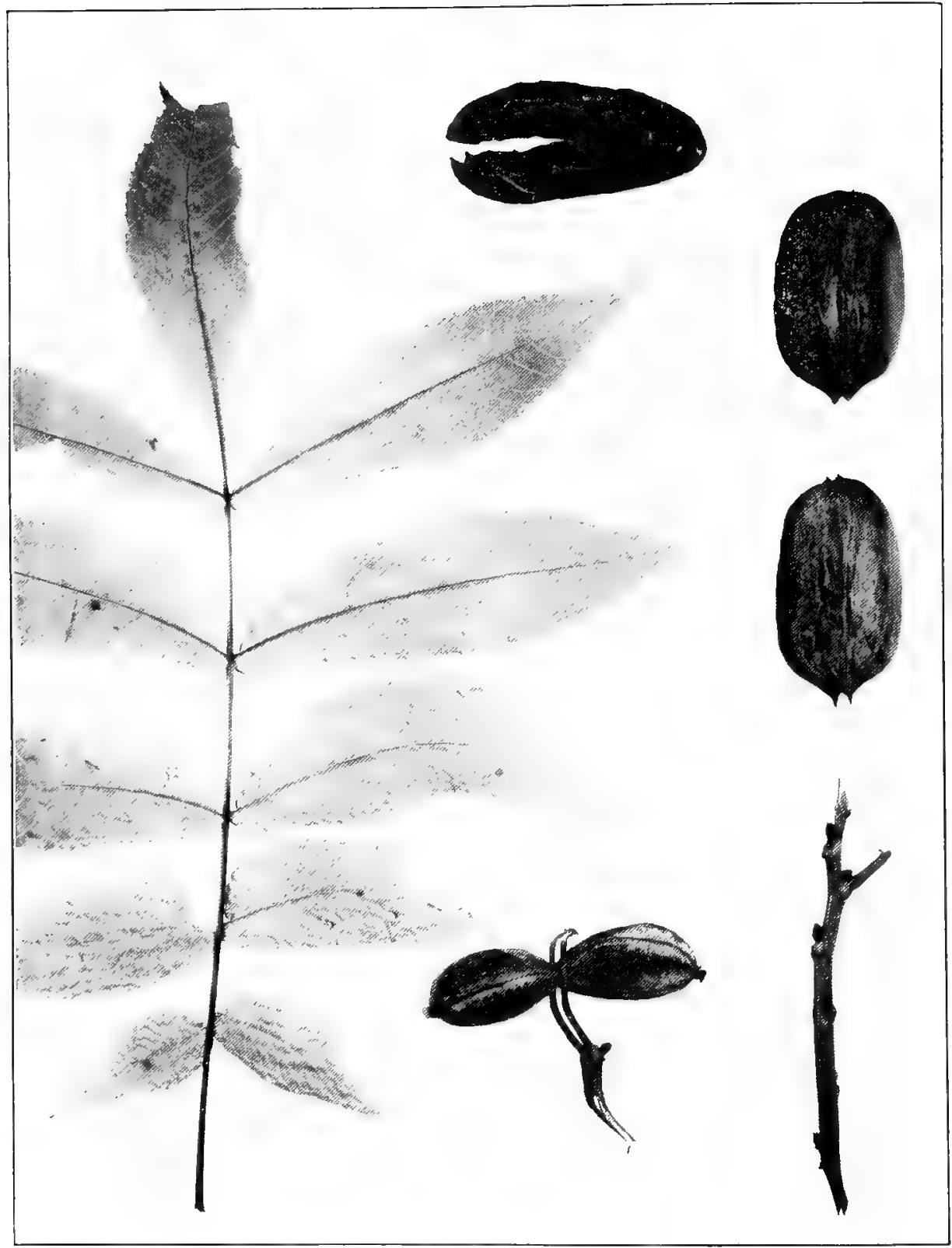

('ARYA ILLINOENSIS (Wangenheim) K. Korh. I'Ecan. (x 1/2.) The two nuts to right are from the Mreallister hybrid peran treo. 
It followed the north fork of White River as far as Greene County, and the south fork of White River as far as Seymour. A pioneer told me he remembered a small colony in the eastern part of Washington County in the bottoms near the Muscatatuck River. In Indiana it is found only in very low land which is subject to overflow.

Remarks.--So far as the wood is concerned, the pecan is the poorest of all hickories. It has only about one-half the strength and stiffness of the shell-bark hickory. Although the wood is inferior, the pecan has the distinction of producing the best nut of any native tree of America. The pecan was well known to the Indians, and some authors say the range of the species was extended by planting by the Indians. It has been a nut of commerce ever since the area of its range has been settled. It was planted by the pioneers, and recently nurserymen took up the subject of growing stock by budding and grafting from superior trees. At present there are about 100 horticultural varieties. The horticulturist has developed forms twice the size of the native nuts, and with shells so thin as to be styled "paper-shelled." The pecan has been extensively planted for commercial purposes in the southern states, but information obtained from owners of pecan trees in Indiana indicate that the winters are too severe for profitable pecan culture in Indiana. During the winter of 1917-18 the whole of a tract of 13 year old pecan trees on the Forest Reserve in Clark County was killed back to the ground. In Noble County about one mile south of Wolf Lake is a tree planted about 50 years ago that is about $9 \mathrm{dm}$. in circumference that frequently sets nuts but they never mature on account of the early frosts.

2. Carya cordifórmis (Wangenheim) K. Koch. Pignut Hickory. Plate 23 . Large tall trees with tight bark, usually a light gray, sometimes darker, fissures shallow and very irregular; twigs at first green, somewhat hairy, soon becoming smooth or nearly so, and a yellowish-brown, or reddish-brown by the end of the season; leaves and leaflets variable, the prevailing type of trees have smaller leaves with with Jong and narrow leaflets, the unusual form has larger leaves up to $4 \mathrm{dm}$. in length with terminal leaflets up to $2 \mathrm{dm}$. in length and 8.5 $\mathrm{cm}$. in width, and the last pair almost as large; fruit sub-globose or rarely oblong, 2-3.5 $\mathrm{cm}$. long; wings of sutures extending to below the middle, rarely one reaching the base; husk about $1.5 \mathrm{~mm}$. thick, tardily separating to about the middle; nut ovoid or oblong, slightly flattened laterally, often as wide or wider than long, depressed, obcordate, with a short or long point at the apex, ovoid or rounded at the base, smooth or rarely with four distinct ridges; shell very thin and brittle; kernel very bitter; wood heavy, very hard, strong, tough and close-grained. 
Plate 203.

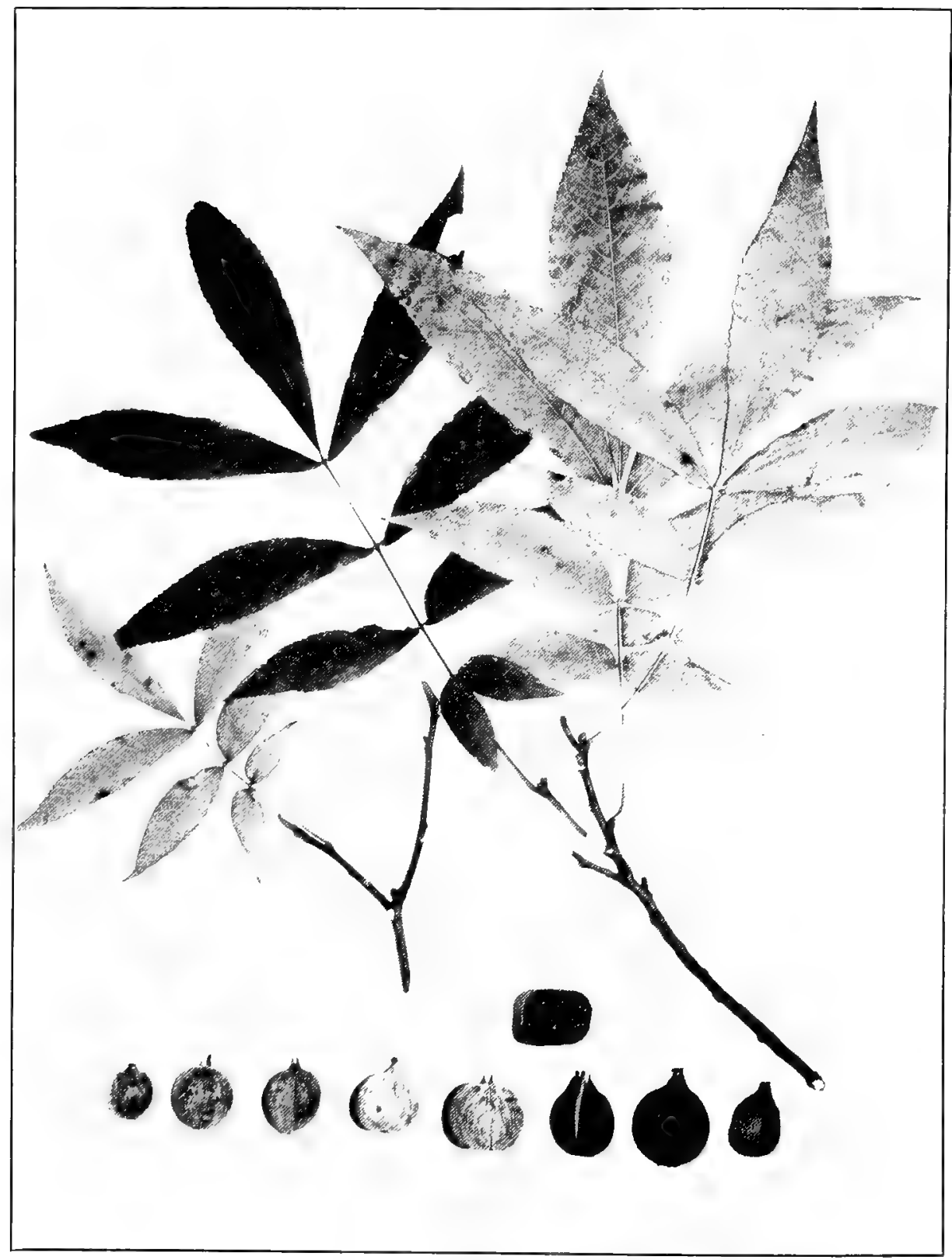

CARYA CORDIformis (Wangenheim) K. Koch. Pignut Hickory. $(\mathrm{x} \quad 1 / 2$.

The nuts are from different trees to show variation. 
It has about 92 per cent of the strength and about 73 per cent of the stiffness of shell-bark hickory.

Distribution.- Valley of the St. Lawrence River west to Nebraska and south to the Gulf States. In Indiana a map distribution of the species in the State shows that it has been found in practically all of the counties on the west, north and east borders. It is usually found in rich soil along streams and in rich woods, and may be found in all of the counties of the State. Despite the fact that no animal agency was active against the propagation of this tree, it was rarely found more than as an infrequent tree throughout our range.

Remarks. - The hickories as a class, except the pecan, can not stand "civilization," especially much tramping about the base. It appears that the pig-nut hickory is the most easily affected. In Parke County about Coxville great numbers of the trees have been killed by the borers. For the uses of the wood see shell-bark hickory. Since this species does not produce as much marketable lumber as the shell-bark hickory, and the nuts are valueless, it should not be recommended for planting in the farmer's woodlot. The rossed bark of this species is preferred by manufacturers of split-bottomed chairs, and is known by them as "yellow-bud" hickory.

3. Carya ovàta (Miller) K. Koch. Shellbark Hickory. Plate 24. Large and very tall trees; bark of young trees tight, beginning to scale when the trees reach $1-2 \mathrm{dm}$. in diameter, separating intolong thin strips on old trees; twigs at the end of the season usually stout, $3-5 \mathrm{~mm}$. in diamter near the tip, but some are slender and as small as $2.5 \mathrm{~mm}$. in diameter, at first covered with hairs, becoming smooth at the end of the season or remaining hairy, reddish-brown; winter buds hairy, the terminal one on vigorous shoots long-ovoid, outer scales sharp-pointed; ordinary leaves $2-4 \mathrm{dm}$. long; leaflets $3-5$, the lateral sessile or nearly so, the terminal one on a stalk about $1 \mathrm{dm}$. long, up to $10 \mathrm{~cm}$. wide and $22 \mathrm{~cm}$. long, leaflets variable in shape from ovate to oval, oblong-oval or obovate, all long taper-pointed, hairy beneath when they unfold and remaining hairy until maturity or sometimes becoming almost glabrous; fruit variable in size, $3-6 \mathrm{~cm}$. long, usually subglobose, furrowed along the sutures at least near the outer end; husk freely splitting to the base, except one tree which was noted where the husk remains on the nut, rarely opening for only a short distance at the apex, very variable in thickness from 4-10 $\mathrm{mm}$; nut exceedingly variable, compressed, 4 -angled, the angles generally visible to the base, $2-3 \mathrm{~cm}$. long, more or less pointed, rarely rounded at the base or obcordate at the apex, generally ovate to oval in outline, some almost freakish in shape; shell generally thin; kernel.sweet; wood heavy, 
Plate 24.

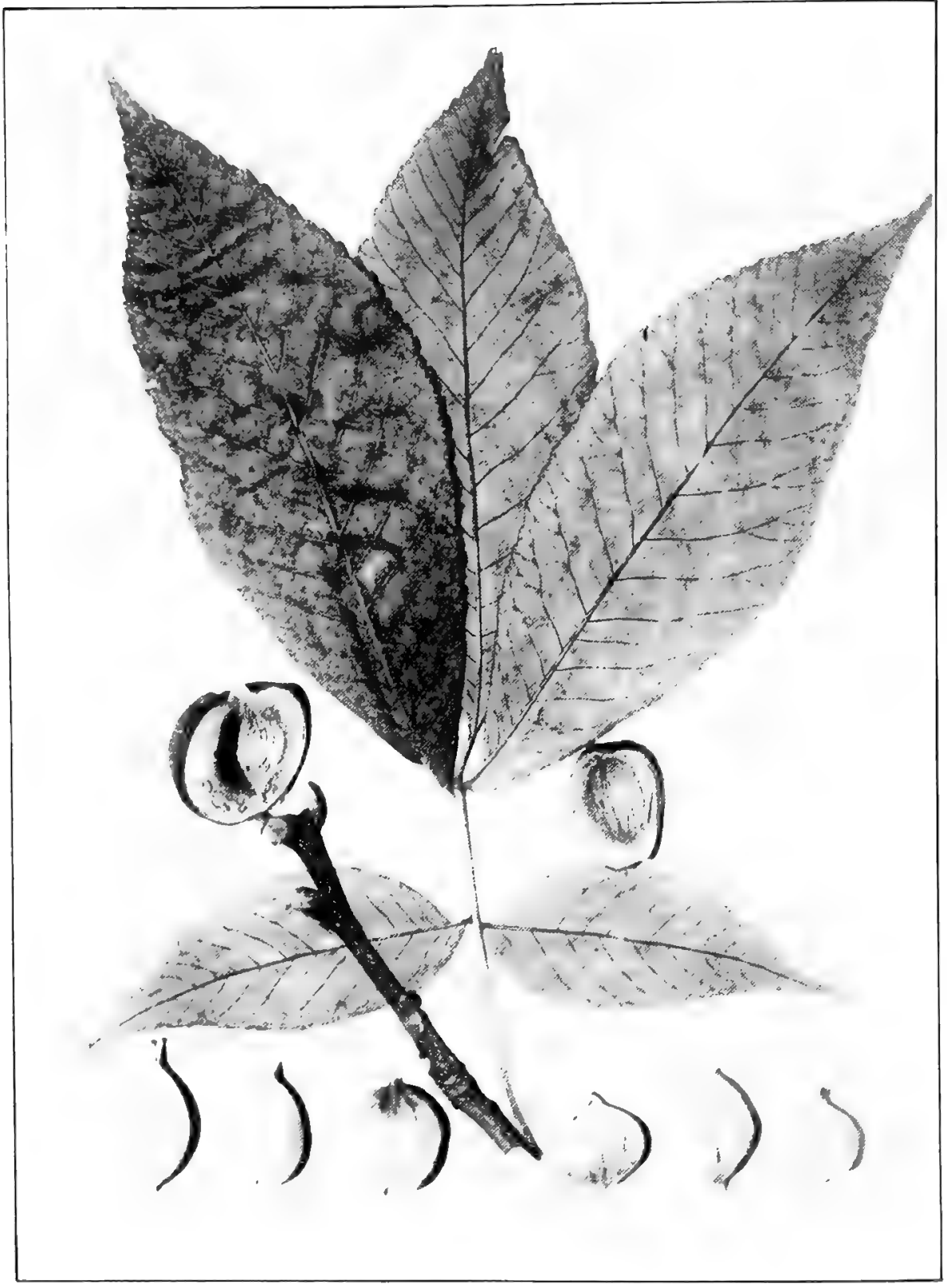

Carya ovata (Miller) K. Koch. Shellbark Hickory. (x 1/2.) The nuts are from different trees to show variation. 
very hard and strong, close-grained, light brown, sap wood white and thin on old trees.

Distribution.--Quebec west to southern Minnesota, Kansas and eastern Texas, thence eastward to the Atlantic through the north part of the Gulf States. It is frequent to common in all parts of Indiana except on the hills of the southern part. It prefers rich moist soil and is generally found in bottom lands or on rolling land, and if in dryer situations on the siles of hills. It is generally associated with red oak, big shellbark hickory, swamp white oak, sweet gum, linn, white ash, slippery elm, sugar maple, beech, etc. In the forest it is a tall straight tree with few main branches for a crown. No tree carries its taper better than this species. When grown in the open the side branches do not shade off, and it grows to a medium height with a wide spreading crown.

Remarks.-The writer has one specimen from Wells County which no doubt should be referred to this species, but the description has not been drawn to cover it. The twigs are very slender and pubescent; the leaves are normal and pubescent; the fruit is obovoid, $2-4 \mathrm{~cm}$. long; husk less than $1 \mathrm{~mm}$. thick at outer end and $2 \mathrm{~mm}$. thick at the base; nut obovoid, 1-8 cm. long, little compressed, rounded at the base, rounded at the apex, slightly angled, angles obscure on lower half; otherwise as the type.

The species is very variable and no dependence can be placed upon such characters as pubescence of the twigs, leaves or fruit, size of the twigs, color of the anthers, size or shape of the nuts.

The wood of the shellbark and the big shellbark hickonies is the most used of all the hickories because it is generally freer from knots and blemishes. Hickory is used principally for carriage and wagon stock, agricultural implements, handles and fuel. The supply of hickory is fast waning, and in the near future will be limited.

The hickories are very slow growing trees. They develon a long tap root, hence are hard to transplant. Hickory should constitute an important part of the woodlot. If this species is not well represented, germinated nuts should be planted. The nut of this species usually sells for $\$ 3.00$ to $\$ 5.00$ per bushel, which should encourage land owners to plant it in the open along fences and about the orchard. It should be remembered that hickory will not stand much tramping by stock.

3a. Carya ovata variety fraxinifòlia Sargent. Trees and Shrubs $2: 207: 1913$. Is described as "having leaflets lanceolate to slightly oblanceolate, acuminate, thick and firm in texture, lustrous above, pubescent along the midribs below, the terminal 1.4-1.5 dm. long from 4.4-5 $\mathrm{cm}$. wide, and raised on a slender puberulous petiolule, the lateral 
leaflets unsymmetrical at the base, sessile, those of the lowest pair $7-9 \mathrm{~cm}$. long, and from $2.5-3 \mathrm{~cm}$. wide. Sargent" says "this variety oceurs in Indiana," basing his authority upon my specimens of which he has duplicates. Heimlich ${ }^{2}$ reports this variety from White County, and at the same time he reported the variety from Daviess, Martin and Wells Counties, based upon specimens collected by the author and determined by Sargent. I have carefully studied the speeimens from Daviess, Martin and Wells Counties, and they do not agree with sargent's description of the variety. While most of the leaves of the specimens in question agree with the description, some do not, which excludes it from the variety.

3b. Carya ovata variety Nuttallii Sargent. Trees and Shrubs $2: 207: 1913$. This variety is described as having "nut rounded, obcordate or rarely pointed at apex, rounded or abruptly pointed at the base, much compressed, prominently angled, about 1.5 rm. long and 1-1.2 cm. thick; the involucre 4-10 $\mathrm{mm}$. thick, splits freely to the base. Except in size of the fruit there appears to be no character by which the variety can be distinguished from the common Shaghark." Heimlich ${ }^{3}$ reported this variety from Dekalb County, based upon specimens collected by the author and determined by Sargent. The nuts of the specimens from Dekalb County are $2 \mathrm{~cm}$. long. The author has specimens from Wells County that agree with the description.

4. Carya laciniòsa (Michaux filius) Loudon. Big Shellbark Hickory. Plate 25. Large tall trees with trunks like those of the shellbark hickory; bark of young trees tight, beginning to scale when the trees reach a diameter of $1-2 \mathrm{dm}$., on older trees separating and sealing off into long thin narrow strips; twigs at the end of the scason stout, 4-7 mm. thick near the tip, the twigs of the season hairy at first, becoming glabrous or nearly so by the end of autumn, yellowish or late in autumn a rusty brown, frequently retaining the leaf-stalks of the leaves of the previous season until spring which is peculiar to this species; terminal buds large, ovoid to ovoid-oblong, 10-25 mm. long; ordinary leaves 3-5 dm. long; leaflets 5-9, prevailing number 7 , ovate to oblonglanceolate or obovate, the largest 1-2 dm. long, velvety beneath when they unfold and remaining hairy beneath until maturity, rarely nearly glabrous; fruit ovate, subglobose, oblong or obovate, $3.5-7 \mathrm{~cm}$. long; dry husk 3.5-11 mm. thick; nut variable, generally much compressed, up to $5.5 \mathrm{~cm}$. long, usually circular in outline, but varying from ovate to obovate and oblong, usually each side has 2 or 3 ridges which extend

Bot. Gaz. Vol 66:236:1918.

${ }_{3}$ Proc. Ind Acad. Sci 1917:435:1918

iProc. Ind. Acad. Sci. 1917:4351918. 
Plate 25.

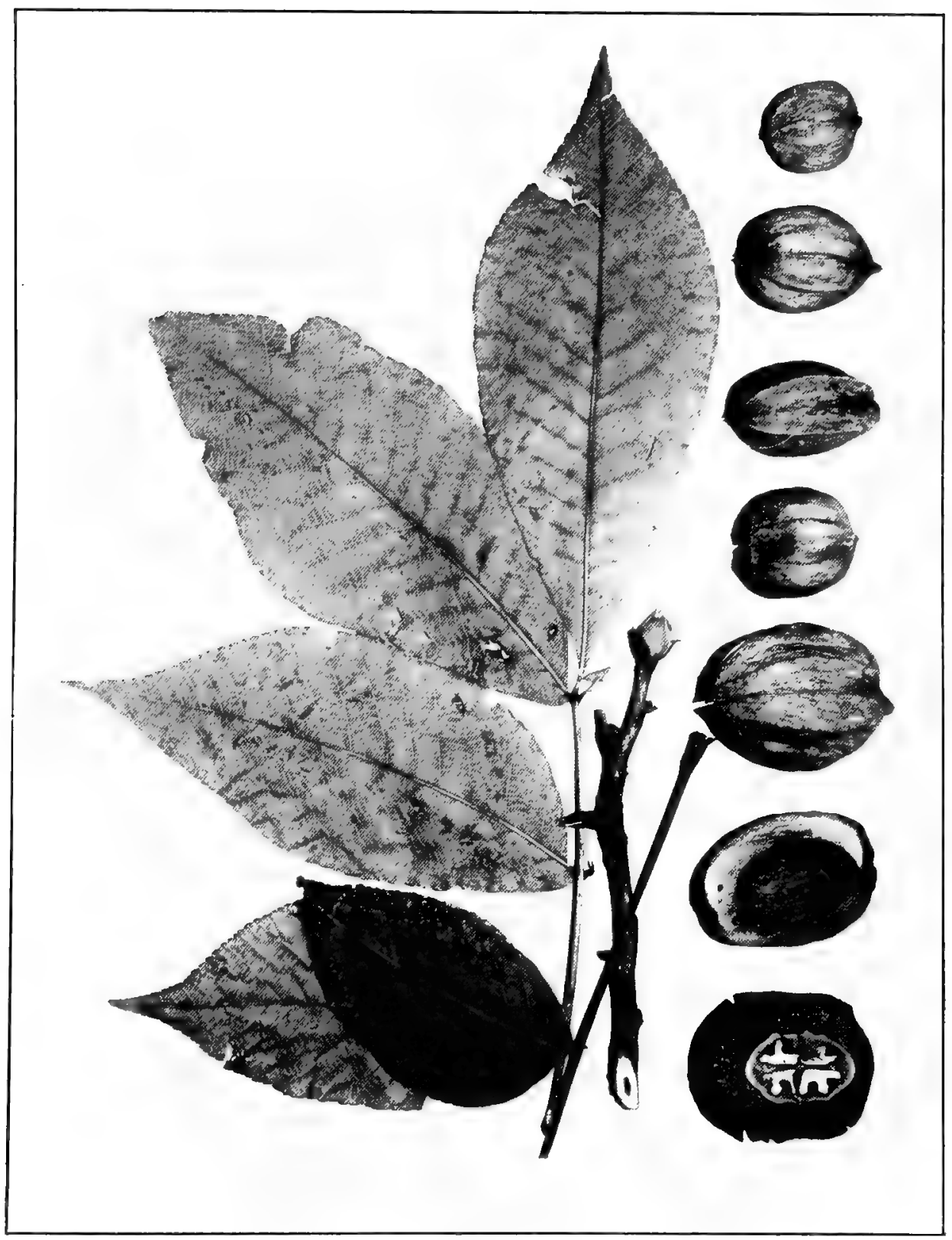

CARYA LACiniosa (Michaux filius) Loudon, Big Shell-bark Hickory. ( $\begin{array}{ll}x & 1 / 2\end{array}$

The nuts are from different trees to show variation. 
more or less often to the base; shell very thick; kernel sweet; wood and uses same as that of the shellbark hickory.

Distribution.- Southwestern Ontario south to Alabama and west to Louisiana, Nebriska and Iowa. Found throughout Indiana, except there are as yet no records from the extreme northwest counties. It is frequent to common in moist rich woods, or in river bottoms which is its favorite habitat. It is usually associated with the shellbark hickory where it grows in moist situations. Sometimes in the river bottoms it grows in situations too wet for the shellbark hickory. In the lower Wabash bottoms it becomes a common tree.

Remarks. - This hickory is also known as the big scalybark hickory and hard-head hickory. The nuts are an article of commerce and by some are preferred to the shellbark hickory although the nuts are hard to rrack. This objection is easily overcome by wetting the nuts, and drying them by using heat which eracks the shell, making them easy to crack.

5. Carya álba (Linnæus) $K$. Koch. Whitw Hickory. Plate 26. Medium sized tall trees up to $10 \mathrm{dm}$. in diameter; bark tight, of two types, one light colored, thin and fissured into a net-work. This form has been seen only in the river bottoms of the southwestern part of the State. The common type of bark is thick, with thick ridges, dark but on the older trees it weathers to a light gray and becomes thickly covered with lichens; terminal twigs of branches at end of season stout, 3.5-7 mm. in diameter near the tip, densely hairy at first and remaining hairy throughout the scason or becoming almost glabrous, reddishbrown; terminal bud large, ovate, 10-20 $\mathrm{mm}$. long; ordinary leaves 2-4 $\mathrm{dm}$. long, the rachis and under side of leaflets densely hairy when they unfold, remaining pubescent until maturity; leaflets $5-9$, prevailing number 7, long-oval, ovate-lanceolate, or obovate; fruit usually globose, more rarely short elliptic, ovate or obovoid, the husk rather tardily opening to nearly the base, or only checking open at the top; dried husk $3-8 \mathrm{~mm}$. thick; nut variable in shape, little compressed, somewhat glohose, a little longer than wide, more rarely wider than long or short elliptic, usually $2.5-3.5 \mathrm{~cm}$. long, generally rounded at the base and short-pointed at the apex, more rarely pointed at the base and long pointed at the apex, cone specimen is at hand that is almost a square hox), usually with 4-6 angles, on some forms obscure; shell thick; kernel very small, sweet; wood and uses same as shellbark hickory.

Distribution. - Southwestern Ontario sonth to the Gulf and west to Texas, Missouri and Iowa. Found throughout. Indiana, except there are no lecords from the extreme northwestern counties. This species except in the lower Wabash Valley is confined to the uplands. It is 
Plate 26.

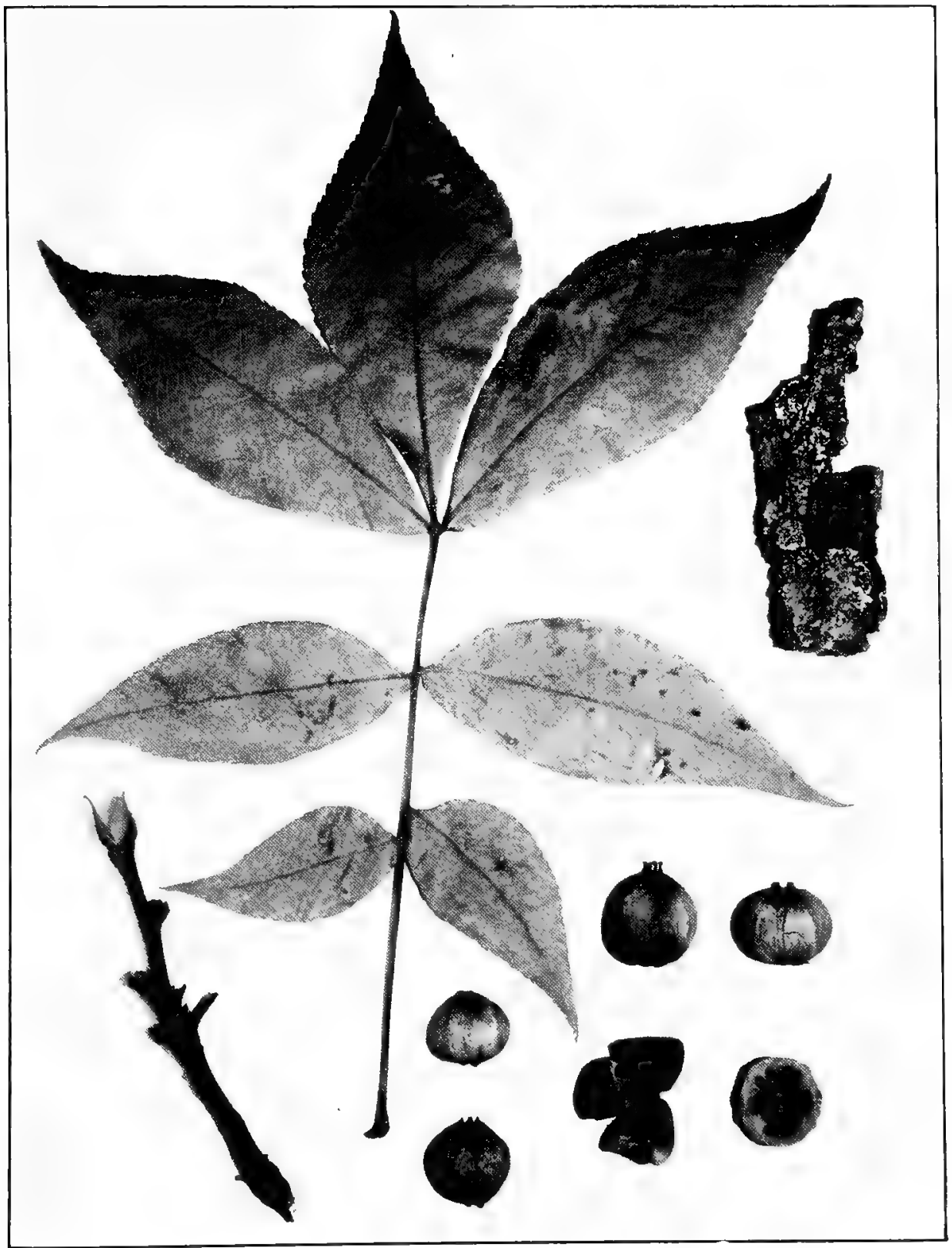

CARYA ALBA (Linnæus) K. Koch. White Hickory. ( $\mathrm{x} 1 / 2$.) The nuts are from different trees to show variation. 
rat her a rare tree in northern Indiana, but becomes more or less frequent in the western part of the State south of the Wabash River and more or less frequent to common on the hills in all of the State south of Marion County. It is most abundant in the unglaciated area.

Remarks. - This species is called mockernut by text books, and bull hickory in the vicinity of New Albany.

5a. Carya alba variety subcoriàcea Sargent. Trees and Shrubs $2: 207: 1913$. Only one tree of this variety is known in Indiana and it is located in Posey County on the bank of the cypress swamp about 13 miles southwest of Mt. Vernon. Specimens from this tree were sent to sargent and he referred them to this variety. ${ }^{1}$ It differs from the type in the larger size and shape of the fruit and nut. The dried fruit is $5 \mathrm{~cm}$. long, oblong. The nut is oblong, $4.4 \mathrm{~cm}$. long, pointed at hoth ends, or some nuts somewhat ovate in shape and more rounded at the base, little compressed and strongly angled; shell very thick, $5 \mathrm{~mm}$. at the thinnest place; kernel very small and sweet. The nut easily distinguishes it from all forms of hickory. The author has bought hickory nuts for table use for several years from Posey county and this nut is frequently found in the assortment which shows that this variety is more or less frequent in that section.

6. Carya glàbra (Miller) Spach. Black Hrckory. Plate 27. Very tall medium sized trees, up to $7 \mathrm{dm}$. in diameter; bark tight, usually dark, fissures shallow on some and quite deep on others; twigs reddishbrown, glabrous, terminal buds small, ovoid, about 7-12 mm. long; orlinary leaves 2-3 $\mathrm{lm}$. long; leaflets generally lanceolate, sometimes quite wide, or wider beyond the middle, prevailing number 5 , the terminal usually 11-19 cm. Iong, somewhat pubescent on unfolding, more or less pubescent below at maturity, usually only the midrib, axils and larger veins with hairs; fruit generally smooth and obovoid, rarely glohose or oval, $22-40 \mathrm{~mm}$. long; husk sometimes not opening, more often one or more of the sutures open to less than half way, 1-2 mm. thick; nut about 20-30 mm. long and 16-25 mm. wirle, rounded at the apex, clongated and rounded at the base, angles wanting or obseure; shell very lared and thick, about $1.5 \mathrm{~mm}$. thick at the thinnest point; kernel sweet and astringent; wood and uses same as that of the shellbark hickory.

Distribution.- Southern Ontario south to the Culf states and west to Texas and Iowa. This species is reported for all parts of the State. However, the records for the northern counties were made when this species was not separated from Carye ovalis, and since the latter species is quite frequent in the northern counties it is best to refer the early

Bot. Gaz. 66.237:1918. 
Plate 27.

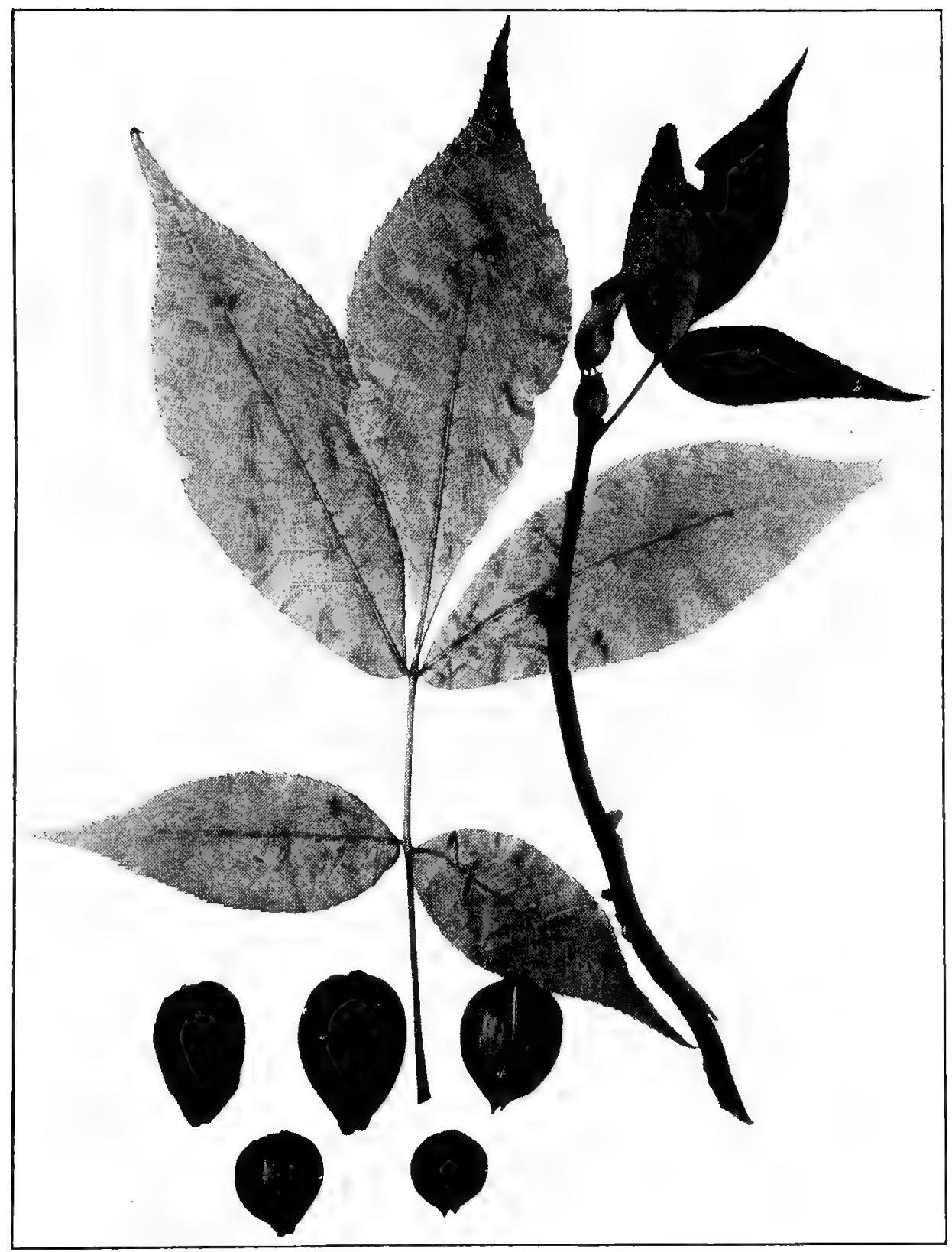

CARYA GLABRA (Miller) spach. Black Hickory. (x 1/2.) Fruit from different trees to show variation. 
records to Carya ovalis. The most northern station based upon an existing specimen is the north side of the Mississinewa River east of Eaton in Delaware County. It is a frequent, common to very common tree on the hills in the southern part of the State. It has its mass distribution in the unglaciated part of the State, although it is locally a frequent to a common tree of the hills of the other southern counties. It appears that this species has the ability to invade areas after the virgin forest is cut, and it is not an uncommon sight to see this species in almost pure stands on the hills of cut-over lands.

Remarks.- This species is often called pignut. Sargent wisely suggests that this name be used exclusively for Carya cordiformis. The great abundance of this species in Brown, Morgan and Monroe Counties has been instrumental in building up a large business in the manufacture of hickory chairs and furniture. Frames of furniture are made from the very young trees, and backs and seats from the bark of old trees, which are cut, stripped of their bark, and often left to rot.

6a. Carya glabra variety megacárpa Sargent ${ }^{1}$. This variety was reported for Indiana by Heimlich. ${ }^{2}$ His report was based on a specimen collected by the author in Franklin County. It was named by sargent who has a duplieate specimen. Sargent in his revision of the hickories does not include Indiana in its range. The size of the fruit ss the eharacter that marks the varety and I do not believe this is sufficient to warrant its separation. I have, therefore, included all Incliana forms under the type.

7. Carya ovàlis (Wangenheim) Sagrent. Smald-fruited Hickorr. Plate 28. Medium sized tall trees; bark usually tight on the trunk for a distance up to $1.5-3 \mathrm{~m}$, then becoming more or less s'aly like the shellbark hickory, on some trees the bark is very thick and is quite scaly but it cloes not flake off in thin plates as the shellhark hickory; twigs purplish or reddish-brown, generally smooth by the end of the season, generally $3-4 \mathrm{~mm}$. thick near the tip; terminal winter buds ovoid, $7-10 \mathrm{~mm}$. long, covered with yellow seales and more or less pubescent; average size leaves $2-3 \mathrm{dm}$. long; leaflets $3-7$, prevailing number usually 7 , sometimes 5 , usually lanceolate, frequently oval or slightly obovate, the terminal $12-21 \mathrm{~cm}$. long, at maturity usually pubescent beneath in the axils of the veins, more rarely also the veins covered with hairs; fruit varies greatly in size and shape, the most common form is obovoid, more rarely oval, or subglobose, $25-42 \mathrm{~mm}$. in length, granular and covered with yellow scales; husk usually splitting to the base, although tardily on some, often quite aromatic, dry husk 1.1-3 mm. thick; nut variable in size and shape, from elliptic

Bot. Gaz. 66:244:1918.

${ }_{2}$ Proc. Ind. Acad. Sci. 1917:436:1918. 
Plate 28.

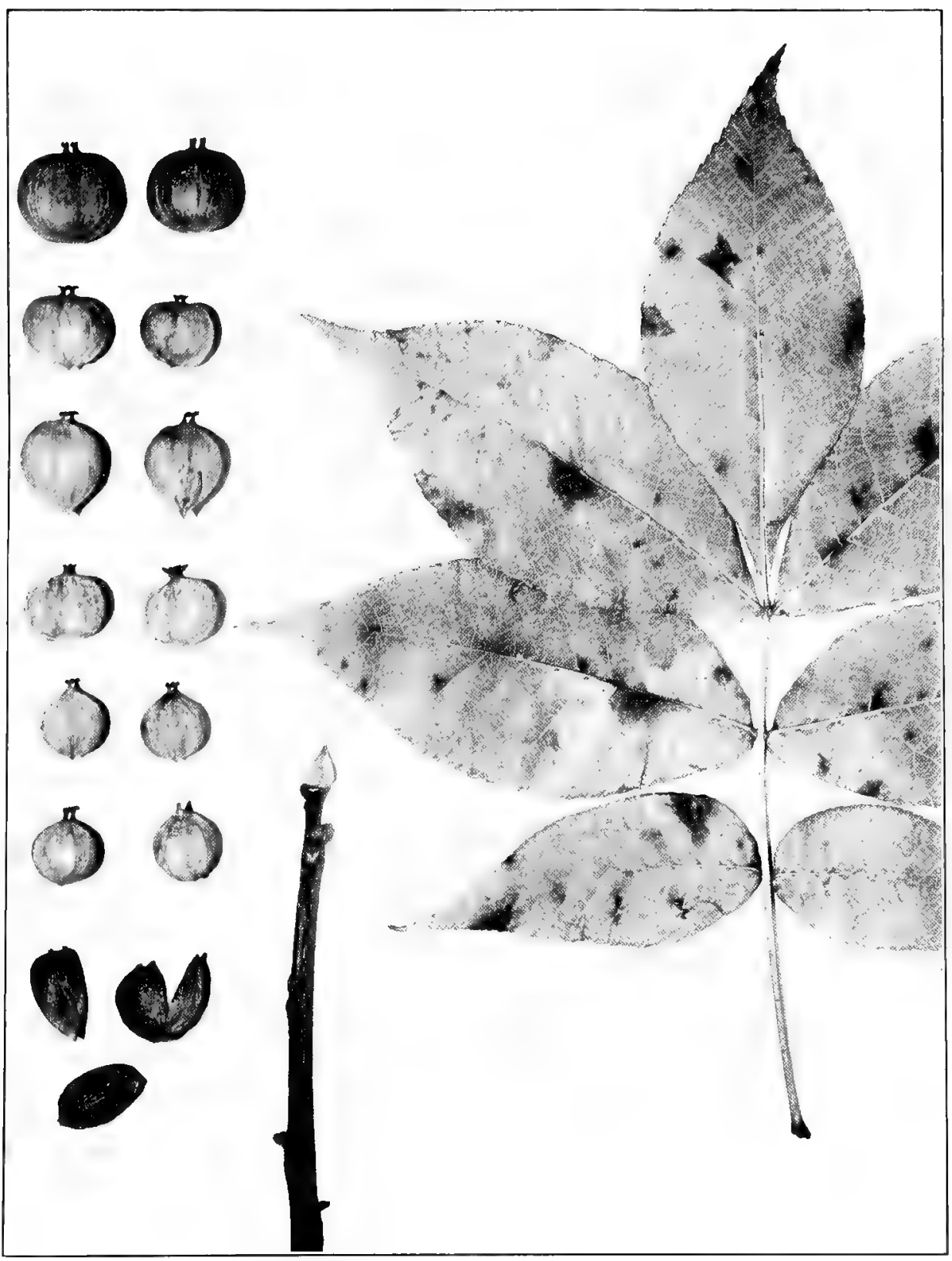

CARYA OVALIS (Wangenheim) Sargent. Smald-Fruited Hickory. ( $x$ l/2.) The nuts show the species and its varieties. 
to obovoid, $15-30 \mathrm{~mm}$. long, compressed, generally about 20 per cent wider than thick, usually rounded at the base, generally slightly obovoid with the apex rounded, or obcordate; a common form has the four sides rounded, as wide as long or almost so, with the ends abruptly rounded so as to appear almost truncate, the elliptic form with both ends pointed is our rarest and smallest form; the surface on all forms is quite smooth, except the elliptic forms which have the angles usually extending from the tip to the base, on other forms the nuts are usually not prominently angled and on some the angles are very obscure except at the apex; shell usually thin, 1-1.5 mm. thick; kernel sweet; wood and uses the same as that of the shellbark hickory.

Sargent has described five varieties of this species, three of which he credits to Indiana. The writer has sent him specimens from over 100 trees of this species, and he has variously distributed them to the type and varieties. Heimlich has reported Sargent's determination of many of these specimens in the Proc. Ind. Acad. Science, 1917:436-439: 1918. The writer cannot agree with the determinations and believes further field study is necessary to discover chardeters by which the several forms can consistently be divided.

To stimulate the study of this species, the original description of the varieties together with sargent', characterization of the type are quoted hecause they are contained in a book not usually found in libraries. To these descriptions are added new characters which sargent gives in his revision of the hickories in Bot. Craz. 66:245-247:1918.

Carya ovalis (type).

"In the shape of the fruit and in the thickness of its involucre this tree is of four distinct forms; in all of them the involucre splits freely to the base, or nearly to the base, the shell of the nut is thin and the seed, although small, is sweet and edible. The extremes of these forms are very distinct, but there are forms which are intermediate between them, so that it is difficult to decide sometimes to which of the forms these intermediate forms should be referred. The first of these forms, as the fruit agrees with Wangenheim's figure, must be considered the type of the species. The fruit is oval, narrowed and rounded at the base, acule at the apex, usually from $2.5-3 \mathrm{~cm}$. long and about $1.5 \mathrm{~cm}$. in diameter. The involucre is from $2-2.5 \mathrm{~mm}$. thick and occasionally one of the sutures remains closed. The nut is oblong, slightly flattened, rounded at the base, acute or acuminate and four-angled at the apex, the ridges extending for one-third or rarely for one-half of its length, from $2-2.5 \mathrm{~cm}$. long and ahout $1.5 \mathrm{~cm}$. in diameter. The shell is usually about $1 \mathrm{~mm}$. thick." "The type of this species and its varieties have glabrous or rare y slightly pubescent leaves, with usually 7 thin leaflets."

${ }_{1}$ Trees and shrubs 2:208-209:1913 and Bot. Gaz. 66:247:1918. 
7a. Carya ovalis variety obcordàta (Mublenberg) Sargent. "The fruit varies from subglobose to short-oblong or to slightly obovate, showing a tendency to pass into that of the other varieties of the species. It varies from 2-3 cm. in diameter, and the involucre, which is from $2-5 \mathrm{~mm}$. thick, splits freely to the base or nearly to the base by narrowly winged sutures, one of them rarely extending only to the middle of the fruit. The nut is usually much compressed, often broadest above the middle, slightly angled sometimes to below the middle, rounded at the base and much compressed, often broadest above the middle, slightly angled sometimes to below the middle, rounded at the base and rounded and often more or less obcordate at the apex."

7b. Carya ovalis variety odoràta (Marshall) Sargent. "The name may have been given by Marshall to this variety on account of the strong resinous odor of the inner surface of the fresh involucre of the fruit, which I have not noticed in that of the other forms. The fruit is subglobose or sometimes slightly longer than broad, flattened and usually from $1.3-1.5 \mathrm{~cm}$. in diameter. The involucre varies from $1-1.5 \mathrm{~mm}$. in thickness and splits freely to the base by distinctly winged sutures. The nut is rounded or acute at the base with a short point, rounded at the apex, very slightly or not at all ridged, pale colored, from 1.2-1.5 cm. long and wide and from $1-1.2 \mathrm{~cm}$. thick."

7c. Carya ovalis variety obovàlis Sargent. "In the fourth form the fruit is more or less obovate, about $2.5 \mathrm{~cm}$. long and $2 \mathrm{~cm}$. in diameter, and the involucre varies from $2-4 \mathrm{~mm}$. in thickness. The nut is much compressed, pointed or rounded at the apex, rounded at the base, usually about $2 \mathrm{~cm}$. long, nearly as broad and about 1.5 cm. thick." "The fruit resembles in shape that of Carya glabra, but the involucre is thicker and splits easily to the base or nearly to the base."

7d. Carya ovalis variety obcordàta, f. vestita Sargent. Bot. Gaz. 66:246:1918. This is a form described from a specimen collected by the author on the border of Dan's Pond in Knox County. It differs from "the variety obcordata in the thick tomentose covering of the branchlets during their first year. The leaves of this form are slightly pubescent in the autumn on the under surface of the midribs. Although the nuts are more compressed than those of the ordinary forms of var. obcordata, the fruit is of that variety. The branchlets are unusually stout for a form of Carya ovalis and are covered with rusty tomentum during their first year and are more or less pubescent in their second and third seasons."

Distribution.-Western New York west to Illinois and south to North Carolina, Georgia, Alabama, Mississippi, Arkansas and Mis- 
souri. The species is found in all parts of the State, although the distribution of the varieties has not been worked out. The habitat of this species is high ground, and only rarely is it found in low ground. It prefers hills, slopes, base of the terraces of streams, and in the northern part of the State gravelly ridges and sandy soil. In all of its range it is usually associated with white and black oak. It is infrequent in the southern part of the State but north of the Wabash River it becomes more frequent and in some places it becomes common to very common. It is a common tree in Wells County north of the Wabash River and in the northern part of Lagrange County, and in hoth places a wide range of forms occur, some of which are not covered hy the preceding description. No one of our trees offers a better opportunity for intensive study than this hickory.

Remarks. - Text books call this species the small-fruited hickory. It is not commonly distinguished from the other hickories, but in Wells County where it is common the boys call it "Ladies' Hickory."

8. Carya Búckleyi variety arkansàna Sargent." Plate 29. Medium sized trees, bark tight, dark, deeply furrowed; mature twigs more or less pubescent, reddish brown; terminal buds ovoid, about $8 \mathrm{~mm}$. long, thickly covered with yellow scales, and more or less pubescent; leaves $2-3.5 \mathrm{dm}$. long, rachis permanently pubescent; leaflets $5-7$, prevailing number 7 , lanceolate, terminal one about $15 \mathrm{~cm}$. long, tawny pubescent on unfolding, more or less glabrous at maturity; fruit ellipsoid to slightly ohovoid, very aromatic, about $3.5-4 \mathrm{~cm}$. Iong, covered with yellow seales; husk usually splitting to below the midclle, 3-4 mm. thick; nut oblong to slightly obovoid, $3-3.5 \mathrm{~cm}$. long, scarcely compressed, rounded at each cnd, the four ridges faint except at the apex; shell thick, about $2 \mathrm{~mm}$. at the thinnest point; kernel sweet; wood same as the white hickory which it most closely resembles.

Distribution.- Southwestern Indiana, south in the Mississippi Valley to Louisiana and Texas. Known in Indiana only from one tree in Knox Count y on the sand ridge on the east side of what was formerly a cypress swamp, about two miles north of Decker. The soil is the Knox sand. It is associated with black and black jack oaks.

Remarks.- The description has been drawn from ample material from this single tree.

${ }_{1}$ Bot. Gaz. 66:249:1918. 
Plate 29.

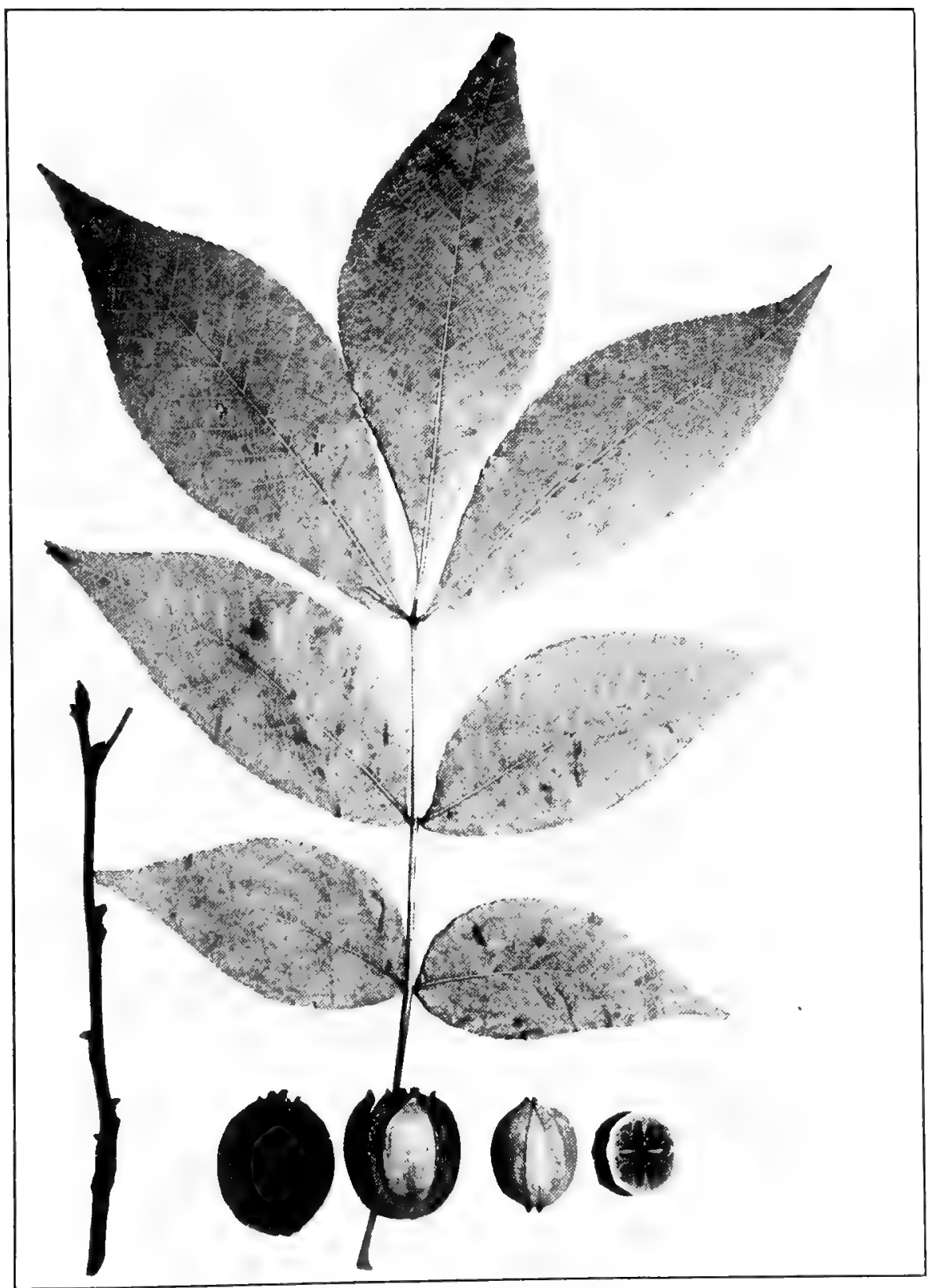

CARYA BUCKLEYI var. ARKANSANA Sargent. ( $x$ 1 2 2.$)$ 
Betulàceae. The Birch Fanily.

Trees or shrubs with simple, petioled, alternate (in pairs on the older branches of Betula) leaves; staminate flowers in long drooping catkins, 1-3 in the axil of each bract, the pistillate in short lateral or terminal aments; fruit a nut or samara.

Staminate flowers solitary in the axil of each bract, without a calyx, pistillate flowers with a calyx; nut wingless.

Bark of tree smooth; staminate aments in winter enclosed in hud scales; nut exposed, its subtending bract more or less irregularly 3 -cleft.................. 1 Carpinus.

Bark of older trees shreddy; staminate aments in winter naked; nut enclosed in a bladder-like bract........2 Ostrya.

Staminate flowers $3-6$ in the axil of each bract, with a calyx, pistillate flowers without a calyx; nut winged.

Winter buds sessile; stamens 2; fruit membranous and hoplike; fruiting hract deciduous at the end of the season when the nut escapes..................... 3 Betula

Winter buds stalked; stamens 4 ; fruit woody and cone-like; fruiting bracts woody and persisting after the nuts escape, 4 Alnus.

\section{Carpinus. The Hornbeam.}

Carpinus caroliniàna Walter. Water Beech. Blue Beech. Plate 30. A small tree up to $3 \mathrm{dm}$. in diameter, usually $1-1.5 \mathrm{dm}$. in diameter with fluted or ridged trunks; bark smooth, close, gray; twigs hairy at first, soon becoming glabrous; leaves ovate-oblong, average leaves 6-10 cm. long, pointed at the apex, double-serrate, hairy when young, glabrous at maturity except on the veins and in the axils beneath, pubescent, not glandular, staminate catkins appearing in early spring; nut at the base of a 3 -cleft bract about $2 \mathrm{~cm}$. long, nut broadly ovate, compressed, pointed and about $5 \mathrm{~mm}$. long; wood heavy, hard, tough and strong.

Distribution.-Nova Seotia west to Mimnesota and south to Florida and Texas. In Indiana it is frequent to common throughout the State in moist rich woods. It prefers a moist rich soil; however, it has a range from the tamarack bog to the dry black and white oak slope. It is tolerant of shade and is seldom found outside of the forest.

Remarks. - This tree is too small and crooked to be of economic importance. It is regarded as a weed tree in the woodland, and should be removed to give place to more valuable species. 
Plate 30.

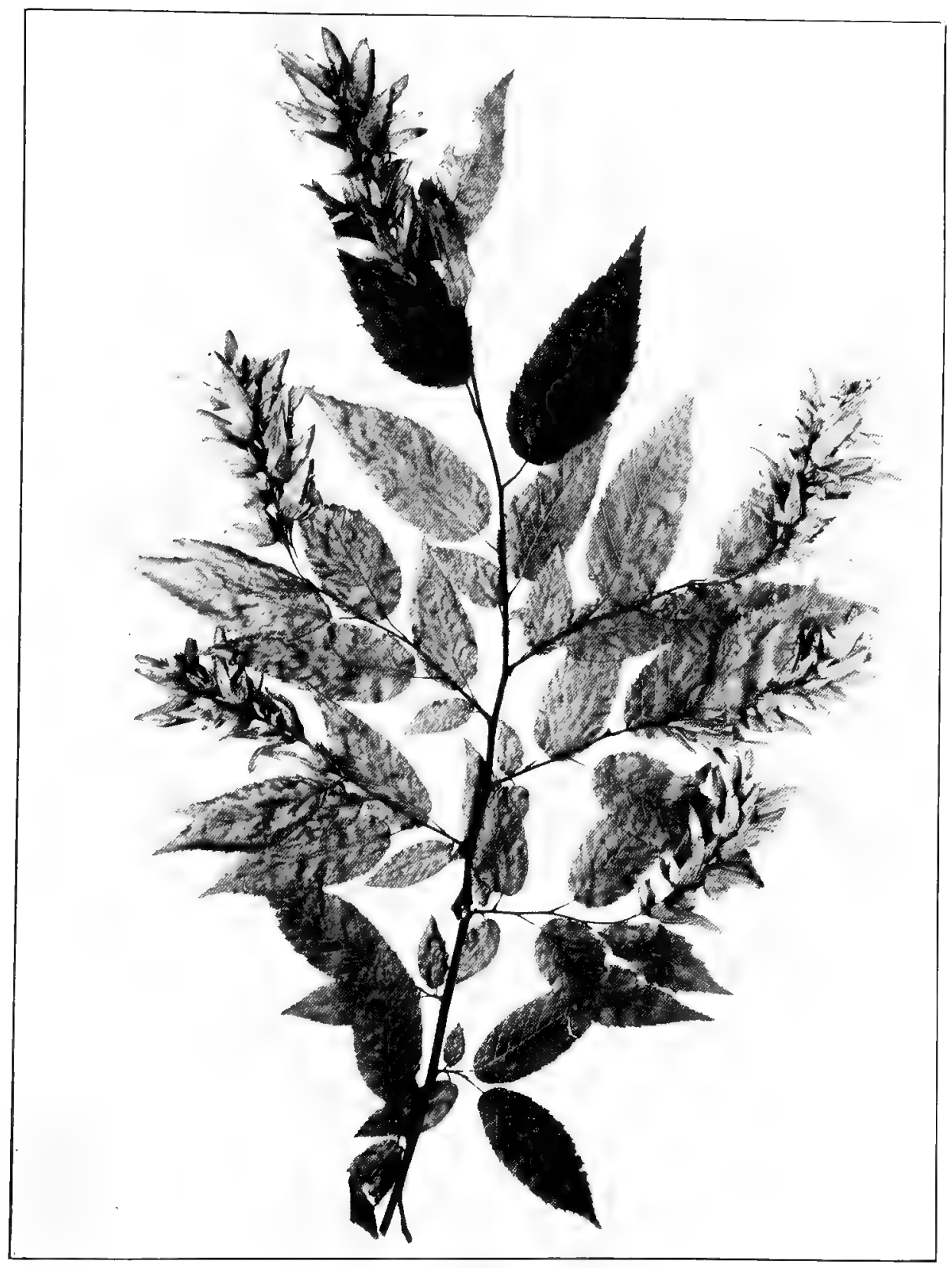

Carpinus Caroliniana Walter. Water or Blde Beech. (x 1/2.) 


\section{2. ÓSTR ya. The Hop Hornbear.}

Ostrya virginiàna (Miller) Willdenow. Ironwood. Plate 31. small trees up to $5 \mathrm{dm} .{ }^{1}$ in diameter, usually about $1-2 \mathrm{dm}$. in diameter; bark smooth and light brown on small trees, shreddy on older trees; shoots hairy, becoming at the end of the season glabrous or nearly so and a reddish-brown; leaves oblong-ovate, other forms rare, average size about $7-12 \mathrm{~cm}$. long, acuminate, usually double-serrate, hairy on both surfaces when they unfold, glabrous or nearly so above at maturity, more or less pubescent beneath, especially on the midrib and veins; staminate spikes develop in early winter; fruit hop-like about $2-4 \mathrm{~cm}$. long; nut oblong-ovate about $7 \mathrm{~mm}$. long and half as wide, compressed, light brown; wood very hard, tough, close-grained, strong, light brown.

Distribution.- Nova Seotia west to Manitoba, south to the Gulf States and west to Texas. It is frequent to common in all of the counties of the State. However, it is entirely absent in the lower Wahash bottoms, except rarely on high grounds in this area. It prefers well drained dry soil, and is nost frequent when it is associated with beech and sugar maple, although it is often quite plentiful in white oak woods. It is shade enduring and is one of the under trees in the forest where it grows very tall and slender and free from branches. When it grows in exposed places such as bluffs, it retains its side branches and is usually bushy.

Remarks. - The trees are too small to be of much economic importance. It is 30 per cent stronger than white oak, and 46 per cent more elastic. These exceptional qualities were recognized by the Indians and it was used by them where wood of great strength and hardness was desired. Likewise the pioneer used it where he could for handles, wooden wedges, ete. Since it grows neither large nor fast, it is usually regarded as a weed tree in the woodland, and should be removed to give place to more valuable species.

Ostrya virginiàna variety glandulosa Spach. This is the name given to the form which has the twigs, petioles, peduncles and often the midrib and veins of the leaves beneath covered more or less with short erect, reddish, glandular hairs.

It is found with the species, but is not so frequent.

\section{BÉTULA. The Birches.}

Trees and shrubs with bark tight, sealy or separating into very thin plates and peeling off transversely, whitish or dark colored; staminate catkins developing in autumn and dehiscing in early spring before or

${ }_{1}$ In 1916 in Allen Connty along Cedar Creek. I measured a spceimen that was 15.6 an. in circ. h.h. with a clear bole of about $3 \mathrm{~m}$. 
Plate 31.

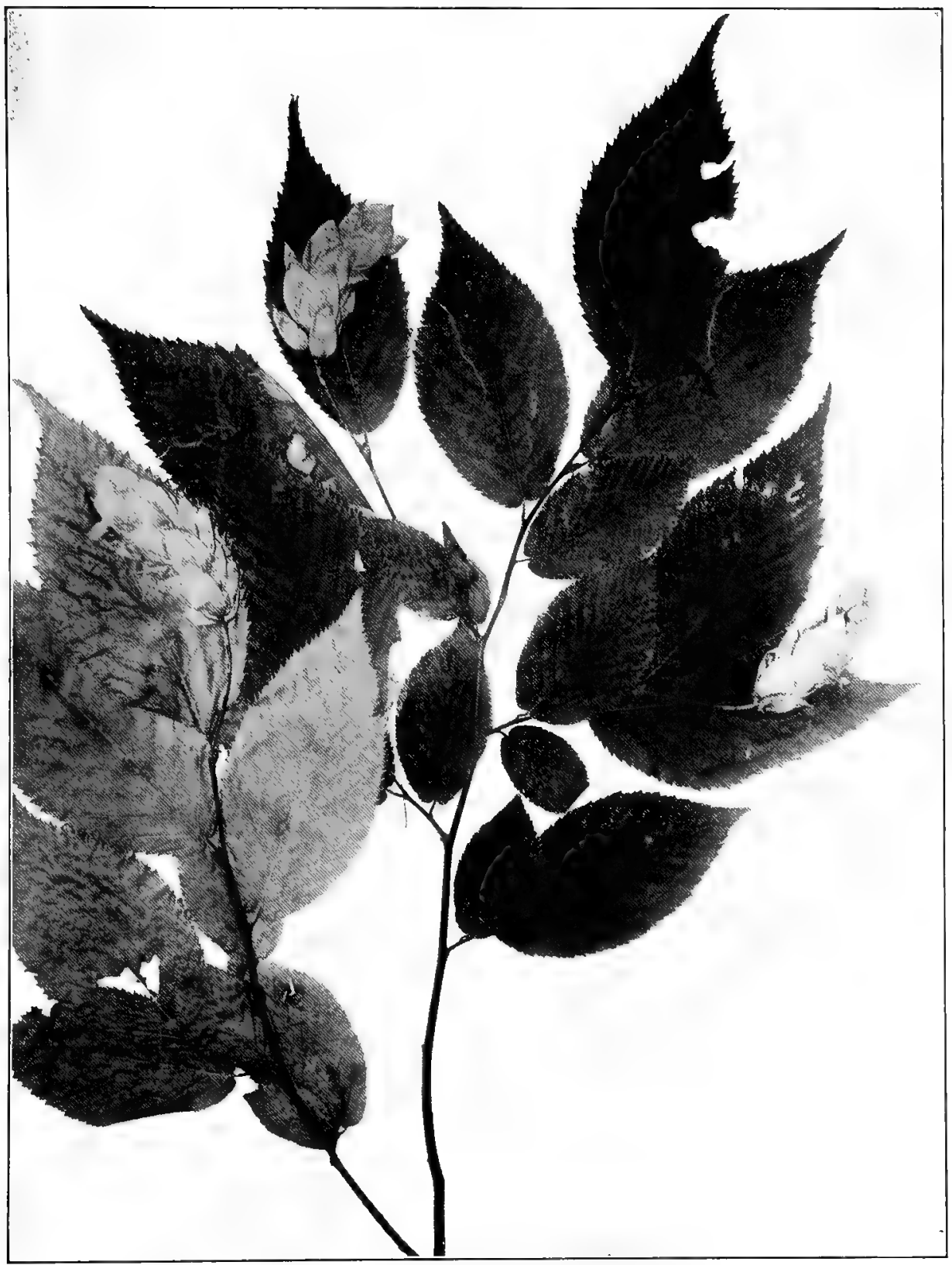

OSTRYA VIRGINIANA (Miller) $\mathrm{K}$. Koch. Ironwood. (x 1 , 2.$)$ 
with the appearance of the leaves, pistillate catkins ovoid or cylindric; fruit a small winged flat seed, bearing at the apex the two persistent stigmas.

Bark of twigs usually with a slight wintergreen favor; leaves with 7-15, usually $9-\mathbf{1 1}$ pairs of prominent veins; rounded or slightly cordate at the base; fertile eatkins generally

$10 \mathrm{~mm}$. or more in diameter.

1 B. Iutea.

Bark of twigs usually bitter, not wintergreen flavored; leaves with 4-11, usually 4-9 pairs of prominent veins, more or less obtusely angled at the hase; fertile cathins generally less than $10 \mathrm{~mm}$. in diameter (rarely $10 \mathrm{~mm}$. or more, B. nigra).

Bark of trunk chalky-white; fruiting aments drooping or spreading.

Bark below base of lateral hrauches darkened-triangular in outline; leaves long acuminate and lustrous above; staminate catkins usually solitary.

2 B. populifolia.

Bark below base of lateral branches not darkened; leaves ovate and not lustrous ahove; staminate catkins usually

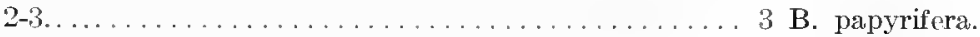

Bark of trunks dark; fruiting aments erect or nearly so.... 4 B. nigra.

1. Betula lùtea Michalux filius. Birch. Yellow Birch. Plate 32. Medium size trees; bark of small trees and of the branches of old trees smooth, silver or dark gray, freely peeling off in thin strips, becoming on older trees a dark brown, rarely tight, usually fissured into wide plates and rolling back from one edge; the shoots of the year hairy, greenish gray, becoming glabrous or nearly so and reddish-brown by the end of the second year, not aromatic when bruised but when chewed sometimes a faint wintergreen orlor can be detected; winter buds pointed, reddish-brown, the lower seales more or less pubescent, generally with a fringe of hairs on the margins; leaves usually appearing in pairs, ovate to ovate-oblong, 4-14 cm. long, taper-pointed, oblique and wedge-shape, rounded or slightly cordate at the base, sharply and rather coarsely serrate, hairy on both sides when they appear, becoming at maturity glabrous or nearly so above, and remaining more or less pubescent below, especially on the veins, both surfaces with few to numerous resinous dots; petioles permanently hairy, generally $5-13 \mathrm{~mm}$. long; flowers appear in May; staminate spikes in clusters at the ends of the branches, about $6 \mathrm{~cm}$. long, scales broadly ovate, blunt, fringed with hairs, green-tipped with a margin of reddishbrown; pistillate spikes solitary in the axils of the leaves, mature spikes $2.5-5 \mathrm{~cm}$. long, generally $2.5-3 \mathrm{~cm}$. long, commonly about half as thick as long, recurved to ascending, commonly about horizontal, sessile or on short stalks; scales very variable, $5-11 \mathrm{~mm}$. long, generally $7-8 \mathrm{~mm}$. long, sometimes as wide as long but generally about one-fourth longer than 
Plate 3:

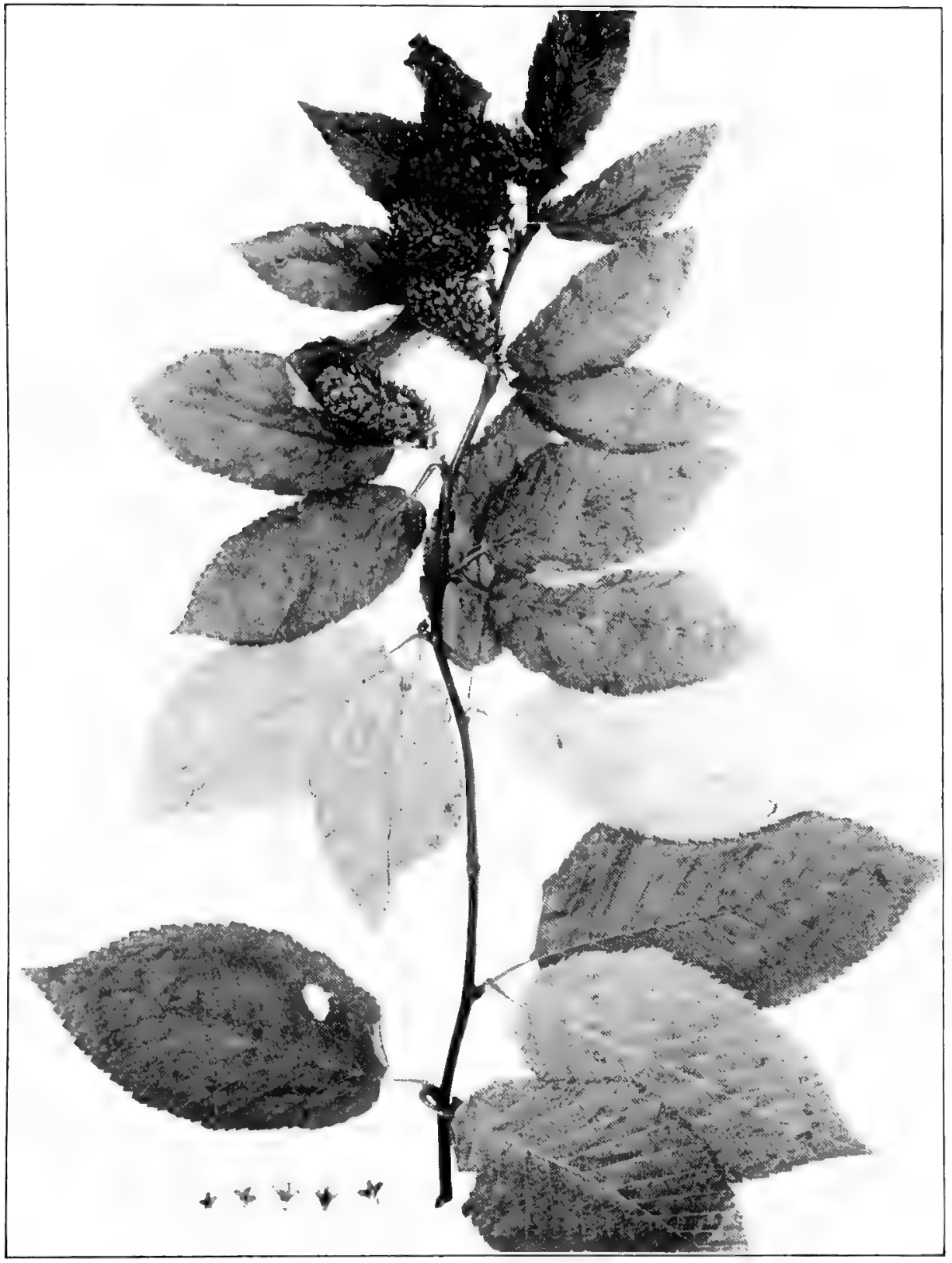

BETUla LUTEA Michaux filius. Yellow Brnch. (x 1/2.) 
wide, densely pubescent on the back, or rarely glabrous on the back, ciliate, glabrous or nearly so on the inside, commonly with a few brown or black glands on the margin, commonly lobed to more than onethird of their length, lobes ascending or divaricate, the lateral generally the larger and almost as long as the narrower middle lobe; nuts divested of the wings, slightly obovate, about $3 \mathrm{~mm}$. long, wings about two-thirds as wide as the nut and usually with a fringe of hairs at the blunt apex.

Distribution. - The distribution of this species is variously given as from Newfoundland west to Manitoba and south in the Alleghenies to Georeia. It is now definitely known that the species of Betula hybriclize which may account for the peculiar forms often encountered. That there are geographic races or Mendelian -egregates of this species is evideneed by the defferent interpretations given this species by different authors. Betula alleghanensis Britton appears to be one of them. The descriptive difference between Betula lenta and Betula lutea is not clear, which has resulted in many authors crediting Betula lenta to Indiana and the area west of Indiuna.

The preceding deseription does not agree with that of Betula iutea exactly, and has been drawn to cover the specimens at hand from Indiana which the author has from Allen, Crawford, Lagrange, Iake, Marshall, Porter and Steuben Counties. It has recently been reported from White County by Heimlich." He sass: "Specimens were taken from two trees about two miles south of Buffalo near the water's edge of the river." The writer has visited this locality and found here, and also on the island above the bridge a little farther down the river, Betula nigra, but could not find Betula lutea. Since Heimlich did not report Betula nigra, which unmistakably occurs here, I assume he has confused the two species. It is very local in its distribution, and appears to be confined to swamps, borders of lakes, and streams in the extreme northern part of the State. It has not been seen south of the northern end of the State, except a few small trees found clinging to the walls of the cliffs of a ravine about one mile east of Taswoll in Crawford County. The walls of this ravine are about 25 meters high; associated with it were a few trees of hemlock, and on the top of the cliffs, laurel (Kalmia latifolia).

Large trees of this species in Indiana are usually from 4-6 $\mathrm{dm}$. in diameter and about $15 \mathrm{~m}$. high. The number in any one station is usually few, although there were formerly patches where it was plentiful. Van Gorder ${ }^{2}$ reports for Noble County Betula lenta which should be transferred to this species, and he says: "There is a marsh of several acres of birch in Section 15 of York Township." The largest area now

1 Proc. Ind. Acad, Sci, 1917:443:1918.

Ind. Geol. Rept. 18:61:1894. 
known is that contained in the large tamarack swamp near Mineral Springs in Porter County. In this swamp are found tamarack and white cedar. It was in this swamp that the writer found a peculiar form of birch which has been determined as Betula Sandbergi. Since this species ${ }^{1}$ is recognized as a hybrid of Betula papyrifera and Betula pumila variety glandulifera, and the last parent of this hybrid is not found in the vicinity, a discussion of this form is not presented. In the immediate vicinity are found only Betula lutea and Betula pumila. Betula papyrifera is found about a mile distant to the south. It is assumed that this form is a cross between Betula lutea and Betula pumila.

2. Betula populifòlia Marshall. Gray or White Birch. Plate 33. A small tree; bark a chalky white, not separating into thin layers, inner bark orange, on the trunks of old trees nearly black; shoots at first covered with numerous glands, becoming smooth and yellowish or reddish-brown; leaves generally long-deltoid, average blades $3-6 \mathrm{~cm}$. long, usually long taper-pointed, truncate or nearly so at the base, irregularly double-serrate, slightly pubescent on the veins when young, soon becoming glabrous; fertile catkins $1.5-3 \mathrm{~cm}$. long and about 7 $\mathrm{mm}$. in diameter; bracts of eastern trees differ from those of Indiana trees which are about $3-4 \mathrm{~mm}$. long, lobed to about $1 / 3$ of the distance from the apex, lateral lobes the largest and strongly divaricate, puberulent on the back; seed strongly notehed at the apex; nut slightly obovoid; wings much broader than the nut.

Distribution.- - Nova Scotia west to southern Ontario and south to Delaware and Pennsylvania. In Indiana it has been reported from Lake, Laporte, Porter, St. Joseph and Tippecanoe Counties. There may be some doubt about the Tippecanoe record, since many of the older records were made from cultivated trees. The numbers of the species in Indiana were always limited. It is not able to meet changed conditions and it has already almost disappeared from our area. I was told that formerly this species was found all about a lake in Laporte County, but it has all died out. Its appearance in Indiana is peculiar sinee it is not found west of us, or north in Michigan or east in Ohio. This small group of trees near Lake Michigan is three or four hundred miles from the nearest of their kind.

Remarks.-This species is called white and gray birch. The largest tree scen in Indiana was about $2 \mathrm{dm}$. in diameter and $13 \mathrm{~m}$. high.

3. Betula papyrífera Marshall. Paper or Canoe Birch. Plate 34. Rather a small tree; bark thin, creamy white; chalky, dark near the base on old trees, separating in thin papery layers; shoots green, glandular and hairy, becoming glabrous and reddish-brown; leaves ovate or rhombic-ovate, acute to long tapcr-pointed, truncate, rounded or

Minnesota Bot. Studies 4:454:1916. 
Plate $3: 3$

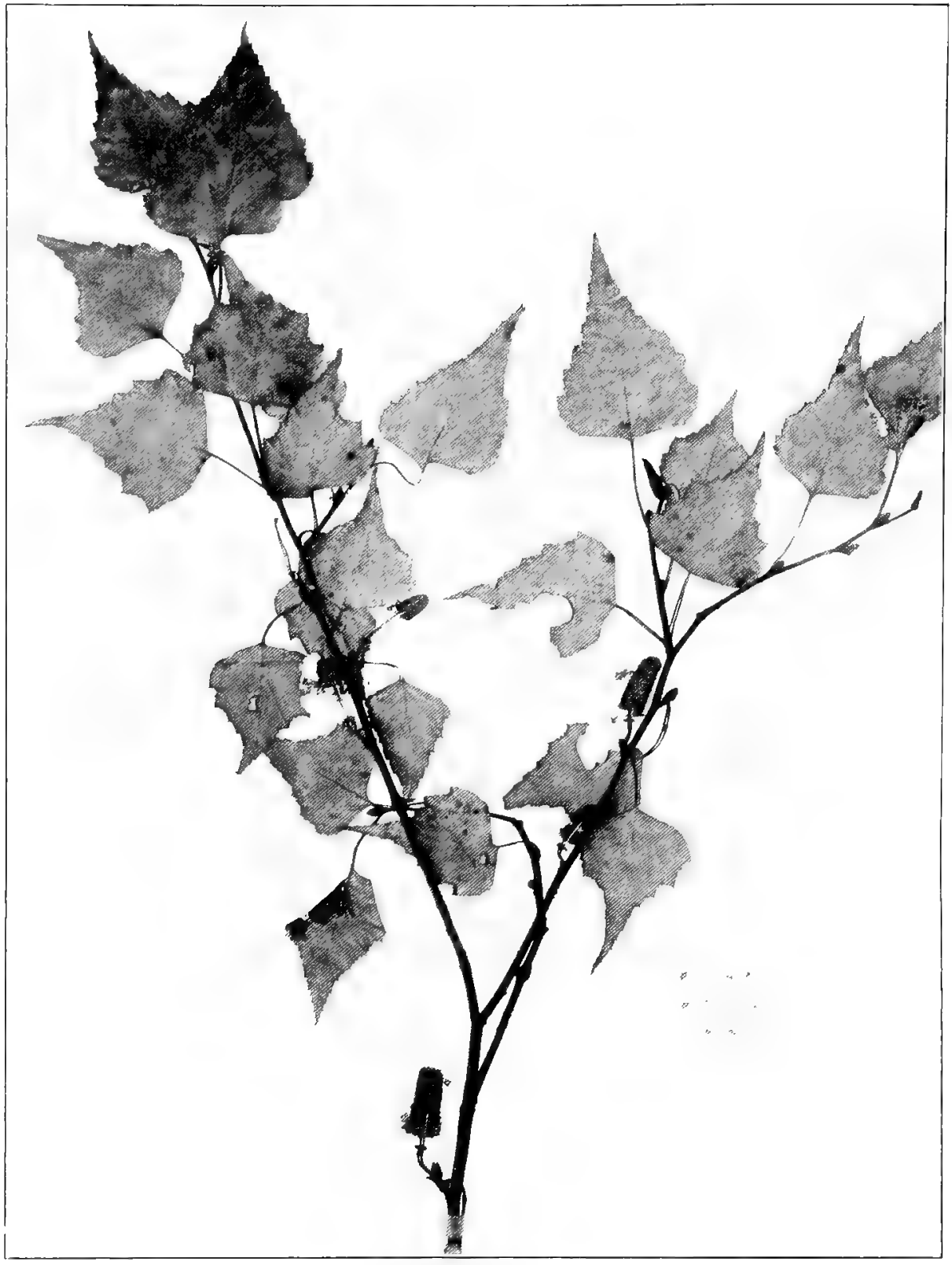

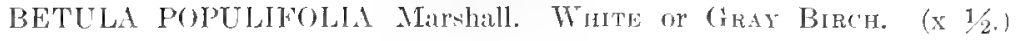


Plate 34.

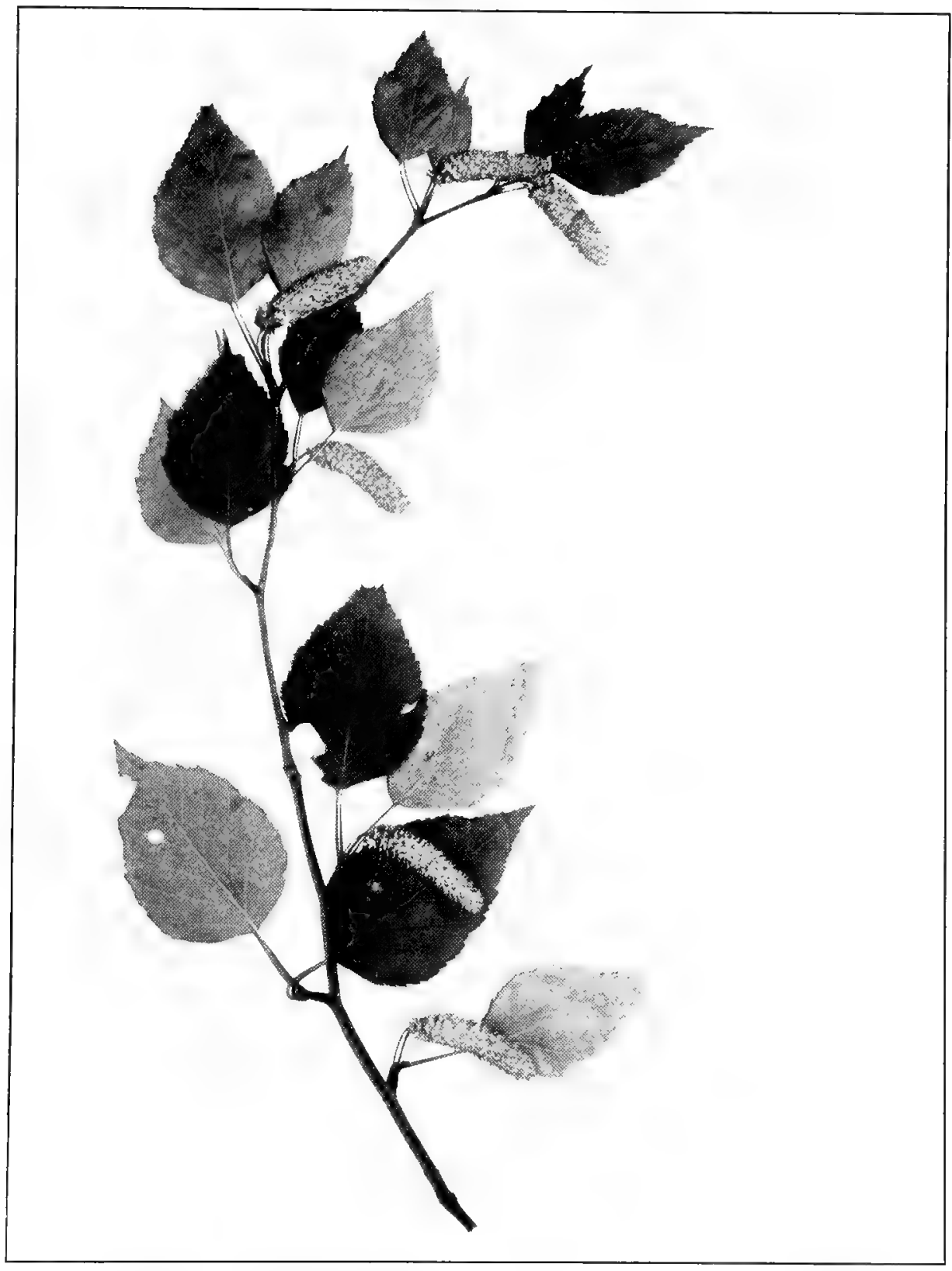

Betula Papyrifera Marshall. Paper or Canoe Birch. (x 1'́2.) 
wedge-shape at the base, average blades $5-8 \mathrm{~cm}$. long, usually mregularly double-serrate, hairy at first, becoming glabrous above or nearly so, remaining more or less pubescent below, especially on the veins and with tufts of hairs in the axils of the veins, minutely glandular on both surfaces, cometimes with only a few glands on the midribs above; fertile catkins $2-4 \mathrm{~cm}$. long and about $6-9 \mathrm{~mm}$. wide, bracts about $4 \mathrm{~mm}$. long, pubescent on both faces, lobed to about one-third the distance from the apex, the lateral lobes the largest, divaricate or slightly recurved; seed deeply notched at apex, nut oval, pubescent at the apex, wings as broad as, or broader than the nut.

Distribution.-Alaska to Labrador, south to New York, northern Indiana, Colorado and Washington. In Indiana it has been reported from Lake, Laporte, Marshall and St. Joseph Counties. It has not been found as a native in Ohio. This species is another example of a northern form finding its southern limit near Lake Michigan.

Remarks. - This species in other parts of the country is known as white, paper and canoe birch. I have not seen specimens more than $2 \mathrm{dm}$. in diameter in Indiana.

4. Betula nigra Linnæus. Black or Red Birch. Plate 35. A medium sized tree; bark on young trees peeling off transversely in thin reddish-brown strips which roll back and usually persist for several years, bark of older trees dark brown, furrowed and separating int o short plates or peeling off in strips; young twigs hairy, becoming glabrous and reddish at the end of the season; leaves rhombic-ovate, acute, short and broadly wedge-shaped at the base, blades of ordinary leaves $4-8 \mathrm{~cm}$. long, irregularly toothed, glabrous above and pubescent beneath, rarely entirely glabrous; fertile catkins generally $2-3 \mathrm{~cm}$. long, and usually slightly less than $1 \mathrm{~cm}$. wide; bracts $6-10 \mathrm{~mm}$. long, pubescent, ciliatc, lobed to near the middle, the lobes about equal; nuts broadly ovate, broader than its wings, pubescent at the apex; wood light, strong, close-grained, heart wood light brown.

Distribution.-Massachusetts west to Minnesota and south to Florida and Texas. In Indiana it is found more or less frequent in the counties hordering the Kankakee River, and as far east as St. Joseph, Marshall and Miami Counties. Along the Kankakee River it is frequently a tree of $6-8 \mathrm{dm}$. in diameter. This species has not been found in Michigan, northeastern Indiana or northern Ohio. It has never been noted near Lake Michigan, and the nearest point is Cedar Lake in Lake County about 20 miles south of the Lake. It is more or less frequent along certain streams throughout the southwestern part of the State. It is found as far north as Putnam and Marion Counties and eastward as far as Bartholomew, Scott and Clark Counties. There are no records for this species for eastern Indiana or western Ohio. About 
I'LATE :35.

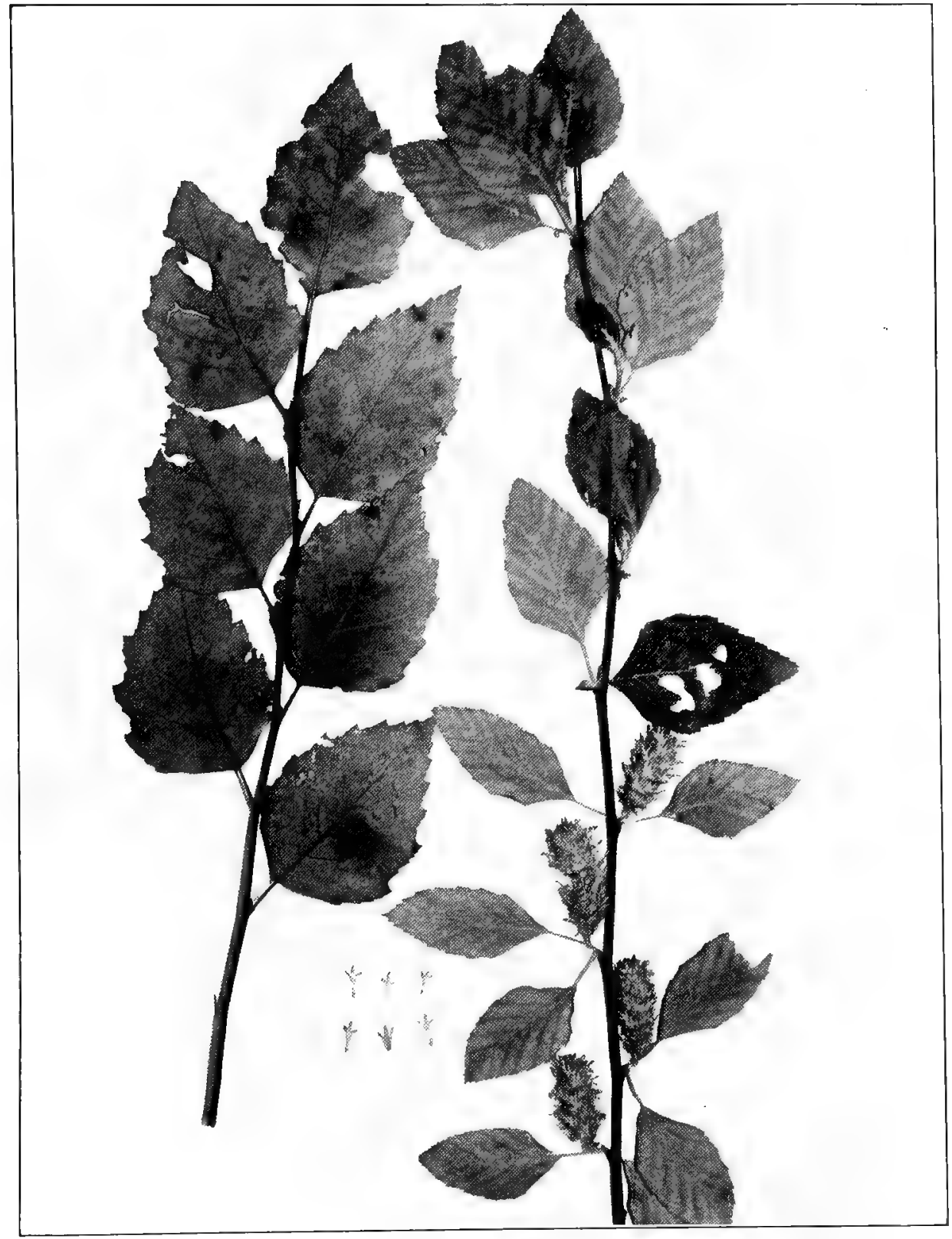

BETUla NIGRA Linnæus. Black or Red Birch. (x $1 / 2$. 
Hovey Lake in Posey County it reaches its greatest size, where trees up to $8 \mathrm{dm}$. in diameter and $30 \mathrm{~m}$. high are to be found. In the "flats" in certain parts of Jackson and Scott Counties it becomes a common tree, associated with pin oak and sweet gum.

Remarks.- This is the most abundant birch of Indiana. In fact all other species are too rare to be of economic importance. The fact that other species of birch are so rare in Indiana, is the reason that this species is simply called "Birch." Outside of Indiana it is known as red birch and river birch. The principal use of this wood in this State is for heading.

All of the birches, especially the horticultural forms, are used more or less for ornamental planting. They are beantiful trees but are short liverl.

\section{4. ÁLNUS. The Alders.}

Trees or shrubs; bark astringent; staminate and pistillate catkins hegin to develop early in summer and flower the following year early in the spring before the leaves appear; bracts of the fertile cat kins thick and woody, ohdeltoid with 3-rounded lobes at the apex; nuts obovate, reddish-brown.

Leaves sharply double-serrate, the ends of the primary veins

forming the apex of the larger teeth, glaucous benenth;

nuts with a narrow thick margin............. 1 A. incana.

Leaves single-serrate, pale beneath; nuts without margins... 2 A. rugosa.

1. Alnus incàna (Linnæus) Muenchhausen. Speckled Alder. Plate 36. Shrubs or small trees; hark generally smooth and a reddish-brown with a tinge of gray, with grayish dots, hence its name; twigs hairy at first, becoming smooth by the end of the season and a golden or reddish-brown with many fine dark specks; leaves broadlyoval, acute or short-pointed at apex, usually broadly rounded at the hase, average blades $6.5-11 \mathrm{~cm}$. long, glaucous beneath, hairy on both sides on unfolding, at maturity becoming glabrous above or with a few hairs on the veins, beneath remaining more or less hairy until late in autumn when usually only the veins are hairy; pistillate catkins resembling small cones, $1-1.5 \mathrm{~cm}$. long and usually $7-12 \mathrm{~mm}$. wide, near the ends of the branches, usually in clusters of 2-7.

Distribution.-Newfoundland to the Saskatchewan, south to New York, northeastern Ohio, northern Indiana and Nebraska. In Indiana it is confined to the northern tier of counties. I have specimens from Elkhart, Lagrange, Lake and Porter Counties. It was reported from Carroll County hy Thompson, but in the absence of a verifying specimen I am inclined to think this citation should be referred to Aluus 
Plate 30.

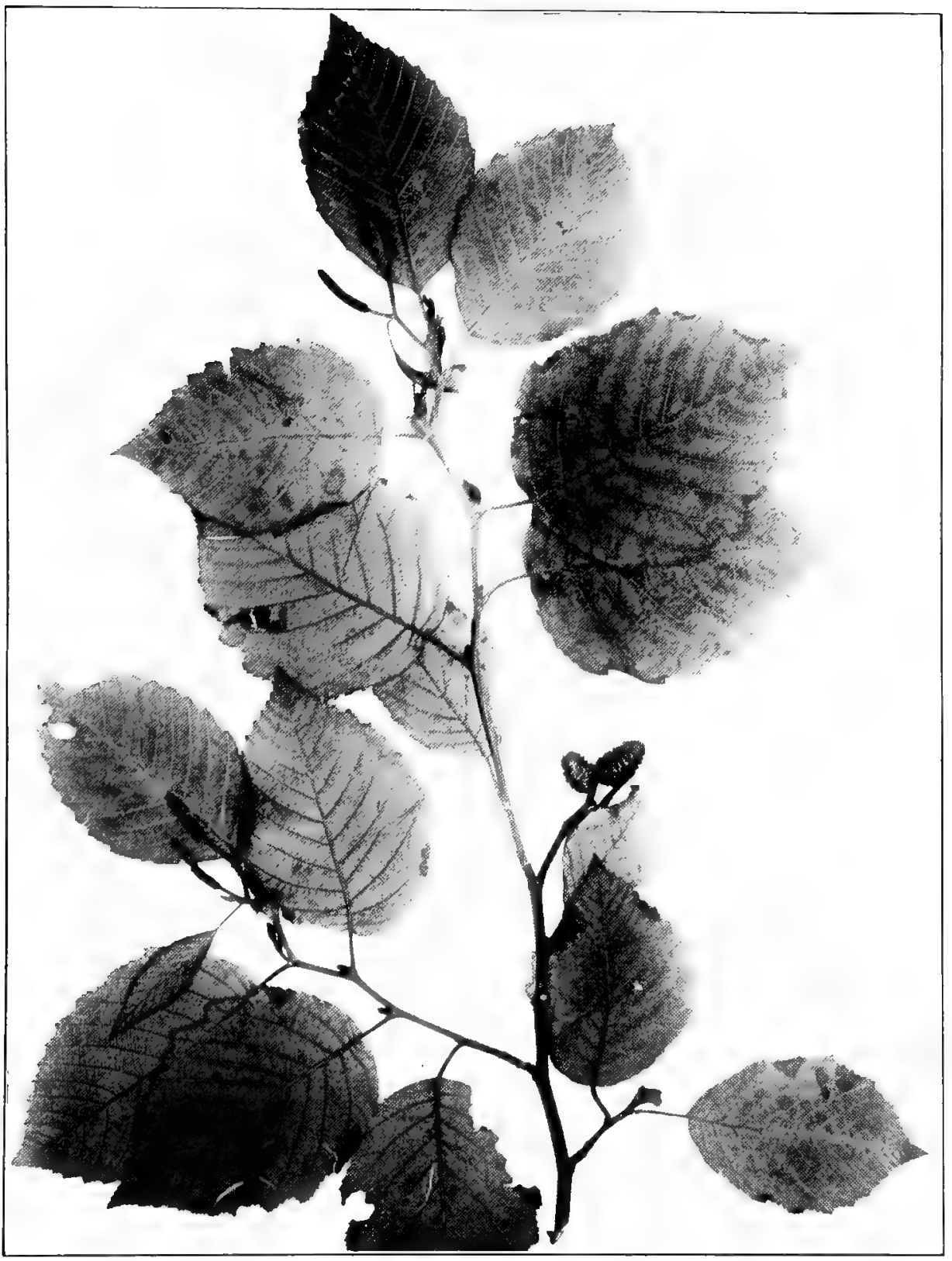

ALNUS INCANA (Linnæus) Muonchhausen. SPECKLed Aldér. ( $x^{1}$ i.) 
rugosa. This species grows in low ground on the borders of streams, borders of swamps and in almost extinct sloughs near Lake Michigan. It is also found along Pigeon River in the eastern part of Lagrange County. In the vicinity of Mineral Springs in Porter County it is locally a common shrub or tree. It has the habit of stooling: out, and conmonly the several specimens will be deflected from a vertical from 20-45 degrees. The largest specimens are from 1-1.4 $\mathrm{dm}$. in diameter and about $10 \mathrm{~m}$. high.

Remarks.- This species could be used to good advantage in ornamental planting in low ground. It grows rapidly, is easly transplanted and its foliage is dense and attractive.

2. Alnus rugòsa (DuRoi) Sprengel. Sмоотн Alder. Plate 37. Shrubs with fluted or angled trunks, resembling Carpinus; bark thin, smooth or nearly so, reddish-brown, weathering gray; twigs hairy at first, becoming gray or reddish-brown by the end of the season and more or less glabrous and covered with small dark specks; leaves obovate, barcly acute or rounded at apex, wedge-shape at base, average blades 6-10 cm. long, hairy on both surfaces while young, becoming smooth or nearly so above, remaining more or less hairy beneath, especially on the veins, under surface of leaves sufficiently glutinous to acthere to paper if pressure be applied, margins set with short callous teeth, about .5-1 mm. long; fertile catkins cone-shape, 10-20 mm. long and about $7 \mathrm{~mm}$. in diameter, borne at the ends of branches in elusters of $2-5$.

Distribution.-Maine to Minnesota, south to Florida and Texas. In Indiana it is quite local. It has been reported in many of the counties of northern Indiana north of the Wabash River. It has been found in several of the southern counties and as far north as Salt Creck in Monroe County. No reports for the central part of the State. It is absent also in all of the eastern counties of the State, and the western part of Ohio. It is found growing in clumps in wet woods, swamps, cold bogs and along streams. It is usually a tall slen der shrub; however, a spccimen has been seen that measured $7 \mathrm{~cm}$. in diameter and $5 \mathrm{~m}$. in height.

Remarks. - (of no value except for ornamental planting in wet ground.

FAG ÄCEAE. The Beech Family.

Trees with simple, alternate, petioled leaves; flowers of two kinds; fruit a onc-seeded nut. This is the most important family of trees occurring in the State. 
Plate 37.

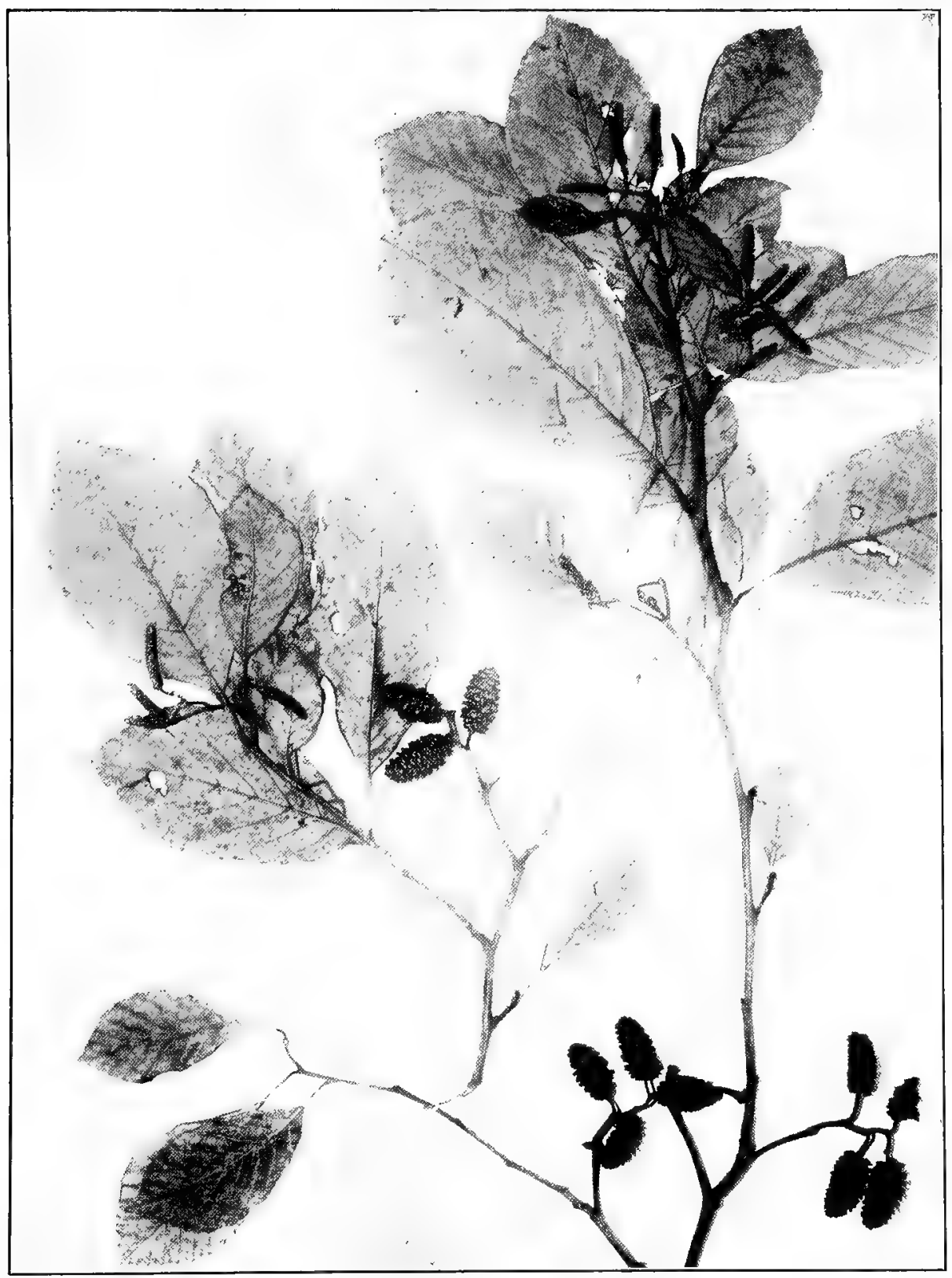

ALNUS RUgosA (Du Roi) Sprengel. Smooth Alder. (x 1/2.) 
Winter buds long and slender, at least 4 times as long as mide; staminate flowers in globose heads on drooping peduncles; nuts sharply 3-angled.

\section{Fagus.}

Winter buds not long and slender and less than 4 times as long as wide; staminate flowers in slender eathins; nuts not as above.

Staminate catkins erect or spreading; nut flattened on one side and enclosed in a spiny, woody husk.......2 Castanea.

Staminate catkins drooping; nuts not flattened on one side, seated in a scaly, woody cup ............... 3 Quercus.

\section{FÀGUS. The Beech.}

Fagus grandifòlia Ehrhart. BEech. Plate 38. Large tall trees with bark from light to dark gray; twigs densely covered at first with long hairs, soon becoming glabrous and turning to a reddish-brown; terminal winter buds about $2 \mathrm{~cm}$. long; leaves ovate to ovate-oblong, long taper-pointed to merely acute, wedge-shape to cordate at base, regularly and usually minutely serrate, average blades $7-12 \mathrm{~cm}$. long, silky when young, becoming at maturity glabrous above and nearly so beneath except on the veins; flowers appear in May; fruit a bur, supported on a club-shaped pubescent penduncle about $1.5 \mathrm{~cm}$. long, covered with short recurved prickles, densely rufous-pubescent, its 4valves enclosing the wo triangular brown nuts; nuts edible; wood very hard, strong, usually tough, difficult to season, close-grained, takes a high polish, sap wood white, heart wood reddish.

Distribution.- Nova Scotia, southern Ontario to Wisconsin, south to the Gulf States and Tcxas. It is found in every county of the State, although it is local in the prairie and dry sandy regions of the northwestern part of the State. It is a frequent to a very common tree on the high ground in many parts of the State. If the high ground and hills of the State are not forested with white and black oak, becch is almost certain to be the prevailing species. Wherever beech is found it is usually a frequent. to a common tree, and it is not uncommon to see areas which are almost a pure stand of this species. It is also a frequent to a common tree in southern Indiana in what is called the "flats." Here it is associated with sweet gum and pin oak. On the slopes of hills of the southern counties it is associated with a great variety of trees. In the central part of the State its most frequent associate is the sugar maple. In the northern counties it has a wider range of associates, including white oak, ash, slippery elm, buckeye, ironwood, etc. It should be added that tulip is a constant associate except in the "flats." In point of number it ranks as first of Indiana trees. 
Plate 38.

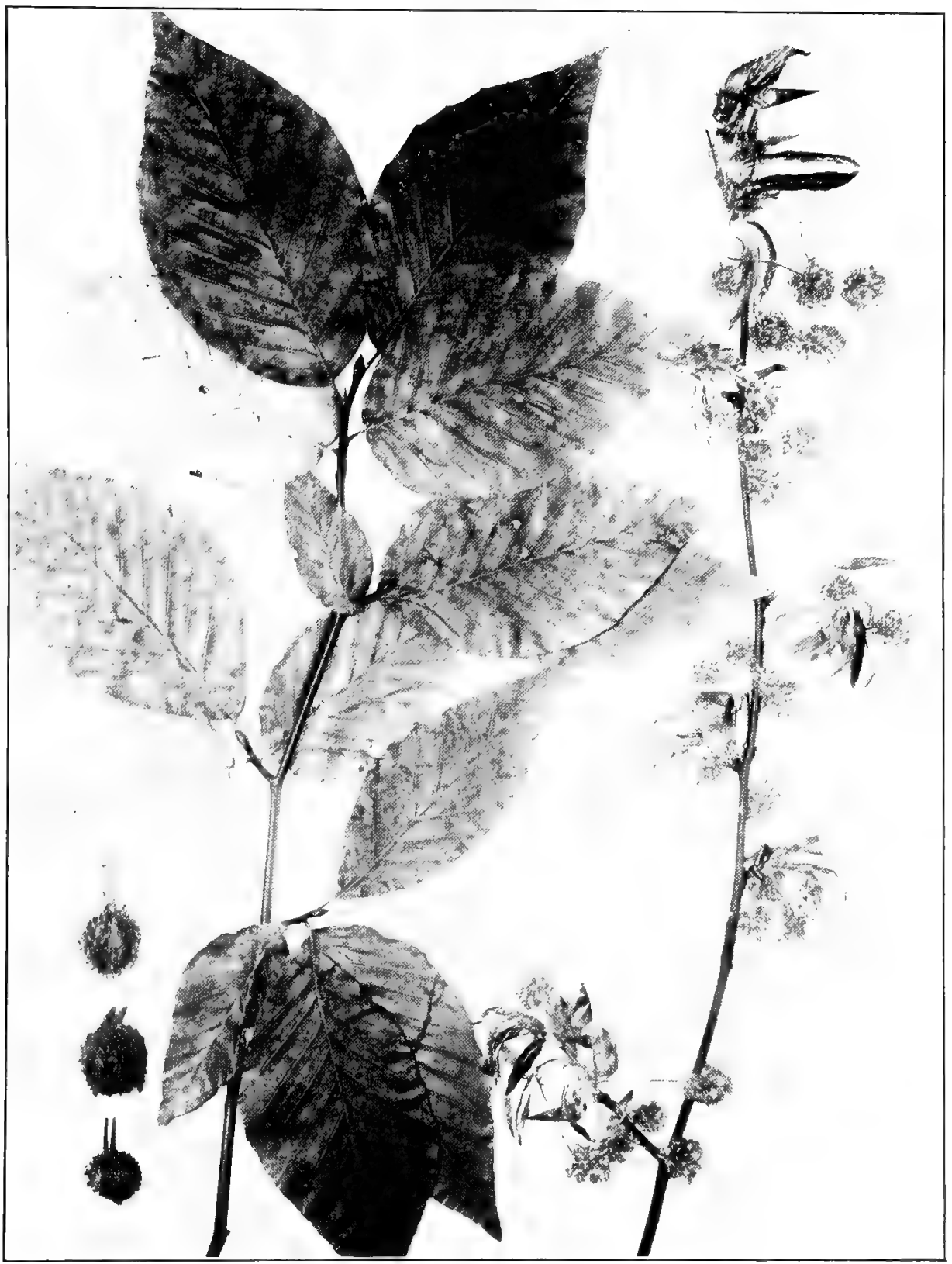

FAGUS GRANDIFOLIA Ehrhart. BeEch. (x 1/2.) 
Remarks.- Specimens with the habit of retaining their branches which lop downward, usually have thicker sap wood and are harder to split. This form is popularly styled the white beech. The form with smooth tall trunks with upright branches usually has more heart wood, splits more easily and is popularly distinguished as red beech. The term yellow beech is variously applied. This species is a large tree in all parts of the state, although the largest specimens are found in the southeastern part of the State. In the virgin forests trees almost 1 $\mathrm{m}$. in diameter and $30 \mathrm{~m}$. high were frequent.

Beech was formerly used only for fuel, but in the last few decades it has been cut and used for many purposes, and the supply is fast diminishing. The beauty of this tree both in summer and winter, sunshine or storm makes it one of the most desirable for shade tree planting, but I have failed to find where it has been successfully used. It is one of the few trees that does not take to domestication. When the original forest is reduced to a remnant of beech, as a rule, the remaining becch will soon begin to die at the top. It is difficult to transplant. When planted the hole should be filled with earth obtained from under a living tree, in order to introduce the mycorrhiza that is necessary to the growth of the tree.

\section{Castànea. The Chestant.}

Castanea dentàta (Marshall) Borkhausen. Chestnut. Plate 39. Large trees with deeply fissured bark, smooth on young trees; young twigs more or less hairy, soon becoming glabrous and a reddish-brown; leaves lanceolate, average blades $13-22 \mathrm{~cm}$. long, taper-pointed, wedgeshape or obtuse at the hase, coarsely serrate, teeth usually incurved, at maturity glabous on both sides; flowers appear after the leaves in the latter part of June or early in July, the staminate catkins from the axils of the leaves of the year's growth, 1.5-3 $\mathrm{dm}$. long, pistillate flowers in heads on short stalks in the axils of the leaves, usually on the branch beyond the greater part of the staminate catkins; fruit a globular spiny bur 5-7 cm. in diameter which contains the nuts; nuts usially 1-3, rarely 5, flattened on one side, edible; wood light, soft, not strong, checks and warps on seasoning, yellowish-brown, durable in contact with the ground.

Distribution.-Maine, southern Ontario, Michigan, south to Delaware and in the mountains to Alabama, and west to Arkansas. In Indiana it is found locally in the south central counties. The most northern station where I have seen trees that are native to a certainty is in Morgan County a short distance north of Martinsville. There are a few trees on the south bank of White River in Mound Park about 
Plate 80.

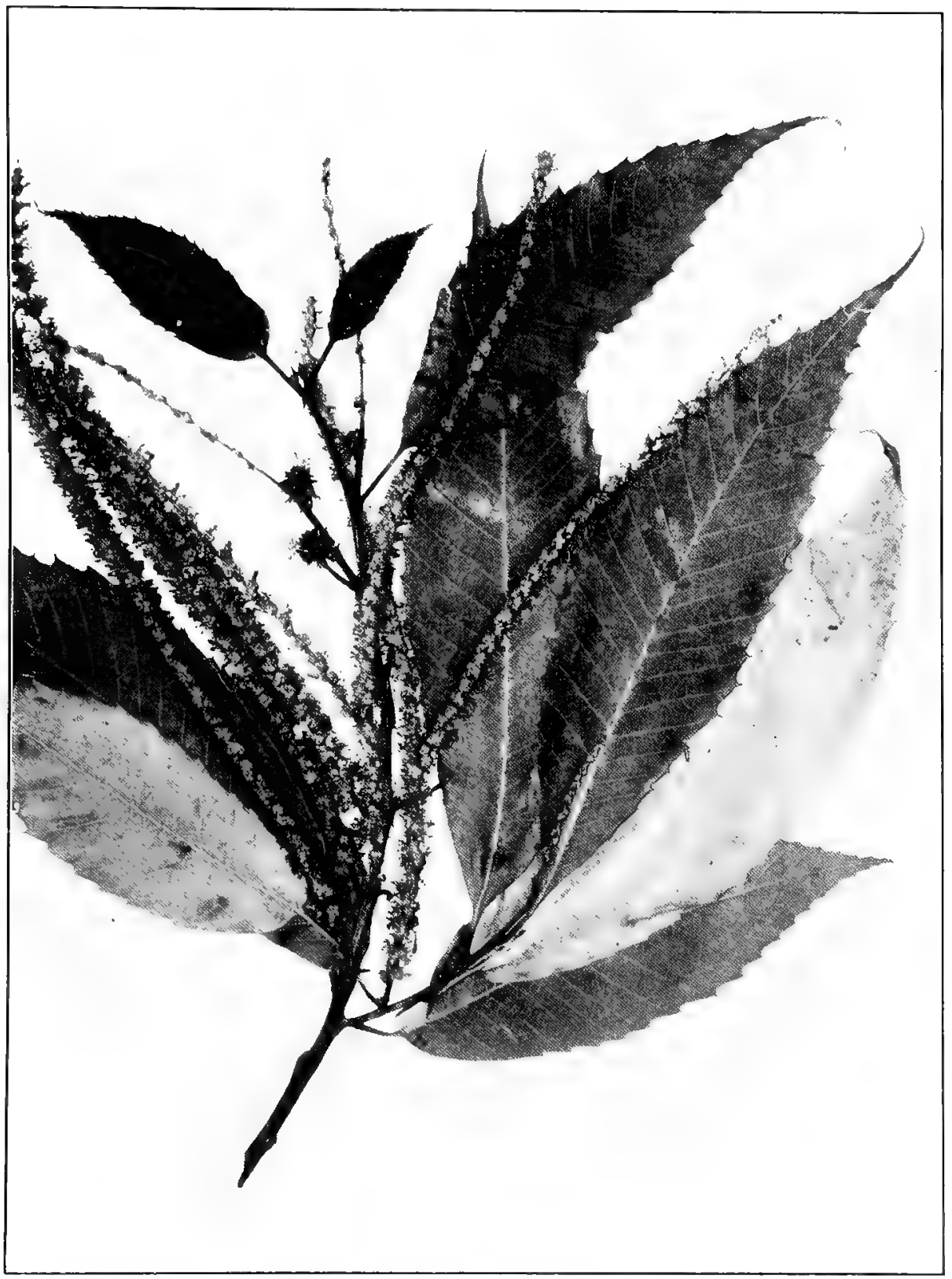

CASTANEA DENTATA (Marshall) Borkhausen. Chestnut. (x 1/2.) 
2 miles east of Anderson. This site was formerly an Indian village, and the trees may have been introduced here. The late $\mathrm{A}$. C. Benedict formerly of the state Geological Survey, told me he saw a colony in 1878 in Fayette County on the farm of Dr. B. Ball, about 3 miles west of Connersille on the east side of Little Williams Creek. The trees were at least $6 \mathrm{dm}$. in diameter. The western line of distribution would be a line drawn from Martinsville to a point a few miles west of Shoals and south to Tell City.

Remarks. - The greatest numbers of this species are found on the outcrops of the knobst one in Clark, Floyd, Harrison, Jackson, Lawrence, Martin, Orange and Washingt on Counties. It grows on high ground, associated with white and black oak, beech, ete. The species in all of our area grows to be a large tree. In the Ind. Geol. Rept. 1874:70:1875 there is a reference to a "stump in Jackson County that was $9 \mathrm{ft}$. and 2 in. in diameter." This species is rather gregarious in habit, and rarely are isolated trees found. It is quite local in its distribution, but where found it is usually a common tree. The bark was much used in taming, and the timber for poles, ties and posts. The demand for this species has led to heavy cutting, so that the present supply is practically limited to inferior or small trees. The nut crop in this State is usually badly infested by the weevil.

This species is casily propagated by seed or seedlings. It is recommended for forest planting in all parts of its natural range and other parts of the State where the soil is very sandy and free from limestone. This species never attains to an old age when growing close to the limestone. It grows rapidly and requires little pruning. The only objection to planting it for forestry purposes is that it might be infested by the chestnut bark disease which is fatal to this tree. This disease is far to the east of us, and there are wide barriers to its western migration. Since a chestnut grove would soon grow into post and pole size, in the event the grove would be killed by the bark disease, the crop could be harvested and the loss would be more of the nature of a disappointment than a financial one. If planted in a cleared area the seedlings should be spaced about $5 \times 5$ fcet if no cultivation can be done. If the trees can be cultivated, plant $7 \times 7$ or $8 \times 8$ feet and grow corn for one or two years between the rows.

\section{QUERCUS. The OAKs.}

The leaves of Indiana oaks are deciduous; flowers appear in April or May, very small, the staminate on slender pendulous catkins, the pistillate solitary or in clusters in scaly bud-like cups; fruit an acorn which takes one or two years to mature, ripening in September or 
October. The species that mature their fruit the first year are popularly and commercially classed as "white oaks." Those that mature their fruit the second year are classed as "red, black or bristle-tipped oaks."

The oaks are the largest genus of Indiana trees, and commercially are the most important of all trees of the State. They are the Jongest lived of all the trees that occur in the State, and while they have numerous insect enemies none of them prove fatal to it, except a certain gall insect.

Note:-In collecting leaf specimens of oaks for identification it should be borne in mind that the foliage is quite variable. The leaves of secdlings, coppice shoots and of vigorous shoots of old trees sometimes vary considerably in size, form and leaf-margins. Also leaves of old trees that grow in the shade usually have the margins more nearly entire than the typical leaves. For example leaves may be found on the lower and interior branches of a pin oak which are not lobed to beyond the middle, which throws them into the red oak group.

Bark gray, (except in No. 5) more or less scaly; mature leaves never with bristle tips; fruit maturing the first year.

Mature leaves smooth beneath................ 1 Q. alba.

Mature leaves pubescent beneath.

Primary veins beneath show regular pinnate venation.

Some of the primary veins beneath end in a sinus....2Q. bicolor.

All primary veins beneath end in teeth of the margin...

Tips of leaves of fruiting branches sharp-pointed, usually forming an acute angle; fruit sessile or nearly so........................ Muhlenbergii

Tips of leaves of fruiting branches rounded or if sharp-pointed, it rarely forms an acute angle; fruit peduncled.

Petioles green and woolly pubeseent beneath (rarely almost glabrous); under surface of leaves velvety to the touch; bark gray, scaly, of the white oak type; trees of low ground...4 Q. Michauxii.

Petioles yellowish and smooth beneath, or rarely somewhat pubescent; under surface of leaves leaves not velvety to the touch; bark dark, and tight, of the red oak type; trees of high ground (in Indiana confined to the "knobstone" area) .................. 5 Q. Prinus.

Primary veins beneath show irregular venation.

Last year's growth pubescent; acorns generally less than $12 \mathrm{~mm}$. in diameter. 6 Q. stellata.

Last year's growth glabrous or nearly so; acorns more than $12 \mathrm{~mm}$. in diameter. 
Leaves sinuate dentate, sometimes lobed near the base, velvety to the touch beneath; peduncles of fruit longer than the peticles.......... 2 Q. bicolor.

Leaves irregularly lobed, harsh or rarely velvety or smooth to the touch beneath; peduncles of fruit shorter than the petioles.

Cup of fruit fringed; apex of lobes of leaves geverally rounded; trees of lowland.

Cup of fruit not fringed; apex of lobes of leaves generally acute; trees of swamps in the extreme southwestern counties of Indiana.... 8 Q. lyrata.

Bark dark, tight and furrowed; leaves with bristle tips; fruit maturing the second year.

Leaves entire ........................ 9 (Q. imbricaria.

Leaves more or less deeply lobed, the lobes and teeth conspicuously bristle pointed.

Mature leaves smooth beneath, except tufts of hairs in the axils.

Leares lobed to about the middle, the lateral lobes hroadest at the base; cup saucer-shaped; nut about

1.5-2 $\mathrm{cm}$. in diameter; terminal buds reddish. 10 Q. rubra.

Leaves lohed to beyond the mid'dle, frequently those grown in dense shade not so deeply lobed, some or all of the lateral lobes broadest toward the apex.

Cup saucer-shaped, rarely enclosing the nut for more than $l_{3}$ its length; trees of the low lands and swamps.

Leaves glossy above; hlades usu tlly 10-12 cm. long; cups usually $1.5 \mathrm{~cm}$. or less broad; terminal huds chestnut brown................. palustris.

Leaves dull ahove, usually about $15 \mathrm{~cm}$. long; cups $1.5-2.5 \mathrm{~cm}$. broad, rarely as narrow as $1.5 \mathrm{~cm}$.; terminal buds grayish hrown...........12 Q. Sehnerekii.

Cup hemispheric, generally enclosing the nut for half its length; trees of the uplands.

Inner bark yellowish or orange; kernel of nut yellowish or orange, and very bitter.

Terminal buds usually $5 \mathrm{~mm}$. or less in length, ovoid and generally blunt, reddish-brown; scales of cup closely appressed; trees local in the extreme northwest part of the State.13 Q. cllipsoidalis. Terminal buds usually longer than $6 \mathrm{~mm}$., usually angled and sharp-pointed; seales of cup not closely appressed; trees of all parts of the State....................... velutina.

Inner hark reddish or gray; kernel white and not very bitter.... ................. coccinea.

Malure leaves more or less pubescent on the whole under surface. 
Leaves grayish or yellowish pubescent beneath; scales of eup with a reddish-brown border; nut enclosed for about 1.3 its length..................... falcata.

Leaves brownish or rusty pubescent beneath, sometimes appearing grayish; seales of eup without a dark border; nut enclosed for about half of its length.

Leaves expanded at the apex, and generally with three lobes; mature twigs generally scurvy-pubeseent $17 \mathrm{Q}$. marilandice. Leaves deeply lobed; mature twigs generally glahrous.14 Q. velutina.

1. Quercus álba Linnæus. White OAk. Plate 40. Large trees with gray, fissured bark, flaky on the branches, on the upper part of the trunks of some trees the bark loosens at the fissures and peels back, forming flat strips which remain attached at one side; twigs at first hairy, becoming smooth; leaves mostly obovate in outline, generally $8-20 \mathrm{~cm}$. long on petioles $0.5-2 \mathrm{~cm}$. long, more or less deeply lobed into 5-9 lobes, the lobes ascending and generally blunt and entire, sometimes the lobes have one or two secondary lobes, leaves narrowed and oblique at the base, smooth ahove, smooth and glaucous beneath; acorns sessile or on stalks up to $2 \mathrm{~cm}$. long; nuts quite variable on different trees as to size and shape, ovoid or oblong, 18-30 mm. long; cup flat on the botton, tuberculate and encloses about $1 / 4$ of the nut; seales blunt and woolly.

Distribution.-Maine, southern Ontario, Minnesota south to Florida and Texas. Found in all parts of Indiana. In point of number it is exceeded only by the beech, although it has a more general distribution. It is adapted to many types of soil, and is found in almost all situations in Indiana except in very wet soils. It is sparingly found in the sand dune area. On the clay soils of the northern part of the State it is a frequent to an abundant tree, and in the southern part of the State it often forms complete stands on the slopes of the hills.

The white oak is one of the largest and possibly the longest lived tree of Indiana. While it is able to adapt itself to many situations, it grows to the largest size in a porous, moist and rich soil.

Remarks. - Wood heavy, hard, close-grained, tough, strong and durable. On account of its abundance, and wide range of uses, it has always been the most important timber tree of Indiana.

Formerly the woods were full of white oak 1-1.5 meters (3-5 ft.) in diameter, but today trees of a meter $(3 \mathrm{ft}$.) in diameter with long straight trunks are rare indeed. Michaux who traveled extensively in America 1801-1807, while the whole Mississippi Valley was yet a wilderness, remarks: "The white oak is the most valuable tree in America." He observed the ruthless destruction of this valuable tree, and predicted that the supply would soon be depleted, and that America 
Plate 40.

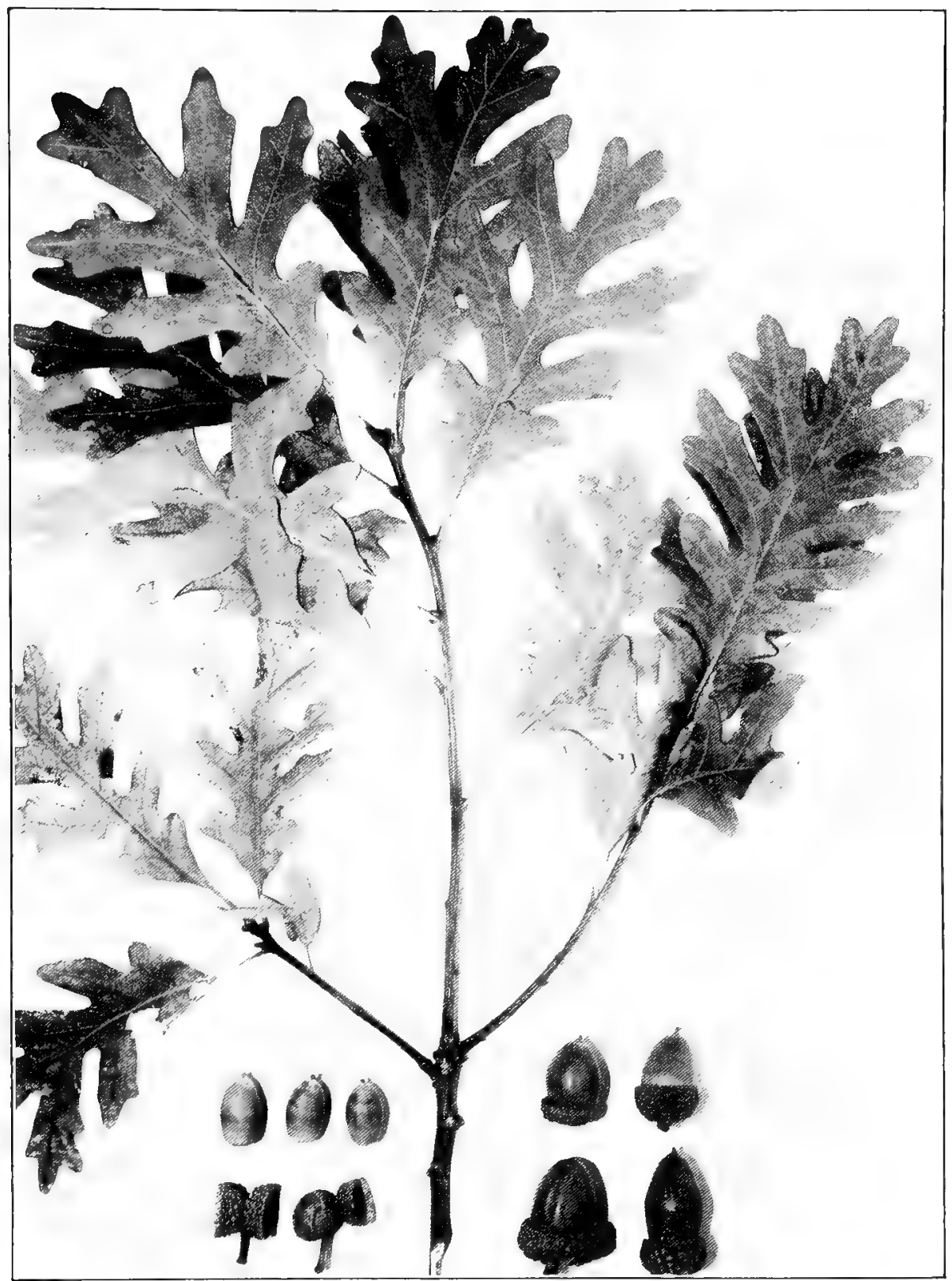

(QUHRCUS ALBA Linnæus. White OAK. ( $\mathrm{x}, 2$, 2 ) Acorns from different trees to show variation. 
would be sorry that regulations were not adopted to conserve the supply of this valuable tree. Michaux's prediction has come true, and yet no constructive measures have been provided to insure the Nation an adequate supply of this timber. It should be remembered that it requires two to three hundred years to grow a white oak a meter in diameter, and if we are to have white oak of that size in the next generation the largest of our present stand must be spared for that harvest.

White oak was formerly much used in construction work, but it has become so costly that cheaper woods take its place. At present it is used principally in cooperage, interior finish, wagon and car stock, furniture, agricultural implements, crossties, and veneer. Indiana has the reputation of furnishing the best grade of white oak in the world.

Little attention has been given this valuable species either in horticultural or forestal planting. This no doubt is due in a great measure to the slow growth of the tree. It should be used more for shade tree, ornamental and roadside tree planting. Thereare good reasons why white oak should be much used in reforestation. The cheapest and most successful method of propagating white oak is to plant the seed in the places where the trees are desired to grow. This is best done by planting the acorns as soon as they fall or are mature. The best results will be obtained if the nuts are planted with the small end down, and covered about an inch deep with earth. If the ground is a hard clay soil and the small end of the nut is placed down a half inch of earth on the nut is sufficient. Rodents often destroy the nuts, and if this danger is apprehended it is best to poison the rodents or to stratify the seed, or grow seedlings and plant them when they are one year old. In forestal planting it is suggested that the planting be $4 \times 4$ feet.

The white oak is quite variable in the lobing of the leaves, and in size and shape of the fruit, and in the length of its peduncle. The variable lobing of the leaves has lead several authors to describe varieties based on this character. The latest is that of Sargent ${ }^{1}$ who desscribes: "The trees with leaves less deeply divided, with broad rounded lobes and usually smaller generally sessile fıuit," as Quercus alba variety latiloba.

Quercus alba x Muhlenbérgii (X Quercus Deami Trelease). This rare hybrid was discovered in a woods ahout 3 miles northwest of Bluffton Indiana by L. A. Williamson and his son E. B. Williamson in $1904 .^{2}$

The tree is still standing and in 1918 bore a heavy crop of sced. A liberal quantity was sent for propagation to the Arnold Arboretum, New York Botanical Gardens, and Missouri Botanical Gardens. The 
Arboretum succeeded in germinating several seed. The New York Gardens succeeded in getting 5 seedlings. The Missouri Gardens failed to get any to germinate. About a gallon of seeds was planted in the Clark County State forest nursery and all failed.

2. Quercus bícolor Willdenow. Swamp White OAK. Plate 41. Large trees; leaves on petioles 5-20 mm. long, 8-18 cm. long, obovate, wedge-shaped or narrowly rounded at base, rounded or pointed at the apex, margins coarsely dirided with rounded or blunt teeth or somewhat pinnatifid, primary venation beneat homewhat regular, but usually some of the veins end in a sinus of the margin, both surfaces hairy at first, becoming smooth above and remaining velvety pubescent beneath; the upper surface of the leaf a bronze or dark green and the under surface grayish due to the dense tomentum, which in some instances becomes sparse and short, in which case the under surface is a light green; acorns usually in pairs on stalks $2-7 \mathrm{~cm}$. long; nuts ovoid, $2-2.5 \mathrm{~cm}$. long, enclosed for $1 / 3-1 / 2$ their length in the cup; scales of cup acute to very long acuminate, scurvy pubescent and frequently tuberculate; kernel sweetish.

Distribution.-Maine, southern Ontario, southern Minnesota south to Georgia and Arkansas. Found in all parts of Indiana. It is always found in wet places. In most of its range it is associated with the bur oak from which it is not commonly separated. In the northern counties it is usually associated with pin and bur oak, and white elm; in the flats of the southeastern part of the State it is usually associated with cow oak and sweet gum, while in the southwestern counties it is found most commonly with Spanish and pin oak.

Remarks.-Commercially the wood is not distınguished from white oak, and the cut is sold for that species.

3. Quercus Muhlenbérgii Engelmann. Chinguapin Oak. Sweet OAK. Yellow OAK. Chestnut OAK. Plate 42. Largetrees; leaves on petioles $1-3 \mathrm{~cm}$. long, blades very variable in size, shape and leaf margins, generally 10-20 cm. long, oblong-lanceolate to broadly obovate, narrowed or rounded and more or less unequal at the base, taper-pointed at the apex, the apex always forming an acute angle, margins coarsely and rather regularly toothed, primary veins beneath regular and straight, and end in a prominent gland in the point of the teeth, teeth more or less incurved, leaves smooth and dark green above, and grayish pubescent beneath; acorns generally sessile, but often on short stalks up to $1 \mathrm{~cm}$. long; nut ovoid to oblong ovoid, $10-18 \mathrm{~mm}$. long, enclosed for $1 / 4^{-1} / 2$ its length in a very thin cup; scales of cup ovate, bluntpointed or merely acute, sometimes tuberculate near the base of the cup, grayish pubescent without; kernel sweet, and the most edible of all of our oaks. 
'LATE 41 ,

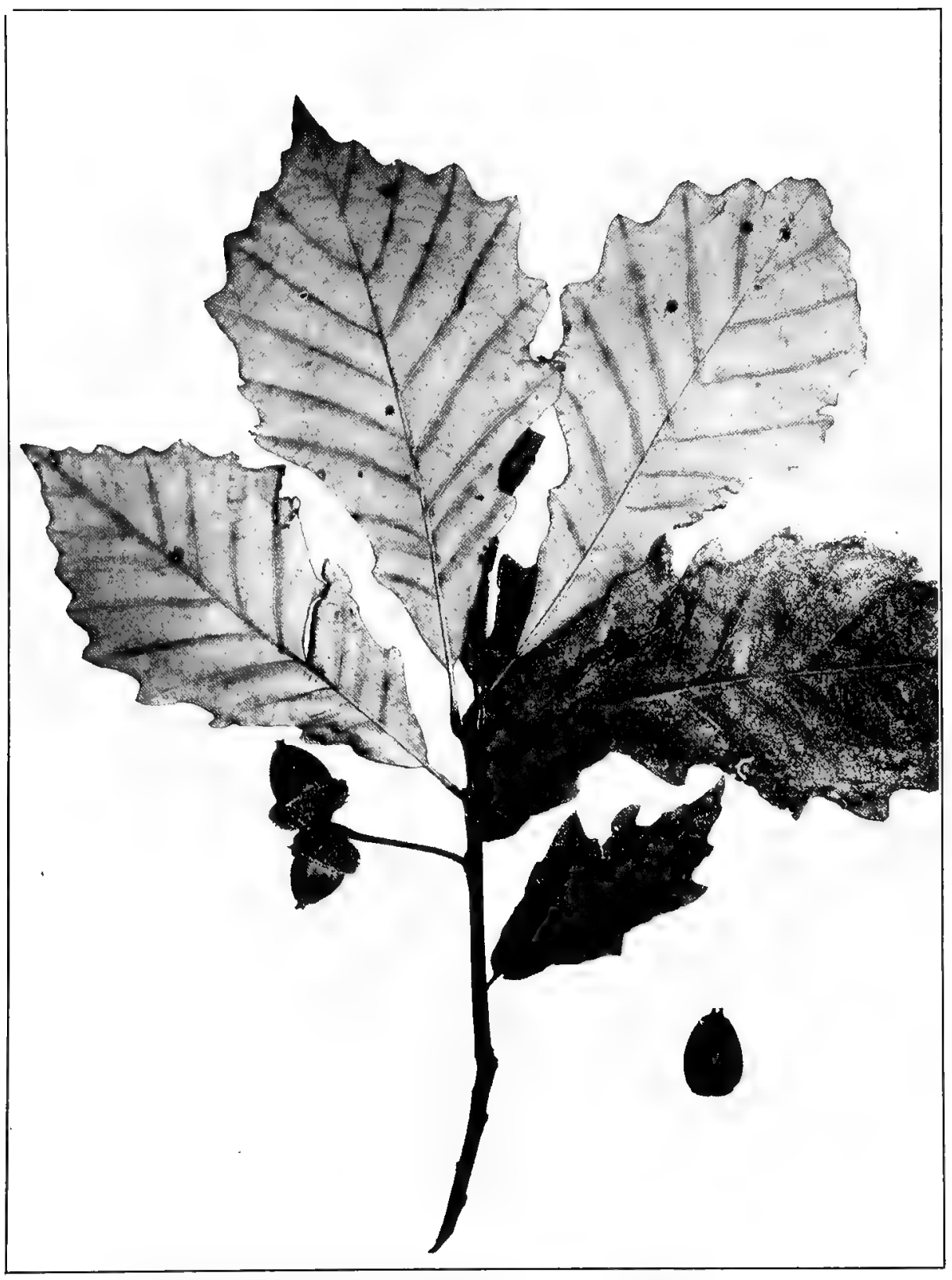

QUERCUS BICOLOR Willdenow. SWAmp White OAK. (x 1'2.) 
Plate t'.

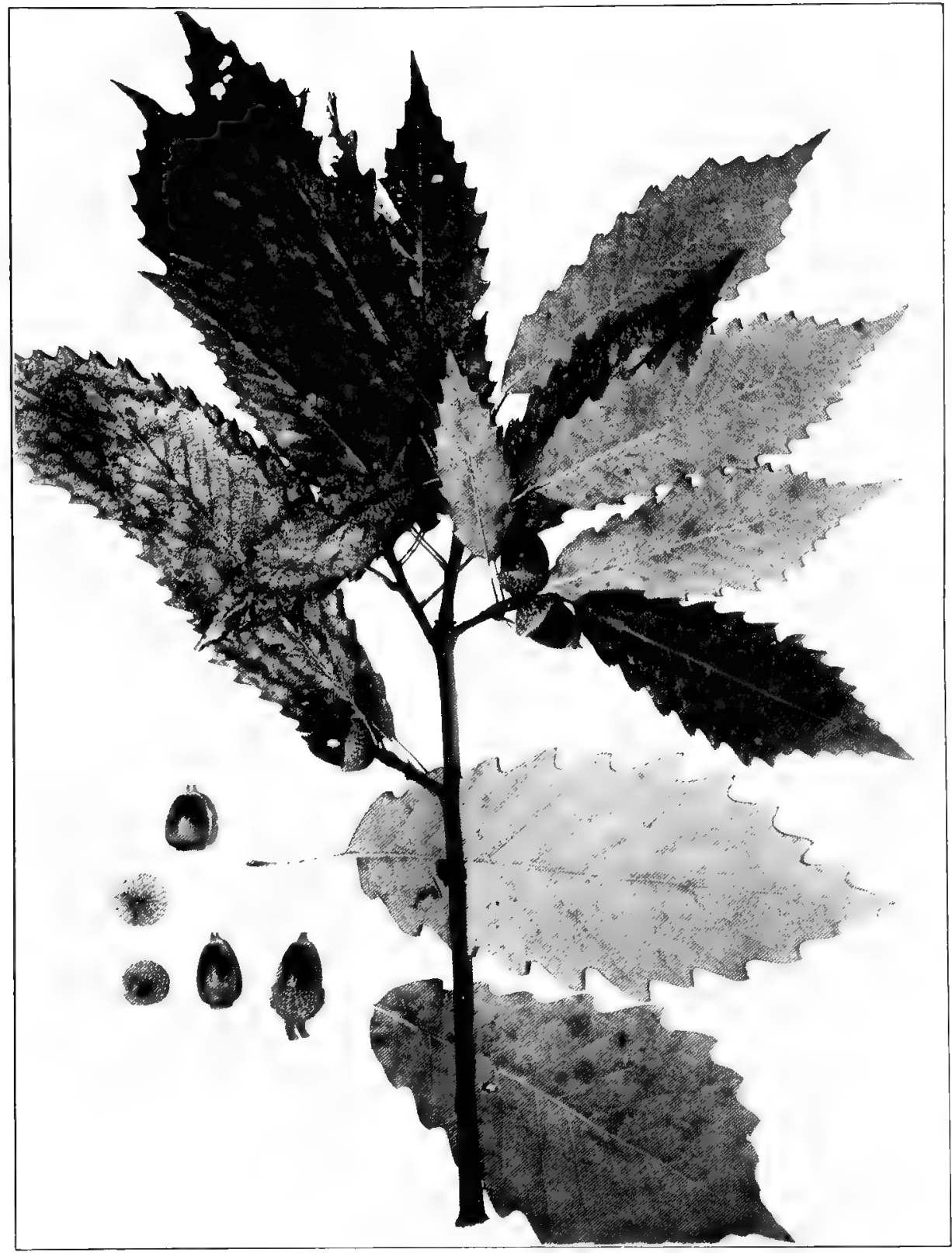

QUERCTS MUHLENBERGII Engelmann. ChINQUAPIN OAK. ( $\left.\quad 1 / 2{ }^{4}\right)$ Detarherl arenrns and leaves from different trees. 
Distribution.-Vermont, southwestern Ontario to Wisconsin and south to Florida and west to Texas. Found in limited numbers in all parts of Indiana, although Hill's record for Lake county is the only record in the block of the 12 northwest counties. It is without a doubt found in every county south of the Wabash River. It is a rare or an infrequent tree in practically all parts of its range. It is generally found on the dry banks of streams, river terrace banks, rocky bluffs of streams, and only rarely in level dry woods. In the southern counties it is sometimes found on clay or rocky ridges. In most of its range it is now so rare that most of the inhabitants do not know the tree.

Remarks. - Wood similar to white oak, and with the same uses.

In White County a pioneer was found who knew the tree only by the name of pigeon oak. He said it received this name from the fact that the wild pigeons were fond of the acorns.

The leaves of this tree vary greatly in size, shape, and leaf margins. The fruit also varies on different trees in the shape of the nut, and the depth of the eup. These variations have lead some authors to separate the forms and one histological study ${ }^{1}$ seems to support minor differences. It has been observed that the leaves in the top of some trees may be thick, narrow and with long incurved teeth, while the leaves of the lower branches will be strongly obovate, thinner, and the teeth more dentate. In a general study it is best to include the polymorphic forms under one name. The distribution of the shallow and deep cup forms is so general that no regional or habitat areas can be assigned to either of them in Indiana.

4. Quercus Michaúxii Nuttall (Quercus Prinus Sargent). Cow OAk. Basket Oak. Plate 43. Large trees; leaves on petioles $1-3 \mathrm{~cm}$. long, generally 1-2 dm. long, obovate, narrowed or narrowly rounded at the base, short taper-pointed, the apex generally blunt, the margins coarsely toothed, the teeth broad and rounded or more rarely acute, shaded leaves sometimes with margins merely undulate, hairy on both surfaces when young, becoming at maturity a dark yellow green and glabrous above, sometimes remaining somewhat pubescent along the midrib and the principal veins, leaves grayish and woolly pubescent beneath; acorns solitary or in pairs, sessile or on very short stalks, up to almost a $\mathrm{cm}$. in length; nuts ovoid or oval with a broad base, enclosed for about $1 / 3$ their length by the cup, the cups thick and generally $2-3 \mathrm{~cm}$. broad; scales ovate, acute, rather blunt-pointed and more or less tuberculate near the base of the cup, tomentose on the back; kernel sweet.

Elliott: Histological variations of Qucreus Muhlenbergii. University of hansas Scienco Bul. 9:45:54:8 Plates;1914. 
PLATE 4:3

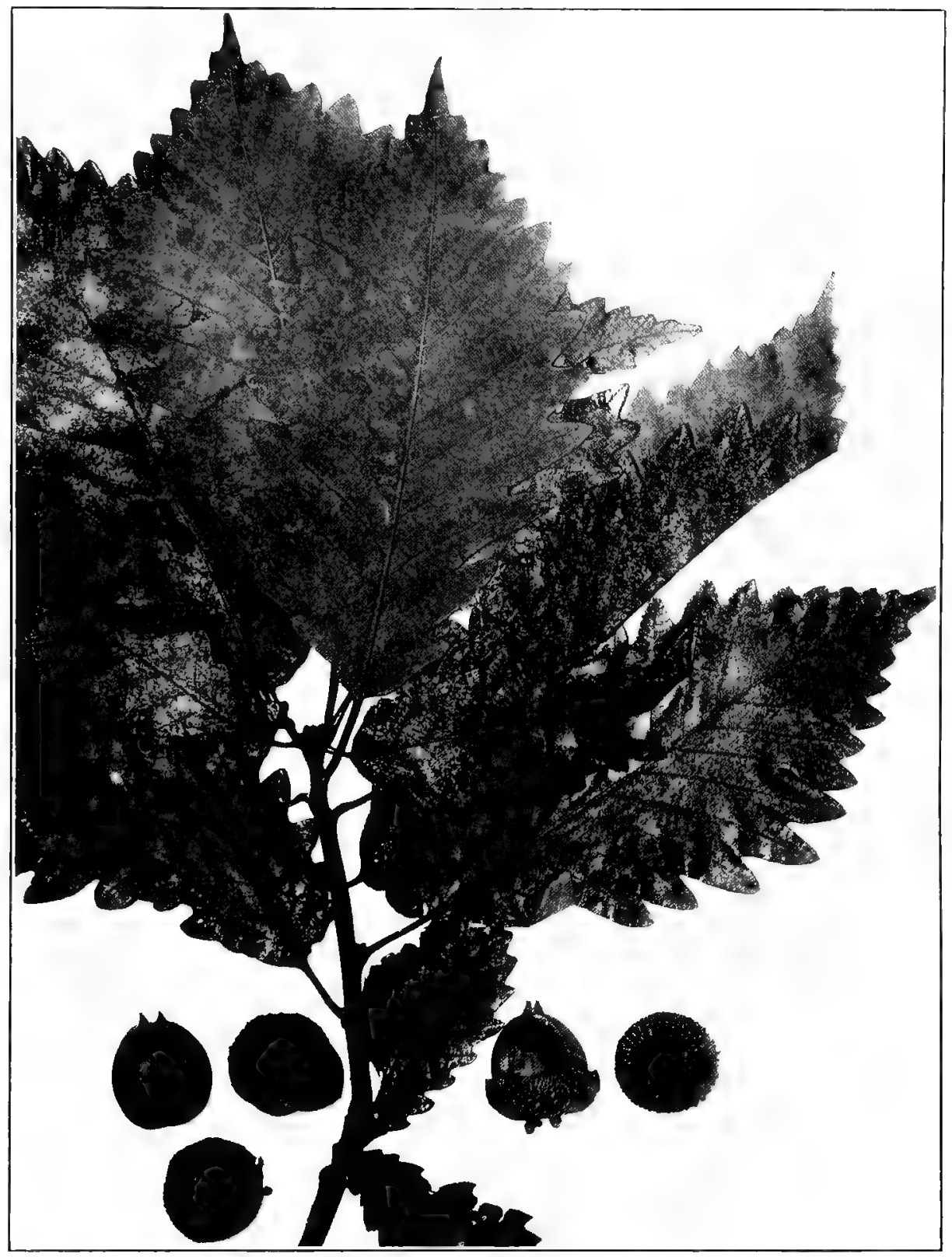

QUERCUS MICHAUXII Nuttall. Cow or Basket OAK. ( $\begin{array}{ll}x & 1 / 2 .)\end{array}$ 
Distribution.-Delaware, southern Indiana, Missouri, south to Florida and west to Texas. In Indiana it is believed that its distribution is pretty well known and well defined. It is an inhabitant of low wet woods, although large trees may be found in fairly dry woods which have been made dry by drainage. In discussing the distribution it must be remembered that this species was reported as Quercus Prinus before the sixth edition of Gray's Manual which was published in 1890. Gorby's reference to Miami County should be ignored, because he compiled his list of trees from a list of common names to which he appended the scientific names. His list includes several species which are not native, and his water willow (Dianthera americana) is an herbaceous plant. Wilson's ${ }^{2}$ report for Hamilton County I believe also to be an error. Wilson preserved no specimen. Since Hamilton County has no cow oak habitat, and Wilson was not acquainted with the species, I think this reference should be transferred to the broadleaf form of Quercus Muhlenbergii. The author has collected and distributed authentic specimens from a point $2 \frac{1}{2}$ miles southwest of Napoleon in Ripley County. This species is reported by Meyncke for Franklin County as scarce, and by Collins for Dearborn County. Since the habitat of the species is found in these counties, it is fair to admit them into the range of the specles. This specles is a frequent to a very common tree in the flats of Clark, Scott, Jefferson, Jackson, Jennings, and Ripley Counties, where it is usually associated with beech and sweet gum. It is now known to range as far north as the northern parts of Jackson, Jennings and Ripley Counties. It is an infrequent tree of the Lower Wabash Valley as far north as southern Knox County and no doubt followed eastward along White River. It follows the Ohio River east ward at least to a point six miles east of Grandview in Spencer County. It no doubt was an occasional tree along the Ohio River up to Dearborn County. It has also been reported by Aiken for Hamilton County, Ohio. In the Lower Wabash Valley it is associated with Spanish and pin oak.

Remarks.- Wood and uses similar to white oak. In the flats of southeastern Indiana it is generally called white oak, and in some places it is known as bur oak. It grows very rapidly and to a large size. A tree was measured in 1919 in the Klein woods about 4 miles north of North Vernon that was 3.57 meters (11 feet, 7 inches) incircumference, breast high, and was estimated to be $15 \mathrm{~m}$. (50 feet) to the first branch.

This species when grown in the open forms a large oval head, and in moist soil would make one of the best shade and roadside trees to be had.

1689. Ciorby: Trees and shrubs indigenous to Miami County, Ind. Geol. Rept. 16:168-170: 1889.

${ }_{2}$ Wilson: Flora of Hamilton and Marion Countics. Indiana. Proc. Ind. Acad. Science. $1804: 156-176: 1895$. 
It is not known how it would adapt itself to high ground, but it is believed this species is worthy a trial as a shade tree. It is apparently hardy in the northern counties.

Quercus Bèadlei Trelease. (Quercus alba x Michauxii). This hybrid between the white and cow oak was found by the writer in 1913 in the White River bottoms 3 miles east of Medora in Jackson County.

The tree measured 3.54 meters (139 inches) in circumference breast high. Sperimens were distributed under No. 19,037, and the determination was made by William Trelease, our leading authority on oaks.

5. Quercus Prinus Linnæus. (Quercus montana Willdenow of some recent authors). Chestiut OAK. Plate 44. Medium to large sized tree; bark dark, tight, deeply fissured, the furrows wide, and the ridges continuous; leaves on petioles 1-3 cm. long, 1-2 dm. long, obovate to lanceolate, those growing in the shade usually the widest, rounded at the base, usually narrowly so or even wedge-shaped, short or long taperpointed at the apex, the apex blunt, margins coarsely and nearly regularly crenate-toothed, the teeth broad and rounded, dark green above at maturity, a lighter and usually a yellow or grayish green beneath, only slightly hairy above when young, soon becoming entirely glabrate, very pubescent beneath when young and usually remaining so until maturity; petioles, midrib and primary veins beneath are usually conspicuously yellow, which is a distinctive character of this species; acorns solitary or in pairs, on short stalks usually about $1 \mathrm{~cm}$. long, sometimes sersile; nuts large ovoid or oblong-ovoid, $2-3 \mathrm{~cm}$. long, enclosed generally for about $1 / 3$ their length in a thin cup; scales with triangular blunt tips, generally somewhat tuherculate and pubescent on the back; kernel sweet.

Distribution. - Maine, northern shore of Jake Erie, to west central Indiana and south to northern Georgia and Alabama. In Indiana its distribution is limited to the knobstone and sandstone area of the State. Its distribution has been fairly well mapped. Two large trees on the edge of the top of the bluff of the Ohı River at Marble Hill which is located in the south corner of Jefferson County is the eastern limit of its range. It crowns some of the ridges, sometimes extending down the adjacent slopes a short distance, from Floyd County north to the south side of Salt Creek in Brown County. Its range then extends west to the east side of Monroe County, thence southwestward to the west side of Martin County, thence south to the Ohio River. Where it is found it is generally such a common tree that the areas are commonly called rhest nut oak ridges and are regarded as our poorest and most stony land. In Floyd and Clark counties it is usually associated with scrub pine. In the remainder of its range it is generally associated with black jack 
Plate 4 .

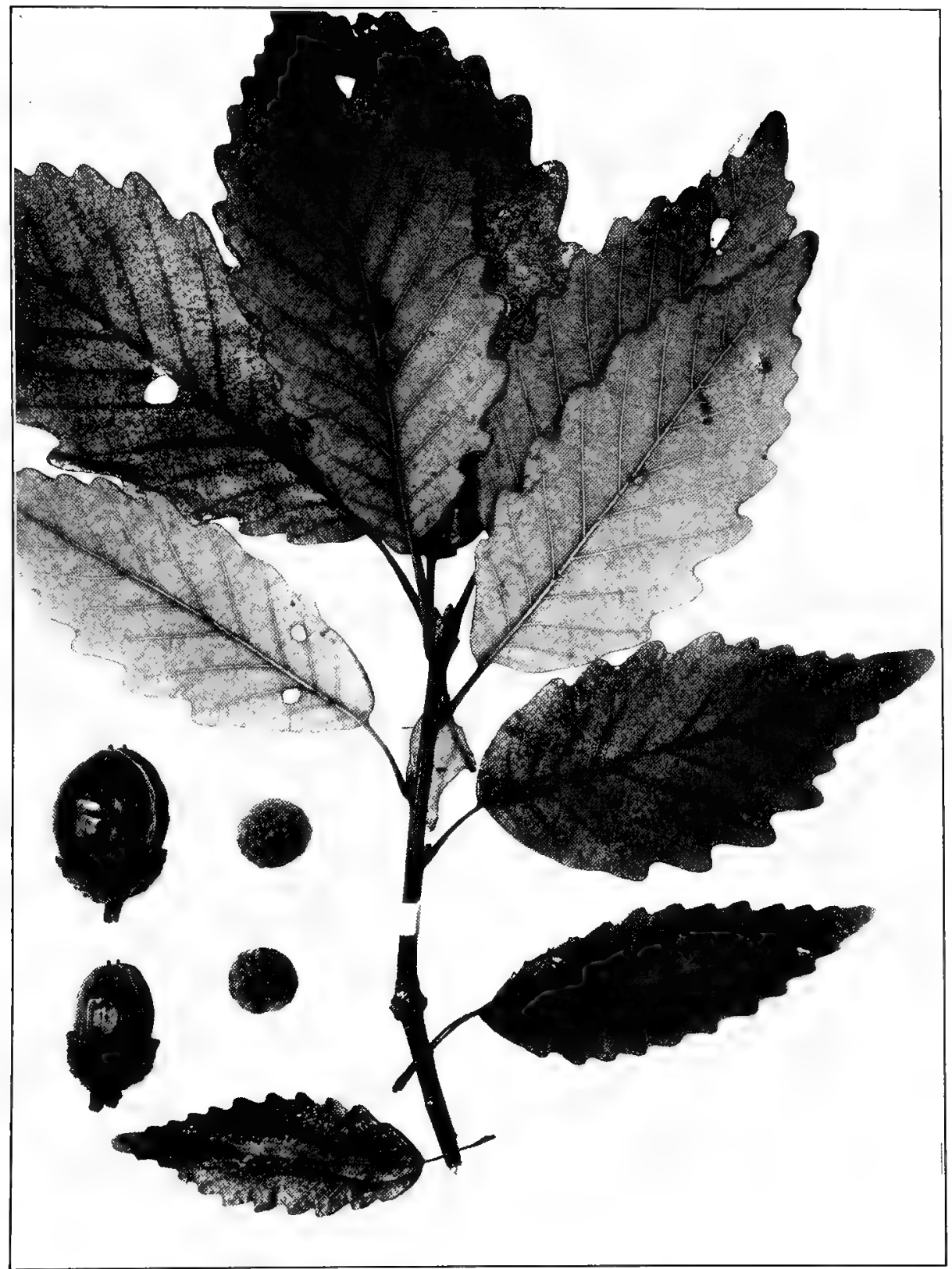

QUERCUS PRINUS Linnæus. ChestNUT OAK. ( $x$ l/2.) Acorns and loose leaves from different trees. 
post and black oaks. In our area this species is never found closely associated with limestone, and reports of this species being found on limestone areas should be referred to Quercus Muhlenbergii.

Remarks. - Wood similar and uses generally the same as white oak. The tree usually grows in such poor situations that it never acquires a large diameter, and it is only when a tree is found in a cove or in richer and deeper soil that it grows to a large size. The amount of this species is very limited and it is therefore of no especial economic importance as a source of timber supply. The bark is rich in tannin. The crests of chestnut oak ridges are often cut bare of this species. The trunks are made into cross ties, and the larger branches are peeled for their bark. The nuts germinate on top of the ground as soon as they fall, or even before they fall. Usually a large percentage germinate. The tree grows rapidly where soil conditions are at all favorable. It is believed that this species should be used to reforest the chestnut oak ridges of the State, and possibly it would be one of the best to employ on the slopes of other poor ridges.

6. Quercus stellàta Wangenheim. Post OAK. Plate 45. Medium to large trees; bark resembles that of the white oak except on old trees the fissures are deeper when compared with a white oak of equal size, and the ridges are usually broken into shorter lengths; twigs stout, yellowish-brown at first, remaining this color more or less to the end of the season, at first densely covered with hairs which remain throughout the season, and usually one year old branchlets are more or less tomentose; leaves on hairy petioles $0.3-3 \mathrm{~cm}$. long, generally about $1 \mathrm{~cm}$. long; leaves obovate in outline, commonly $1-2 \mathrm{dm}$. long and about $2 / 3$ as wide, and generally lobed into five princupal lobes which are disposed as follows: the two basal are formed by two deep sinuses just below the middle of the leaf. which cut off a large roughly triangular portion, one angle of which forms the base, the top two angles prolonged on each side into a rounded lobe which may be long or short; the terminal lobe is produced by two deep sinuses which constrict the blade at about $1 / 4-1,3$ its length from the apex; the two basal and two terminal sinuses form the two lateral lobes which in size are equal to about one half of the leaf area; the lateral lobes are generally ascending with the terminal portion usually inclented with a shallow sinus which produces two short lobes; the terminal lobe of the leaf commonly has two or three shallow secondary lobes; all the lobes of the leaf are rounded; base of leaf narrowed or rounded; leaves very thick at maturity, when they first appear both surfaces are densely covered with a yellowish pubescence, at maturity the upper surface is a dark glossy green, and smooth or nearly so, except some leaves retain fascicles of hairs, and the midrib 
Plate 45.

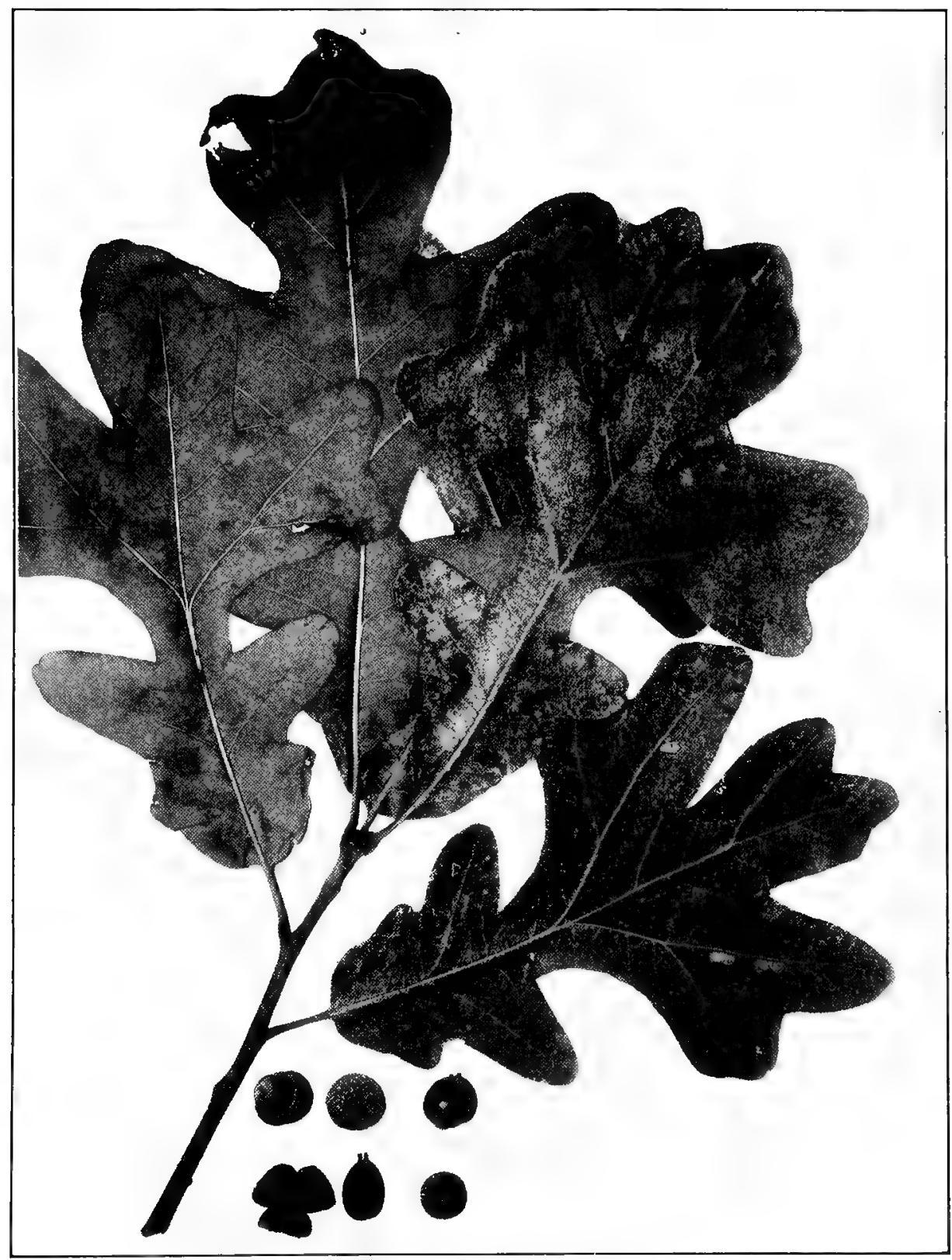

QUERCUS STELLATA Wangenheim. Post OAk. ( $\mathrm{x}$, 后. Acorns from different trees. 
and principal veins may be more or less rough pubescent, the under surface at maturity is a gray-green, and remains more or less densely covered with fascicles of hairs; acorns single or in clusters, sessile or nearly so; nuts small, ovoid 10-15 $\mathrm{mm}$. long and $6-10 \mathrm{~mm}$. wide, inclosed for about $1_{2}$ their length in the cup; scales ovate, gray or reddish brown, tomentose on the back, blunt except those near the top of the cup which are sometimes acute; kernel sweet.

Distribution.-Massachusetts, Indiana, south to Florida, and west to Oklahoma and Texas. In Indiana it is confined to the southwestern part of the State. In our area it is found on the crest of ridges in the knob area where it is generally associated with black, and black jack oaks, hence in our poorest and thinnest soils. West of the knob area it takes up different habitats. From Vigo County southward it is found on sand ridges associated with black and black jack oaks. West of the knob area it is frequently found in black oak woods and in Warrick County about two miles southwest of Tennyson it is a frequent tree in the Little Pigeon Creek bottoms which are a hard light clay soil. Here it is associated with pin oak and cork elm (Ulmus alata). In the Lower Wabash Valley, especially in Point Township of Posey County in the hard clay of this area it is a frequent to a common tree, associated with Spanish, pin, swamp, white and shingle oaks, and sweet gum. In this area it grows to be a large tree.

This species has been reported for Hamilton County by Wilson, but I regard this reference a wrong identification which will relieve Hamilton County of the reputation of having "post oak" land. It was reported, also, by Gorby for Miami County. Since Gorby's list is wholly unreliable, it is best to drop this reference. Higley and Raddin ${ }^{1}$ reported a single tree near Whiting. Nieuwland ${ }^{2}$ reported this species from near Mineral Springs in Porter County, the report being based on his number 10,207 which I have not seen. There is no reason to doubt these references, because it is not an unusual thing to find a southern form jump from southern Indiana to a congenial habitat about Lake Michigan.

Remarks. - Wood is similar but tougher than white oak, and its uses are the same as white oak. Since in our area the tree is usually medium sized, most of the trees are worked up into crossties. A tree in a black oak woods 4 miles east of Washington in Daviess County measured 2.22 meters ( $871 / 2$ inches) in circumference breast high. This species in some localities is called iron oak, and in Gibson County on the sand dune area it is called sand bur oak.

\footnotetext{
${ }_{1}$ Higley and Raddin: Flora of Cook County Illinois, and a part of Lake County Indiana. Bul. Chicago Acad. Sci. Vol. 2: 106:1891.

2. Nieuwland: Notes on our local flora. Amer. Mid. Nat. Vol. 3:230:1914.
} 
Plate 4 li.

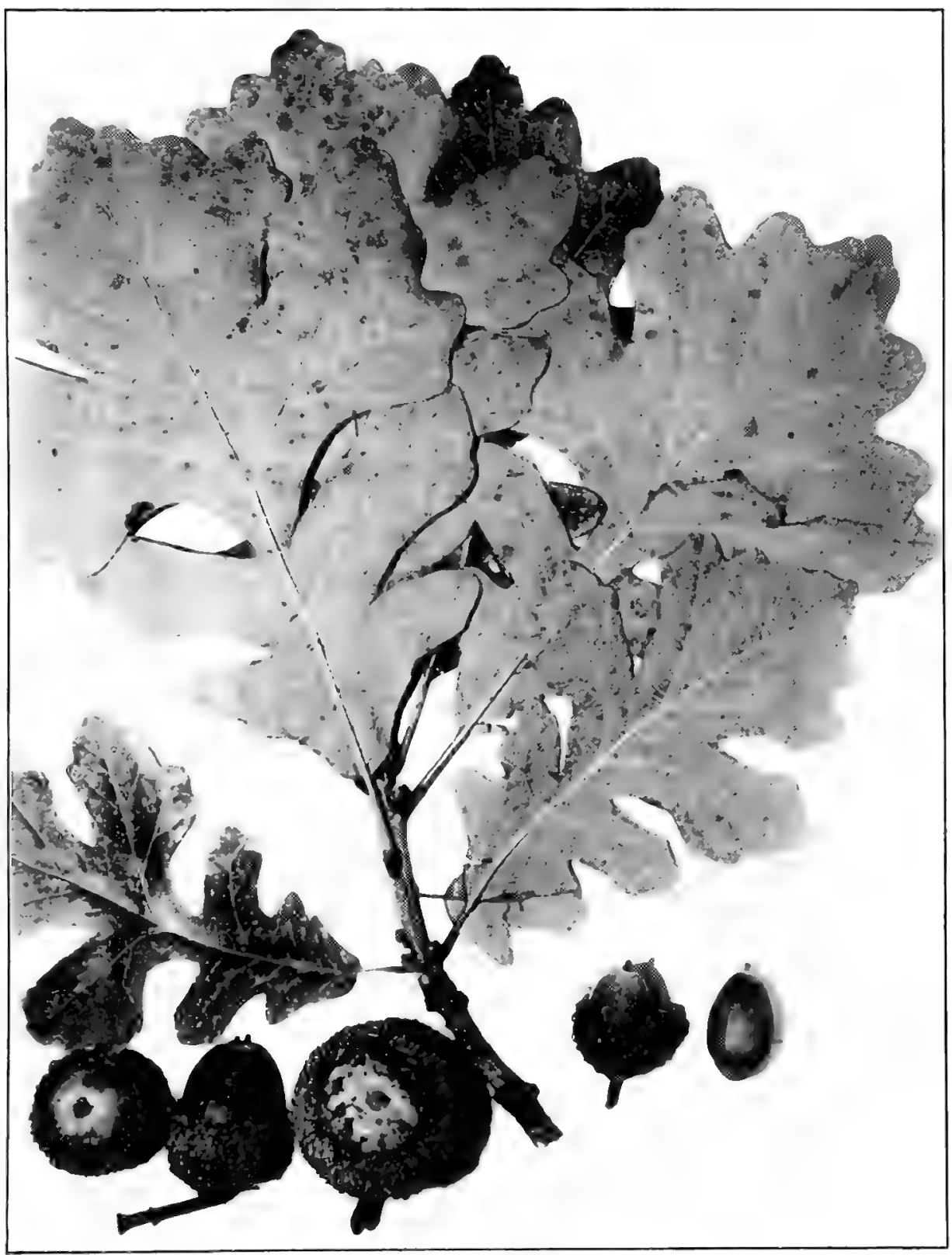

()UERCUS MACROCARPA Michaux. BUR OAK. (x 1/2.) Acorns from different trees.

The right two belong to the variety OLIV AEFORMIS. 
7. Quercus macrocàrpa Michaux. BUR OAK. Plate 46. Large trees; branchlets of young trees generally develop corky wings which are usually absent on mature trees; leaves on petioles $1-2 \mathrm{~cm}$. long, obovate in outline, generally $1-2.5 \mathrm{dm}$. long, the margins more or less deeply cut so that there are usually 7 lobes, sometimes only 5 , or as many as 9 or 11 , sometimes the sinuses extend to the midrib, giving the leaf a "skeleton" appearance, the lobes are very irregular in shape and variously arranged, but often appear as if in pairs, lobes rounded and ascending, the larger lobes are sometimes somewhat lobed, the three terminal lobes are usually the largest and considered as a whole would equal in size one half or more of the entire leaf area, the base of the leaf is wedgeshape or narrowly rounded; leaves at maturity are dark green and smooth above, or somewhat pubescent along the midrib, a gray-green and woolly pubescent beneath; acoms usually solitary, sometimes in pairs or clusters of three, sessile or on short stalks, sometimes on stalks as long as $2.5 \mathrm{~cm}$; nuts very variable in size and shape, ovoid to oblong, often very much depressed at the apex, $2-3 \mathrm{~cm}$. long, enclosed from $1 / 3$ to almost their entire length in the cup which is fringed at the top; cups thick and large, sometimes $4.5 \mathrm{~cm}$. in diameter; scales tomentose on the back and somewhat tuberculate, blunt near the base of the cup, but at and near the top of the cup they become long attenuate and on some trees appear almost bristle like; kernel sweet.

Distribution.- Nova Scotia to Manitoba, south to Georgia and west to Texas and Wyoming. Found in all parts of Indiana, although we have no reports from the knob area where no doubt it is only local. It is a tree of wet woods, low borders of streams, etc., except among the hills of southern Indiana, it is an occasional tree of the slopes. In favorable habitats it was a frequent to a common tree. Its most constant associates are white elm, swamp white and red oak, linn, green and black ash, shellhark hickory, etc. It is sometimes called mossy-cup oak.

Remarks. - Wood and uses similar to that of white oak. In point of number, size and value it ranks as one of the most valuable trees of the State. Michaux says: "A tree three miles from Troy, Ohio, was measured that was fourteen feet and nine inches in diameter six feet above the ground. The trunk rises about fifty feet without limbs, and with scarcely a perceptible diminution in size."

7a. Quercus macrocarpa var. olivaefórmis (Michaux filius) Gray. This varicty is distenguished from the typical form by its shallow cup, and the long oval nut which is often $3 \mathrm{~cm}$. long. The cup is semihemispheric, and encloses the nut for about one-half its length. 
Authentic specimens are at hand from Wells County, and it has been reported from Gibson and Hamilton Counties. No doubt this form has a wider range.

8. Quercus lyràta Walter. Overcup OAK. Plate 47. Medium sized trees; bark generally intermediate between that of the swamp white and bur oak; leaves on petioles $5-30 \mathrm{~mm}$. long which are generally somewhat reddish toward the base, $10-20 \mathrm{~cm}$. long, obovate or oblongobovate, margins very irregularly divided into 5-9 short or long lobes, ascending and generally acute, ordinarily the three terminal lobes are the largest, base of leaves wedge-shape, or narrowly rounded, upper surface at maturity dark green and smooth, the under surface densely covered with a thick tomentum to which is added more or less long and single or fascicled straight hairs; when the leaves are as described on the under surface they are gray beneath; however, a form occurs which is yellow green beneath and has little or no tomentum, but is thickly covered with long single or fascicled straight hairs; acorn single or in pairs, on stalks generally about $1 \mathrm{~cm}$. long, sometimes the stalks are $3 \mathrm{~cm}$. long, the stalk lies in a plane at a right angle to the base of the acorn which is a characteristic of this species; nut depressed globose, about $1.5 \mathrm{~cm}$. long, generally almost completely enclosed in the cup, or sometimes enclosed only for about $2 / 3$ its length; cup generally very thick at the base, gradually becoming thinner at the top, and often it splits open; scales tomentose on the back, those near the base, thick and tuberculate on the back and blunt, but those near the top of the cup are acute or long attenuate; kernel sweet.

Distribution.-Maryland to Missouri, ${ }^{2}$ and south to Florida and west to Texas. In Indiana it is found only about river sloughs or deep swamps in the southwestern counties. At present it is known only from Knox, Gibson, Posey and Spencer Counties. It was reported by Nieuwland ${ }^{2}$ for Marshall County on the authority of Clark. This specimen was taken during a survey of Lake Maxinkuckee, and is deposited in the National Museum. I have had the specimen examined by an authority, who reports that it is some other species. Its habitat is that of areas that are inundated much of the winter season. It is so rare that its associates could not be learned. In one place it grew in a depression lower than a nearby pin oak, and in another place it grew in a depression in a very low woods, surrounded by sweet gum, big shell bark hickory, and pin oak. It is generally found singly in depressions, but it is a common tree on the low border of the west side of Burnett's pond in Gibson County.

Remarks. - Wood and uses similar to that of white oak. In our area it is usually known as bur oak.

Nieuwland: Notes on our local flora. Amer. Mid. Nat. Vol. 3:230:1914.

12Prof. B. Shimek told me that recently a few trees were found about 30 miles west of Iowa City, Iowa. 
Plate 47.

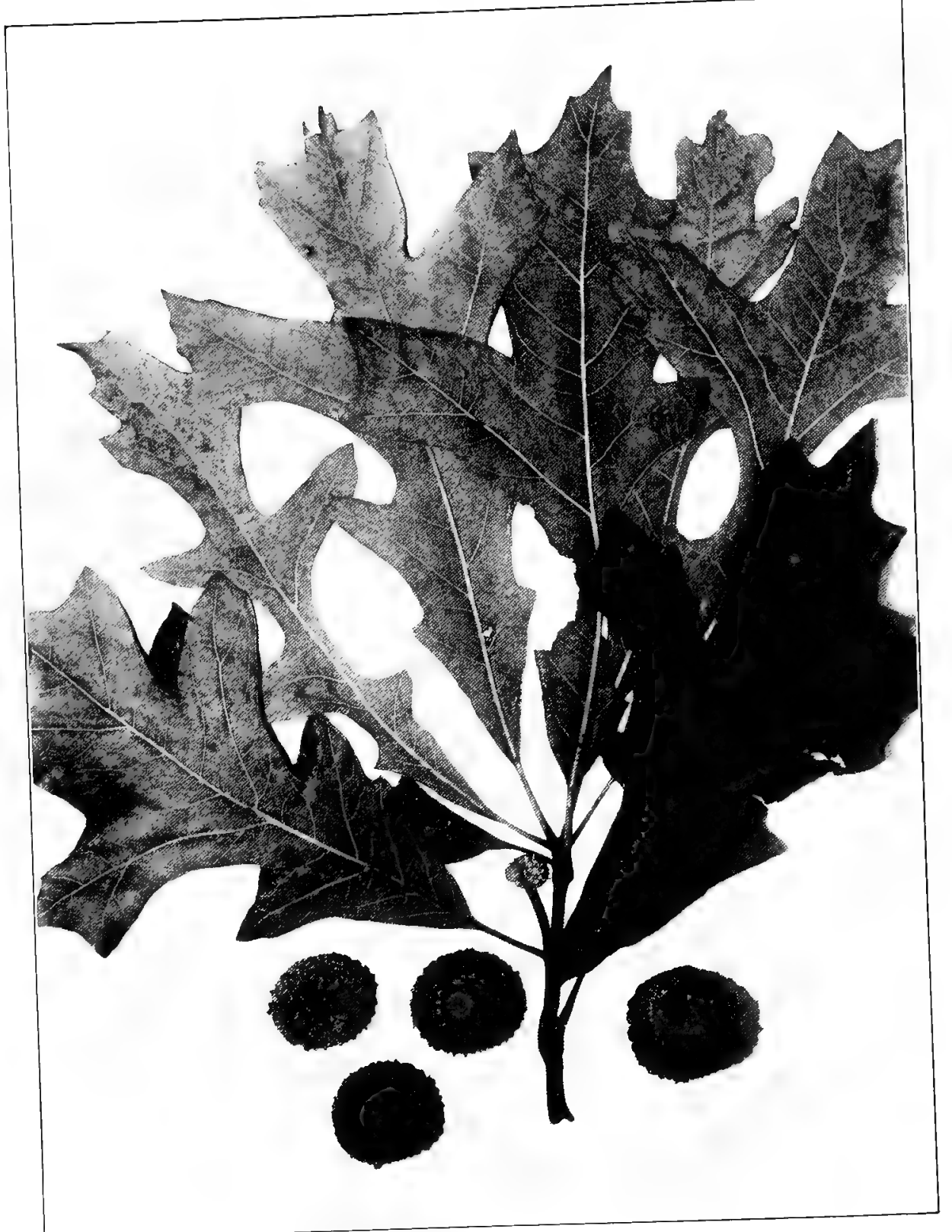

QUERCUS LYRATA Walter. OVERCUP OAK. (x 1/2.) Acorns from different trees. 
9. Quercus imbricària Michaux. Shingle OAK. Plate 48. Medium to large sized trees; leaves on petioles generally $0.5-1 \mathrm{~cm}$. long, $7-16 \mathrm{~cm}$. long, elliptic to oblong-lanceolate, narrowed or rounded at the base, apex generally sharp-pointed and ending with a bristle, sometimes very wide leaves are blunt at the apex, margins entire, when they first appear the upper surface is somewhat woolly and the under surface whitish with a dense tomentum, soon glabrous and a dark green above, remaining more or less densely woolly or pubescent beneath; acorns sessile or nearly so, solitary or in pairs; nuts ovoid, about $1 \mathrm{~cm}$. long and enclosed for about $1 / 2$ their length in the cup; cup rounded at the base; scales pubescent on the back and obtuse.

Distribution.- Pennsylvania, Michigan to Nebraska, south to Georgia and west to Arkansas. Found throughout Indiana. It is essentially a tree of low ground, but it is sometimes found near the base of slopes, and in the knob area it is sometimes found on the crest of ridges. In all parts of Indiana except the southwestern part it is found only locally and then usually in colonies of a few trees. In Wells County, I know of only two trees located at the base of a slope bordering a pond in Jackson Township. In the southwestern part of the State it is frequent to a common tree in its peculiar habitat. It appears that when drainage basins decrease in size, and leave sandy river bottoms, and bordering low sand dunes, that the shingle oak is the first oak to occupy the area. On the sand ridges it is crowded out by the black, black jack and post oaks. In the bottoms it is succeeded by pin, Schneck's, Spanish, swamp white and post oaks. Special notes were made on its distribution on a trip through Gibson, Pike, Daviess, Greene and Sullivan Counties, going from Francisco northward through the Patoka bottoms where in many places it forms pure stands. Usually in situations a little higher than the pin oak zone. Thence eastward to Winslow and then north to Sandy Hook in Daviess County, thence north to Washington, Montgomery, Odon, Newberry, Lyons, Marco and Sullivan. In its habitat all along this route it was a frequent to a very common tree. A few miles northeast of Montgomery is a small area. which a pioneer informed me was originally a prairie. Typical prairie plants are yet found along the roadside and fences in the area. I was informed that the shingle oak was the only species found on the area, and on the border of the area. It is believed the mass distribution of the species was in the area indicated by the preceding route. Both east and west of this area the species becomes less frequent.

Remarks. - Wood similar to red oak, but much inferior. Evidently it is rather a slow growing tree, but it might find a use as a shade or ornamental tree in sandy habitats where the pin oak would not thrive. It is also called black oak, peach oak, jack oak and water oak. 
Plate 48.

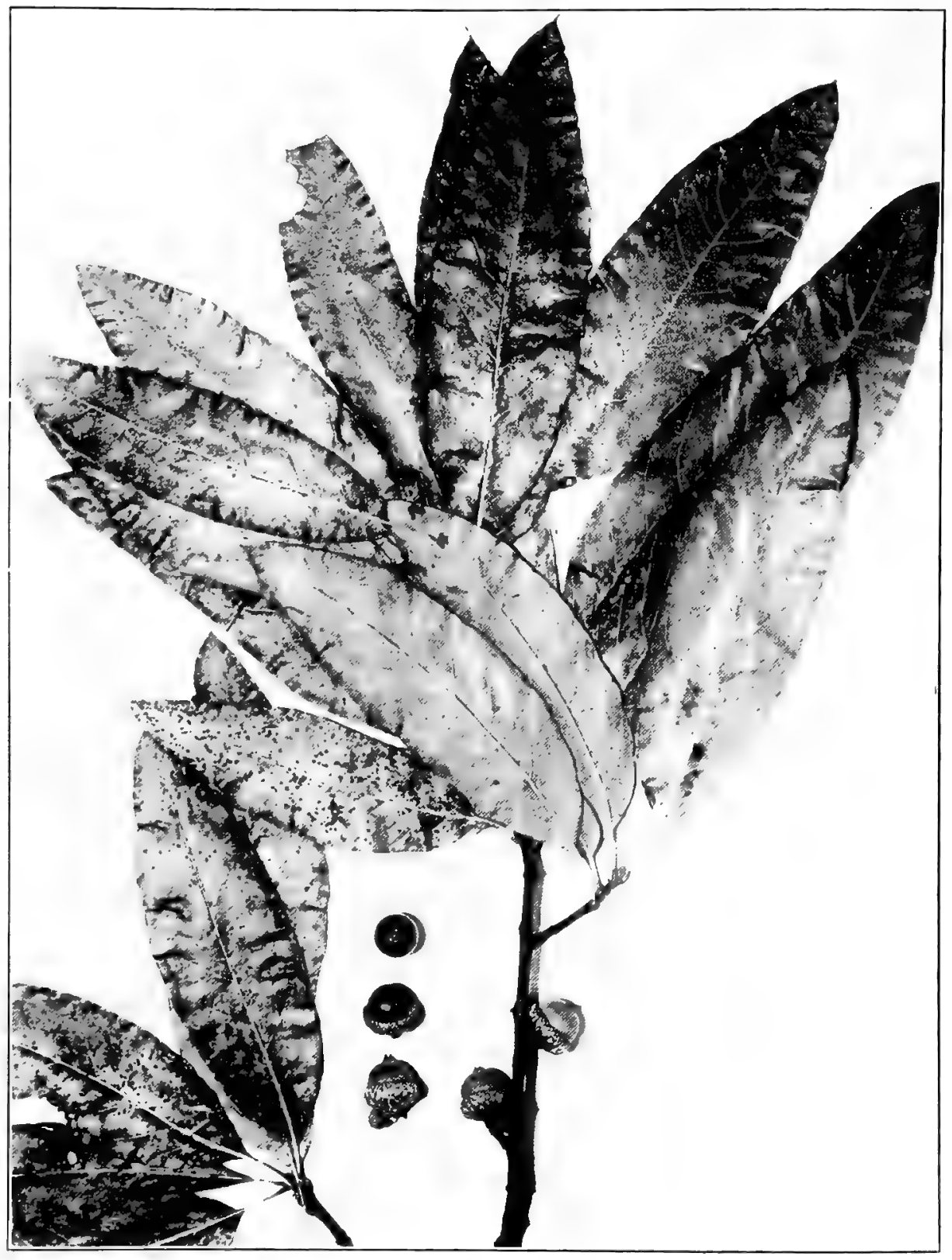

QUERCUS IMBRICARIA Mirhaux. Shingle OAK. (x $1 / 2$.) 
10. Quercus rùbra Linnæus. [Quercus maxima (Marshall) Ashe of some recent authors]. RED OAK. Plate 49. Large trees; winter buds ovoid, pointed, reddish, outer scales glabrous, sometimes pubescent on the edges; twigs soon smooth and reddish; leaves on petioles $2.5-5 \mathrm{~cm}$. long, $10-20 \mathrm{~cm}$. long, oval to oblong-obovate, broadly wedgeshape or truncate at the base, the margins divided by wide or narrow sinuses generally into 7-9 lobes, sometimes as many as 11, the lobes not uniform in size or shape, lobes broadest at the base and ending generally in 1-5 bristle points, pubescent above and below at first, soon becoming smooth at maturity and a dark green above, paler and yellowish-green beneath and smooth or with tufts of tomentum in the axils of the veins; acorns solitary or in pairs, sessile or on very short stalks; nuts ovoid, flat at the base, and rounded at the apex, $2-3 \mathrm{~cm}$. long, enclosed for about $1 / 4$ their length in the shallow cup; cups $2-3 \mathrm{~cm}$. in diameter, thick, saucer-shape, flat or only slightly rounded at the base; scales ovate, blunt, appressed, and pubescent on the back; kernel somewhat bitter, eaten by hogs and cattle, but not relished by wild animals.

Distribution.-Nova Scotia to Minnesota, south to Florida and west to Texas. Found throughout Indiana, although local in the knob area. Its preferred habitat is that of moist, rich and fairly well drained woods. It does not thrive in situations that are in undated much of the winter season such as the pin oak will endure. In the southern part of the State, especially in the flats it is frequently found on the high bluffs of streams and very large forest trees are frequent on a dry wooded slope of ten acres, on the Davis farm four miles south of Salem. In a. congenial habitat it was a frequent to a common tree, although such a thing as nearly a pure stand would never be met with, such as was often formed by the white, black, shingle or pin oak.

Remarks.-Wood hard, heavy, strong, close-grained, but not as good as white oak in any of its mechanical qualities. Commercially all of the biennial oaks are usually considered as red oak. The true red oak, however, is generally considered the best of all the biennial oaks. Until recently, when white oak became scarce, red oak was not in much demand, and was used principally for construction material. Now it is substituted in many places for white oak, and the uses now are in a great measure the same as those of white oak.

The red oak grows rapidly, and is able to adapt itself to many soil conditions. It has been used in European countries for two centuries for shade and ornamental planting. It reproduces easily by planting the acorns, and should receive attention by woodlot owners as a suitable species for reinforcing woodlands, or in general forest planting. 


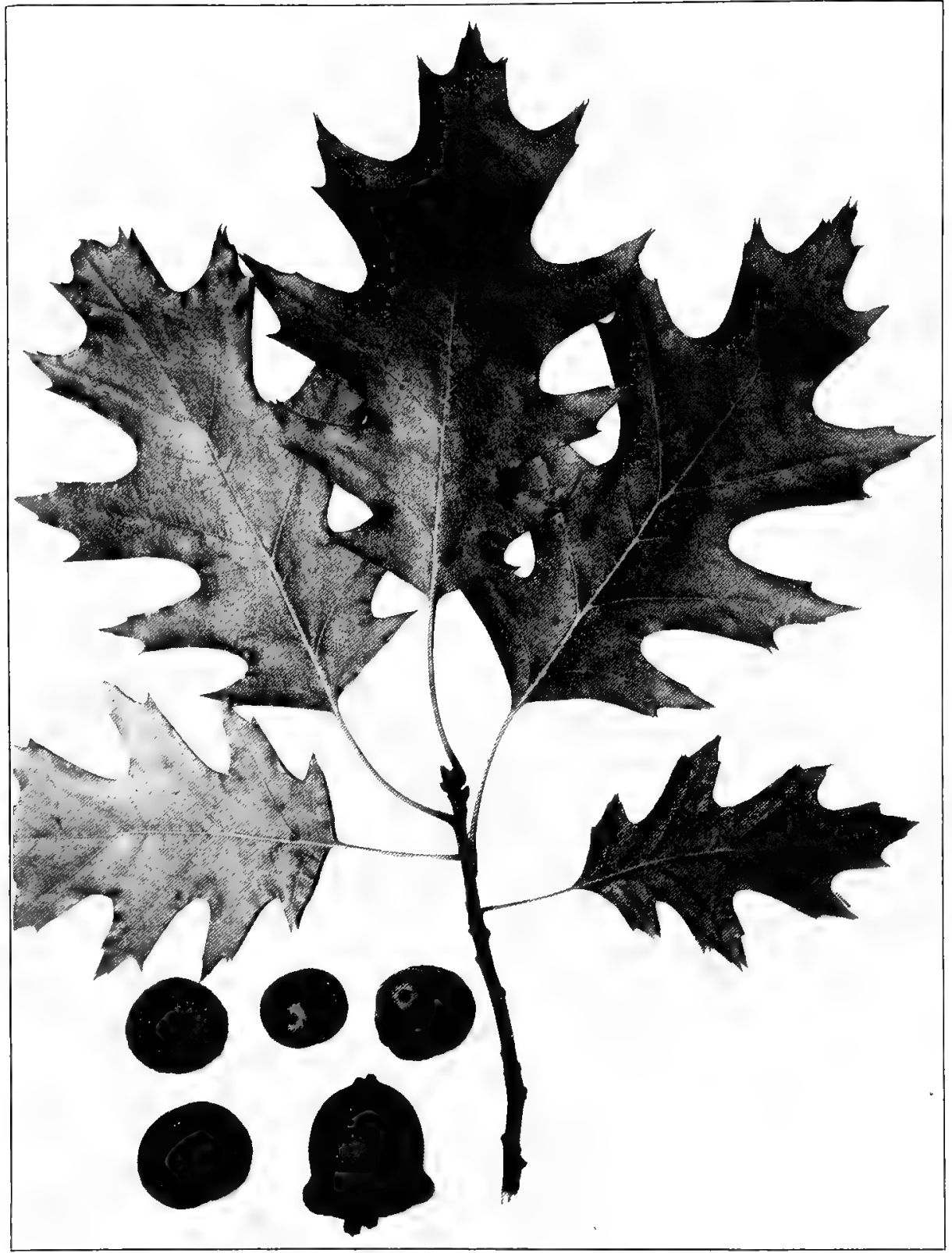

QLERCUS RUBRA_Linnæus. RED OAK. (x 1/2.) Acorns from different treses. 
11. Quercus palústris Du Roi. PIN OAK. Plate 50. Medium to large trees with very tight bark, the furrows shallow and generally wide; twigs at first pubescent, soon becoming smooth and reddishbrown; leaves on petioles generally $1-5 \mathrm{~cm}$. long, blades about 7-15 cm. long, usually about $2 / 3$ as wide, sometimes as wide as long, ovate to obovate in outline, narrowed to broadly truncate at the base, the margins divided into 5-7 lobes by deep and wide sinuses, except leaves that grow in the shade, the sinus cuts the blade to more than half way to the midrib, the lobes are widest at the base, or sometimes widest near the apex, the lobes usually somewhat toothed or lobed and end in 1-7 bristle tips, leaves hairy when they first appear, soon becoming glabrate and a glossy dark green above, a paler green beneath and smooth except tufts of hairs in the axils of the principal veins; acorns sessile or nearly so, single or in clusters; nuts subglobose or ovoid, generally $10-12 \mathrm{~mm}$. long, the ovoid form somewhat smaller, covered about $1 / 4$ their length by the shallow cups; cups saucer-shape and generally flat on the bottom, those with the ovoid nuts are rounded on the bottom; scales pubescent on the back, and rounded or blunt at the apex.

Distribution.-Massachusetts, southwestern Ontario, Michigan to Iowa and south to Virginia and west to Oklahoma. Found in every county of Indiana. It is found only in wet situations where it is a frequent to a common tree. It prefers a hard compact clay soil with little drainage hence is rarely met with on the low borders of lalies where the soil is principally organic matter.

Remarks. - Wood similar to red oak, but much inferior to it. It is tardy in the natural pruning of its lower branches, and when the dead branches break off they usually do so at some distance from the trunk. The stumps of the dead branches which penetrate to the center of the tree have given it the name of pin oak. It is also sometimes called water oak, and swamp oak.

For street and ornamental planting it is one of the most desirable oaks to use. It is adapted to a moist soil, grows rapidly, and produces a dense shade. When grown in the open it develops a pyramidal crown.

The nut of this species always has a depressed form, except a tree or two in Wells County which produce ovate nuts which are cone-pointed, and in bulk about half the size of the ordinary form. This form should be looked for to ascertain its area of distribution.

12. Quercus Schnéckii Britton. Schneck's Oak. Plate 51. Large trees; bark somewhat intermediate between pin and red oak; twigs gray by autumn; winter buds large, about $0.5 \mathrm{~cm}$. long, ovoid, glabrous and gray; leaves on petioles $2-6 \mathrm{~cm}$. long, blades generally $8-18 \mathrm{~cm}$. long, generally truncate at the base, sometimes wedge-shaped, 
Plate .ju.

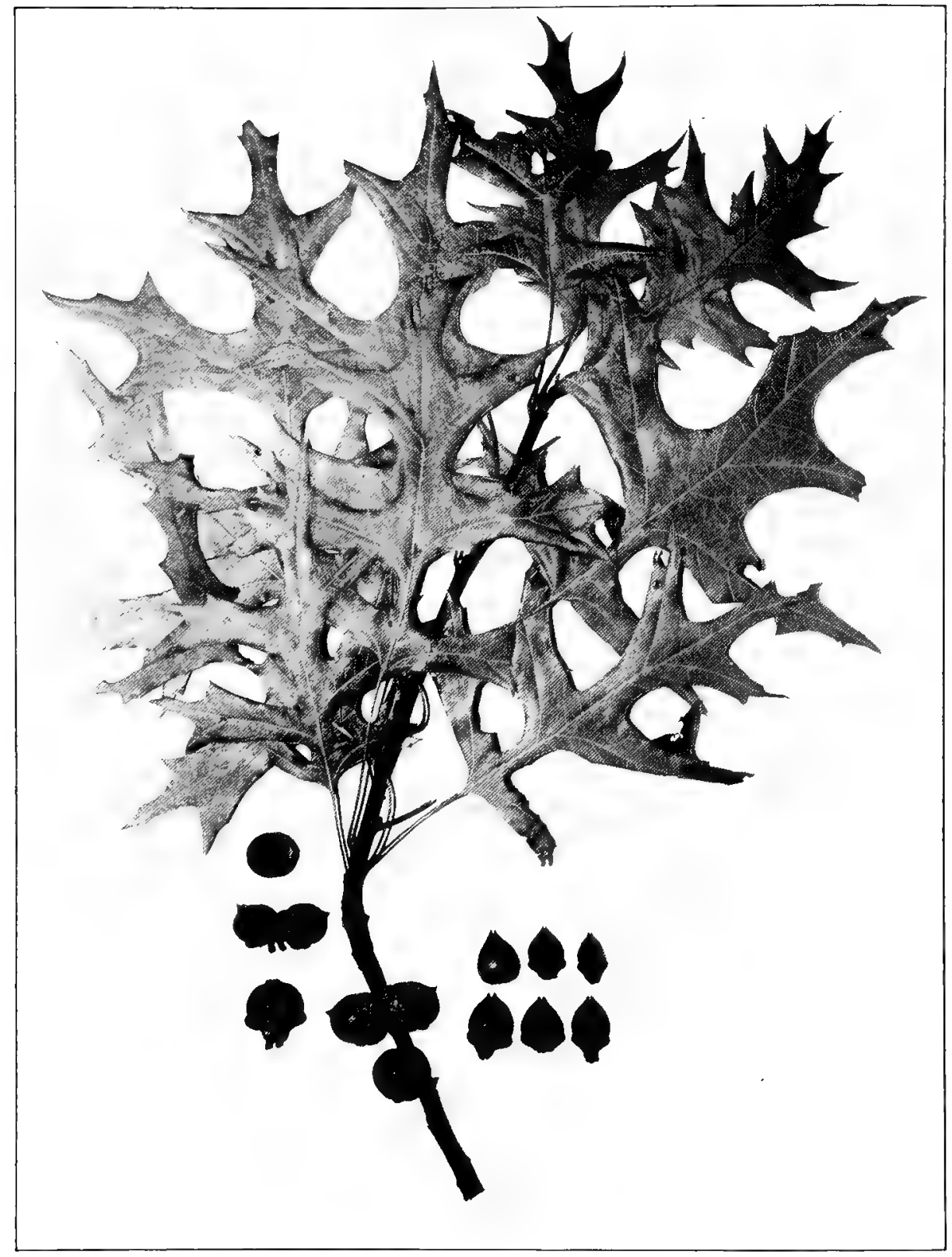

QUERCUS PALUSTRIS Muenchhausen. ( $x$ 1/2.)

Acorns from different trees. Those on the left the common form, those on the right the rare form. 
PLATE 51.

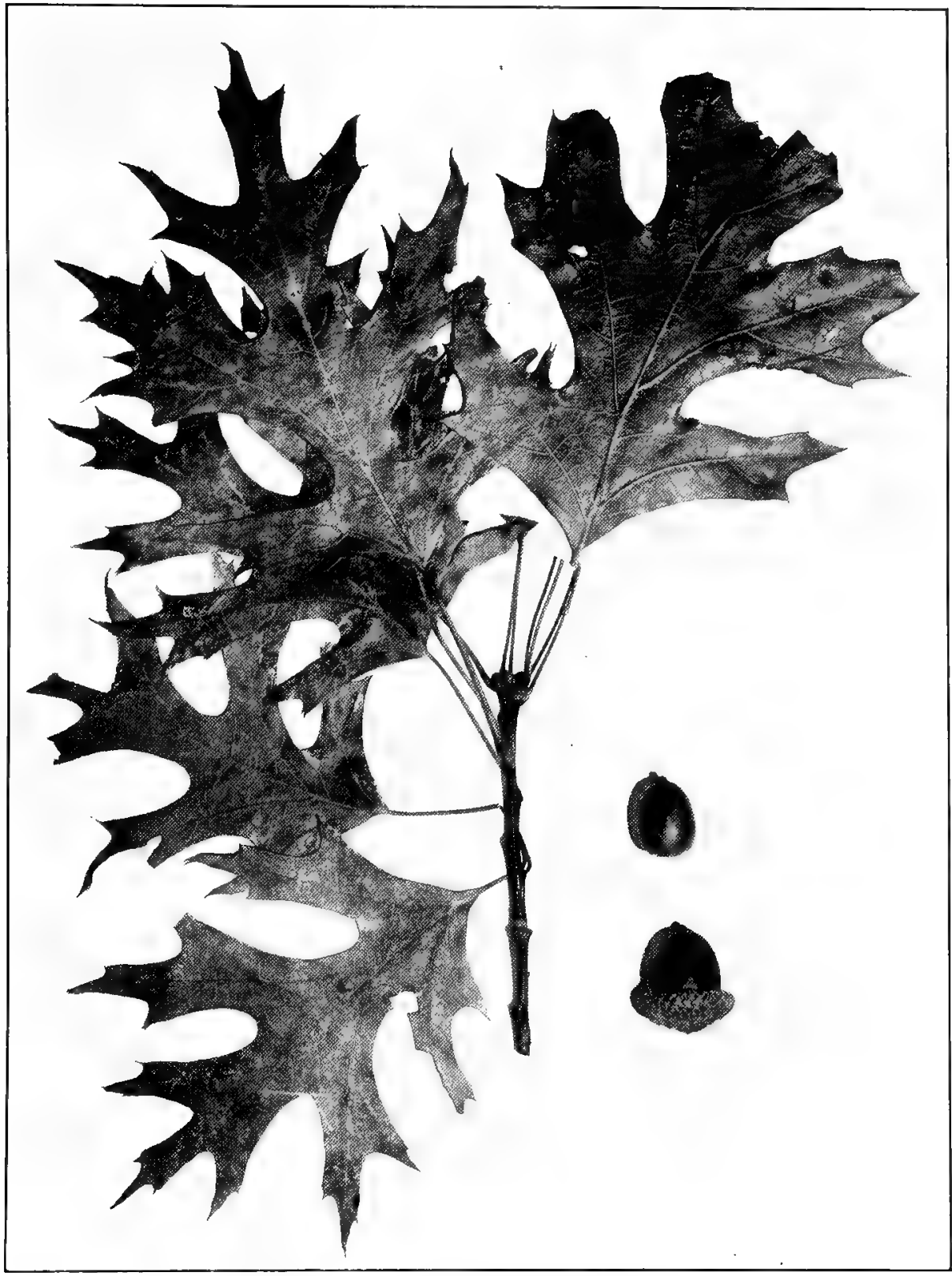

QUERCUS SCHNECKII Britton. Schneck's OAK. (x 1/2.) Specimens from type tree. 
leaves ovate to obovate in outline, divided into 5-7 lobes, by deep rounded and wide sinuses, the sinuses cutting the blade to more than half way to the midrib, except the leaves of lower branches that grow in the shade, the lobes variable in shape and size, usually the lowest are the shortest and smaller, the middle the longest and largest, the lobes are sometimes widest at the base, and sometimes widest at the apex, the end of the lobes are more or less toothed or lobed; the leaves at maturity are bright green, glossy and smooth above, a paler and yellow green and smooth beneath except tufts of hairs in the axils of the principal veins; acorns solitary or in pairs, usually on stalks about $0.5 \mathrm{~cm}$. long; nuts ovoid, sometimes broadly so, or oblong, broad and flat or slightly convex at base, usually $1.5-2 \mathrm{~cm}$. long, enclosed in the cup from ${ }^{1}-1 / 3$ their length; cups flat or convex at the base: scales generally pubescent on the back, gray or with a reddish tip on those of the Lower Wabash Valley, or reddish gray and with margins more or less red of trees of the Upper Wabash Valley.

Distribution.- In Indiana this species has been reported only from Wells, Bartholomew, Vermillion, Knox, Gibson and Posey Counties. This species was not separated from our common red oak until after all of the local floras of Indiana had been written, and it may have a much wider range than is at present known. In Wells County it is the prevailing "red oak" of the county, and no doubt is distributed throughout the Wabash Valley. In this area it is associated with all moist ground species. In the lower Wabash Valley, especially in Gibson, Knox and Posey Counties it is assoriated with Spanish, pin, and shingle oaks, sweet gum, etc. Several trees were noted in Knox County in Little Cypress swamp where it was associated with cypress, pin oak, white elm, red maple and swell-butt ash.

Remarks. - This anomalous red oak has a range from Indiana to Texas. When the attention of authors was directed to it, severa] new species were the result. Later authors are not agreed as to whether this form, which has such a wide range and hence liable to show considerable variation within such a long range, is one or several species. C. S. Sargent who for years has studied this form throughout its range has seen the author's specimens and calls those with shallow cups typical or nearly typical Quercus shumardii Buckley' and those with the deep cups Quercus Shumardii variety Schneckii (Britton) Sargent.

The writer has made rather an intensive study of the forms in Wells County and in the Lower Wabash Valley and has not been able to satisfy himself that, allowing for a reasonable variation, there is even a varietal difference in Indiana forms. The description has been drawn to cover all of the forms of Indiana. 
Dr. J. Schneck of Mt. Carmel, Illinois, was one of the first to discover that this form was not our common red oak, and when he called Dr. Britton's attention to it Dr. Britton named it Quercus Schneckit in honor of its discoverer.

13. Quercus ellipsoidàlis. E. J. Hill. HILL'S OAK. Plate 52. Medium sized trees; inner bark yellowish; twigs pubescent at first, becoming smooth and reddish brown by autumn; leaves on petioles $2-5$ $\mathrm{cm}$. long, ovate to slightly obovate or nearly orbicular in outline, 7-15 cm. long, wedge-shape or, truncate at the base, margin divided into 5-7 long lobes by wide sinuses which usually extend to more than half way to the midrib, sinuses rounded at the base, lobes broadest at the base or the apex, ending in 1-7 bristle points, leaves at first pubescent, both above and below, soon becoming glabrous above, and smooth beneath except tufts of hairs in the axils of the prineipal veins; acorns nearly sessile or on short stalks, single or in pairs; nuts oval to oblong, 12-20 $\mathrm{mm}$. long, enclosed for $1 / 3-1 / 2$ their length in the cup; scales obtuse, light reddish-brown, pubescent on the back; kernel pale yellow and bitter.

Distribution.- Northwestern Indiana to Manitoba and south to Iowa. In Indiana it has been reported only from Lake and Porter Counties by Hill, and from White County by Heimlich. According to Hill, who has made the most extensive study of the distribution of this species in our area, the tree is found on sandy and clayey uplands, and in moist sandy places. It closely resembles the pin oak for which it has been mistaken. It also resembles the black and scarlet oaks. We have very little data on the range or distribution of the species in this State.

14. Quercus velùtina Lamarck. BuAck OAK. Plate 53. Medium to large sized trees; inner bark yellow or orange; leaves on petioles $2-8 \mathrm{~cm}$. long, ovate oblong or obovate, very variable in outline and in size, those of young trees and coppice shoots being very large, those of mature trees usually $12-18 \mathrm{~cm}$. long, wedge-shape or truncate at the base, the margin divided into 5-9 lobes by wide and usually deep sinuses which are rounded at the base, the lobes variable in shape and size, the terminals of many of the lobes toothed or slightly lobed and ending in one or more bristles, leaves pubescent on both sides at first, soon becoming smooth, glossy and a dark green above; leaves of fruiting branches usually smooth beneath except the tufts of brown hairs in the axils of the principal veins, or rarely more or less pubescent over the whole under surface, the under surface of leaves of sterile branches and young trees usually are the most pubescent beneath, the leaves of some trees are much like those of the scarlet oak, but on the whole are larger; acorns sessile or nearly so, single or in pairs; nuts ovoid, oblong or sub 
Plate 52.

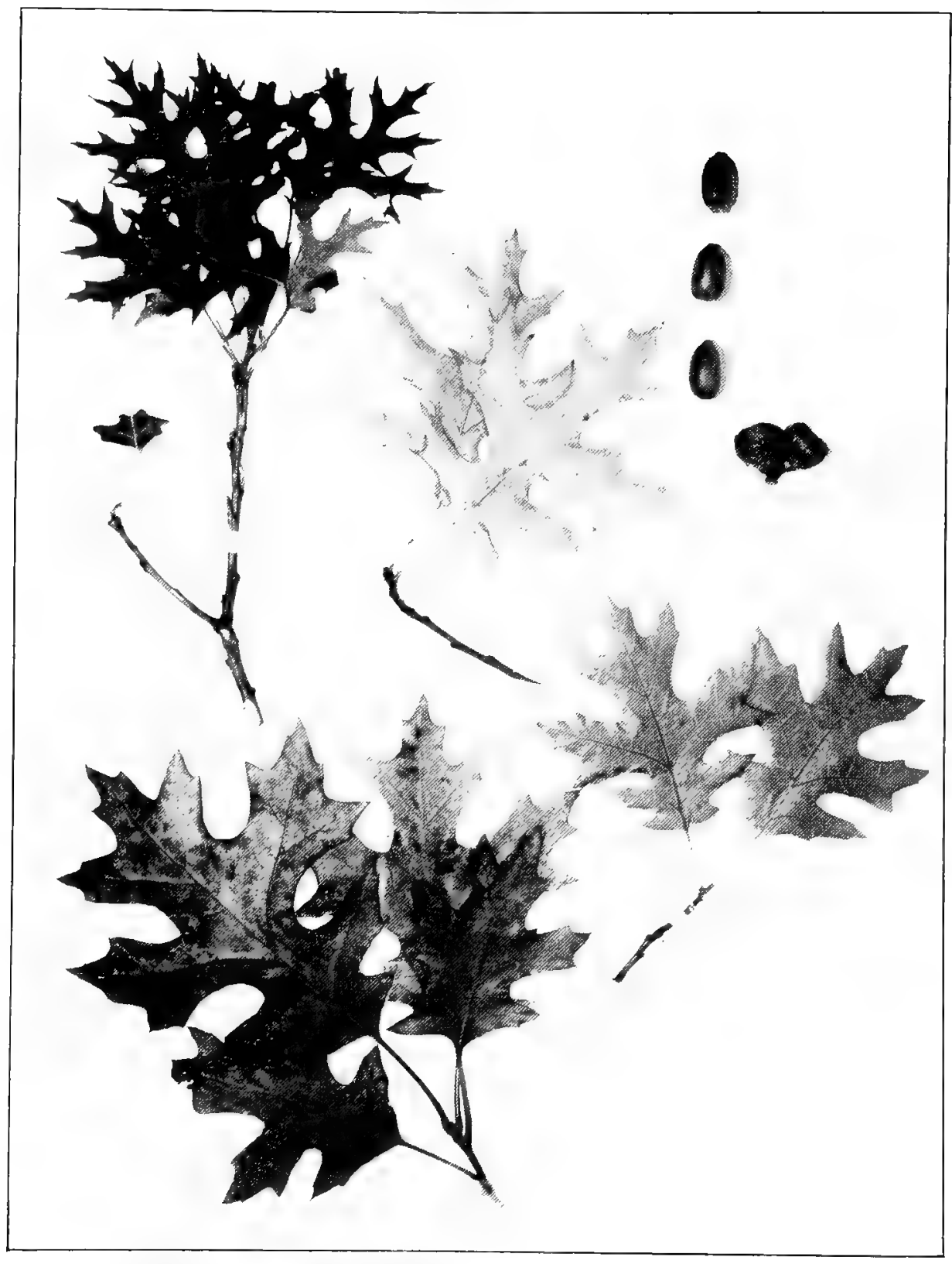

QUERCUS ELLIPSOIDALIS E. J. Hill. HILL'S OAK. (x 1/2.) sperimens from type tree. 
Plate 53.

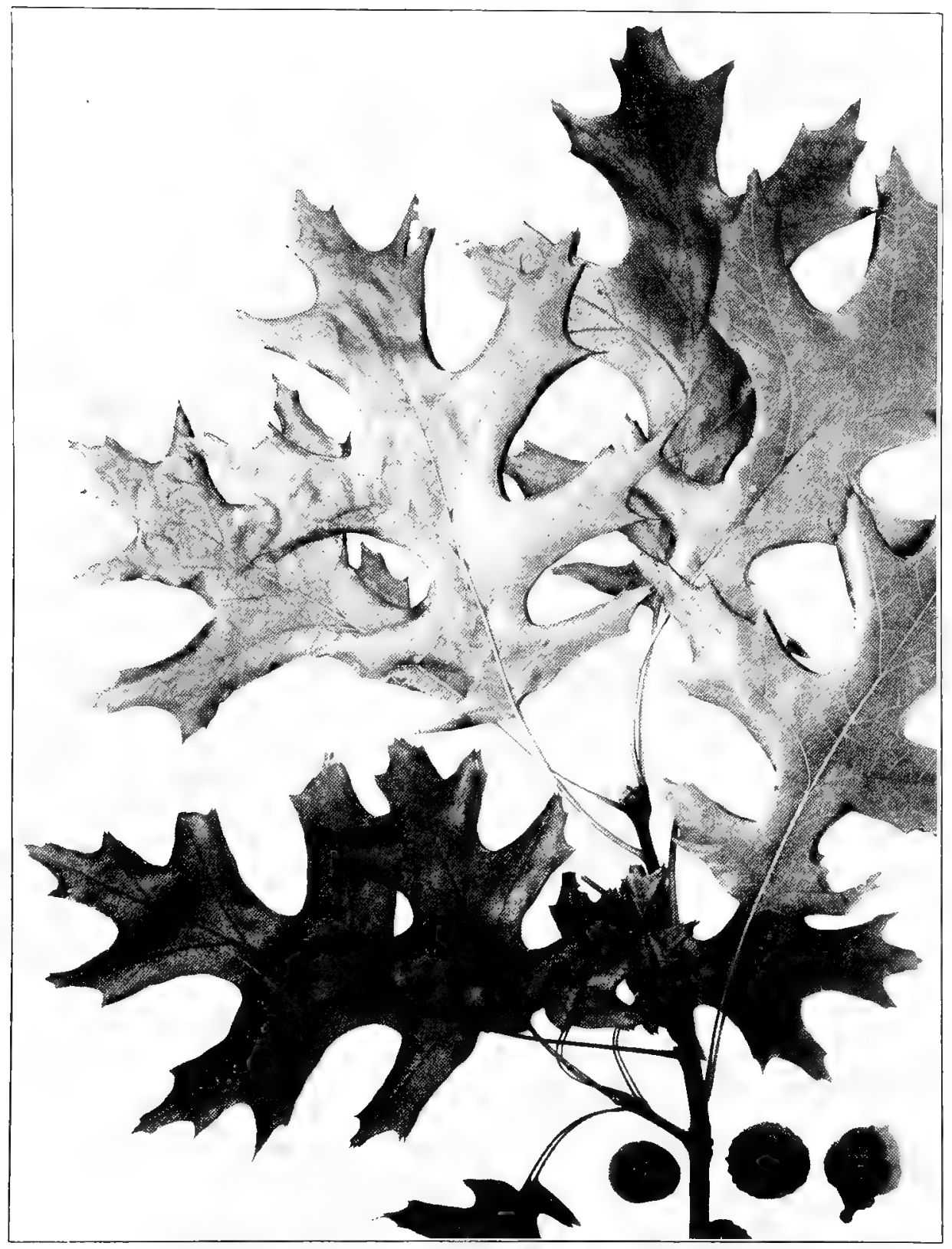

QUERCUS VELUTINA Lamarek. BLACK OAK. ( 1 1/2.) 
globose, $1.5-2 \mathrm{~cm}$. long, enclosed for about half their length in the cupshaped cup; scales light-brown, densely pubescent on the back, obtuse, loose above the middle of the cup; kernel bitter.

Distribution.-Maine, southern Ontario, southern Minnesota, southern Nebraska south to Florida and west to Texas. Found throughout Indiana. It was no doubt found in every county or nearly every county of the State. It of course would be a rare tree throughout the rich black loam soils of the central Indiana counties. The black oak is confined to the poorer soils of the State, such as clay and gravelly ridges, sand dunes, sand ridges, and the hills of southern Indiana that are not covered with beech or white oak. It is a frequent to a common tree in the southwestern part of the State in the bottom lands where it is associated with Schneck's, shingle, and post oaks. In the northern part of the State it is generally associated with the white oak and if the soil is very poor it will form almost pure stands. On the poor ridges of southern Indiana it is generally associated with the white, and scarlet oaks, and invades habitats still poorer which are occupied by post, black jack, or chestnut oaks. Wherever the black oak is found it is generally more than a frequent tree and is usually a common tree or forms the principal stand. While the black is not so uniformly distributed over the State as the white oak, yet in point of numbers it nearly equals it, or may even exceed it.

In Floyd and Harrison Counties are certain small areas which were known to the early settlers as the "barrens." These areas were treeless. They were covered with a growth of some sort of oak which the natives call "scrub" oak, hazel, and wild plum. The height of the growth in any part would "not hide a man on horse back." These areas are now all under cultivation, and are no longer distinguished from the forested areas. However, many parts of the barrens are now covered with forests, but these forests are a complete stand of black oak. Last year one of these areas was cut off, and the age of the trees were ascertained to be about 65 years old. The barrens of southern Indiana and adlacent States offer a good problem for ecologists.

Remarks. - Wood similar to that of red oak, but often much inferior. The uses of the best grades of black oak are practically the same as red oak.

Where the black and scarlet oaks are associated, the scarlet oak is rarely separated from it. The two species superficially much resemble each other. The black oak is always easily distinguished by cutting into the inner bark which is yellow, while that of scarlet oak is gray or reddish. The inner bark imparts a yellow color to spittle, and the scarlet does not. When mature fruiting branches are at hand they may be separated by the appearance of the acorns. The scales of the cups of the 
black oak are dull, and loosely imbricated near the top while those of the scarlet oak are rather glossy and closely imbricated. The scales of the scarlet oak, however, become somewhat loose after the acorn has matured, and fallen for some time.

This species is sometimes called yellow oak. Since the chinquapin oak is also often called yellow oak, it is best to always call this species black oak.

15. Quercus coccínea Muenchhausen. Scarlet OAK. Plate 54. Medium sized trees with bark resembling the black oak, inner bark gray or reddish; twigs reddish by autumn; winter buds reddish-brown and pubescent; leaves on petioles $2.5-6 \mathrm{~cm}$. long, broadly oval to obovate, blades $7-15 \mathrm{~cm}$. long, truncate or wedge-shape at the base, the blade divided into 5-7 lobes by deep and wide sinuses which cut the blade more than half the distance to the midrib, sinuses rounded at the base, the lobes variable in size and shape, usually the lowest are the shortest and smallest, the middle lobes the largest and longest, the lobes widest either at the base or the apex, the terminal part toothed or lobed, the terminal lobe generally 3 -lobed or 3 -toothed, both surfaces of the leaves at first pubescent, soon smooth and a dark glossy green above, and paler and smooth beneath except tufts of hairs in the axils of the principal veins; acorns sessile or nearly so, solitary or in pairs; nuts ovoid to oblong, $1.5-2 \mathrm{~cm}$. long, enclosed for about half their length in the thick cup-shape cup; scales triangular but blunt, closely appressed, pubescent on the back except the center which is generally elevated and smooth and shiny, giving the cup a glossy appearance which easily separates it from its nearest ally the black oak whose cup is a dull, ash or reddish gray color; kernel white within, and less bitter than the black oak.

Distribution.-Maine, southern Ontario to southern Nebraska, south to North Carolina, Alabama and Arkansas. It has been reported for the northwest counties and the southern part of Indiana, but we have no records for the east-central portion of the State. Clark reports it as common about Winona Lake, but does not report Quercus velutina which is a common tree of the vicinity, and it is believed that Clark has confused the two species. In the northern part of the State its habitat is that of sand and gravel ridges associated with black oak. In the hill part of southern Indiana it is intimately associated with the black oak on the poorer ridges. We have no authentic records for the southwestern counties. The author has Schneck's specimens on which the record for Gibson and Posey County was based. I determined the specimens as belonging to the Spanish oak, and William Trelease verified the determination. I have no doubt that scarlet oak occurred on the sand ridges of that area. 
Plate 54.

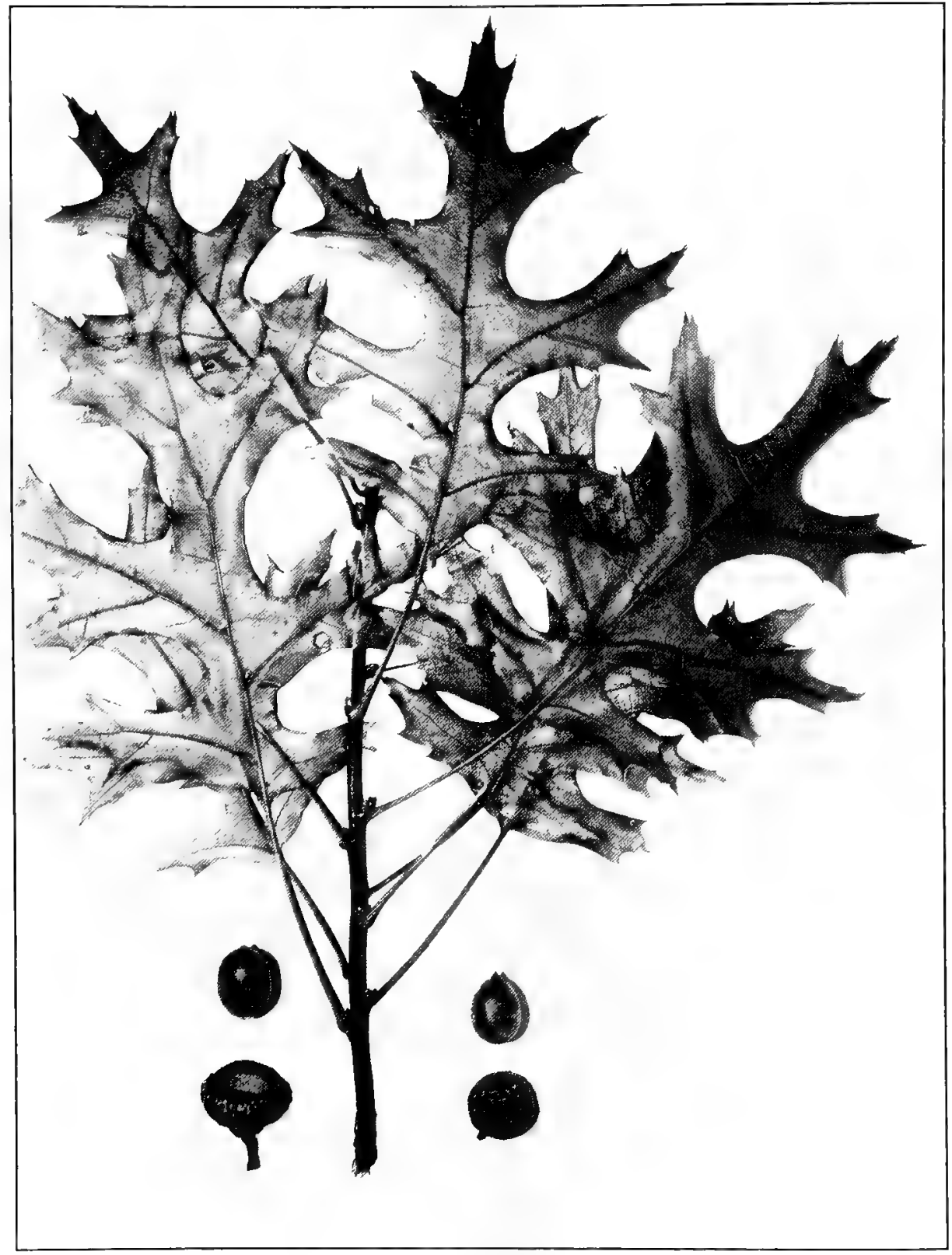

QUERCUS COCCINEA Muemehhasen. SCARLeT OAK. ( $\mathrm{x} / 2$.) 
In the northern part of the state it is a rare or infrequent tree, while in favorable habitats in the hill country of the southern part of the State it is a frequent to a common tree.

Remarks.- Wood similar but much inferior to red oak. The cut in this State is marketed as black oak, from which it is rarely separated.

16. Quercus falcàta Michaux. Spanish OAK. Plate 55. Large trees; bark thick, rather deeply fissured, furrows usually narrow, ridges generally broad and broken into short lengths, the outer bark is reddish, except sometimes it becomes grayish by weathering; twigs densely pubescent at first, remaining more or less pubescent during the first year, or becoming smooth or nearly so and a reddish brown by autumn; leaves on petioles $0.5-6 \mathrm{~cm}$. long, ordinarily about $2-3 \mathrm{~cm}$. long, blades very variable in outline, ovate, ovate-oblong or obovate, usually somewhat curved, wedge-shaped, rounded or truncate at the base, shallow or deeply lobed, generally about $2 / 3$ of the distance to the midrib; lobes $3-11$, commonly $5-9$, the number, size and shape of the lobes exceedingly variable, the longest lateral lobes are generally near the middle of the leaf, sometimes the lowest pair, sometimes the upper pair are the longest, terminal lobe triangular or oblong, generally widest at the base, although frequently widest at the apex, lateral lobes widest at the base and gradually becoming narrower, towards the apex, rarely somewhat wider at the apex, generally somewhat curved, lobes generally sharp-pointed, sometimes wide-angled or rounded at the apex, margins of lobes entire, wavy, toothed or lobed, sinuses wide and rounded at the base; leaves densely pubescent on both surfaces at first, gradually becoming smooth and dark green above by autumn, the under surface remaining covered with a tomentum which is grayish or yellowish; acorns sessile or nearly so, solitary or in pairs; nuts broadly ovoid, generally 10-12 mm. long, broadly rounded at the base, rounded at the apex, enclosed about one-half their length by the cup; cups strongly convex at the base; scales blunt, grayish and pubescent on their backs, their margins reddish and generally smooth.

Distribution.-New Jersey and Missouri, south to Florida and west to Texas. The known distribution in Indiana would be that part of the State south of a line drawn from Vincennes to North Madison. It is local except in the southwestern counties. In our area it is found on both high and low ground. In Jefferson and Clark Counties it is found only in the flats where it is associated with beech, sweet gum, pin oak, red maple and black gum. A colony was found in Washington County on high ground, about elght miles southwest of Salem associated with black and post oak. In Harrison County about two miles southeast of Corydon it was found on the crest of a ridge with white and black oak. In Daviess County about four miles east of Washington it is 
Plate 5.5.

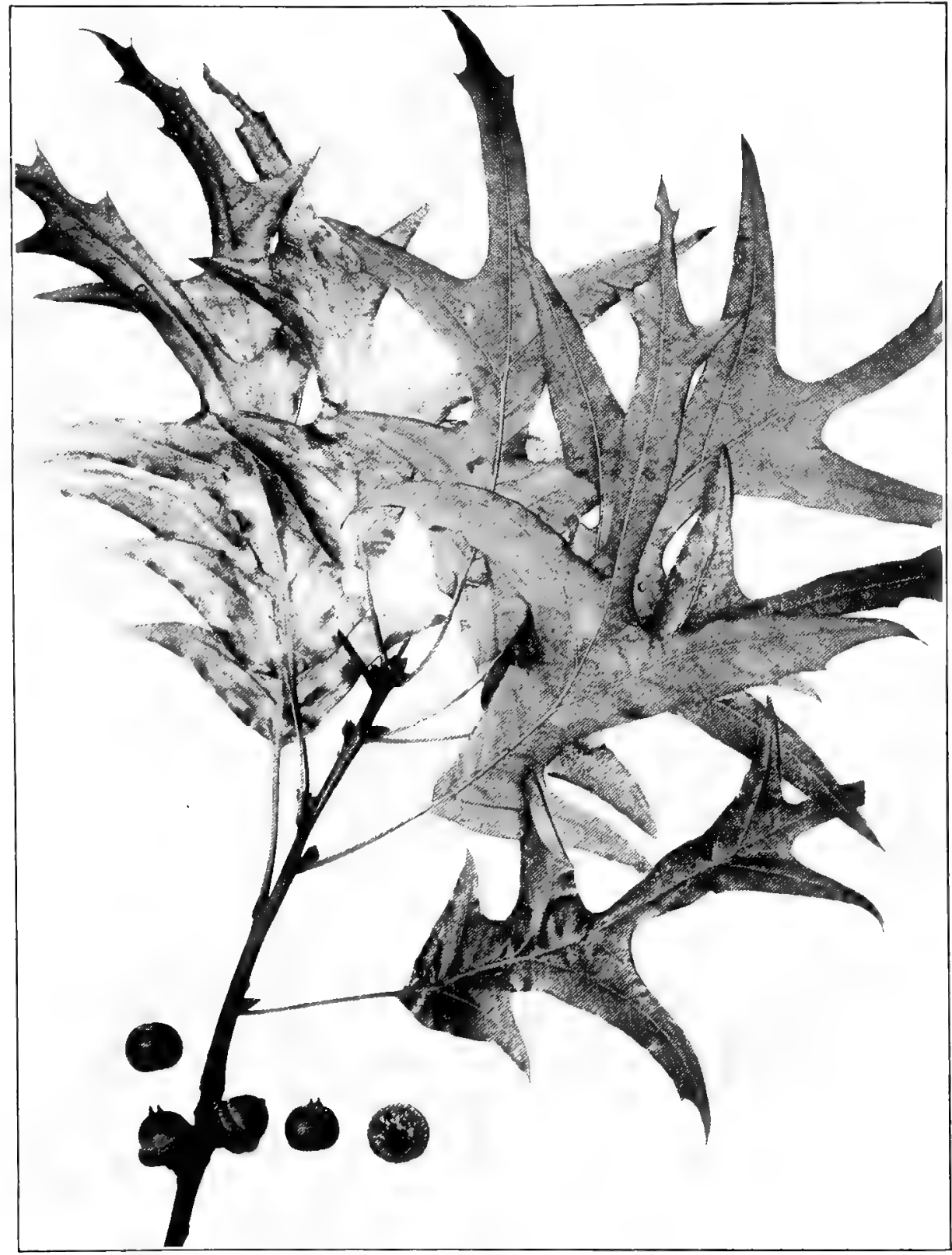

QUERCUS FalCath Mirhaux. Spansh OAK. ( $x$, g.) 
associated with black and post oak. In Knox, Gibson, Pike and Warrick Counties it is local on sand ridges with black oak. It occurs in the greatest abundance in the river bottoms of Gibson, Posey and Spencer Counties, where it is generally associated with pin, Schneck's, shingle, swamp white, black and post oaks, and sweet gum. In the last named counties it is fairly well distributed, and is a frequent to a common tree. Brown's ${ }^{1}$ report for Fountain County should not be recognized without a verifying specimen, since his list was compiled from a list of common names of the trees which he obtained.

Remarks. - Wood and uses similar to that of red oak. In Indiana it is all sold as red oak. In all parts of its range in Indiana it is known as red or black oak. However, the best accepted common name of this species throughout its range is Spanish oak, and since no other species is known by this name, it should be used for this species.

The bark of this species varies considerably in color and tightness. The leaves are exceedingly variable in form. The leaves on the same tree will vary from 3-lobed to 11-lobed. Usually the lobing is deepest in the leaves nearest the top of the tree. Leaves of small trees, coppice shoots, and of the lower branches of some trees are often all or for the greater part 3-lobed. The color of the pubescence of the lower surface the leaves varies from a gray to a yellow-gray. The variations have lead authors to divide this polymorphic species into several species and varieties. The author has included all the forms that occur in Indiana under one name.

This species is variously known as Quercus digitata, Quercus triloba, Quercus pagodaefolia, and by the most recent authors as Quercus pagoda and Quercus rubra and its varieties. Specimens in the authors collection from Jefferson County were reported by Sargent ${ }^{2}$ as Quercus rubra var. triloba.

17. Quercus marilándica Muenchhausen. BLACK JACK OAK. Plate 56. Mature trees generally $10-30 \mathrm{~cm}$. in diameter; bark resembles that of a gnarled black oak; twigs generally scurvy-pubescent the first year; leaves on petioles from nearly sessile to $2.5 \mathrm{~cm}$. long, usually less than a $\mathrm{cm}$. long, blades $7-15 \mathrm{~cm}$. long, broadly obovate, often almost as wide as long, narrowly rounded at the base, with three primary lobes at the apex, sometimes with two small lateral lobes, the apex is sometimes almost rounded and the position where the lobes usually occur is indicated by three primary veins which end in a bristle, the apex of the leaf is generally about equally divided into three lobes by two very shallow rounded sinuses, the lobes are rounded or merely acute, sometimes the terminal lobes develop a secondary lobe, leaves very

,Brown: Trees of Fountain County, Ind. Geol. Rept. Vol. 11:123:1882.

2Sargent: Notes on North American Trees. Bot, Gaz. Vol. 65:427:1918. 
Plite 56.

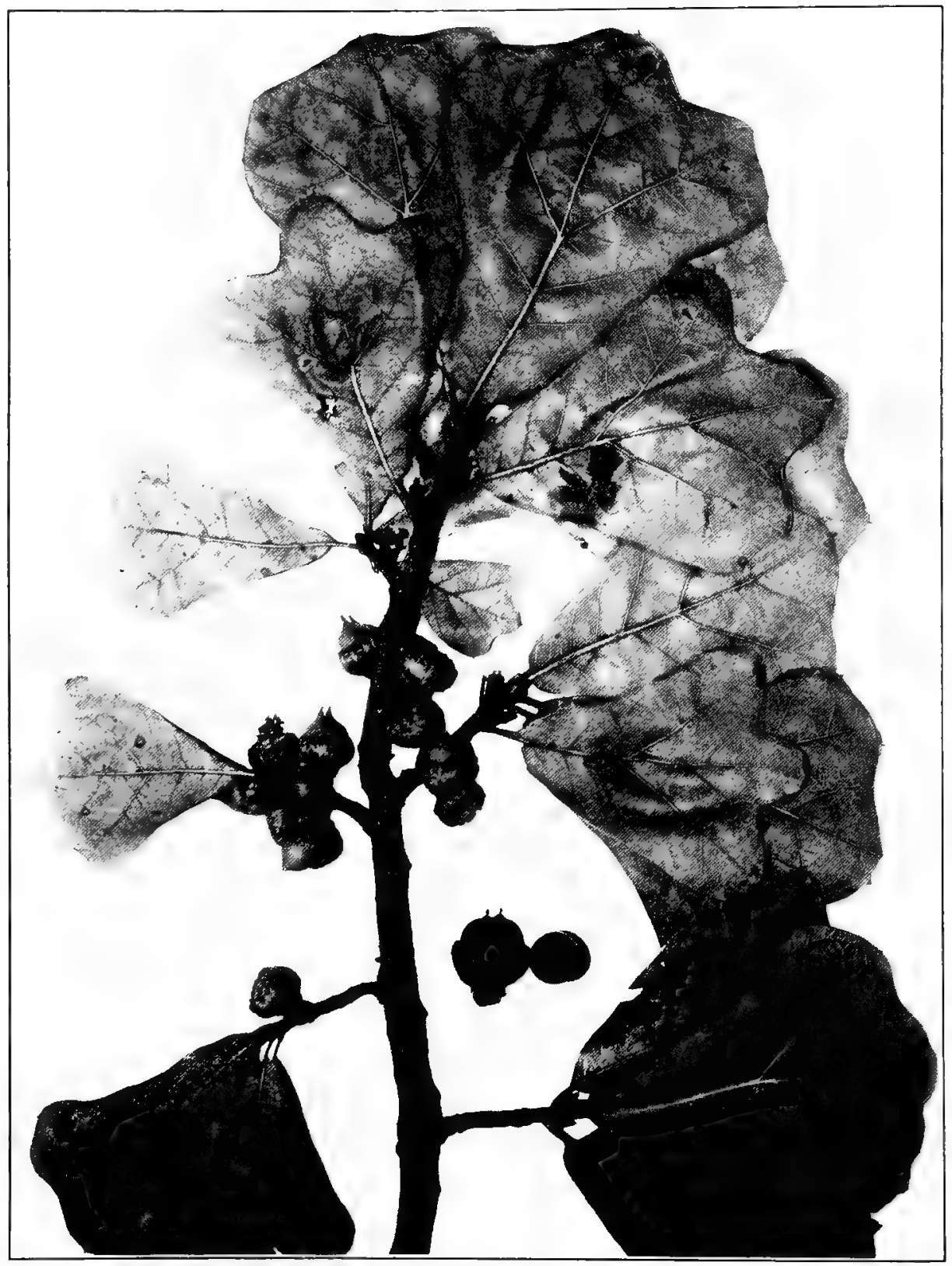

QUERCUS MARILANDICA Muenehhausen. BLACK JACK OAK. (x 1/2.) 
pubescent both above and beneath when they first appear, becoming smooth and glossy above at maturity, and remaining more or less pubescent beneath; acorns sessile or nearly so, single or in pairs; nuts ovoid or oblong, $1-1.5 \mathrm{~cm}$. long, broadly rounded at the base, rounded or somewhat conic at the apex, enclosed for about half their length in the cup-shaped cup; scales blunt, not closely appressed, pubescent on back, light reddish-brown; kernel bitter.

Distribution.--New York to Nebraska, south to Florida and west to Texas. In Indiana it is known to the author from Sullivan, Greene and Clark Counties and southwestward. It has been reported from Jefferson County by Barnes which is no doubt correct. Doubtful records are those by Brown for Fountain County, Miami County by Gorby, and Phinney's report for the area of Delaware, Jay, Randolph and Wayne Counties. It has been reported for the vicinity of Chicago by Higley and Raddin. It may be local on sterile, sandy ridges of the northern part of the State, but very local if it does occur. It is generally found in very poor soil on the crest of ridges associated with black and post oak. However, it has been found in Greene, Sullivan and Knox counties on sand ridges and at the base of sand ridges associated with black and post oak. The species has a very limited mass distribution and is only occasionally found and in colonies of a few trees each.

Remarks. - Trees too small and scarce to be of any economic importance.

\section{ULMĀCEAE. The Elm Family.}

Trees or shrubs with simple, alternate, 2-ranked, petioled leaves; sepals 3-9, petals none, stamens as many as the sepals and opposite them, stigmas 2 .

Branchlets with solid pith; leaves with primary veins parallel;

flowers borne on the twigs of the preceding season...... 1 Ulmus.

Branchlets with chambered pith at the nodes; leaves 3-veined at the base; flowers borne on the twigs of the season... 2 Celtis.

\section{1. ÚLMUS. The Elms.}

Trees with furrowed bark; leaves short petioled, with lateral veins prominent and parallel, oblique or unequally heart-shaped at the base, taper-pointed at the apex, mostly double-serrate; flowers of Indiana species expanding before the leaves in March or April; fruit a samara surrounded with a wide membranous margin, maturing in the spring. 
Inner bark mucilaginous; leaves very rough above; flowers nearly sessile; fruit not ciliate.............. $1 \mathrm{U}$. fulva,

Inner bark not mucilaginous; leaves smooth or somewhat rough above; flowers on slender pedicils; fruit ciliate.

Branches without corky wings; sides of samara glabrous... $2 \mathrm{U}$. americana.

Branches (at least some of them) with corky wings; at least one side of the samara pubescent.

Buds ovate, not twice as long as wide, obtuse, or shortpointed, dark brown; seales pubescent and ciliate; leaves usually not twice as long as wide, base of petiole glahrous heneath; calyx lobes $7-9 \ldots \ldots \ldots$

Buds small, narrow, twice as long as wide, very sharppointed, light brown; scales glabrous or merely puberulent; leaves usually twice as long as wide, hase of petiole pubeseent all around

3 U. Thomasi.

1. Ulmus fúlva Michaux. Slippery Elm. Red Elm. Plate 57 Fairly large trees with deeply fissured reddish-brown bark without white streaks between the layers of the ridges, twigs very pubescent and green at first, becoming gray or reddish-brown at the end of the season and remaining more or less pubescent for a year or more; buds ovate, a very dark reddish brown, the scales more or less pubescent; leaves ovate, oval or slightly obovate, average blades $8-15 \mathrm{~cm}$. long, hairy on both surfaces at first, remaining more or less pubescent beneath until maturity, and becoming very rough above with a few scattered hairs remaining, fragrant when dried, fragrance remaining for years; fruit ripening the last of April or the first of May before or with the unfolding of the leaves; samara orbicular or obovate, usually longer than wide, average size $13-17 \mathrm{~mm}$. long and 9-12 mm. wide, the margin as wide or wider than the seed, margin glabrous, seed densely pubescent on both sides; wood hard, strong, light when well seasoned and.not warping as badly as white elm.

Distribution.-Quebec south to Florida, west to Texas, Nebraska and North Dakota. Found in all parts of Indiana. In the prairies or in the "flats" it may be absent in one or more contiguous counties and may be entirely absent on the crests and upper slopes of ridges. It prefers a moist well drained soil, and where it is found it is usually a frequent to a common tree, although rarely is it found as a very common tree. It is usually associated with sugar maple, beech, white ash, linn, tulip, white oak, etc.

Remarks. - This tree usually is from 3-6 dm. in diameter and tall for its diameter. However, larger trees occur. In the Ind. Geol. Rept. 6:70:1875 mention is marle of a tree in Jackson County that was "18 feet in circumference." The uses of the wood are similar to that of white elm. The inner bark collected in spring is much used in medicme under the name of slippery elm. 
Plate 57.

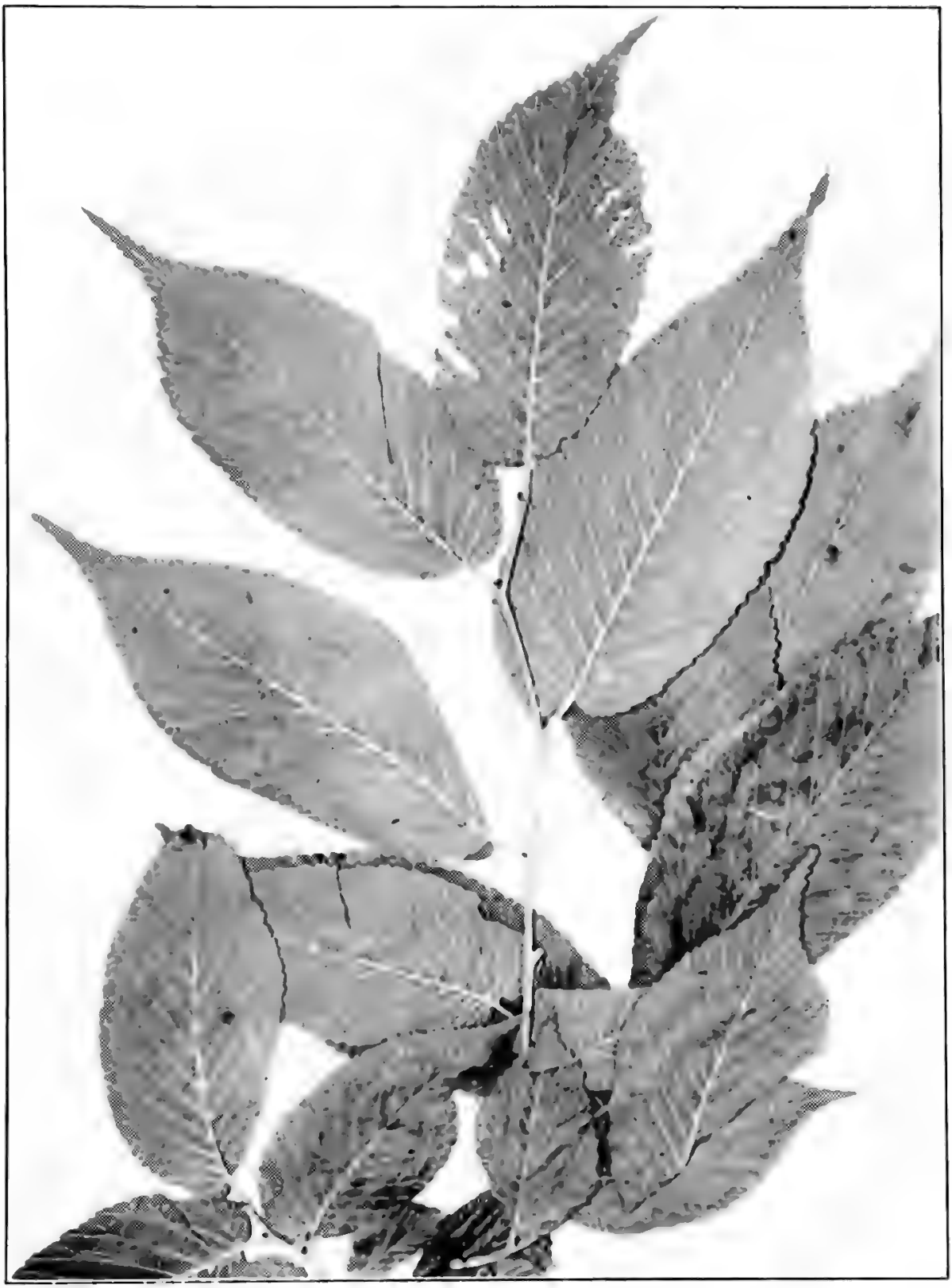

ULMUS FUt. Michaux. Red or Slippert Elm. (x 1/2.) 
2. Ulmus americàna Linnæus. White Erm. Plate 58. Large trees; bark deeply fissured, gray, the ridges showing white streaks between the layers; twigs more or less hairy at first and usually becoming glabrous by the end of the season; buds ovate, acute and glabrous; leaves ovate, oval or obovate, average blades $8-12 \mathrm{~cm}$. long, hairy on both sides on expanding, becoming at maturity glabrous above and smooth or rough, sometimes very rough on vigorous young shoots, remaining pubescent beneath, rarely glabrous; fruit ripening before or as the leaves unfold, generally oval in shape, about $1 \mathrm{~cm}$. long, both surfaces glabrous, margins about as wide as the seed and fringed with hairs; wood hard, tough, flexible, generally hard to split, warps badly in seasoning.

Distribution.-Quebec to Florida, west to Texas and Nebraska. Found throughout Indiana, and doubtless in every county. It is frequent to common or very common on the flood plains of streams, in wet woods and in low ground generally.

Remarks. - This species is also called water elm, swamp elm, gray elm, bitter elm, sour elm and in southwestern counties it is often called red elm. In Perry County it is often called hub elm. It is generally known as "elm" and when this term is used, it refers to this species. The wood has a very wide range of uses. The greatest amount has been used for hoops, staves and heading. Large quantities have been used in the manufacture of agricultural implements, hubs, furniture, basket handles, etc. White elm is usually considered very difficult to split, but I was informed by a pioneer timber cutter that the heart wood of the veterans of the forest splits as well as oak, and that he worked many a tree up into staves. He told me that he made into staves a tree in Paulding County, Ohio, that was eight feet in diameter at the stump. There is little attempt being made by woodlot owners to propagate this tree. However, the natural propagation of the species is probably greater than any other species because it produces seed at an early age, and culls of the forest are not cut because they are not good for fuel which leaves them to produce seed. Then the seed are light, and are scattered to great distances by the wind and water. It is propagated very easily from seedlings.

The tree when grown in the open has a tendency to be bushy and unless it is given some pruning will have a very short clear trunk. It has always been regarded as one of the best species for shade tree planting. For beauty of form it is not excelled by any tree for shade or ornamental planting. However, it has several insect enemies that require spraying to keep them under control. 
Plate 58.

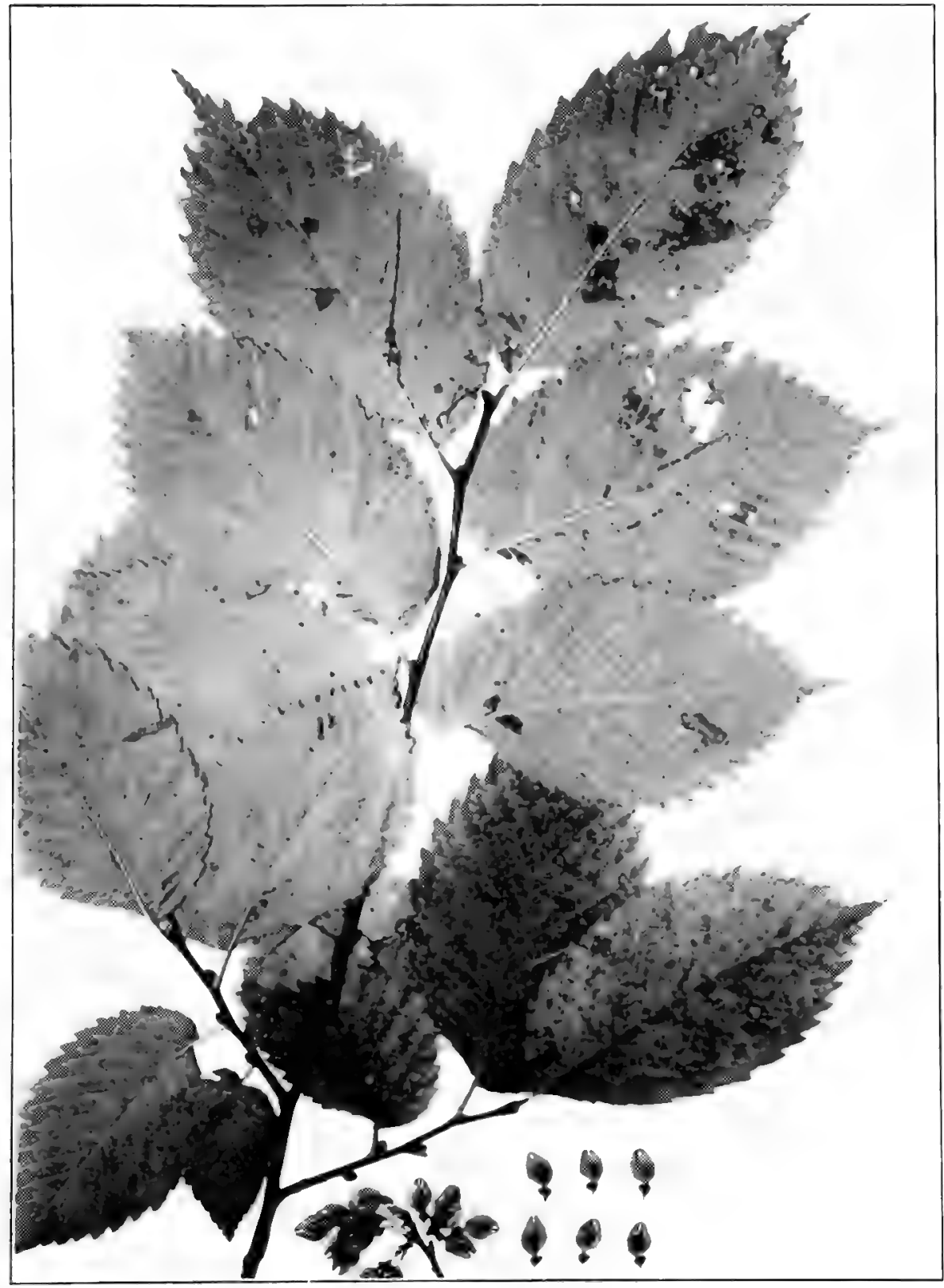

ULMUS AMERICANA Linnæus. White ELM. ( $\mathrm{x}$ 1/2.) 
3. Ulmus Thomási Sargent. Hickory Elm. Rock Eum. Plate 59. Large trees; bark deeply fissured and grayish like the bark of the white elm; twigs light brown, generally densely hairy and remaining more or less pubescent until the end of the season or later, the twigs of some specimens are glabrous or only slightly hairy at first and soon become glabrous and somewhat glaucous, after the first year some of the branchlets begin to develop 1-4 corky ridges from a few millimeters to 5 or $6 \mathrm{~mm}$. in thickness, the ridges are wide and rounded at the top, dark gray, brown and discontinuous, rarely a corky ridge will appear on a branchlet the first year; leaves oval or obovate, average b]ades $8-15 \mathrm{~cm}$. long, at maturity glabrous and smooth or rough to very rough above, permanently pubescent beneath especially on the veins; fruit ripens late in May or early in June when the leaves are from $1 / 2$ to $2 / 3$ grown; samara oval, usually $1.5-2 \mathrm{~cm}$. long, oblique at the base, with a beak $2-5 \mathrm{~mm}$. long at the apex, both faces pubescent, wing about as wide as the seed; wood hard heavy, strong, flexible, uses the same as white elm.

Distribution.--Southern Quebec and Ontario south to northern New Jersey and west to Minnesota and Missouri. The distribution in Indiana has not been studied. The frequency of its occurrence is not known, and all of the known stations are given. The published records are as follows: Dearborn (Collins); Franklin (Meyncke); Hamilton (Wilson); Jefferson (Baines) and (Deam); Noble (VanGorder); Parke (Hobbs); St. Joseph (Nieuwland); Steuben (Bradner); Wayne (Petry and Markle); Wells (Deam). Additional records are Hendricks, Noble, Ripley, Vermillion and Wayne by Deam. The published record for Posey County by Deam and Schneck should be referred to Ulmus alata. It prefers a well drained soil and is most frequently found near the base of the slope or on the top of flood plain banks of streams, in ravines, or in a habitat like a beech-sugar maple woods. It is reported to have been frequent in Franklin, Noble and Wells Counties.

Its appearance and habit of growth is so much like the white elm that it is not commonly distinguished from it, which accounts for the lack of definite knowledge of its range in our area.

4. Ulmus alàta Michaux. WINGEd Elm. Plate 60. Small to medium sized trees; bark rather closely fissured, grayish or reddishbrown, in appearance like white elm; twigs hairy at first, generally remaining more or less pubescent throughout the season, rarely becoming entirely glabrous before the end of the season, a light brown gradually becoming a gray-brown; branchlets usually begin to develop two thin narrow corky ridges, becoming by the end of the second year 4-7 mm. thick, the year's growth of corky layer a light brown, the older layers a darker brown, the two main corky ridges are on oppo- 
Plate 59.

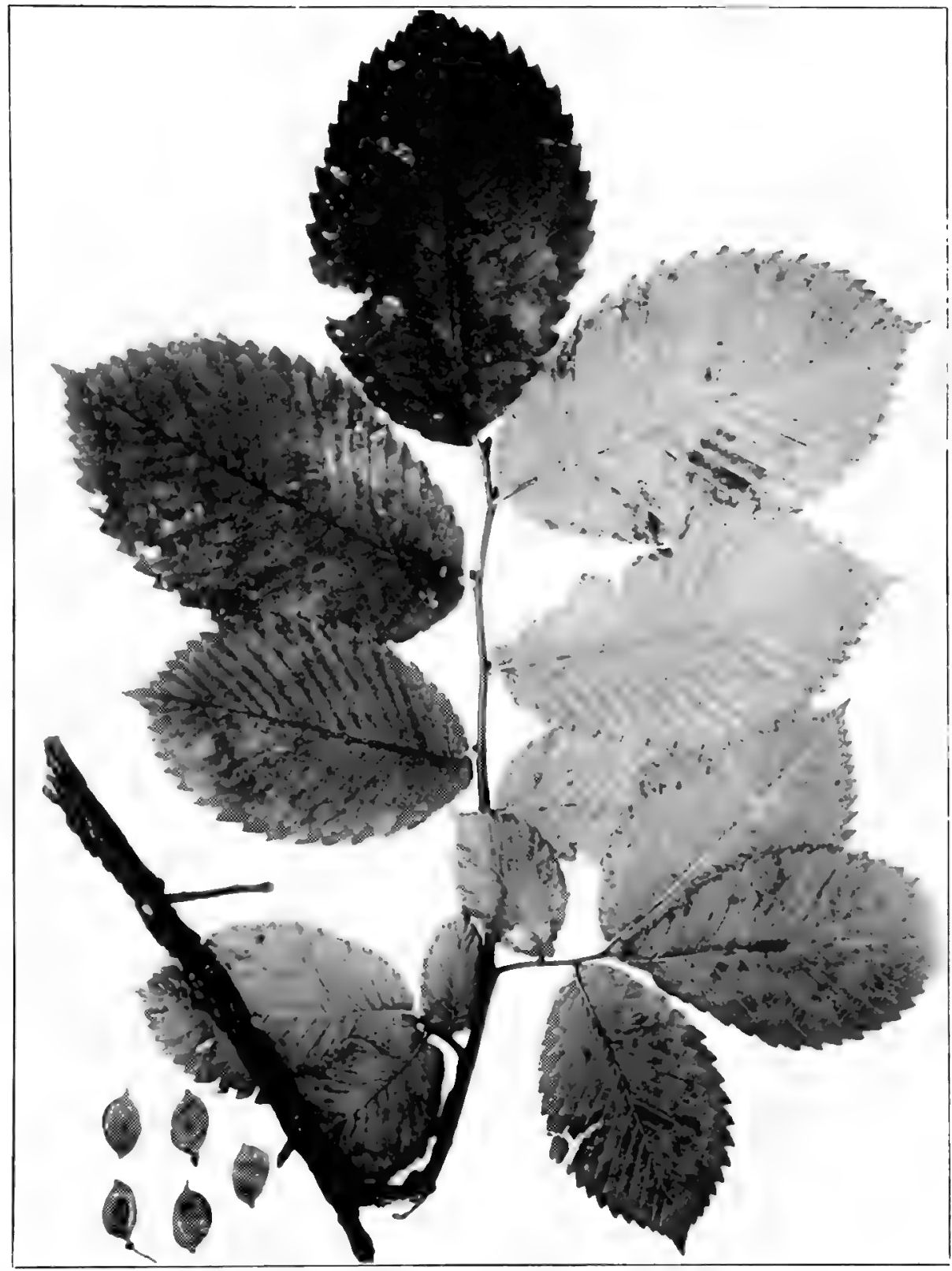

ULMUS THOMASI Sargent. Hickory or Rock Elar. ( $\mathrm{x}, \frac{1}{2}$.) 
Plate 60.

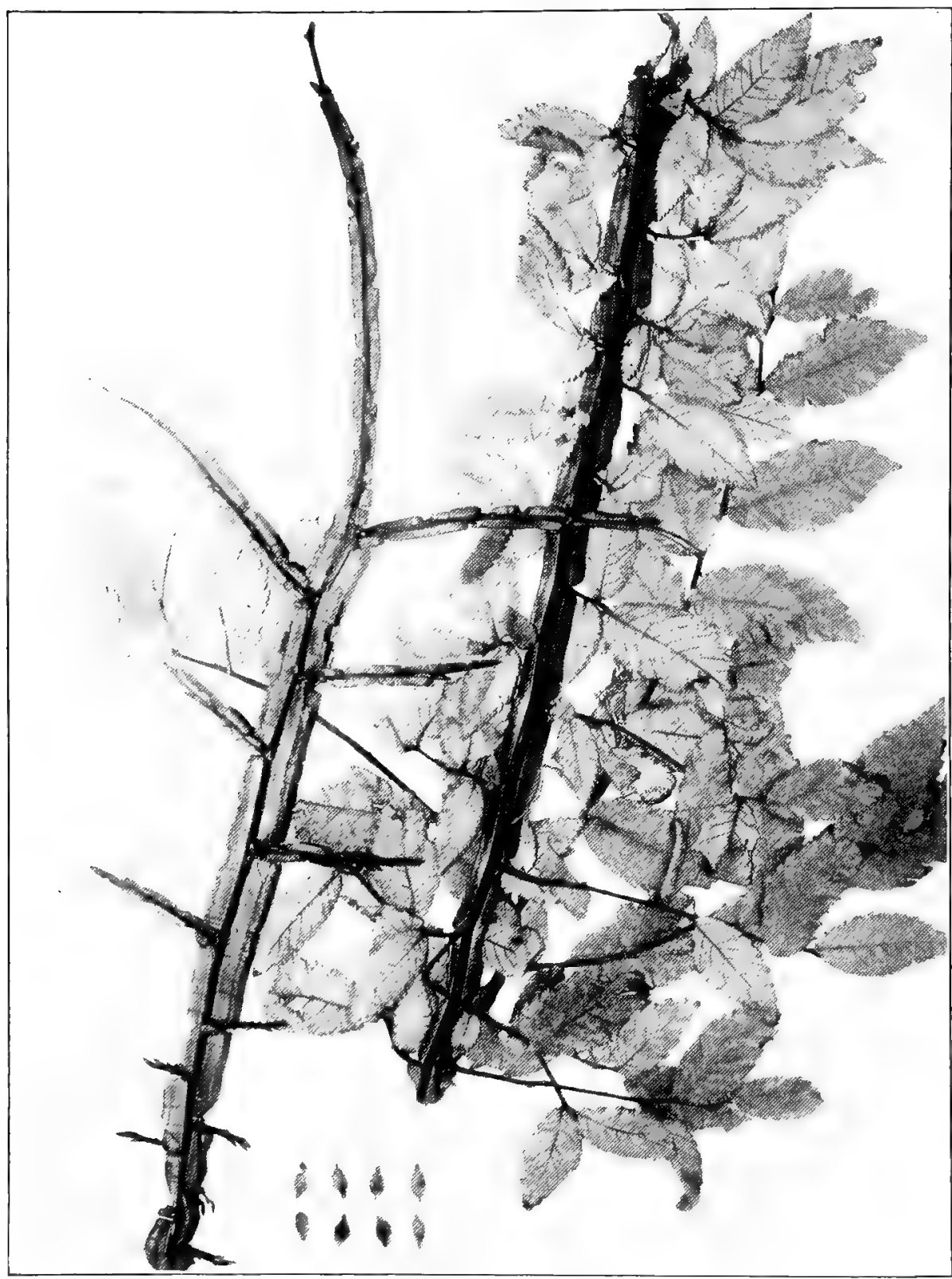

UlmUs ALATA Mirhaux. Winged Elar. ( $\quad 1,2)$. 
site sides of the twigs, and between these there are generally additional corky excrescences, especially on the older branches; leaves oblonglanceolate or oval, some somewhat falcate, a verage blades $4-8 \mathrm{~cm}$. long, pubescent on both sides on unfolding, becoming at maturity glabrous or nearly so above, some are rough above at maturity, remaining pubescent until maturity beneath; petioles short, generally $2-3 \mathrm{~mm}$. long, rarely $5 \mathrm{~mm}$. or longer; fruit ripening before or with the unfolding of the leaves; samara 6-10 $\mathrm{mm}$. long, pubescent on both faces.

Distribution.- Virginia west through southern Indiana to southern Missouri, south to the Gulf and west to Texas. In Indiana it is confined to the southwestern part of the State. Gorby's report for Miami should be ignored. It has been reported as far north as Vigo and Monroe Counties by Blatchley, and as far east as Clark County by Baird and Taylor. The author has collected it in Crawford, Dubois, Martin, Orange, Perry, Posey, Spencer and Warrick Counties.

The tree has two rather distinct habitats. In the hill counties it is found on the sides of cliffs, steep slopes or on the top of the ridges with such species as the black, chestnut and scarlet oaks and chestnut. In this habitat it is usually a small scrubby tree with an excessive number of side branches. Such specimens usually have the corky ridges well developed on all of the branches and the tree presents a weird appearance. The second habitat is in the hard clay flats of the southwestern counties. In Warrick County along Big Pigeon Creek west of Boonville I measured a specimen $21 \mathrm{dm}$. in circumference and I estimated the clear bole at $8 \mathrm{~m}$. It was associated with sweet gum, black gum, white elm, red birch, red oak, etc. It is found throughout this county both in the "flats" and on the sandy ridges. In Posey County it is a frequent tree in the low woods about 10 miles southwest of Mt. Vernon. In these woods it acquires a diameter of 3-6 dm. and is associated with post oak, Spanish oak, sweet gum, shingle oak, etc. It is to be noted that specimens that grow in these conditions and those that acquire a large size do not develop such conspicuous corky branches. A large tree over $6 \mathrm{dm}$. in diameter was noted in the eastern part of Gibson County growing in low sandy soil which was destitute of corky branches so far as could be seen from the ground. All of the branches examined were free from corky ridges, and only a few corky excrescences were present. The specimen could easily be identified by the leaves. Another large tree $12 \mathrm{dm}$. in circumference in a black oak woods 4 miles south of Marengo in Crawford County was also free from corky ridges.

This is an interesting tree and requires further study to establish its range in Indiana and to learn its habits. In Jasper, Indiana, it is a frequent shade tree. No doubt the trees were obtained from a nearby woods along the Patoka River where this species is known to occur. 


\section{Céltis. The Hackberries.}

Trees with pith of branchlets ehambered; flowers in Indiana species appear before the leaves, the leaves generally with 3 primary veins at the base; staminate flowers usually in clusters, the pistillate solitary or few together in the axils of the leaves, and near the end of the twigs; fruit a globose drupe, sometimes elongated, pulp thin and sweet, frequently remaining on the tree until late winter, relished by birds; stone bony, wrinkled.

Some of the American species of hackberry are very variable. The habitat of the species varies from deep swamps to arid rocky slopes. In fact, a single species as now understood may have a variable habitat. The following variations may be noted on the same tree or on different trees of the same species. The twigs may be glabrous, or pubescent; the leaves may vary in size, shape and texture, leaf margin, and in the roughness or smoothness of the surfaces; the petioles may be smooth or hairy; the pedicels may be glabrous or pubescent, shorter or longer than the petioles; the fruit also varies in shape. Leaves have been seen on the same tree which were smooth above, while others were quite rough above, the difference being due to the exposure to light.

The original descriptions of the species are too short to sufficiently characterize the species, which adds to the confusion. However, C. S. Sargent ${ }^{1}$ has recently revised the species and varieties of our area.

Prof. Sargent has examined and named all of my material for me. Mr. B. F. Bush, who has extensively studied the hackberries in the field, also has examined my specimens.

The writer has paid special attention to the hackberries of the State for the past few years and is still in doubt as to the status of the species that occur in the State. Since I am not following the determinations made by Sargent and Bush, and am following the nomenclature of the first edition, I regard the present treatment as tentative only.

Margins of all the leaves sharply serrate all around except at

hase; nutlets $6-8 \mathrm{~mm}$. long.

1 C. oceidentalis.

Margins of leaves of fruiting branches generally entire, or some with a few teeth on one side or with a few teeth on both sides; margins of the leaves of vegetative branches and shoots similar to those of fruiting hranches or with the margins serrate nearly all around; nutlets $5-6 \mathrm{~mm}$. long.

Leaves of a rather broad ovate type; mature fruit a dark cherry-red; usually shrubs, sometimes very small trees, of a dry habitat.

Leaves of an ovate-lanceolate type; mature fruit a light rherry-red; medium-sized trees of a wet habitat..... 3 C. mississippiensis. 
Plate 61.

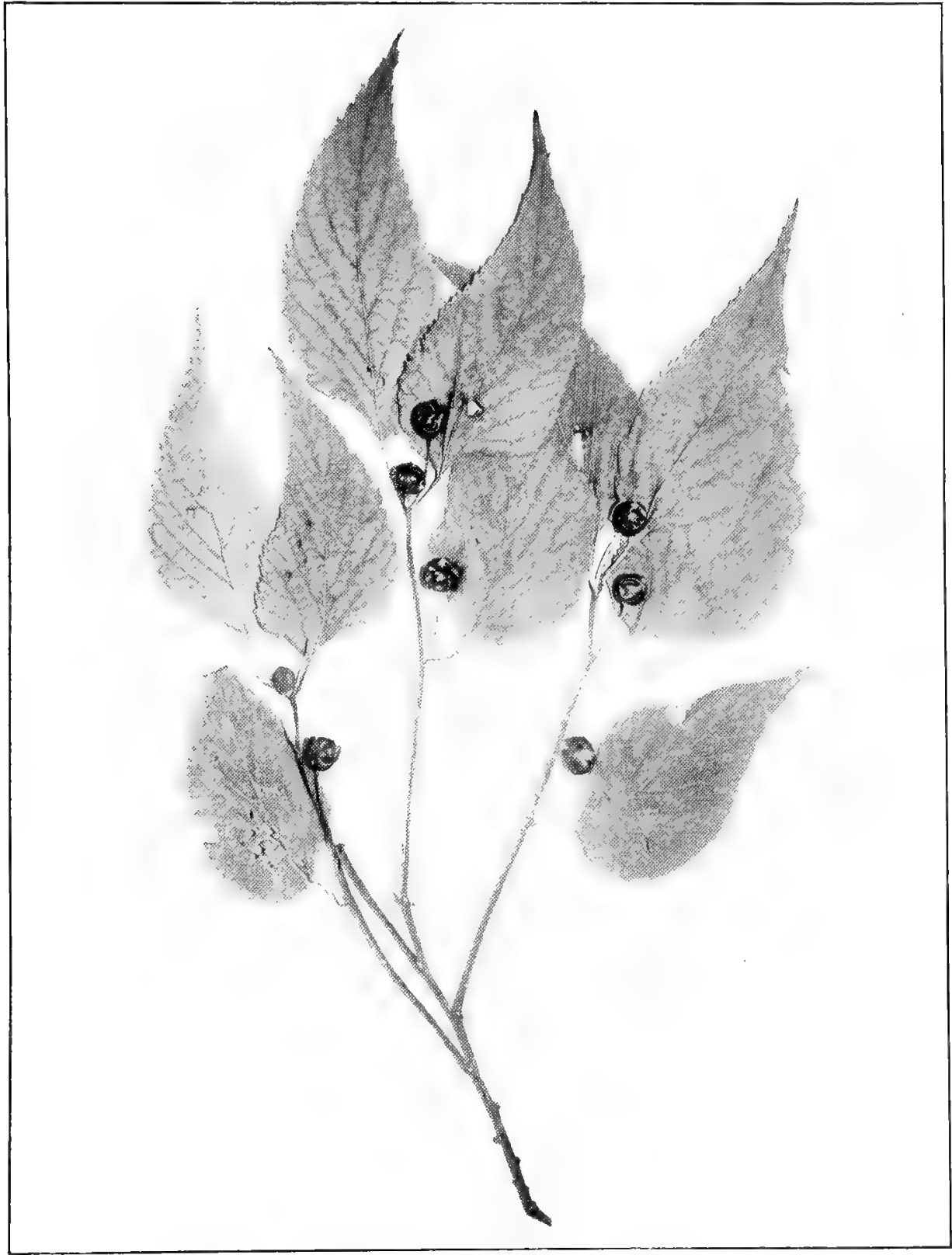

CELTIS OCCIDENTALIS Linnæus. HACKBERRY. ( $x$ 1/2.) 
1. Celtis occidentàlis Linnæus. HackBerry. Plate 61. Medium to large-sized trees; bark of old trees irregularly furrowed, sometimes some of the surface warty and rough; twigs smooth or pubescent, the fruiting ones generally smooth; leaves of an ovate type on petioles $0.5-2 \mathrm{~cm}$. long, the blades of fruiting twigs $5-15 \mathrm{~cm}$. long, those of vegtative twigs sometimes larger, oblique or slightly cordate at base, graclually tapering to a point at apex, or long acuminate at the apex, often becoming thick at maturity, especially those exposed to full sunlight, generally smooth above at maturity, especially those of fruiting twigs, or sometimes rough, especially those of vegetative branchlets or those growing in the shade, the under surface more or less pubescent along the veins at maturity; fruit matures in late autumn, very dark red, sometimes appearing almost black, globose or somewhat oblong, generally about $9-10 \mathrm{~mm}$. in diameter, borne on pedicels which are longer or up to twice as long as the petioles; the pedicels which are always ascending are straight or somewhat curved upwards; nutlets globose, a little longer than wide.

Distribution.-Valley of the St. Lawrence River, southern Ontario, to North Dakota, and south to the Gulf States and west to Texas. More or less frequent along streams throughout the State, except in the hilly counties of the southern part of the State. It is always found in moist soil, except in the hilly counties where it may be found on wooded slopes or on high rocky bluffs bordering streams. In all of our area the species is practically confined to drainage basins, and is generally close to streams.

Remarks.-The wood is yellowish-white and before seasoning very much resembles ash for which it was generally sold. It has good bending qualities and is now much sought after for hoops. It was formerly often known as hoop ash. The supply is now becoming scarce, but when bought sells for the same price as good white elm.

Some writers include under the name Celtis occidentalis only those forms which are small trees and have ovate, short-pointed leaves. This type of tree has not been found in Indiana. The form with long acuminate pointed leave which is the common form in our area, is regarded as a variety of Celtis occidentalis. Trees having the upper surface of the leaves very rough are called Celtis crassifolia Lamarek, or are merely regarded as a variety of Celtis occidentalis. This form is found throughout our area.

The hackberry is sometimes used as a shade tree. It can scarcely be recommended because its leaves and twigs are often affected by galls which detract from its appearance.

2. Celtis pùmila (Muhlenberg) Pursh. Dwarf Hackberry. Plate 62. Bark thin, smooth and gray on shrub-like forms, warty 
Plate 62.

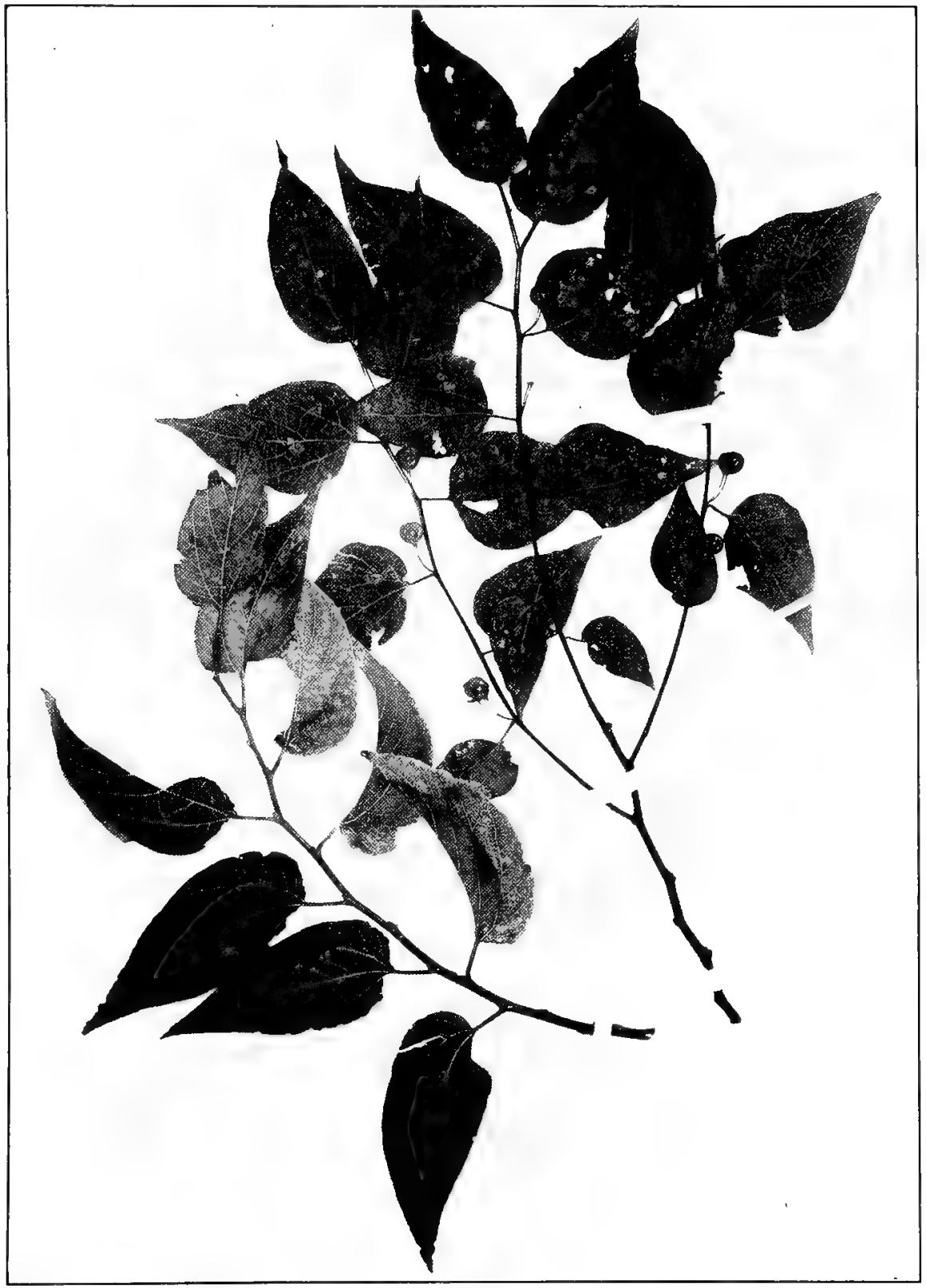

1 CEltis PUMila var. DEAmiI Sargent. Dwarf Hackberry. (x 1/2.) 
or deeply fissured on the larger forms; ridges flat and broken, dark graybrown; twigs at first hairy, becoming smooth or nearly so by autumn; leaves of an ovate type, broadly-ovate, oblong-ovate to narrow ovate, on petioles $0.5-1.5 \mathrm{~cm}$. long, blades of fruiting branchlets $3-10 \mathrm{~cm}$. long, those of sterile twigs sometimes larger, oblique, rounded or somewhat cordate at the base, taper-pointed, sometimes acuminate at the apex, margins entire or with a few teeth usually about or above the middle, becoming thick and smooth above at maturity, sometimes rough, especially on vigorous shoots, generally somewhat pubescent along the veins beneath; fruit matures late in the autumn, usually an orange or light cherry color late in summer, becoming a very dark cherry color late in the autumn, globose to ellipsoidal, on pedicels about as long as the petioles; sometimes the pedicels are shorter but usually about onehalf longer; pedicels generally ascending, rarely recurved, when recurved the pedicels are short.

Distribution.--Pennsylvania to northern Illinois, south to Florida and west to Arkansas. Local in Indiana. It has been collected by the writer in Lake County near the mouth of the Grand Calumet River where it was collected by E. J. Hill who has given us the most detailed account of this species. Also collected on a high, gravelly hill on the east side of Hog-back Lake, Steuben County; on a rocky wooded slope in Hamar's Hollow southeast of Mitchell in Lawrence County; on a "knoh" in Floyd County; on a rocky wooded slope near Big Spring in Washington County; frequent on a rocky wooded slope near the Ohio River east of Elizabeth in Harrison County; on the bank of Blue River near Militown in Crawford County; and in Perry County along the bluffs of the Ohio River about six miles east of Cannelton, and also on the crest of a ridge about six miles southwest of Derby. It has also been reported by Nieuwland for Clark in Marshall County.

Remarks. - This species is usually a small shrub, and usually bears fruit when only 1.5-2 meters ( 5 or 6 feet) tall. Only a few trees have been seen that were $40 \mathrm{~cm}$. ( 4 inches) in diameter. The small size at which this species fruits, easily distinguishes it from other species in our area. Its habitat also serves to distinguish it. Along Lake Michigan it grows on the dry sand dunes, and in southern Indiana it grows on dry rocky slopes.

Sargent who has examined all of my specimens credits Indiana with the typical species, and separates from it a form which he calls Celtis pumila variety Deamii ${ }^{2}$. This varicty is based upon my No. 18,727, and the type sperimen has been photographed to illustrate this species.

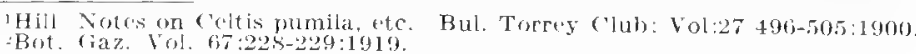


The writer is not able to separate the two forms in our area, and believes that all belong either to Celtis pumila or to the new variety.

3. Celtis mississippiénsis Bosc. (Celtis laevigata Willdenow) Sugarberry. HackBerry. Plate 63. Medium sized trees with the bark of the trunk of large trees irregularly covered with wart-like excrescences, rarely somewhat irregularly fissured, bark of the upper part of trunk and larger branches resembling that of the beech; leaves of an ovate-lanceolate type, as a whole narrower than the preceding species; on petioles 5-12 mm. long, blades of fruiting twigs $4-8 \mathrm{~cm}$. long, usually rounded at the base, sometimes oblique, slightly cordate or somewhat narrowed at the base, usually gradually long-taper pointed at apex, margins generally entire, rarely a few teeth toward the apex, green on both surfaces, generally mature leaves are smooth above and below, more rarely somewhat rough above, and with some pubescence along the veins beneath; fruit in late summer an orange red color, gradually becoming darker until late autumn when it becomes red; pedicels shorter or longer than the petioles, usually slightly longer and ascending, fruit nearly globose, a trifle smaller than the preceding, and about two-thirds as large as the first.

Distribution.- Virginia, southern Indiana, Missouri, eastern Kansas, south to the Gulf States and west to Texas. In Indiana it is confined to the southwestern counties. It is now known to definitely occur in Sullivan, Gibson, Posey, Warrick and Spencer Counties. Two trees were noted also, in the Muscatatuck bottoms near Delany Creek in Washington County. A "single bush about eight feet high" was reported from Jefferson County by Young. This may have been the preceding species. It was also reported by Haymond from Franklin County.

Remarks. - With one exception all the specimens of this species have been found in very low ground. Usually it is associated with such low ground species as pecan, sweet gum, swell-butt ash, and the cane. One very peculiar specimen was found on the crest of a ridge about seven miles north of Salem in Washington County. It was a tree about fifteen feet tall, and had very narrow entire leaves.

\section{moràceae. The Mulberry Family.}

Trees or shrubs with a milky sap; leaves simple, alternate, petioled, 3-5 nerved at the base; fruit fleshy.

Branches without spines; leaves serrate; pistillate flowers in spikes........................... 1 Morus.

Branches with spines; leaves entire; pistillate flowers in heads, 2 Marlura. 
Plite (i3).

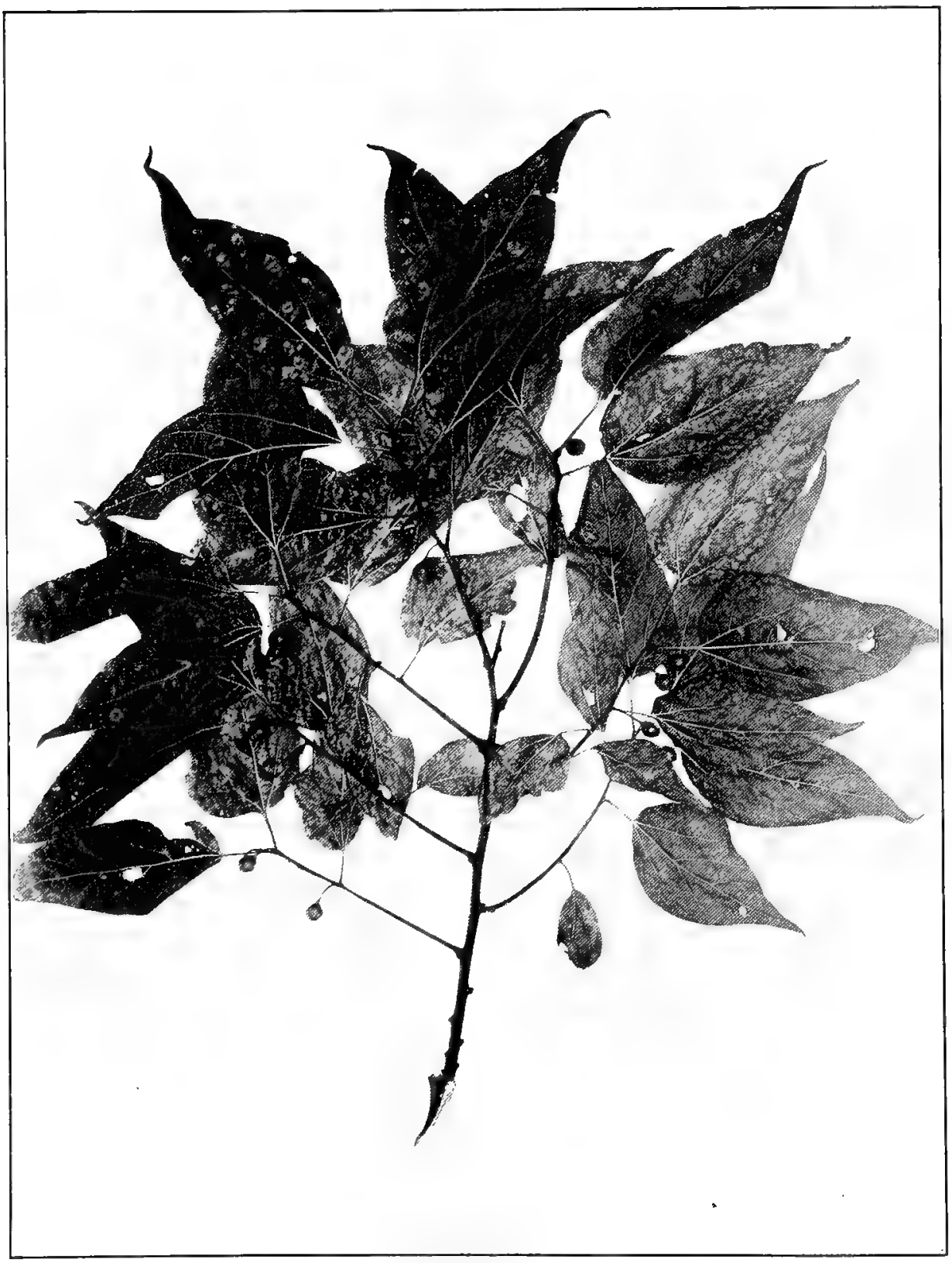

CELTIS MISGISSIPPIENSIS Bose. Stgarberry. (x 1/2.) 


\section{Mòrus. The Mulberries.}

Trees with leaves 3 -nerved at the base; flowers of two kinds on different branches of the same tree or on different trees; the staminate in long catkins, calyx 4-parted, petals none, stamens 4, the pistillate catkins short; fruit an aggregate of drupes.

Leaves softly pubescent beneath................. I M. rubra.

Leaves glabrous beneath, or with a few hairs on the veins or in the axils.

2 M. alba.

1. Morus rùbra Linnæus. Red Mulberry. Plate 64. Medium sized trees with short trunks and round heads; twigs at first green and puberulent, soon becoming glabrous and later usually turning gray; leaves ovate or somewhat orbicular, frequently 2-3 lobed, average mature blades $10-15 \mathrm{~cm}$. long, more or less cordate at the base, abruptly taper-pointed, rough and glabrous above and finely pubescent beneath; fruit ripening in June or July, $1.5-3 \mathrm{~cm}$. long, dark purple or nearly black, edible; wood light, soft, rather tough, coarse-grained, and durable in contact with the soil.

Distribution.- Southern Ontario west to eastern Dakotas, south to the Gulf States and west to Texas. Found throughout Indiana, although there are no records for the extreme northwestern counties. Throughout our area it must be regarded as infrequent. It is only here and there that you find a tree, and I have never seen it where there were even a small number of trees close together. In the northern part of the State it is usually found in a moist well drained soil, associated with trees such as beech and sugar maple, or in lower ground with slippery elm and linn. It has no particular affinity for streams. In the southern part of the State it is found in both rich and poor soils. However, it is most often met with near the base of slopes.

Remarks. - This tree seldom has a clear bole of more than 3-5m. and is usually a tree about $20 \mathrm{~cm}$. in diameter, rarely as large as $6 \mathrm{dm}$. in diameter, although there is a record" of a tree in Georgia that was " 7 feet in diameter at 3 feet above the ground."

The wood has been a favorite for fence posts since pioneer times. It transplants easily. The fruit is a favorite with birds and for this reason it should be planted about orchards and in woodlots. It is some-

${ }_{1}$ Garden \& Forest 9:375:1896. 
154

Plate 6 it.

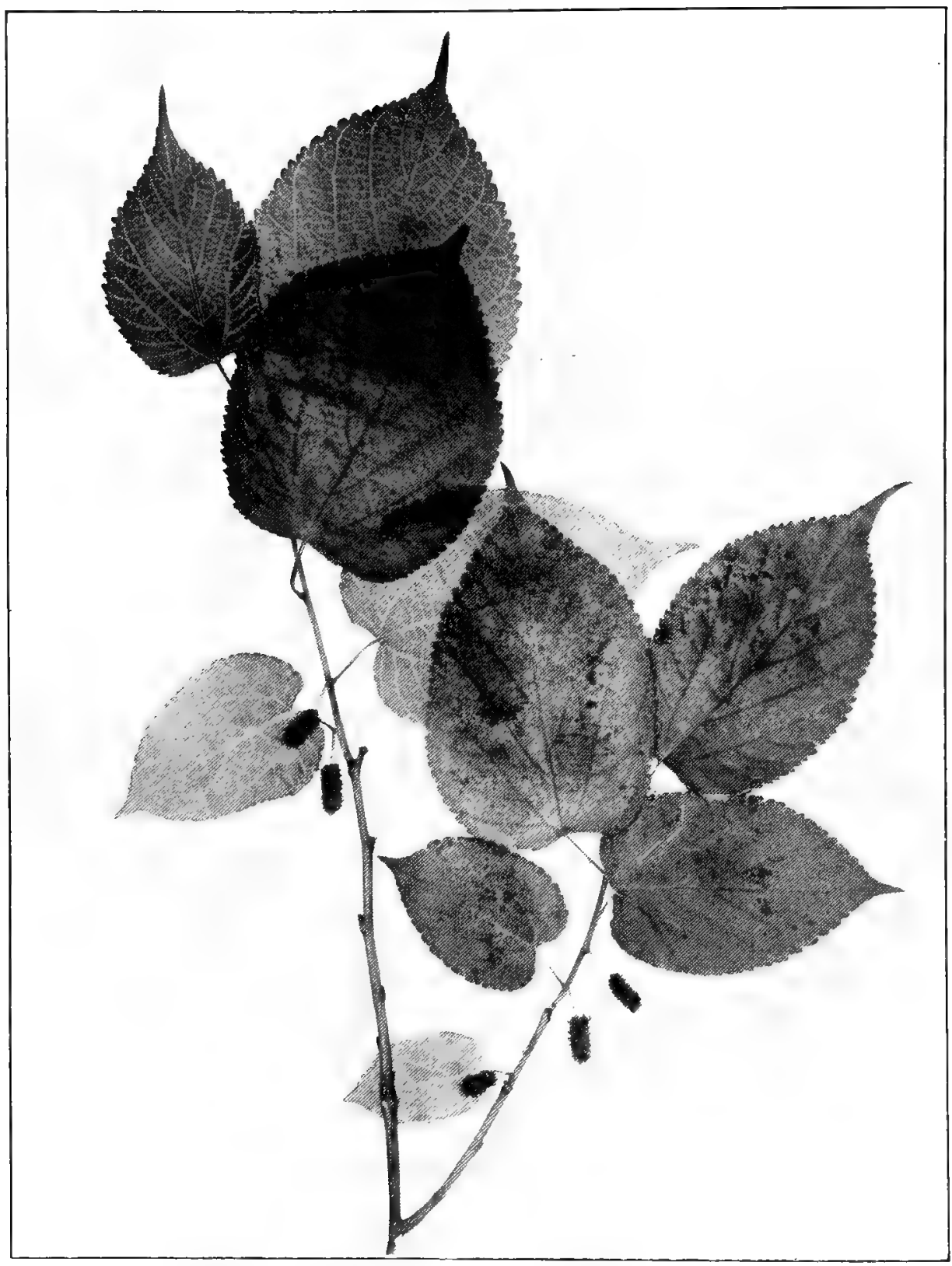

MIORL'S RUBRA limmets. Red MUtierry. ( $\left.x^{1} 1_{2}\right)$ 
times called the red mulberry to distinguish it from the following species. ${ }^{1}$

\section{MaClútra. The Osage Orange.}

Maclura pomífera (Rafinesque) Schneider. Hedge. Osage Orange. (Toxylon pomiferum Raf.) Plate 65. Trees with brown shreddy bark on old trees; mature twigs greenish gray, zigzag; spines about 10-15 mm. long; leaves ovate to oblong lanceolate, average blades 7-12 cm. long, wedge-shape, rounded or cordate at the base, long taper-pointed at the apex, margins entire, pubescent on both sides while young, becoming at maturity lustrous and glabrous above, remaining pubescent beneath; fruit globose, about $1 \mathrm{dm}$. in diameter; wood heavy, very hard and strong, the most durable in contact with the soil of any of our post timbers.

Distribution.-Missouri and Kansas south to Texas. Introduced into Indiana for hedge fences. There is some question as to the ability of this species to escape. I have heard that it frequently sends up root shoots at several feet from hedge fences, and that it frequently seeds itself along old hedge fences. For the past few years I have given the species especial attention and I have never seen it as an escape except in three instances.

Remarks.- This species was formerly much planted for farm fences, but since land has become so valuable, its use has been discontinued, and the old fences are being dug up. The tree grows a short trunk, and one was noted in Grant County that was at least $6 \mathrm{dm}$. in diameter that was estimated to be less than fifty years old. This species is subject to the San Jose scale and in some localities it has been killed by it. It has been but little used for forest planting, and the plantations are not yet old enough to measure their success.

\section{MAGNOLIÀCEAE. The Magnolia Family}

Trees or shrubs with alternate and petioled leaves; flowers large, terminal and solitary with numerous stamens and pistils.

${ }^{1}$ Morus alba Linnæus. White Mulberry. A small crooked tree; leaves ovate, sometimes lobed, blades $6-13 \mathrm{~cm}$. long, cordate at the base, acute at apex, at maturity glab rous above and glabrous beneath or with some hairs on the veins and in the axils of the veins. fruit subglobose or oblong, $1.2 \mathrm{~cm}$. long, white to pinkish. This is an introduced tree and has been reported as an escape in many parts of the State, especially by the older botanists. Morus alba variety tatarica Loudon, the Russian mulberry, has been reported as an escape The writer has seen single specimens as an escape in woods in Cass and Marshall Counties. It can be distinguished by practically all of the leaves being more or less lobed and the reddish fruit. This form was introduced into the United States in great numbers about flfty years ago by the Mennonites. It was especially recommended by nurserymen for fence posts and it has been planted to some extent in Indiana, but it cannot be recommended. It grows too slowly and is too crooked to compensate for any lasting qualities the wood may have. Morus nigra has been reported from Indiana by Phinney, Brown and McCaslin as a forest tree. Since this is an introduced tree, and is not supposed to be hardy in our area, their reports should be transferred to some other species. 
Plate 65.

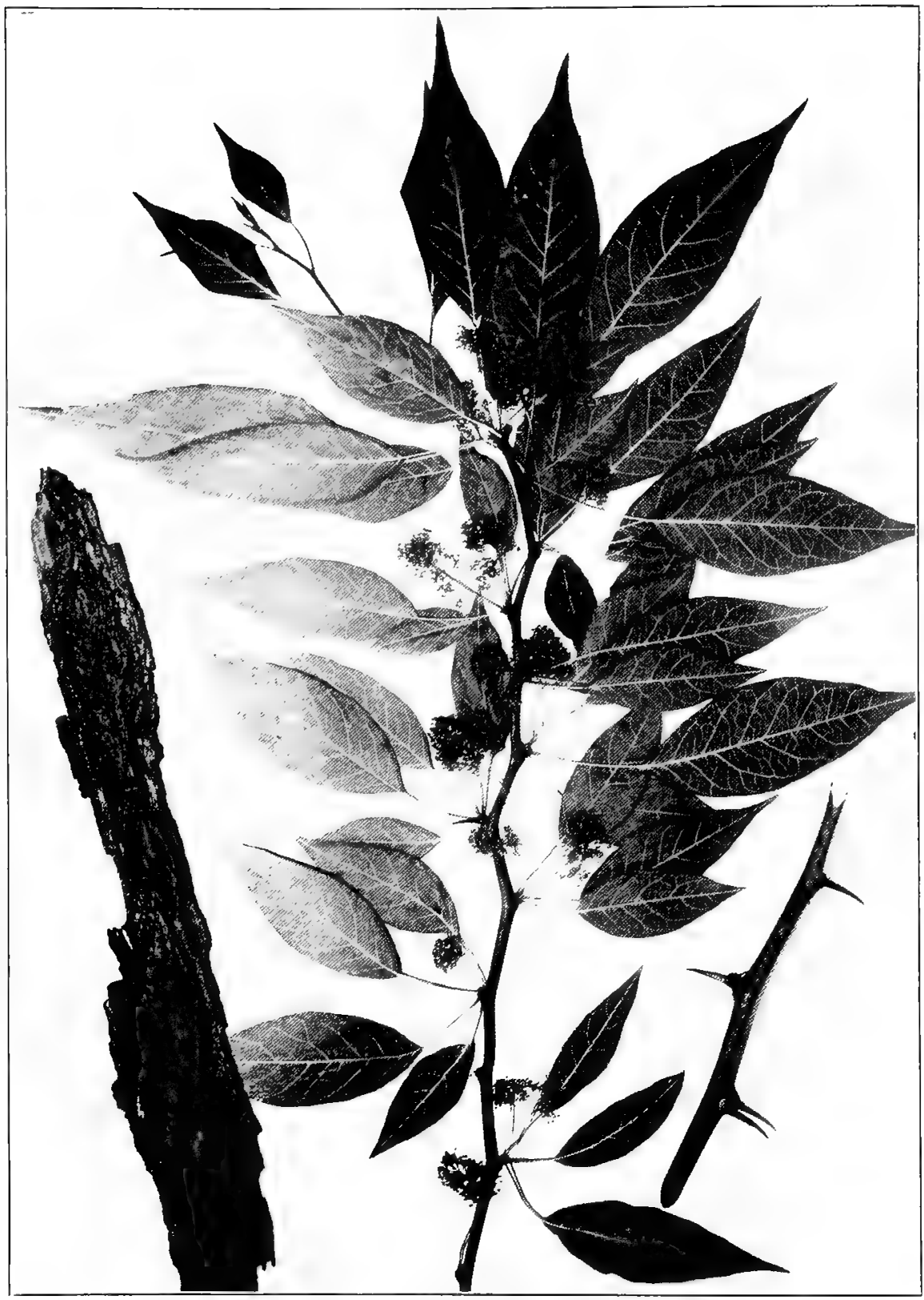

MaCluRa POMifera (Rafinesque). Schneider. Osage Orange. (x 1/2.) 
Buds silky white pubescent; leaves entire; fruit fleshy, dehiscent....

1 Magnolia.

Buds glabrous; leaves lobed; fruit a cone of dry carpels, indehiscent........................... 2 Liriodendron.

\section{MAG Nòlia. The Magnolias.}

Magnolia acuminàta Iinnæus. Cucumber Tref. Plate 66. Large trees with furrowed bark which is gray and much resembles the tulip tree except the ridges are shallower and closer; twigs downy at first, becoming glabrous or nearly so and a light to a cherry brown by the end of the season; leaves oval, average blades $15-22 \mathrm{~cm}$. long, rounded to truncate at the base, abruptly short-pointed, pubescent on both sides at first, becoming glabrous above, and remaining pubescent beneath, rarely entirely glabrous; flowers about $6 \mathrm{~cm}$. long, bell-shaped, pale yellowish-green; fruit cylindrical, 5-7 cm. long, 1-2 cm. diameter, the large scarlet seeds begin to push out of their receptacle in September; wood light, soft, not strong, close-grained and durable.

Distribution.- North shore of Lake Erie, western New York, eastern Ohio, southern Indiana, southern Illinois and along the Appalachian Mountains to southern Alabama and west to Arkansas. It doubtless occurred in all or nearly all of the counties in southern Indiana south of a line drawn from Franklin to Knox Counties. It no doubt was extremely local. For instance a pioneer 81 years old who had always lived in Washington County told me that there were two trees on his farm near Pekin, and these were the only two trees he knew of in the vicinity. These trees were popular because the neighbors came for the fruit to put into whisky for making bitters which were a specific for all ailments. I have seen only a shrub on the Forest Reserve in Clark County. On a beech and sugar maple ridge about 4 miles northwest of Medora in Jackson County on the Geo. W. Scott farm two trees were still standing in 1915. Mr. Scott, a pioneer, said the species was found on the ridge for about 2 miles and that there were about a half dozen trees to the acre, and the largest was about a meter in diameter. It is known in two other places in this county. A tree is still standing in Lawrence County on the Sam Mitchell farm $2 \frac{1}{2}$ miles south of Bedford. Mr. Mitchell is a pioneer and says that a few trees were found in the vicinity on the ridges. It has been reported for Franklin, Floyd and Jefferson Counties. There is hearsay evidence that it occurred in other countes.

Remarks. - The cucumber tree has been too rare in Indiana to be of economic importance. The greatest interest with us is its distribution. The uses of the wood are similar to that of tulip with which it is bo- 
Plate 66.

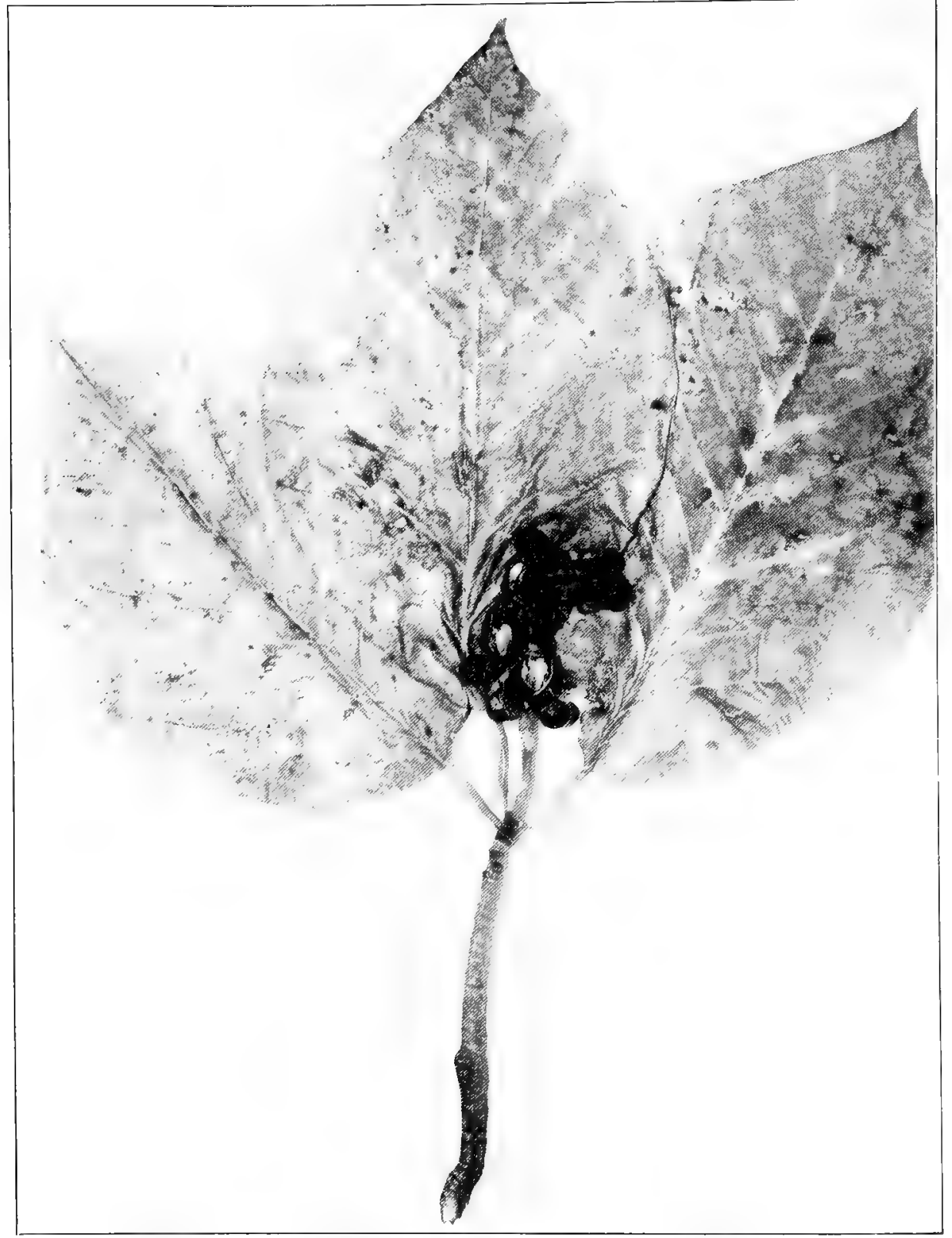

MagNolia ACUMiNATA Linnerus. Cucuaber Tree. (x 1/2.) 
tanically related. It is said that the greater part of the lumber which is produced in the south is sold as tulip. The seeds of this tree are extremely bitter and no bird, squirrel or mouse will carry or touch them. However, man after macerating them in whisky can use them for medicine.

\section{LIRIODENDRON. The Tulip Tree.}

Liriodendron Tulipífera Linnæus. Tulip. Yellow Poplar. Plate 67. Large trees with deeply furrowed grayish bark; twigs glabrous and glaucous at first, becoming reddish-brown by the end of the season, then gray or dark brown; leaves very variable, 4-6 lobed, average blades 5-12 cm. long, truncate and notched at the apex, more or less rounded, truncate or cordate at the base, glabrous above and below at maturity or with a few hairs on the veins beneath; flowers appear in May or June, large bell-shaped, about $4 \mathrm{~cm}$. deep, greenish-yellow, sometimes tinged with orange-red; fruit upright, cone-shaped, 5-7 cm. long; wood light, weak, soft, stiff, straight and moderately coarse-grained, seasons and works well. Sap wood white, heart wood a light yellow.

Distribution.-Vermont, southern Ontario, southern Michigan, south to Florida and west to Arkansas and Missouri. Found throughout Indiana, and doubtless is tound in every county. It is rare to infrequent in most of the counties north of the Wabash River. It gradually becomes more frequent toward the south and where its habitat is found it is frequent to common. It prefers a moist rich well drained soil and thrives best in protected coves and near the lower part of slopes of hills. It is found with beech, sugar maple and white oak. It is rarely found in a black loam soil, but prefers a sandy soil. It was generally a common tree and of very large size in practically all of the counties in the southern two-thirds of the State.

Remarks. - This tree is generally known by botanists as tulip tree. By lumbermen it is usually known as yellow poplar, or more often shortened to poplar. It is also known as blue, white and hickory poplar, or as white wood. The tulip tree is the second largest tree of Indiana. In the Ind. Geol. Rept. 6:70:1875, is the following: "I measured four poplar trees that stood within a few feet of each other; the largest was thirty-eight feet in circumference three feet from the ground, one hundred and twenty feet high, and about sixty-five feet to the first limb. The others were, respectively eighteen and a half, eighteen and seventeen feet in circumference at three feet from the ground." The range of the uses of the wood is not so great as the oak, but it has many use. The demand has been so great that practically all of the large trees have been cut. Small trees have so much sap or white wood that they are not sought for lumber, but can be used for pulp and excelsior. 
Plate 67.

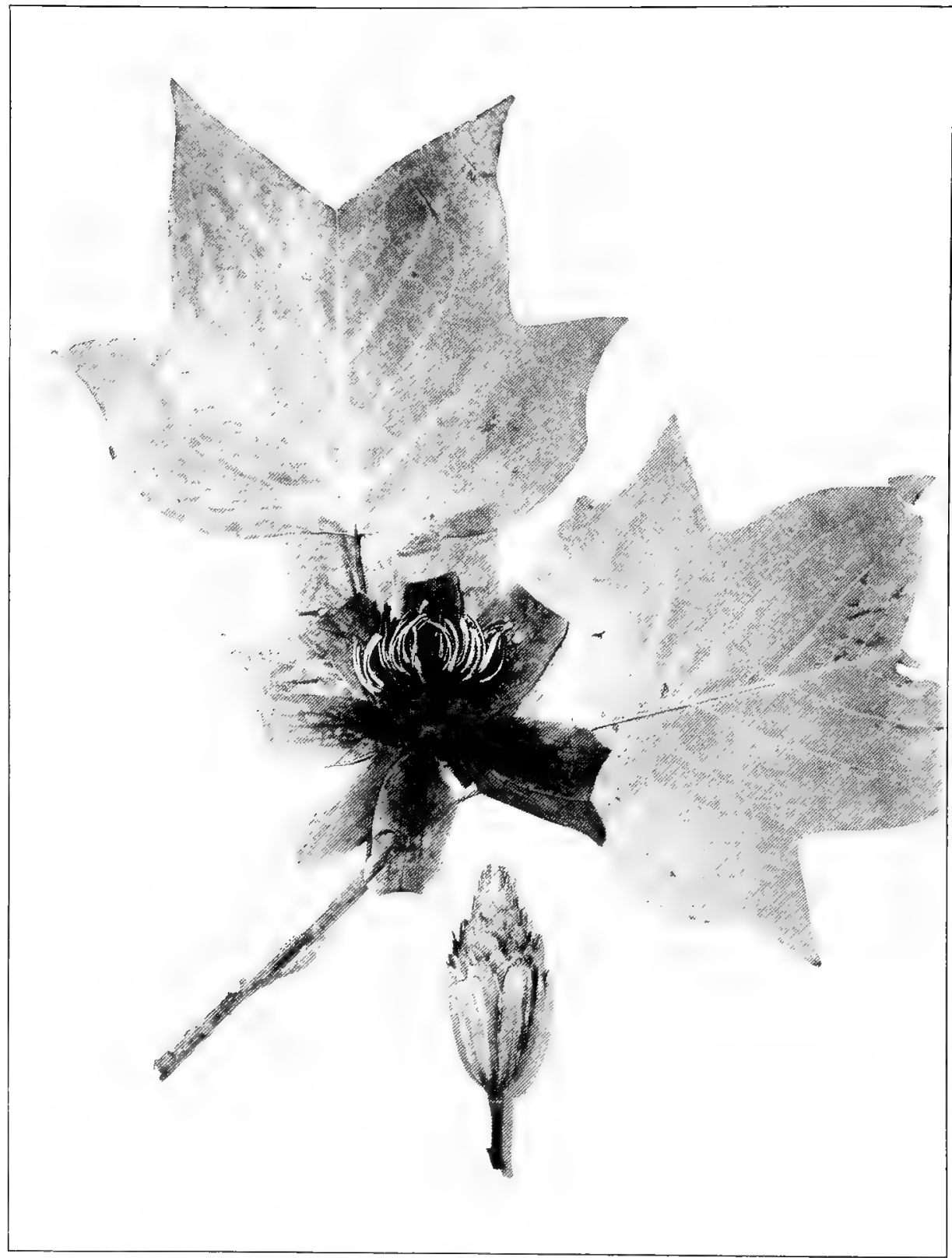

LIRIODENDRON TULIPIFERA Linnæus. Tulip or Yellow Poplar. (x 1/2.) 
The tulip transplants easily, grows rapidly, tall and with short side branches. Experiments in growing this tree indicate that it is one of the very best trees for reinforcing the woodlot, and other forest planting. It can be recommended for roadside planting because it grows tall and has a deep root system. Where conditions of life are not too severe it could be used for shade tree planting.

ANONÀCEAE. The Custard Apple Family.

ASIMINa. The Pawpaw.

Asímina tríloba (Linnæus) Dunal. Pawpaw. Plate 68. Shrubs or small trees; bark smooth except on very old trees when it becomes somewhat furrowed; twigs at first covered with rusty brown hairs, becoming glabrous and reddish-brown by the end of the season; leaves obovate-lanceolate, average blades $16-30 \mathrm{~cm}$. long, abruptly taper-pointed, wedge-shape at base, margins entire, somewhat rusty pubescent at first, becoming at maturity glabrous above, and glabrous or nearly so beneath; flowers appear in May or early June, maroon color, drooping; fruit edible, ripening in September and October, 7-13 cm. long, greenish-yellow, smooth, pulp white or yellow, with a few large, dark-brown flattened seeds; wood light, soft and weak.

Distribution.-New York, north shore of Lake Erie, southern Michigan, Nebraska, south to Florida and west to Texas. Found in all parts of Indiana, although it is found in the greatest abundance in the central counties. It prefers a moist rich soil, although it is quite adaptive. Sometimes it is found in a black loam soil in low woods or about lakes, but its preference is for a beech and sugar maple woods or habitats approximating it. In the southern counties it is absent on the sterile wooded ridges, but may be a common shrub at the base of the slopes. It is a constant companion of the tulip tree and where one will grow the other is likely to be found. It is a great tree to send up suckers, hence it is always found in clumps, or forms real thickets. This species with us is usually 2-7 meters high; however, there are records of large trees. Collett in Ind. Geol. Rept. 5:404:1874, in a geological report of Gibson County says: "A forest of pawpaw bushes attracted our attention by their tree-like size, being nearly a foot in diameter."

Remarks. - This species is also known as the yellow and white pawpaw. Recently some enthusiasts have christened it the "Hoosier Banana". There has been an attempt for years to cultivate the pawpaw, and some varieties have been named. The fruit is variable. The one with a white pulp is rather insipid and is not considered good to eat. The form with a yellow pulp is the kind that is regarded as the most pal- 
Plate lis.

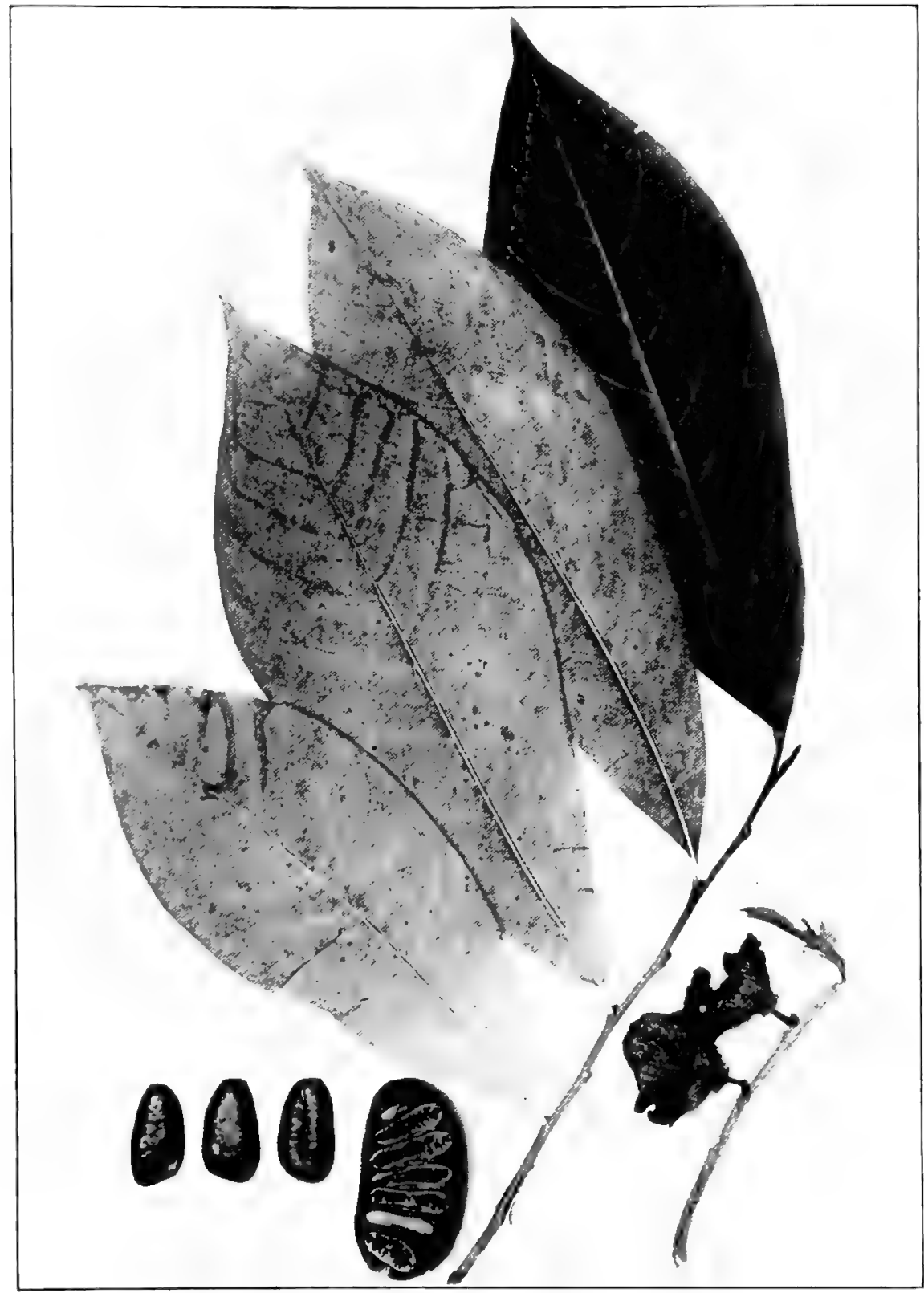

ASIMIINA TRILOBA (Linnaus) Dunal. PAwPAw. (x 1/2.) 
atable. The two forms are not botanically separated but Prof. Stanley Coulter has made some observations on the two forms in the Ind. Geol. Rept. 24:745:1899. He says: "Two forms, not separated botanically are associated in our area. They differ in time of flowering, in size, shape, color and flavor of the fruit, in leaf shape, venation and odor and color of the bark. They are of constant popular recognition and probably separate species, never seeming to intergrade."

It is desirable for ornamental planning on account of its interesting foliage, beautiful and unique flowers and delicious fruit. It is very difficult to transplant a sucker plant, and in order to get a start of this species it is best to plant the seed or seedlings. It is usually found growing in the shade, but does well in full sunlight.

Mr. Arthur W. Osborn of Spiceland, who has done much experimental work in propagating this species, reports some interesting cases of pawpaw poisoning. He says he knew a lady whose skin would be irritated by the presence of pawpaws. Some individuals after eating them develop a rash with intense itching. In one instance he fed a person, subject to the rash from eating the pawpaw, a peeled pawpaw with a spoon, and the subject never touched the pawpaw, and the results were the same. The American Genetic Association has taken up the subject of improving the fruit of this tree, and there is no doubt but that in the future this species will be of considerable economic importance. The tree is free from all insect enemies, and since it can be grown in waste places, there is no reason why it should not receive more attention than it does.

\section{LAURÀCeaE. The Laurel Family. SÄSSAFRAS. The SASSAFras.}

Sassafras officinàle Nees and Ebermaier. SAssafras. ReD Sassafras. White Sassafras. Plate 69. Small to large trees; bark aromatic, smooth on young trees, reddish-brown and deeply furrowed on old trees, resembling that of black walnut; branchlets yellowishgreen, splotched more or less with sooty spots; twigs at first more or less hairy, soon becoming smooth or remaining more or less hairy until autumn, more or less glaucous, especially the smooth forms; buds more or less pubescent, the axillary ones usually more or less hairy, the outer scales of the terminal one usually smooth and glaucous; leaves simple, alternate, ovate, elliptic to obovate, blades $5-16 \mathrm{~cm}$. long, entire or with 1-5 lobes, narrowed at the base, the apex and terminal of the lobes acute, both surfaces hairy when they expand, generally becoming smooth above and beneath, or more often remaining more or less pubescent 
Plate 69.

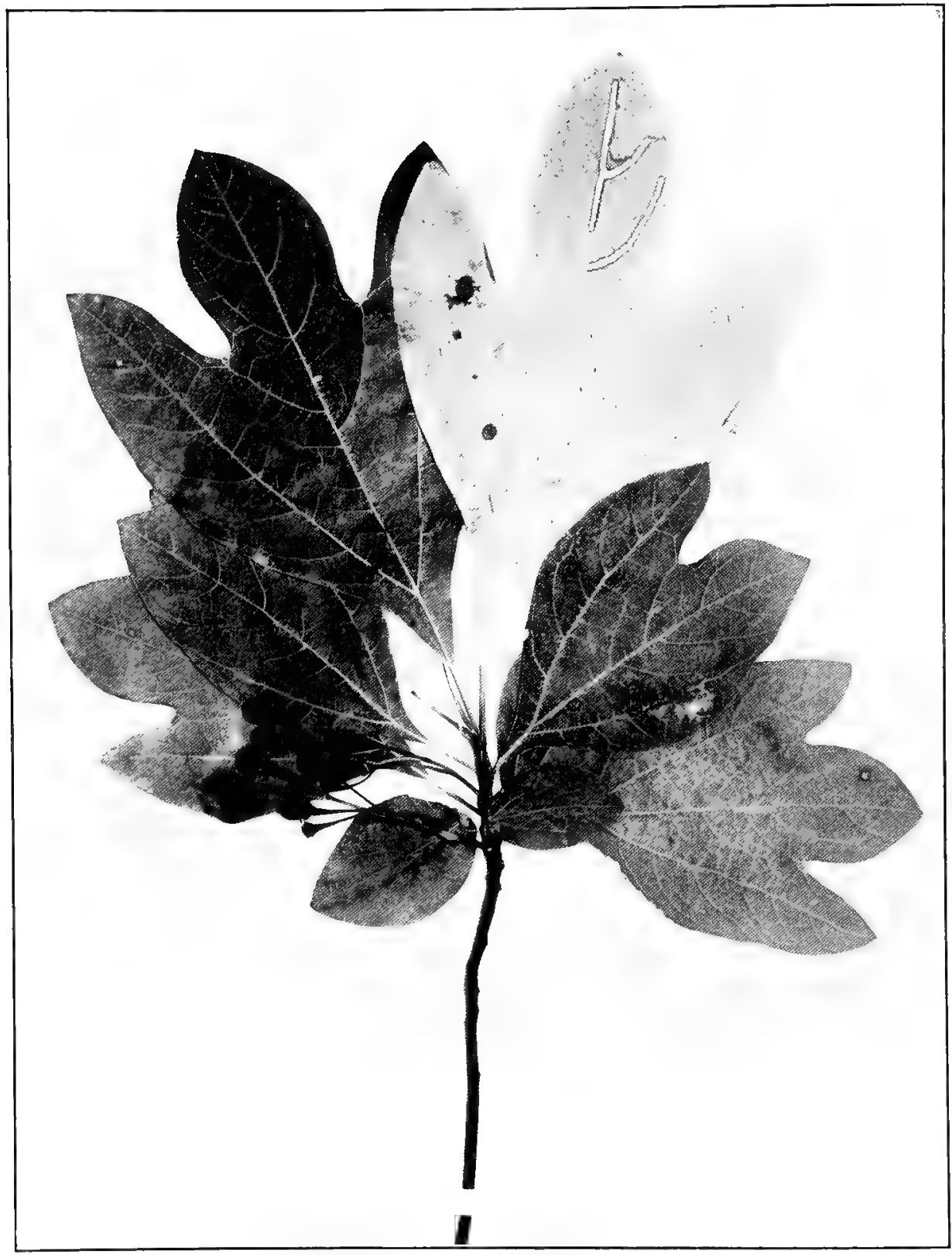

SASSAFRAS OFFICINALE Nees and Ebermaier. SAssafras. ( $\mathrm{x}$ 1/2.) 
beneath, the midrib and two lateral veins usually prominent beneath; petioles $0.5-5 \mathrm{~cm}$. long, hairy at first, becoming smooth or more often retaining some pubescence; flowers appear before or with the leaves in April or May, small, yellow or greenish, the male and female generally on different trees, on racemes up to $4 \mathrm{~cm}$. long; flower stalks usually pubescent, sometimes smooth; fruit an oblong, blue-black, glaucous berry which matures late in summer; fruit generally $7-10 \mathrm{~mm}$. long, on at stalk including the pedicel and raceme up to $9 \mathrm{~cm}$. long.

Distribution.-Maine, southern Ontario to Iowa and south to Florida and west to Texas. No doubt it was formerly found in every county of Indiana. In the northern part of the State it is more local in its distribution than in the southern counties. In the northern counties where it is local it is found in colonies on sandy or clayey ridges. Sassafras is usually considered an indicator of poorer soils, hence, in the central counties it is often very local. It is frequent to common throughout the hilly counties of the southern part of the State. In this part of the State it becomes a pernicious weed tree. It soon invades fence rows and fallow fields, and is extremely difficult to kill out. It is rarely found in wet situations; however, in Sullivan and Clay Counties large trees have been observed in low alluvial ground, associated with the white elm, etc.

Remarks.-Wood light, soft, coarse-grained, aromatic, heartwood brownish. In our area sassafras wood is used principally for posts and crossties. The roots contain a volatile oil which is much used in mecliicine and perfumery. Every one is familiar with the sassfras peddler who in the Spring sells a small bundle of roots or bark for making sassafras tea. The tea is reputed "to thin the blood." The aromatic character of the wood led the earliest inhabitants to attribute many medicinal and other qualities to the wood which, in many instances bordered on superstition. In some of the southern States bedsteads were made of sassafras with the belief that they would produce sounder sleep. Floors were made of sassafras to keep out the rats and mice. Perches of chicken houses were made of sassafras poles to keep off the lice. To successfully make soap, it was necessary to stir the contents of the kettle with a sassafras stick.

The sassafras is usually about one-fourth of a meter in diameter. However, on the Charles Hole farm about three miles southeast of Butlerville grew two of the largest trees of which we have record. The trees grew within seven meters of each other on a slope now grown up with large sugar maple. They were cut by Mr. Hole's father, on whose farm they were located. The largest was cut in the later sixties and the smaller in the early seventies. The stumps were seen by the writer in 
1918. Both are now hollow although the outside is quite solid after having been cut about fifty years. Chips were cut from the root spurs and the wood was almost as aromatic as if the tree had just been cut. "The stumps have been burned at least three times," says Mr. Hole, yet the smaller now measures $1.09 \mathrm{~m}$. (43 inches) in diameter at a meter high. The largest st ump now measures $1.22 \mathrm{~m}$. (48 inches), in diameter at a meter high. Mr. Hole says that the smallest tree had a clear bole of at least 18 meters, and the largest tree was $.92 \mathrm{~m}$. (36 inches) in diameter 20 meters from the stump.

Sassafras deserves more consideration than it has received as a shade and ornamental tree. The autumnal coloring of its foliage is scarcely surpassed by any tree; and it is free from injurious insect pests. It adapts itself to almost all kinds of soils, and grows rapidly. It is, however, transplanted with difficulty; this means only more care in digging the tree and planting it.

Commonly the sassafras is classed as red and white sassafras. The roots of the white sassafras are said to be whiter, the aroma of the wood has a suggestion of camphor, and the wood is less durable. This belief is common throughout the area of its distribution, but so far as the writer knows, no scientific work has been published to verify this division of the species.

Sassafras is extremely variable, but most botanical authors have considered the many variations as one species. Nuttall in 1818 was the first author to make a division of the forms, and he has been followed by some recent authors. Nuttall separated those forms with smooth twigs, buds, and under surface of leaves, from those with pubescent twigs, buds, and under surface of leaves. Nieuwland ${ }^{1}$ separates a variety from the smooth forms which be calls Sassafras albida variety glauca, and reports it as occuring in the counties in the vicinity of Lake Michigan.

The writer has at hand 46 specimens from 41 counties in Indiana, including all of the Lake Michigan Counties, and he has not been able to find a single character that is constant enough to make a division of our forms, consequently all the Indiana forms are included under one and the old name for sassafras.

\section{Altingiàceae. Sweet Gum Family.}

Liquidámbar Styraciflua Linnæus. Sweet Gum. Plate 70. Large trees with resinous sap; bark deeply furrowed, grayish; twigs when very young somewhat hairy, soon becoming glabrous, a light reddish-brown by the end of the season, later a gray, usually some or all 
Plate 70.

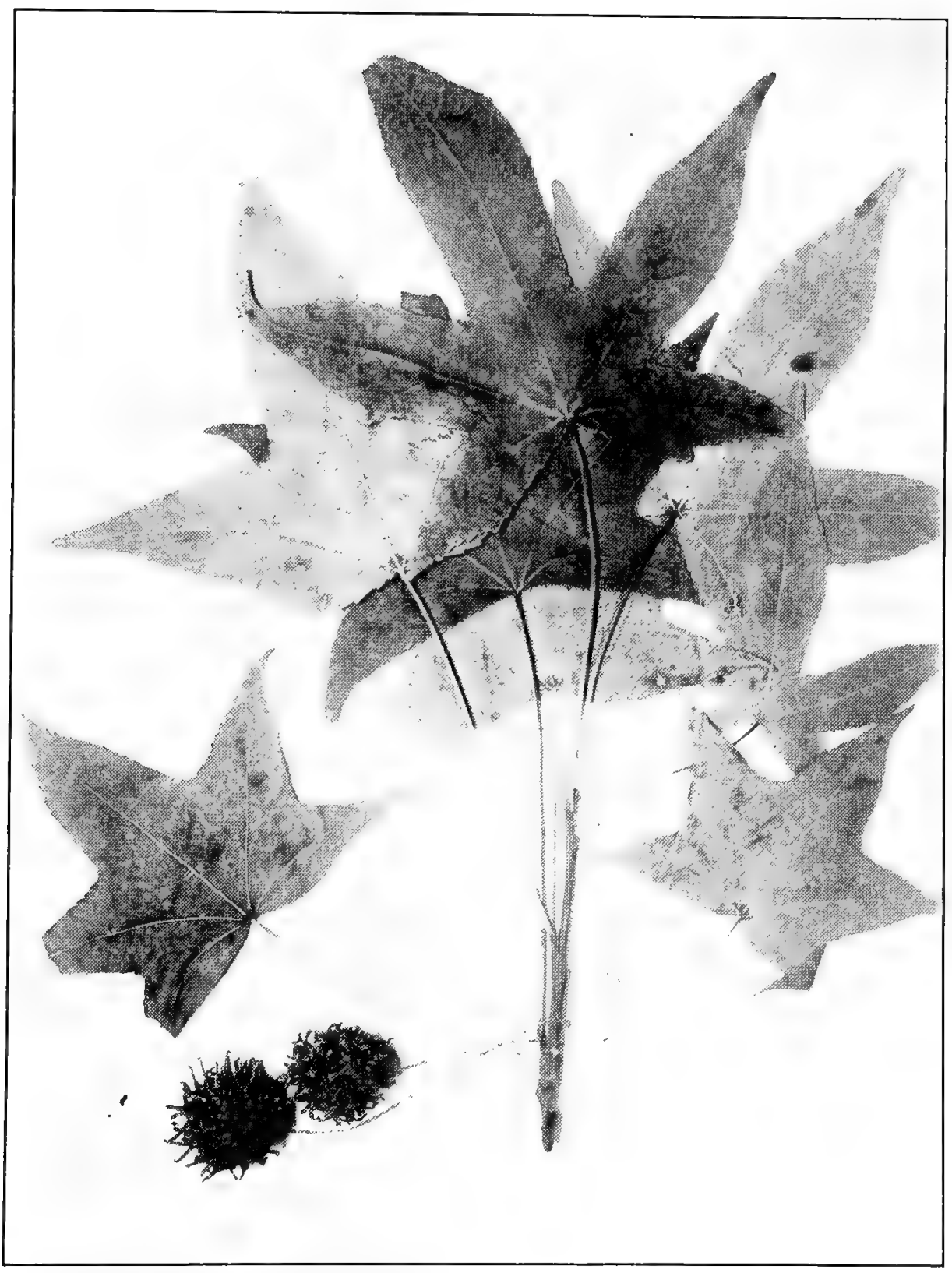

LIQUIDAMBAR STYRACIFLUA Linnæus. SWEET or RED Gum. (x 1/2.) 
of the branchlets develop one or more corky ridges running lengthwise of the branchlets, or in some cases only corky excrescences; leaves simple, alternate, long-petioled, orbicular in outline, cleft into 5 medge-shaped lobes, rarely 7 lobes, average blades $5-12 \mathrm{~cm}$. long, truncate or cordate at the base, margins finely serrate, hairy on both surfaces on unfolding, soon becoming glabrous above, and remaining more or less hairy beneath especially in the axils of the veins, at maturity turning to a dull or brilliant red; flowers in heads, expanding in April or May; fruit a globular, horny aggregate of carpels, $3-4 \mathrm{~cm}$. in diameter including the horns; wood heavy, hard, not strong, closegrained, inclined to shrink and warp in seasoning, takes a good polish, heart wood a rich brown which can be finished to imitate walnut or mahogany.

Distribution.-Connecticut, southern Ohio to Missouri, south to Florida and west to Texas, and in the mountains in Mexico south to Guatemala. In Indiana it is confined to wet woods in the southern half of the State. The most northern records are from Franklin, Shelby, Putnam and Parke Counties. Wherever it is found it is usually a frequent to a commion or very common tree. It is most frequently associated with the beech, but in the very wet woods it is found with pin oak, red birch, cow oak and white elm.

Remarks. - This species grows rapidly; is somewhat hard to transplant; grows straight and tall with few side branches, and adapts itself to a wet, compact soil. In the "flats" of southern Indiana where it is associated with pin oak, red birch and beech, it is to be preferred for forest planting to these or any other species that could be grown in the "flats." It is practically free from all injurious insects. Sweet gum should be one of the principal species in wet places of the woodlots of southern Indiana.

This species is one of the best for ornamental plantmg in all parts of the State where it is hardy. It is doubtful if it is wise to use it in the northern part of the State. Several trees in the northern part of the State are known to be quite hardy, but there are reports that it sometimes winter-kills. It can also be recommended for roadside and street planting.

\section{Platanàceae. The Plane Tree Family. PLátanus. The Plane Tree.}

Platanus occidentàlis Linnæus. Srcamore. Plate 71. The largest tree of the State; bark thin, smooth, on age separating into thin plates and exfoliating, base of the trunks of very old trees some- 
Plate 71.

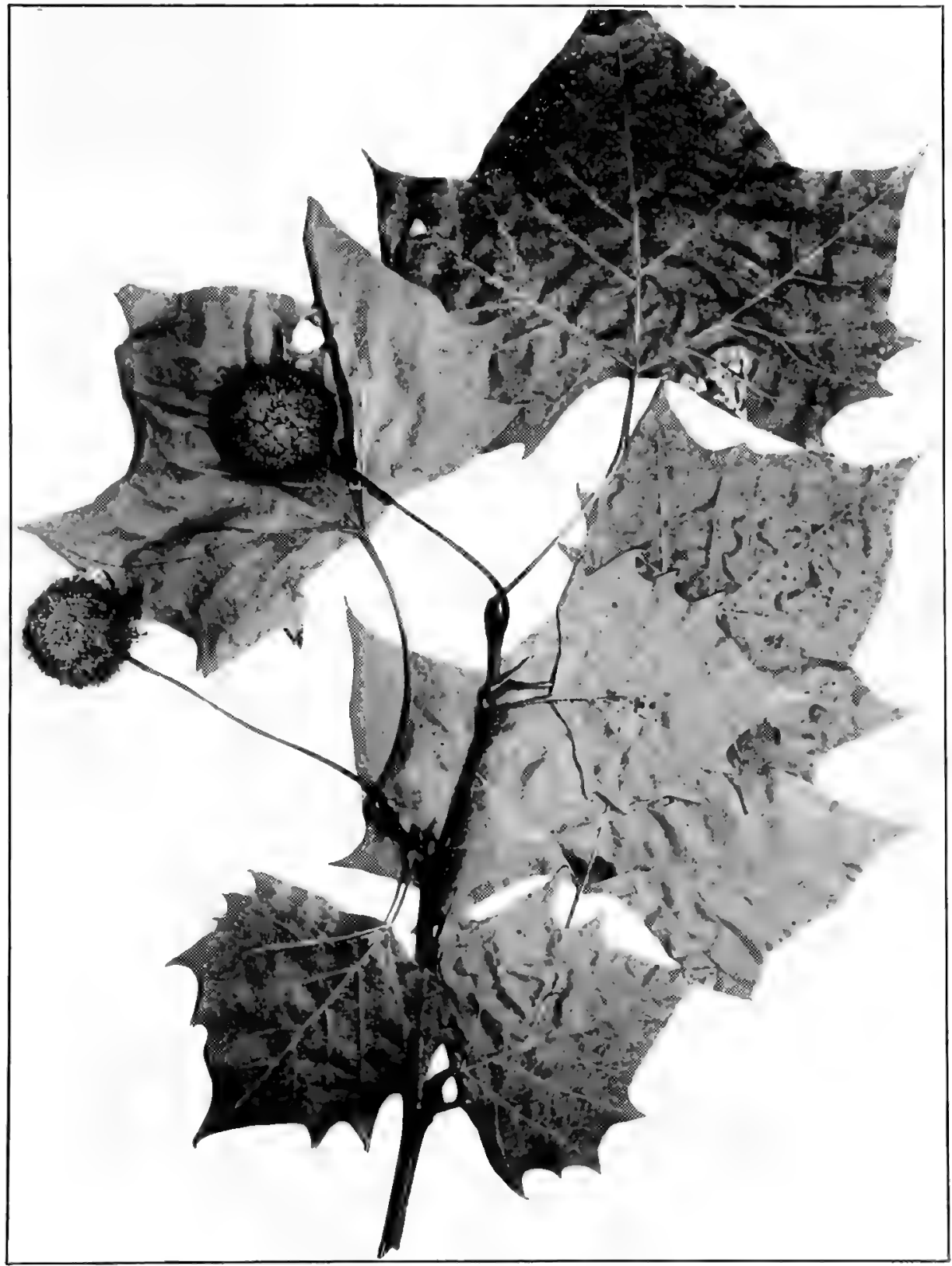

PLATANUS OCCIDENTALIS Linnæus. Sycamore. $\left(x \frac{1}{2}\right)$ 
what roughened or fissured, gray to grayish-green, splot ched with white; twigs at first covered with a scurvy pubescence, becoming at maturity glabrous except a ring at the node about the leaf-scar, gray or light brown, and zigzag; leaves alternate, long-petioled, nearly orbicular in outline, the blades somewhat deltoid, blades large, variable in size and shape, average blades 9-17 cm. long, frequently much larger on vigorous shoots, generally with $3-5$ main lobes, sometimes the lobes are indistinct and the leaves appear only irregularly toothed, margins toothed, rarely entire between the lobes, truncate or cordate at the base, acute or acuminate at the apex; one form has been noted with leaves obovate, scarcely lobed and with a wedge-shaped base; leaves covered on both sicles at first with a dense tomentum, becoming at maturity glabrous above-rarely tardily pubescent, nearly glabrous beneath, except on the veins and in the axils, petioles remaining pubescent; flowers appear in May with the leaves in heads on long woolly peduncles; fruit a globose head of many seeds, $2-3.5 \mathrm{~cm}$. in diameter, maturing late in the year; the seed are scattered by the wind during the winter months; wood heavy, hard, weak, close-grained, difficult to split and work, takes a high polish; when used as a container it does not communicate an objectional taste or odor to contents.

Distribution.-Maine, Ontario to Nebraska, south to the Gulf States and west to Texas. Found in all parts of Indiana, although there are no records for the extreme northwestern counties. It is a tree of a low ground habitat, and is found principally in low ground along streams, about lakes, and ponds. In such habitats it is a frequent tree in all parts, except in the "flats" of the southern counties. In some places it is a common to a very common tree, especially along the upper courses of White River.

Remarks. - In this State this species is always called the sycamore tree. It is the largest tree of the State, and the largest deciduous tree of the United States. Indiana has the distinction of having the largest living sycamore in the United States. It is located near Worthington, Indiana, and "in 1915, measured 43 feet and 3 inches in circumference at five fect above the ground." See frontispiece. The sycamore grew to great diameters in all parts of the State. It was commonly hollow, because it is believed the tree in early life is usually more or less injured by floating ice and debris which starts inner decay. Hollow sycamore logs were commonly used by the pioneers in which to smoke their meat, and sections of hollow logs about $12 \mathrm{dm}$. (4 feet) long were used to store grain in, and were known as "gums."

The value of sycamore lumber has been very much underestimated. It has many uses such as butcher blocks, interior finish, furniture, 
piling, tobacco boxes, veneer berry boxes, handles, wooden ware, etc. Indiana has led in the production of sycamore lumber for years.

The sycamore is well adapted for shade, ornamental and forestry purposes. It transplants easily, grows rapidly, stands pruning well and is comparatively free from injurious insects. It grows straight, tall and usually with a rather narrow crown. It prefers a moist soil, but adapts itself to dry situations. For planting overflow lands, or on the banks of streams it is one of the best species we have. It is also one of the best species for roadside tree planting, because it is deep rooted, grows tall, and does not produce a dense shade.

\section{Maláceae. ${ }^{1}$ The Apple Family.}

The trees of this family that occur in our area have simple, alternate leaves; perfect, regular flowers, 5-merous calyx and corolla; fruit a more or less fleshy pome.

Flowers in racemes, cavities of mature fruit twice as many as

the styles, seeds less than $4 \mathrm{~mm}$. (1/8 inch) long.......2 Amelanchier.

Flowers in cymes or corymbs, cavities of mature fruit as many

as the styles, seeds more than $4 \mathrm{~mm}$. (1/8 inch) long.

Fruit green, mature carpels papery.............. 1 Malus.

Fruit red, orange, blue-black or yellow, mature carpels

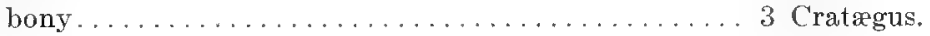

\section{MALus. The Apples.}

Malus angustifolia has been reported from the State, but it is a species of more southern range. Both Malus ioensis and Malus lancifolia may easily be mistaken for this species.

Leaves and petioles glabrous or only slightly pubescent; calyx tube and outside of calyx lobes glabrous or only slightly pubescent.

Leaves distinctly lobed, at least those of vigorous shoots; petioles pubescent above.................. 1 M. glaucescens.

Leaves serrate, not lohed; petioles glabrous......... 2 M. lancifolia. Leaves (at least the Iower surfaces) and petioles densely tomentose; calyx lobes densely tomentose on both sides... 3 M. ionesis. 
1. Malus glaucéscens Rehder. American Crab Apple (11. fragrans Rehder). Plate 72. Bark reddish, fissured and scaly; leaves on glandless petioles, petioles usually $2-4 \mathrm{~cm}$. (3/4-1/2 inches) long, leaves narrow ovate to almost triangular, those on the lateral branchlets of the ovate type, those of the terminal branchlets and vigorous shoots of the triangular type, $3-8 \mathrm{~cm}$. (1/ $/ 2-3$ inches) long, acute at the apex, mostly rounded or somewhat cordate at the base, sometimes tapering, those of the triangular type usually truncate, margin of the ovate type of leaves more or less sharply serrate, the basal third of the leaf with shallow teeth or entire, margins of the triangular type more deeply serrate to alnost lobed, hairy above and below when they expand, becoming smooth both above and below, sometimes a few hairs are found on the veins beneath at maturity, bright green above, paler beneath; flowers appear in May when the leaves are about half grown, usually 5 or 6 in a eluster, white or rose-color, very fragrant, $3-4 \mathrm{~cm}$. (1. 2 -2 inches) broad when fully expanded; calyx lobes lanceolate-acuminate, tomentose on the inside, glabrous outside; fruit depressedglobose, without angles, yellow-green, $2-4.5 \mathrm{~cm} .\left(3_{4}-2\right.$ inches $)$ thick, $2-2.5 \mathrm{~cm} .(3 / 4-1$ inch) long, very fragrant and covered with a waxy bloom.

Distribution.-Central New York, lower peninsula Michigan, western New Jersey to northern Alabama and Missouri. Found in all parts of Indiana. No doubt in the original forests it was rare, but the removal of the large trees has been favorable to its growth until today it is somewhat frequent in moist open woods, along streams and neglected fences. It is most frequent among the hills in southern Indiana, and in all its distribution it is usually found in clumps.

In our area it is a small tree about $10-20 \mathrm{~cm}$. (4-8 inches) in diameter and 4-6 m. (12-18 feet) high, with a spreading crown. An exceptionally large tree is located on the south bank of Round Lake in Whitley County which measures $1.3 \mathrm{~m}$. (51 inches) in circumference at one meter (3 feet) above the ground where the first branch appears.

Specimens which were collected by the person whose name follows the county have been seen by the writer from the following counties of Indiana: Allen (Deam) 1919; Brown (Deam) 1911; Clark (Deam) 1913; Daviess (Deam) 1910; Decatur (Deam) 1911; Delaware (Deam) 1911; Floyd (Very) 1896; Fountain (Deam) 1919; Hamilton (Mrs. Chas. C. Deam) 1913; Kosciusko (Deam) 1910; Laporte (Deam) 1911; Morgan (Deam) 1910; Noble (Deam) 1919; Owen (Deam) 1911; Posey (Deam) 1911; Randolph (Deam) 1916, 1919; Steuben (Deam) 1905; Warren (Deam) 1911; Wayne (Deam) 1919; Wells (E. B. Williamson) 1896, (Deam) 1898, 1907, 1916, 1919. 
Plate 72.

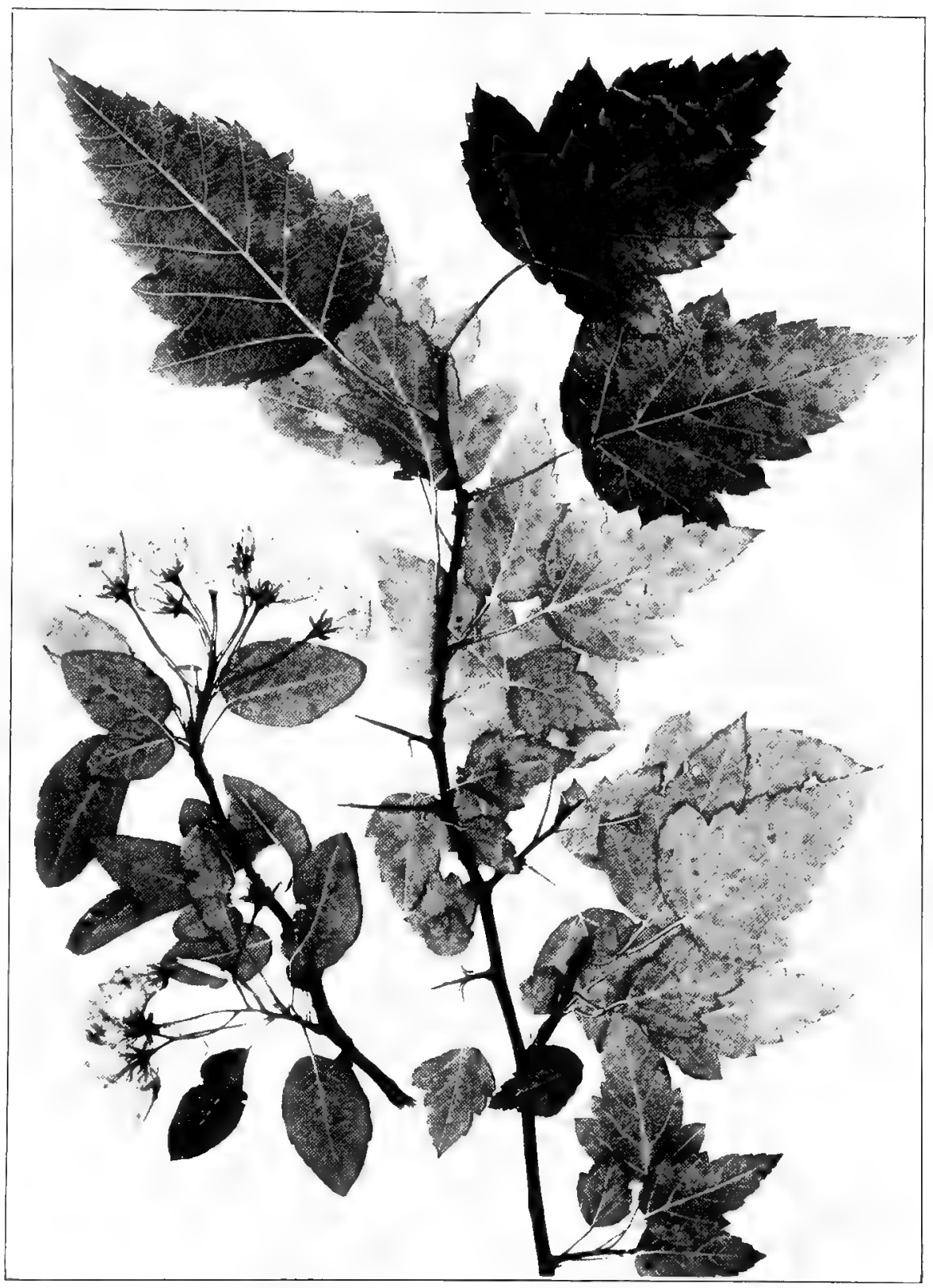

MalUs GlaUCescens Rehder. American Crab Apple. (x 1/2.) 
2. Malus lancifòlia Rehder. Narrow-leated Crab Apple. ( $M$. coronaria of manuals, in part.) Plate 73 . Leavesovate, oblong to oblong-lanceolate, $1.5-3 \mathrm{~cm} .(1 / 2-1 / 4$ inches $)$ wide, $3.5-8 \mathrm{~cm}$. (1/2-3 inches) long, acute or shortly acuminate at the apex; rounded or broadly cuneate at the base, finely serrate often doubly serrate, slightly tomentose when young, becoming entirely glabrous; bright yellow-green on hoth sides. Flowers 3-3.5 cm. broad, 3-6 in a cluster, pedicels slender, glabrous. Calyx lobes oblong, lanceolate, glabrous outside, slightly villous inside, fruit sub-globose, $2-3 \mathrm{~cm}$. (3/1 $-1 \frac{1}{3}$ inches) in diameter, green.

Distribution.- Pennsylvania to the mountains of North Carolina, west to Indiana and south to Missouri.

Specimens have been seen from the following counties of Indiana: Allen (Deam) 1919; Daviess (Deam) 1919; Delaware (Deam) 1911; Dubois (Deam) 1919; Fountain (Deam) 1919; Henry (Deam) 1917, 1919; Jay (Deam) 1919; Jennings (Deam); Knox (Deam) 1918, 1919; Noble (Deam) 1919; Posey (Deam) 1919; Spencer (Deam) 1919; Starke (Deam) 1911; Union (Deam) 1919; Vermillion (Deam) 1911.

3. Malus ioénsis (Wood) Britton. Western Crab Apple. Iowa Crab Apple. Plate 74. Leaves oblong to ovate-oblong, $4-10 \mathrm{~cm}$. (1, $12-4$ inches) long, $2-8 \mathrm{~cm}$. (3/4-3,4 inches), wide, obtuse or acute at the apex, rounded or broadly cuneate at the base, dentate-crenate or doubly so, slightly pubescent above, becoming glabrous, dark green, slightly rugose above, densely white-tomentose below, remaining so at least along the veins; petioles $1.5-4 \mathrm{~cm}$. (1/2-1/2 inches) long, densely white-tomentose; corymbs 2-5 flowered, pedicels pubescent; calyx densely white-tomentose, calyx lobes lanceolate-acuminate, densely tomentose on both sides; flowers similar to those of Malus coronaria; fruit globose, without angles, green, $2-3.5 \mathrm{~cm} .(3 / 4-1 / 2$ inches $)$ thick, 2-3 cm. (3/1-1/, inches) long.

Distribution.- Indiana, central Kentucky, Louisiana, Wisconsin, southern Minnesota, eastern Kansas and Texas. A tree in habit, similar to Malus glaucescens.

Specimens have been seen from Allen (Deam) 1915; Benton (Deam) 1919; Cass (Deam) 1916; Daviess (Deam) 1919; Delaware (Deam) 1911; Floyd (Very) 1896; Huntington (Deam); Jasper (Deam) 1919; Knox (Deam) 1917; Lake (Deam) 1919; Lagrange (Deam) 1915; Laporte (Deam) 1913, 1919; Newton (Deam) 1919; Porter (Deam) 1915; Posey (Deam) 1919; Putnam (Grimes); Sullivan (Deam) 1917, 1919; Tippecanoe (Dorner) 1900, (Deam) 1917; Vigo (Deam) 1917, 1919; Warren (Deam) 1919; White (Deam) 1916; Whitley (Deam) 1919. 
Plate 73.

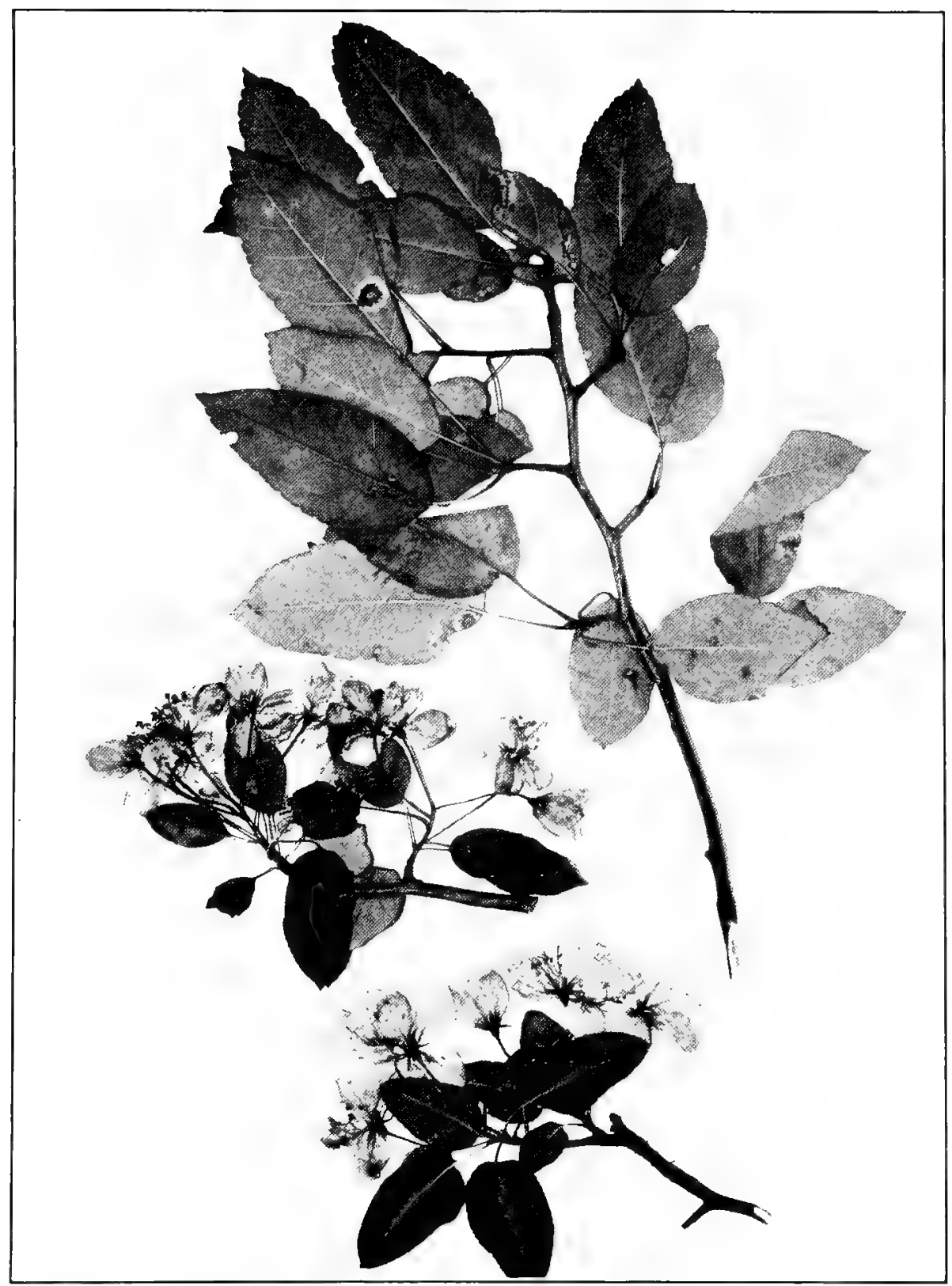

Malus lancifolta Rehder。 Narrow-leaved Crab Apple. (x 1/2.) 
Plate 74.

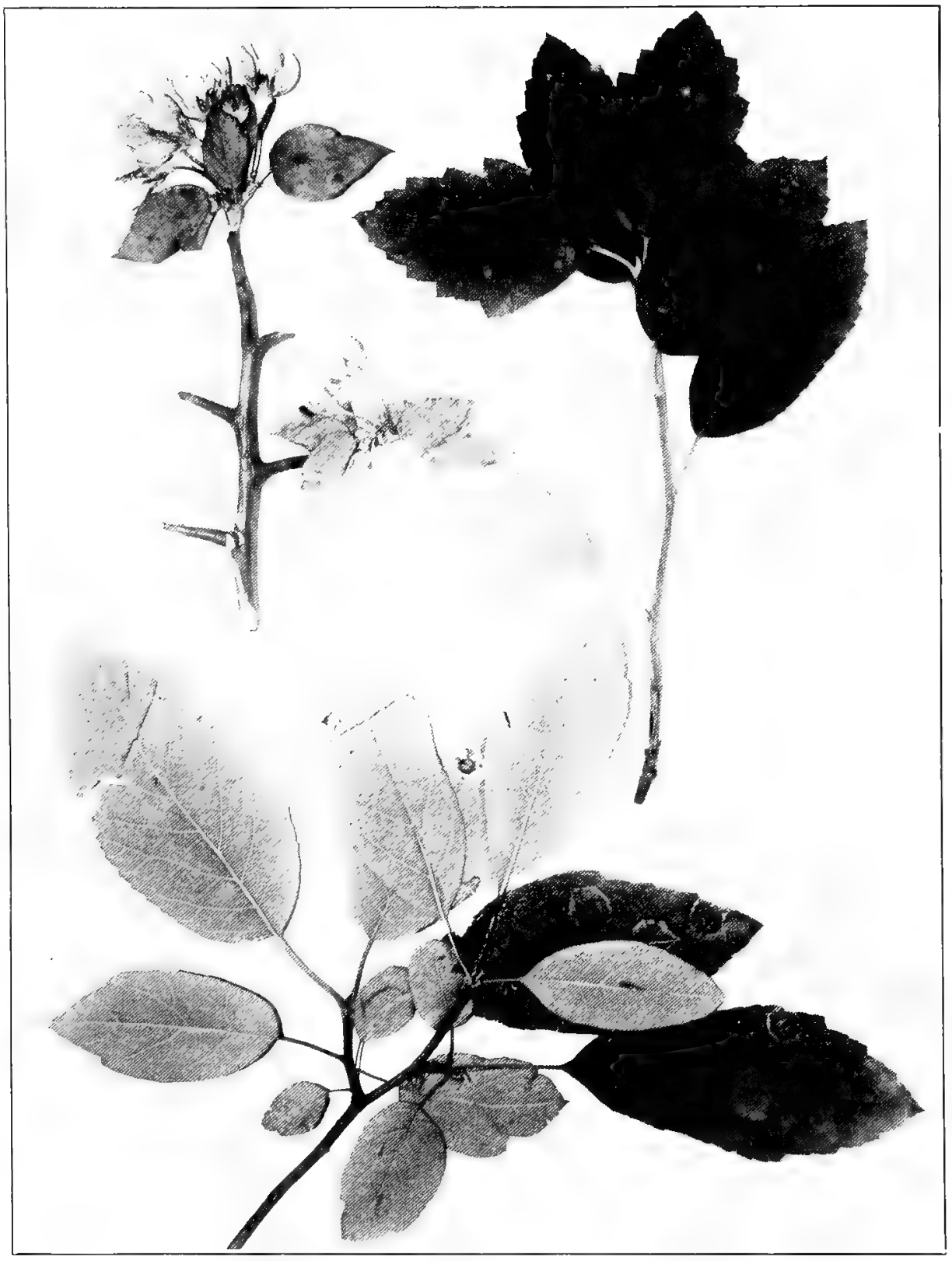

MALUS IOExsis (Wood) Britton. Westrin Crab Apple. (x1\%2.) 
Malus ioensis x lancifolia $n$. hyb. Specimens collected by Deam in Grant County in 1907 and Huntington County in 1919 appear to be this cross. It would be strange indeed if such closely related species as these Malus and many Crataegus would not cross.

\section{AMELÁNChiER. The Service Berries.}

Leaves densely white tomentose when young, becoming green. 1 A. canadensis. Leaves nearly or quite glabrous................ 2 A. lævis.

1. Amelanchier canadénsis (Linnæus) Medicus. Juneberry. Service Berry. Plate 75. Leaves obovate, ovate, oval or oblong, 4-10 cm. (1/2-3 inches) long, $2.5-5 \mathrm{~cm}$. (1-2 inches) wide, cordate at base, acute, or acuminate at apex, sharply and doubly serrate; blades and petioles densely white tomentose when young, persisting particularly on petioles with age, green or yellowish green, not unfolded at flowering time; racemes short, dense, silky tomentose pedicels, $15-25 \mathrm{~mm}$. $(1 / 2-1$ inch) long in fruit; petals linear or linear-oblong $10-14 \mathrm{~mm}$. $(3 / 8-$ $5 / 8$ inch) long; calyx 2.5-3 mm. broad, campanulate, glabrous or somewhat woolly, calyx lobes oblong-triangular, obtuse, tomentose 2-3 $\mathrm{mm}$. long, abruptly reflexed at the base when the petals fall; summit of ovary glabrous; fruit scanty, maroon-purple, dry and tasteless; flowers in April or May; fruit ripening June or July.

Distribution.-Southern Maine to southern Michigan, Iowa, Kansas, Missouri and south to Georgia and Louisiana.

Bushy tree or shrub sometimes 10 meters (35 feet) high.

Specimens have been seen from the following counties: Clark (Deam) 1913; Clay (Deam) 1913; Crawford (Deam) 1911; Floyd (Deam) 1913; Fountain (L. A. Williamson) 1908; Jackson (Deam) 1911; Jefferson (Deam) 1918; Jennings (Deam); Lagrange (Deam) 1915; Tippecanoe (Dorner) 1900; Warren (Deam) 1911.

2. Amelanchier laévis Wiegand. Smooth Juneberry. Service Berry. (Amelanchier canadensis of Manuals, in part.) Plate 76. Leaves ovate-oval to ovate-oblong or sometimes obovate or elliptical, 4-6 cm. (1/2-21/4 inches) long, 2.5-4 cm. (1-1//2 inches) wide, apex short, acuminate, base cordate, rounded or sometimes acute, sharply serrate, glabrous or with a few hairs when young, dark green and slightly glaucous when mature, one-half or two-third grown at flowering time; petioles glabrous; racemes many flowered, drooping, glabrous or nearly so; fruiting pedicels $30-50 \mathrm{~mm}$. (11/4-2 inches) long; petals oblong-linear, 10-18 mm. (3/8-3/4 inch) long; calyx campanulate, 2.75-5 mm. wide, glabrous, sepals triangular, lanceolate, $3-4 \mathrm{~mm}$. long, abruptly reflexed at base when petals fall; summit of ovary glabrous; 
Plate 75.

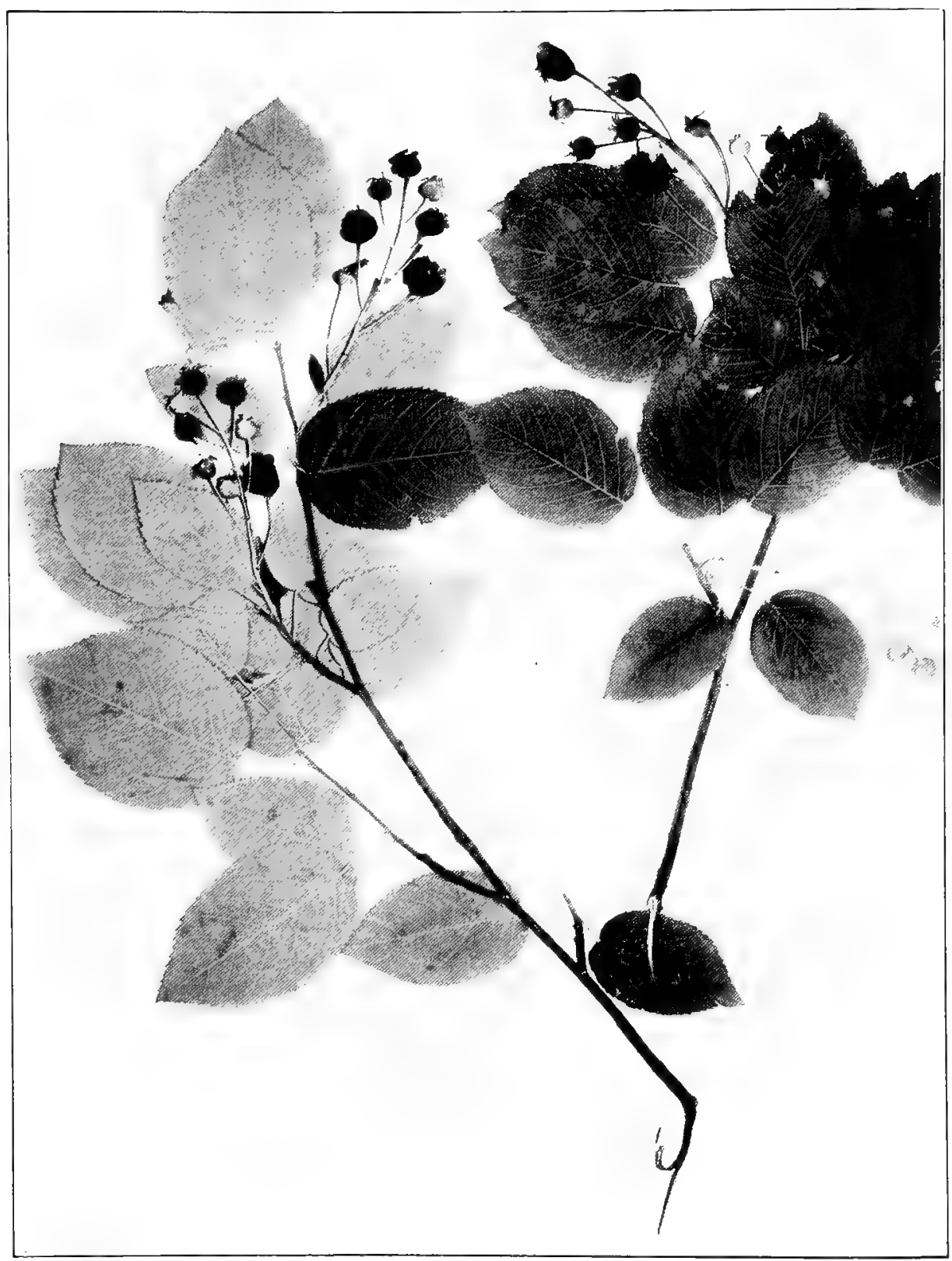

AMELANCHIER CANADENSIS (Linnæus) Medicus. June or Service BERRY. ( $x$ 1/2.) 
Plate 76.

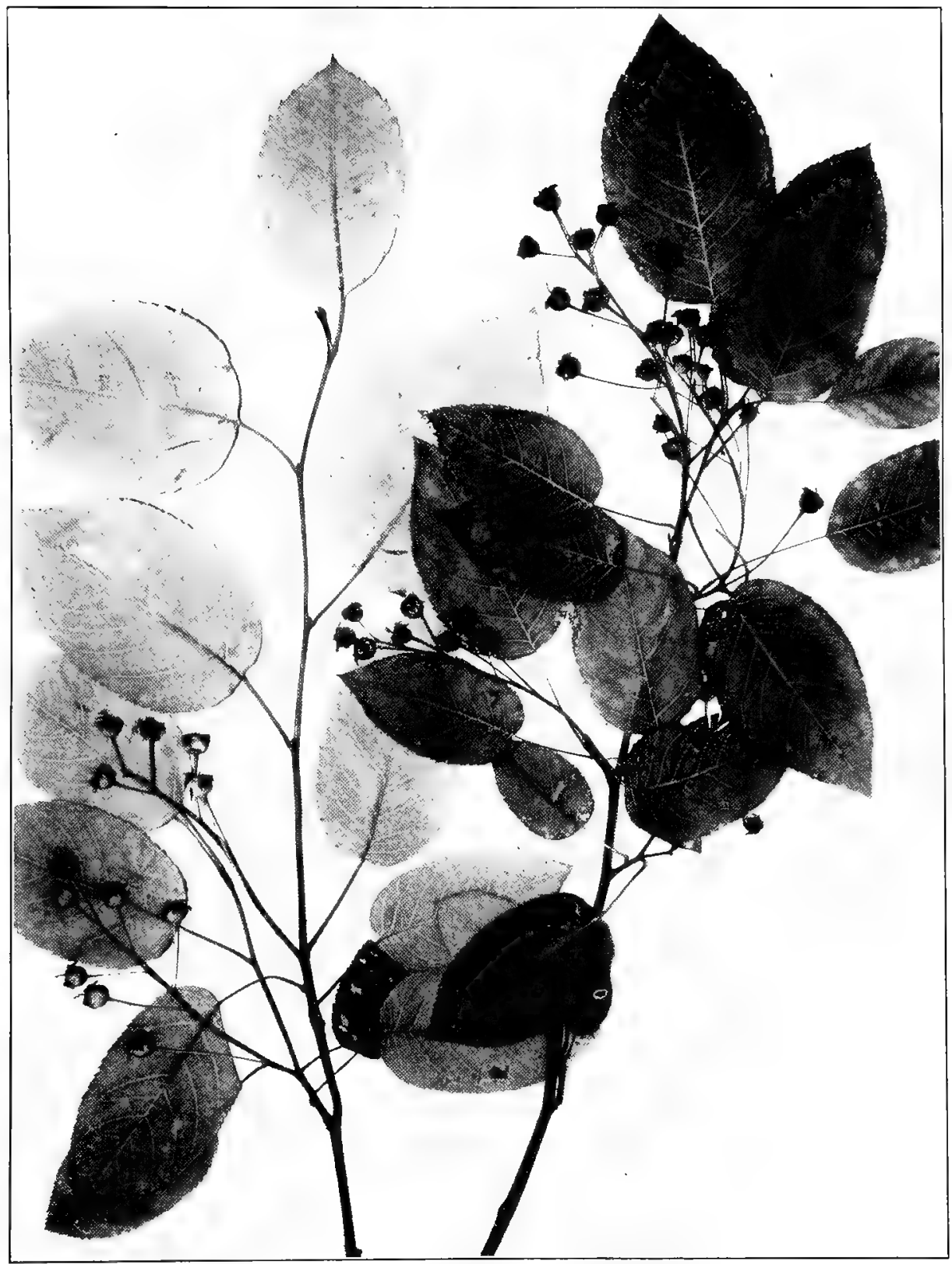

AMELANChier LAEVIS Wiegand. Smooth Juneberry or Service Berry. $(\mathrm{x} 1 / 2$. 
fruit purple to nearly black, glaucous, edible; flowers in April or May; fruit, June or July.

Distribution.-Newfoundland, northern Michigan, Kansas, Missouri and south in the mountains to Georgia and Alabama.

Specimens have been seen from the following counties: Brown (Deam) 1910; Dubois (Deam) 1912; Grant (Deam) 1916; Jackson (Deam) 1918; Jefferson (Deam) 1918; Lagrange (Deam) 1915; Lake (Deam) 1911; Laporte (Deam) 1911, 1913; Lawrence (Deam) 1918; Owen (Deam) 1912; Perry (Deam) 1919; Porter (Deam) 1911 and (Agnes Chase); Putnam (Mrs. Chas. C. Deam) 1913; Ripley (Deam) 1915; St. Joseph (Deam) 1916; Steuben (Deam) 1905; Wells (Deam) 1898.

Trees or shrubs, sometines 13 meters ( 45 feet) high. In the mountains of Vermont the fruit is often abundant, very juicy and sweet, and in much demand both by man and the birds. The berries on the long racemes ripen at different times and are perhaps two weeks in maturing, thus furnishing food for some time.

\section{Crataègus. Thorn apples. Red Haws.}

Large shrubs or small trees, most at home in a limestone region. This genus has been studied a great deal in this country. Much work is still necessary in Incliana since there are a number of other species that belong in this range. The "knob country" and southwestern Indiana are likely to produce the best results.

A. Leaves not deltoid-cordate; pubescent or glabrous.

I. Leaves broadest at the middle or apex, cuneate.

a. Leaves broadest towards the apex.

Leaves not impressed-veined above, shining.......... I. Crus-galli.

1 C. Crus-galli.

Leaves impressecl-veined above, dull.............. II. Punctatæ.

Fruit glabrous; calyx lobes entire.

Fruit ellipsoidal; nutlets usually 3 or 4 .

Leaves bright yellow-green, slightly impressed above;

fruit ellipsoidal.........2 C. cuneiformis.

Leaves dull gray-green, strongly impressed-veined; fruit short ellipsoidal. ............. 3 C. punctata.

Fruit globose............. 4 C. Margaretta.

Fruit villous; calyx lobes glandular-

serrate..............5 C. collina.

b. Leaves hroadest at the middle.

Laves impressed-voined; nutlets deeply

pitted on inner face..................... III. Marracanthæ. 
Leaves dark green, glabrous and shining above, coriaceous.

Fruit sometimes $16 \mathrm{~mm}$. ( $2 / 3$ ineh)

thick; stamens usually 10 ; leaves

and anthers large.........6 C. suceulenta.

Fruit sometimes $12 \mathrm{~mm}$. ( $1 / 2 \mathrm{inch}$ )

thick; stamens 15-20; leaves and

anthers small............ 7 C. neo-fluvialis.

Leaves gray-green, pubescent and

dull above, subcoriaceous....... \& C. Calpodendron.

Leaves not impressed-veined; nutlets without pits.

Calyx glandular margined, fruit more than $8 \mathrm{~mm}$.

(1/8 inch) thick; leaves not trilobate........IV. Rotundifoliæ

9 C. chrysocarpa.

Calyx lobes not glandular margined; fruit $48 \mathrm{~mm}$.

$\left(\frac{1}{16}-1 / 8\right.$ inch thick); leaves often trilohate towards

the apex....................... . Virides.

Fruit bright red, glaucous,

$4-6 \mathrm{~mm}$. (1/6-1/4 inch) thick;

leaves serrate.........10 C. viridis.

Fruit dull dark red, $6-8 \mathrm{~mm}$.

(1/4-1/3 inch) thick; leaves

coarsely serrate........11 C. nitida.

II. Leaves broadest at the base.

a. Leaves $1.5-6 \mathrm{~cm}$. (1/2-21/2 inches) long and wide, mem-

branaceous; calyx lobes usually entire.

Leaves yellow-green, often slightly pubescent; fruit soft

at maturity. .......................... Tenuifoliæ.

Fruit ellipsoidal, ovoid or pyriform ...12 C. macrosperma.

Fruit compressed, globose or subglobose.13 C. basilica.

Leaves blue-green, glabrous; fruit hard at maturity....... VII. Pruinosæ.

Leaves elliptic-ovate............14 C. Jesupi.

Leaves usually cordate.

Fruit conspicuously angled, strong-

ly pruinose............15 C. rugosa.

Fruit without conspicuous angles,

slightly pruinose..........16 C. filipes.

Leaves usually cuneate.

Leaves deltoid............17 C. Gattingeri.

Leaves ovate.............18 C. pruinosa.

b. Leaves $3-10 \mathrm{~cm}$. (1-4 inches) long and wide; calyx lobes usually serrate..................... VIII Cocciners.

Mature leaves usually glabrous above; young foliage bronze-green; anthers pink.

Corymbs and fruit glabrous.......19 C. coccinioides.

Corymbs and fruit pubescent or tomentose.

20 C. coceinea.

Mature leaves tomentose above; young

foliage yellow-green; anthers yel-

low...................21 C. mollis.

B. Leaves conspieuously deltoid-cordate..............IX. Cordatæ.

22 C. Phænopyrum. 
1. Crataegus Crus-gálli Limnzus. Cock-spur Thorn. NewCastle Thorn. Plate 77. Bark dark gray, scaly; spines many, strong, straight, $3-18 \mathrm{~cm}$. (1-7 inches) long; leaves obovate to elliptical, 2-10 $\mathrm{cm}$. (3,4 inches) long, $1-4 \mathrm{~cm}$. (1, $11^{1}, 2$ inches) wide, sharply serrate, except towards the base, acute or rounded at the apex, cuneate, dark green and shining above, coriaceous, glabrous or occasionally slightly pubescent; petioles slightly winged above, glandless, $1-2 \mathrm{~cm} \cdot(3 / 8-3 / 4$ inch) long; corymbs glabrous or occasionally pubescent, many flowered; flowers appear in May or June, about $1.5 \mathrm{~cm}$. (2/3 inch) wide; stamens 10-20; anthers usually pink; calyx lobes lanceolate-acuminate, entire; styles and nutlets usually 2; fruit ripens in October, ellipsoidal-ovoid to subglobose, about $1 \mathrm{~cm}$. ( ${ }^{3} 8$ inch) thick, greenish to red; flesh hard and dry, rather thin.

Distribution.-Northern New York to Ontario, eastern Kansas and south through western Connecticut to Georgia and Texas. Introduced near Montreal, about Lake Champlain and Nantucket Island. Well distributed in Indiana (but apparently more common in the southern part of the State).

A small tree, sometimes $10 \mathrm{~m}$. ( 35 feet) high, with spreading branches and a broad crown; but often a large shrub. This is a variable species and has received many names.

I have seen specimens trom the following counties: Allen (Deam); Crawford (Deam); Dearborn (Deam); Decatur (Mrs. Chas. C. Deam); Delaware (Deam); Dubois (Deam); Franklin (Deam); Gibson (Schneck), (Deam); Grant (Deam); Hancock (Mrs. Chas. C. Deam); Jackson (Deam); Knox (Schneck); Lawrence (Deam); Marion (Mrs. Chas. C. Deam); Posey (Deam); Owen (Grimes); Randolph (Deam); Scott (Deam); Tippecanoe (Deam); Vermillion (Deam); Vigo (Blatchley); Washington (Deam); Wells (Deam).

2. Crataegus cuneifórmis (Marshall) Eggleston. (C. pausiaca Ashe). Marshall's Thorn. Plate 78. Bark dark brown, scaly; spines numerous, 2-18 (cm. ${ }^{3} 4_{4}^{-7}$ inches) long; leaves oblanceolateobovate, acute at the apex, cuneate at the base, serrate or doubly serrate $3-6 \mathrm{~cm}$. (1/2-1 1/2 inches) wide, dark vivid yellow-green, glabrous and impressed veined a hove when mature, subcoriaceous; petioles $1-2 \mathrm{~cm} \cdot\left(3 / 8^{-3} / 4\right.$ inch) Jong, slightly winged above; corymbs usually slightly pubescent, many flowered; flowers appear in May, $1.2-1.5 \mathrm{~cm} .(1 / 2-2 / 3$ inch) wide; calyx lobes lanceolate-acuminate, entire; stamens, 10-15; anthers dark pink; styles and nutlets 2-4; fruit ripens in October, ellipsoidal-pyriform, searlet or clark red, about $8 \mathrm{~mm}$. (3́ inch) thick, flesh hard, thick.

Distribution. - Western New York and Pennsylvania to southwestern Virginia, west to central Illinois. 
Plate 77.

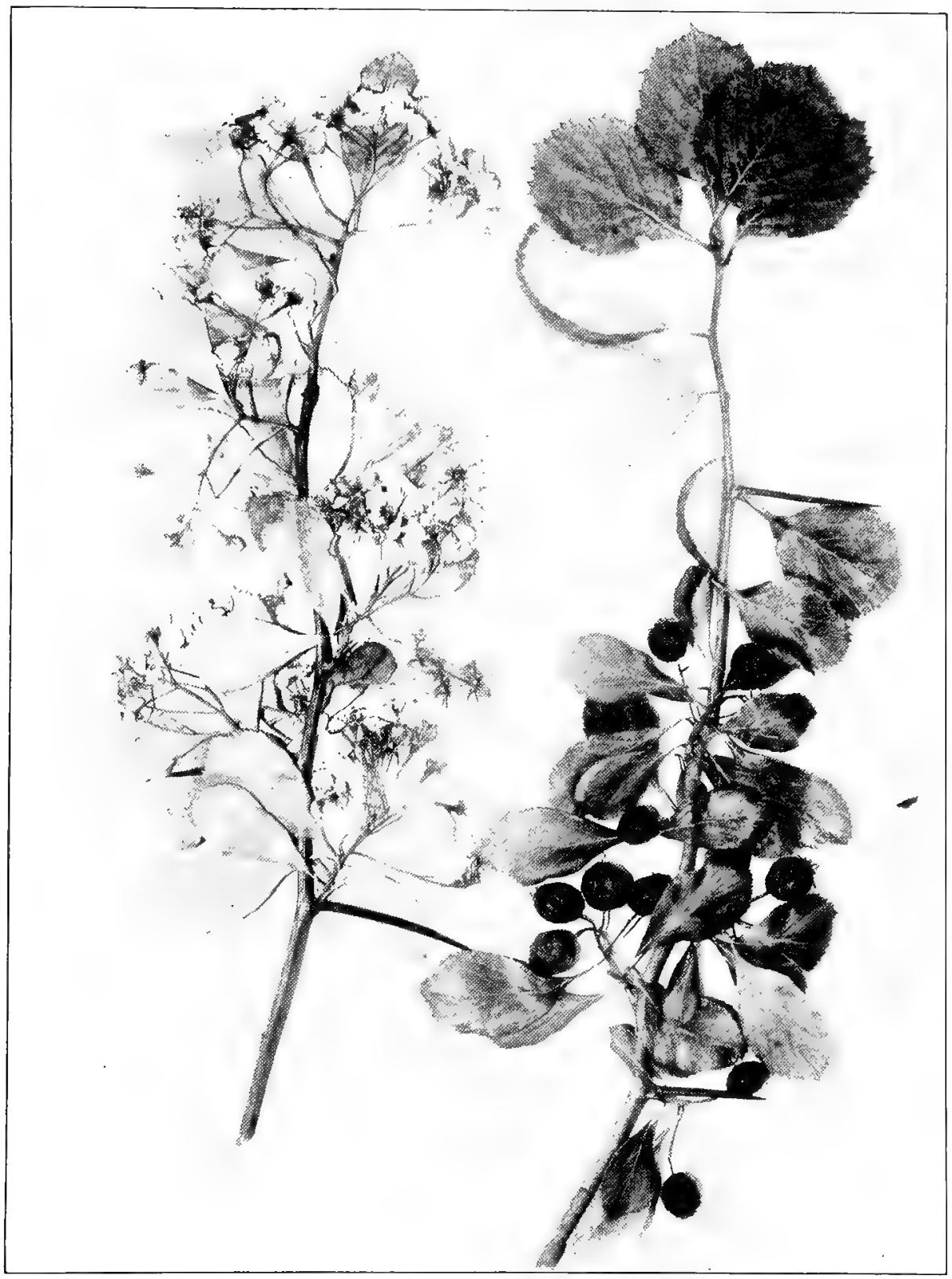

CRATAEGUS CRUS-GALLT Linnæus. COCK-SpUr Thorn. ( $x$ 1,2.) 
Plate TS.

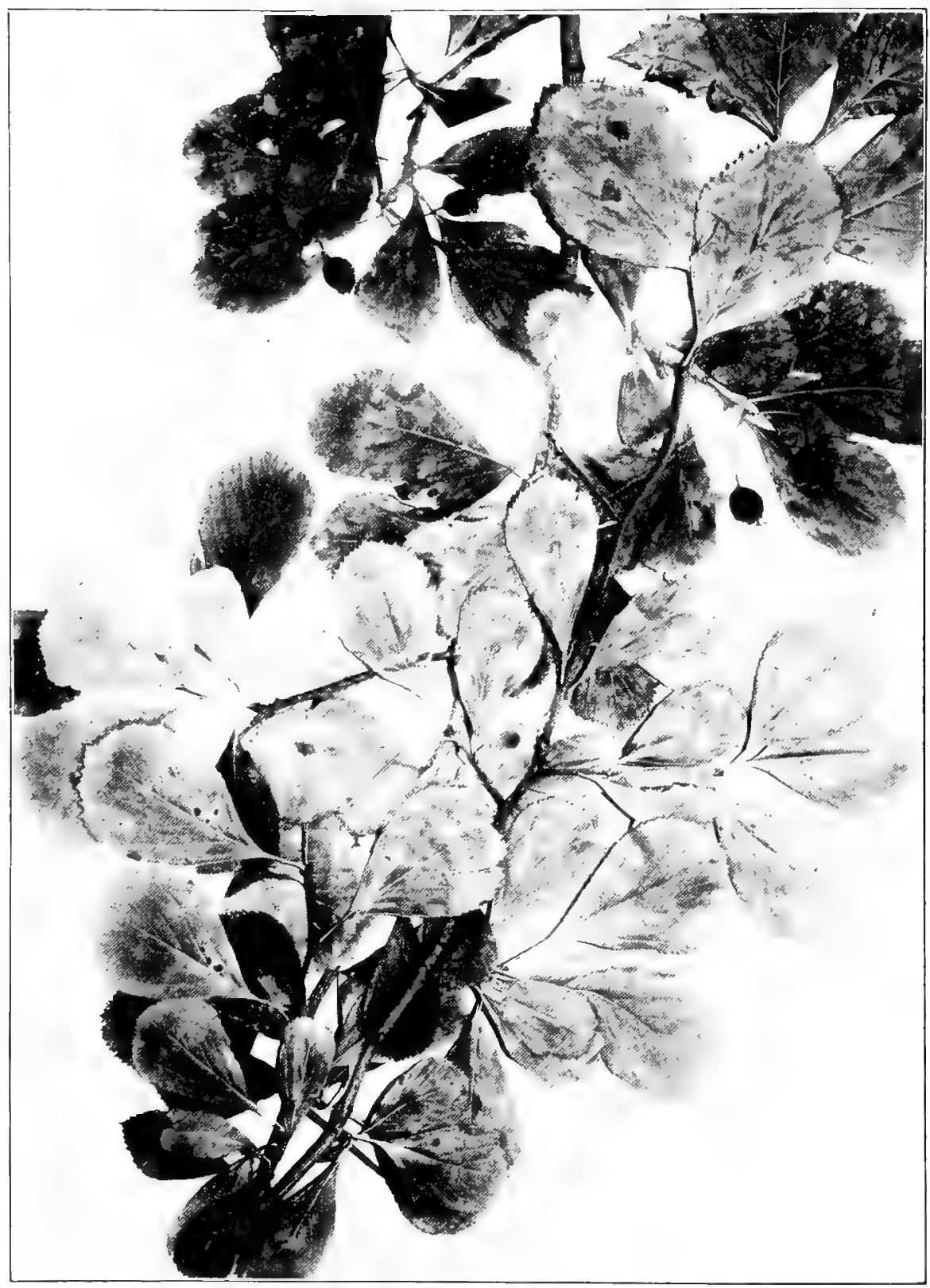

CRATAEGUS CUNEIFORMIS (Marshall) Eggleston. Marshall's Thorn. $\left(\begin{array}{ll}x & 1 / 2 .\end{array}\right)$ 
A small tree sometimes $8 \mathrm{~m}$. (25 feet) high, with spreading branches, forming a flat or round crown. This species is intermediate between Crus-galli and punctata and has been found as yet only in a region where both these species are known.

I have seen specimens from the following counties: Clark (Deam); Floyd (Deam); Gibson (Schneck), (Deam); Hamilton (Mrs. Chas. C. Deam); Knox (Schneck) ; Marion (Mrs. Chas. C. Deam); Posey (Deam); Vigo (Blatchley); Wells (Deam).

3. Crataegus punctàta Jacquin. Large-fruited Thorn. Dotted HAw. Plate 79. Bark grayish-brown, scaly; leaves light grey, 2-5 $\mathrm{cm}$. (3/4-4 inches) long, $1-5 \mathrm{~cm}$. (1/4-2 inches) broad, dull gray-green and markedly impressed-vein above, pubescent, becoming nearly glabrous above when mature, acute or obtuse at the apex, sharply cuneate at the base, serrate, doubly serrate or lobed at the apex, subcoriaceous; petioles $1-2 \mathrm{~cm}$. (3/8-3/4 inch) long, slightly winged above; corymbs tomentose or canescent, many flowered; flowers appear in June, about $2 \mathrm{~cm}$. ( $5 / 6$ inch) wide; calyx lobes lanceolate, acuminate, entire; stamens about 20; anthers white or pink; styles and nutlets usually 3 or 4 ; fruit ripens in October or November, green, yellow or red, short-ellipsoidal, $1.2-2.5 \mathrm{~cm} .\left(1 / 2^{-1}\right.$ inch) thick, flesh hard, thick; calyx lobes spreading.

Distribution.-Quebec to Pennsylvania, southeastern Minnesota, Iowa, Kentucky and south to the high Alleghenies. Well distributed over Indiana. A small tree, sometimes $10 \mathrm{~m}$. (35 feet) high, with distinctly horizontal branches and a broad, flat crown.

Specimens have been seen from the following counties: Allen (Deam); Bartholomew (Deam); Dearborn (Deam); Fulton (Deam); Gibson (Deam); Grant (Deam); Hamilton (Mrs. Chas. C. Deam); Hendricks (Deam); Howard (Deam); Jennings (Deam); Johnson (Deam); Marion (Deam); Noble (Deam); Putnam (Grimes); Vermillion (Deam); Vigo (Blatchley); Wayne (Deam); Wells (Deam).

4. Crataegus Margarètta Ashe. Judge Brown's Thorn. Mrs. Ashe's ThORN. Plate 80. Bark dark grayish-brown; spines curved, $2-4 \mathrm{~cm}$. ( $3 / 4-1 \frac{1}{2}$ inches) long; leaves oblong-obovate or ovate, sometimes broadly so, $2-6 \mathrm{~cm}$. (3/4-21/2 inches) long, $2-4 \mathrm{~cm}$. (3/4-11/2 inches) wide, obtuse or acute at the apex, cuneate or rounded at the base, serrate or doub]y serrate with 2 or 3 pairs of acute or obtuse lobes towards the apex, glabrous when mature, dark green above, membranaceous; petioles $1-3 \mathrm{~cm}$. (3/8-1/4 inches) long, slightly winged; corymbs slightly pubescent, becoming glabrous, 5-12 flowered; flowers appear in May, $1.5-2 \mathrm{~cm} .\left(1 / 2^{-5 / 6}\right.$ inch $)$ wide; stamens about 20 ; anthers yellow; styles and nutlets usually 2 ; calyx lobes lanceolate-acuminate, slightly 
Plate 79.

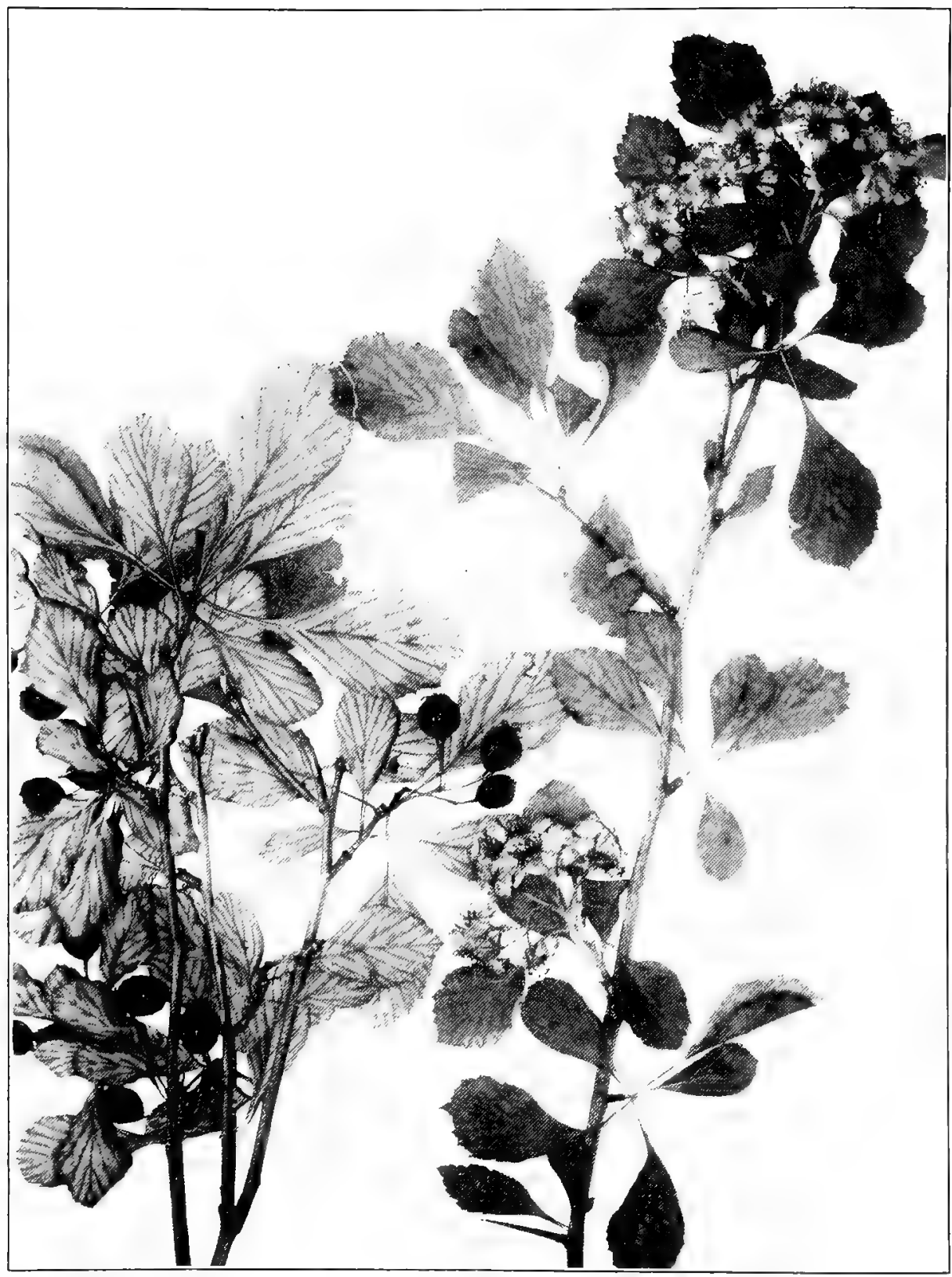

CRATAEgus PUnCTATA Jacquin. Large-Fruited Thorn. ( $x$ 1/2.) 
Plate 80.

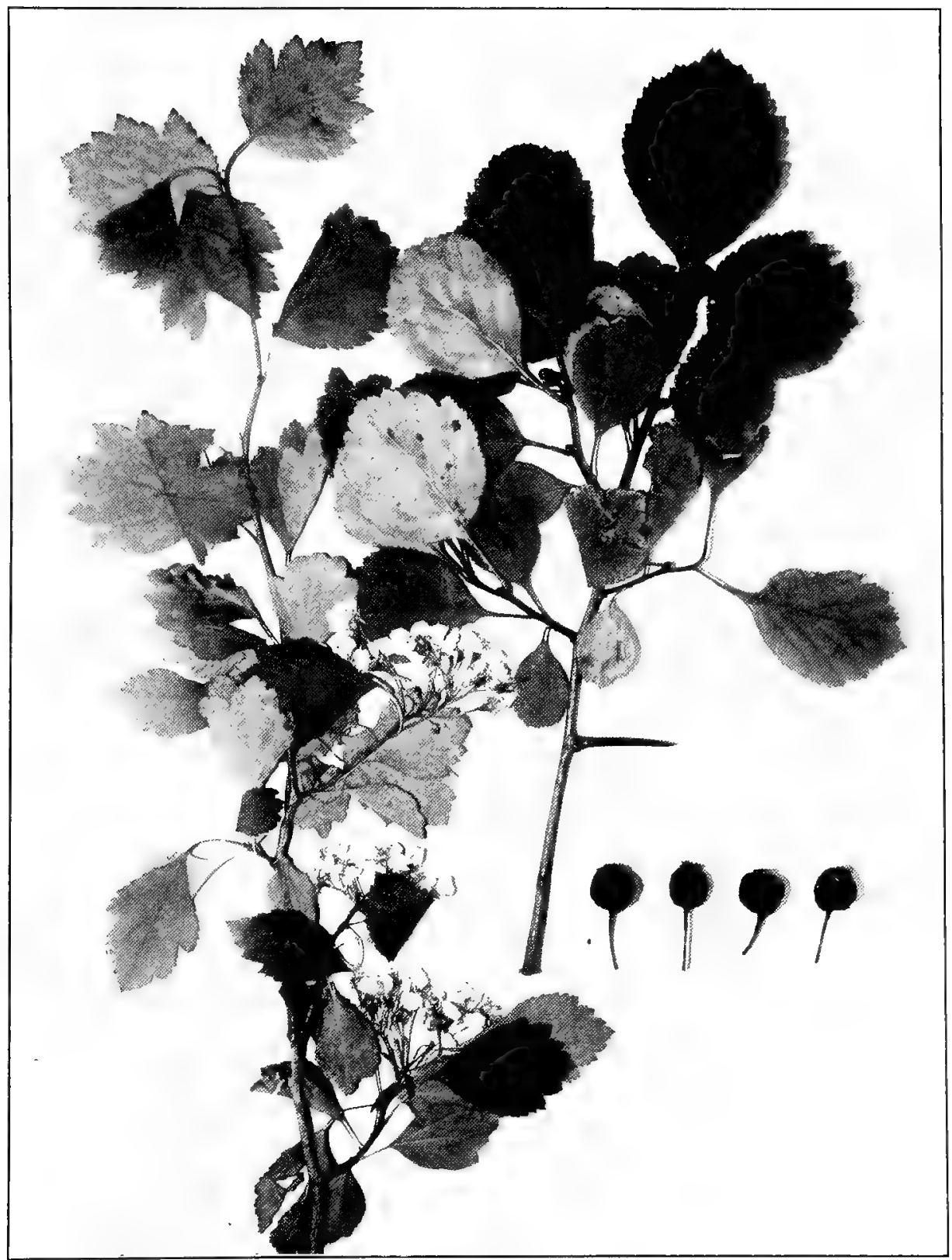

CRatæaus Margaretta Ashe. Judge Brown's Thorn. Mrs. Ashe's THORN. (x 1/2.) 
pubescent inside; fruit ripens in October, dull rusty green, yellow or red, compressed-globose, to short ellipsoidal, angular, $8-25 \mathrm{~mm}$. (1/2-2/3 inch) thick, flesh-yellow, mealy, hard, thick; calyx lobes reflexed, deciduous.

Distribution.- Southern Ontario to central Iowa, western Virgınıa, Tennessee and Missouri. Known in Indlana only from the northern part of the State

A small tree sometimes $8 \mathrm{~m}$. (25 feet) high, with spreading branches.

Specimens have been seen from the following counties: Allen (Deam); Blackford (Deam); Cass (Mrs. Ida Jackson); Delaware (Deam); Elkhart (Deam); Fulton (Deam); Grant (Deam); Henry (Deam); Huntington (Deam); Johnson (Deam); Lagrange (Deam); Lawrence (Deam); Noble (Deam); Randolph (Deam); Steuben (Deam); Tipton (Mrs. Chas. C. Deam); Wayne (Deam); Wells (Deam).

5. Crataegus collina Chapman. Chapman's Hill Thorn. Plate 81. Bark dark gray, scaly; spines numerous, about $3-7 \mathrm{~cm}$. (1-2//2 inches) long; often numerous branched thorns on the trunk $15-20 \mathrm{~cm}$. (6-8 inches) long, brown; leaves obovate to oblanceolate, $2-6 \mathrm{~cm}$. ( $3 / 4-21 / 4$ inches) long, $1.5-5 \mathrm{~cm}$. (1/2-2 inches) wide, acute or obtuse at the apex, strongly cuneate, serrate or doubly serrate with obtuse lobes towards the apex, subcoriaceous, yellow-green, young leaves somewhat pubescent, becoming glabrous with age; petioles about $2.5 \mathrm{~cm}$. ( 1 inch) long, slightly hairy, somewhat winged; corymbs and calyx pubescent; flowers about $15 \mathrm{~mm}$. (3/4 inch) wide; stamens 10-20, usually 20, anthers usually yellow; styles and nutlets, 4-5; calyx lobes glandularciliate or glandular-serrate; fruit ripens in October, globose or compressed-globose, red or orange-red, $9-12 \mathrm{~mm}$. (3/8-1/2 inch) thick; calyx tube somewhat prominent, the lobes reflexed.

Distribution.- Virginia to Georgia, Indiana, Missouri and Mississippi.

Only one station known in Indiana; Deam's No. 12449 from Dearborn County.

A tree sometimes 8 meters (25 feet) high with spreading branches and a broad flat crown.

6. Crataegus succulénta Schrader. Long-spined Thorn. Plate 82. Bark gray; spines numerous, strong, $3-10 \mathrm{~cm}$. (1//2-4 inches) long, chestnut-brown; leaves rhombic-ovate to obovate, $3-8 \mathrm{~cm}$. (11/4-31/4 inches) long, $2.5-6 \mathrm{~cm}$. (1-21/2 inches) wide, acute at the apex, broadly cuneate at the base, serrate or doubly serrate with fine teeth, often lobed towards the apex, coriaceous, dark shining green above, pubescent along the veins beneath; petioles $1-2 \mathrm{~cm} .\left(3 / 8^{-3} / 4\right.$ inch) long, slightly winged above; corymbs slightly villous, many-flowered; 
Plate 81.

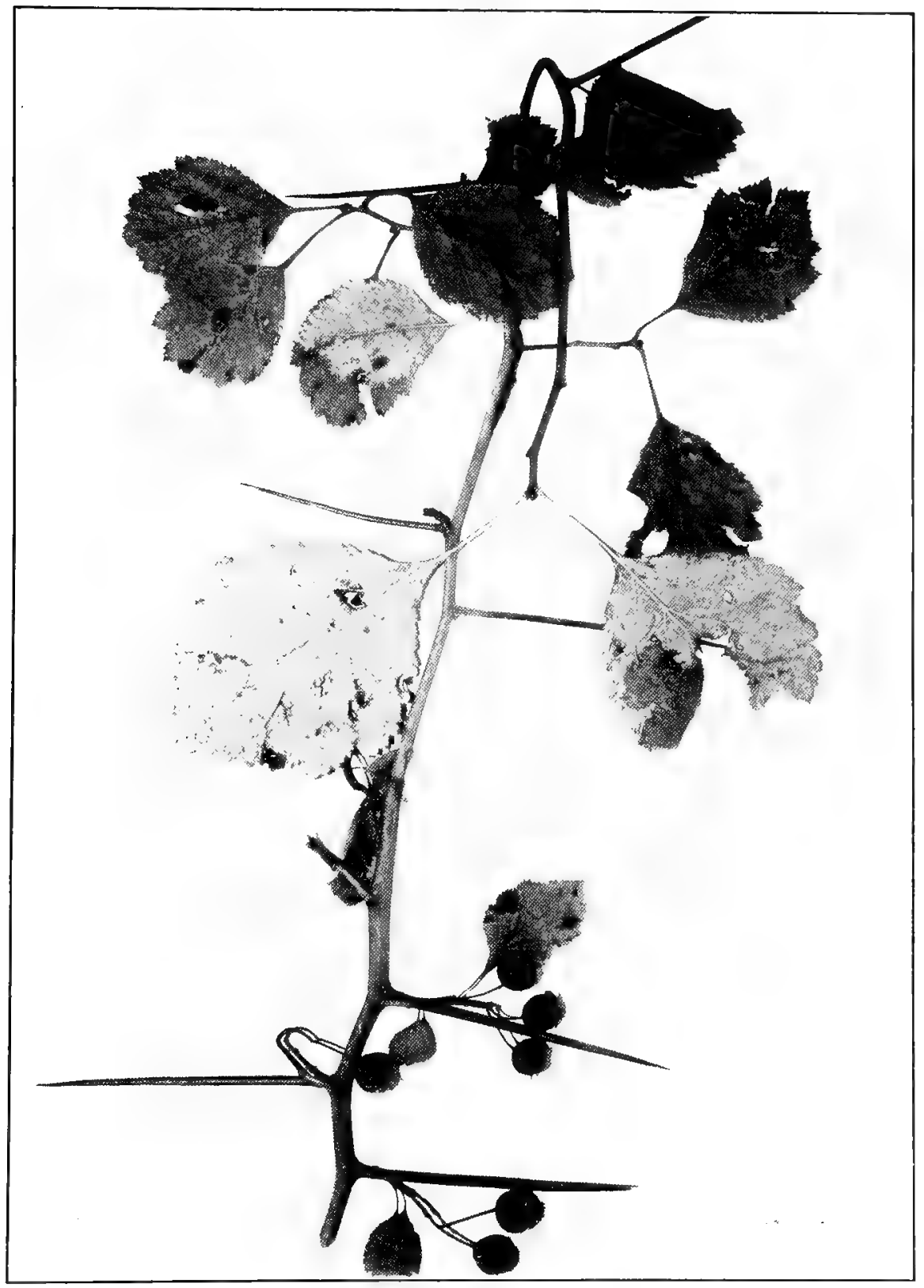

CRAT EGUS COllina Chapman. Chapman's Hill Thorn. ( $x$ 1/2.) 
Plate 8.2.

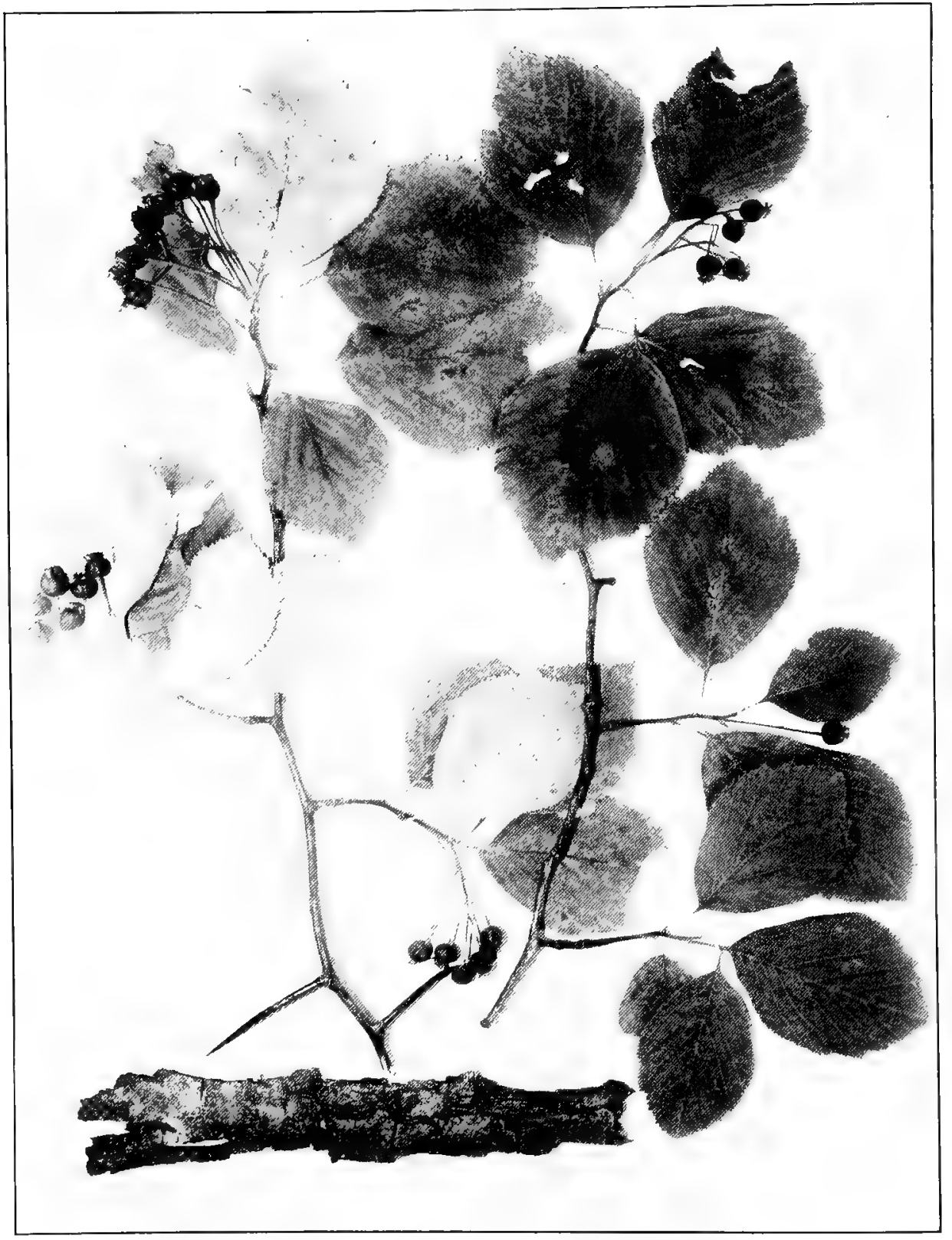

CRATAGUS SUCCULENTA Schrader. Long-SPined Thorn. (x 1/2.) 
flowers appear in May, about $2 \mathrm{~cm}$. (3/4 inch) broad; stamens 10-20, usually 10 ; anthers pink or occasionally yellow or white, large; styles and nutlets usually 2 or 3 ; calyx lobes lanceolate-acuminate, glandularlaciniate, villous; fruit ripens in September, subglobose, $5-15 \mathrm{~mm}$. $(1 / 4-2 / 3$ inch) thick, dark red, shining, flesh thin, glutinous; nutlet with deep pits on the inner faces; calyx-lobes villous, reflexed.

Distribution.-Nova Scotia to Minnesota, Nebraska and south in the higher Alleghenies to North Carolina and in the Rocky Mountains to southern Colorado. As yet reported only from northern to central Indiana.

A small tree sometimes $6 \mathrm{~m}$. (20 feet) high, with ascending branches and a broad, irregular crown; more often, however, a large shrub.

Specimens have been seen from the following counties: Allen (Deam); Cass (Mrs. Ida Jackson); Fulton (Deam); Noble (VanGorder); Putnam (Grimes); Tippecanoe (Deam); Wells (Deam).

Horticultural Uses.-Highly ornamental for parks and hedges because of the abundant flowers, dark green shining leaves and its dark red shining fruit.

7. Crataegus neo-fluviàlis Ashe. New Rrver Thorn. Plate 83. Bark grayish; spines numerous, $2.5-8 \mathrm{~cm}$. (1-3 inches) long; leaves elliptical-ovate to obovate, $2.5-8 \mathrm{~cm}$. (1-3 inches) long, $2-6 \mathrm{~cm}$. $\left(3 / 4-2 \frac{1}{2}\right.$ inches) wide, acute or obtuse at the apex, cuneate at the base, sharply and doubly serrate, with obtuse or acute lobes towards the apex, coriaceous, dark green and shining above, pubescent along the veins beneath; petioles $1-2 \mathrm{~cm}$. $(3 / 8-3 / 4$ inch) long, slightly winged-above; corymbs and calyx-tubes glabrous or slightly villous, many-flowered; flowers appear in May, 1.2-1.6 cm. (1/2-2/3 inch) broad, stamens 15-20, anthers usually pink, small; styles and nutlets usually 2 or 3 ; calyx lobes more villous on the inside, lanceolate-acuminate, glandularlaciniate; fruit ripens in September, globose or short ellipsoidal, dark red, 4-13 mm. (1/4-1/2 inch) thick, flesh thin, glutinous, nutlets with deep pits in the inner faces; calyx lobes reflexed, glabrous or slightly hairy.

Distribution.-Western Vermont to eastern Wisconsin, Iowa and south in the Alleghenies to North Carolina.

A small tree sometımes $8 \mathrm{~m}$. (30 feet) high, with ascending and spreading branches.

Specimens have been seen from Allen (Deam); Fulton (Deam); Shelby (Deam); Wells (Deam).

8. Crataegus Calpodéndron (Ehrhart) Medicus. Pear-thorn. PEAR or RED HAw. Plate 84. Bark pale gray to dark brown, furrowed; spines occasional, slender $3-5 \mathrm{~cm}$. (11/4-2 inches) long; leaves 
Plate s:;

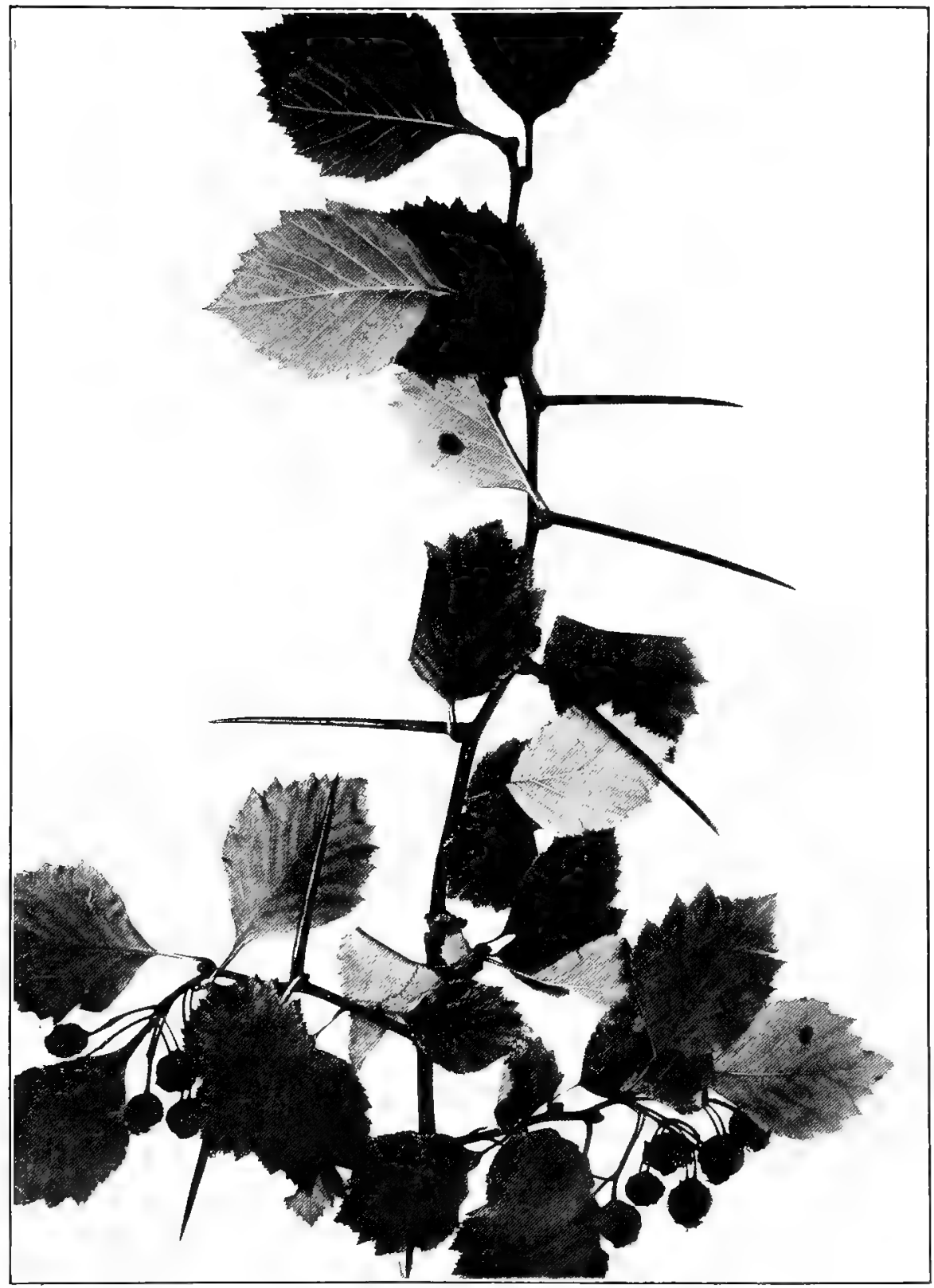

CRATAgUs NEO-Fluvialis Ashe. New Riverthorn (x 1,2́.) 
Plate St.

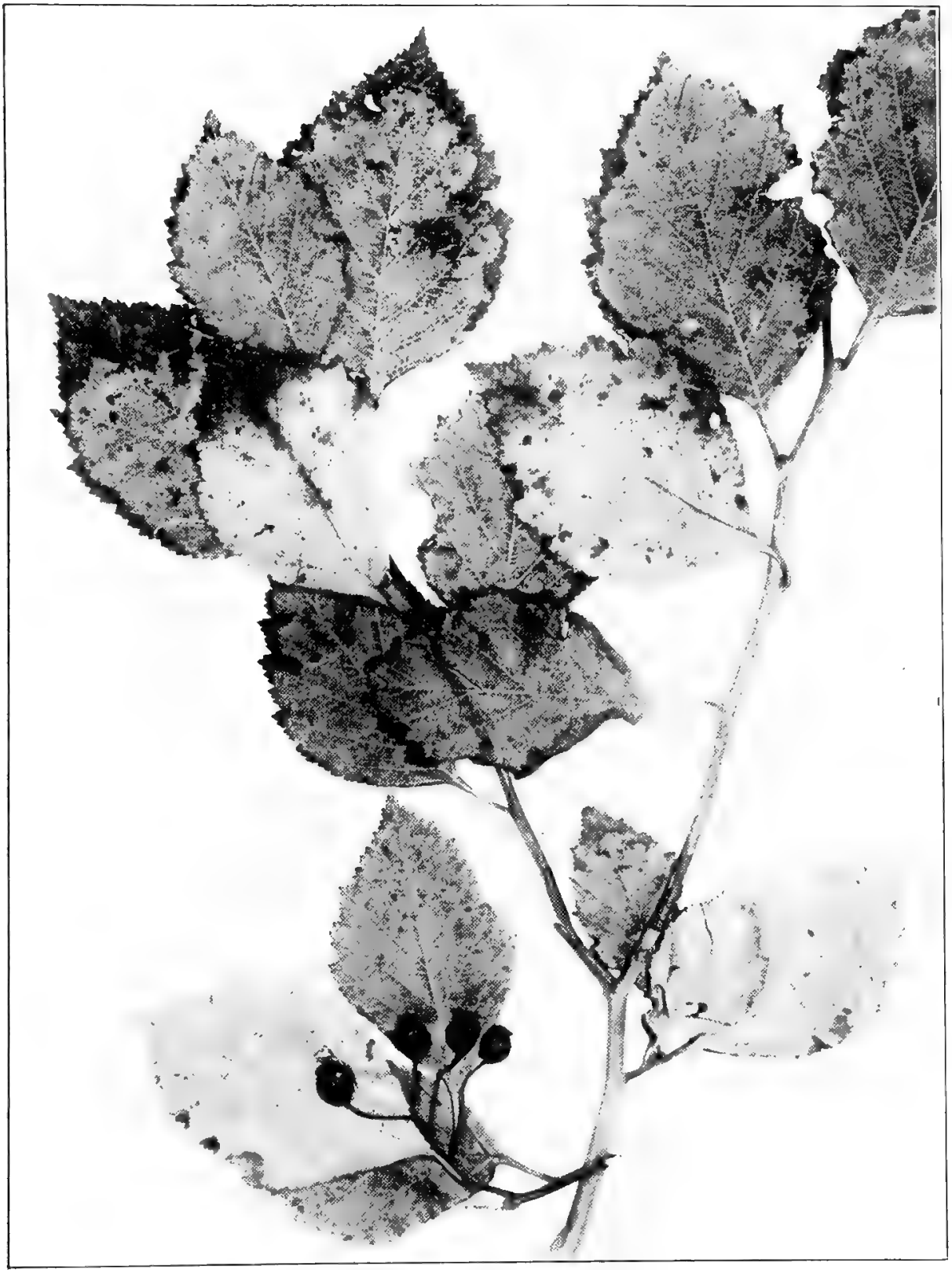

CRAT EGUS CALPODENDRON (Ehrhart) Medicus. PEar-Thorn. ( $x$ 1, 2.) 
rhombic-ovate, $4-11$ cm. (1/2-1/2 inches) long, $3-8 \mathrm{~cm}$. (1//4.3 inches wide, acute or acuminate at the apex, finely and'doubly serrate, those on the vegetative shoots obtuse and more entire than the others, pubescent on both sides, becoming scabrate above, subcoriaceous, dull green above; petioles about $2 \mathrm{~cm}$. (3/4 inch) long, wing margined, glandular hairy; corymbs white-tomentose, many flowered; flowers appear in June, about $1.5 \mathrm{~cm}$. (2/3 inch) broad; stamens about 20; anthers small, pink; styles and nutlets usually 2 or 3 ; calyx lobes lanceolateacuminate, glandular laciniate; fruit ripens in September, pyriform to ellipsoidal, orange-red or red, $8-10 \mathrm{~mm}$. (1/3 inch) thick, flesh glutinous; nutlets with deep pits in their inner faces; calyx lobes reflexed.

Distribution.-Central New York, northeastern New Jersey to Minnesota and Missouri and south in the mountains to northern Georgia.

A litrge shrub or occasionally a tree $6 \mathrm{~m}$. (20 feet) high, with ascending branches forming a broad crown.

Specimens have been examined from the following counties; Boone (Deam); Floyd (Deam); Hancock (Mrs. Chas. C. Deam); Harrison (Deam); Marion (Mrs. Chas. C. Deam); Posey (Deam); Putnam (Grimes); Tippecanoe (Stanley Coulter); Wells (Deam); White (Deam); Whitley (Deam).

9. Crataegus chrysocárpa Ashe. (Crataegus Dodgei Sargent. Crataegus rotundifolia, Borckhausen.) Round-Leaved Thorn. Plate 85. Bark dark red-brown, sealy; spines numerous, chestnut-brown, curved, 2-5 cm. (1-2 inches) long; leaves ovate-orbicular or obovate, 3-6 cm. (11/4-21/4 inches) long, 2-6 cm. (3/4-2 1/4 inches) wide, acute at the apex, broadly cuneate at the base, doubly serrate with rather coarse teeth and with 3 or 4 pairs of acute lobes, subcoriaceous, dark yellow-green and shining above, slightly pubescent or glabrous; corymbs glabrous or slightly pubescent; flowers $10-15 \mathrm{~mm}$. (1/2-3/4 inch) wide; stamens 5-10; anthers light yellow; styles and nutlets usually 3-4; calyx lobes lanceolate, acuminate, usually entire, but glandular margined; fruit depressed globose to short ovoid, about $10 \mathrm{~mm}$. $(1 / 2$ inch) thick, flesh soft; calyx lobes reflexed.

Distribution.-Nova Scotia and New Brunswick to Saskatchewan, south to Nebraska and Pennyslvania and in the mountains to North Carolina and New Mexico.

Round topped shrub or tree sometimes 8 meters (25 feet) high.

sperimens have been seen from the following counties: Delaware and Lagrange (Deam). 
Plate 85.

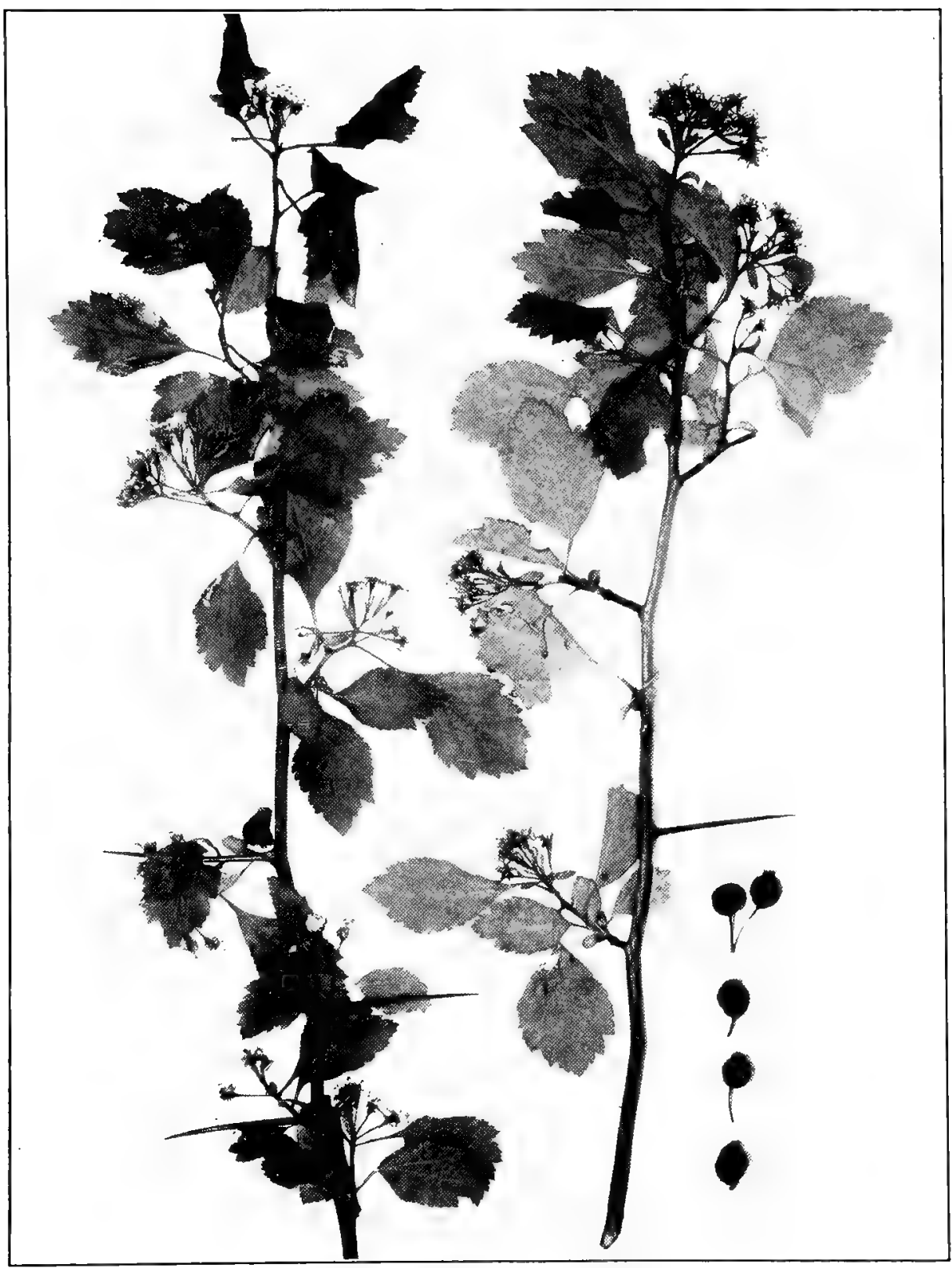

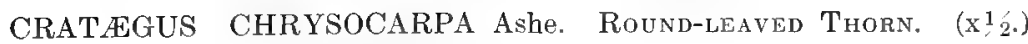


Plate si.

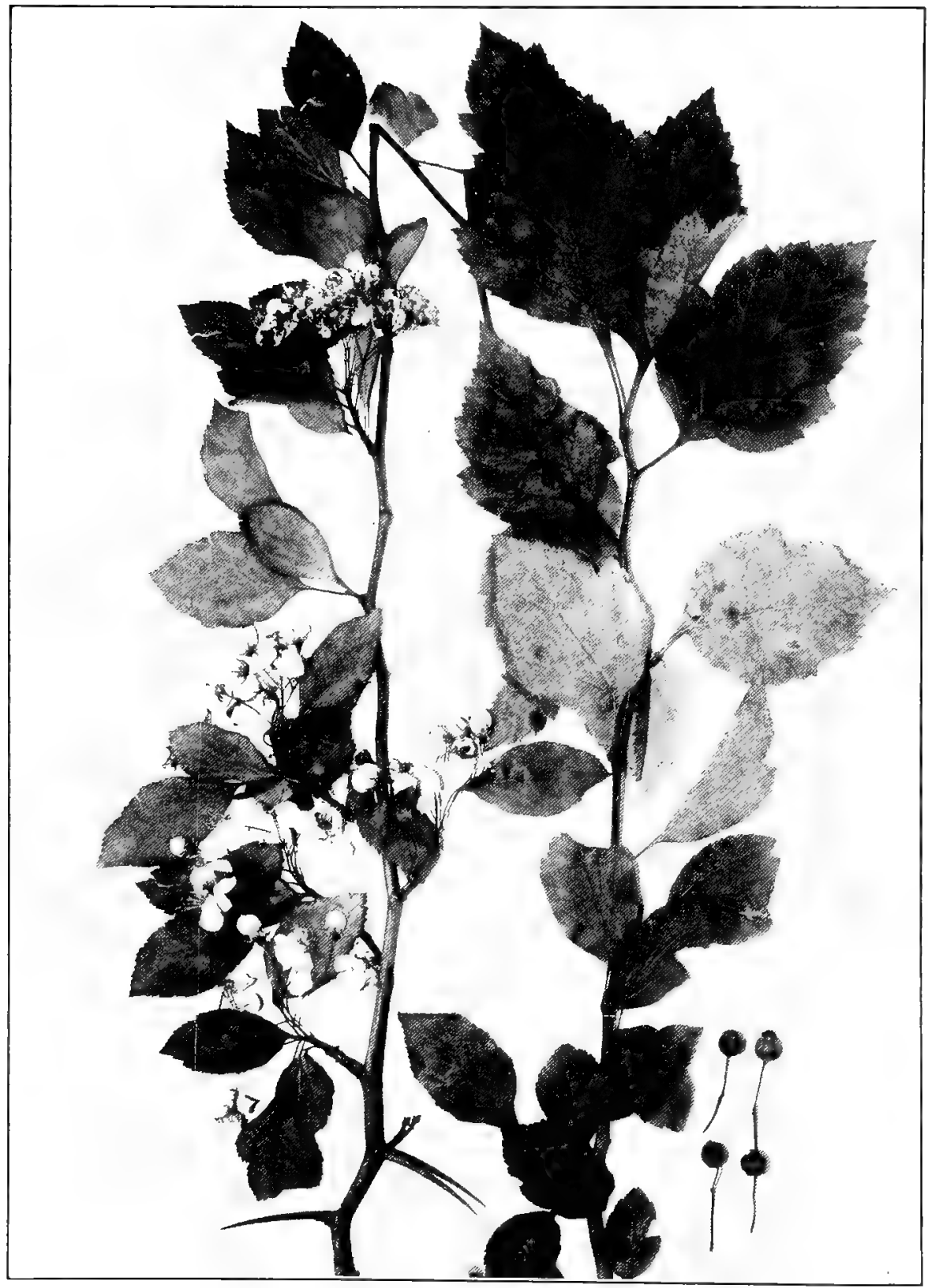

CRAT EGUS VIRIDIs Limeus. Southers Thors, ( $\mathrm{x}$ 1/2.) 
10. Crataegus víridis Linnæus. Southern Thorn. Plate 86. Bark gray to light orange; spines uncommon, $2-5 \mathrm{~cm} .(3 / 4-31 / 4$ inches) long; leaves oblong-ovate, $2-8 \mathrm{~cm}$. (3/4-31/4 inches) long, 2-5 $\mathrm{cm}$. (1/2-2 inches) wide, acute, acuminate or even obtuse at the apex, serrate or doubly serrate, often with acute or obtuse lobes towards the apex, dark green, shining and slightly impressed veined above, sometimes pubescent along the veins beneath; petioles $1-2 \mathrm{~cm} .\left(3 \frac{1}{8}-3 / 4\right.$ inch) long, slightly winged above; corymbs glabrous, many flowered; flowers appear in May, $1-1.5 \mathrm{~cm}$. (1/2-2/3 inch) broad; stamens about 20; anthers usually yellow, sometimes pink; styles and nutlets 4 or 5 ; calyx lobes lanceolate-acuminate, entire, slightly pubescent inside; fruit ripens in October, globose or compressed-globose, bright red or orange, glaucous, 4-6 mm. (1/4 inch) thick, flesh thin, hard, edible.

Distribution.-Moist, alluvial soil along streams and lakes, southeastern Virginia to northern Florida and southwestern Indiana to eastern Kansas and Texas.

A tree from 6-11 m. (20-35 feet) high, with ascending branches and a broad crown.

Specimens have been examined from the following counties: Dubois (Deam); Gibson (Schneck), (Deam); Knox (Schneck); Posey (Deam).

11. Crataegus nítida (Engelmann) Sargent. Shining Thorn. Plate 87. Bark dark and scaly; spines occasional, 3-5 cm. (1-2 inches) long; leaves oblong-ovate to oval, $3-8 \mathrm{~cm}$. (11/4-3 inches) long, 2-6 $\mathrm{cm} .(3 / 4-21 / 4$ inches) wide, acute at the apex, cuneate at the base, coarsely serrate or twice serrate with acute lobes towards the apex, dark green and shining above, glabrous; petioles $1-2 \mathrm{~cm} .\left(3 / 8^{-3} / 4\right.$ inch) long, slightly winged above, slightly villous when young; corymbs glabrous, many-flowered; flowers appear in May, $1.2-2 \mathrm{~cm} .\left(1 / 2^{-3 / 4}\right.$ inch) broad; stamens about 20; anthers light yellow; styles and nutlets 3-5; calyx lobes lanceolate-acuminate, entire; fruit ripens in October, globose to short-ellipsoidal, darkdull red, $6-9 \mathrm{~mm} .(1 / 4-1 / 2$ inch) thick; flesh yellow, mealy, hard.

Distribution.- River bottoms southwestern Indiana to southern Illinois. A tree sometimes $9 \mathrm{~m}$. (30 feet) high, with ascending and spreading branches and a broad crown.

Specimens have been seen from Gibson (Schneck); Posey (Deam).

12. Crataegus macrospérma Ashe. Variable Thorn. Plate 88. Bark brown, scaly; spines numerous, stout, curved, $2-7 \mathrm{~cm}$. (3/4-23/4 inches) long; leaves broadly elliptical-ovate to broadly ovate, $2-7 \mathrm{~cm}$. (3/4-2 3/4 inches) long and wide, acute at the apex, rounded, truncate or rarely cordate at the base, serrate or doubly serrate, slightly villous, becoming glabrate, dark yellow-green above, 
Plate 87.

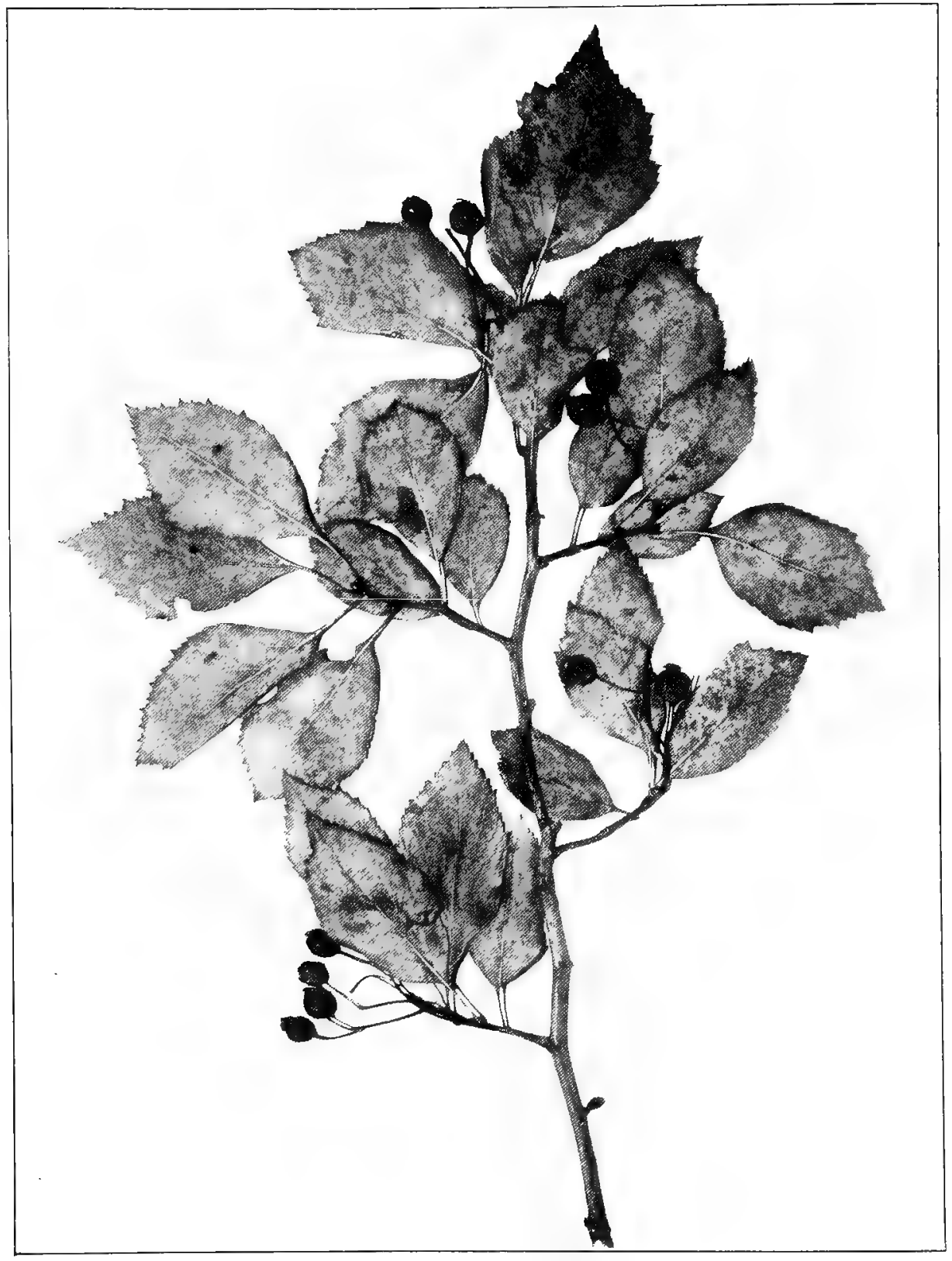

CRATEGUS NITIDA (Englemann) Sargent. Shining Thorn. (x 1/2.) 
Plate 88.

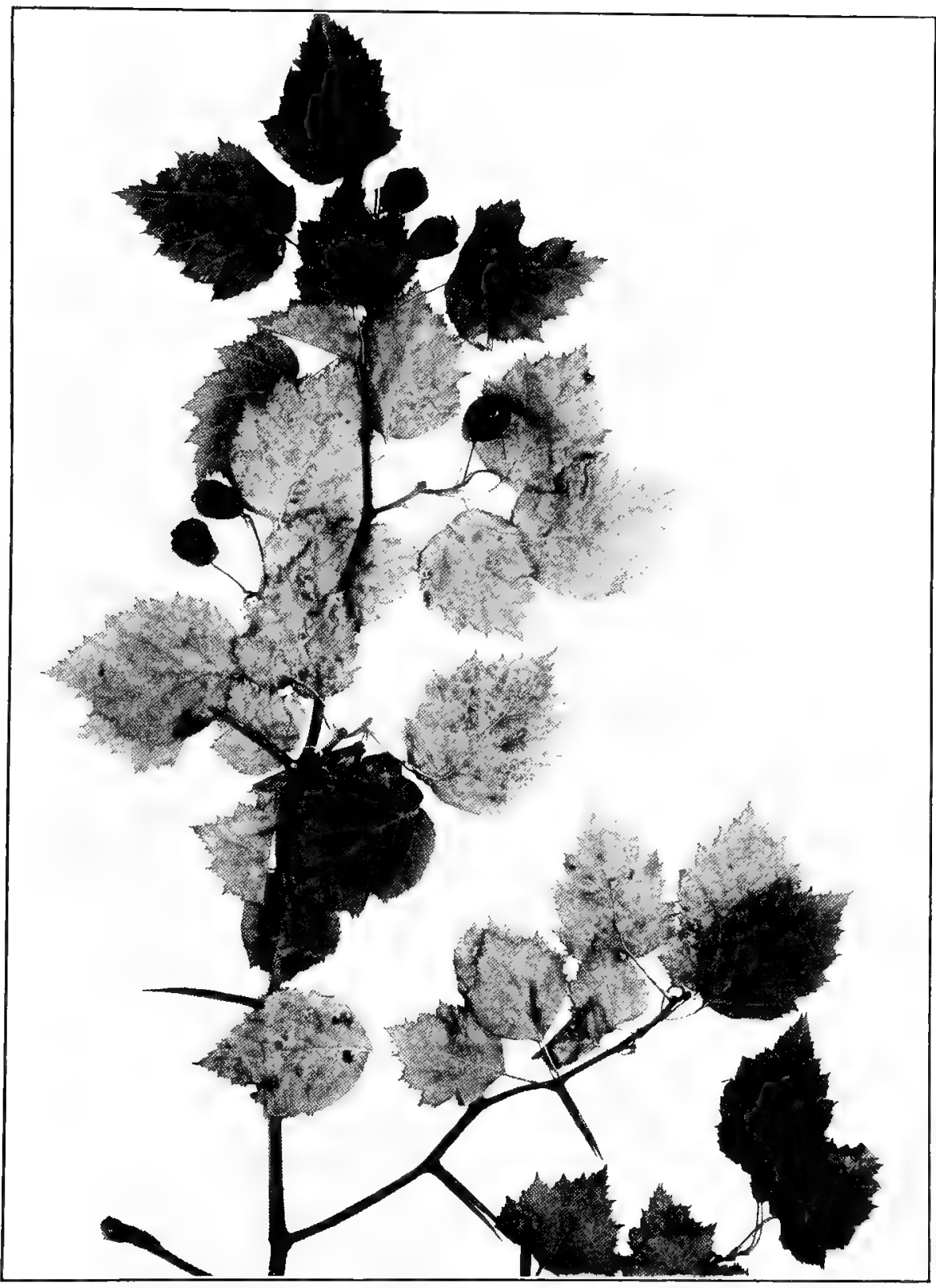

CRATAgUS MaCrosperma Ashe. Vartable Thorn (x 1/2.) 
membranaceous; petioles slender, 2-3 cm. (1/2-11/4 inches) long, slightly winged above; corymbs glabrous or slightly villous, manyflowered; flowers appear in May, 1.5-2 cm. (1, $2-3 / 4$ inch) broad; stamens $5-20$, usually $5-10$; styles and nutlets usually 3 or 4 ; calyx lobes lanceolate-acuminate, entire; fruit ripens in August or September, ellipsoidal or pyriform, scarlet to crimson, often glaucous, $1-1.8 \mathrm{~cm}$. $(1 / 3-3 / 4$ inch) thick, flesh succulent, edible; calyx lobes persistent, erect or spreading.

Distribution.- Nova Scotia and Maine to southeastern Minnesota and south in the mountains to North Carolina and Tennessee.

['sually a large shrub but occasionally a small tree, sometimes $8 \mathrm{~m}$. (25 feet) high, with ascending branches.

Specimens have been seen from the following counties: Allen (Deam); Bartholomew (Deam); Clark (Deam); Decatur (Deam); Fulton (Deam); Hancock (Mrs. Chas. C. Deam); Madison (Deam); Porter (Deam); Randolph (Deam); Shelby (Mrs. Chas. C. Deam); Washington (Deam); Wells (Deam); Whitley (Deam).

Crataegus macrosperma Ashe, var. matura (Sargent) Eggleston. Lobes of the leaves acuminate, often recurved; fruit ripens early.

Distribution.-Known in Indiana only from Deam's specimen No. 14187 from Wells County.

13. Crataegus basilica Beadle. (Crataegus alnorum Sargent. Crataegus Edsoni Sargent). Edson's ThonN. Plate 89. Bark brown, scaly; spines $2.5-4 \mathrm{~cm}$. (1-11/2 inches) long, stout, curved; leaves ovate, 3-7 cm. (1 1/4-23/4 inches) long, acute at the apex, broadly cuneate or truncate at base, serrate or doubly serrate with acute lobes, dull dark yellow-green above, paler beneath; corymbs glabrous, many flowered; flowers $15-20 \mathrm{~mm}$. (5/8-7/8 inch) broad; stamens about 20; anthers pink; styles and nutlets $3-5$; fruit subglobose, slightly angular, dark cherry-red, $12-15 \mathrm{~mm}$. (1/2-5/8 inch) thick, flesh suceulent; calyx lobes erect or spreading.

Distribution.-New England to southern Michigan, northern Indiana and Pennsylvania to mountains of North Carolina and Tennessice.

A broad shrub or small tree sometimes 4.5 meters (15 feet) high, branches ascending.

ipecimens examined: Wells (Deam).

11. Crataegus Jésupi Sargent. Jesup's Thorn. Twin MounTAIn Thorn. Plate. 90. Bark grayish-brown; spines stout, straight 2-4 cm. (3/4-1/2 inches) long; leaves elliptical-ovate, $3.5-7 \mathrm{~cm}$. (11/2-3 inches) $l o n g, 2-5.5 \mathrm{~cm}$. (1-2 inches) wide, acute or acuminate at the apex, broadly cuneate to truncate-cordate, serrate or doubly serrate, with 4 or 5 pairs of acute lobes, ycllow-green above, paler beneath, glabrous; 
Plate S!).

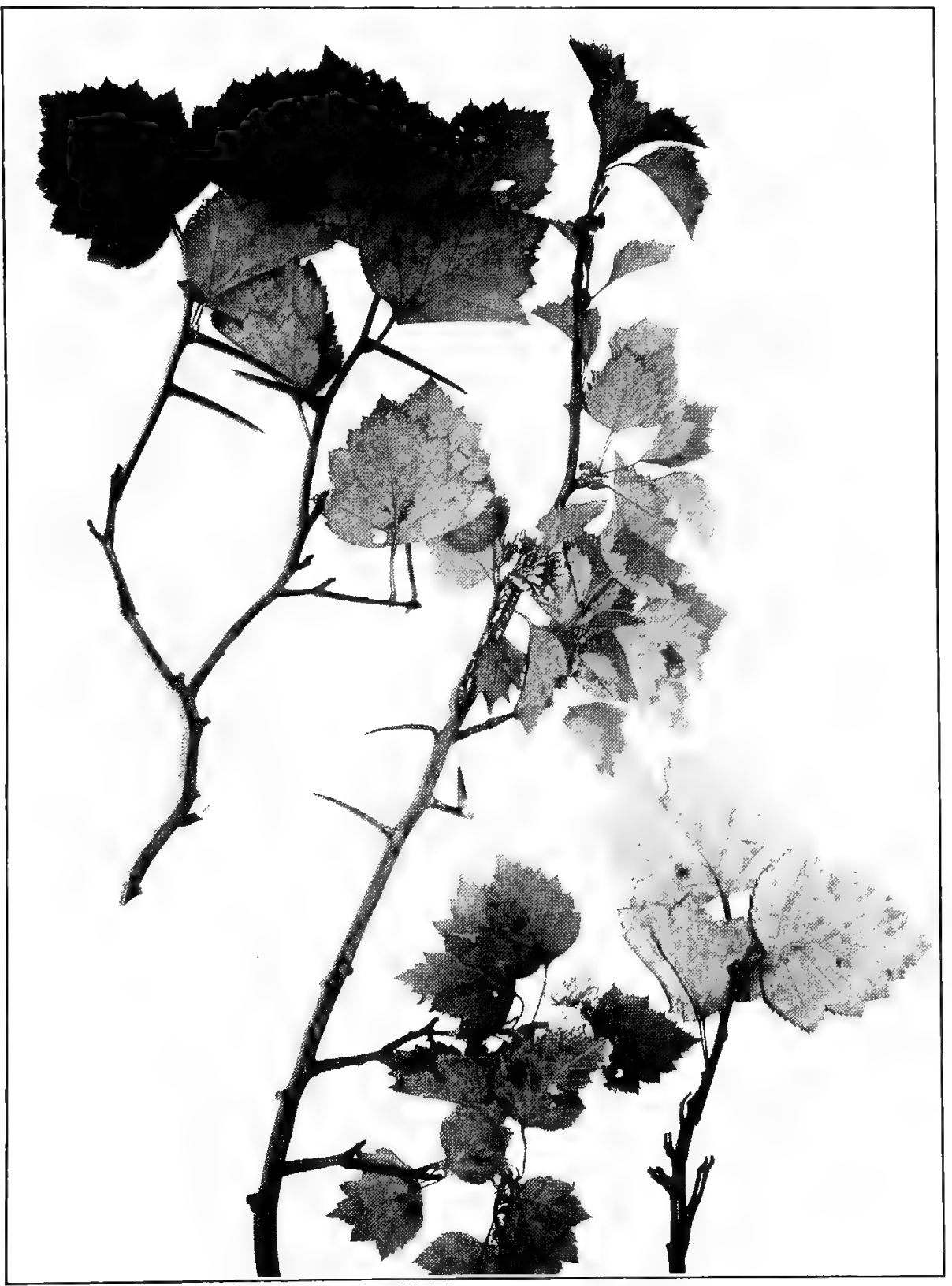

CRATæGUS BASILICA Beadle. EDson's Thorn. ( $x$ 1/2.) 
Plate 90.

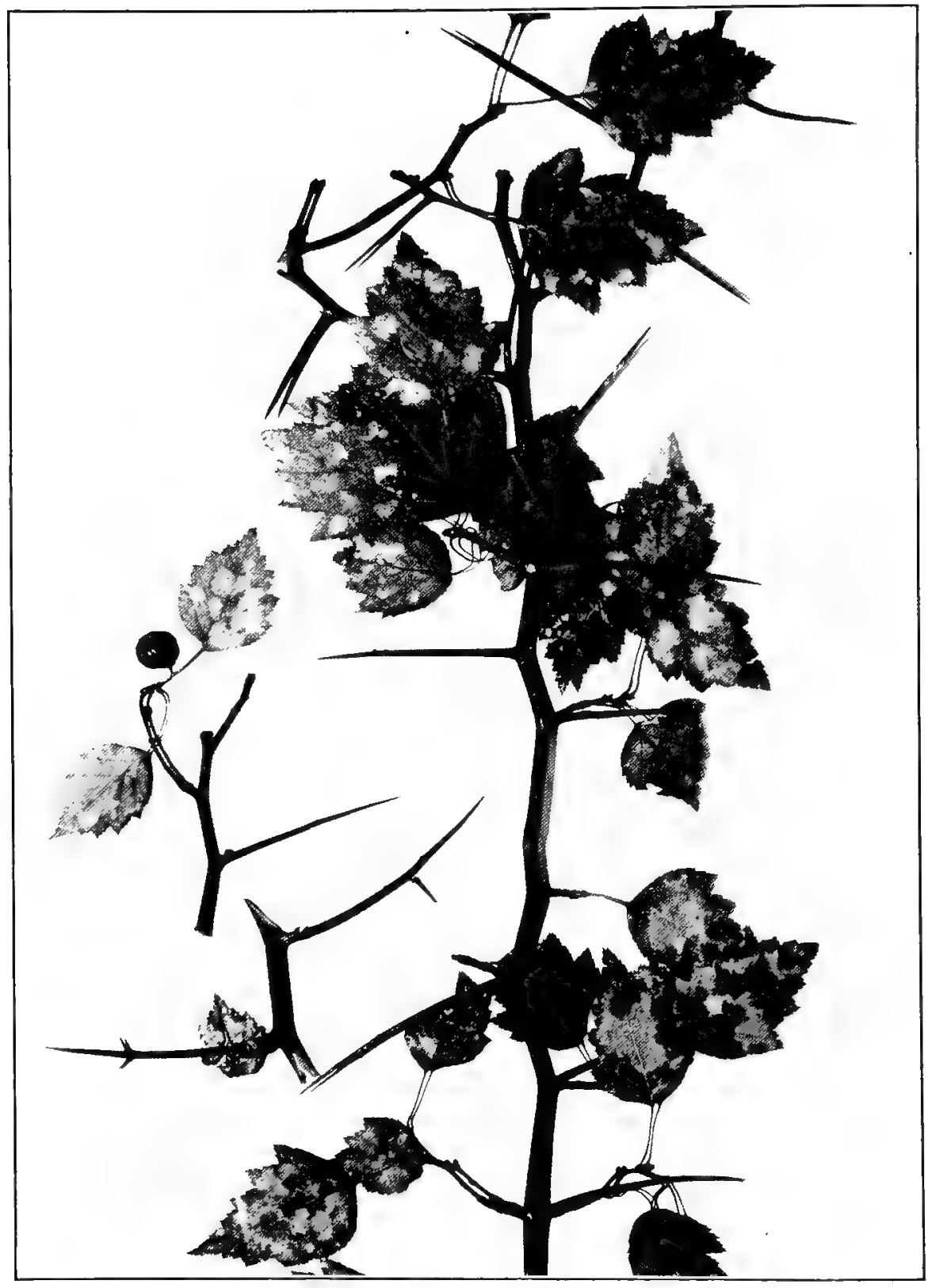

CRAT EGUS JesUPI Sargent. Jesup's Thorn. (x 1/2.) 
petioles slender, $2-3.5 \mathrm{~cm}$. (3/4-1/2 inches) long, slightly winged above; corymbs glabrous, many-flowered; flowers appear in May, about $2 \mathrm{~cm}$. (5/6 inch) broad; stamens about 10 ; anthers dark red; styles and nutlets usually 3 or 4 ; calyx lobes entire; fruit ripens in October, shortellipsoidal to pyriform, dark red, slightly angled, lacking bloom when mature, about $1 \mathrm{~cm}$. ( $3 / 8$ inch) thick, flesh yellow, firm; calyx lobes mostly deciduous.

Distribution.-Western Vermont, to southwestern Wisconsin and south to Pennsylvania and Owen County, Indiana.

A shrubby tree, sometimes $6 \mathrm{~m}$. (20 feet) high, with ascending branches and a round crown.

Specimens examined: Owen (Mrs. Chas. C. Deam).

15. Crataegus rugòsa Ashe. (Crataegus deltoides Ashe). Fretz's Thorn. Plate 91. Spines numerous, 3-6 cm. (1 1/4-21/2 inches) long, stout curved; leaves broadly ovate, $3-7 \mathrm{~cm}$. (1-23,4 inches) long and broad, acute or acuminate at the apex, cordate or truncate at the base, serrate or twice serrate with 4-6 pairs of broad acuminate lobes, glabrous, membranaceous; petioles $1-3 \mathrm{~cm}$. (3/8-11/4 inches) long, glabrous; corymbs many-flowered, glabrous; flowers appear in May, about $2 \mathrm{~cm}$. (5/6 inch) broad; stamens 10-20; anthers pink; styles and nutlets usually 4 or 5 ; calyx lobes deltoid-acuminate, entire or slightly serrate at the base; fruit ripens in October, depressed-globose, bright red, angular, glabrous, waxy, $1-1.5 \mathrm{~cm}$. (1/2-2/3 inch) thick, flesh yellow, somewhat succulent; calyx lobes persistent, spreading, the tube rather prominent.

Distribution.-Southwestern New England to southern Indiana and the mountains of North Carolina.

A shrub or tree sometimes $6 \mathrm{~m}$. (20 feet) high, with ascending branches and an irregular crown.

Specimens examined: Allen (Deam); Decatur (Deam); Grant (Deam); Jennings (Deam); Owen (Deam); Perry (Deam); Wells (Deam).

16. Crataegus fillipes Ashe. Mrss Beckwith's Thorn. (Crataegus silvicola var. Beckwithae (Sargent) Eggleston. Plate 92. Spines numerous, curved, chestnut-brown, 2.5 to $6 \mathrm{~cm}$. (1-21/2 inches) long; bark slightly scaly; leaves $2-7 \mathrm{~cm}$. (3/4-23/4 inches) long, $2-6 \mathrm{~cm}$. $(3 / 4-21 / 2$ inches) wide; leaves ovate, acute or acuminate at apex, rounded, truncate or on vegetative shoots cordate at base, serrate or doubly serrate, lower pair of acuminate lobes often deeply cut, membranaceous, glabrous; corymbs glabrous; flowers about $2 \mathrm{~cm}$. $(3 / 4 \mathrm{inch})$ broad; stamens about 10; anthers pink; styles and nutlets 3-5; fruit globose or compressed globose, cherry-red, $8-10 \mathrm{~mm}$. (1/3 inch) thick, ripens in October. 
Plate 91.

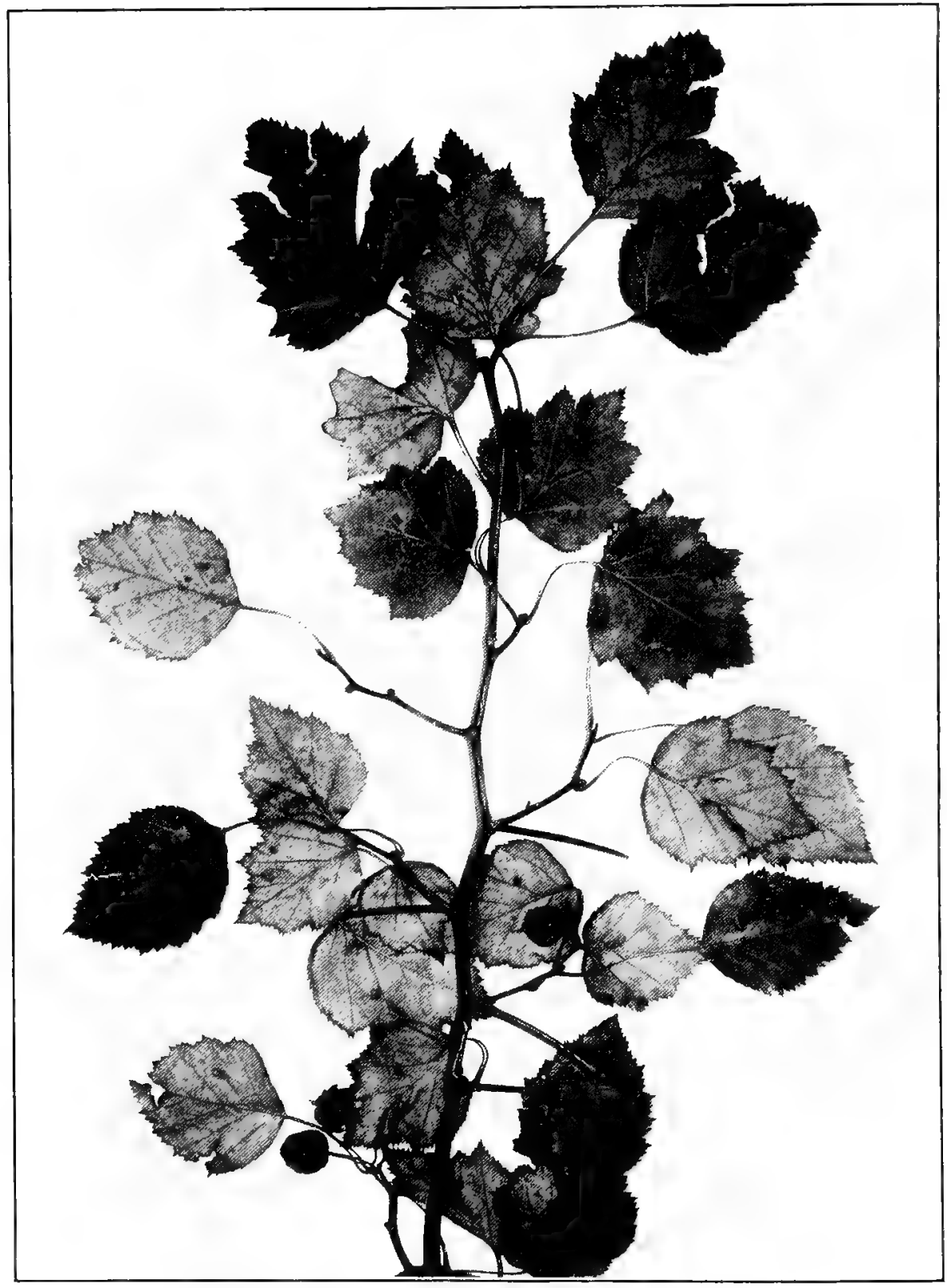

CRATEGUS RUGOSA Ashe. Frete's ThorN. ( $x$ 1/2.) 
Plate 92.

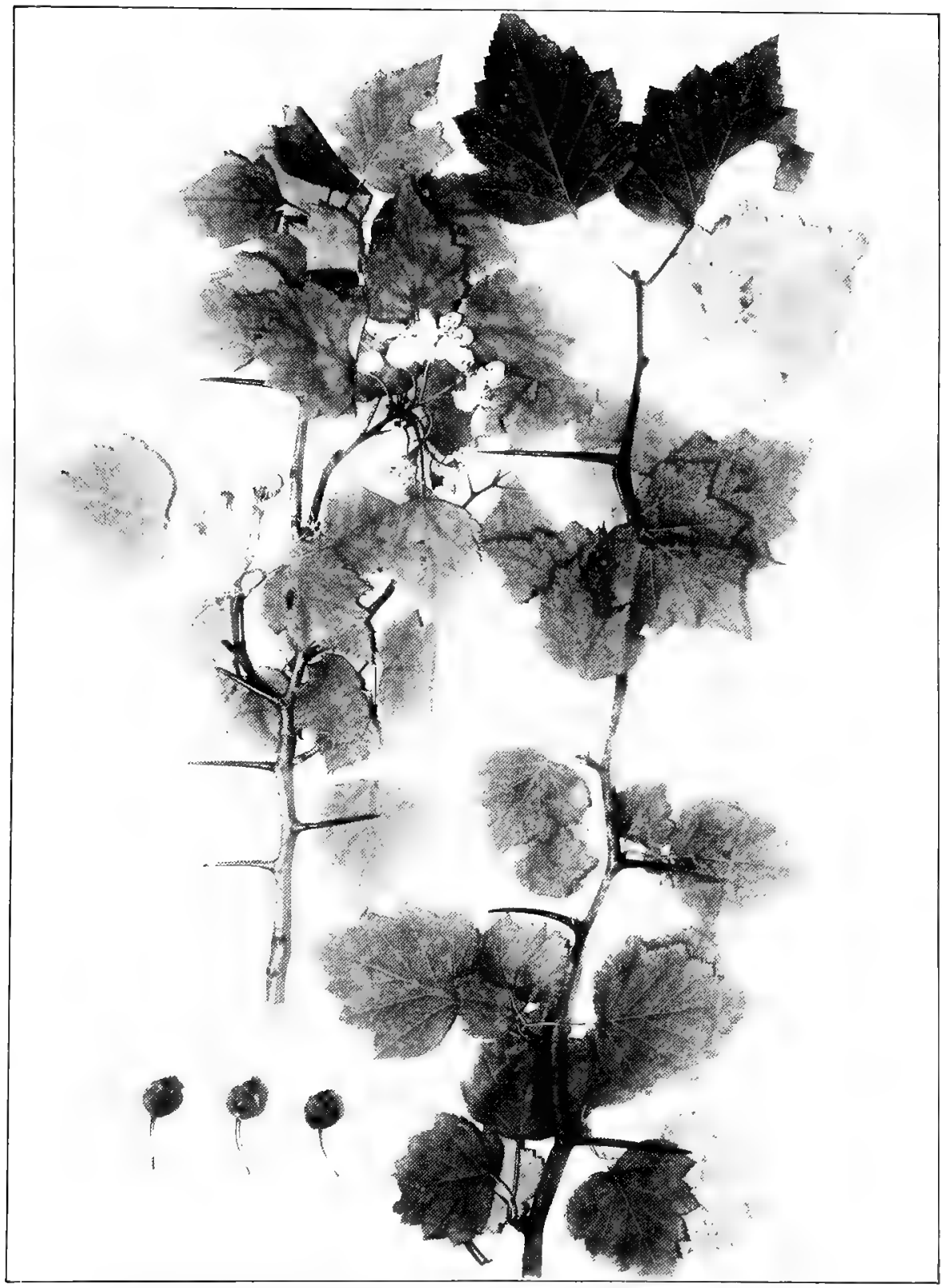

CRategus Filipes Ashe. Miss Beckwith's Thorn. (x 1/2.) 
Distribution.-Western New England to central Michigan and south to Pennsylrania and southern Indiana.

A shrub or tree sometimes 9 meters (30 feet) high, with irregular ascending branches.

Specimens have been seen from Perry County, Deam's No. 27104.

17. Crataegus Gat tíngeri Ashe. (Crataegus coccinea var. oligandra Torrey and Gray). Dr. Clapp's Thorn. Gattinger's Thorn. Plate 93. Spines numerous, $2.5-6 \mathrm{~cm}$. (1-2 inches) long; leaves narrowly ovate to deltoid, 2.5-6 cm. (1-21/2 inches) long, $2-5 \mathrm{~cm}$. (3/4-2 inches) wide, acuminate at the apex, broadly cuneate or rounded at the base, serrate or doubly serrate, lobed towards the apex, membranaceous, glabrous, dark green above; petioles glabrous, $2-3 \mathrm{~cm}$. (3/4-11/4 inches) long; corymbs glabrous, many-flowered; flowers appear in May, about 2 cm. (34 inch) broad; stamens 10-20; anthers small, pink; styles and nutlets usually 3 or 4; fruit ripens in October, globose, angular, red, slightly waxy, 0.8-1.2 cm. (1/3-1/2 inch) thick, flesh hard; calyx tube prominent, the lobes triangular, spreading.

Distribution.- Southern Pennsylvania and southern Indiana to West Virginia and central Tennessee.

Shrub or small tree sometimes $4.5 \mathrm{~m}$. (15 feet) high, with ascending, irregular branches.

Specimens seen from: Floyd (Dr. Clapp, before 1840); Knox (Schneck); Perry (Deam); Steuben (Deam); Wells"(Deam).

18. Crataegus pruinòsa (Wendland) K. Koch. Waxy-Fruited Thorn. Plate 94. Bark dark brown; spines numerous, slender, 3-6 cm. (11/4-21/2 inches) long; leaves elliptic-ovate to broadly ovate, 2.5-6 cm. (1-21/2 inches) long and wide, acute or acuminate at the apex, abruptly cuneate, rounded or occasionally cordate at the base, serrate or doubly serrate with 3 or 4 pairs of broad acute lobes towards the apex, blue-green, glabrous, membranaceous; petioles 2 or $3 \mathrm{~cm} .(3 / 1$ $11 / 4$ inches) long, glabrous; corymbs glabrous, many-flowered; flowers appear in May, about $2 \mathrm{~cm}$. (5/6 inch) broad; stamens 10-20; anthers pink or sometimes yellow or white; styles and nutlets 4 or 5 ; calyx lobes lanceolate-acuminate, entire, slightly serrate at the base; fruit ripens in October, depressed-globose to short-ellipsoidal, strongly angled, waxy, apple green, becoming scarlet or purple, 1.2-1.5 c.m. $(1 / 2-2 / 3$ inch), thick, firm, yellow, sweet; calyx tube prominent, the lobes sprearling, persistent.

Distribution.-Rocky, open woods, western New England to Michigan and south to North Carolina and Missouri. Well distributed in Indiana. 
Plate 93.

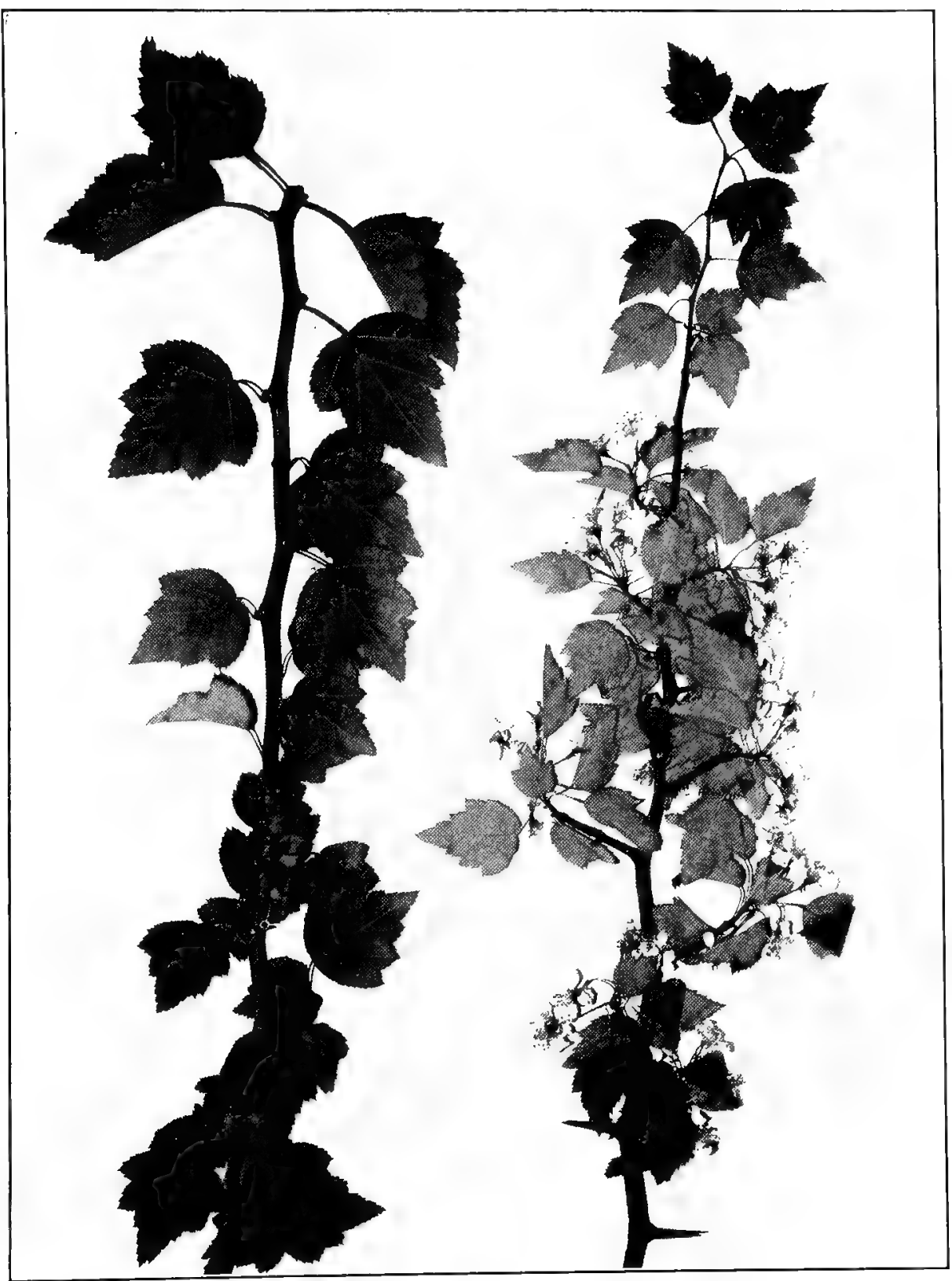

CRat Ægus GatTingeri Ashe. Dr. Gattinger's Thorn. (x 1/2.) 
Plate 94.

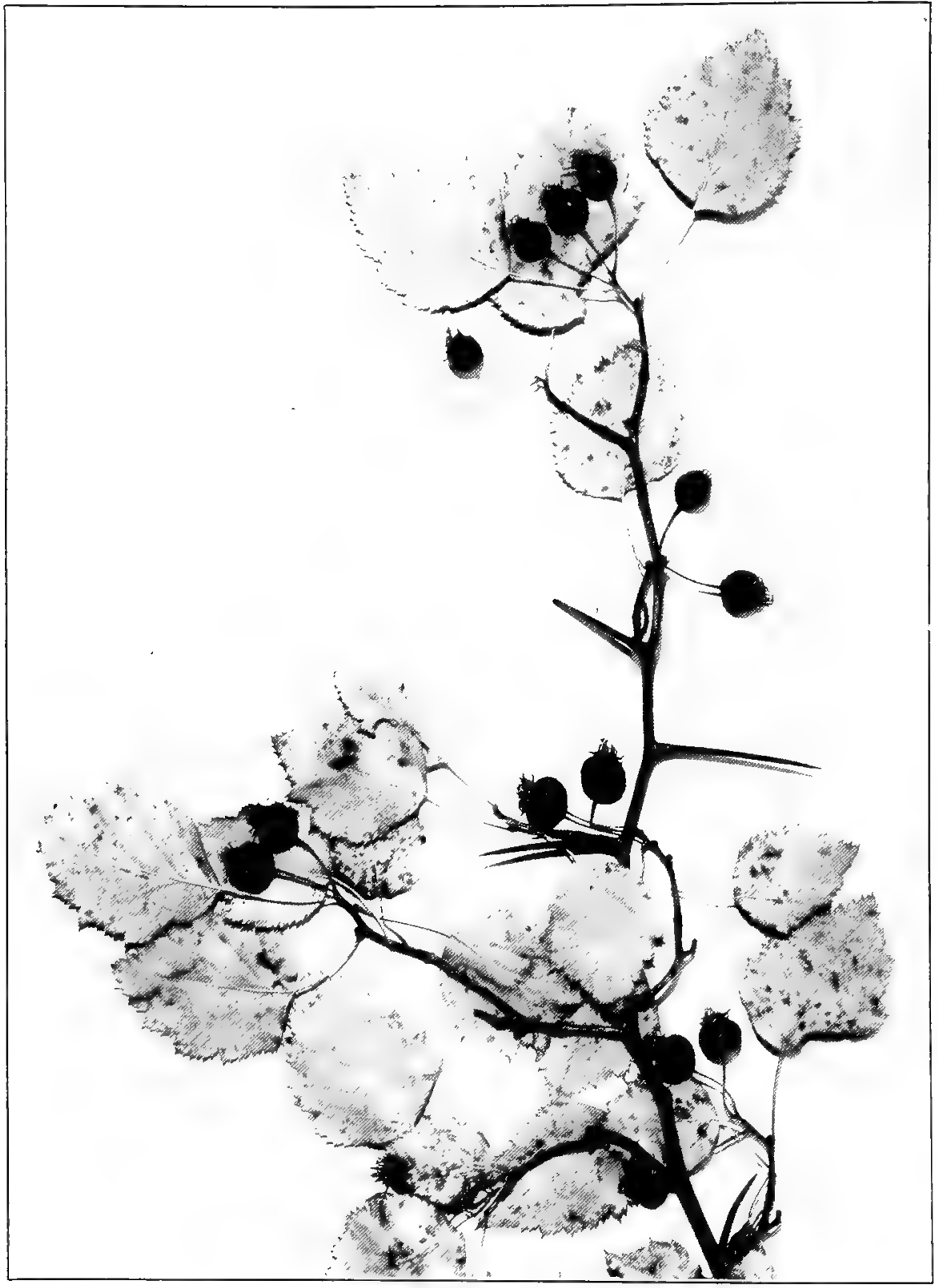

CRATegus PRUIAOSA (Wendland) K. Koch. Waxy-fruted Thorn. $\left(\begin{array}{lll}x & 1 & 2\end{array}\right)$ 
A small shrubby tree sometimes $6 \mathrm{~m}$. (20 feet) high, with irregular branches and crown.

Specimens have been seen from the following counties: Allen (Deam); Clark (Deam); Decatur (Deam); Delaware (Deam); Gibson (Deam); Hamilton (Deam); Hancock (Mrs. Chas. C. Deam); Lagrange (Deam); Madison (Deam); Marion (Deam); Monroe (Deam); Porter (Deam); Putnam (Grimes); Randolph (Deam); Steuben (Deam); Sullivan (Deam); Tipton (Deam); Vermillion (Deam); Warren (Deam); Wayne (Deam); Wells (Deam).

19. Crataegus coccinioides Ashe. EgGert's Thorn. (Crataegus Eggertii Britton). Plate 95. Bark grayish-brown, scaly; spines curved, $2-6 \mathrm{~cm}$. (3/4-21/2 inches) long; leaves broadly ovate, $4-9 \mathrm{~cm}$. (1/ $1 / 2-31 / 2$ inches) long $3.5-8 \mathrm{~cm}$. (13/4-3 inches) wide, acute at the apex, rounded or truncate at the base, doubly serrate with several pairs of broad, acute lobes, dark green above, paler and slightly tomentose along the veins beneath, membranaceous; petioles 2 to $3 \mathrm{~cm}$. $(3 / 4-1 / 4$ inches) long, slightly pubescent; corymbs glabrous, 5-12 flowered; flowers appear in May, about $2 \mathrm{~cm} .(5 / 6$ inch) broad; stamens about 20 ; anthers pink; styles and nutlets usually 4 or 5 ; calyx lobes ovate, acute, glandularserrate; fruit ripens in September, subglobose, obtusely angled, 1.5-2 cm. (3/4-1 inch) thick, flesh reddish, subacid, edible; calyx tube prominent, the lobes spreading.

Distribution.-Montreal Island to Rhode Island and west to eastern Kansas and Missouri.

A small tree sometimes $6 \mathrm{~m}$. (20 feet) high, with ascending and spreading branches and a broad, round-topped crown.

Specimens have been seen from: Floyd (Dr. Clapp, before 1840), (Deam); Gibson (Schneck); Marion (Deam); Martin (Deam); Vigo (Blatchley); Whitley (Deam).

20. Crataegus coccínea Linnæus. Scarlet Thorn. Red Haw. (Crataegus pedicillata Sargent). Plate 96. Bark light gray, spines stout, curved, 2-6 cm. (3/4-2 inches) long; leaves broadly ovate, $3-10$ $\mathrm{cm}$. (11/4-4 inches) long, $3-9 \mathrm{~cm}$. (11/4-3/2 inches) wide, acute or acuminate at the apex, broadly cuneate to truncate at the base, serrate, doubly serrate or lobed, slightly pubescent, becoming scabrous above, nearly glabrous beneath, membranaceous; corymbs glabrous or sometimes slightly villous, many-flowered; flowers appear in May, $1.5-2 \mathrm{~cm}$. ( $2 / 3-5 / 6$ inch) broad; stamens 10-20; anthers pink; styles and nutlets 3-5; fruit ripens in September, pyriform to short ellipsoidal, scarlet or red, glabrous or slightly pubescent, $1.5-2 \mathrm{~cm} .(3 / 4-5 / 6$ inch $)$ thick, flesh thick, dry and mealy; calyx lobes lanceolate-acuminate, glandularserrate, erect or spreading, rather persistent. 
Plate 95.

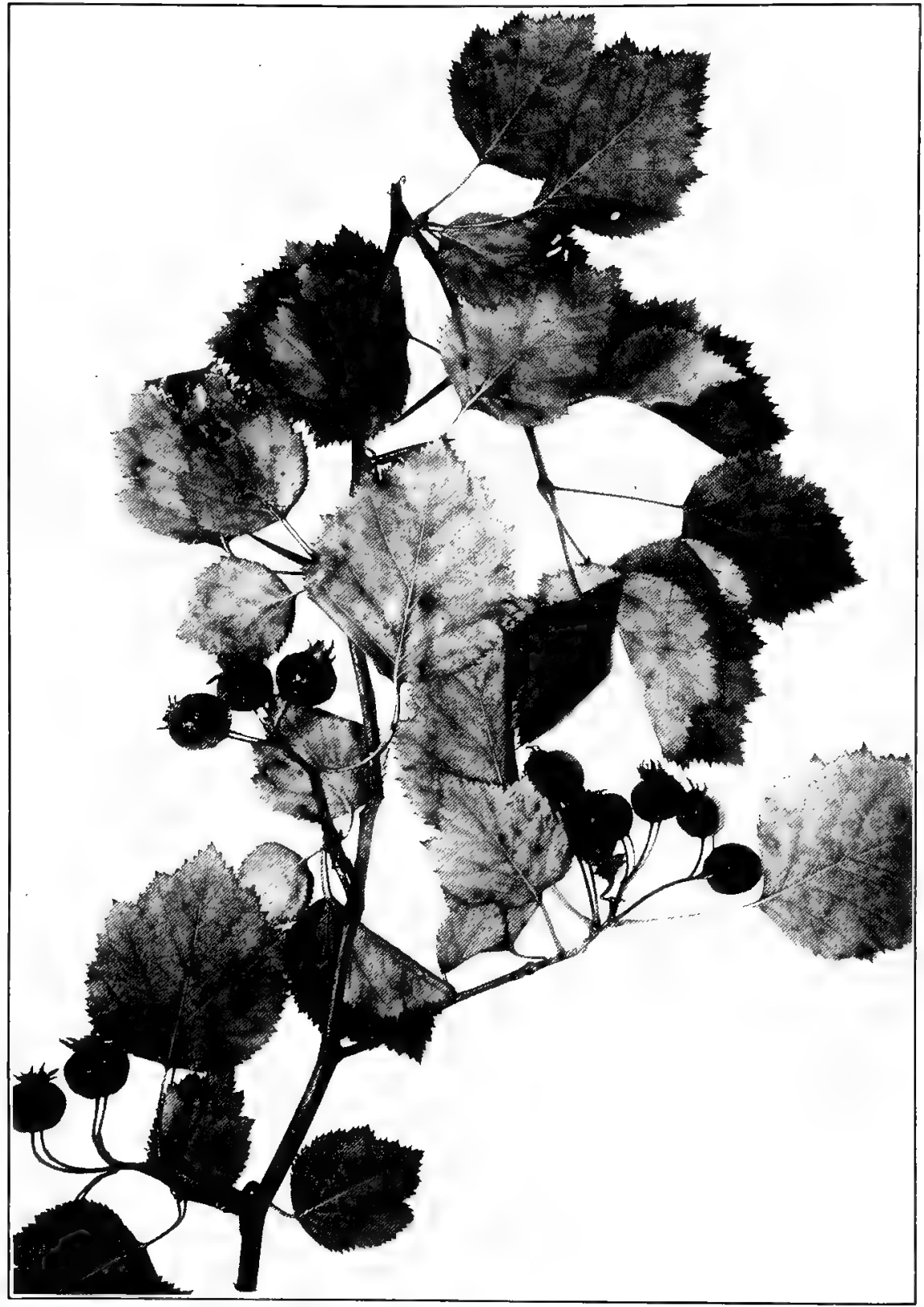

CRAT EGUS COCCINOIDE' Ashe. Equert's Tharn. (x 1/2.) 
Plate 96.

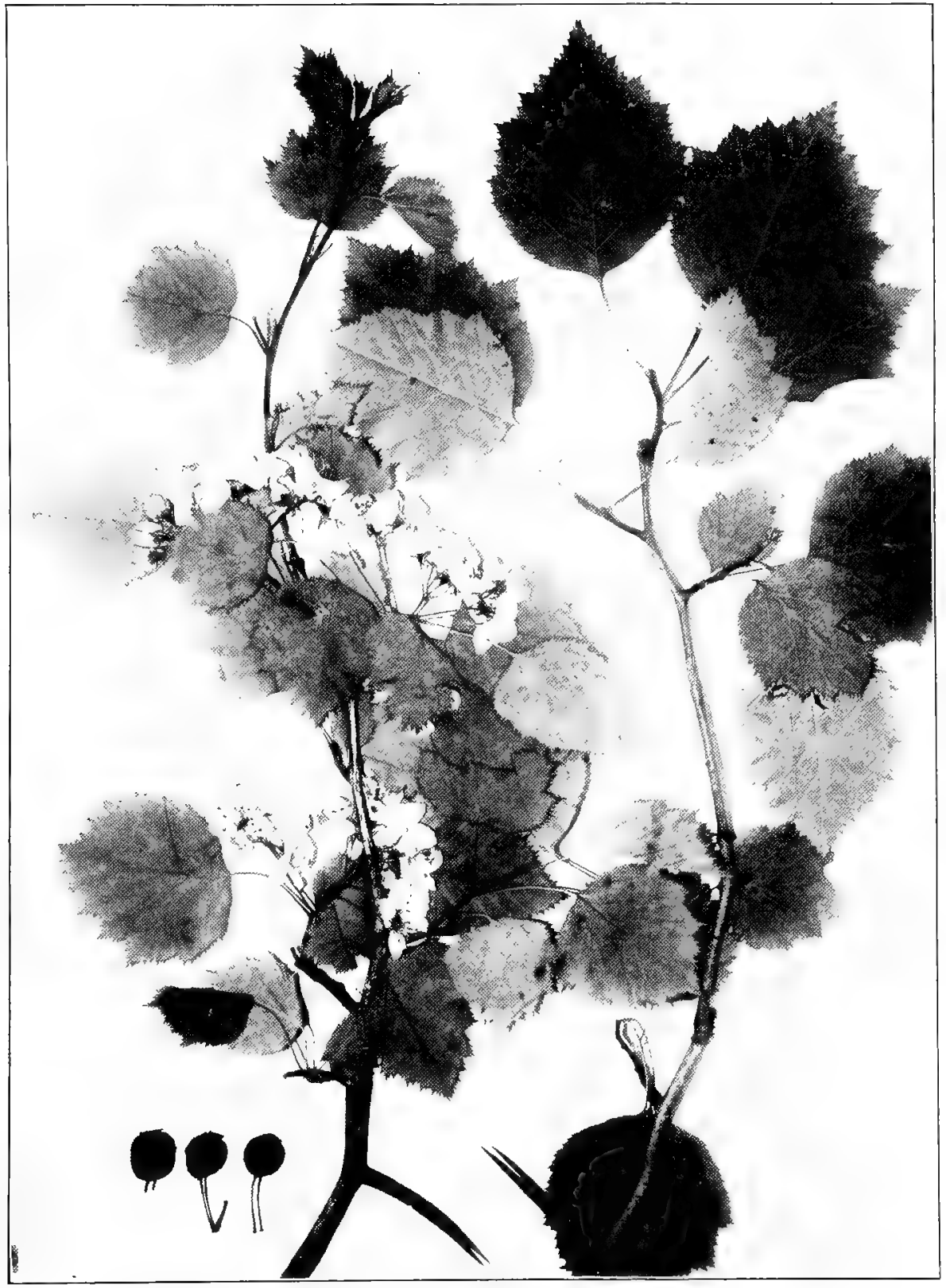

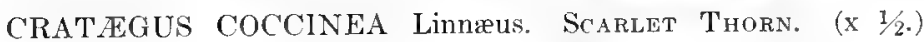


Distribution.--Connecticut to Ontario, Illinois, Delaware and Pennsylvania.

A small tree sometimes $8 \mathrm{~m}$. (25 feet) high, with ascending and spreading branches and a broad, round-topped crown.

Specimens have been seen from the following counties: Floyd (Deam); Knox (Deam); Noble (VanGorder); Steuben (Deam); White (Deam).

Horticultural Uses. - This fine tree has been in the gardener's hands several conturies. There are specimens in the Kew Gardens, England, more than two hundred years old.

20a. Crataegus coccinea var. Ellwangeriàna, n. nom. (Crataegus pedicillata var. Ellwangeriana (Sargent) Eggleston). Corymbs densely villous; fruit slightly villous.

Distribution.- Known in Indiana from Deam's specimen No. 27355 from Warren County.

21. Crataegus móllis (Torrey and Gray) Scheele. Red-Fruited ol Downy Thorn. Red Haw. Plate 97. Bark grayish-brown, fissured and sealy; spines curved, 3-5 cm. (1-2 inches) long; leaves broadly ovate, acute at the apex, cordate to truncate at the base, serrate or twice scrate with narrow acute lobes, 4-13 cm. (11/2-5 inches) long, 4-10 cm. (1/2-4 inches) wide, slightly rugose, densely tomentose beneath, tomentose abore, becoming scabrous, membranaccous; petioles $2-4 \mathrm{~cm}$. (3/4-11/2 inches) long, tomentose; corymbs tomentose, many-flowered; flowers appear in May, about $2.5 \mathrm{~cm}$. (1 inch) broad; stamens about 20; ant hers light yellow; styles and nutlets 4 or 5 ; fruit ripens in September, short-ellipsoidal to subglobose, scarlet, $1.5-2.5 \mathrm{~cm} .(1 / 2-1 \mathrm{inch})$ thick, flesh thick, yellow, edible; calyx lobes glandular-serrate, swollen, erect or spreading, deciduous.

Distribution.- Southern Ontario to South Dakota, south to central Tennessee and Arkansas. This thorn is well distributed over Indiana.

A small tree often $13 \mathrm{~m}$. (40 feet) high, with ascending and spreading branches, forming a broad, round-topped crown.

Specimens have been examined from the following counties: Allen (Deam); Cass (Mrs. Ida Jackson); Dearborn (Deam); Decatur (Deam); Delaware (Deam); Floyd (Deam); Gibson (Schneck), (Deam); Hancock (Deam); Hendricks (Deam); Henry (Deam); Jackson (Deam); Knox (Schneck), (Deam); Madison (Deam); Marion (Mrs. Chas. C. Deam); Montgomery (Grimes); Posey (Deam); Putnam (Grimes); Shelby (Deam); Sullivan (Deam); Vermillion (Deam); Wells (Deam); Whitley (Deami). 
Plate 97.

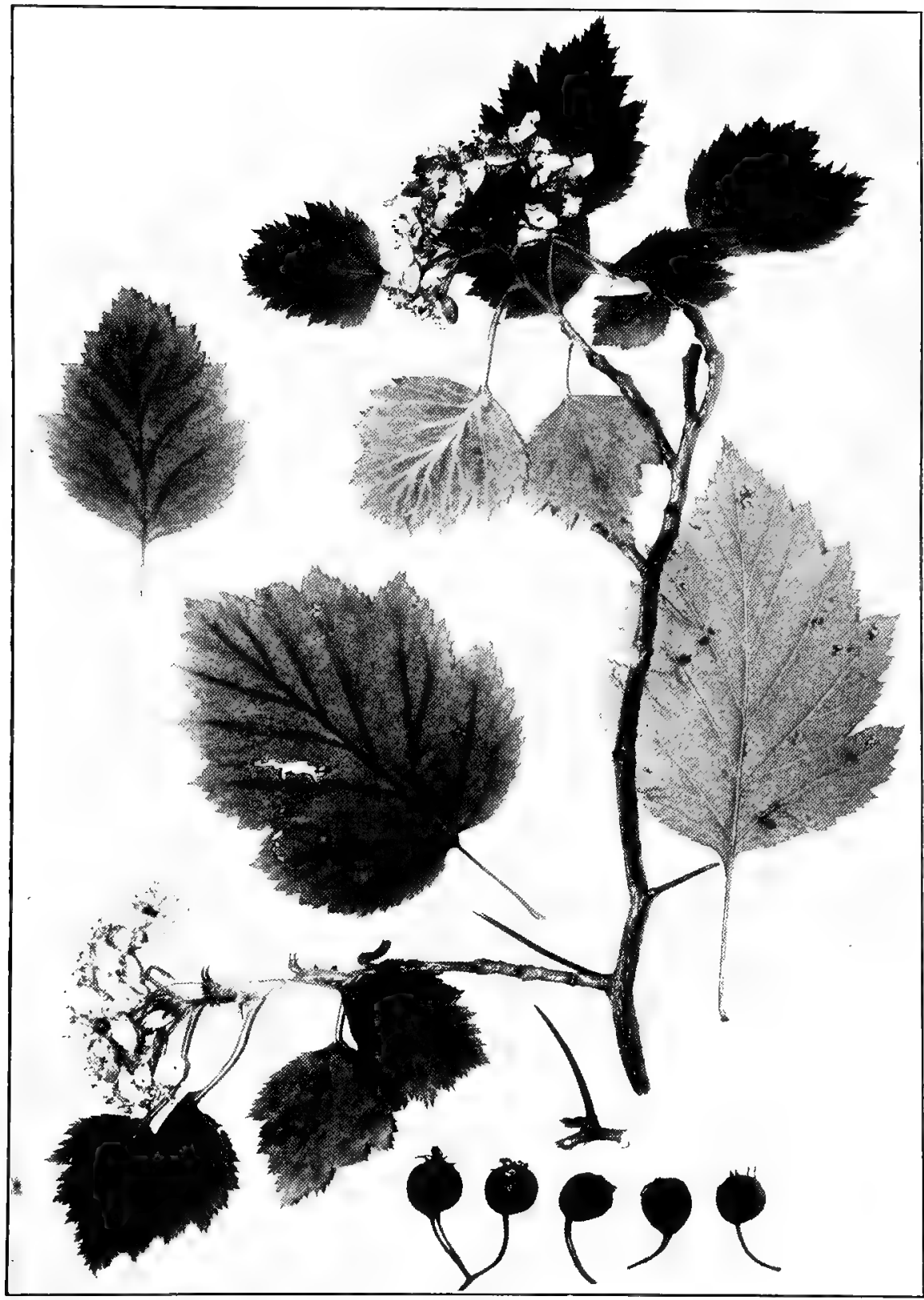

CRATAGUS MOLLIS (Torrey and Gray) Scheele. Red-Fruited Thorn. ( $\begin{array}{ll}x & 1 / 2 .)\end{array}$ 
22. Crataegus Phaenopyrum (Linnæus fils) Medicus. Washington Thorn. Scarlet Haw. (Crataegus cordata Aiton). Plate 98. Bark grayish-brown, scaly; spines numerous, slightly curved, $2-5 \mathrm{~cm}$. (3,4-2 inches) long; leaves ovate-triangular, $2-8 \mathrm{~cm}$. (3, $4-3$ inches) long and wide, simply or doubly serrate, often 3-5 lobed, acute at the apex, rounded to cordate at the base, bright green above, glabrous; petioles s'ender, $1.5-5 \mathrm{~cm}$. (1/2-2 inches) long, glabrous; corvmbs glabrous, manyflowered; flowers appear in June, $8-12 \mathrm{~mm} .(1 / 3-1 / 2$ inch) broad; stamens about 20; anthers pink; styles and nutlets usually 5; calyx lobes deltoid, entire, deciduous; fruit ripens in October or November, depressedglohose, scarlet, 4-6 mm. (1/6-1/4 inch) thick, nutlets with a bare apex and smooth back, flesh thin, firm.

Distribution.-Virginia to Georgia, Indiana to Arkansas. Moist rich soil. Naturalized in Pennsylvania and New Jersey. Possibly it may be naturalized at the Indiana station. More knowledge of distribution in southern Indiana is needed to settle this question.

A shrubby tree sometimes $9 \mathrm{~m}$. (30 feet) high, with nearly erect hranches and an oblong crown.

Specimens have been seen from Wayne (Deam). It also occurs in the Wabash Valley.

Horticultural Uses.- This is one of the most desirable thorns for ornamental planting and hedges. Its scarlet autumn foliage and beautiful little scarlet fruit persist for a long time. It is also one of the American thorns long in cultivation, both in Europe and the United States.

Crataegus álbicans Linnæus. This species was reported for Indiana by Heimlich. ${ }^{1}$

The material at hand is not sufficient to make a satisfactory determination, hence it is omitted in the text.

According to the treatment of the genus Crataegus in Briton and Brown's Illustrated Flora, 2nd Edition, the range of the following species extend into Indiana.

Throughout the State-

In the northern part of the State-

\section{(4. Boyntoni.}

In the southern part of the State-

C. berherifolia.

(". denaria.

C. ferunda.

('. orata.
C. Brainerdi.
C. lurorum.
C. roanensis.
C. heata.
C. villipes.
C. Fringlei. 
Plate 98.

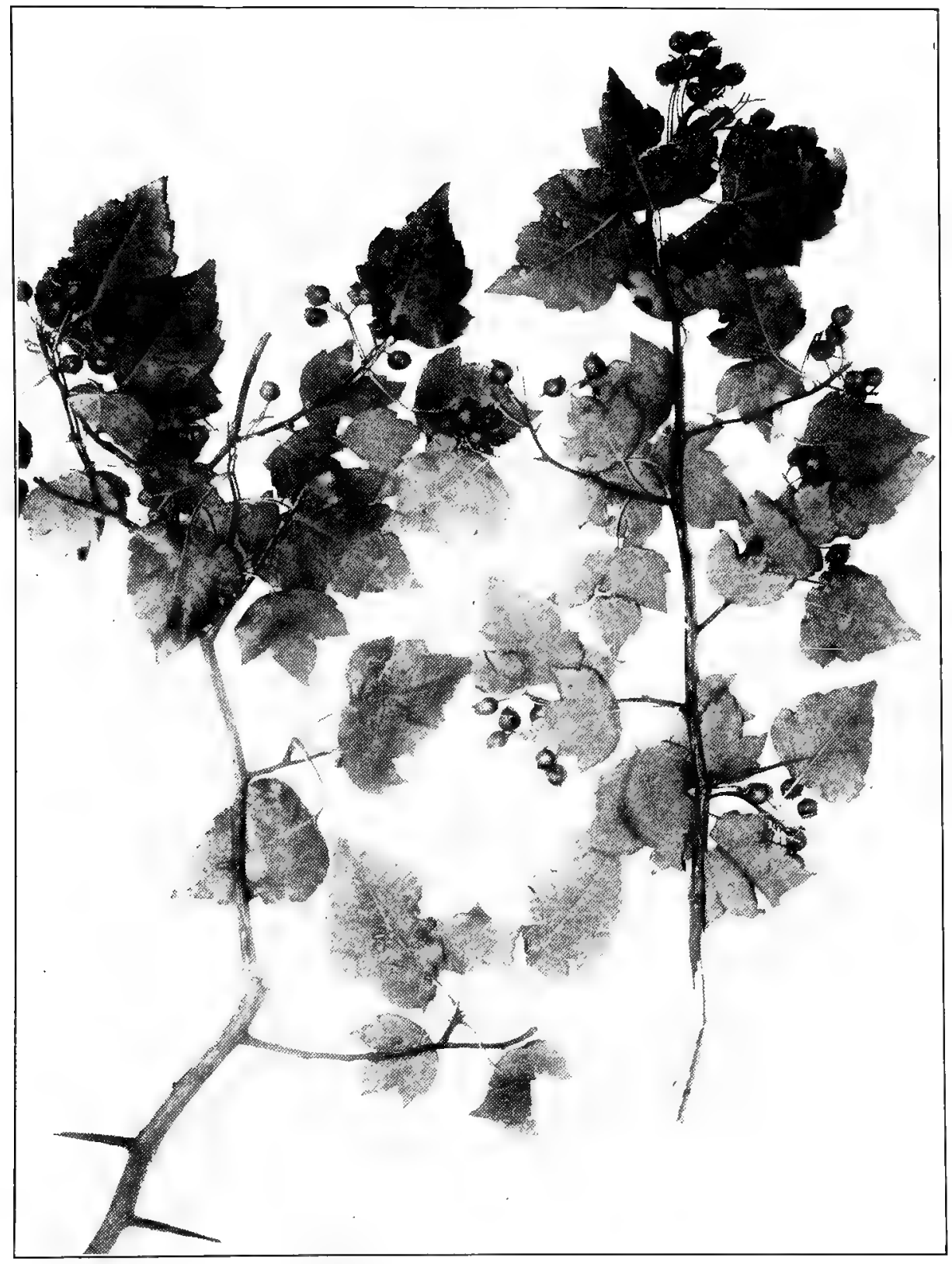

CRATAGUS PHANOPYRUM (Linnæus filius) Medicus. WAshingron THORN. ( $1 / 2$.) 


\section{A Mygdalíceae. The Plum Family.}

Trees or shrubs with alternate, simple, petioled and usually serrate leaves; flowers perfect, calyx and corolla 5 numerous, stamens 15-30; fruit a 1 -seeded drupe.

The characters which separate the species are not at all constant, and the species often vary much in the extremes of their range.

\section{PRínUS. The Plums and Cherries.}

Flowers in umbel like clusters, or somewhat corymbose, appearing before or with the leaves on branchlets of the preceding year.

Margins of leaves with sharp teeth.

Petioles glabrous beneath................ 1 P. americana.

Petioles more or less pubescent all around......... 2 P. americana

Margins of leaves with blunt or crenate teeth. var. lanata.

Teeth of center of leaves about 10 per em.; calyx lobes glandular; fruit more than $10 \mathrm{~mm}$. in diameter.

Principal leaves of fruiting branches generally more than $4 \mathrm{~cm}$. broad; flowers white and generally more than $17 \mathrm{~mm}$. wide

3 P. nigra.

Prineipal leaves of fruiting branches generally less than $4 \mathrm{~cm}$. broad; flowers white which on age show a tinge of pink and generally less than $17 \mathrm{~mm}$. wide. $4 \mathrm{P}$. hortulana.

Teeth of center of leaves about 20 per em.; calyx lobes glandless; fruit less than $10 \mathrm{~mm}$. in diameter......5 P. pennsylvanica. Flowers in racemes, appearing after the leaves on twigs of

1. Prunus americàna Marshall. Wild Red Plum. Plate 99 Small trees with crooked branches; bark of old trees exfoliating in irregular plates; twigs smooth; leaves obovate or oval, 5-9 cm. long, $2.5-5 \mathrm{~cm}$. wide, narrowed or sometimes rounded at the base, acuminate at apex, margins sharply serrate or doubly serrate, glabrous above and smooth below, or hairy on the veins and sometimes more or less pubescent over the whole under surface, inner surface of petiole more or less hairy and sometimes bearing one or two glands; flowers appear in April or May before or with the leaves in clusters of 2-4 or sometimes singly, about $2 \mathrm{~cm}$. in diameter, calyx smooth or with some hairs near the base of the lobes which are pubescent within and smooth or hairy without, lobes entire or cut-toothed above the middle, glandless or with inconspicuous glands; fruit ripens in August or September, usually globose, about $2 \mathrm{~cm}$. in diameter, red; stone doubly convex, oval to nearly orbicular, surface usually smooth. 
Plate 99.

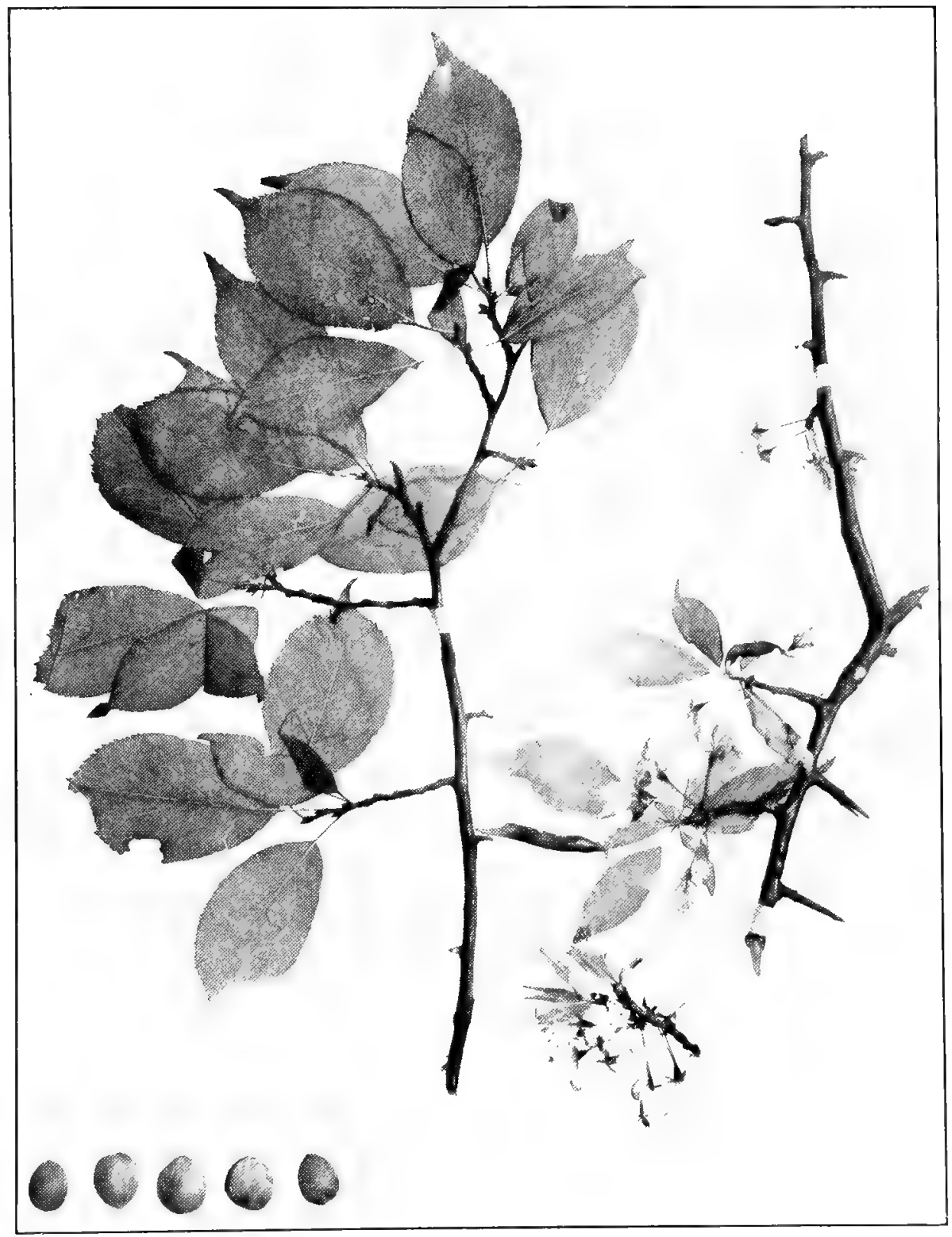

PRUNUS AMERICANA Marshall. WILd RED PLUM. (x 1/2.) 
Distribution. - Massachusetts to Florida, west to Manitoba and south to New Mexico. Found throughout Indiana. While it has a general distribution, it is not generally distributed through the forests, but is local in colonies in low grounds along streams or in low places in the forest. In the southern counties it is found on the ridges and commonly about the basins of sink-holes. Large single trees may be found but they are usually surrounded by many smaller ones which are root shoots. From this habit of the tree to produce root shoots large colonies are formed which has given rise to the term "plum thickets."

Remarks.- The wood of this tree is of no economic importance, but the species from a horticultural standpoint is one of the most important of all of the plums. Many named varieties belong to this species.

It should be noted that all species of plums are quite variable, and one must not be surprised to find specimens that will not come entirely within the descriptions.

2. Prunus americana var. lanàta Sudworth. Woolly-leaf Plum. Plate 100. Small trees with the charact eristic wild plum tree bark, except on age it becomes mole furrowed; twigs generally puberulent or sometimes smooth; leaves obovate, oblong-obovate, or sometimes somewhat ovate, generally about $6-10 \mathrm{~cm}$. long, and $4-6 \mathrm{~cm}$. wide, rounded at the base, acute or short acuminate at the apex, margins sharply serrate, or doubly serrate, upper surface covered with short appressed hairs, lower surface permanently pubescent with longer hairs; petioles more or less pubescent and often bearing one or more glands; flowers appear in April or May in umbels of 2-4, upper part of calyx, and its lobes pubescent both inside and out, the Iobes more or less cut-toothed and bearing inconspicuous glands; fruit ripening in September, globose, recklish with a bluish bloom; stone nearly orbicular and turgid.

Distribution. - Indiana west to Indian Territory and south to the Gulf. The range of this variety has not been well understood, and it is believer that forms of this variety in the northern part of its range have been included in the preceding species. It is certain that in our area the two forms are separated with difficulty; especially is this true of certain individuals. Specimens at hand show it to oceur in Floyd, Clark, Bartholomew, Martin, Warren, Vermillion, Gibson, Warrick, and Perry Counties.

Remarks. - This form intergrades with the preceding to such an extent that there is little difference between the extremes of the two forms.

3. Prunus nigra Aiton. Canada Plum. Plate 101. Small trees with the characteristic bark of the genus; twigs smooth; leaves obovate or oval, $5-11 \mathrm{~cm}$. long and $3-6 \mathrm{~cm}$. wide, rounded or somewhat 
Plate 100.

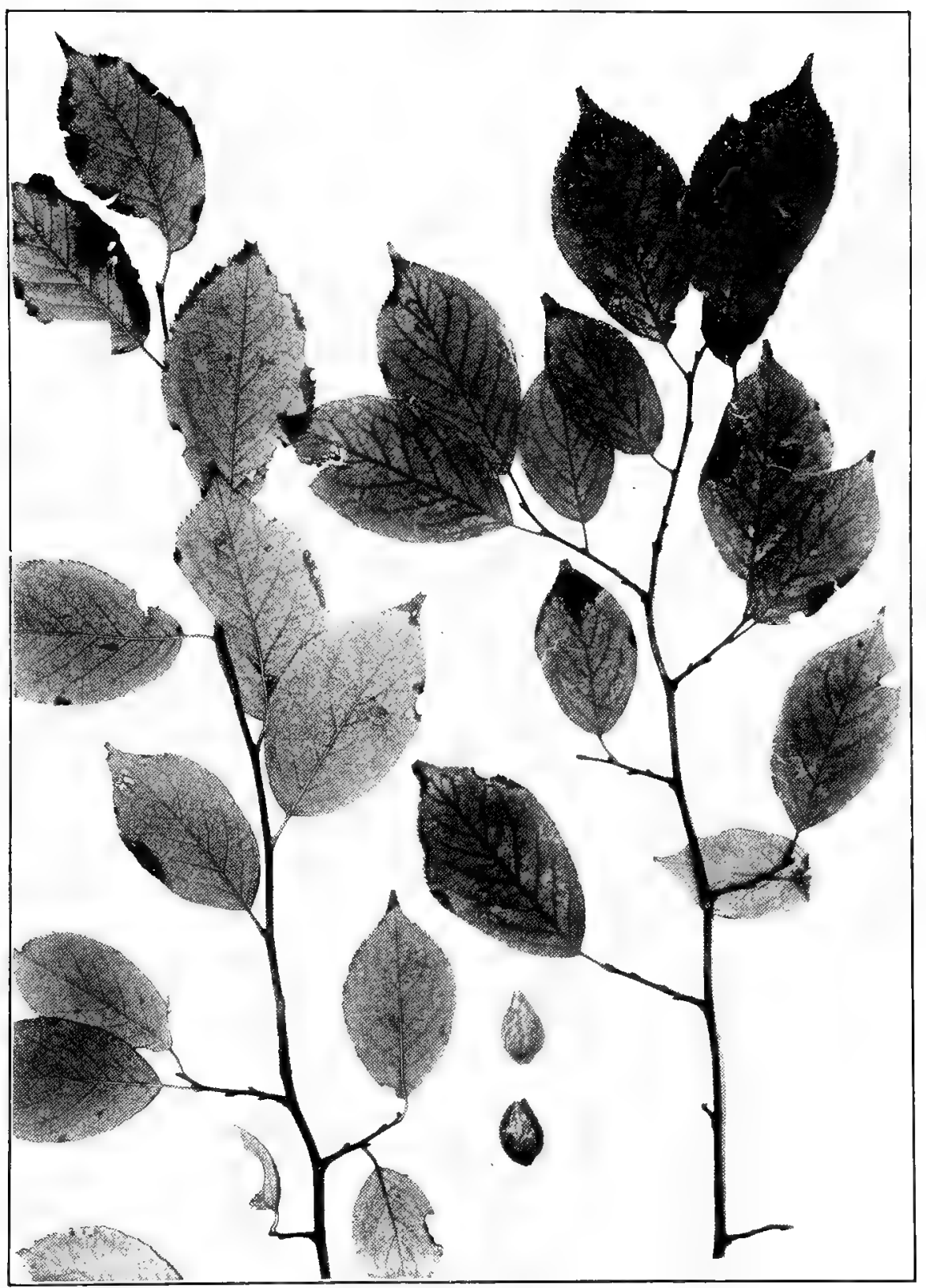

PRUNUS AMERICANA variety LANATA Sudworth. Woollx-leaf Plum. $(x$ 1 2 . $)$ 
Plate 101.

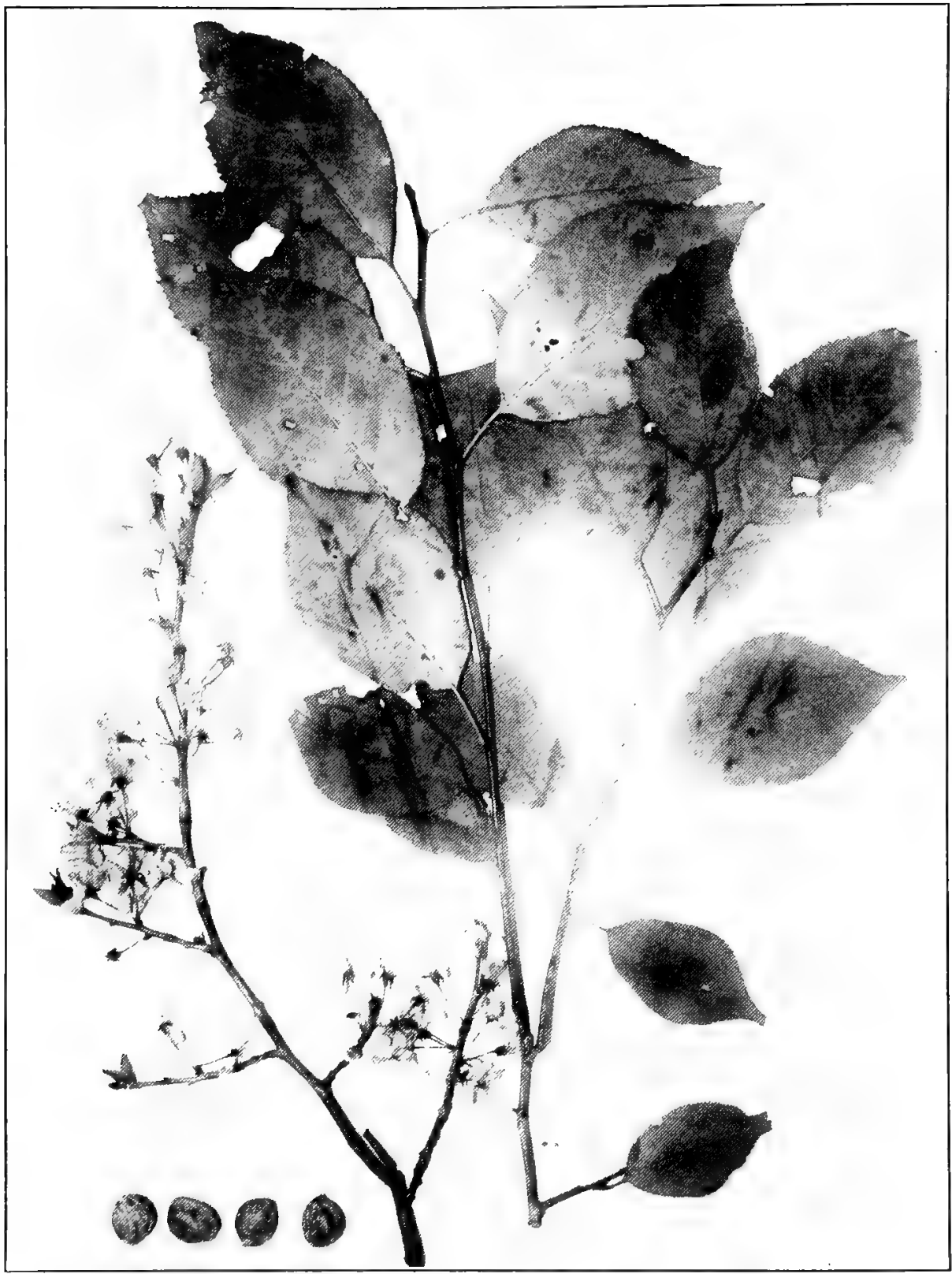

PRUNug Nigra Aiton. Canada Plom. (x 1/2.) 
narrowed at the base, abruptly short acuminate toward the apex, smooth or sparsely coveredabove with a short appressed pubescence, more or less pubescent beneath especially along the veins, usually pubescent on the veins at maturity, margins crenate-serrate, the teeth ending in persistent glands, petioles more or less pubescent on the inner surface, and generally bearing a pair of glands, which number varies from 1 to 3 , or sometimes absent; flowers appear in April or May in umbels of 2-3, about $2 \mathrm{~cm}$. in diameter-the largest of the genus in Indiana, calyx smooth, the lobes smooth without and within, except toward the base which is pubescent, the lobes reddish and the margins studded with numerous red glands; fruit ripens in July, globose, red; stone short oval and very flat.

Distribution.- New Brunswick to Massachusetts and west to Minnesota and south to central Indiana. In Indiana it is definitely known only from Wells, Blackford and Marion Counties. No doubt it ranges throughout the northern part of Indiana, but it has not been separated from Prunus americana. Higley and Raddin ${ }^{1}$ in 1891 , when our text books did not separate this species, in a flora which included a part of Lake County Indiana, remark: "There are two distinct forms of Prunus americana; one with slender branches and large flowers with glandular calyx, found in swamps and another found with stout branches and much smaller flowers with the calyx less glandular, grows in dry soil." This no doubt refers to the species under discussion.

In 1898 the author found this species growing in a swamp in Wells County, and transplanted a specimen to high ground in his orchard. It has persisted ever since, growing vigorously and freely suckering from the roots, but it has been quite susceptible to the San Jose scale.

4. Prunus hortulàna Bailey. Wxud Goose Plum. Plate 102. Small trees with bark exfoliating in plates or rolls on old trees; twigs smooth; leaves oblong-oval, oval, slightly ovate or obovate, generally $6-11 \mathrm{~cm}$. long and $2.5-5.5 \mathrm{~cm}$. wide, rounded and often slightly oblique at the base, acuminate at the apex, margins finely serrated with short rounded and glandular teeth, generally glossy and smooth above, more or less pubescent all over beneath with long hairs, the midrib and lateral veins usually prominent below, petioles pubescent on the inner face and usually bearing one or more glands; flowers appear with the leaves in April or May in umbels of 2-4; calyx glabrous, the lobes glabrous on the outer face, and more or less pubescent within, margins glandular; fruit ripens in August, generally globose, red; stone generally short oval, very turgid, face reticulated.

${ }_{1}$ Higley and Raddin: Flora of Cook County Illinois and a part of Lake County Indiana. Bul. Cliic. Acad. Sci. Vol. 2:33:1891. 
Plate 102.

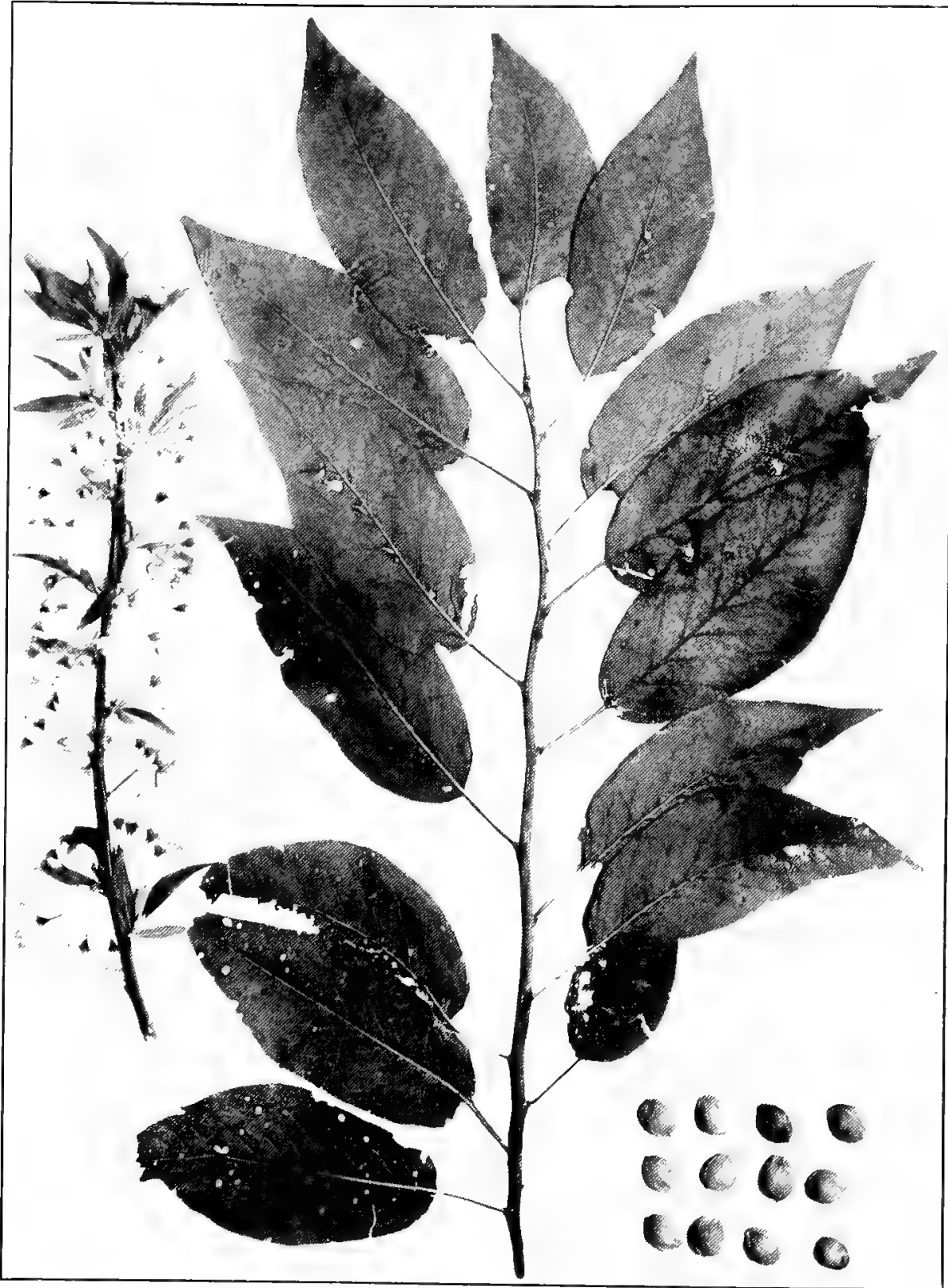

PRUNus hortulana Bailey. Wild Goose Plum. ( $x$ 1/2.) 
Distribution. - Central Kentucky northwestward to central Iowa and southwestward to Kansas and east to northwest Tennessee. In Indiana the specimens at hand show it to be confined to the southwestern part of the State, although Pepoon ${ }^{1}$ reports a single tree found near Dune Park in Porter County. It is found on sandy roadside cuts, base of sandy wooded slopes, etc., and is a common tree in Sullivan County for miles on the wooded bank of the terrace of the Wabash River.

5. Prunus pennsylvánica Linnæus filius. Wild Red Cherry. Plate 103. Small trees with smooth cherry-like bark, somewhat roughened near the base on old trees; twigs smooth, at least at maturity; leaves oval, oval-lanceolate, or ovate, sometimes slightly falcate, 4-10 $\mathrm{cm}$. long, and $1.5-4 \mathrm{~cm}$. wide, rounded or narrowed at the base, long acuminate at the apex, margins finely serrate with glandular incurved teeth, glossy and smooth above, generally smooth beneath, sometimes pubescent along the midrib and veins, petioles generally smooth, rarely pubescent; flowers appear with the leaves in May in umbels of 3-7, or sometimes raceme-like but the rachis shorter than the pedicels; calyx glabrous, the lobes glabrous within and without, entire and glandless; fruit ripens in August, globose, 6-7 mm. in diameter, red; stone roundishoval, surface granular.

Distribution.- Newfoundland and New England to the Rocky Mountains, south to Colorado and eastward through northern Indiana to Pennsylvania and thence in the mountains to North Carolina. In Indiana it is definitely known to occur only in Lake, Porter, Laporte, St. Joseph and Lagrange Counties. It is frequently found on the black oak ridges about Lake Michigan. All other reports of this species for Indiana should be looked upon with suspicion. The one by Chipman from Kosciusko County may be correct. The one by Ridgeway ${ }^{2}$ for Posey County is undoubtedly an error. No doubt Phinney's ${ }^{3}$ record for Central Eastern Indiana (Jay, Delaware, Randolph and Wayne Counties) is an error.

The range of the species is to the north of our area, and like a few others it is found about the Great Lakes south of its general range. In Ohio it is reported only from Cuyahoga County which borders Lake Erie.

6. Prunus serótina Ehrhart. Wild Cherry. Cherry. Wild Black Cherry. Plate 104. Medium to large sized trees; bark of young trees smooth, becoming on old trees irregularly fissured and

Trans. Ill. Acad. Science, 1916:132.

2Amer. Nat, 6:660:1872.

${ }_{3}$ Rept. Ind. Geol. Surv. 12:208:1883. 
Plate 103.

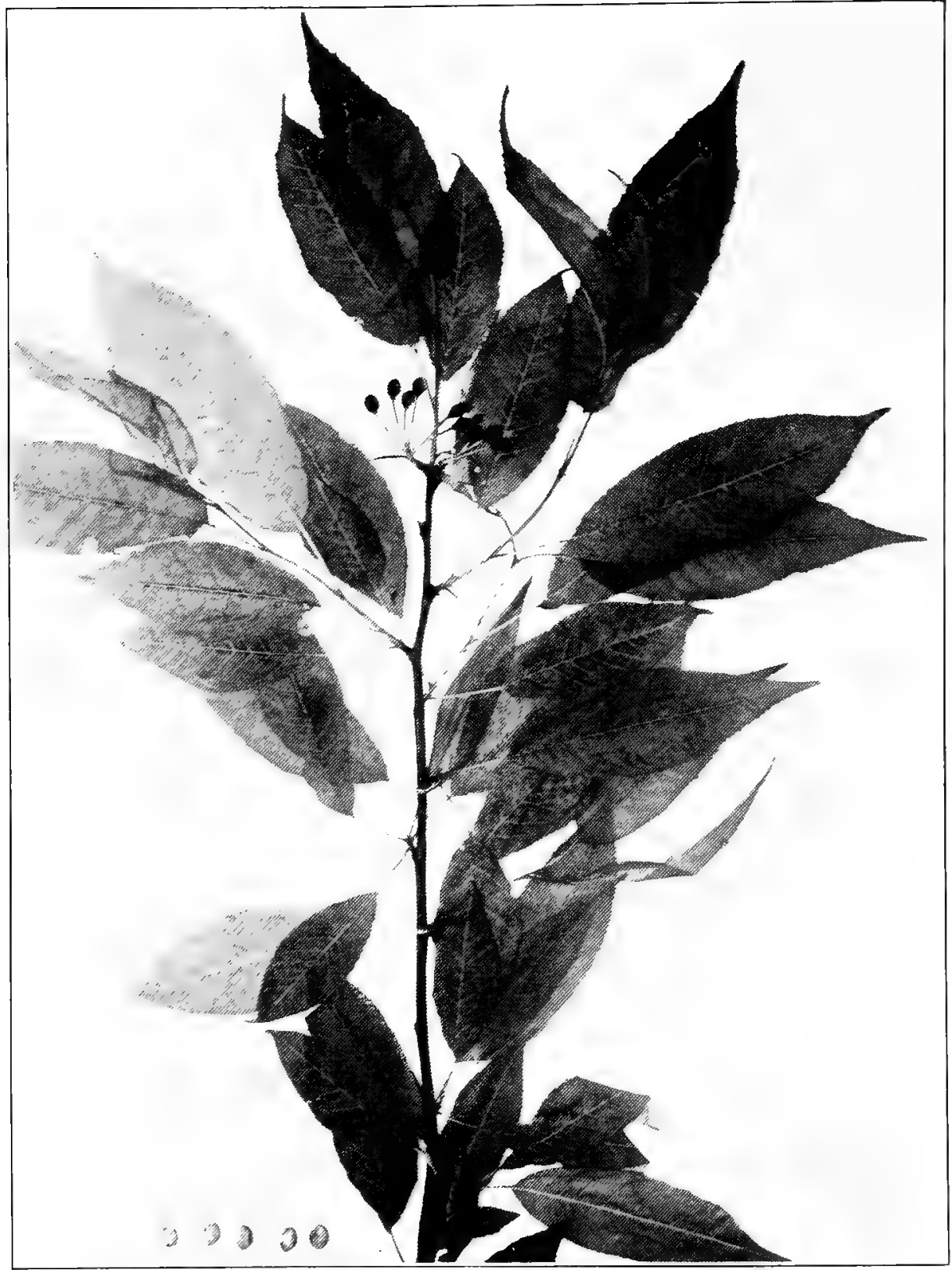

PRUNUS PENNSYlvanicA Iinneus fils. Wild Red Cherry. ( $x$ 1/2.) 
PLATE 104.

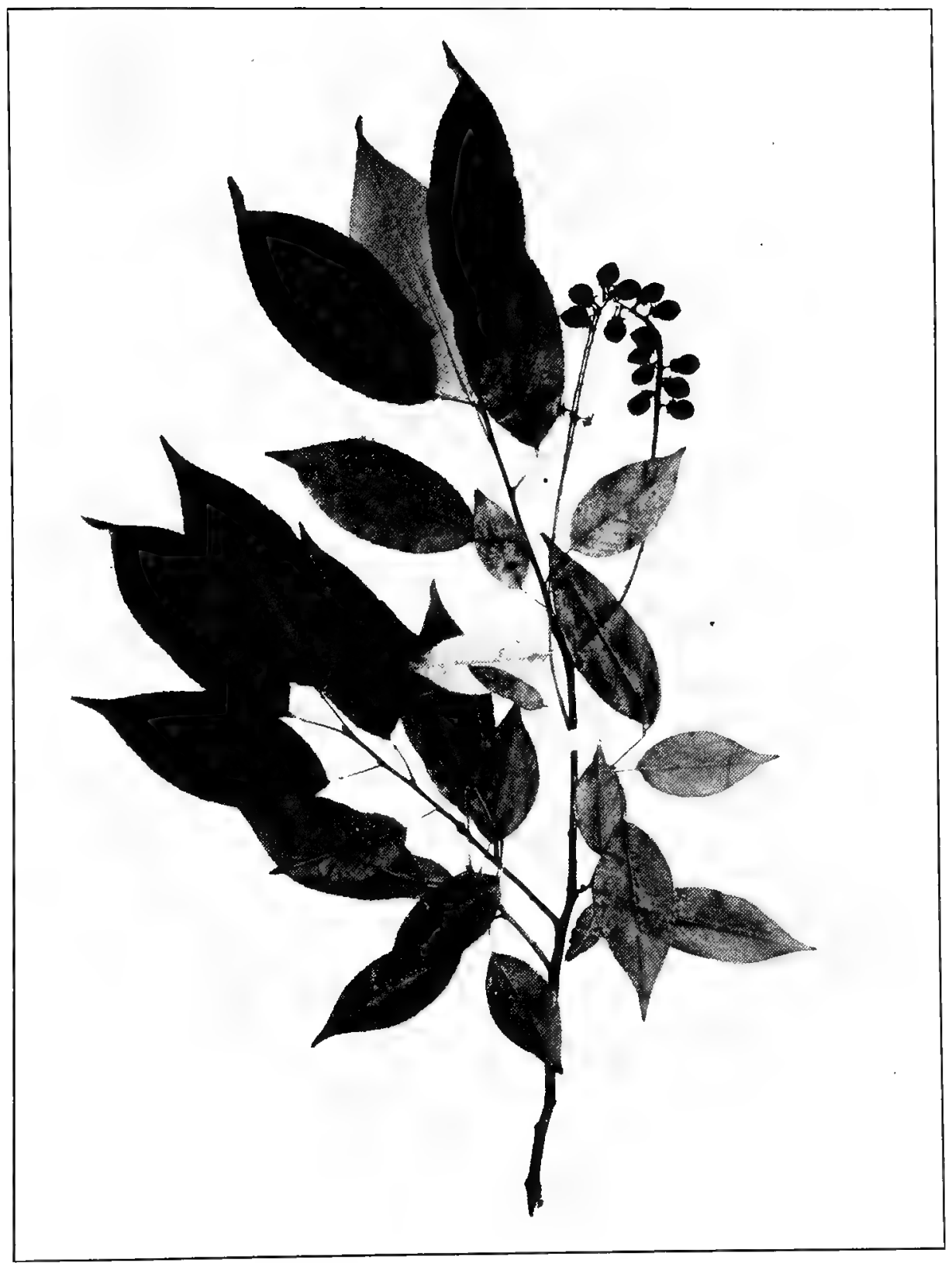

PRUNUS SEROTINA Ehrhart. Wild Black Caerry. (x 1/2.) 
separating in small scaly plates; twigs slender and smooth, sometimes pubescent while young; leaves oval, oblong-oval, ovate or narrowly ovate, generally $5-12 \mathrm{~cm}$. long and $2-4 \mathrm{~cm}$. wide, generally nurrowed at the base, sometimes rounded, short or long acuminzte at the apex, margin finely serrate with incurved sharp callous teeth, smooth above and below, sometimes slightly pubescent beneath while young; flowers appear in May when the leaves are almost grown, on the ends of the year's growth, in racemes generally $5-10 \mathrm{~cm}$. long; fruit ripens in July and August, globose, about $6-10 \mathrm{~mm}$. in diameter, dark red to almost black.

Distribution.- Nova Scotia to South Dakota, south to Florida and west to Texas. Found in all parts of Indiana. It prefers a moist loose soil and is usually found with beech, sugar maple, tulip, white ash and white oak. In the original forest it was a rare to a frequent tree, and only rarely and locally did it ever become common. It grew to be several feet in diameter and was as tall as the highest trees of the forest. The trunk of the tree, however, was inclined to be crooked. It has now become a frequent tree along fences.

Remarks. - The wood of wild cherry from pioneer times has been a favorite wood, and for this reason the tree soon disappeared and today large trees are very rare. The wood is strong, close-grained, reddishbrown, and very much resembles mahogany. In value it stands second in Indiana woods. It is used principally for furniture, office and store fixtures.

The wild cherry grows readily from seed; is not difficult to transplant; adapts itself to almost all kinds of soils and grows rapidly. In Spring it is one of the very first trees to put out its leaves. It is not shade enduring, which no doubt, in a great measure, accounts for its rarity in the primeval forests. When grown in the open the tree usually produces an abundance of fruit which is much relished by birds. This species has many good features, and might be used to advantage in forest planting.

\section{CAESAlPinàceate. The Senna Family.}

Leaves simple; flowers pink; seed pod papery............ 1 Cereis.

Leaves compound; flowers not pilk; seed pod woody or leathery.

Trees with thorns; stamens 3-5, longer than the corolla; pods flat and leathery; seeds about $1 \mathrm{~cm}$. ( $1 / 2$ inch) long....2 Gleditsia.

Trees without thorns; stamens 10, shorter than the corolla; pods swollen, woody; seeds about $2 \mathrm{~cm}$. (1 inch) long.... 3 Gymnorladus. 


\section{Cércis. The Rediud.}

Cercis canadénsis Linnæus. Redbud. Plate 105. Small trees; bark of trunk of old trees fissured, reddish-brown; twigs glabrous, light brown, becoming a dark brown; leaves alternate, broadly ovate, average blades $6-14 \mathrm{~cm}$. long, cordate at base, short-pointed, sometimes short-acuminate or rarely rounded at the apex, margins entire, glabrous or pubescent on unfolding, at maturity usually glabrous on both sides, or with a few hairs in the axils of the veins or along the veins, sometimes more or less pubescent beneath, and with hairs on the veins above; petioles generally 2-6 $\mathrm{cm}$. long; flowers appear in April or May before the leaves, in clusters of 4-8 on the branches of the preceding season, pink or rose color; pods $5-10 \mathrm{~cm}$. long, thin, flat and glabrous; wood heavy, hard and weak.

Distribution.--In Canada along the shores of Lake Erie and Ontario, New York west through Michigan to Iowa, south to the Gulf States and west to Texas. Found throughout Indiana except there are no records from the counties bordering Lake Michigan. In the northern part of the State it is rare or frequent in alluvial soil along streams or in rich woods. In the southern part of the State it is a frequent to a common tree in ravines and on slopes. It is never found in wet situations, and consequently is absent in the "flats" of the southern counties.

Remarks. - The redbud is the common name for this tree through-

out the State. In one locality it was known as the fish blossom because the larger fish spawn when this tree is in flower. In text books it is also called Judas tree. It is usually a tree 1-1.5 dm. in diameter and $5-10 \mathrm{~m}$. high. It is of no economic importance and is classed as a weed tree in the woodlot and should be removed.

It is frequently recommended for ornamental planting. It prefers a rich moist soil, and is shade enduring, although it sueceeds best in the open or in a light shade.

\section{Gledítsia. The Honey Locust.}

Pods more than $8 \mathrm{~cm}$. long; seeds oval............. 1 G. triacanthos. Pods less than $8 \mathrm{~cm}$. long; seeds orbicular.

2 G. aquatica.

1. Gleditsia triacánthos Linnæus. Honey Locust. Plate 106. Medium to large sized trees; bark of old trunks fissured and peeling off in strips; spines on trunk large and often much branched, sometimes $4 \mathrm{dm}$. long; spines on branches not so large, generally more or less forked; twigs at first green, turning a light brown; leaves pinnate or bipinnate, 1-2 dm. long, rachis permanently pubescent; leaflets 9-14 pairs, fewer on the bipinnate forms, petiolules about $1 \mathrm{~mm}$. long, form 
PLATE 10.T

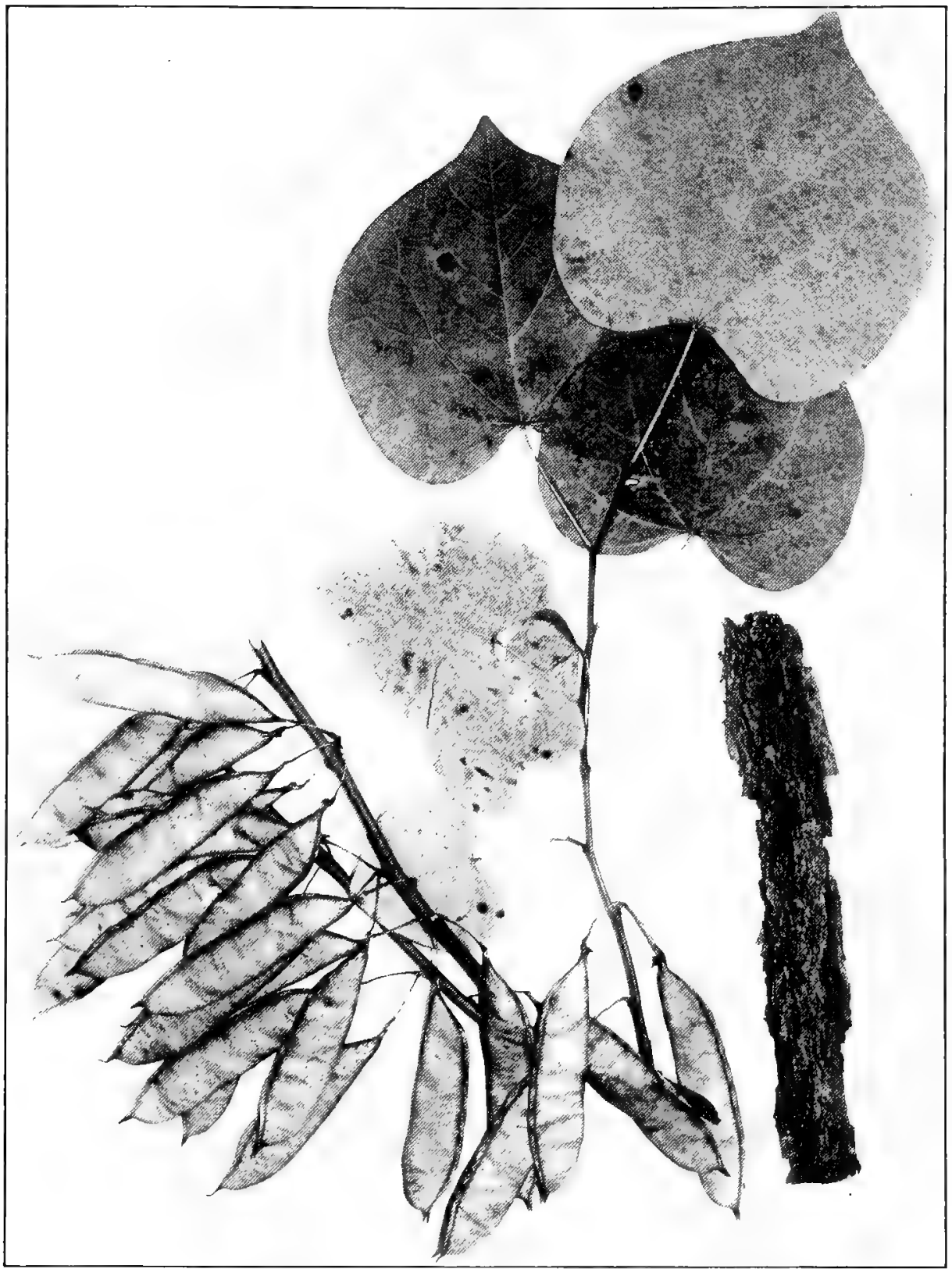

CERCIS CANADENSIS Linnæus. Rediud. ( $x$ 1/2.) 
Plate 106.

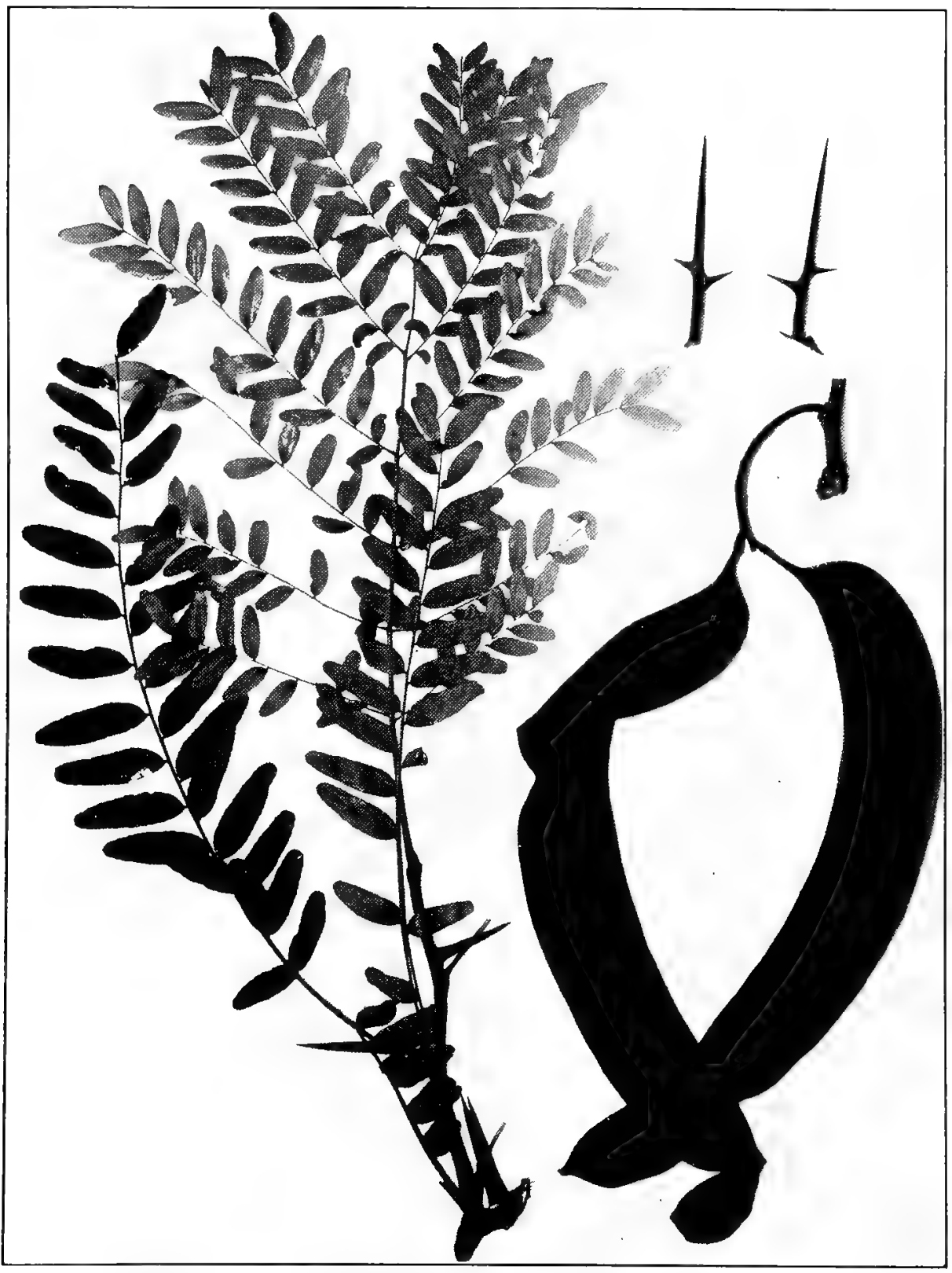

GLEDITSIA TRIACANTHOS Linnæus. Honey Locust. (x 1/2.) 
variable from ovate to lanceolate, sometimes somewhat falcate, generally 2-3 cm. long, usually more or less pubescent beneath; flowers appear in May or June, inconspicuous, greenish-yellow, rich in honey, their appearance being announced by the hum of the swarm of insects visiting them; fruit a flat, linear twisted pod, 2-4 dm. long, glabrous andlustrous or pubescent on the sides; seeds several, oval, about $6 \mathrm{~mm}$. wide, and $10 \mathrm{~mm}$. long, glabrous and chestnut brown; wood heavy, hard, strong, coarse-grained and takes a good polish.

Distribution.-Pennsylvania, southern Michigan to Iowa, and south to the Gulf States and west to Texas. Found infrequently throughout Indiana along streams, except that it is absent about Lake Michigan and that in the southwestern counties it becomes a frequent tree in the Wabash bottoms. In its native habitat it is rarely found except near a stream, pond, lake, etc. However, in the southeastern counties it has spread all over many of the hillsides which were once cleared and have been abandoned for agricultural purposes and left to natural forest regeneration. It was interesting to learn how this tree was able to propagate itself on the steep bare slopes. It was found that the seeds were scattered by cattle that greedily eat the fruit. It is a medium sized tree, except in the Wabash bottoms of the southwestern part of the State where it grows to be one of the largest trees of the forest, and is more luxuriant than in any other part of its range.

Remarks. - In making a study of the fruit of this species, it was found that the sides of all the pods of all the specimens at hand except one are glabrous, even those of young fruit. The margins of the pods are pubescent. However, a specimen collected on August 27 th in Vermillion County has the entire pod covered with long hairs. In consulting the literature on the subject it is found that some authors describe the fruit as glabrous while others describe it as hairy. It would be interesting to study the significance of this character to learn if each form has a geographic range.

The wood is used principally for interior finish, furniture, posts and crossties. The tree has a grace that recommends it for ornmental planting despite its thorns. However, a thornless variety is now offered by nurserymen. It adapts itself to all kinds of soils, although it prefers a moist rich soil; grows rapidly and is comparatively free from insect damage.

2. Gleditsia aquálica Marshall. Water Honey Locust. Plate 107. A medium sized tree with rather smooth bark, which becomes rough and flaky on large trees; twigs greenish, turning to a light brown by the end of the year; branchlets a greenish-gray brown; spines all usually more or le'ss flattened, those of the branchlets and branches, 
Plate 107.

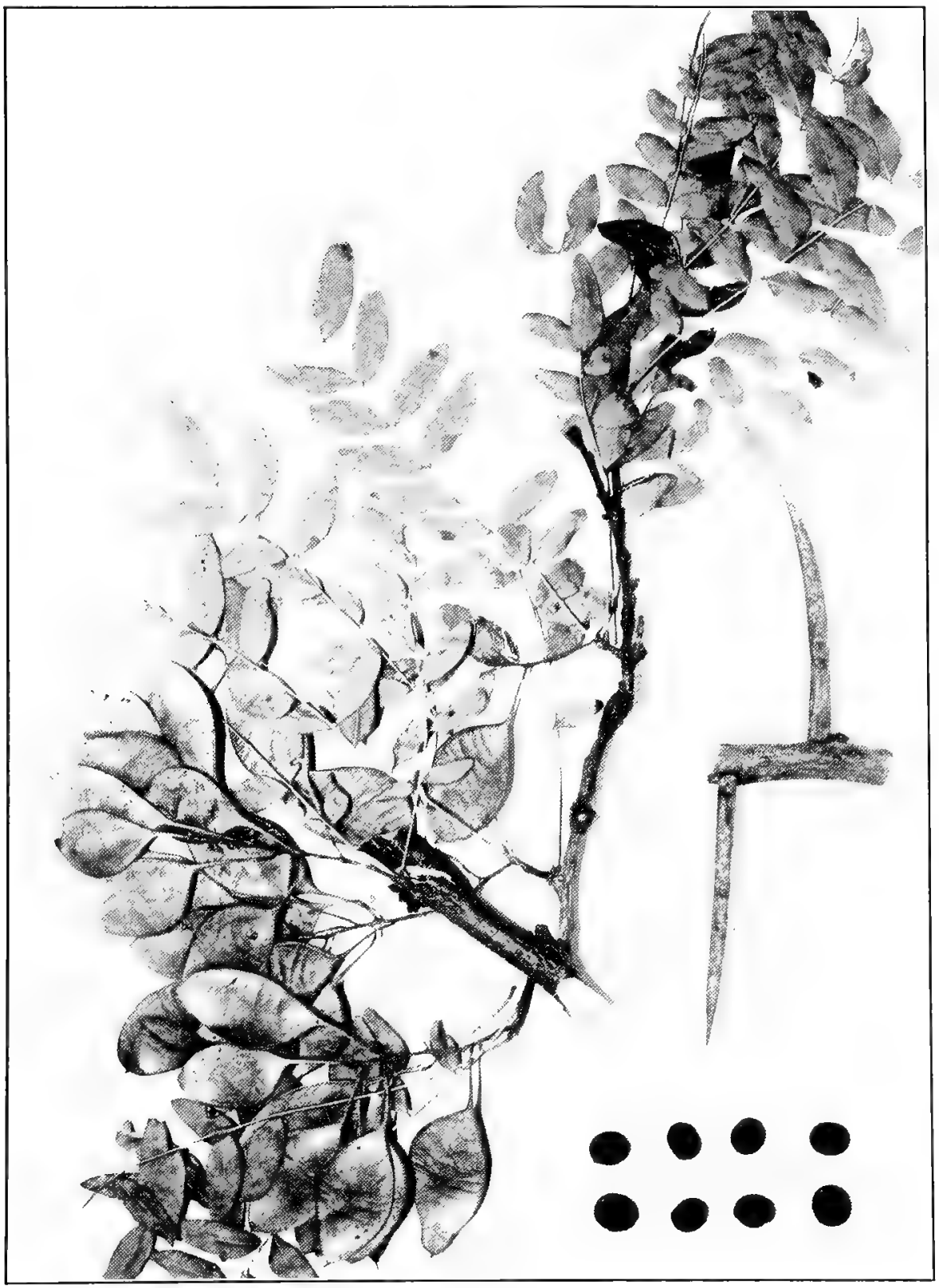

GLeditsia AqUatica Marshall. Water Honey Locust. (x 1/2.) 
rather few and usually simple, $4-10 \mathrm{~cm}$. long, those of the trunk branched, spines do not develop on the year's growth; leaves from old wood pinnate, from the year's growth bipinnate; rachis grooved and pubescent or puberulent above and smooth below; leaflets generally 7-11 pairs, variable in shape and size, generally lanceolate and $1.5-2.5 \mathrm{~cm}$. long, on petiolules about $1 \mathrm{~mm}$. long, glabrous; flowers similar to the preceding species; fruit a glabrous, shining, oblique pod about $4-5 \mathrm{~cm}$. long, containing 1 seed; seeds orbicular, flat, chestnut brown, about $1 \mathrm{~cm}$. in diameter.

Distribution.-Atlantic Coast from North Carolina south to Florida, and the Mississippi Valley from southwestern Indiana southward to Texas. In Indiana this species is rare and limited to the banks of river sloughs, locally called ponds and to one cypress swamp. It is known to have occurred on the banks of Wabash and Dan's ponds and Little Cypress swamp in the southwest corner of Knox County, and in Gibson County on the bank of a slough near Skelton and about Burnett's pond. The reference to Posey County is without a verifying specimen, although it may be found in the county. The writer has visited about every place in the county where the species might occur, and has never found it. Gorby's ${ }^{1}$ reference for Miami County is without doubt an error. In our area it is a low crooked tree and grows with its base submerged more or less during the year. The idea of the proportions of this tree can be obtained from the measurements taken from the largest tree now known in Indiana, which is located on the shore of Dan's pond in Knox County. It measures $158 \mathrm{~cm}$. (66 inches) in circumference at $1 \mathrm{~m}$. above the ground, and is estimated to be $10 \mathrm{~m}$. (30 feet) high. This species is too rare to be of economic importance.

Gleditsia aquatica $x$ triacanthos. Dr. Schneck ${ }^{2}$ found two honey locust trees which he described as hybrids of the two species. The one was located on the bank of Dan's pond in Knox County, and the other in Gibson County. The original description is as follows: "In both instances the pods are the distinguishing feature. These are very much alike in both trees, being about 5 inches long, 11/2 inches wide, smooth, shining, of a light brown color and entirely destitute of pulp. Otherwise the tree cannot be distinguished from the trees among which they stand. They are both about 50 feet high, with short stems and spreading branches, and stand about 5 miles apart." The writer has five fruiting specimens from these two trees, taken by Dr. Schneck. Two of the sheets have the round and branched spines of G. triacanthos.

Ind. Geol. Rept. 16:169:1889. 2Plant World $7: 252: 1904$. 


\section{GyMnócladus. The Coffee Tree,}

Gymnocladus dioíca (Linnæus) Koch. Coffeenut Tree. Plate 108. Medium sized trees; bark of trunks fissured, the ridges often curling up along the sides, very hard; twigs at first hairy, becoming glabrous and mottled gray-brown by the end of the season, robust, usually about $1 \mathrm{~cm}$. in diameter; leaves alternate, twice pinnate, $3-9 \mathrm{dm}$. long, leaflets usually 6-10 pairs, ovate, generally from $3-4 \mathrm{~cm}$. long, generally oblique and rounded, wedge-shape or truncate at the base, acute or very sharp-pointed at the apex, petiolules about $1 \mathrm{~mm}$. long, pubescent on both sides at first, becoming glabrous or nearly so at maturity; flowers of two kinds, the male and female on separate trees, appearing in May or June; fruit a pod generally about 1-2 dm. long, thick, curved; seeds generally 4-7, large, flattened about $2 \mathrm{~cm}$. in diameter; wood heavy, not hard, coarse-grained and takes a high polish.

Distribution.-New York, southwestern Ontario to southern Minnesota south to Tennessee and Arkansas. This species has been reported or is known to exist in 33 counties in various parts of the State. It no doubt was native to every county of the State, except it be those bordering Lake Michigan from which we have no reports. It is a rare tree in all parts. Only exceptionally is it found even frequently. A few trees may be found in one place, and it will not be found again for many miles. No doubt there are many areas with a radius of 5 to 10 miles where this tree never occurred. It is usually found in alluvial soil along streams, or nearby terraces.

Remarks.-This species generally is not very tall, and is usually found in open places in the forest or cut-over lands. However, one specimen was seen in Posey County that was as tall as a specimen of pecan of equal size that grew nearby. This species was so rare in this vicinity that I was asked to drive three miles to identify this tree which no one could name.

Coffeenut, which is sometimes called Kentucky coffeenut, has always been so rare as to be of little economic importance. It has no qualities to recommend it for ornamental planting.

\section{FaBÀceae. The Pea Family.}

Trees, shrubs, vines or herbs with alternate leaves, mostly compound; flowers with five petals which are pea-like (papilionaceous); stamens generally 10 ; fruit a legume. 
Plate 108.

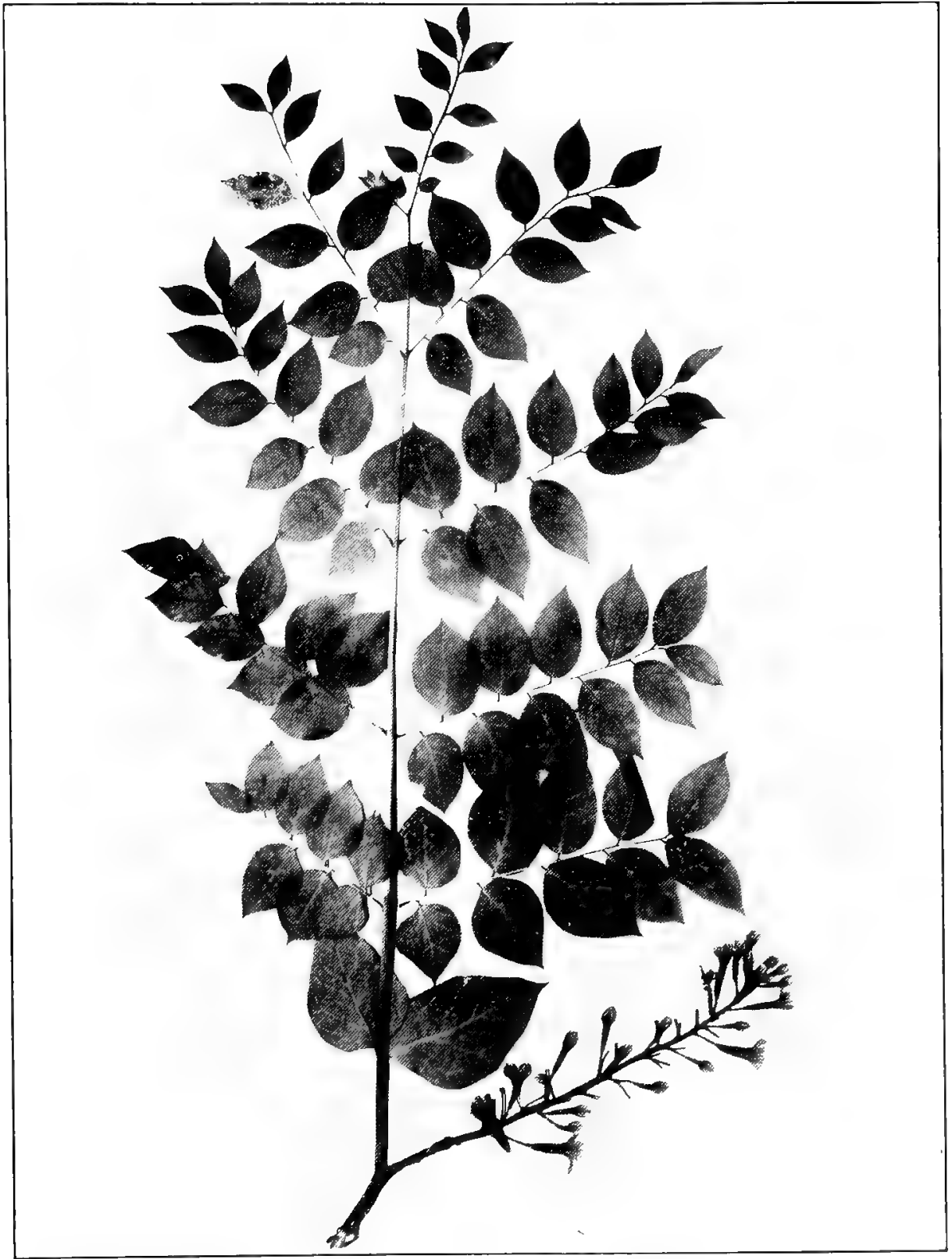

Gymocladus DioiCA (Linnæus) Koch. Cofreenut Tree. (x 9/20). 


\section{ROBÍNiA. The Locusts.}

Robinia Pseùdo-Acàcia Linnæus. Locust. Black Locust. Plate 109. Medium sized trees with deeply furrowed bark; twigs at first green and hairy, becoming at the end of the season glabrous and a light brown, the stipules developing in about a year into a pair of woody spines about $2 \mathrm{~cm}$. long; leaves pinnate, 1.5-3 dm. long; leaflets 7-17 on short stalks, ovate to oblong, 2-6 $\mathrm{cm}$. long, rounded at base, rounded or pointed and with asmall indenture at apex, margin entire, pubescent on both sides at first, becoming at maturity glabrous above and remaining more or less pubescent below, especially on the midrib; flowers in loose racemes, white, expanding in May or June; fruit a flat and slightly curved pod about $5-10 \mathrm{~cm}$. long, glabrous; seeds usually 4-8 in each pod, about $4 \mathrm{~mm}$. long and $2.5 \mathrm{~mm}$. wide; wood heavy, very hard, closegrained, takes a good polish, very durable in contact with the soil.

Distribution.-Appalachian Mountains from Pennsylvania south to northern Georgia, and in Arkansas. In Indiana it is found as an escape in all parts and was doubtless native along the Ohio River, at least in the southeastern part of the State. Thomas says: "We had gazed at the majestic beech of this country (near Rising Sun) three feet in diameter; we had seen the honey locust, the black walnut, a buckeye of equal magnitude; and then we saw with surprise, the black locust almost a rival in stature." Drake ${ }^{2}$ says: "The flowering locust is abundant in Kentucky. Along the Ohio River it is rarely found more than 30 miles north of the river."

Remarks. - This tree is generally known as the locust tree, but is sometimes called the yellow locust.

Locust wood is somewhat lighter than white oak, but it is 34 per cent stiffer and 45 per cent stronger. These remarkable qualities added to its durability in contact with the ground make it one of the most desirable trees for forest planting. The wood has been used principally for posts, ties, tree nails, etc. The locust when grown close together usually grows to 8-12 inches in diameter. There are, however, specimens that have grown in the open that are almost three feet in diameter. The pioneers used it extensively for ornamental planting, and it has escaped from such planting in all parts of the State. It propagates easily by root shoots which is the principal mode of spreading, except where the seed fall on exposed soil.

The locust has of recent years been extensively planted for post timber. It is very easily propagated from seedlings and grows rapidly. It is adapted to all kinds of soil, except a wet one. It prefers a well

Thomas' Western Travels, page 111:1819.

${ }^{2}$ Drake in Picture of Cincinnati, page 83, 1815. 
Plate 10:\%.

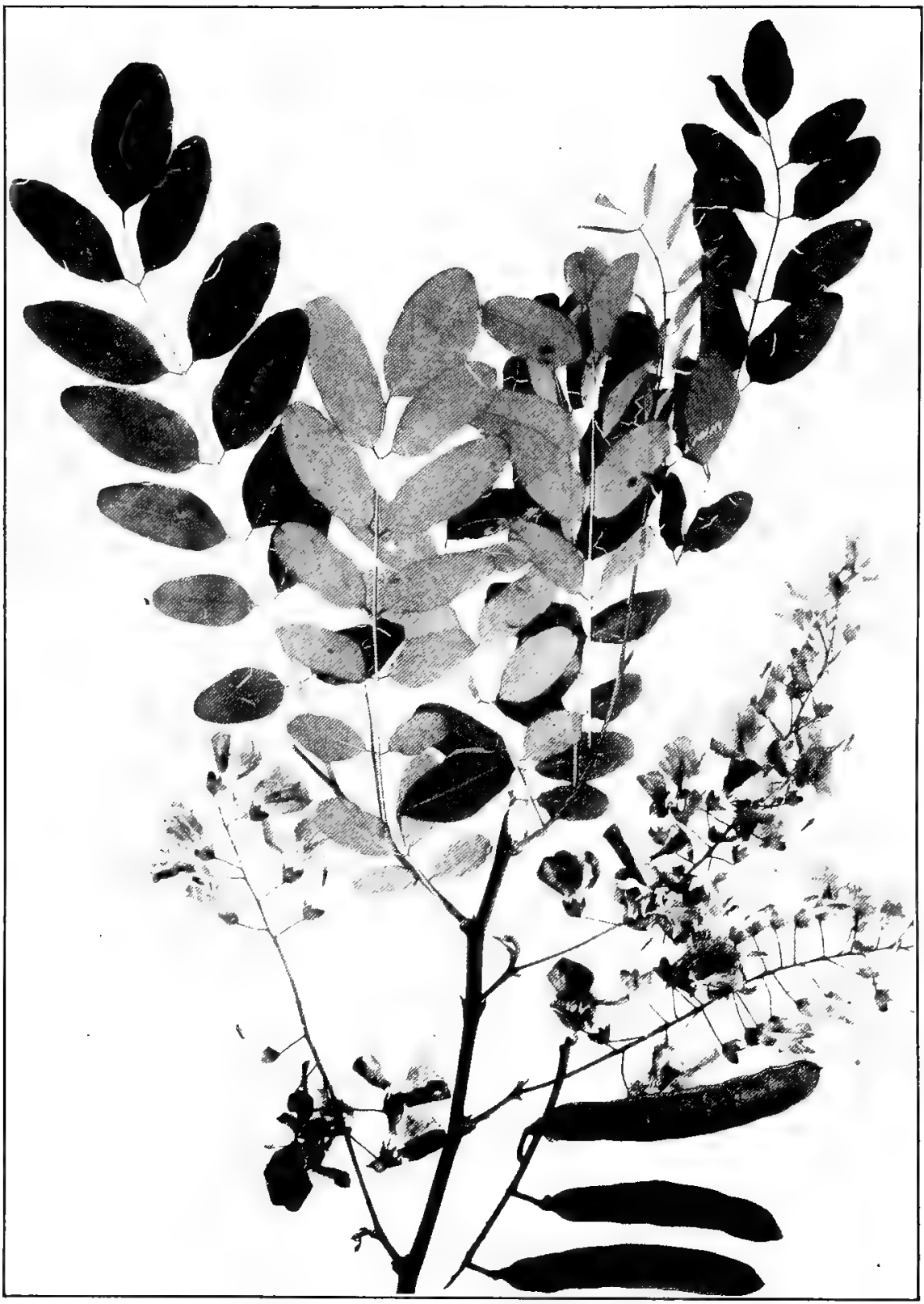

ROBINIA PSEUDO-ACACIA Linnæus. BlaCK LoCUST. $(x$ 1/2.) 
drained soil and seems to grow as fast in a loose clay soil as in a black loam. When used for forest planting the spacing should be from $5 \times 5$ feet to $8 \times 8$ feet. The spacing should be governed by the quality of the soil, and the amount of pruning that can be done. The locust has the habit of having the terminal to end in a fork and having one or more very large side branches. The best management requires that the very large side branches be removed as soon as they are noted, and one part of the terminal forks be cut off.

The locust until recently gave great promise of being an important tree for planting sterile, washed and eroded slopes, on which it usually thrives and in many cases grows thriftily. However, reports from all parts of the State show that locust groves wherever planted are being killed by the locust body borer. The locust has also been attacked by the twig borer, bag worm and the leaf miner. At present there are no known economic means of controlling these destructive pests, and until they can be controlled, the planting of locust for commercial purposes will not prove profitable.

\section{SIMARUBĀCEAE The Quassia Family. \\ AILÁNThus. Tree of Heaven.}

Ailanthus altíssima (Miller) Swingle. Tree of Heaven. Stink Tree. (Ailanthus glandulosa Desfontaines). Plate 110. Medium sized trees with dark gray bark, thin, rough or fissured on old trees; branchlets very robust; twigs smooth; leaves compound and very large, especially on coppice shoots, usually about 4-6 dm. long, odd-pinnate, arranged spirally on the branchlets; leaflets $13-41$, ovate-oblong, acuminate, oblique at base, entire or with a few blunt teeth toward the base, smooth or hairy when they unfold, becoming smooth at maturity, dark green above, lighter beneath; flowers appear in June in large terminal panicles, the staminate and pistillate on different trees; fruit maturing in autumn, consists of many light brown, twisted and broadly-winged samaras which are about $1 \mathrm{~cm}$. wide and $4-5 \mathrm{~cm}$. long.

Distribution.-A native of China. Introduced and spreading in cities, and into fields and woods in the southern part of the State. The most notable occurrence is in Jefferson County on the wooded bluffs of the Ohio River between Madison and Hanover.

Remarks. - Where the sugar and black maple can not be used for shade tree planting this tree should receive attention. It adapts itself to all kinds of soils, and to all kinds of growing conditions such as smoke, etc. The crown is of an oval or rounded type. It stands pruning and injury to trunk or branches quite well. It is practically free from 
PLATE 110.

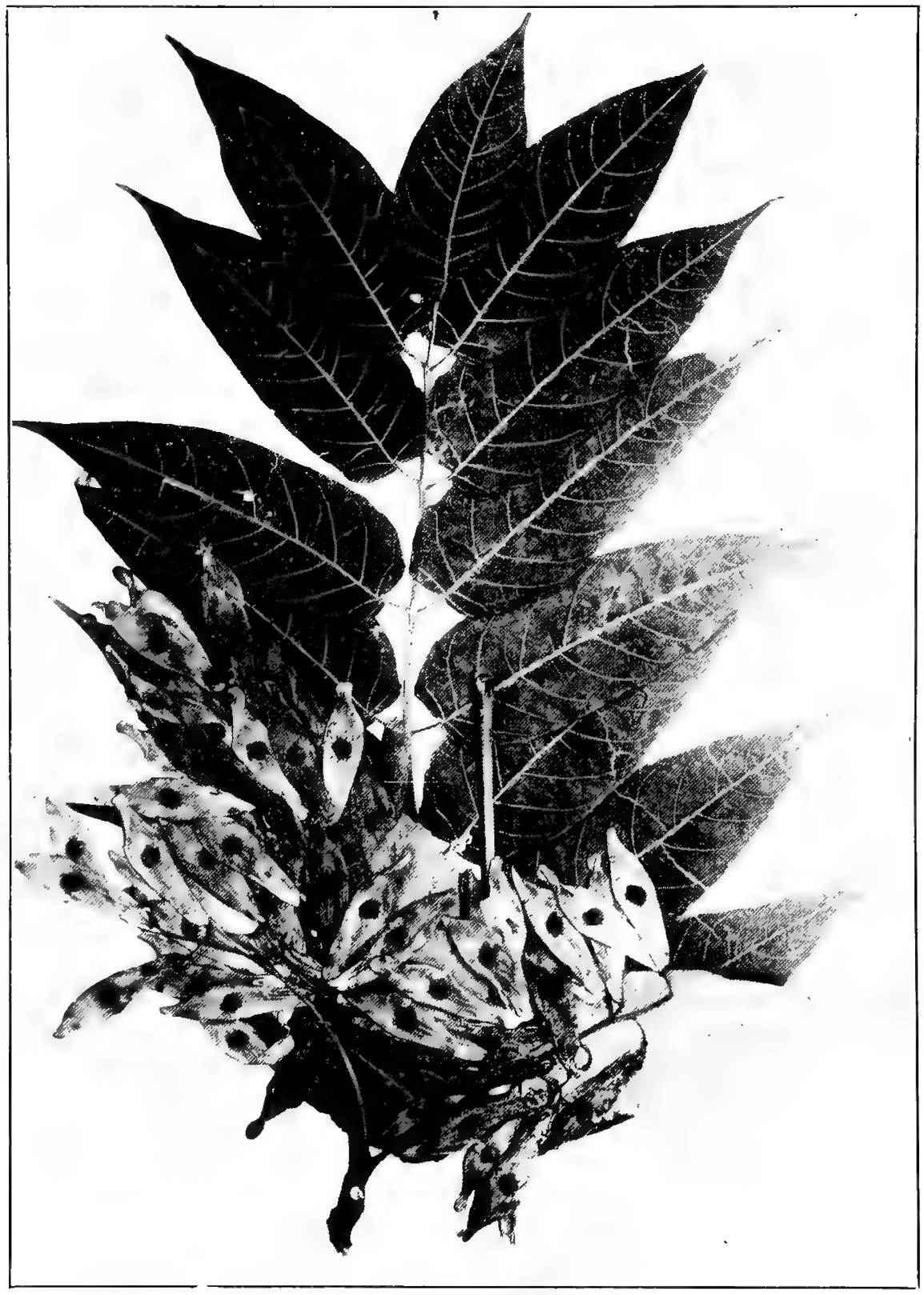

AilantiuUs altissima (Miller) Swingle. Ailanthus or Tree of Heaven. $\left(\begin{array}{lll}x & 1 & 2\end{array}\right)$ 
all diseases and insect injury. The leaves appear late but they do not fall until the first killing frost when they are killed, and frequently practically all of the leaves will fall in one day. The staminate flowers exhale a fetid odor for a few days which is about the only objectionable feature in this tree. In order to obviate this objection, nurserymen are now offering for sale pistillate trees which have been grafted on common stock.

\section{aCERÀCene. The Maple Family.}

ÀCER. The Maples.

Trees with terete branches; scaly buds; long petioled, opposite leaves; fruit consists of two long-winged samaras which are joined at their base, separating at maturity. The sap of some of the species, when concentrated, yields the maple sugar and sirup of commerce.

Leaves trifoliate or pinnate ................... 1 A. Negundo.

Leaves simple.

Winter buds blunt; flowers appear from lateral buds before the leaves; fruit maturing in the spring or early summer.

Leaves entirely glabrous beneath at maturity, 5 -lobed; the two sinuses between the three largest lobes generally somewhat closed, formed as it were by the ares of two circles which meet to form the sinus, and which if they were extended outward would cross each other within a few $\mathrm{dm}$. of the sinus; fruit more or less pubescent at maturity.................. 2 A. saccharinum.

J Leaves are never all entirely glabrous at maturity, 3-5 lobed; the two largest sinuses are generally angular with straight sides which if extended outward would never cross; fruit smooth at maturity.

Twigs smooth at maturity; leaves at maturity smooth beneath except a few hairs in the axils of the veins, or more rarely the entire lower surface covered more or less with a short pubescence; mature fruit generally $2-3.5 \mathrm{~cm}$. long............. 3 A. rubrum.

Twigs more or less pubescent at maturity; leaves beneath covered with a dense tomentum which remains until maturity or sometimes becoming scanty; fruit about $4-5 \mathrm{~cm}$. long.............. var. Drummondii.

Winter buds acute, sometimes somewhat blunt; flowers appear from terminal buds after the leaves; fruit maturing in the autumn.

Leaves yellow green beneath; base of the petiole of the terminal leaves enlarged at the base, smooth or somewhat pubescent about the enlarged base..... 4 A. nigrum. 
Leaves not yellow green beneath; base of the petiole of the terminal leaves not enlarged, petioles smooth, or if pubescent at the base the pubescence will be more or less evident the entire length of the petiole.

Petioles smooth; leaves 3-5 lobed, blade as long or longer than wide, not densely pubescent beneath at maturity..................... 5 A. saccharum.

Petioles smooth; leaves 3-lobed, blades wider than

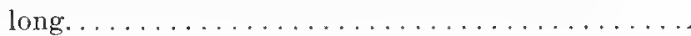

A. saccharum var. Rugelii.

Petioles pubescent, rarely smooth; leaves 5-lobed, rarely 3 -lobed, the under surface densely pubescent

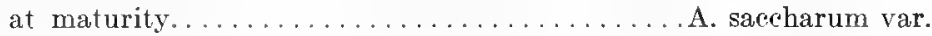
Sehneckii.

1. Acer Negíndo Linnæus. Box Elder. Plate 111. A mediumsized tree with a short trunk and round head; bark of young trees smooth and gray, becoming thick on old trees, light to dark brown and more or less furrowed or rarely somewhat flaky; twigs smooth and greenish; leaves of average size are $1.5-3 \mathrm{dm}$. long, generally with 3 leaflets on the flowering branches, sometimes 5 or rarely with 7 , on sterile branches or on growing shoots $3-7$, the petioles generally $1 / 3-$ $1 / 2$ the length of the leaf and glabrous or nearly so at maturity; leaflets all on stalks more or less pubescent, the lateral stalks short, the terminal ones much longer, leaflets of varying size and shape, the margins usually varying from lobed to serrate or entire, pinnately veined, smooth above at maturity and remaining more or less pubescent beneath, especially along the veins; flowers appear just before the leaves the last of April or the first of May, the staminate and pistillate on separate trees; fruit matures late in summer, the body of the samara green and more or less pubescent.

Distribution.--New England to Florida, west to Minnesota and south to eastern Texas. In Indiana, it is found throughout the State in moist or wet places along creeks and rivers, and infrequently on the highlands along roadsides and fences. Its original distribution in the State can only be conjectured. Judging from its tolerance to shade and its habitat, and from the earliest reports of its occurrence in the State, this species was quite rare in the northern part of the State, becoming infrequent to frequent in its habitat in the southern part of the State. Even today it is rather local in its distribution. I have never seen it on the low mucky border of a lake.

Remarks. - This species on account of its rapid growth was formerly much used in our area as a shade tree. It is believed that most of the trees now found along roadsides, fences, clearings and on the drier banks of streams are from seed distributed by the wind from planted 
Plate 111.

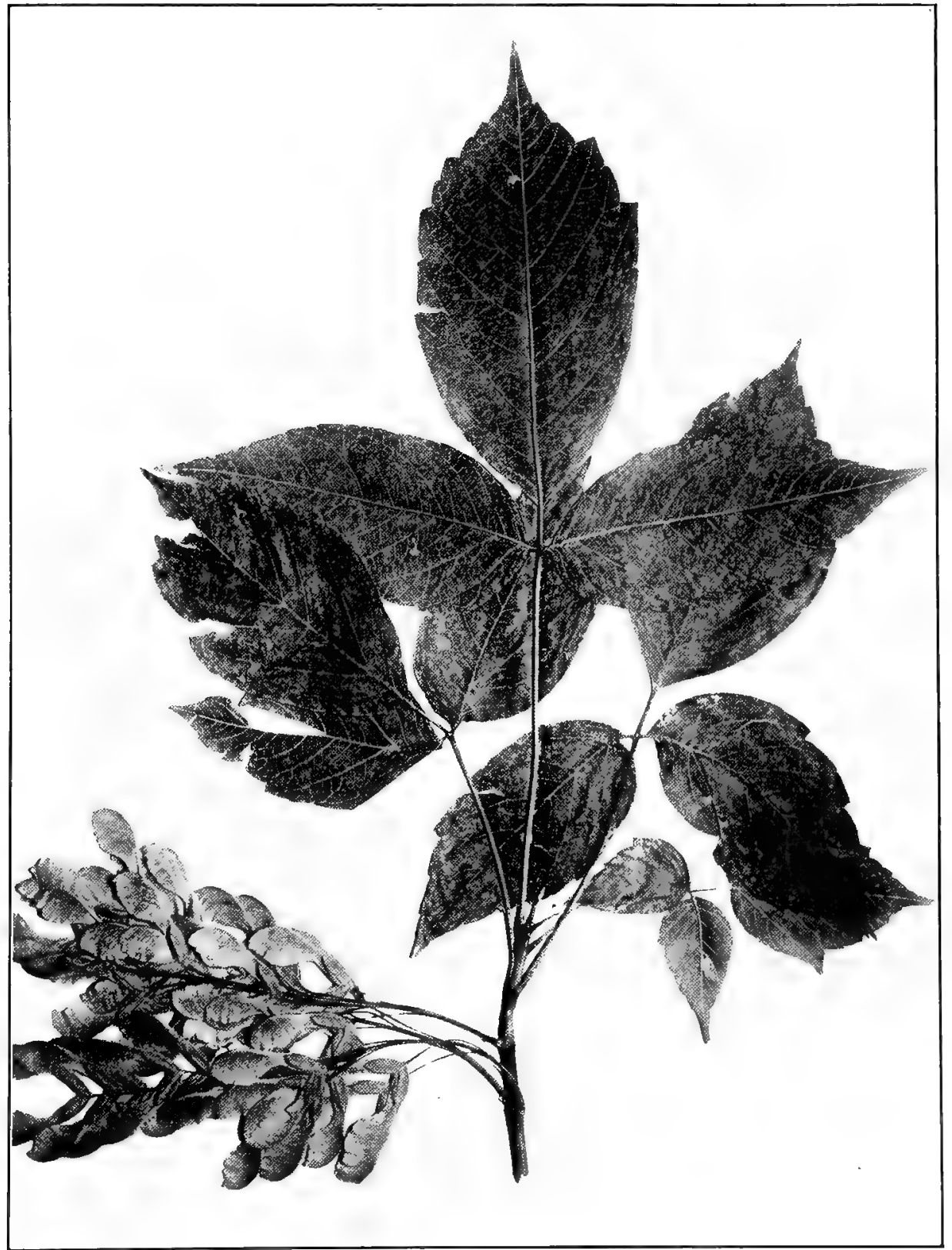

ACER NEGUNDO Linnæus. Box Erder. (x 1/2.) 
trees. This species is now little used as a shade tree and is never recommended because it sheds its leaves early, and is subject to injury from disease and insects.

1a. Acer Negundo variety violàceum Kirchner. (Rulac Nuttallii Nieuwland). This variety is distinguished by its glaucous twigs and by the body of the fruit being glabrous at maturity. In most instances when the bloom is rubbed from the twigs they show a purple tinge, hence the varietal name.

Distribution.- - I have this variety in Indiana from the following counties: Brown, Cass, Elkhart, Franklin, Fulton, Hendricks, Henry, Jennings, Lagrange, Martin, Posey, St. Joseph, Vermillion and Wayne.

2. Acer saccharìum Linnæus. Silder Maple. Soft Maple. White Maple. Plate 112. Medium sized trees; bark of small trees smooth and gray, becoming on old trees reddish-brown, and freely splitting into thin seales; branchlets light to reddish-brown and generally turning upward at their tips; leaves generally about $1 \mathrm{dm}$. long, generally somewhat cordate at the base, sometimes truncate, deeply 3 -lobed, each of the lateral lobes with an additional lobe below, margins of all of the lobes more or less irregular or even lobed, the two principal sinuses generally show a tendency to close, leaves hairy beneath when young, glabrous above and below at maturity and very glaucous beneath; flowers appear in March or April in the axils of the leaves of the previous year, the staminate and pistillate in separate clusters on the same or different trees; fruit on pedicels $1.5-6 \mathrm{~cm}$. long, maturing in the spring or early summer, green, densely hairy while young and remaining more or less hairy at maturity, 4-7 cm. long, wings 1-2 cm. wide.

Distribution. - New Brunswick to Florida, west to South Dakota and south to Texas. Locally frequent to very common in all parts of Indiana. This species is always found in wet or moist places, and in the lower Wabash bottoms in low overflow lands or in or about old sloughs it often forms the principal stand. It is more frequently associated with black willow, white elm, red birch, sycamore, ete.

Remarks. - The silver maple has been used extensively for shade tree planting. The branches are very brittle, and ice storms sometimes break off so many branches that the tree may be barlly injured. The shade trees of this species are in many parts of the state being killed by stale insects, and for this reason it should not be used. On account of its rapid growth it has also been much used for windbreaks but this practice should be discouraged and better species used. 
Plate 112.

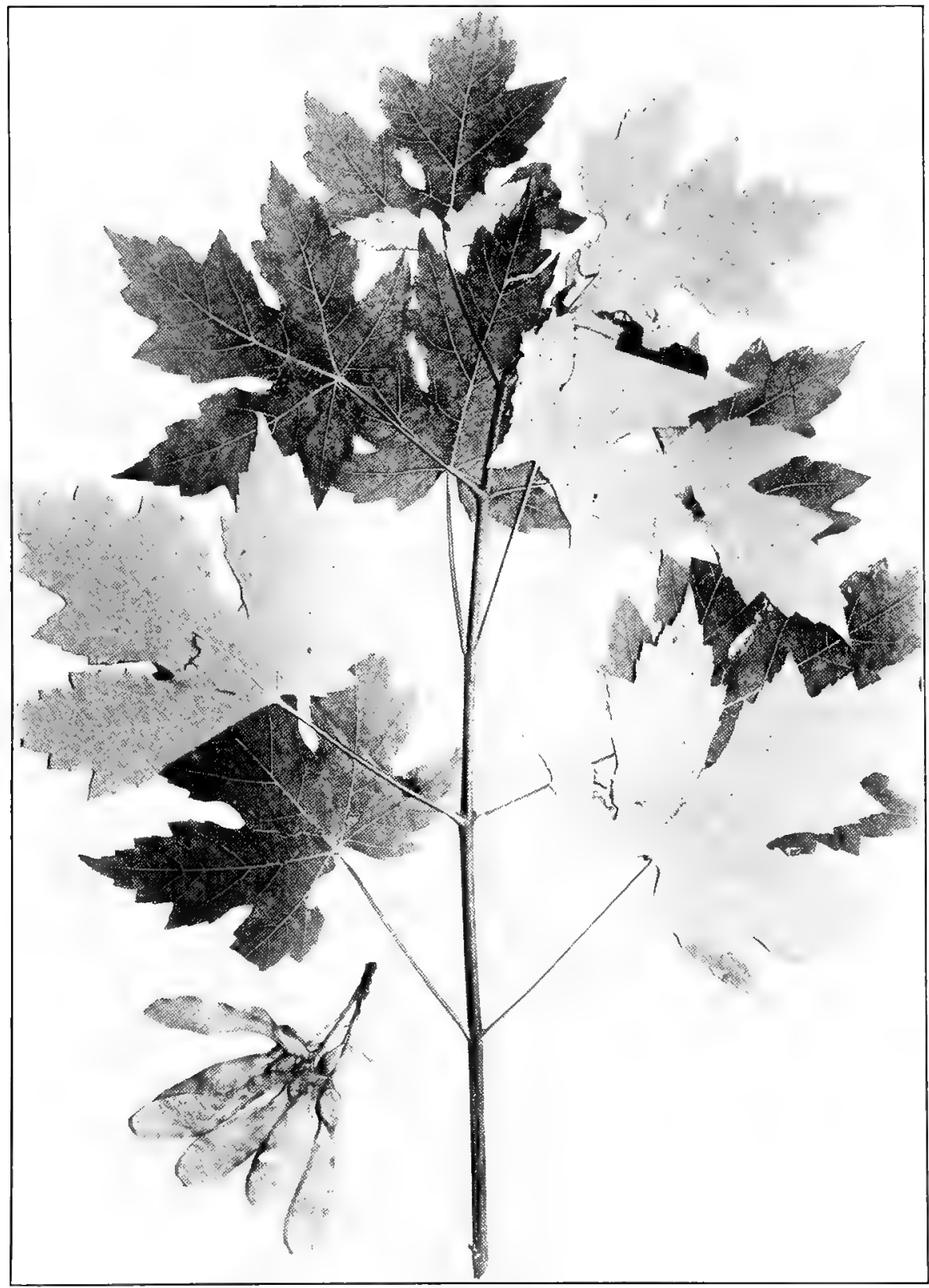

ACER SACCHARINUM Linnæus. Silver Maple. (x $1 / 2$. 
3. Acer rùbrum Linnæus. Red Maple. Soft Maple. Swamp Maple. Plate 113. Medium to large sized trees; bark of small trees smooth and gray, becoming dark brown on old trees, somewhat furrowed and scaly; branchlets smooth and reddish; twigs generally smooth but sometimes hairy, becoming glabrous by autumn; leaves 5-12 cm. long, 3-5 lobed, more or less cordate at the base, sometimes truncate or rounded, sinuses acute, those of 3-lobed leaves generally wider angled than those of 5-lobed ones, the lobes more or less irregularly serrate or dentate, hairy while young, glabrous above and more or less hairy beneath at maturity, glaucous beneath; flowering period March or April; flowers red or reddish, in the axils of the leaves of the previous year, the staminate and pistillate in separate clusters on the same or different trees; fruit maturing late in spring, on pedicels $3-8 \mathrm{~cm}$. long, generally red, sometimes green, glabrous at maturity, rarely somewhat pubescent, $1.5-3.5 \mathrm{~cm}$. long.

Distribution.- Newfoundland to Florida, west to Minnesota and south to Texas. It is found in all parts of Indiana. Its preferred habitat is that of low ground about lakes, swamps, along streams and in the "flats" in the southeast part of the State. Throughout its range in Indiana where it is found in low ground, it is in places rich in organic matter, except in the "flats" of the southern part of the State where it grows in a hard clay soil with sweet gum, red birch, ete. In contrast the silver maple is generally found growing in wet places with little organic matter; especially is this true in the lower Wabash bottoms. The red maple grows also on high ground. In the northern part of the State it is only an occasional tree of gravelly ridges or on high ground about lakes or along streams. In the southern part of the State it is a local to a frequent tree in most parts of the "knob" area where it is associated with white oak, black oak, black gum, etc. It is also an occasional tree on the top of bluffs and cliffs.

Remarks. - The red maple is not abundant enough in Indiana to be of any economic importance. It grows rapidly and should replace the silver maple for shade tree planting since its branches are not broken off as easily by ice storms and it is more resistant to insect attack.

3a. Acer rubrum variety Drummóndii (Hooker and Arnott) Torrey and Gray. This variety of the red maple is a form found in the dense swamps of the lower Wabash Valley. It is distinguished from the type by its $t$ wigs which generally remain more or less hairy until maturit $y$; by the under surface of the leaves remaining more or less tomentose during the summer, and by its larger fruit. This variety is known with certainty only from Little Cypress Swamp in Knox County about 12 miles southwest of Decker. Here it is a frequent to a common tree 
Plate 113

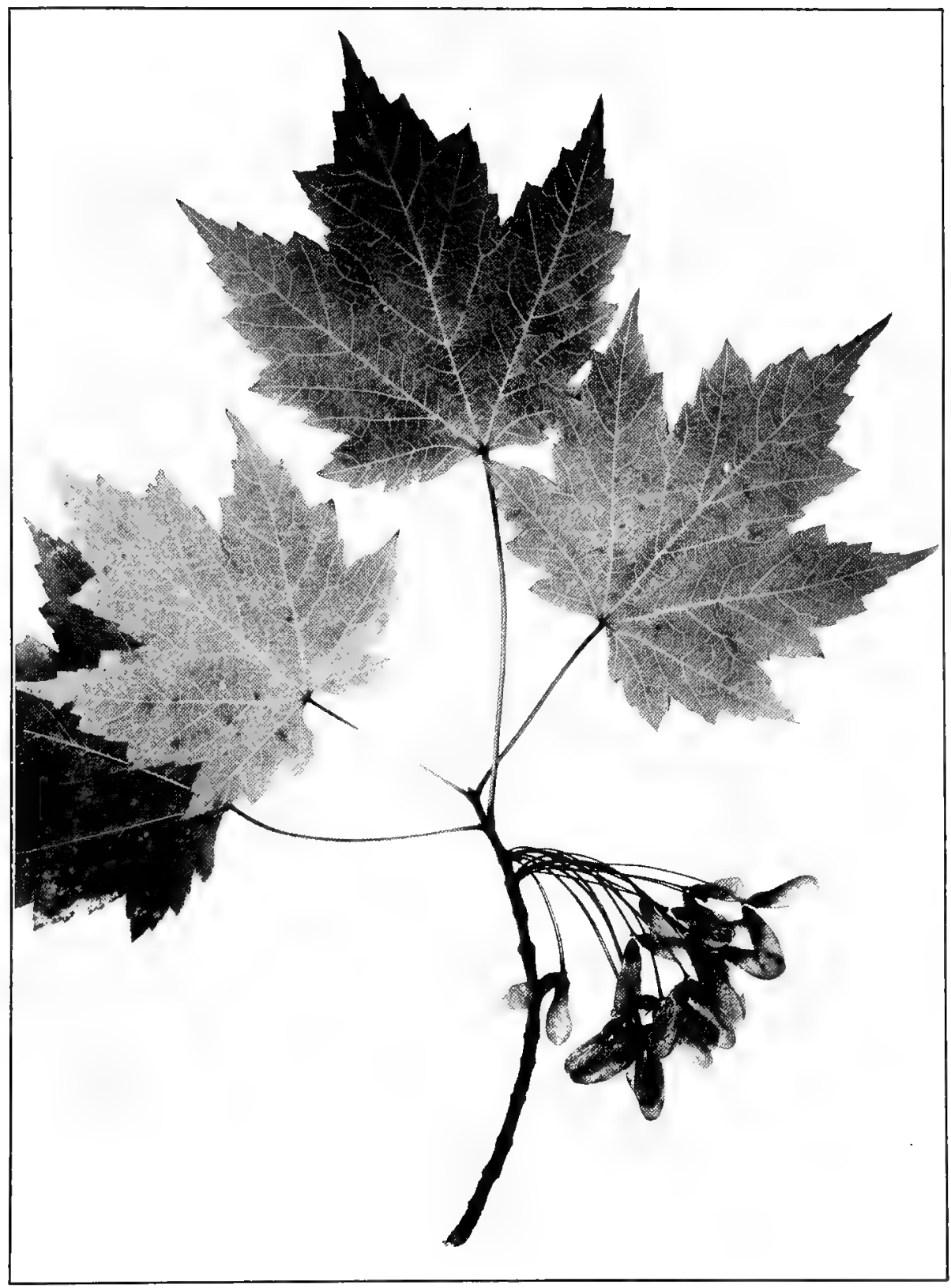

ACER RUBRUM Linnæus. Red Maple. (x 1/2.) 
associated with cypress, swell-butt ash, buttonbush, sweet gum, etc. All of the trees of this locality have 5-lobed leaves.

A specimen collected in the "bottoms" about two miles east of Huntingburg in Dubois Count y has 3 -lobed leaves which are tomentose beneath at fruiting time and has fruit intermediate in size between the type and variety Drummondii which I doubtfully refer to variety tridens Wood.

4. Acer nigrum F. A. Michaux. Black Maple. Black Sugar. Plate 114. Medium to large sized trees with dark furrowed bark on old trees; leaves a little wider than long, $6-15 \mathrm{~cm}$. long, on petioles usually $3-15 \mathrm{~cm}$. long which are more or less swollen at the base and by maturity develop a scale like appendage on each side of the petiole at the baseespecially on each of the terminal pair of leaves, sometimes with foliar stipules which are $2-3 \mathrm{~cm}$. long on stalks of equal length, leaves with three main lobes, the two lower lohes generally have a small lobe at their base, margins of lobes entire and undulating, sinuses between main lobes generally rounded at the base, wide and shallow, hase with a narrow sinus, the lower lobes often overlapping, rarely somewhat dentate, dark green above and a paler yellow green below, hairy on both surfaces when young, becoming at maturity glabrous above and remaining more or less pubeseent beneath; flowers appear in May when the leaves are about half grown on long hairy pedicels, the staminate and pistillate in separate clusters on the same or different trees; fruit matures in autumn, the samaras about $3 \mathrm{~cm}$. long.

Distribution.-Quebec to Georgia, west to South Dakota and south to Louisiana. Found in all parts of Indiana and invariably associated with sugar maple, and of ten with beech in addition. Frequently almost pure stands of sugar maple may be found with the black maple absent. Where found it is usually a frequent to common tree, and when it occurs on a wooded slope it is more frequent near the base and appears to be able to advance farther into moist situations than its congener.

Remarks.- This tree cannot be distinguished from the sugar maple by its form, but at short range can be separated from it by its richer green foliage and by the drooping habit of the lower lobes of the leaves. It is commonly separated from the sugar maple by the darker color and by the narrower and shallower furrows of the bark, but these characters will not always separate the two speries. Hence, when buying black maple trees from a nurseryman you may receive the sugar maple. Those who distinguish the two species agree that the black maple is the more desirable tree for shade tree planting. The black and sugar muple are the two most desirable trees for shade tree planting in Indiana. They are long lived, have a very desirable form, beautiful 
Plate 114.

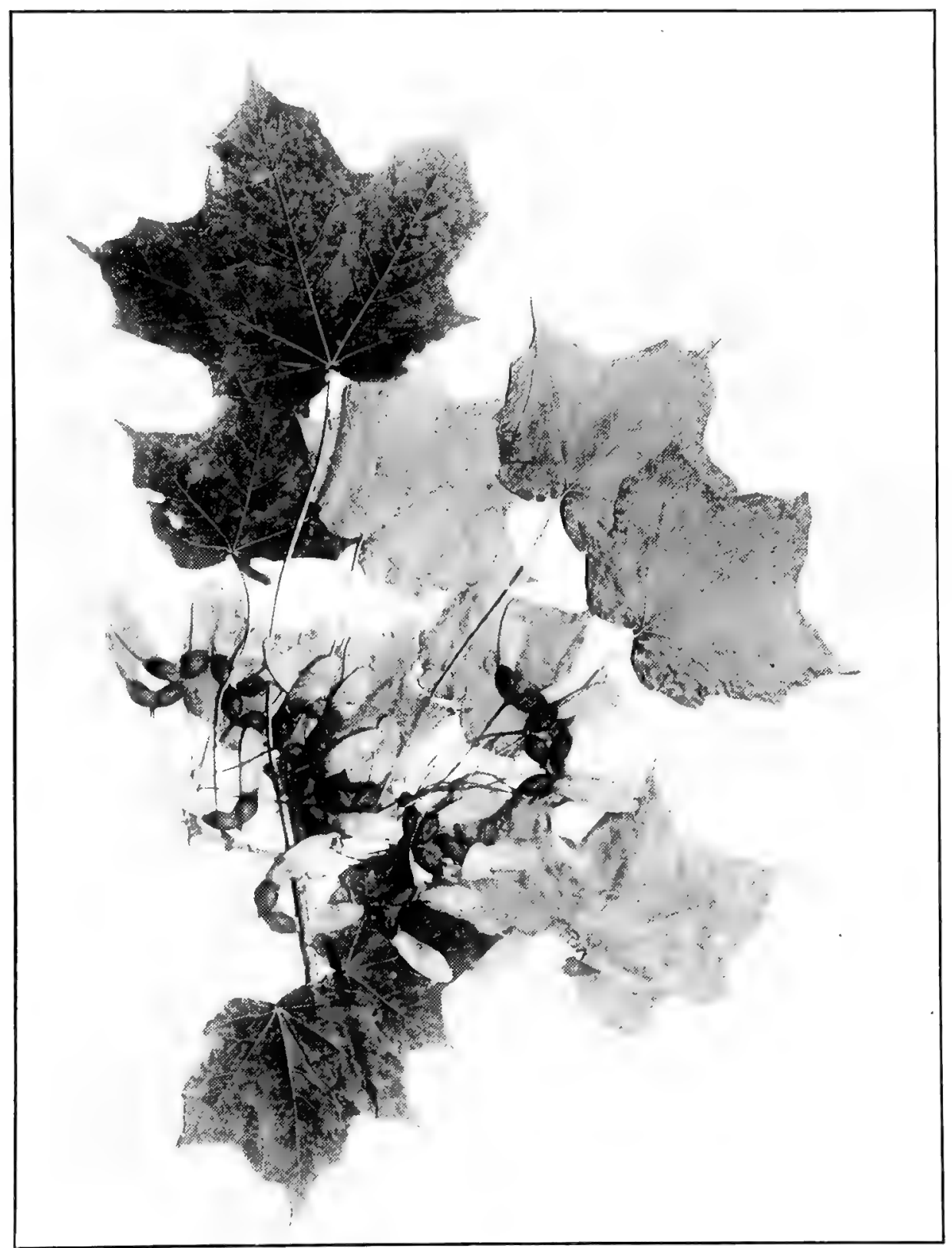

aCER Nigrum. F. A. Michaux. Black Maple. (x 1/2.) 
foliage, a long leaf period, and are quite free from disease and insect injury.

5. Acer sáccharum Marshall. Sugar Maple. Sugar Tree. Hard Maple. Rock Maple. Plate 115. Usually large, tall trees. The bark of small trees is smooth or rough, becoming fissured on old trees, tight or on very old trees sometimes the ridges loosen on one edge and turn outward. The leaves are extremely variable on different trees, and frequently show a wide variation on the same tree, as to form and in the presence or absence of hairs on the petioles and on the under surfare of the leaves. In our area all of the forms which have the majority of the leaves longer than wide or about as wide as long, may be considered as falling within the type. The average sized leaves are 6-12 cm. long, 3-5 lobed, more or less cordate at the base, generally with a broad sinus, sometimes truncate or slightly wedge-shape, sinuses generally wide-angled and rounded at the base, sometimes acute, hairy beneath when young, becoming smooth at maturity except for a few hairs along the veins or in the main axils of the veins, or sometimes remaining more or less pubescent over the whole under surface, more or less glaucous beneath; flowers appear in April or May, on hairy pedicels $3-7 \mathrm{~cm}$. long, the staminate and pistillate in clusters on the same or different trees; fruit ripening in autumn, samaras glabrous and usually 2-4 cm. Jong.

Distribution.--Newfoundland to Georgia, west to Manitoba and south to Texas. A frequent to a very common tree in all parts of Indiana. It is confined to rich uplands, or along streams in well drained alluvial soil. Throughout our area it is constantly associated with the beech. It is absent in the "flats" of the southeastern part of the State, and on the crest of the ridges of the "knob" area of Indiana, but it is a frequent or common tree on the lower slopes of the spurs of the "knobs."

Remarks.- The under surface of the leaves of the sugar maple in the northern part of its range are green, while those of the southern part of its range are quite glaucous beneath. To distinguish these two intergrading forms the southern form has been called Acer saccharum var.glaucum Sargent ${ }^{1}$. Allof the trees seen in Indiana have leaves more or less glaucous beneath. This character, however, is not always evident in dried specimens. The writer prefers not to apply the varietal name to the forms of our area. The sugar maple always has been and will continue to be one of the most important trees of the State. In its mass distribution in Indiana it ranks not less than third. In the quality and uses of its wood it is equalled or exceeded only by

, Bot. Gaz. Vol. 67:233:1919. 
Plate 115.

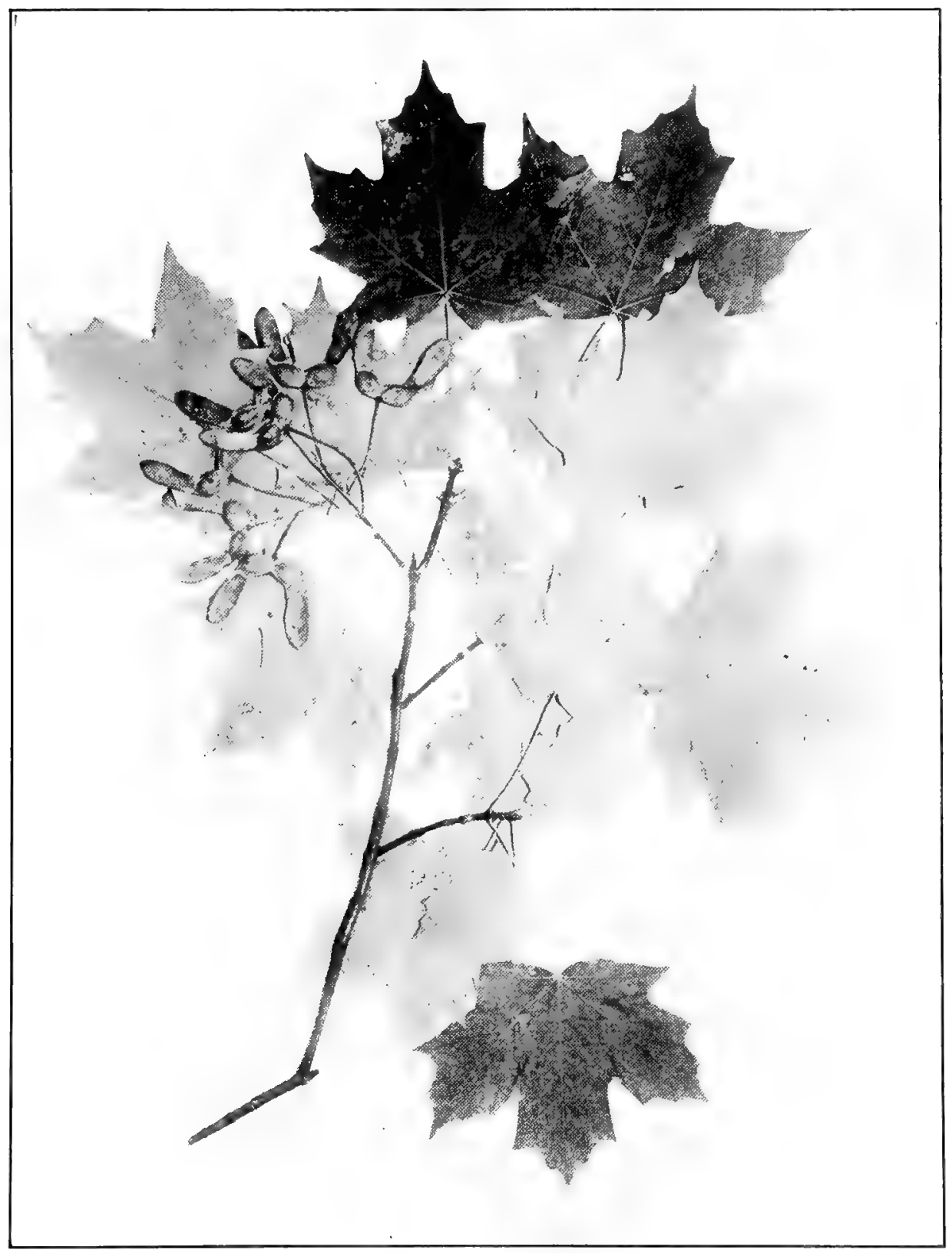

ACER SACCHARUM Marshall. Sugar Maple. (x 1/2.) 
the oak, ash and hickory. When compared with white oak it is a little lighter but thirty per cent stronger and fifty-three per cent stiffer. The greatest amount of the annual cut of maple is worked into flooring which is shipped to all parts of the world. It is much used in the manufacture of furniture and ranks third in use for veneer and hard wood distillation, and as a fuel wood is excelled only by hickory. Since, pioneer times the sap of this tree has been made into sirup and sugar and their manufacture now forms a valuable industry. On an average it takes 3 to 4 gallons of sap to make a pound of sugar, and an average sized tree will annually yield about 3 to 4 pounds of sugar.

The sugar maple on account of its slow growth has not been used much in reforestation. It is very tolerant of shade, can adapt itself to almost al: kinds of soils, thrives either in a pure or mixed stand, and is practically free from injury of insects and diseases. It has, however, been extensively used as a shade tree. For this purpose it is scarcely excelled by any other tree. When grown in the open it almost invariably assumes a symmetrical oval form, and the autumnal coloration of its foliage is rarely surpassed by any of our trees. Where a large tree is desired for street or ornamental planting the sugar maple can safely be recommended.

5a. Acer saccharum variety Rugélii (Pax) Rehcler. This variety of the sugar maple has leaves much wider than long, smaller and 3lobed. The lobes are long acuminate and usually entire, sometimes the lower lobe has a small lobe near the base. This variety is included in our flora on the authority of C. S. Sargent who has given this name to specimens from Indiana in the writer's herbarium. The specimens so named are from the southern part of the State. While there is a wide range of difference in the shape of the leaves of the typical 5-lobed Acer saccharum and its variety Rugelii, all intermediate forms can be ('asily found. The leaves of a tree will vary most on those trees whose average shaped leaves are farthest from the typical form.

5b. Acer saccharum variety Schnéckii Rehder. This varicty in its extreme form is well marked by having the petioles and under surface of the leaves densely covered with hairs. The variety is characterized hy having a "fulvous pubescence," but the 18 specimens at hand show the color of the pubescence on both young and mature specimens to range from white to fulvous. The leaves of all specimens at hand are 5-lobed and show a variation of leaves with petioles and under surface of leaves denscly pubescent to those with petioles glabrous and with densely pubescent under surface. The habitat is that of a dry soil and associated with beech. It has heen found in Gibson, Martin, Perry, Posey and Vanderburgh countiss. 
Aesculàceae. The Buckeye Family.

AÉsCULUS. The Buckeyes.

Trees with dark or ashy-gray colored bark; twigs stout; buds large, leaves opposite, palmately divided into 5-9 ovate or oblong divisions, the divisions serrate; flowers in terminal panicles; fruit a 3-lobed capsule. The fruit is poisonous to stock, although it rarely proves fatal.

Anthers protruding from the flower; fruit warty ........ 1 A. glabra.

Anthers included in the flower; fruit smooth.......... 2 A. octandra.

1. Aesculus glàbra Willdenow. BuckeYe. Plate 116. Medium to large sized trees ${ }^{1}$; bark of old trees fissured, not tight; branchlets robust; twigs at first more or less pubescent, remaining more or less hairy until maturity; leaves large, 5-foliate, rarely 6 or 7 foliate, petioles more or less pubescent; leaflets sessile or on very short stalks, ovate-oblong, oval-oblong, or obovate, about $1 \mathrm{dm}$. long, acuminate, narrowed to a wedge-shaped base, more or less pubescent beneath until maturity, especially along the principal veins, margins irregularly serrate except near the base; flowers generally appear in May when the leaves are almost full size, but in the southern part of the State the flowers sometimes appear the last of March, flower clusters 1-1.5 dm. long, the whole inflorescence usually densely covered with white hairs, flowers pale-greenish yellow; fruit a globular spiny capsule, generally $3-6 \mathrm{~cm}$. in diameter, which usually contains 1-3 large glossy chocolate-colored nuts.

The pubescence on the petioles, leaflets and inflorescence is generally white, but often with it are reddish and longer hairs which are scattered among the other hairs, except in the articulations of the flowers, pedicels and leaflets, where they appear in tufts.

Distribution.-Pennsylvania south to Alabama, west to Iowa and south to the Indian Territory. Found in all parts of Indiana. It is usually associated with beech, sugar maple and linn. On account of the poisonous character of its fruit, land owners have almost exterminated it.

From the data at hand it appears that the buckeye was a rare tree in the northern tier of counties. However, as soon as the basin of the Wabash is reached it becomes a frequent to a common tree where beech, sugar maple, and linn are found. In all of our area it prefers a rich moist soil, except in the southern counties it may be found even on the

1S. Coulter: Size of some trees of Jefferson County. Ind. Bot. Gaz. Vol. 1:10:1875 He says: "Fifty trees were measured at three feet above the ground with an average diameter of $2 \mathrm{ft}$. and 9 inches. An equal number of Aesculus octandra were measured at the samo height from the ground with an average diameter of $2 \mathrm{ft}$. and 9 inclies." 
Plate 116.

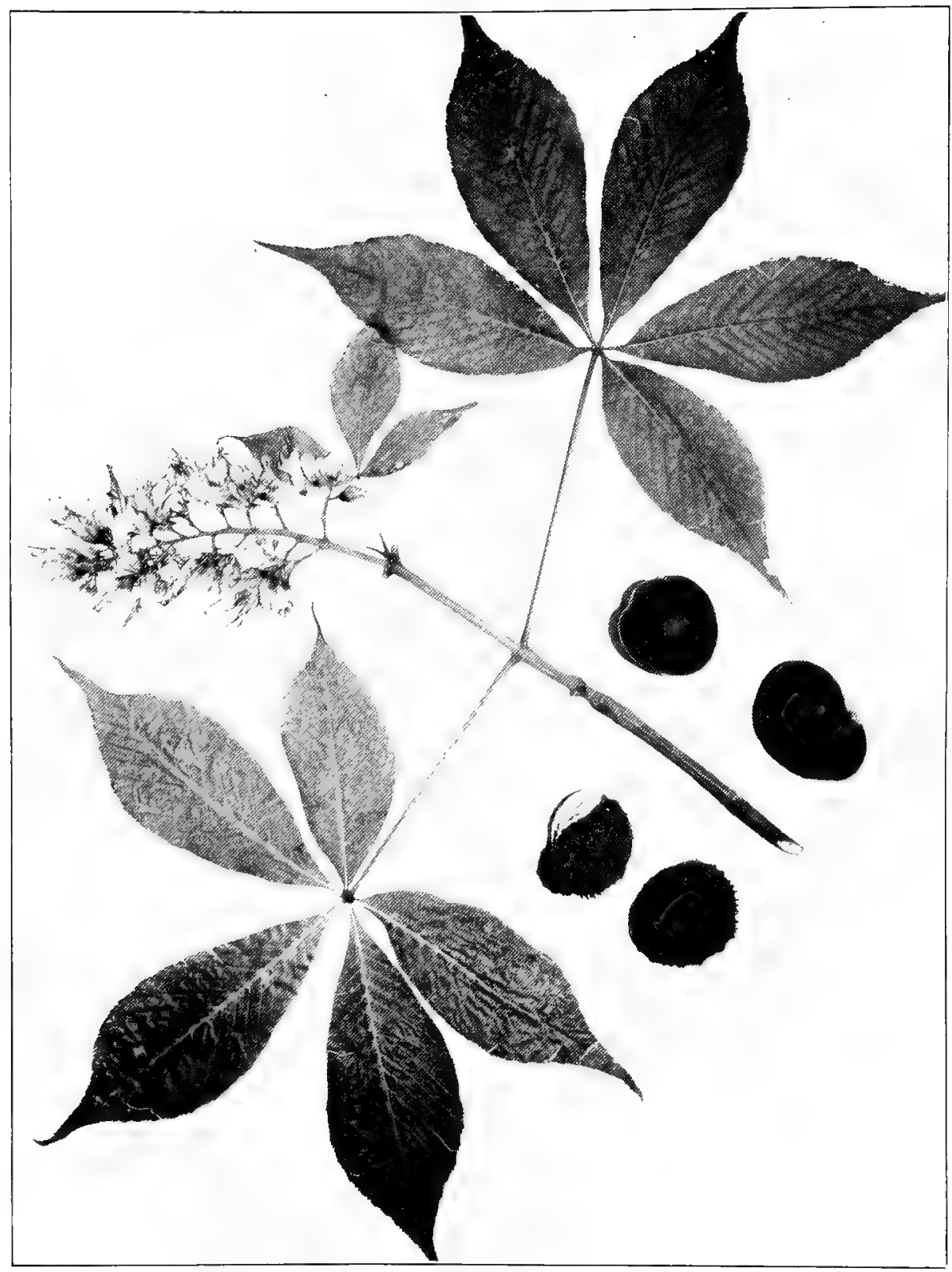

AESCULUS GLABRA Willdenow, Buckeye. ( $\mathrm{x} / 2$. ) 
bluffs of streams with the species just named. In the lower Wabash Valley especially in Posey County it was a rare tree, or entirely absent.

Remarks. - In our area the buckeye is the very first tree to put out its leaves. On this account in early Spring it can be easily distinguished in the forest. This character together with its large clusters of flowers which appear early are features which recommend it for shade tree and ornamental planting. The tree has now become so rare in Indiana as to have no economic importance.

2. Aesculus octándra Marshall. Buckeye. Sweet Buckeye. Plate 117. Medium to large sized trees with smooth bark which on old trees becomes more or less sealy. This tree closely resembles the preceding from which it can be easily distinguished by the following characters. Its smoother and lighter colored bark; by the entire under surface of the leaves remaining permanently pubescent; the hairs more or less fulvous; by the included anthers; and by its smooth capsule.

Distribution.-Western Pennsylvania, westward along the Ohio to Iowa, south to Georgia and west to Louisiana and Texas. In Indiana it is confined to a few counties along the Ohio River. The records of McCaslin for Jay and Phinney for Delaware counties are doubtless errors in determination. The writer has diligently tried to extend the range of this species in Indiana and has found it only in Dearborn, Jefferson, Clark and Crawford Counties, and in no place more than a mile from the Ohio River. No doubt under favorable situations it found its way to a greater distance from the River. On account of the poisonous character of its fruit, it has been almost exterminated, and only along the precipitous bluffs of the Ohio River are trees yet to be found. Doubtless its exact range in our area can never be determined. Dr. Drake ${ }^{1}$ minutely described this species and remarks: "This species delights in rich hills, and is seldom seen far from the Ohio River. It frequently arrives at the height of 100 feet and the diameter of four feet."

Remarks.- The wood is soft, white and resembles the sap wood of the tulip tree for which wood it is commonly sold. Too rare in Indiana to be of economic importance. Young ${ }^{2}$ reported a purple flowered form of buckeye from J efferson County, but since no specimen was preserved and the size of the plant is not given, it will not be considered here. The form was reported as rare under the name of Aesculus flava var. purpurascens.

${ }_{1}$ Drake: Picture of Cincinnatus:79:1815

${ }_{2}$ Young: Botany of Jefferson County, Ind. Geo. Surv. Ind. Rept. 2 255:1871. 
Plate 117.

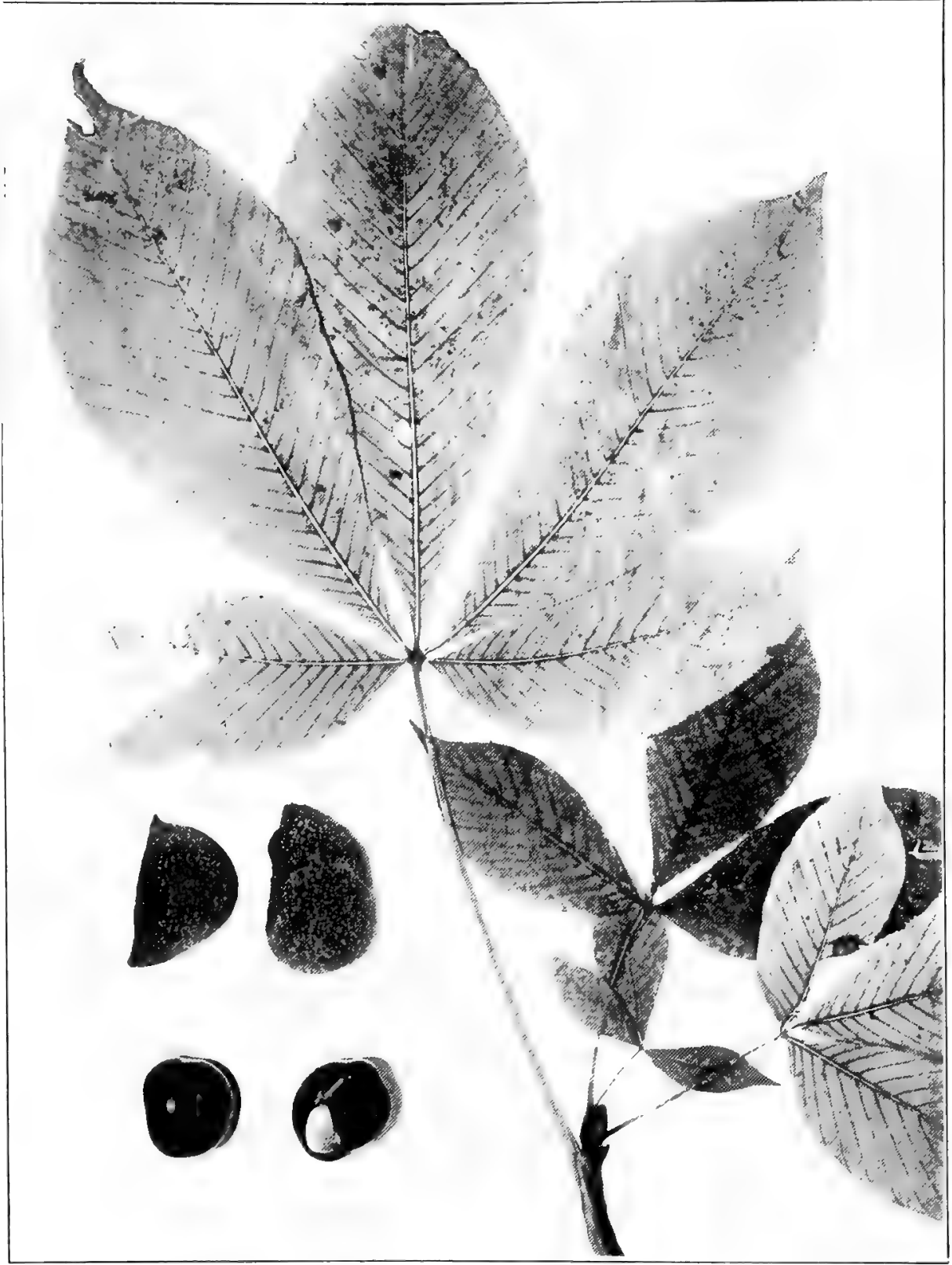

AEsCULUS OCTANDRA Marshall. Siwete Butkeye. (x 1/2.) 


\section{TILIÀCEAE. The Linden Family. \\ TílIA. The Basswoods.}

Trees with medium sized twigs; leaves alternate, mostly taperpointed, oblique cordate or truncate at the base, serrate; flowers in axillary or terminal cymes, white or yellow, fragrant, peduncles of the cymes with a leaf-like bract adhering to about half their length; fruit nut-like, woody, 1-celled.

1. Tilia glàbra Ventenat (Tilia americana Linnæus of authors). Linn. Basswood. Plate. 118. Medium to large sized trees with deeply furrowed bark, much resembling that of white ash or black walnut; twigs when chewed somewhat mucilaginous, usually somewhat zigzag; leaves on petioles $2-6 \mathrm{~cm}$. long, blades ovate to nearly orbicular, $5-15 \mathrm{~cm}$. long, short or long acuminate at the apex, margins more or less coarsely or finely serrate with teeth attenuate and ending in a gland, dark green and smooth above, a lighter green and generally smooth beneath at maturity except tufts of hairs in the axils of the prinicpal veins, or sometimes with a scanty pubescence of simple or stellate hairs beneath; flowers appear in June or July, when the leaves are almost mature; bracts of the peduncles very variable, generally about, 8-10 $\mathrm{cm}$. long, rounded, or tapering at the base, obtuse or rounded at the apex, smooth both above and beneath at maturity; peduncles from very short up to $6 \mathrm{~cm}$. in length; pedicels of flowers variable in length on the same and on different trees, generally about one cm. long; styles pubescent near the base on all of the specimens at hand; fruit woolly, globose or somewhat ellipsoidal, generally about $6 \mathrm{~mm}$. in diameter.

Distribution.-New Brunswick to Manitoba, south to Georgia and west to Texas. More or less frequent to common in rich moist soil in all parts of Indiana. It is the most frequent and common in the lake area of the State but was almost as frequent and common throughout the central part of the State until the hilly area is reached where its habitat disappears for the greater part. In the hill area it is confined to the basins of streams, although sometimes found on the high rocky bluffs of streams. Rare or absent in the flats. In most of its area it is associated with white ash, slippery elm, beech, maple, shellbark hickory, etc.

Remarks. - Wood soft, light, straight and close-grained, white and seasons well. On account of its softness and lightness it has always been a favorite wood where these two factors were important considerations. 
Plate 118.

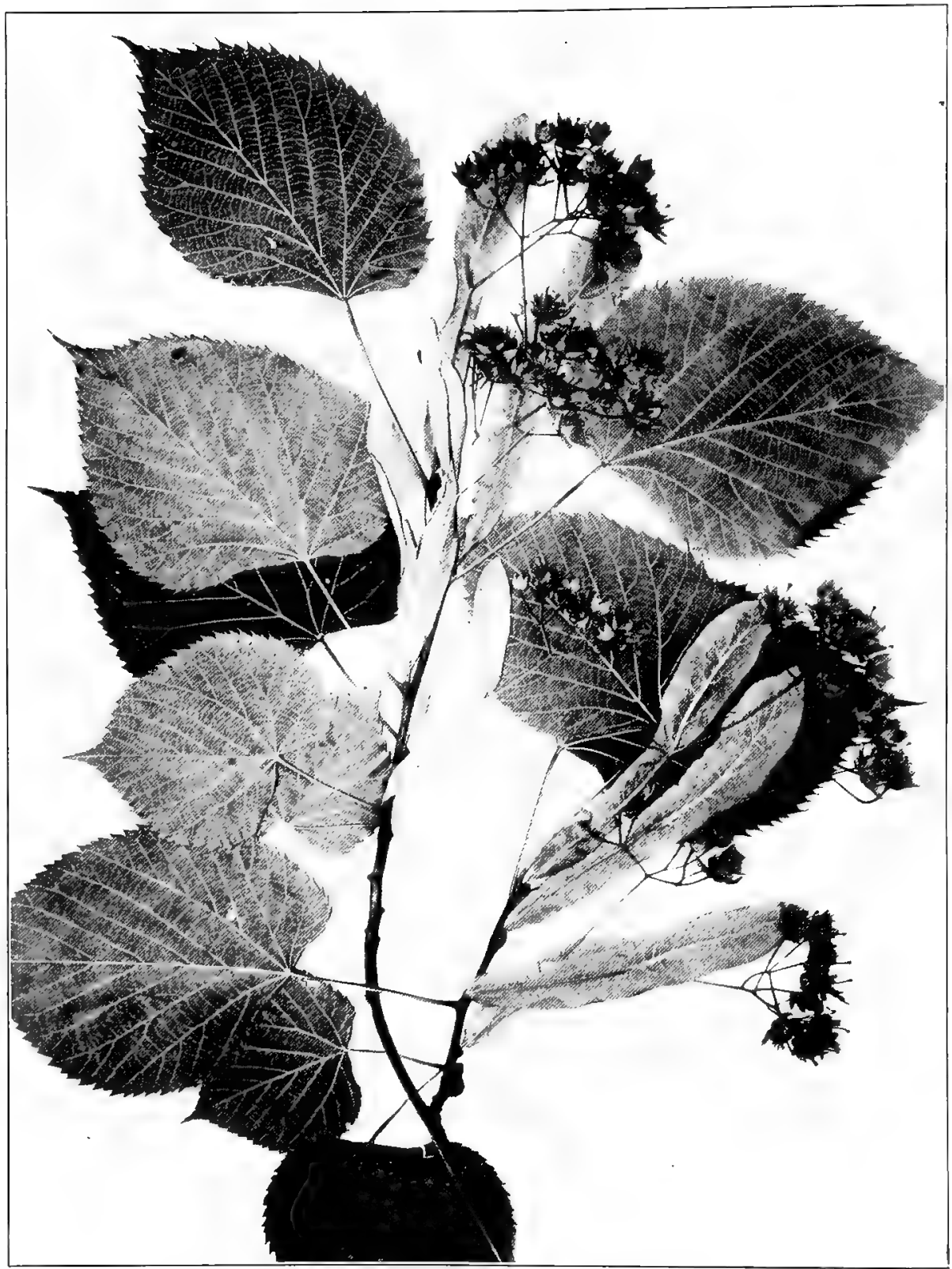

TILIA GLABRA Ventenat. Linn or Basswood. (x 1/2.) 
Is practically odorless, hence, is a desirable wood to contain food products. Its principal uses are lumber, heading, excelsior and veneer. The supply of this species in Indiana is now practically exhausted.

In Indiana this species is commonly called linn, and only in a few counties near the Michigan line is it known as basswood. The name basswood is a corruption of the name bastwood, meaning the inner tough and fibrous part of the bark, which was used by pioneers for tying shocks of corn, and other cordage purposes. However, Dr. Schneck gives the name whittle-wood as one of its common names; and in some localitjes it is called bee tree, because bees find its flowers rich in honey.

Linn is adapted to a rich moist soil, transplants fairly well, and grows rapidly. It has been used to some extent as an ornamental and shade tree, but its use as a street shade tree is no longer recommended because it is not adapted to city conditions, and is killed by the scale. It could, however, be recommended as an integral part of a windbreak, or woodlot where the land owner has an apiary.

2. Tilia heterophylla Ventenat. Linn. Whrte Basswood. Plate 119. Usually large trees; bark similar to the preceding but lighter in color; twigs similar to the preceding species; leaves on petioles $2-8 \mathrm{~cm}$. long, blades ovate to nearly orbicular, generally $7-15 \mathrm{~cm}$. long, generally oblique at the base, oblique-truncate or cordate at the base, abruptly short or long acuminate at the apex, margins serrate with teeth attenuate and ending in a gland, at maturity smooth and a dark yellowgreen above, the under surface generally densely covered with a silvery or gray tomentum, however, on some specimens the pubescence is thin and appears as a stellate pubescence, the tufts of hairs in the principal axils of the veins are reddish brown, in addition to the pubescence reddish glands are often found on the veins beneath; flowers appear in J une or July when the leaves are almost mature; bracts very variable. 4-15 cm. long, generally on short peduncles, rounded or wedge-shape at the base, generally rounded at the apex, sometimes merely obtuse, glabrous both above and below, or more or less densely pubescent beneath and generally sparingly pubescent above; pedicels of flowers variable in length, usually about $1 \mathrm{~cm}$. long; styles of flowers pubescent at the base; fruit globose or somewhat ellipsoidal generally $6-8 \mathrm{~mm}$. in diameter.

Distribution.-This species as understood by Sargent ranges from West Virginia to Indiana and south to Florida and west to Alabama. In Indiana it is confined to counties near the Ohio River. Specimens are in the writer's herbarium from Dearborn, Ripley, Switzerland, J efferson, Clark, Harrison, Crawford, Perry, southeastern Dubois and east Spencer Counties. Practically in all of its range in Indiana it is found on 
Plate 119.

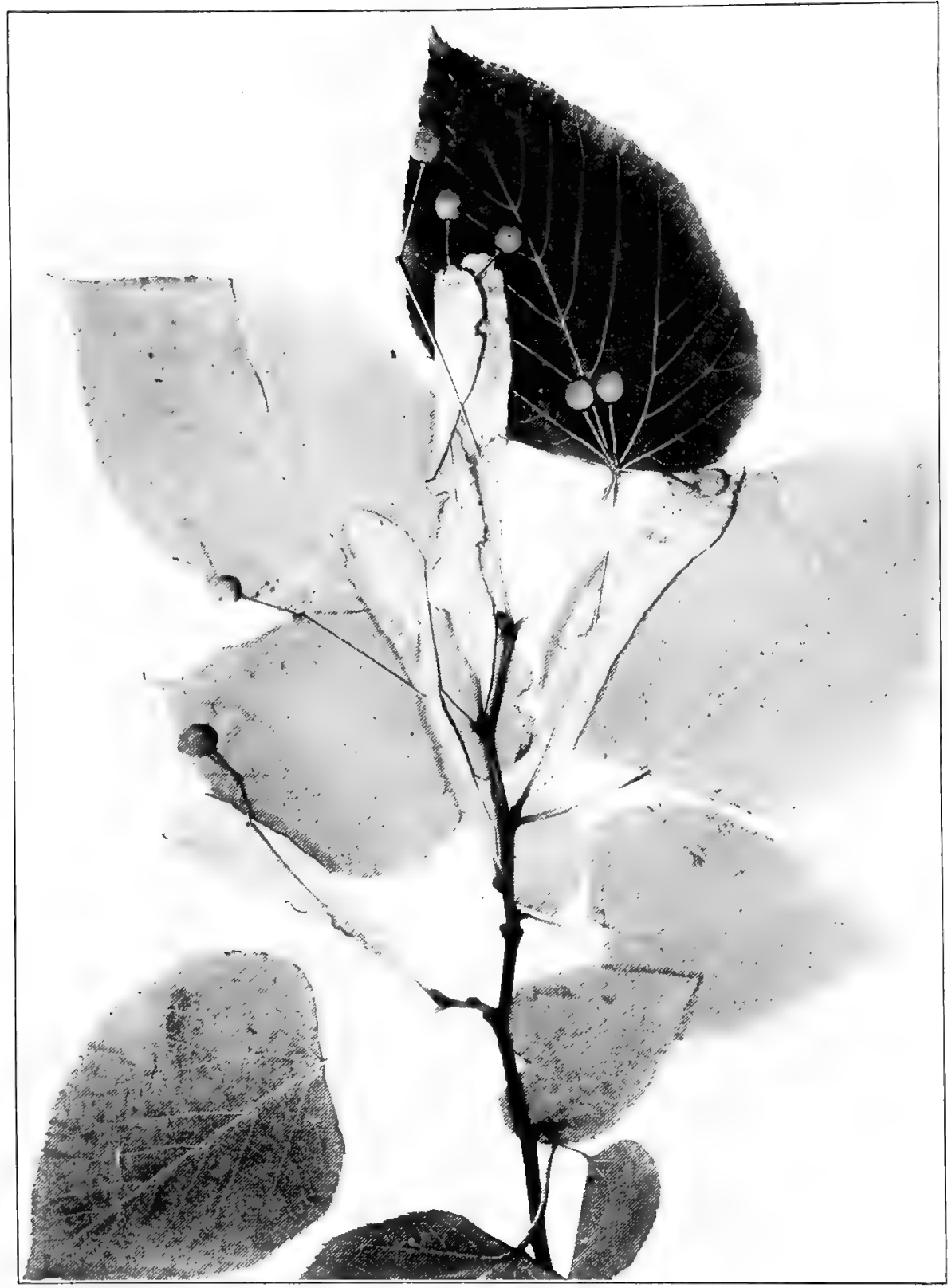

TILIA IHETEROPHYLLA Ventenat. White Basswood. ( $\begin{array}{ll}x_{2} & y_{2} .\end{array}$ 
the tops of high bluffs along streams or on the slopes of deep ravines. It is an infrequent to a common tree where found. In general in the counties just mentioned it supplants the other species of Tilia. It was reported from Wayne County by Phinney, and Schneck says a single tree was found near the mouth of White River. The last named tree may be Tilia neglecta which is said to be found just west in Illinois.

Remarks. - Wood and uses similar to that of the preceding species. In Indiana the species are not commercially separated.

A satisfactory division of the species of Tilia of the United States has long been a puzzle. C. S. Sargent ${ }^{1}$ has recently published his studies of the species and credits Indiana with two species and one variety. His range of Tilia neglecta might include a part of Indiana, and it may be that the pubescent forms of Tilia glabra in our area should be referred to that species. Specimens No. 28043 and 28047 in the writer's herbarium collected from trees on the high bluff of Graham Creek in Jennings County, Sargent refers to Tilia heterophylla variety Michauxii Sargent. While Sargent's key to Titia quite distinctly separates the species and varieties, yet when specimens are collected from an area where the species overlap and seem to intergrade, the task of referring a specimen to the proper species or variety is not an easy one. In fact the writer acknowledges his inability to satisfactorily classify our forms of Tilia, and the present arrangement should be accepted as provisional.

\section{CORNÀCEAE. The Dogwood Family.}

Trees or shrubs; leaves simple, alternate, opposite or whorled; fruit mostly a drupe, 1 or 2 seeded.

Leaves alternate; flowers of two kinds, the staminate in heads,

5-parted; stigmas lateral.................. I Nyssa.

Leaves opposite; flowers perfect, 4-parted; stigmas terminal. 2 Cornus.

\section{NYSSA. The Tupelos.}

Nyssa sylvática Marshall. Gum. Black Gum. Sour Gum. Yellow Gum. Pepperidge. Plate 120. Medium to large sized trees; bark on old trees deeply and irregularly furrowed, the ridges broken up into small lengths; twigs at first pubescent, becoming glabrous; leaves oval-obovate or oblong, blades $5-12 \mathrm{~cm}$. long on petioles $0.5-2 \mathrm{~cm}$. long, rather abruptly acuminate at apex, narrowed at the base, sometimes rounded, margins entire, petioles and both surfaces pubescent when they unfold, becoming glabrous above and glabrous or 1918.

${ }_{\text {SSargent: Notes }}$ on North American Trees. Bot. Gaz. Vol. 66:421-438 and 494-511 
Plate 120.

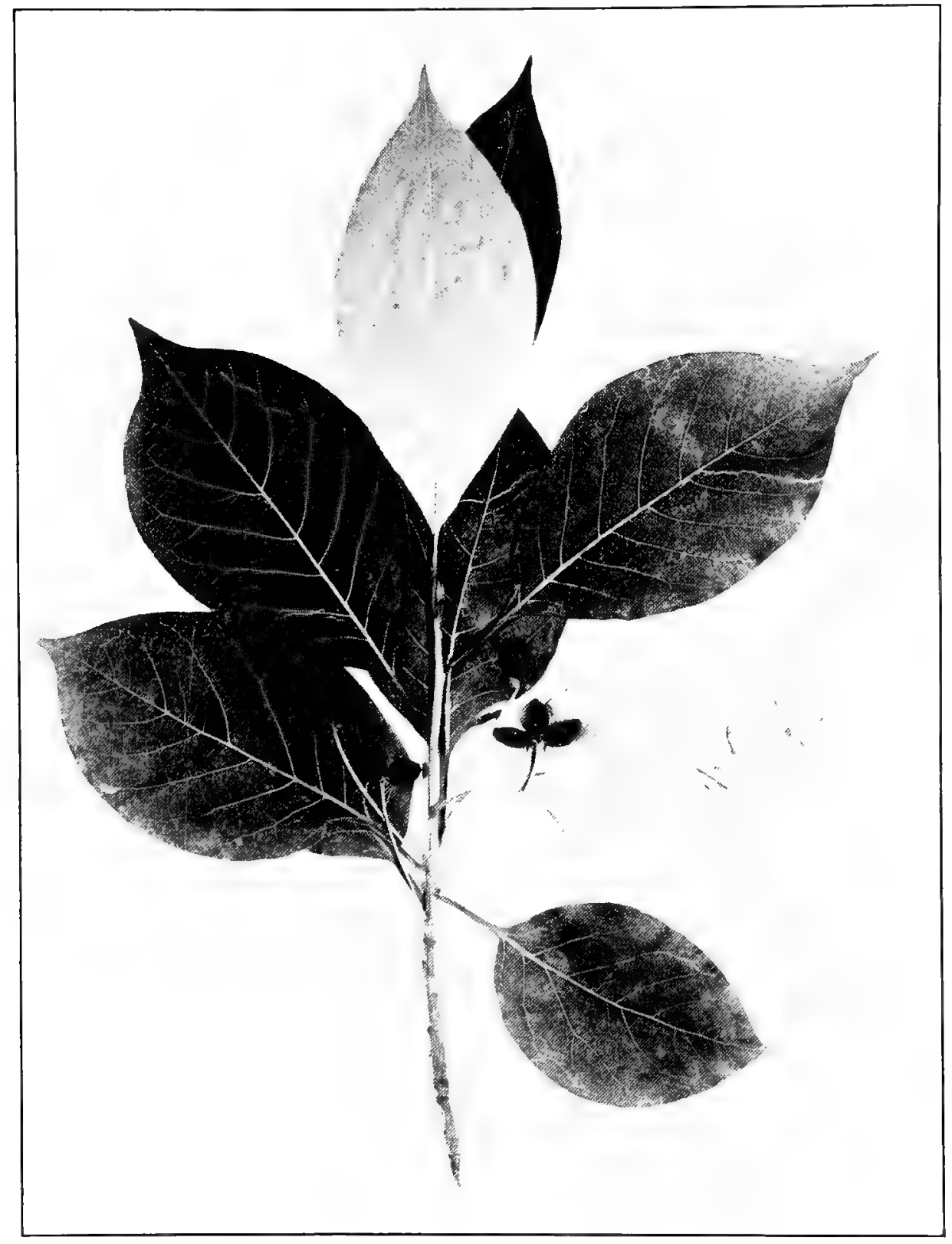

Nyssa sytoftica Marshall. Black Gum. (x 1/2.) 
nearly so beneath at maturity; flowers appear in May or June, the staminate in clusters, numerous, small greenish-white, the pistillate 2-8 or solitary; fruit ripens in autumn, a fleshy drupe, 1-3 of a cluster ripening on a pedicel $2-6 \mathrm{~cm}$. long, ovoid, usually $10-12 \mathrm{~mm}$. long, blueblack, sour and astringent; stone generally cylindric and tapering at each end and with 10-12 indistinct ribs.

Distribution.-Maine, southern Ontario, southern Michigan, southeastern Wisconsin ${ }^{1}$ to Missouri and south to the Gulf. Found throughout Indiana and no doubt was a native of practically every county. It is an infrequent to a very rare tree in the northern half of the State, becoming a common tree in certain parts of the southern counties. In the northern part of the State it is usually found on dry ground associated with the oaks, although it is also found with sugar maple and beech.

Remarks.-Wood heavy, soft, very difficult to split. Woodsmen always speak of two kinds of black gum. There is one form which splits easily which is designated as "yellow gum." This distinction has not been substantiated. The uses of gum are many. The quality of not splitting makes many uses for it. The greater amount of gum is used as rough stuff. In the manufactures it is used for mine rollers, heading, boxes, hatter's blocks, water pipes, firearms, wooden ware, musical instruments, etc.

The distinctive habit of growth of the black gum together with the gorgeous coloring of the autumnal foliage recommend this species for ornamental planting. It has an upright habit of growth, although the trunk is more or less crooked. The crown when grown in the open is usually pyramiclal, composed of horizontal crooked branches.

\section{CòrNuS. DogWOOD.}

Cornus flórida Linnæus. Dogwood. Flowering Dogwood. Plate 121. Usually a small tree $1-2 \mathrm{dm}$. in diameter; bark deeply fissured, the ridges divided into short oblong, pieces; branchlets slender, in winter condition turning up at the tips; twigs green and smooth or nearly so from the first; leaves oval or slightly obovate, blades generally $5-12 \mathrm{~cm}$. long on petioles about $1 \mathrm{~cm}$. long, generally abruptly taperpointed at apex, gradually narrowed and generally oblique at the base, margins thickened and entire, or very slightly crenulate, appressed pubescent both above and beneath, light green above and a grayish-green beneath; flowering heads surrounded by an involucre of

'Wadmond: Flora of Racine and Kenosha Counties. Trans. Wis. Acad. Sci. Vol.16: 857:1909. The author says: "Two trees near Berryville, the only known trees of this species in the state."

2In 1918 I measured a specimen near Yankeetown in Warrick County that had a clear hole of 3 meters ( 10 feet), and a circumference of $11 \mathrm{dm}$. (40 inches) b.h. 
Plate: 1:1.

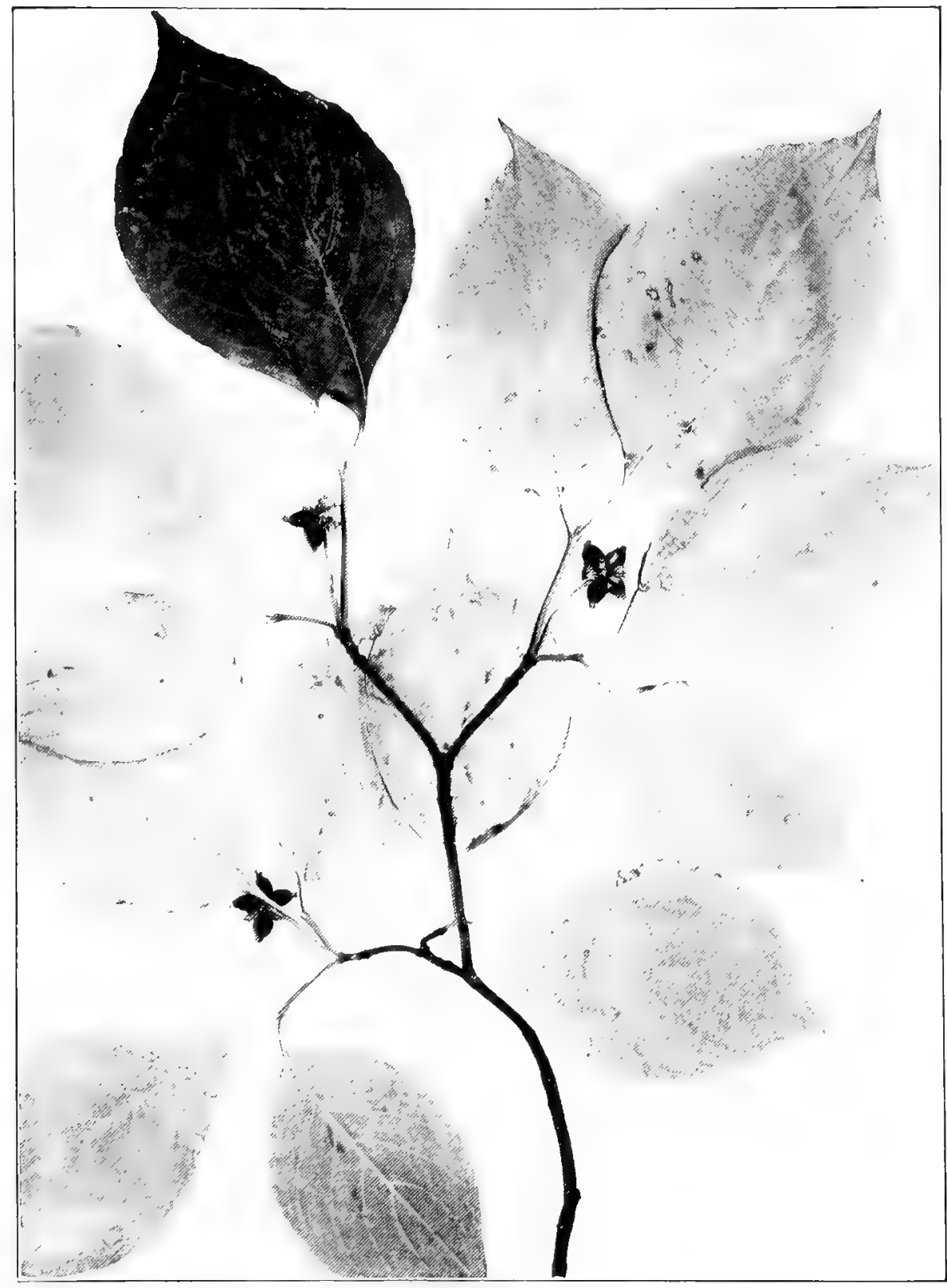

CORNUS FLORIDA Linnæus. Dogwood, (x 1/2.) 
4-large white or pinkish bracts; the mature bracts are obovate, $2-4 \mathrm{~cm}$. long, notched at the apex, appear before the leaves in April or May; flowers are in a head, numerous, small and greenish, opening usually about the middle of May as the leaves appear or even when the leaves are one-third grown; fruit ripens in September or October, an ovoid red drupe about $1 \mathrm{~cm}$. long, usually about 3-5 flowers of a head mature fruit; stone elliptic and pointed at each end.

Distribution.-Southern Maine, southern Ontario, southern Michigan, to Missouri and south to Florida and west to Texas. Found in all parts of Indiana. Frequent to very common in all beech-sugar maple woods of the State. It is very rare or absent in the prairie area of the northwest part of the State, although it has been found in upland woods in all of the counties bordering Lake Michigan. It is also a frequent or more common tree in most parts of the State associated with white oak, or in the southern part of the State with black and white oak. It prefers a dry habitat, and is rarely found in wet situations.

Remarks. - Wood hard, heavy, strong, close-grained and takes a high polish. The Indians made a scarlet dye from the roots. It was used much by the pioneers for wedges, mallets and handles for tools. The trees are so small that they do not produce much wood. The present supply is used principally for shuttles, golfheads, brush blocks, engraver's blocks, ete.

The mature fruit is much relished by squirrels and birds.

The tree is quite conspicuous in the flowering season, and when the fruit is maturing. These features recommend it for ornamental planting, and it is used to some extent. The tree has a flat crown, and is quite shade enduring. It is very difficult to transplant, and when the tree is transplanted, if possible, some earth taken from under a live dogwood tree, should be used to fill in the hole where it is planted.

\section{ERICĀCEAE. The Heath Family.}

Oxydéndrum arbòreum (Linnæus) DeCandolle. Sour Wood. Sorrel Tree. Plate 122. Small trees with a gray and deeply fissured bark, much resembling that of a young sweet gum tree; twigs and branchlets greenish and smooth; leaves alternate, on petioles about a $\mathrm{cm}$. long, oblong-oval, generally $10-15 \mathrm{~cm}$. long, narrowed at the base, acute or acuminate at the apex, margins entire toward the base or sometimes all over, usually about three-fourths is irregularly serrate with very short incurved teeth, glabrous above and beneath except a puberulence on the midrib and sometimes on the petiole to which an occasional prickle is added beneath; flowers appear in June when the leaves are full grown, in large panicles at the end of the year's growth, 
Plate 12․․‥

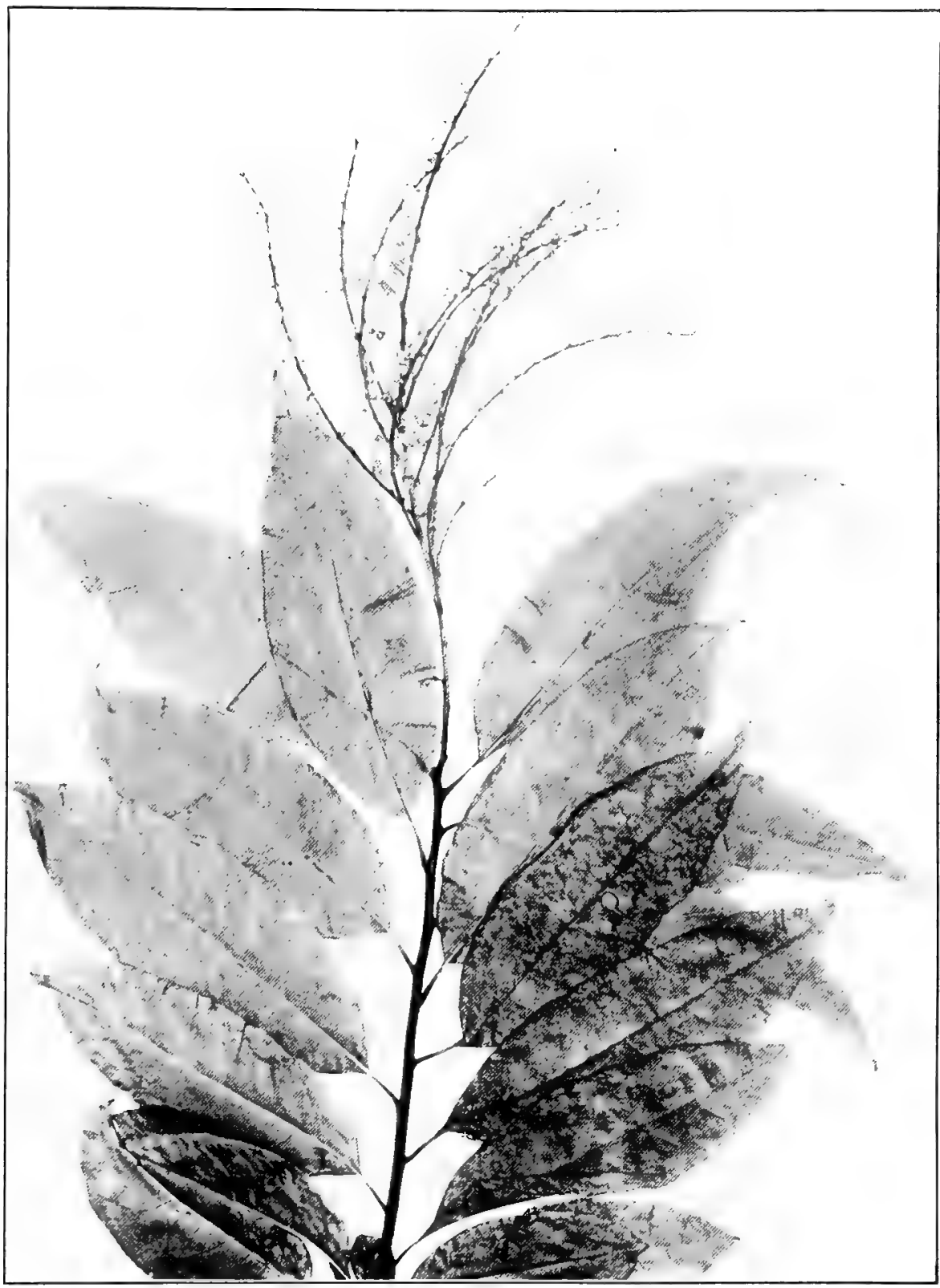

OXYDExDRUM ARBOREUM (Linnæus) DeCandolle. Sour Wood. Sorrel TREE. ( $\quad 1 / 2$. 
white, the whole inflorescence covered with a short gray pubescence; fruit a capsule about $0.5 \mathrm{~cm}$. long on an erect and recurved pedicel of about the same length, maturing in autumn.

Distribution.-A tree of the elevated regions of the area from southeastern Pennsylvania to Florida and west to southern Indiana and south to Louisiana. In Indiana it is definitely known to oceur only in Perry County at the base of a beech spur of the VanBuren Ridge about 7 miles southeast of Cannelton. Here it is a common tree over an area of an acre or two. The largest tree measured was about $1.5 \mathrm{dm}$. in diameter and 12 meters high. Here it is associated with beech, sugar maple, dogwood, sassafras, etc. When coppiced it grows long slender shoots which the boys of the pioneers used for arrows. A pioneer who lived near this colony of trees is the author of this use of the wood and he called the tree "arrow wood."

\section{ebenàceae. The Ebony Family.}

Diospyros virginiàna Linnæus. Persimmon. Plate 123. Small or medium sized trees with deeply and irregularly fissured bark, the ridges broken up into short lengths; twigs pubescent; leaves alternate, oval, oblong-oval or ovate, generally $8-15 \mathrm{~cm}$. long and $3-7 \mathrm{~cm}$. wide, narrowed, rounded or cordate at the base, short pointed at the apex, margin entire but ciliate, slightly pubescent above when young, becoming glabrous on age, more or less pubescent beneath, sometimes glabrous except the midrib and margin; flowers appear in May or J une on the year's growth when the leaves are about half grown, greenish yellow, the staminate on one tree and the pistillate on another; fruit ripens in August, September or October, depressed-globose or oblong in shape, $2-3 \mathrm{~cm}$. in diameter, generally with 1-4 very hard flat seed.

Distribution.-Connecticut to Iowa and south to the Gulf. In Indiana it is confined to the south half of the State. We have no record of wild trees being found north of Indianapolis, except Prof. Stanley Coulter reports three trees growing in Tippecanoe County in situations such as to indicate that they are native. It is doubtful if it was ever more than a frequen t tree in the original forest. In some of the hill counties of the south central part of the State, it has become a common tree in clearings and abandoned fields. It grows long surface roots from which numerous suckers grow which form the "persimmon thickets." It seems to thrive in the poorest and hardest of soils. However, it reaches its greatest size in the alluvial bottoms of the Lower Wabash Valley. Here large and tall trees have been observed on the low border of sloughs, associated with such water-loving plants as 
Plate 1::;

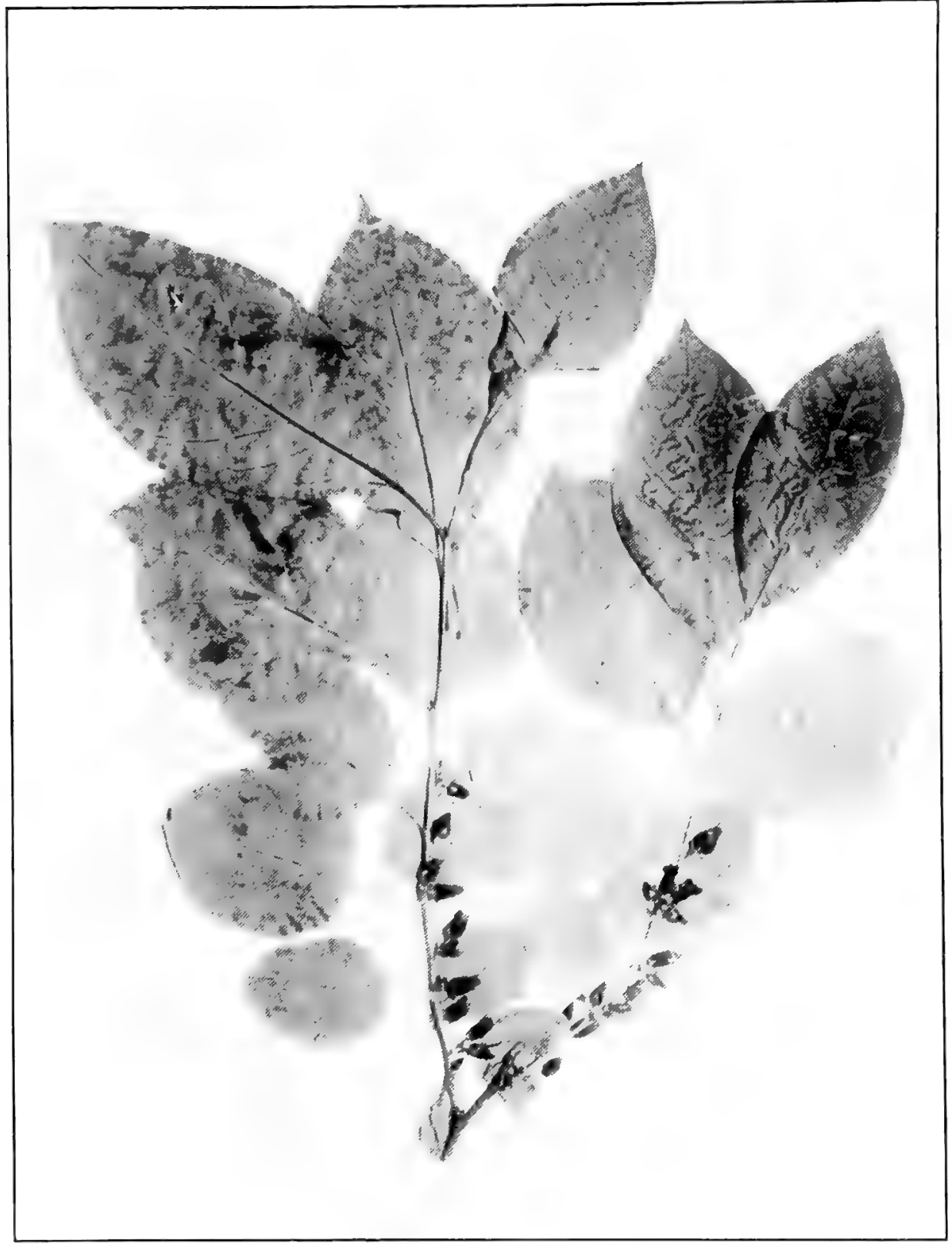

Diospyros VIRGIxiANA Linneus. Permiman. (x 1/2.) 
water-locust, button-bush, swell-butt ash, etc. It thrives equally well on the high sandy ridges of Knox and Sullivan Counties.

Remarks. - The fruit is edible and the horticultural possibilities of this tree have never received the attention they deserve. The opinion is current that the fruit does not ripen and is not edible until it is subjected to a frost. This is an error. The best and largest fruit I have ever eaten ripened without a frost. A large native tree on the Forest Reserve in Clark County ripens its fruit in August, which is of an excelient quality and usually has only one, and rarely more than three seeds. The fruit of this tree is of the oblong type. The fruit varies much in size, time of ripening and quality. Some is scarcely edible. Some of the native trees bear fruit when they are not over eight feet tall, some are usually prolific bearers while others bear sparingly. For this reason if one wishes to grow persimmon trees it is best to buy grafted trees from some reliable nurseryman. The tree is hardy throughout Indiana and while it is a very slow growing tree, it can nevertheless be recommended for ornamental and roadsicle tree planting. It is to be noted that cattle will not browse persimmon, and that hogs greedily eat the ripe fruit. The fruit of many trees does not fall until early winter, and such trees are a granary for several kind of animals of the forest.

The wood is hard, heavy, strong and close-grained. Practically the whole output of persimmon lumber is used in making shuttles. In Indiana the tree is too rare to furnish much lumber.

\section{OLEĀCAE. The Olive Family.}

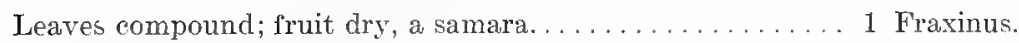

Leaves simple; fruit fleshy, a drupe............... 2 Adelia.

\section{FRÁXINUS. ThE Ashes.}

Trees with opposite, odd-pinnate leaves; flowers appear in April or May in clusters from the axils of last year's leaves, the staminate and pistillate on different or sometimes on the same tree; fruit a 1 seeded samara.

Bark of mature trees furrowed; fruit not winged to the base.

Body of fruit robust, round and rather abruptly passing into the wing; the body rarely winged $1 / 3$ its length.

Shoots and axis of leaves smooth.............. 1 F. americana.

Shoots and axis of leaves velvety pubescent, at least when young........................

Body of fruit flattened and gradually passing into the wing; the body usually winged more than $1 / 3$ its length. 
Shoots glabrous, or practically so 3 F. lanceolata.

Shoots velvety pubescent, at least when young.

Calyx of fruit less than $3 \mathrm{~mm}$. long; body of samara just below the wing less than $3 \mathrm{~mm}$. wide, rarely $4 \mathrm{~mm}$. wide, usually $1.5-2.5 \mathrm{~mm}$. wide; samaras $3-4.5 \mathrm{~cm}$. long, $4 \mathrm{~F}$. pennsylvanica.

Calyx of fruit more than $3 \mathrm{~mm}$. long, generally $4-5 \mathrm{~mm}$. long; body of samara just below the wing more than $3 \mathrm{~mm}$. wice, usually $4-5 \mathrm{~mm}$. wide; santaras generally 4-6 cm. long.................5 F. profunda.

Bark of mature trees sealy or flaky; fruit winged to the base.

Twigs usually 4 angled; leaflets on very short stalks......6 F. quadrangulata.

Twigs round; leaflets sessile ...............7 F. nigra.

1. Fraxinus americàna Linnæus. White Ash. Gray Ash. Plate 124. Large trees with deeply furrowed bark; twigs smooth, greenish gray and often covered with a bloom; leaves generally $2-3.5 \mathrm{dm}$. long, rachis smooth; leaflets $5-9$, usually 7 , generally $5-14 \mathrm{~cm}$. long, on stalks generally $0.3-1 \mathrm{~cm}$. long, the termi nalone on a stalk 2-4 times as long, leaflets ovate to narrow-oblong, narrowed, rounded or oblique at base, short or long acuminate at a pex, sometimes merely acute, margins entire or irregularly serrate, usually not serrated to the base, teeth short, dark green and smooth above, glaucous beneath, sometimes almost green beneath about Lake Michigan and in the northern tier of counties, usually pubescent beneath along the midrib and along the veins, sometimes glabrous; calyx persistent on the fruit, about $1 \mathrm{~mm}$. long; fruit ripens in September and October, linear, $3-4.5 \mathrm{~cm}$. long, variable in size and shape, body of samara cylindrical, somewhat narrower than the $w$ ing and usually $1 / 3-1 / 4$ the length of the samara, each face of the body usually striated longitudinally with about 8 faint lines; wing terminal, generally about $0.5 \mathrm{~cm}$. wide, pointed or notched at apex.

Distribution.- Nova Scotia to Minnesota and south to the Gulf. Frequent to common in all parts of Indiana. It is the most abundant in the northern two-thirds of the State, where it is associated principally with beech, sugar maple, linn, slippery elm and red oak. In the hilly part of the State it is found principally near water courses and in ravines, and rarely on the white and black oak ridges. It is rarely found in the low "flats" of the southeast part of the State, or in the shingle oak bottoms along the Patoka River.

Remarks. - The foliage of the white ash is quite variable in the texture of the leaflets. Leaflets on some trees are quite thin while those of other trees are thick and leathery, and no doubt would be classed by Sargent as variety subcoriacea ${ }^{1}$. 
Plate 124.

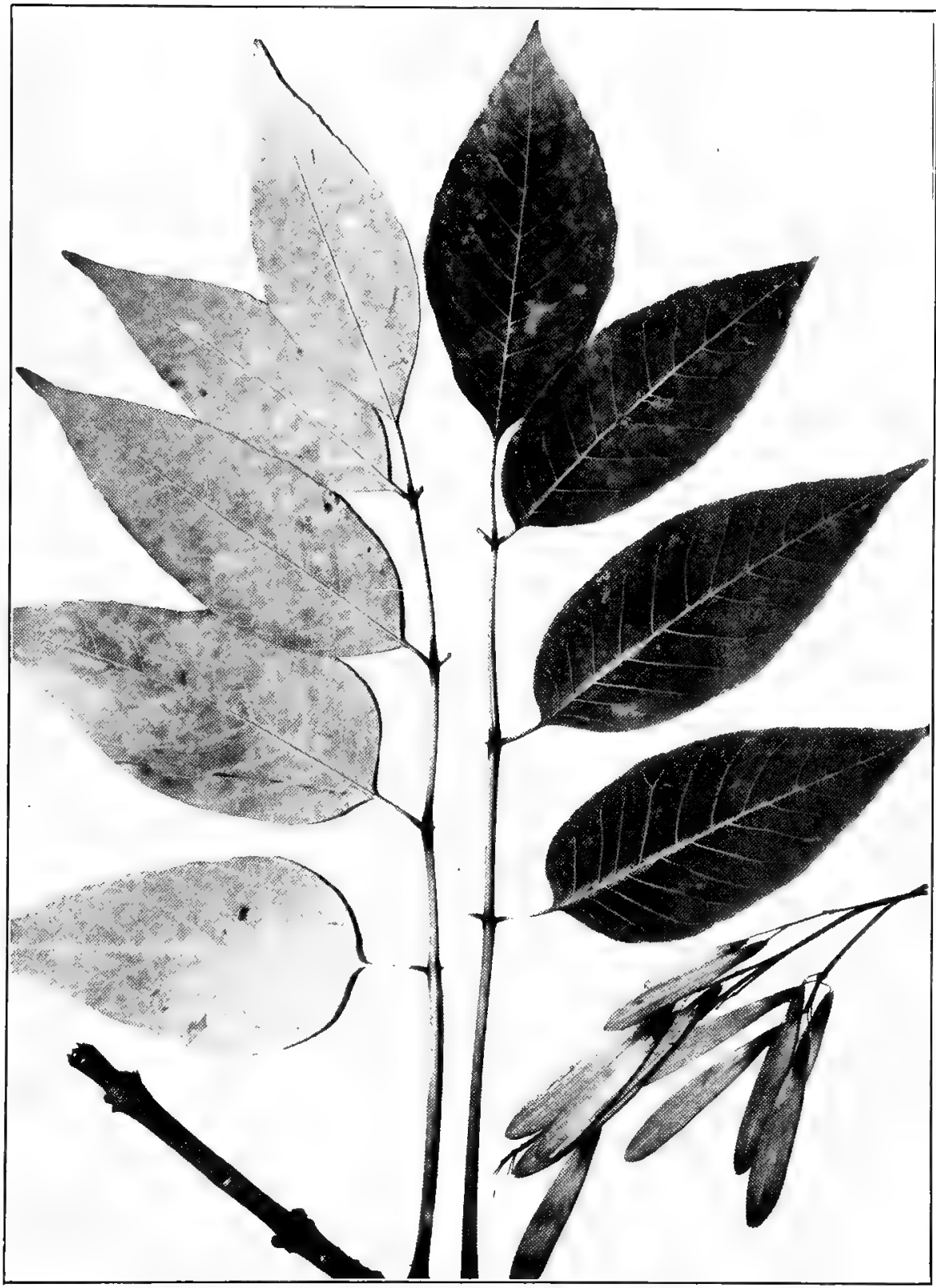

FRAXINUS AMERICANA Linnæus. White Ash. (x 1/2.) 
A form of white ash with reddish-purple fruit is found from Steuben to Clark County. This form is the prevailing type of white ash in Wayne County in the vicinity of Centerville. It has been described by Fernald as forma iodocarpa. ${ }^{1}$

The wood is heavy, hard, strong, elastic, sap wood white and the heart wood light brown. It is one of the most valuable of Indiana woods, and is used by almost all wood using industries. Its principal uses include handles, butter tubs, car and vehicle stock, automobiles and implements.

The white ash has been under cultivation at the Clark County State Forest for fifteen years, and the present indications are that it is one of the very best species to use for forest planting. It is hardy; grows in nearly all kinds of soil, although it prefers a moist, rich soil; transplants suecessfully; grows rapidly; bears pruning well; erect in habit of growth, and so far in our area forest plantings have not been desstroyed by injurious insects. However, in some parts of the State, where trees have grown in the cities, some have been killed by seale insects. Aside from this the white ash would be an excellent tree for roadside planting, because it comes into leaf late, and never produces a dense shade.

At present seed collectors are not able to separate the species of ash, and as a consequence white ash seedlings bought from a nursery are not always true to name. For this reason it is suggested that to obtain seedlings true to name that seed be collected and planted from a tree true to name. The seed should be planted in a sandy soil in rows, about 25 seeds to the foot, and covered about an inch deep with earth. The trees should be planted $4 \times 4 \mathrm{ft}$. to $8 \times 8 \mathrm{ft}$. apart.

2. Fraxinus biltmoreàna Bcadle. Biltmore Ash. Plate 125. Large forest trees, resembling the white ash. Young trees acquire the furrowed bark character earlier than the white ash, furrows of the bark of mature trees are usually dec per, and the ridges correspondingly farther apart; twigs are robust like the white ash and always velvety pubescent except in age when they may become smooth; leaves generally $2-3.5 \mathrm{dm}$. long, rachis pubescent; leaflets 5-11, usually 7-9, generally 5-14 cm. long, on stalks generally $0.3-1 \mathrm{~cm}$. long, the terminal one on a stalk $2-4$ times as long, leaflets broadly ovate to narrow ovate, or oblong to narrow oblong, narrowed, rounded, or oblique at the base, short or long acuminate at apex, sometimes merely acute, margins generally entire, sometimes with a few short teeth toward the apex, dark grcen and smooth above, glaucous and more or less pubescent beneath; fruit similar to the preceding species.

'Rhodora Vol. 14:192:1912. 
Plate 125.

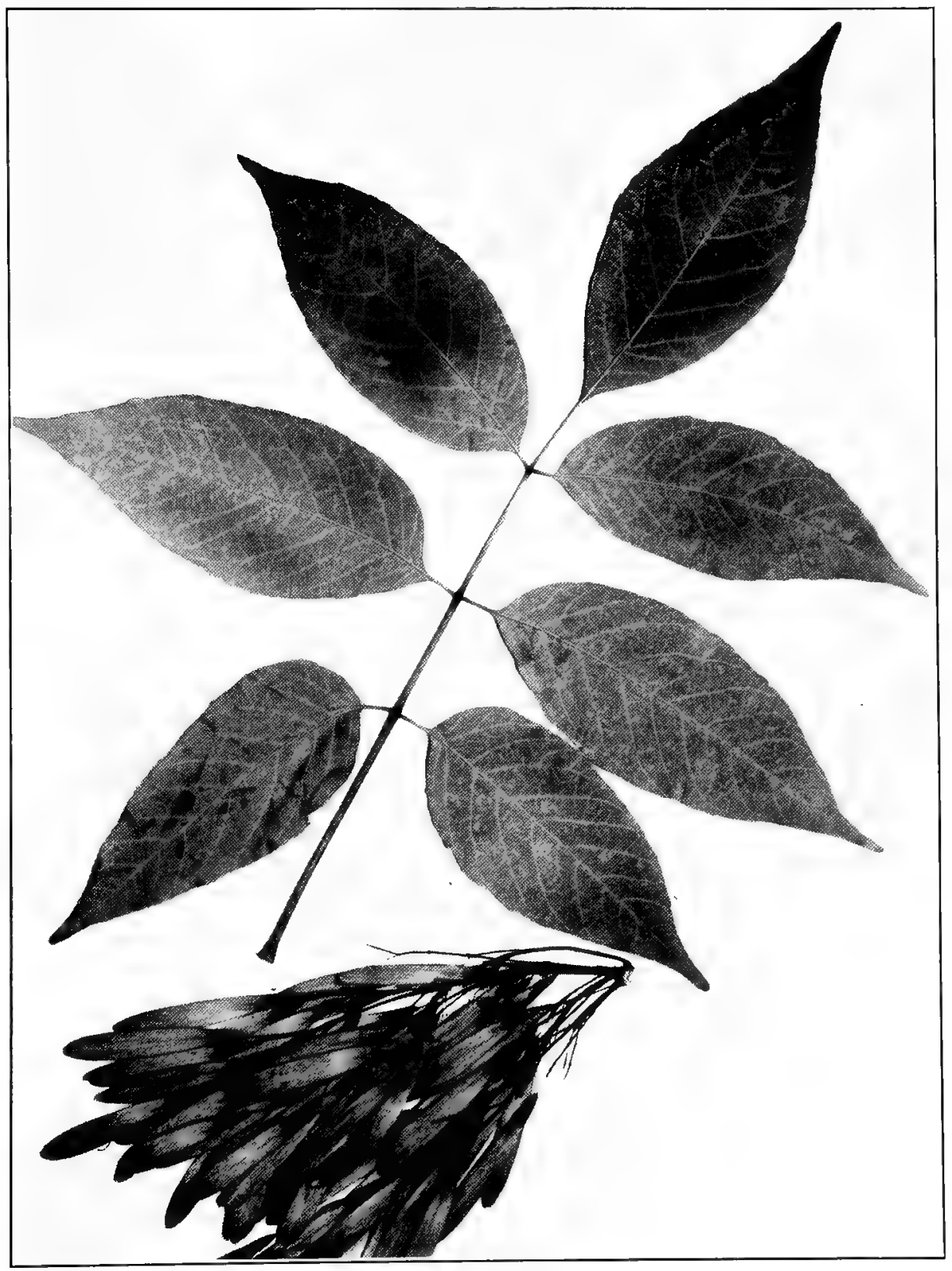

Fraxinus BILTMoreana Beadle. Biltmore Ash, (x 1/2.) 
Distribution.-This species has only recently been separated from the white ash and its range has not been ascertained. It is known to occur in the Appalachian Mountains from Pennsylvania to Georgia. In Indiana it is known to occur as far north as Wells County. It is commonly associated with the white ash, but much less frequent except in a few districts where it is the prevailing type. Such a district is in Gibson County north of Owensville. Here as well as in other parts of Gibson County very large trees have been observed. In the original forest the pioneers called the very large specimens of ash with deeply furrowed bark "the old fashion" ash. It is believed that most of these specimens were of this species. In the hilly parts of Indiana this species is found in situations too dry for the white ash, and for this reason should be given preference in hillside planting.

On the wooded bluff of White River in Fairview Park north of Indianapolis is a specimen that measures $31 \mathrm{dm}$. in circumference, b.h. The deepest furrows on the north side of the tree are $6 \mathrm{~cm}$. deep.

Remarks. - This species is not yet commonly separated from the white ash and is known to the trade as white ash. Mr. Beadle who first recognized the species, named it Biltmore ash in honor of the Biltmore Estate on which the first tree was discovered. Authors ever since have so called it, and the common name which this form should bear is Biltmore ash.

On the Clark County State Forest is a planting of sixteen year old white ash in which are mixed quite a number of Biltmore ash. This species at a distance, can be distingushed from the white ash by the rougher bark of the trunks and the darker green color of its foliage, and in the aut umn by its more colored folinge. A closer view shows that the leaflets of the Biltmore ash stand in a plane above the rachis higher than those of the white ash.

The wood is not commercially distinguished from the white ash, but its mechanical properties rank it somewhat below that species. ${ }^{1}$

3. Fraxinus lanceolàta Borckhausen. White Ash. Green Ash. Swamp Asir. Plate 126. Medium to large sized trees with fissured bark, the ridges and furrows narrower than those of the white ash; twigs slender and glabrous at maturity; leaves generally $2-3 \mathrm{dm}$. long, rachis smooth, rarely slightly pubescent; leaflets $5-9$, usually 7 , generally $5-15 \mathrm{~cm}$. long, on stalks generally about $0.5 \mathrm{~cm}$. or less in length, the terminal one on a stalk 2-4 times as long, leaflets generally narrowoblong or ovate to narrow ovate-oblong, generally with a narrowed base, sometimes rounded and oblique, short or long acuminate at apex, margin entire near the base, the remainder of the margin generally

Siterrett: Itilization of Ash. U. S. Dept. Agri. Bul. 523:1917. 
Plate 126.

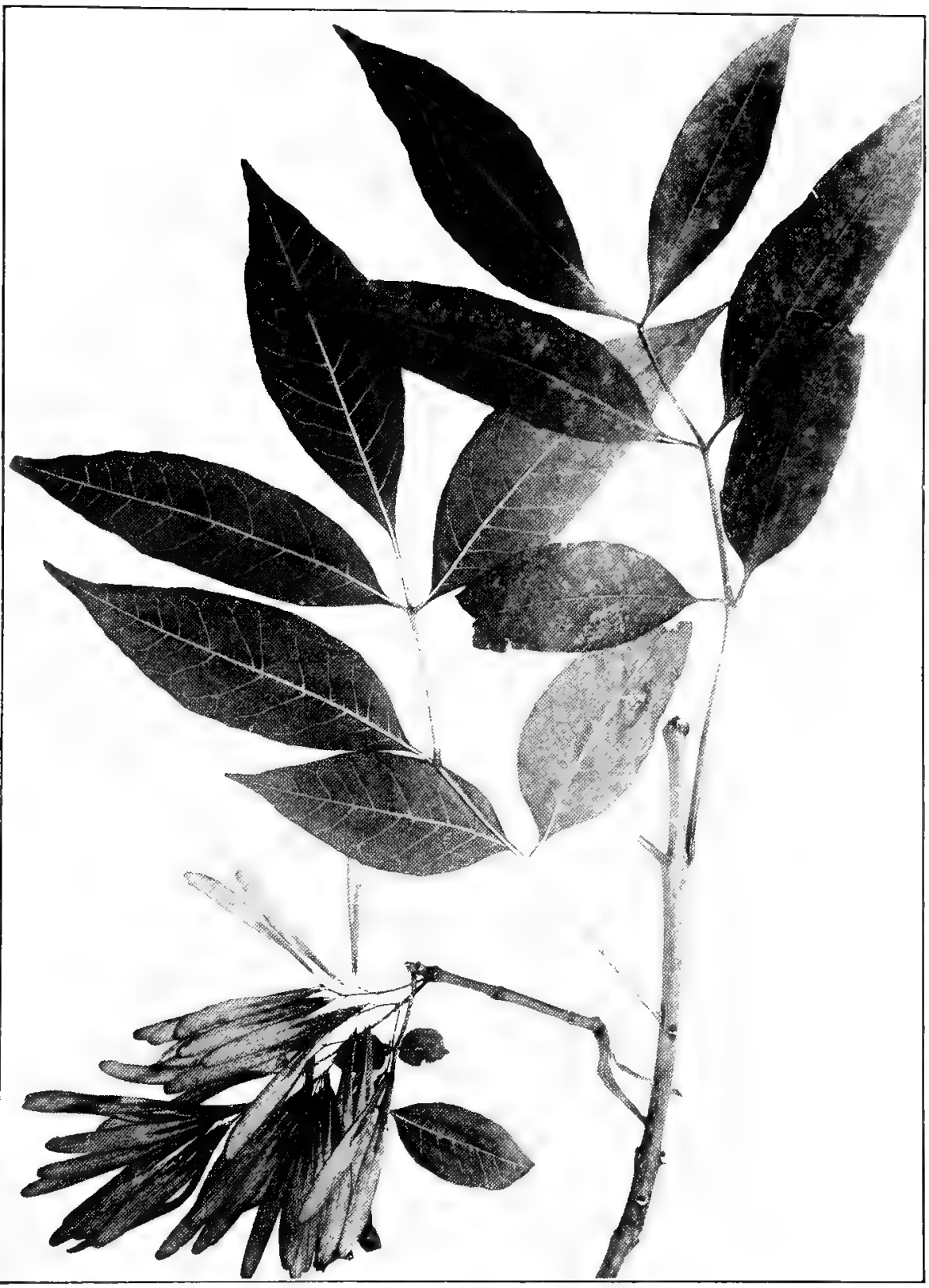

FRAXINUS LANCEOLATA Bcrkhausen. Green Ash. ( $\mathrm{x}$, ý.) 
sparsely serrate with short teeth, dark green and smooth above, a lighter green beneath and more or less pubescent on the petiolules, midrib and veins; calyx persistent, about $1 \mathrm{~mm}$. long; fruit ripens in September and October, linear or spatulate, $3-5 \mathrm{~cm}$. long, variable in size and shape, body $1 / 3-1 / 2$ the length of samara, compressed or flattened and gradually narrowed to the base, usually less than half as wide as the wing, each face of the body usually striated with about $2-4$ lines which are stronger than those near the edge of the body; wing generally $5-6 \mathrm{~mm}$. wide, pointed or notehed at apex, and decurrent on the sides of the body for about one-half of its length.

Distribution.-Lake Champlain to the Saskatchewan and south to the Gulf. Found in all parts of Indiana. It is usually found in low ground along streams, in swamps, and in low woods. It is usually associated with white elm, red maple, cottonwood, aspens, linn, bur oak, etc., in the south to this list should be added silver maple and cypress. It prefers a habitat wetter than that of the white ash, although the two are found together in wet woods. In swampy woods it is often a common tree. While it has a general distribution in the State, it is much more local than the white ash.

Remarks. - This form is not usually separated from the next species, and both are known in books and by nurserymen as green or red ash. The common name, green ash, should be applied to this species to separate it from the true white ash, and the next.

In ash forest plantings on the Clark County State Forest, it is to be noted that this and the next species bear fruit while the trees are as small as $1.5 \mathrm{~cm}$. in diameter, while the white and Biltmore ash which are much older and $6-8 \mathrm{~cm}$. in diameter have never borne fruit. This species and the next bear fruit oftener and in greater abundance than the white or Biltmore ash. It is also to be noted that practically all of the volunteer ash trees found along fences and roadsides, except very large trees, are of the green ash species.

The wood is similar to that of white ash, and the cut is usually sold as that species. However, it ranks below white ash in its mechanical qualities. ${ }^{1}$

While the native green ash is found growing in swamps, it adapts itself to drier situations. It is planted more than any other species of ash in the cold and dry regions of the West and Northwest.

4. Fraxinus pennsylvánica Marshall. Red Ash. White Asm. Swamp Ash. Plate 127. Usually medium sized trees much like the preceding; twigs velvety pubescent at maturity; leaves generally 2-3 dm. long, rachis pubescent; leaflets 5-9, usually 7 , generally 
Plate 127.

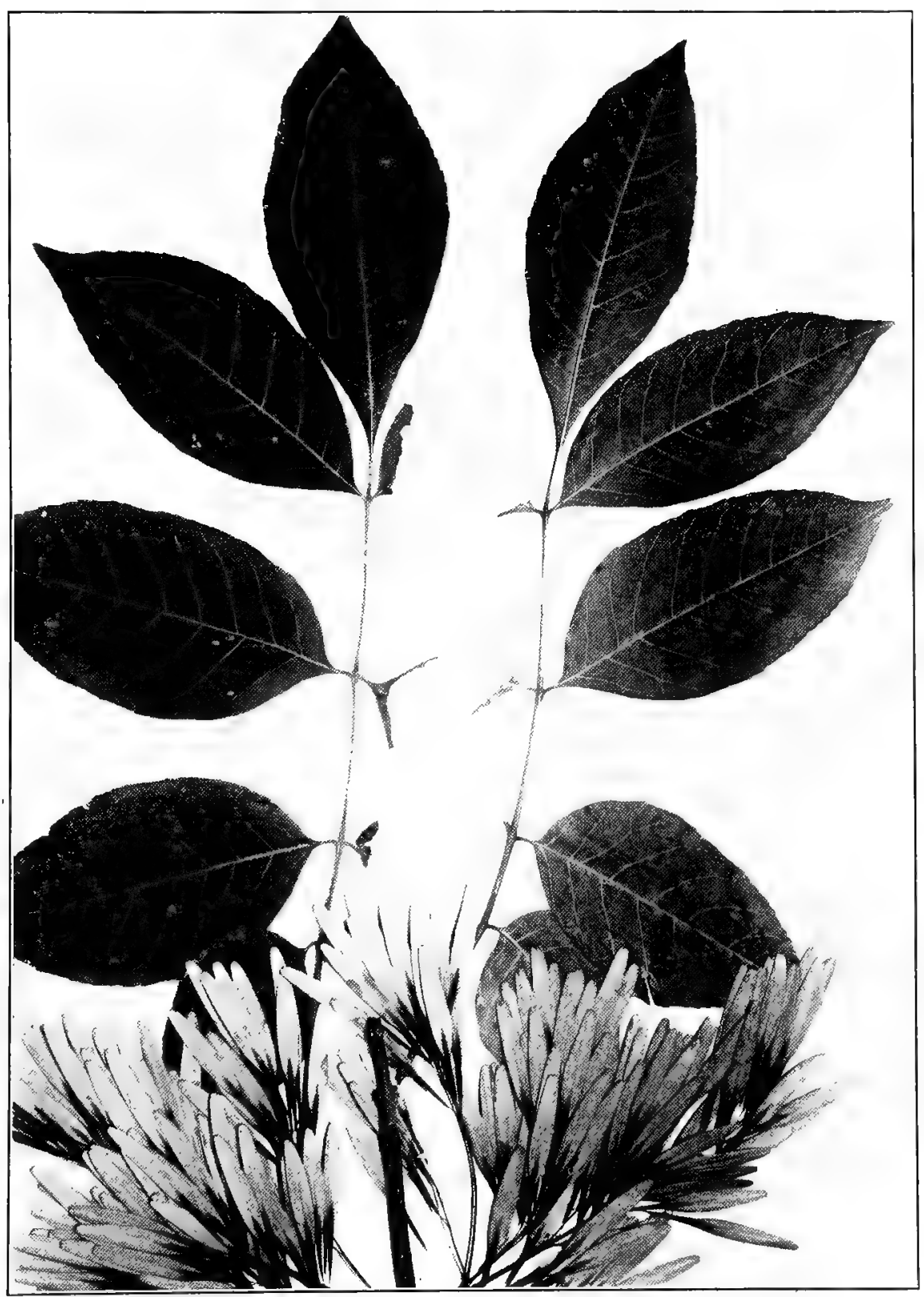

FRAXINUS PENNSYLVANICA Marshall. Red Ash. (x 1/2.) 
$5-15 \mathrm{~cm}$. long. on stalks generally about $0.5 \mathrm{~cm}$. long, the terminal one on a stalk 2-4 times as long, leaflets generally ovate, ovate-oblong, or oblong to narrow-oblong, generally with a narrowed base, sometimes rounded and oblique, short or long acuminate at the apex, margins sometimes entire, generally entire near the base, the remainder more or less serrated with shallow teeth, dark green and smooth above, a lighter green beneath and more or less densely pubescent all over the lower surface, especially on the midrib and veins; calyx persistent, about $1 \mathrm{~mm}$. long; fruit can not be distinguished from the preceding.

Distribution.-Quebec tc Manitoba, and south to Florida. Found sparingly in all parts of Indiana. It is usually found in low ground, but frequently on bluffs, and flood plain banks.

Remarks. - This species is not commonly separated from the white ash group, but in books it is known as the red ash. This is the common name that should be applied to this form.

This species is not usually separated from the preceding, but it is easily distinguished from it by its pubescent twigs. It can be distinguished from the next by its smaller twigs, smaller calyx and smaller fruit.

The wood is similar to that of the white ash, and the cut is usually sold as that species. In mechanical qualities it is on a par with the green ash.

5. Fraxinus profúnda Bush. Swell-Butt Ash. Plate 128. Medium or large trees with fissured bark similar to the white ash; twigs robust and velvety pubescent at least while young; leaves generally $2-4 \mathrm{dm}$. long, rachis densely pubescent, rarely almost smooth; leaflets $5-9$, generally 7 , on stalks $0.5-1 \mathrm{~cm}$. long, the terminal one on a stalk 2-4 times as long, leaflets ovate, narrow-ovate to narrow-oblong, narrowed or rounded and oblique at the base, short or long taperpointed at the apex, margins entire, rarely with a few short teeth, dark green and smooth above, a lighter green and densely pubescent beneath, rarely somewhat smooth; calyx persistent, generally $4-5 \mathrm{~mm}$. long, rarely as short as $3 \mathrm{~mm}$; fruit ripening in September and October, linear, generally 4-6 cm. long, variable in size and shape, body about $1 / 3$ the length of the samara, compressed or flattened and gradually narrowed to the base, the striations on the face of the body not prominent and usually not distinct the full length of the body, samara often unilateral or somewhat falcate; wings notehed or merely rounded at the apex, decurent on the body $1 / 4-1 / 2$ its length, sometimes almost terminal.

Distribution.- Tirginia, Indiana and Missouri, and south to Florida. In Indiana the distribution has not been determined. It is 
Plate $12 S$.

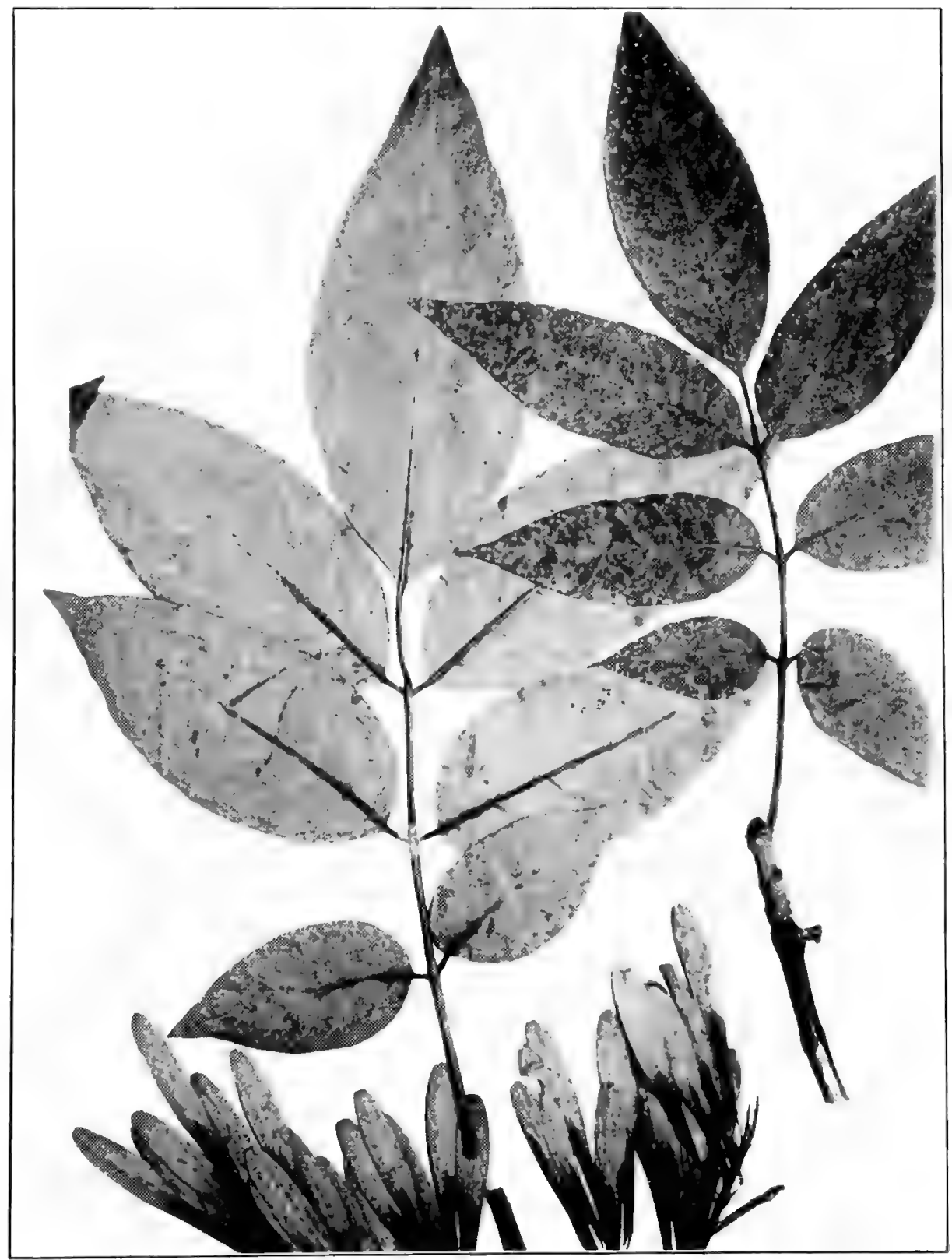

FRaxinus Profunda Bush. Swell-butt or Pumpin Ash, ( $x \frac{1}{2}$.) 
a common to an infrequent tree of the river sloughs and cypress swamps of the southwestern counties. Authentic specimens are at hand from Knox, Gibson, Posey, Perry, Bartholomew, Jackson, Marion and Daviess Counties, and specimens from Hamilton, Tipton and Starke Counties, I doubtfully refer to this species. The preferred habitat of this species is inundated swamps, and when it grows in such situations it generally develops a base swollen to a point somewhat above the water level. In Bartholomew County it was found associated with the cow oak, and the trunk resembled the white ash.

Remarks. - This species is known by authors and commercially as pumpkin ash. The wood is similar to white ash but is inferior to that species. On account of its habitat this species was little cut until the past few years when ash became scarce. During the past few years most of the deep river and cypress swamps have been invaded and all of the ash cut.

6. Fraxinus quadrangulàta Michaux. Buve Ash. Plate 129. Medium to large sized trees with light gray bark, not regularly fissured, scaly at least above; twigs and branchlets more or less distinctly 4angled, the angles of vigorous shoots develop corky wings about $2 \mathrm{~mm}$. high; leaves generally $2-3 \mathrm{dm}$. long; leaflets $7-11$, generally $7-15 \mathrm{~cm}$. long, on short stalks, usually 1-5 mm. long, sometimes sessile, the terminal one on a stalk generally about $1-2 \mathrm{~cm}$. long, leaflets ovate to lanceolate, narrowed or rounded at the base, generally long acuminate at the apex, margins rather regularly and coarsely serrated with short incurved teeth, yellow-green and smooth above, about the same color beneath and generally smooth except along the veins, midrib and petiolules which are permanently pubescent; calyx very small, usually about $0.5 \mathrm{~mm}$. long, and persisting more or less in fruit; fruit ripens last of June to August, samaras twisted, generally $3-4 \mathrm{~cm}$. long and $8-10 \mathrm{~mm}$. wide, rounded at the base, notched or rounded and apiculate at the apex, the apical end of all specimens at hand twisted to the right, the wing surrounds the body.

Distribution.--Southern Ontario to Iowa, and south to northern Alabama and Arkansas. Found sparingly in most parts of Indiana, except the northwest part. There are no records northwest of White and Noble Counties. In the northern two-thirds of the State it is a rare to very rare tree, generally found only along the bluffs of streams. In many areas it is so rare that even the pioneers do not know the tree. It was the most frequent in the southeastern part of the State. Here also it is found principally along the higher banks of streams. While the species is confined principally to high ground it also grew in lower ground. The largest tree seen is on level ground at a fork of the 
Plate 129.

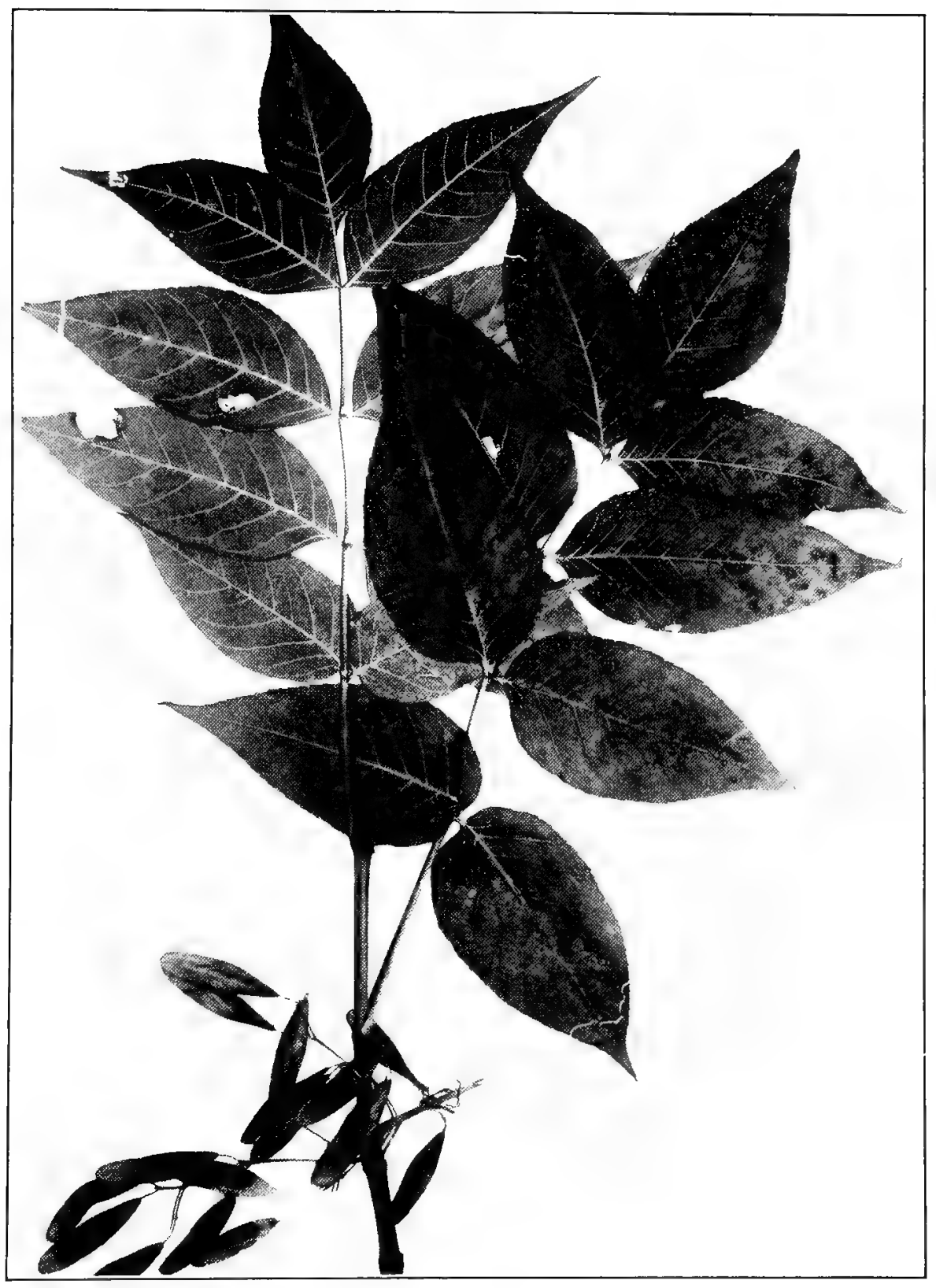

FRAXINUS QUADRANGULATA Michaux. Bude Asm. (x 1/2) 
road between Charlestown and Jeffersonville about 3 miles northeast of Jeffersonville. In 1918 this tree measured $28.2 \mathrm{dm}$. (1041/2 inches) in circumference breast high.

This species has not been observed in the "knob" area of the State or anywhere in the flats of the Lower Wabash Valley. Schneck reports it as rare on the hills of this area. The tree is too rare to definitely determine its associates, although sugar maple is usually found with it.

Remarks. - This species is becoming too scarce to be of much economic importance. The cut is usually sold as white ash. The uses of the wood are practically the same as the white ash.

The fruit and foliage of this species most closely resembles that of the black ash, from which it can be distinguished by its greenishyellow foliage and the habitat in which it grows.

7. Fraxinus nìga Marshall. BLACK Ash. Plate 130. Medium sized, tall and straight trees with a light gray bark, broken up into small thin plates on old trunks; twigs round, robust and smooth at maturity; leaves 2.5-4 dm. long, leaflets generally $7-11$ and $7-13 \mathrm{~cm}$. long, sessile, the terminal one generally on a stalk $0.5-1 \mathrm{~cm}$. long, oblong or oblonglanceolate, narrowed or rounded at the base, and short or long acuminate at the apex, margins coarsely and rather irregularly serrate with short teeth which are usually somewhat incurved, dark green and glabrous above, not much lighter beneath and glabrous or pubescent along the midrib and larger veins; calyx and corolla none; fruit ripens the last of June to August, similar to the fruit of the blue ash, samaras generally $3-4 \mathrm{~cm}$. long, and 7-10 mm. wide, body winged all around, the base of the samara rounded, the apex notehed or rounded, the apical end of the samara twisted more or less to the right in all specimens at hand.

Distribution.- Nova Scotia to Manitoba, south to Virginia and northern Arkansas. Local in all parts of Indiana except in the "knob" area of the State. It is generally found in places that are inundated much of the winter season. Its habitat is in cold swampy woods or similar places about lakes. It has no special affinity for streams. It is local in its distribution. Where it is found it is generally a frequent to common tree. In the lake area of Indiana its habitat conditions are frequent, consequently colonies of it are frequent. South of the lake area of the State it becomes rare to extremely local. In the southwest part of the State it has been sparingly found in a few cypress swamps. It is usually associated with white elm, cottonwood, aspens, red maple, hur oak, and is one of the first species to invade extinct tamarack swamps. 
Plate 1:30.

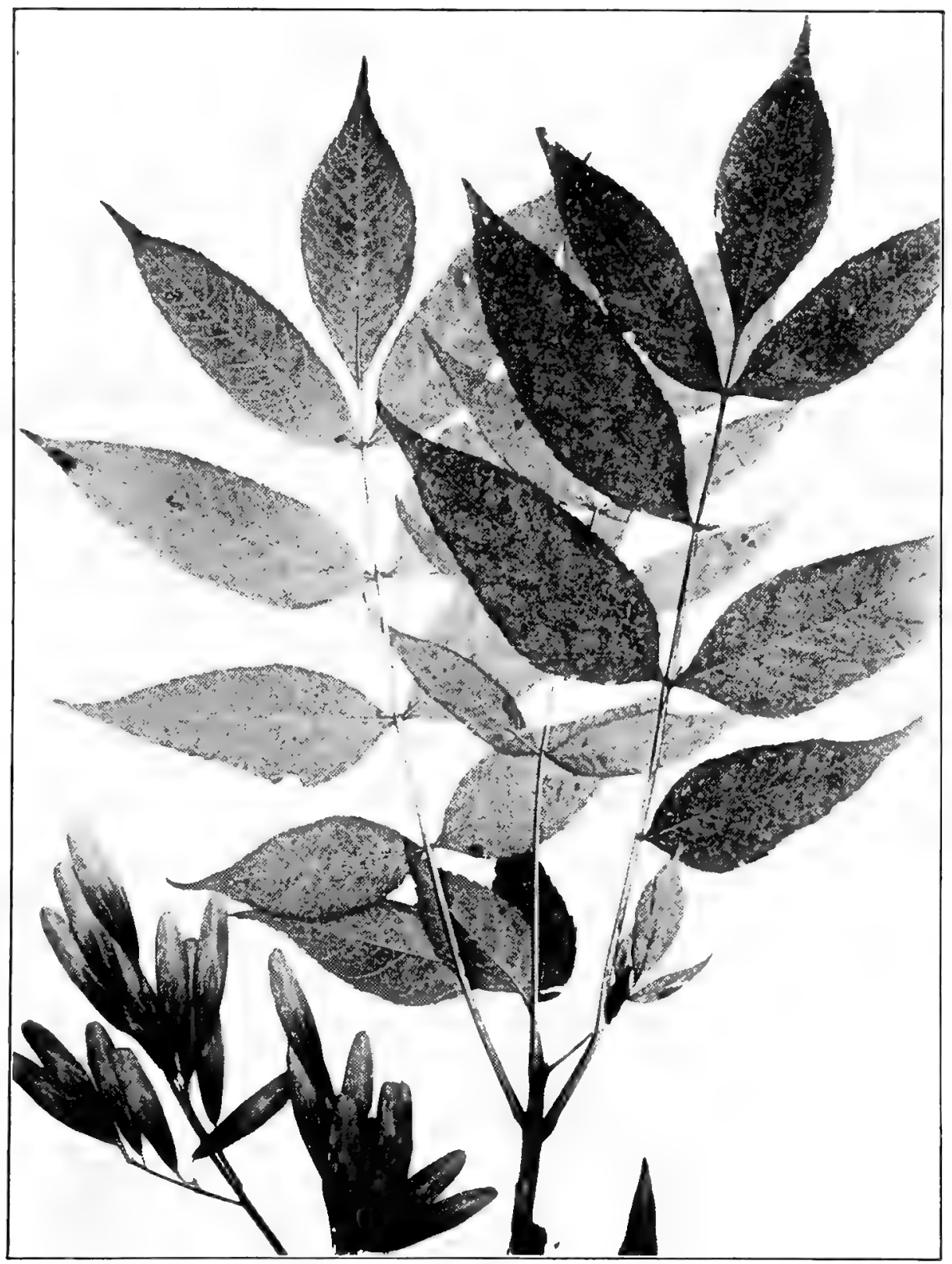

FRAXINUS NIGRA Marshall. Black Ash. (x 1/2.) 
Remarks. - The wood is tougher but in most qualities is inferior to white ash and cannot be used for handles. The layers of growth separate easily which enables the wood to be separated into thin strips. This fact was known to the Indians who used this wood for making baskets. This use was continued by the white man and in addition it was a farorite wood for making hoops, and in many sections it is known as the "hoop ash." The wood has many uses such as for baskets, splint boxes, butter tubs, vehicle stock, interior finish, furniture, etc. The black burls of the trunk are much sought for by veneer manufacturers.

\section{ADELIA.}

Adèlia acuminàta Michaux. Pond Brush. Crooked Brush. Plate 131. Small trees, or shrub like, with gray smooth bark, becoming rough or fissured on large trees, the ridges short and broken; branchlets numerous and somewhat spiny; twigs glabrous; leaves opposite on petioles about $1 \mathrm{~cm}$. long, ovate to elliptic-ovate, $4-11 \mathrm{~cm}$. long, with a long narrow base, long acuminate at the apex, margins entire near the base, the remainder more or less coarsely serrated with short rounded teeth, rarely entire, smooth above and beneath; flowers appear last of March to the first of May, the staminate in small sessile clusters along the branchlets, the pistillate in short panicles; fruit a dark purple drupe, oblong, about $15 \mathrm{~mm}$. long; stone with many longitudinal ribs.

Distribution.- Southwestern Indiana and southern Illinois south to northern Florida and Texas. In Indiana it has been found only in Knox, Gibson, Posey and Perry Counties. It grows on the low borders of river sloughs, swamps and river banks. It is very tolerant of shade and may be found growing under larger trees. It usually forms dense thickets on the bank that surrounds standing water and is usually associated with button-bush. A straight specimen is rarely seen because the area where it grows overflows each winter, and the small trees are usually covered more or less with debris, and then the following scason the side branches assume a vertical growth. The top may be released by the next inundation, and then other branches may assume leadership, and so on until the top is a mass of branches growing in several directions. The specimens found in Perry County grew on the low bank of the Ohio River about 6 miles east of Cannelton. The species is quite local in the area where it is found. It may border one river slough, and be entirely absent from another nearby.

Remarks. - Of no economic use. In books it is called "swamp privet" but in the area where it grows it is not known by that name. 
Plate 1:1.

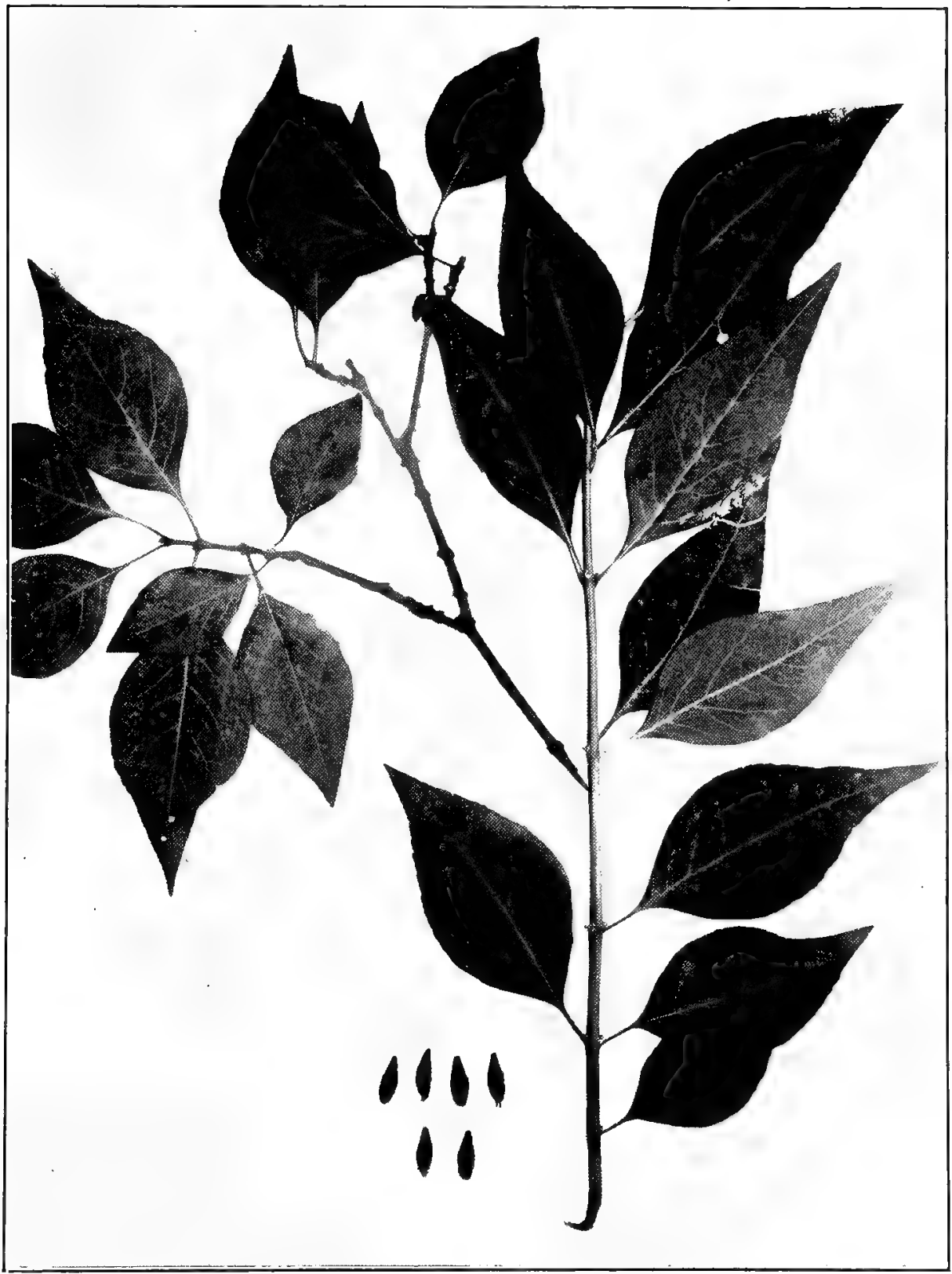

Adelia ACUMinata Michaux. Pond Brush. Crooked Brush. (x 1/2.) 


\section{Bignoniàceate. The Trumpet Creeper Family.}

\section{Catíl ta. The Catalpas.}

Leaves simple, opposite or whorled, with long petioles; flowers in terminal panicles or corymbs; fruit a long round pod which splits into halves; seed many, flat, papery with a tuft of long hairs at each end.

A small genus of widely distributed trees. The species freely hybridize, and have been cultivated and planted so extensively that it is difficult to find typical specimens.

Bark of old trees thin and sealy; odor of bruised leaves fetid;

lower lobe of corolla $\in$ ntire................. 1 Catalpa hignonioides.

Bark of old trees fissured and ridgy; odor of bruised leaves not

fetid; lower lobe of corolla notehed at the apex........ 2 Catalpa speciosa.

1. Catalpa bignonioides Walter. Catalpa. (Catalpa Catalpa (Limnæus) Kiarsten). Plate 132. Medium to large sized trees, usually with a trunk 1-3 meters in length, and a wide crown; bark a grayishhrown, scaly and flaking off in small thin plates; leaves ovate, blades usually 1.5-2 dm. long, cordate at the base, taper-pointed at apex, margins entire, or with 1 or 2 lateral lobes, yellow-green and smooth above, and pubescent beneath; flowering period the last of May to the first of July, about two weeks later than the next species; inflorescence in a rather compact large panicle; flowers white, usually $2-3 \mathrm{~cm}$. across at expanded end; marked on the lower inner surface by two rows of yellow blotches, the lower lobes marked with purplish spots, the lower lobe entire or nearly so; fruit a long pod, generally 4-10 develop in each panicle, usually $1.5-4 \mathrm{dm}$. long, about $1 \mathrm{~cm}$. thick, somewhat flattened, the valves meeting at an angle which forms a ridge which is sensible to the fingers, the valves of the pod are thin, and become flat after they open; seed 2.5-4.5 cm. long, including the tufts of hairs at each end, and about 4-5 mm. wide, the tuft of hairs usually converging to a point.

Distribution.-Supposed to be native to parts of Florida, Georgia, Alabama and Mississippi. It has been introduced throughout the eastern part of the United States. In Indiana it has been used in all parts as an ornamental and shade tree. It has few qualities to recommend it, and since the difference between this and the next species has been known the next species is usually substituted for it.

2. Catalpa speciòsa Warder. Catalpa. Hardy Catalpa. CatalFA. Plate 133. Medium to large sized trees with long and rather straight trunks when grown in the forest; bark dark grayish-brown, fissured and much resembling the bark of a linden or black walnut in appearance; leaves ovate, generally $1.5-3 \mathrm{dm}$. long, cordate or some- 
Plate 132

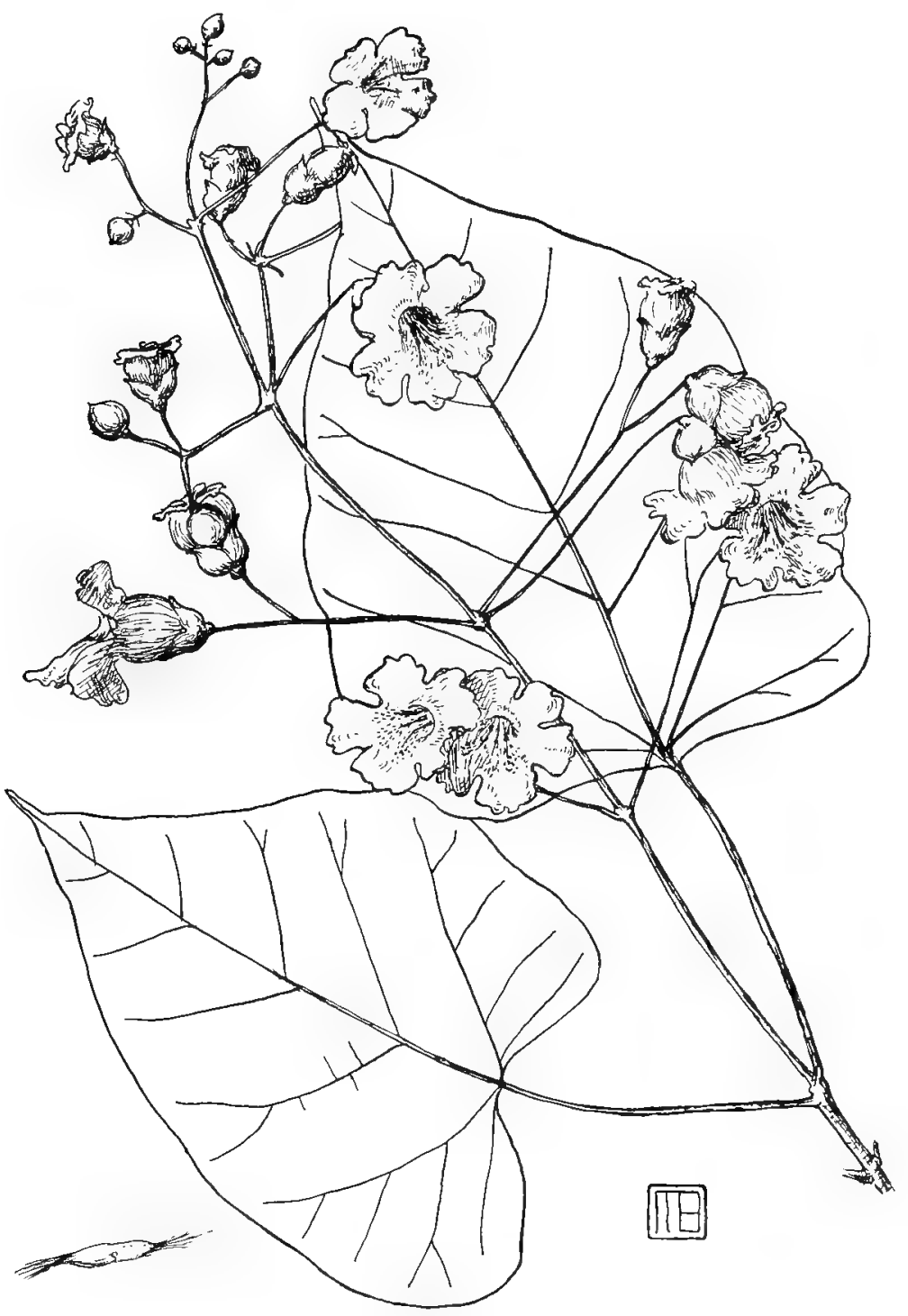

CATAIPA BIGNONIOIDES Waltel. Catalia. (x 1/2.) 
Plate $1:$ :

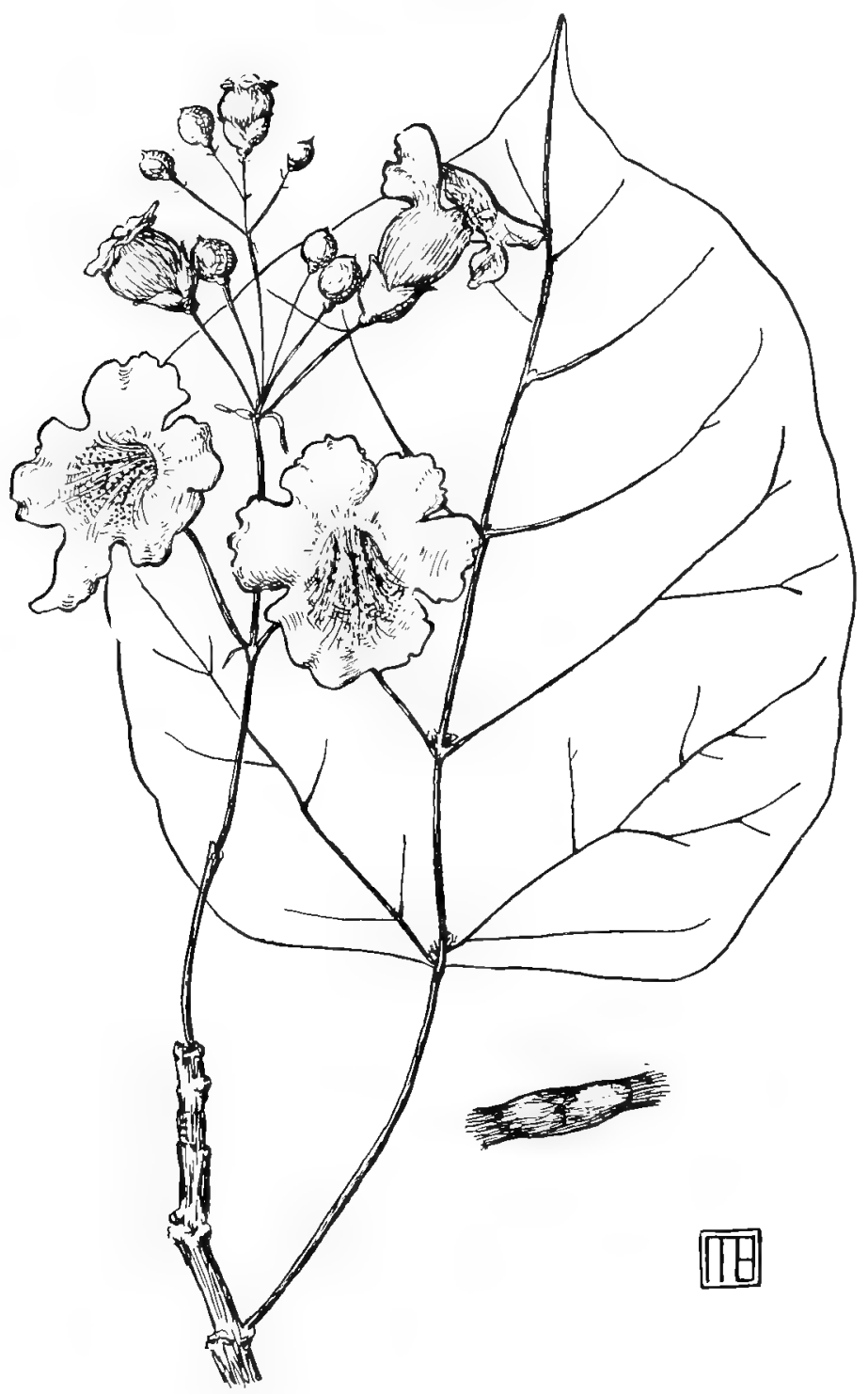

Catalpa speriosa Wardel. Catalla. Hirdy Catalya. (x 1/2.) 
what rounded at the base, long taper-pointed at apex, margins entire, dark green and smooth above, pubescent beneath; flowering period May or June; flowers in large terminal panicles, white with yellow and purplish spots within, expanded part about $4 \mathrm{~cm}$. across; fruit a long cylindrical pod which matures late in autumn or early winter, $2-5 \mathrm{dm}$. long, and about $1.5 \mathrm{~cm}$. in diameter, usually 1 or 2 and rarely 3 pods develop in a panicle, the valves of the pod remaining semi-terete after separating; seed many, thin and papery, 2.5-5 $\mathrm{cm}$. long, and 4-8 $\mathrm{mm}$. wide, body of samara about equals in length the tuft of hairs at each end, the hairs remain separated and are little inclined to form a tuft at the end.

Distribution.- Known to have been a native of the southwestern part of Indiana, and to have followed the valley of the Ohio and Mississippi Rivers to the southeastern part of Missouri and the northeastern part of Arkansas. The tree has practically disappeared from the forests of Indiana, and the exact range in Indiana can never be known. Being such a conspicuous tree, it was thought that the memory of living pioneers might be relied upon to fix the limits of its range in Indiana. One pioneer living near Austin in Scott County said it was a native of the Muscatatuck bottoms, and another said it was a native in the flats of the southwestern part of Clark County. In its native habitat it was found only in very low ground, usually with such associates as pin oak, sweet gum, southern hackberry, big shell-bark hickory, pecan, etc. In its native habitat it was an infrequent to a frequent tree, never a common tree. A pioneer was interviewed who settled in the Knox County bottoms about three miles west of Decker, when the whole area was a virgin forest. He said the catalpa was an occasional tree in the bottoms throughout the area; that he did not recall that it was ever found in as low situations as the cypress; that the tree was as tall as its associates, straight, and usually about $6 \mathrm{dm}$. in diameter, and that he never saw a tree a meter in diameter; that on account of the durable quality of the wood that it was cut for fence posts and rails. A pioneer who lived near the mouth of Deer Creek in Perry County said it was a native in his vicinity. The information at hand would fix the mass distribution of the species to the southwest of a line drawn from Terre Haute to a point about 6 miles east of Grandview in Spencer County.

Remarks.-Attention was directed to this tree about 1880 by Dr. Jno. A. Warder and Dr. Geo. Engelmann, and it has had enthusiastic admirers ever since. In Indiana its most enthusiastic advocate was John P. Brown of Connersville. Its popularity was based upon the durability of its wood and its rapid growth. Nurserymen grew seedlings and through their agents plantations of all sizes were sold in many 
States. The trees were planted to grow posts, telephone poles and crossties. In Indiana there is one plantation 42 years old, but the majority are only 10 to 15 years old. The tree has been planted long enough in our area to definitely conclude that it should not be planted in any part of Indiana for economic purposes. The range of the catalpa sphinx which defoliates the tree is rapidly increasing, and now ranges as far north as Wells County. In the southern part of the State the trees are usually defoliated twice each year by the larvae of this insect, and as a consequence the trees make very little growth, and some owners of plantations have abandoned them on this account. A new insect is appearing which kills the young shoots, which will interfere with the upright habit of the tree. The catalpa is not recommended for forest planting in Indiana, and its use for this purpose has practically ceased.

The catalpa prefers a moist, deep, rich soil, but will grow in almost all kinds of situations. In the northern part of the State, the young trees are frequently winter killed. The tree is quite tenacious of life and when cut off at the ground, usually sends up several coppice shoots.

This species can be recommended for planting for shade for hog lots, and as a specimen tree in parks, etc. It is not a desirable street tree.

\section{CAPrifoliàceae. The Honeysuckle Family. VIBÜRNUM. The Viburnums.}

Viburnum prunifòlium Linnæus. BLAck HAw. Plate 134. Small trees or shrubs; bark of old trees reddish-brown, furrowed and the ridges broken into short lengths; leaves simple, opposite, on petioles $0.5-1.5 \mathrm{~cm}$. long; the lower pairs of leaves are generally smaller and have their petioles more or less winged, red and more or less densely covered with a rusty tomentum which may extend along the midrib and veins beneath or may sometimes cover a considerable part of the lower surface of the leaf while young, sometimes the margined petioles are only rough on the margins; leaf blades very variable in size and shape, usually 4-10 $\mathrm{cm}$. long, ovate to slightly obovate, or narrow-oval to nearly orbicular, narrowed or rounded at the base, pointed at the apex, or sometimes rounded, margins finely serrate, glabrous both above and beneath at maturity; flowers appear the last of April or in May in cymes which are sessile or nearly so, flowers white, numerous, and generally about 0.5 cm. in diameter, fruit ripens in September and October, oval, oblong or nearly globose, generally $10-14 \mathrm{~mm}$. long, dark blue, covered with a bloom, edible, and if not eaten by birds they persist on the branches unt il late autumn; stone oval and very flat. 
Plate 134.

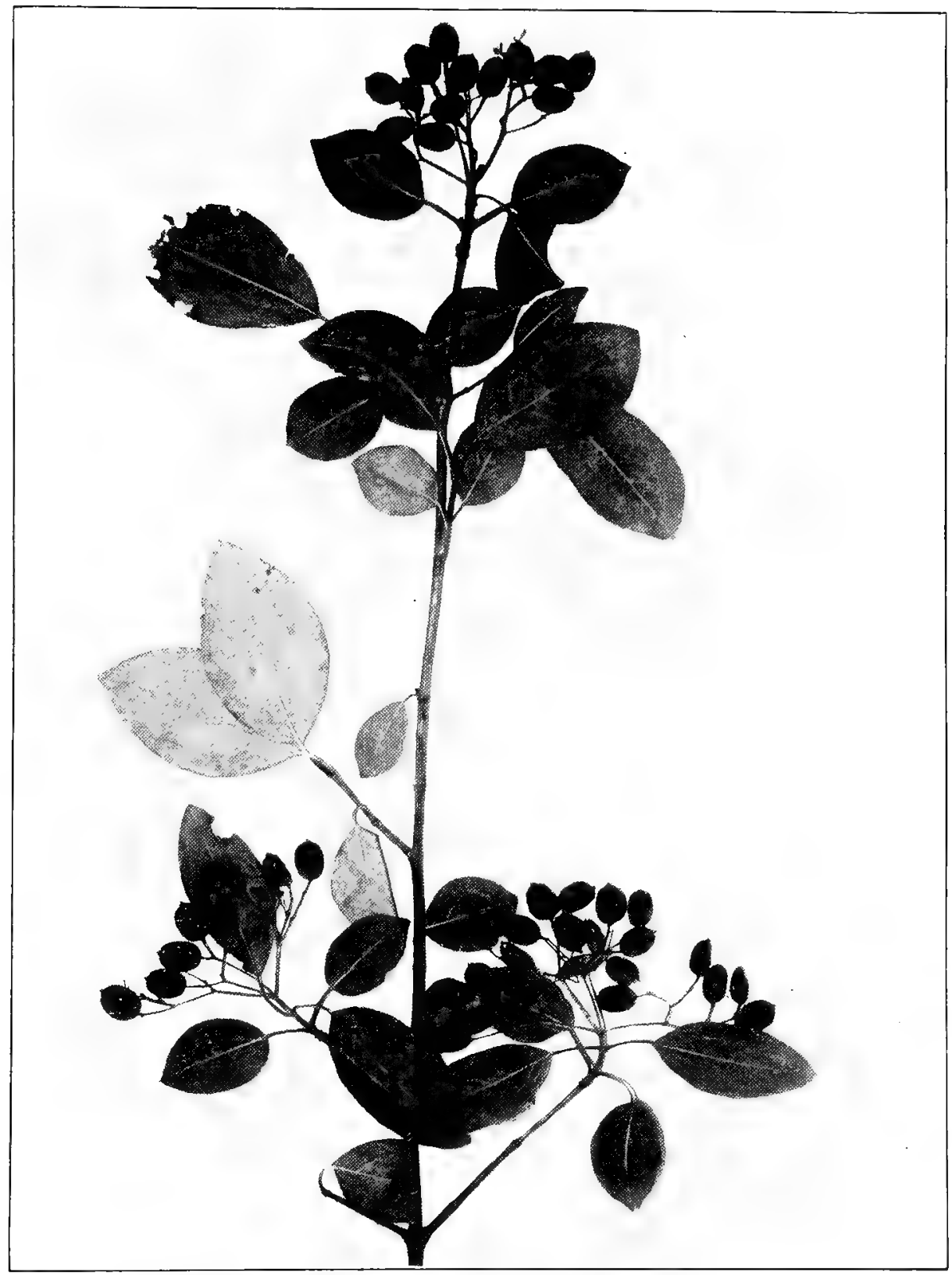

VIBURNUM PRUNIFOLIUM Linnæus. BLACK HAW. (x1/2.) 
Distribution.-Connecticut to Iowa and south to Georgia and west to Texas. It is more or less frequent in moist woods throughout Indiana, except in the hilly counties where it becomes more or less rare. In the hilly counties its place is taken by the southern black haw, Viburnum rufidulum which only rarely attains tree size.

Remarks.-This species could be used to advantage in ornamental planting where small trees or shrubs are required for a screen or back ground. The fruit of the black and red haws attract several species of birds.

This species is quite variable in the shape, and texture of its leaves, and in the size and shape of its fruit. In the southern part of the State specimens are found that have very thick leaves with margined and tomentose petioles which very much resemble the southern species.

\section{SPECIES EXCLUDED.}

The following species have been reported for Indiana but have been excluded for want of satisfactory evidence to warrant their inclusion: The reasons for exclusion are cliscussed under the name of the species. It is needless to say that critical examination has been given doubtful species, and doubtful records, and every effort possible has been made to validate them.

Pinus echinàta Miller. Short-Leaf Pine. This species does not occur in our area and all reference to it should be transferred to Pinus virginiana. References to this species are instances of wrong determination.

Pinus resinòsa Aiton. Norway Pine. This species was reported as an escape in Wabash County by Coulter ${ }^{1}$ for Jenkins.

Pinus rigida Miller. Pitch Pine. Baird and Taylor ${ }^{2}$ reported this species for Clark County. The range of this species is to the east of our area. They also reported Pinus Strobus, which has not been seen since they reported it, and they failed to report Pinus virginiana which is a common tree on the "knobs" of Clark County. A study of their flora of Clark County shows that they did little or no collecting in the "knobs." They also freely reported field crop, garden and flower escapes, and it is believed that their reference to Pinus rigida and Pinus Strobus should be regarded as to cultivated trees.

Àbies balsàmea (Linnæus.) Miller. Balsam Fir. Heimlich ${ }^{3}$ reports this as occurring in Porter County about Dune Park. He

\footnotetext{
${ }_{1}$ Proc. Ind. Acad. Sci. 1900:141:1901.

Mranual Public schools Clark County, Ind. 1878-9, page 62 .

Proc. Ind. Acad. Sci. 1917:403:1918.
} 
cites for his authority Bot. Gaz. Vol. 27: Apr. 1899. The article referred to is Cowles' article on the flora of the sand dunes of Lake Michigan, in which he discusses the flora from Glen Haven in northern Michigan to Dune Park, Incliana in Porter County, which has confused Heimlich in separating the trees reported at several stations. It has never been found in Indiana.

Chamaecyparis thyoides (Linnæus) Britton, Sterns and Poggenberg. White Cedar. The range of this species is east of the Alleghany mountains and no doubt was never native in our area. The first reference to it is by Dr. Drake in his Picture of Cincinnati, published in 1815, page 83, in which he says: "The White Cedar and Cypress are found on the banks of the Wabash." Schneck in his Flora of the Lower Wabash Valley says: "Wet places near the mouth of the Wabash River." I am certain it is not on the Indiana side of the river. Gorby ${ }^{2}$ reports it for Miami County. All of his botanical records are too unreliable to receive serious consideration. Coulter ${ }^{3}$ reports it as found in Allen County on the authority of Dr. C. R. Dryer. I saw Dr. Dryer recently and he says he has no recollections about it.

Juniperus commùnis Linnæus. JunIPER. This species has been reported from all parts of the State. The distribution of the species is to the north of Indiana, and examining herbarium specimens it is found that subulate forms of Juniperus virginiana are frequently named Juniperus communis. In the older floras it was a custom to include cultivated forms, and not distinguish them as such. Since juniper has been for years a common ornamental shrub, especially in cemeteries, it is highly probable that many records have such a basis. It is proposed to drop this species from our flora. I refer Higley and Raddin's ${ }^{4}$ record to the decumbent variety. VanGorder's and Bradner's records may also be the decumbent form. Heimlich's record I regard as an error, see remarks under Abies balsamea.

Populus balsamífera Linnæus. Balsam Poplar. This species was reported by Bradner for Steuben Counry. In a letter from the late Prof. Bradner, he said he had no specimen and had no recollection of the tree. J. M. Coulter reported it for Jefferson County, but Young who also wrote a flora of Jefferson County does not mention it. Baird and Taylor also reported it for Clark County. The last two records may have been from cultivated trees or mistaken for Populus grandidentata which was not reported and is in the area, and is a frequent tree in the "knobs" in Clark County. Heimlich reports it in Proc. Ind. Acad.

${ }_{1}$ Rept. Geol. Surv. Ind. 7:562:1876.

2Rept. Geol. Surv. Ind. 16:168:1889.

${ }_{3}^{2}$ Rept. Geol. Surv. Ind. 24:617:1900.

4Sci. Bul. Chic. Acad. Vol. 2:148:1891. 
Sci. $1917: 404: 1918$ for Cowles. I regard this as an error. See discussion under Abies canadensis on page 290. Since the range of the species is to the north of Indiana, it is here proposed to drop it from our flora. It should be looked for on the "divide" in Steuben County and about Lake Michigan.

Populus cándicans Aiton. Balm of Gilead. This species has been included in a few local floras, but it is believed that it has not yet escaped from cultivation. Phinney" gives it as "an important timber tree of Delaware County," which is an error.

Populus nigra var. itálica Du Ror. Lombardy Poplar. Reference is made to this tree by Blatchley ${ }^{2}$, Meyncke ${ }^{3}$ and Nieuwland ${ }^{4}$ but it is scarcely more than an accidental escape.

Carya aquática Nuttall. WATER Hickory. This species is listed as one of the principal trees occuring along the Wabash in the Coblenz edition of Prince Maximilan's travels in North America. It is recorded as "Water Bitternut (Juglans aquatica)." If it occurs in our area it most likely would be found in the extreme southwestern counties. It has been reported from Gallatin County, Illinois, bordering Posey County on the west. There are two other records of its occurrence in the State, which are doubtful. Ryland $\mathrm{T}$. Brown ${ }^{5}$ reported it in a list of the principal trees of Fountain County in a report of the geology of Fountain County. Carya laciniosa, which is sometimes called swamp hickory and which is more or less frequent in the county, he failed to report. It is believed this reference to Carya aquatica should be referred to laciniosa. B. C. Hobbs also reported it as common in Parke County in a short list of the principal trees. He named only four of the five or more species of hickory that occur in the county, and it is believed since he was no botanist, that he confused the names. Elliott in his Trees of Indiana gives "Carya aquatica" as common, but no doubt this reference should be transferred to some other species.

Carya myristicaefómis Nuttall. NutMeg Hickory. This tree also was reported by Prince Maximilian as occurring along the Wabash River. The known range of the species is from North Carolina to Arkansas, and for this reason the species is not included in this list.

Betula lénta Linnæus. Black Birch. This species has been reported for Indiana as occurring in Fulton, Gibson, Miami, Noble, Posey, St. Joseph and Steuben Counties. Sargent ${ }^{6}$ says: "This species

${ }^{1}$ Ind. Geol. Rept. 11:148:1881.

Blatchley siss. Flora of Monroe County, Ind. June 1887.

${ }^{3}$ Bul, Brockville Nat. Hist. Soc. No. 1:38:1885.

4 A mer. Midland Nat. Vol, $3: 222: 1914$.
${ }^{5}$ It is said that this list and that of Hohb's list of trees of Parke county were prepared by obtaining from farmers a list of the common narnes of the trees to which they attached botanical names.

sargent in a letter to the author 
has until recently been badly misunderstood. The range of the species is southern Maine to northwestern Vermont, eastern Kentucky, and south to Delaware and along the Appalachian Mountains to northern Georgia and Alabama." No doubt all of the Indiana records should be transferred to Betula lutea, except the Gibson and Posey County record which may be Betula nigra.

Castanea púmila (Linnæus) Miller. Chinquapin. This species was given a place in our flora in Coulter's catalogue upon the authority of Sargent, Ridgway and Schneck. Ridgway, in giving an additional list of the trees of the Lower Wabash Valley" says: "There is some doubt as to No. 16 Castanea pumila, which is given on Prof. Sargent's authority; but there is a possibility of an error having been made from the circumstances that the name 'chinquapin' is in that region almost universally applied to the fruit of Quercus Muhlenbergii." The Posey County record was based on a specimen in Dr. Schneck's herbarium, which proves to have been taken from a cultivated tree near Poseyville.

Quercus ilicifòlia Wangenheim. BEAr OAK. This species is credited to our flora by Will Scott in his ecological study of "The Leesburg Swamp" in Kosciusko County, published in the Indiana Academy of Science, 1905 , page 225. In a reply to an inquiry addressed to him he says no herbarium material was preserved. This ecological work was done during the summer months while working at the biological station at Winona Lake. In a footnote in this paper we are informed that for the identification of the trees listed, Apgar's Trees of the Northern United States was used. In this key to the trees, Quercus velutina (Black Oak) is given only as a variety of Quercus coccinea (Scarlet Oak), and the distinction between Quercus velutina with its many formed leaves, and Quercus iticifolia is not made apparent. In view of the fact that the natural habitat of Quercus ilicifolia is sandy barrens and rocky hillsides and its western range is eastern Ohio, it is believed what Mr. Scott had in hand was a variable form of Quercus velutina, which is frequent in that vicinity. The evidence is not encouraging enough to include it.

Quercus nigra Linnæus. Water OAK. This species has been reported by several authors for Indiana. It is believed that a majority of the records should be transferred to velutina and imbricaria or marylandica. Gorby and Schneck call Quercus nigra black jack oak, which is generally the common name for Quercus marilandica. Ridgway in his writings of the flora of the lower Wabash Valley, likewise speaks of Quercus nigra as jack oak and says it is found in poor soil. Coulter in his catalogue of Indiana plants regarded these references to nigra

'Proc. U.S. Nat. Mus, 17:415. 
as errors and did not include it in his list. The report for Crawford County by Deam should be transferred to marilandica. Since the range of the species is not north of Kentucky, the reference to the species in the State should be dropped.

The published records are as follows: Carroll (Thompson); Crawford (Deam); Delaware, Jay, Randolph and Wayne (Phinney); Jay (McCaslin); Fountain (Brown); Miami (Gorby); Parke (Hobbs).

Quercus Phéllos Linnæus. WILLOW OAK. This species has been reported from various counties of the State. The tree is said to grow in swamps and on sandy uplands, ranging from Staten Island, New York, south to Florida and west to Texas, and north to southern Kentucky. If it occurs within our area it no doubt would have been found by Dr. Schneck, who was an enthusiastic student of the oaks. He reported it as occurring in the lower Wabash in his early writings, but his herbarium contained no specimens. The writer while in search for this species in Posey County met three men in widely separated parts of the county who were acquainted with the species in the South and they said they had never seen it in Indiana. One of the men was an old man who had spent his boyhood in Arkansas and he was well acquainted with the willow oak before he came to Indiana. It is believed what has been reported for $Q$. Phellos has been narrow-leaved forms of Q. imbricaria (shingle oak), and that the records should be transferred to that species.

The published records are as follows: Gibson, Knox and Posey (Schneck); Knox (Thomas); Miami (Gorby).

Quercus prinoides Willdenow. Scrub or Dwarf Chesnut OAE. Reported for Marshall County by Nieuwland ${ }^{1}$ on the authority of a specimen deposited in the National Museum collected by Clark. I had this reference checked by $\mathrm{E}$. S. Steele and in a letter to me dated J anuary 4,1917, he says: "I find no specimen labeled Quercus prinoides, but there ss one named $Q$. Prinus. There is no ground for calling it $Q$. prinoides." Since the specimen in question is a very immature one, I propose not to take it into consideration since the range of the species would be extended on a dubious specimen.

Planèra aquática (Walter) J. F. Gmelin. Planer-tree. Water Elm. This tree was included in Coulter's catalogue upon the authority of Sargent, who includes Indiana in the range of the species in his "Forest Trees of North America," Vol. 9, U.S. Census Report, 1880, page 124. Dr. Schneck spent a lifetime along the lower Wabash bottoms and very carefully preserved specimens of all the flora of the region where this species is reported to occur. In his report of the flora of this

${ }^{1}$ American Midland Naturalist $3: 320: 1914$. 
region in 1875 he does not include this tree. An examination of his herbarium material showed no specimens of this tree either from Indiana or Illinois. It is fair to presume if he had been acquainted with the tree he would have had it represented in his herbarium. Since the white elm is frequently called water elm, as well as the planer-tree, it is easy to understand how confusion might arise in separating these trees by non-professional people.

Morus nigra Linnæus. Black Mulberry. This species is reported by Phinney" as one of the "more important and common forest trees observed in Delaware County." He also enumerates Morus rubra. A splendid example of careless work. This species is reported by Brown ${ }^{2}$ for Fountain County, and by McCaslin ${ }^{3}$ for Jay County. These authors reported this species as a native forest tree. Since this species is not a native of the United States the citations no doubt should be referred to our native mulberry, Morus rubra (red mulberry).

Ìlex opàca Aiton. Holly. This species was included in Coulter's Catalogue of the Plants of Indiana on the authority of Robert Ridgeway. I find no reference to this species in the writings of Ridgway.

In Shawnee Park on the west side of Louisville, Kentucky is a large tree of this species. I was told that it was a native. A timber buyer of Tell City told me that there was a native tree on his grandfather's farm in the southern part of Perry County. Since this species has been reported for Grayson County, Kentucky, which is less than forty miles to the south, it is quite probable that a few trees were found as far north as Indiana.

Acer pennsylvánicum Linnæus. Moosewood. The only record of this species occuring in Indiana is in a report of the Trees occuring along the Wabash River by Prince Maximilian. Since the report does not definitely state where the species was observed or how frequently it occured and since the greater part of Maximilian's time was spent on the Illinois side of the Wabash, it is more than likely that he observed it on the Illinois side of the Wabash. While Indiana is within the possible range of the species, it has not been discovered since. If not extinct in our area it is most likely to be found among the hills of the southern counties or in the vicinity of Lake Michigan. Robert Ridgway says that he and Dr. Schneck saw it growing in a wooded cove near a cavern called Flory's Cave in Johnson County, Illinois.

Nyssa aquática Linnæus. Tupelo Gum. Several early authors erroneusly reported Nyssa sylvatica as this species. This species inhabits deep swamps. Dr. Schneck and Robert Ridgway, recognized

\footnotetext{
'Ind. Geol. Rept. 11:148:1881.

2Ind. Geol. Rept. 11:123:1882.

Ind. Geol. Rept. 12:174:1883.
} 
authorities and best acquainted with the swamp area of the south. western counties, at first thought it was a member of our flora, but later decided that it should be excluded.

Michael Catt, 83 years old, who lived nearly 75 years about three miles west of Decker on the border of the cypress swamp in the south part of Knox County, told me that he is positive that the tupelo gum was an occasional tree in the cypress swamp west of Decker.

Fraxinus caroliniàna Miller. WATER Ash. This species was included in Coulter's Catalogue of Indiana Plants upon the authority of Dr. Schneck. It is asserted that specimens were sent to Missouri Botanical Gardens for verification. The writer has carefully examined all the specimens of Fraxinus in the Missouri Botanical Gardens, and all of Schneck's specimens in the herbarium are now correctly named Fraximus profunda. Since this species is not in our range it should be dropped from our flora. 


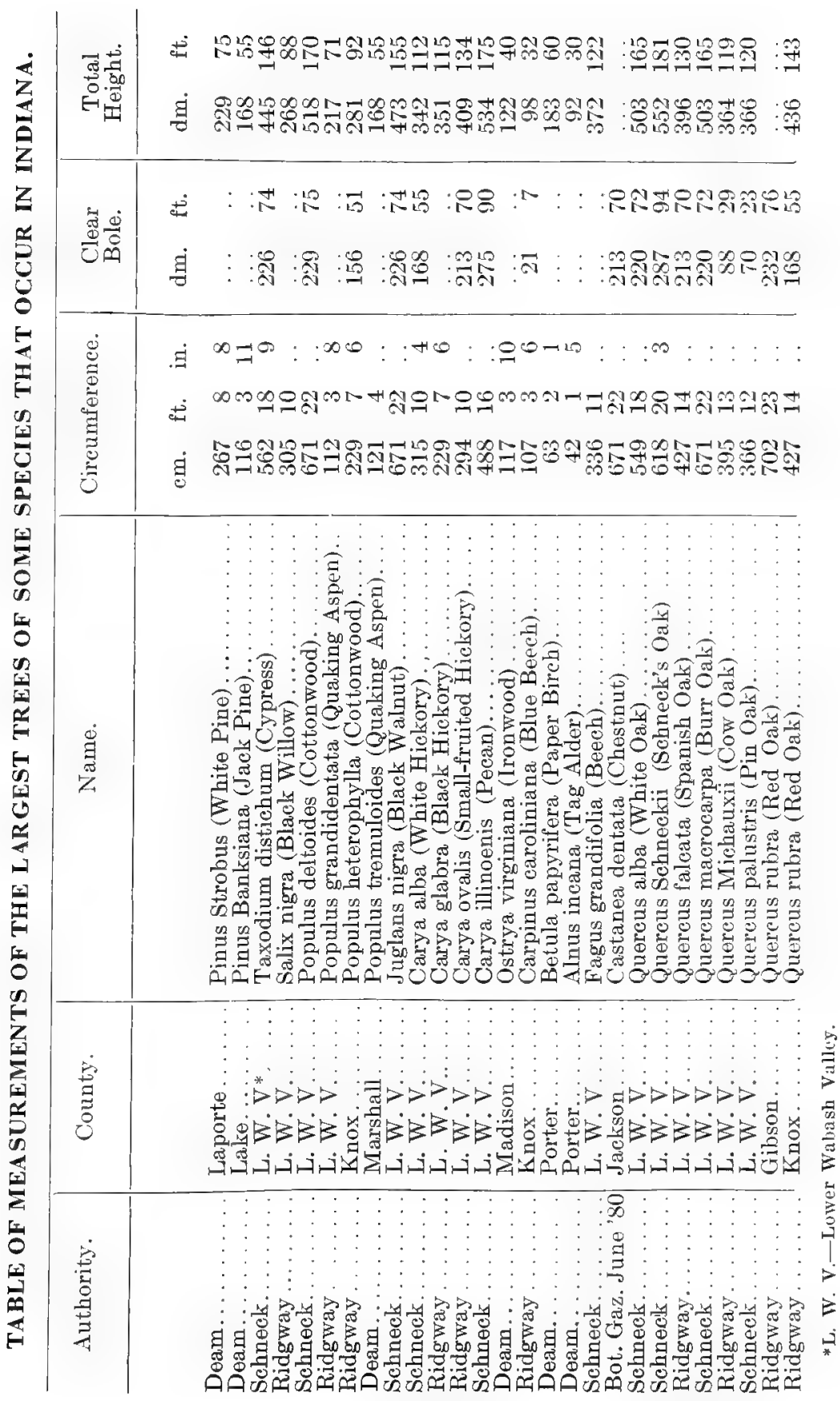




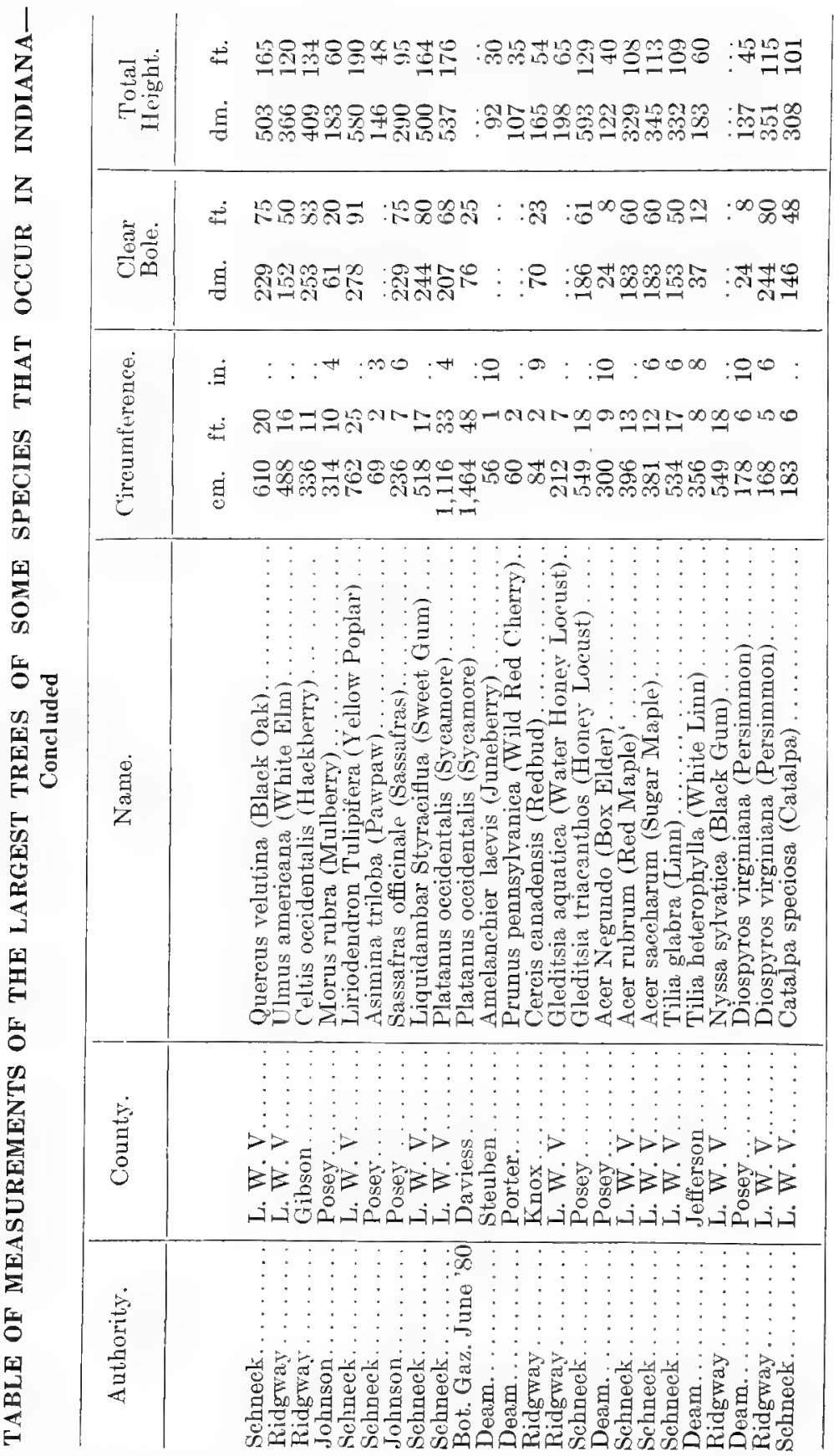




\section{Specific Gravity of Indiana Woods.}

The specific gravity was derived from wood dried at $100^{\circ}$ centigrade (212 Fah.) until it ceased to lose weight.

Carya ovata (Shellbark Hickory) . . . . . . . . . . . . . . . . . . . . . 0.8372

Quereus stellata (Post Oak) . . . . . . . . . . . . . . . . . . . . 0.8367

Viburnum prunifolium (Black Haw) . . . . . . . . . . . . . . . 0.8332

Quereus lyrata (Overcup Oak) .......................... 0.8313

Ostrya virginiana (Ironwood) . . . . . . . . . . . . . . . . . . . 0.8264

Carya alba (White Hickory) . . . . . . . . . . . . . . . . . . . . . . 0.8218

Carya glabra (Black Hickory) .... . . . . . . . . . . . . . . . . . . . 0.8217

Cornus florida (Flowering Dogwood) . . . . . . . . . . . . . . . . . 0.8153

Carya laciniosa (Big Shellbark Hickory) . . . . . . . . . . . . . . . . 0.8108

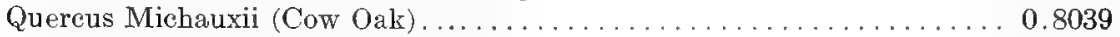

Diospyros virginiana (Persimmon) . . . . . . . . . . . . . . . . 0.7908

Amelanehier canadensis (Juneberry) . . . . . . . . . . . . . . . . . 0.7838

Maclura pomifera (Osage Orange) . . . . . . . . . . . . . . . . . . 0.7736

Quereus bicolor (Swamp White Oak) .................... 0.7662

Carya cordiformis (Pig Hickory) . ... . . . . . . . . . . . . . . . . . . 0.7552

Quereus imbricaria (Shingle Oak) . . . . . . . . . . . . . . . . . . . . . 0.7529

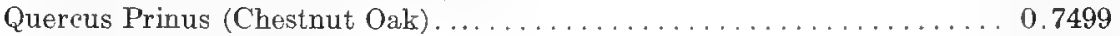

Ulmus alata (Cork Elm) ........................... 0.7491

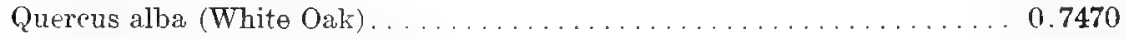

Quereus macrocarpa (Bur Oak) . . . . . . . . . . . . . . . . . . . 0.7453

Quereus coccinea (Scarlet Oak) ........................... 0.7405

Gleditsia aquatica (Water Honey Locust). ... . . . . . . . . . . . . . . . . 0.7342

Robinia Pseudo-Acacia (Black Locust) . . . . . . . . . . . . . . . . . . . 0.7333

Quercus marilandica (Black Jack Oak)..................... 0.7324

Celtis occidentalis (Hackberry) . . . . . . . . . . . . . . . . . . . . . . . 0.7287

Carpinus caroliniana (Water Beech) . . . . . . . . . . . . . . . . 0.7286

Ulmus Thomasi (Hickory Elm) . . . . . . . . . . . . . . . . . . 0.7263

Prunus americana (Wild Plum) ........................ 0.7215

Fraxinus quadrangulata (Blue Ash) . . . . . . . . . . . . . . . 0.7184

Carya illinoensis (Pecan) .... . . . . . . . . . . . . . . . . . . . . . . . . 0.7180

Malus glaucescens (Crab Apple)... . . . . . . . . . . . . . . . . . . . . . . 0.7048

Quereus velutina (Blnck Oak) . . . . . . . . . . . . . . . . . . . . . . . . . 0.7045

Ulmus fulva (Slippery Elm) . . . . . . . . . . . . . . . . . . . . . . 0.6956

Quercus palustris (Pin Oak) ........................... 0.6938

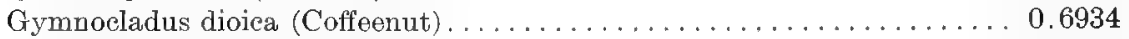

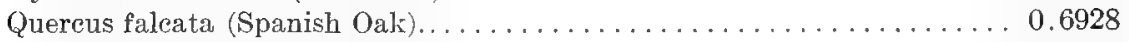

Acer nigrum (Black Maple)............................ 0.6915

Acer saccharum (Sugar Maple)........................... 0.6912

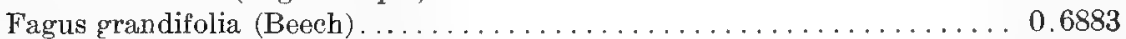

Gleditsia triacanthos (Honey Locust) ..... . . . . . . . . . . . . . . . . 0.6740

Betula lutea (Yellow Bireh) . . . . . . . . . . . . . . . . . . . . 0.6553

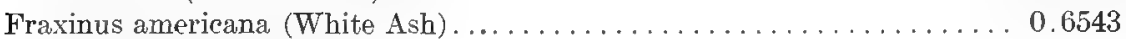

Quereus rubra $(\operatorname{Red}$ Oak) . . . . . . . . . . . . . . . . . . . . . . . . . . 0.6540

${ }^{1}$ Adapted from Sargent's "Trees of North America." 
Ulmus americana (White Elm) . . . . . . . . . . . . . . . . . . 0.6506

Cereis canadensis (Redbud) . . . . . . . . . . . . . . . . . 0.6363

Nyssa sylvatica (Black Gum) . . . . . . . . . . . . . . . . 0.6356

Adelia acuminata (Swamp Privet) ...................... 0.6345

Fraxinus nigra (Water Ash) . . . . . . . . . . . . . . . . . . 0.6318

Fraxinus pennsylyanica (Red Ash) . . . . . . . . . . . . . . . 0.6251

Larix laricina (Tamarack) . ........ . . . . . . . . . . . . . . . . 0.6236

Acer rubrum $($ Red Maple) . . . . . . . . . . . . . . . . . . . . . 0.6178

Juglans nigra (Black Walnut) . . . . . . . . . . . . . . . . . . . 0.6115

Betula papyrifera (Paper Birch) . . . . . . . . . . . . . . . . . . . 0.5955

Liquidambar Sty raciflua (Sweet Gum) .... . . . . . . . . . . . . . 0.5909

Morus rubra (Red Mulberry) . ... . . . . . . . . . . . . . . . . . . 0.5898

Prunus serotina (Wild Black Cherry) . . . . . . . . . . . . . . . . . . 0.5822

Betula nigra (River Birch) . . . . . . . . . . . . . . . . . . . . . . 0.5769

Betula populifolia (White Birch) . . . . . . . . . . . . . . . . . . . . 0.5760

Platanus oceidentalis (Syeamore) . . . . . . . . . . . . . . . 0.5678

Pinus virginiana (Jersey Pine) . . . . . . . . . . . . . . . . . . . . . . 0.5309

Acor saccharinum (Silver Maple)... . . . . . . . . . . . . . . . . . . . 0.5259

Sassafras offirinale (Sassafras) . . . . . . . . . . . . . . . . . . 0.5042

Prunus pennsylvanica (Wild Red Cherry) ................ 0.5023

Juniperus virginiana (Red Cedar)... . . . . . . . . . . . . . . . . . . . 0.4926

Pinus Banksiana (Gray Pine) ............................ . 0.4761

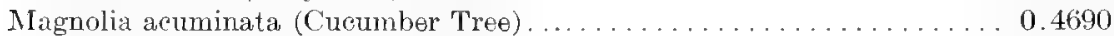

Alnus rugosa (Alder) . . . . . . . . . . . . . . . . . . . . . . . . . . . . 0.4666

Populus grandidentata (Quaking Aspen) . . . . . . . . . . . . . . . 0.4632

Alnus incana (Tag Alder) . . . . . . . . . . . . . . . . . . . . 0.4607

Taxodium distichum (Cypress) . . . . . . . . . . . . . . . . 0.4543

Asculus glabra (Buckeyt).. . . . . . . . . . . . . . . . . . . 0.4542

Tilia glabra $($ Linn $)$. . . . . . . . . . . . . . . . . . . . . . . . . . . . . . 0.4525

Castanea dentata (Chestnut) . . . . . . . . . . . . . . . . . . . 0.4504

Salix amygdaloides (Willow) . . . . . . . . . . . . . . . . . . . . . 0.4502

Catalpa bignonioides (Catalpa). . . . . . . . . . . . . . . . . . 0.4474

Salix nigra (Black Willow) . . . . . . . . . . . . . . . . . . . . . 0.4456

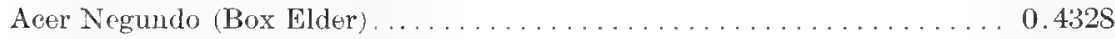

Esculus octandra (Swoet Buckeye)....................... 0.4274

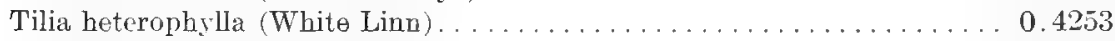

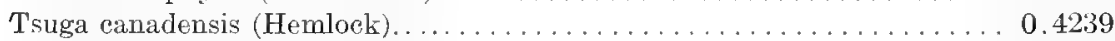

Liriodendron Tulipifera (Yellow Poplar) . . . . . . . . . . . . . . . 0.4230

Catalpa speciosa (Catalpa) . . . . . . . . . . . . . . . . . . . . 0.4165

Populus heterophylla (Downy Cottonwood) . . . . . . . . . . . . . . 0.4089

Juglans cinerea (Butternut) . . . . . . . . . . . . . . . . . . . . . . . . . 0.4086

Populus tremuloides (Quaking Aspen) . . . . . . . . . . . . . . 0. 4032

Asimina triloba (Pawpaw) . . . . . . . . . . . . . . . . . . . . . . . 0.3069

Populus deltoides (Cottonwood) . . . . . . . . . . . . . . . . . . . . 0.3889

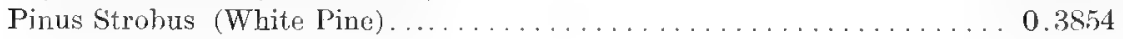

Thuja oreidentalis (Arbor-Vitæ........................ 0.3164 
Plate 135.

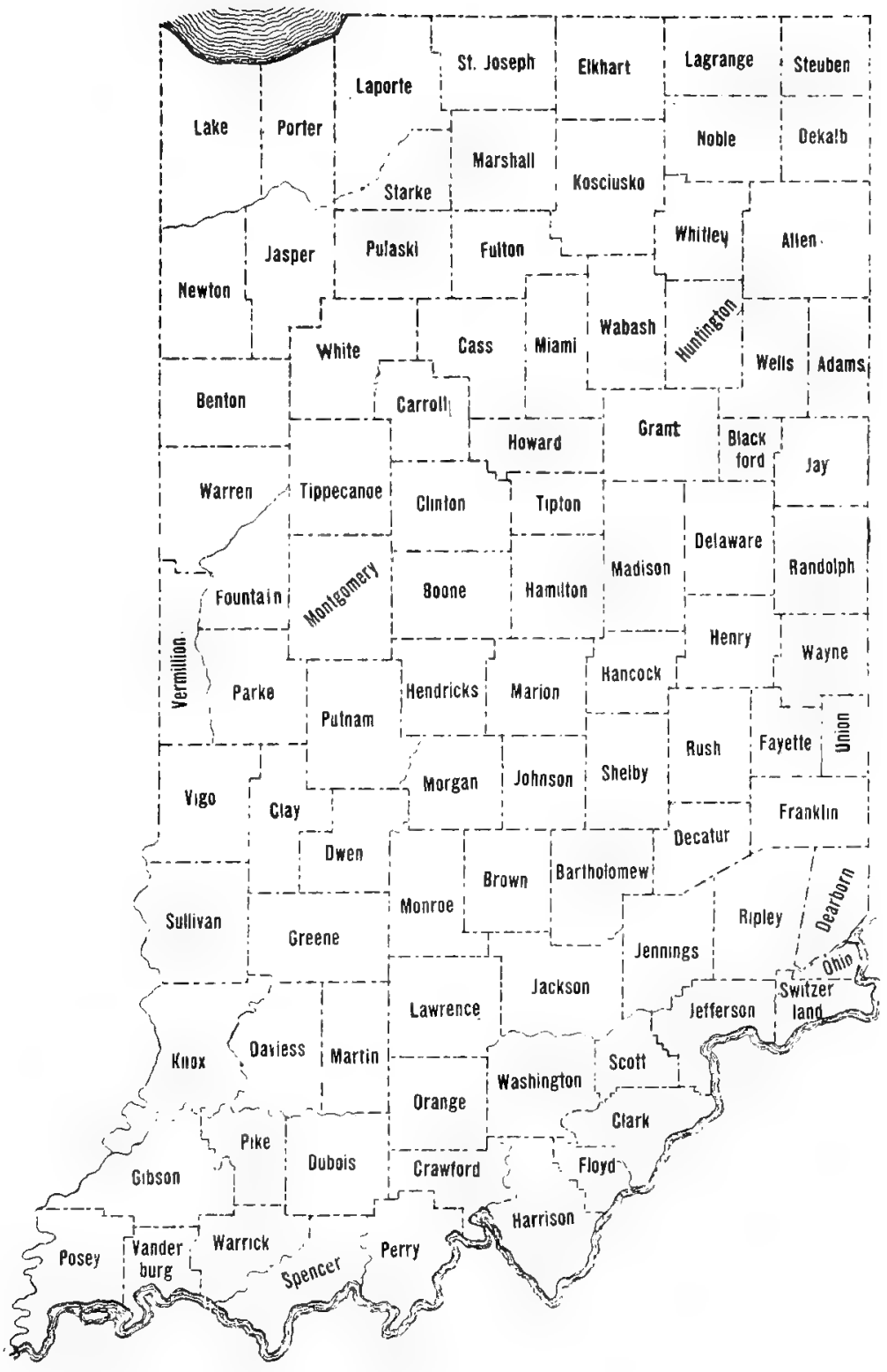

COUNTY MAP OF INUIANA. 


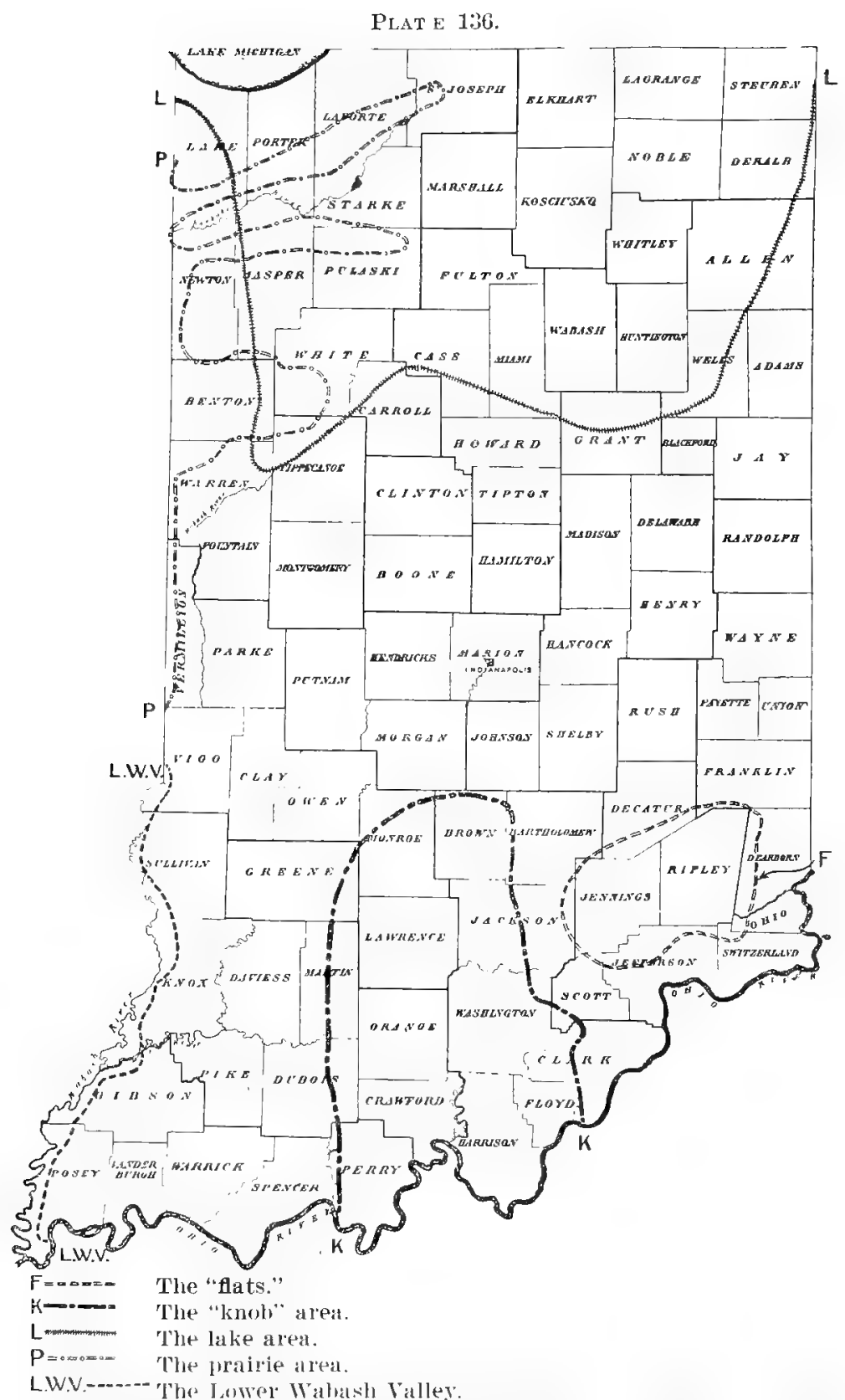

COUNTY MAP OF INDIANA SHOWING CERTAIN AREAS OF FOREST DISTRIBUTION. 
Plate 137.
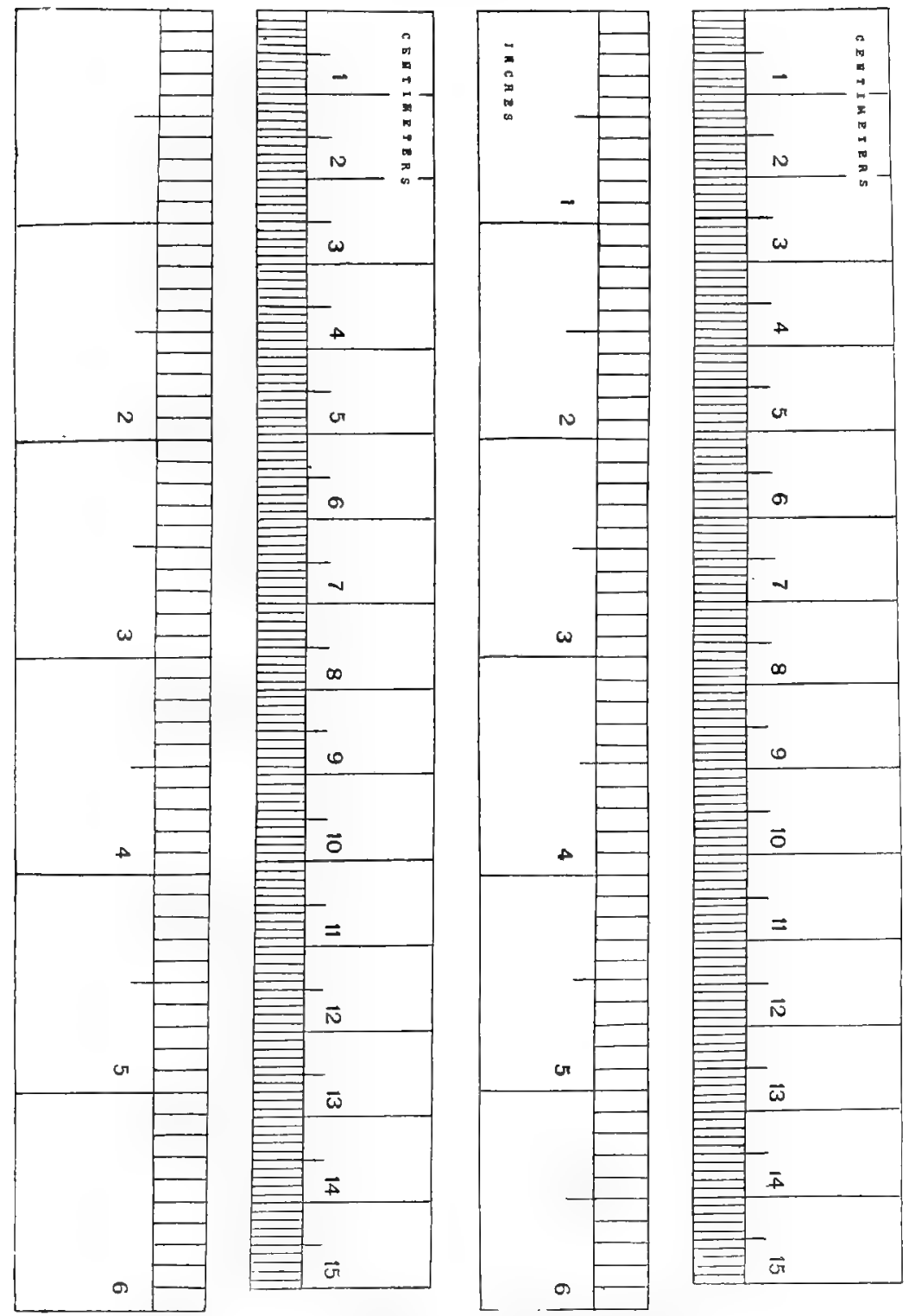

ENGLISH AND METRIC SCALES COMPARED.

These can be cut out and pasted on wood. 



\section{INDEX}

The accepted botanical names are in bold-face type. Synonyms are placed in italics. Where the subject receives the most extended notice the page number is in bold-face type.

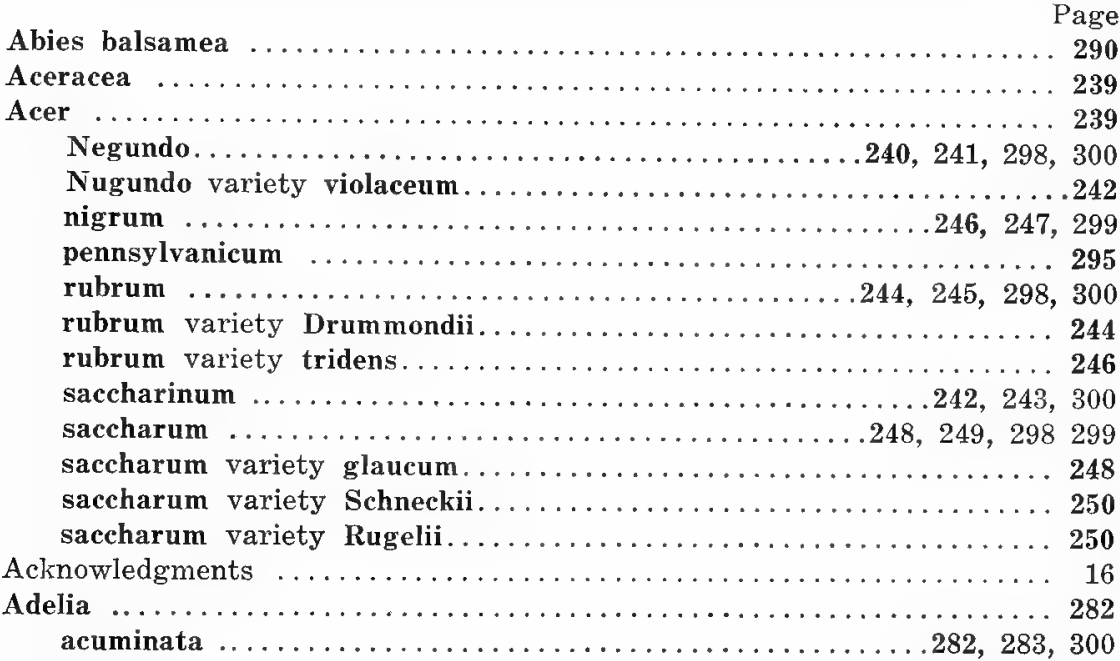

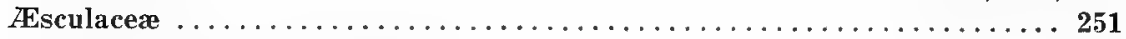

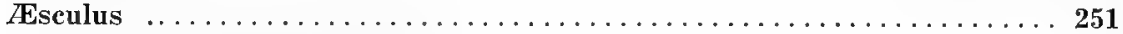

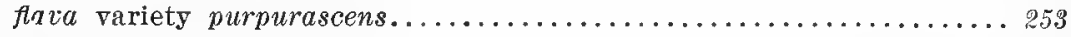

glabra ............................. 251, 300

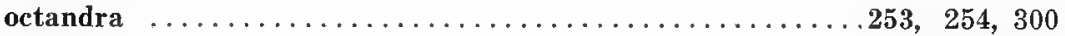

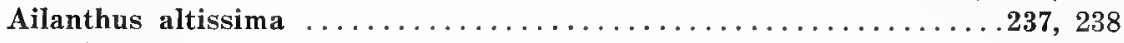

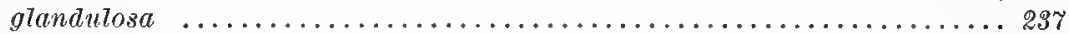

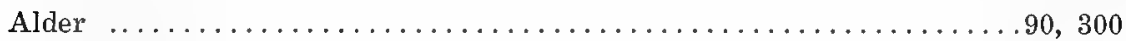

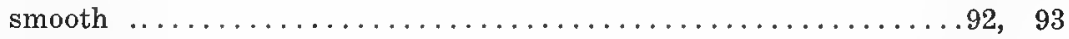

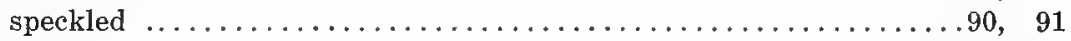

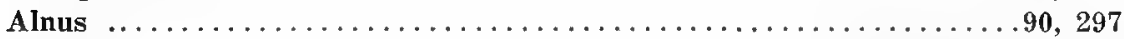

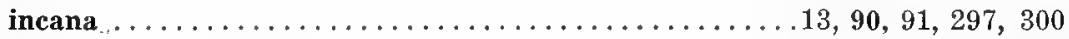

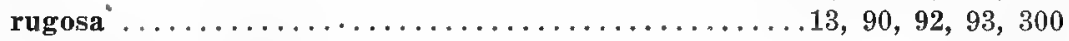

Altingiacæ ....................................... 166

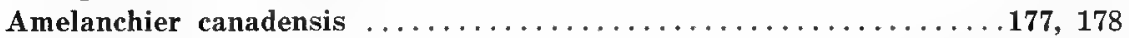

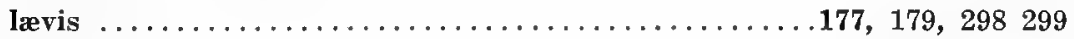

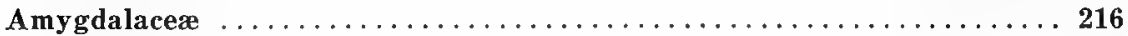

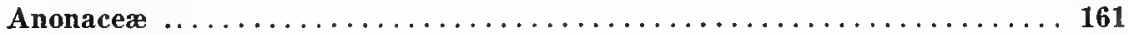

Apple, American crab.......................... 172, 173, 299

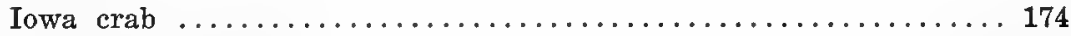

narrow-leaved crab ............................... 175

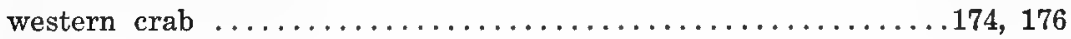

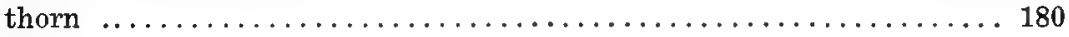


Arbor-Vitæ $32,33,300$

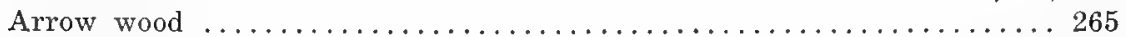

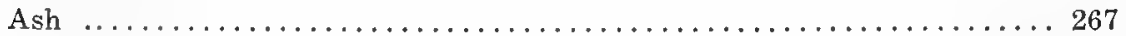

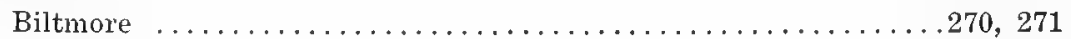

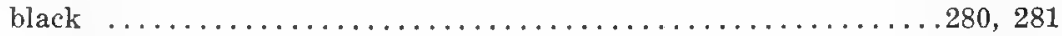

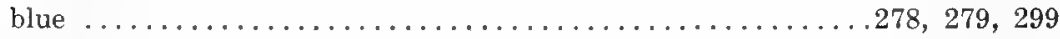

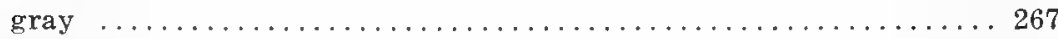

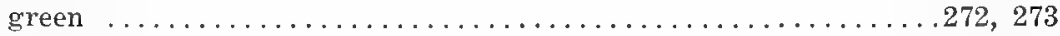

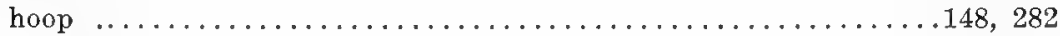

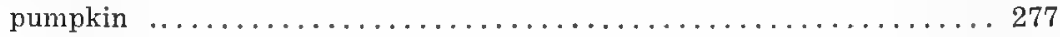

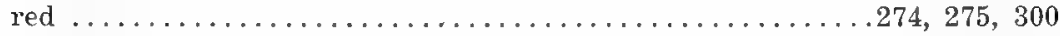

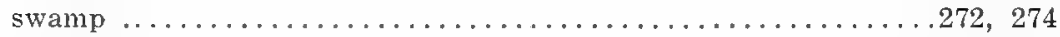

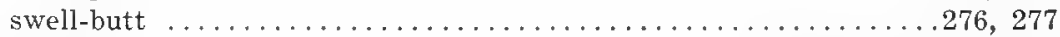

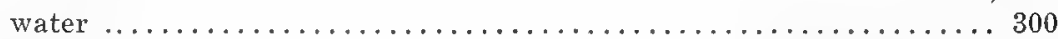

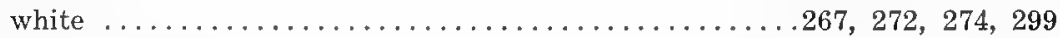

Asimina triloba ........................161, 162, 298, 300

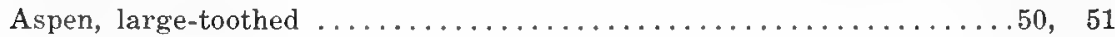

quaking $\ldots \ldots \ldots \ldots \ldots \ldots \ldots \ldots \ldots \ldots \ldots \ldots \ldots \ldots \ldots \ldots \ldots \ldots \ldots \ldots \ldots$

Ball, Carleton $R \ldots \ldots \ldots \ldots \ldots \ldots \ldots \ldots \ldots \ldots \ldots \ldots \ldots \ldots \ldots$

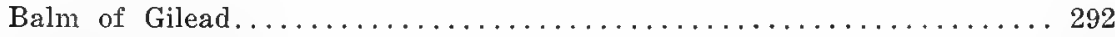

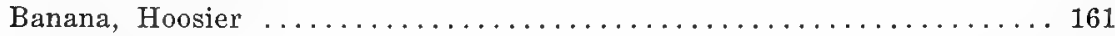

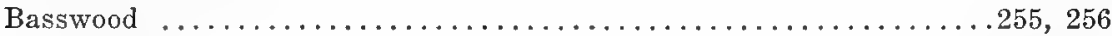

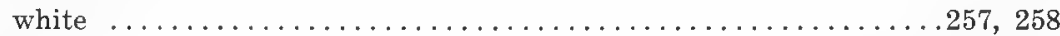

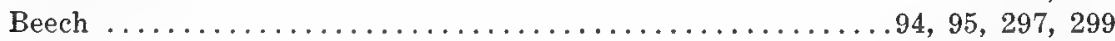

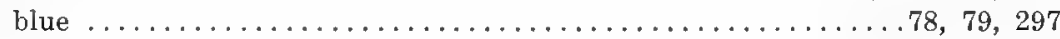

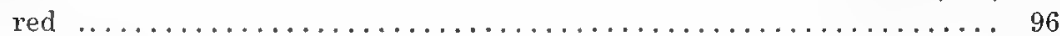

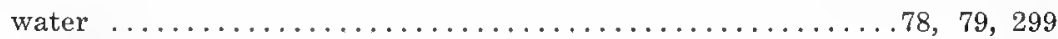

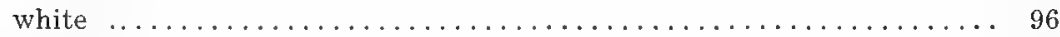

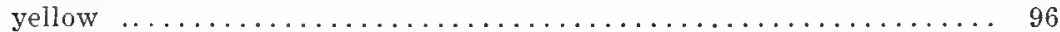

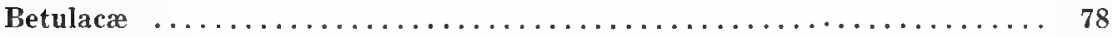

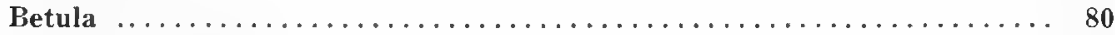

alleghenensis $\ldots \ldots \ldots \ldots \ldots \ldots \ldots \ldots \ldots \ldots \ldots \ldots \ldots \ldots \ldots \ldots$

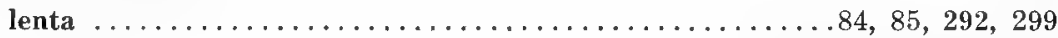

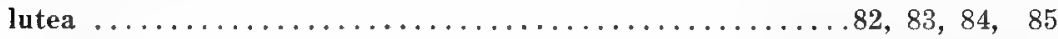

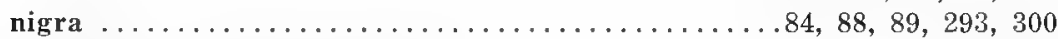

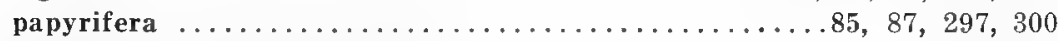

papyrifera $\mathrm{x}$ pumila glandulifera..................... 85

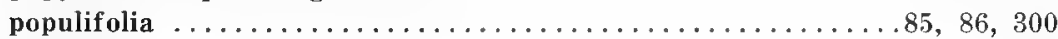

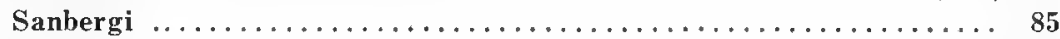

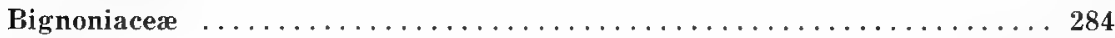

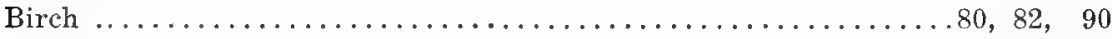

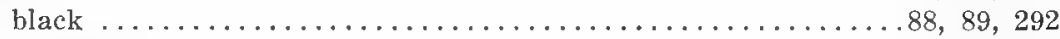

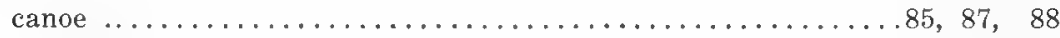

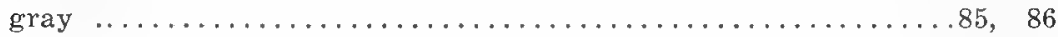

paper. ............................ 85, 88, 297, 300

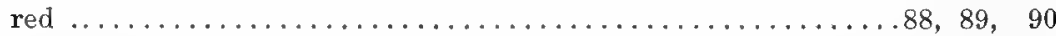

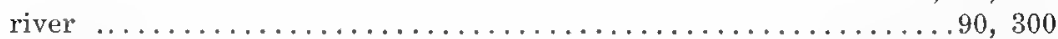

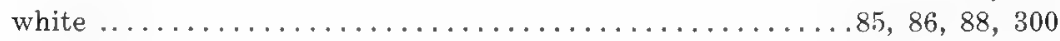

yellow ............................. 82, 83, 299 
Page

Botanic descriptions, comments on ................... 13

Box elder . . . . . . . . . . . . . . . . . . . . . . . . . 240, 241

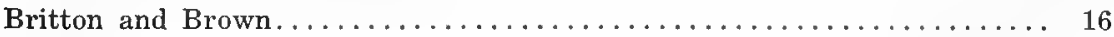

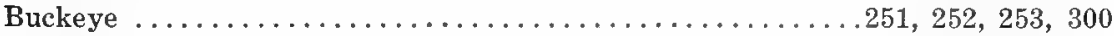

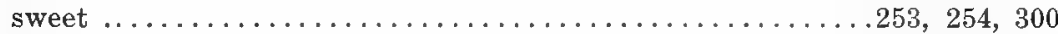

Butternut $\ldots \ldots \ldots \ldots \ldots \ldots \ldots \ldots \ldots \ldots \ldots \ldots \ldots \ldots \ldots \ldots \ldots \ldots \ldots \ldots \ldots \ldots$

Casalpinaceæ $\ldots \ldots \ldots \ldots \ldots \ldots \ldots \ldots \ldots \ldots \ldots \ldots \ldots \ldots \ldots \ldots \ldots$

Caprifoliacea .................................. 288

Carpinus caroliniana. .................... 78, 79, 297, 299

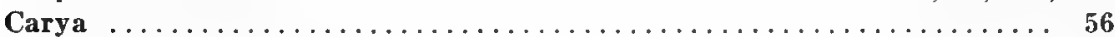

alba $\ldots \ldots \ldots \ldots \ldots \ldots \ldots \ldots \ldots \ldots \ldots \ldots \ldots \ldots \ldots \ldots, 69,299$

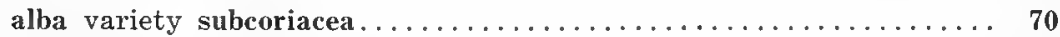

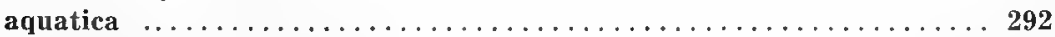

Buckleyi variety arkansana ...... . . . . . . . . . . 76, 77

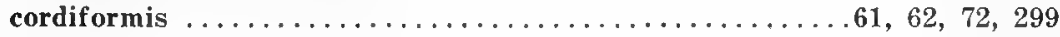

glabra .............................. 70, 71, 299

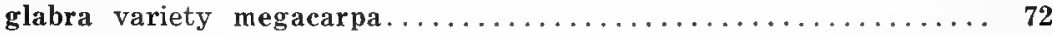

illinoensis . . . . . . . . . . . . . . . . . . . . . . . 59, 60, 299

laciniosa ..........................66, 67, 292, 299

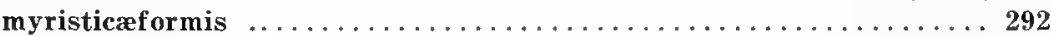

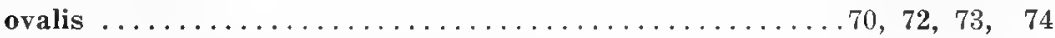

ovalis variety obcordata $\ldots \ldots \ldots \ldots \ldots \ldots \ldots \ldots \ldots \ldots \ldots \ldots \ldots \ldots$

ovalis variety obcordata forma vestita................ 75

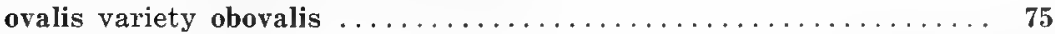

ovalis variety odorata $\ldots \ldots \ldots \ldots \ldots \ldots \ldots \ldots \ldots \ldots \ldots \ldots \ldots \ldots$

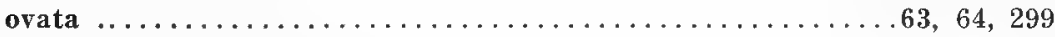

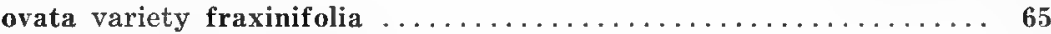

ovata variety Nuttallii........................ 66

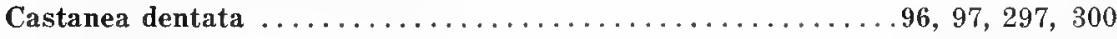

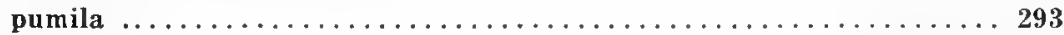

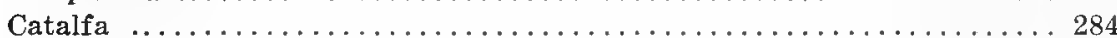

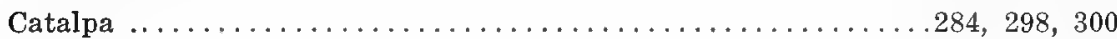

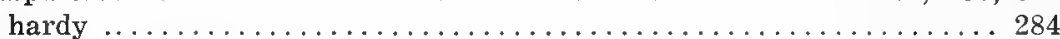

Catalpa ....................................... 284

Catalpa bigonnioides........................13, 284, 285, 300

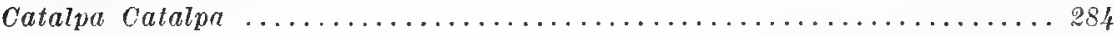
speciosa.......................284, 286, 287, 298, 300

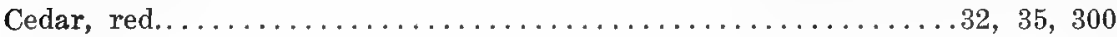

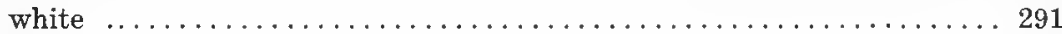

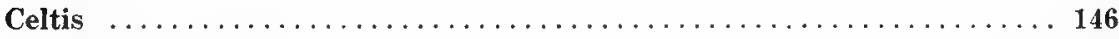

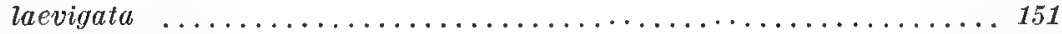

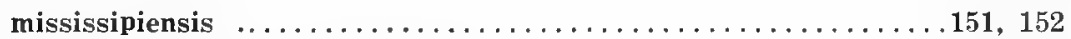

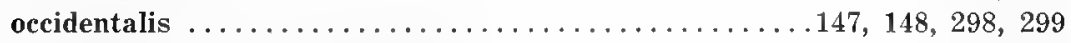

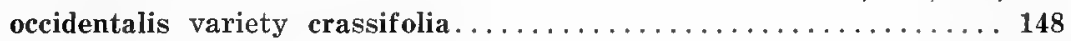

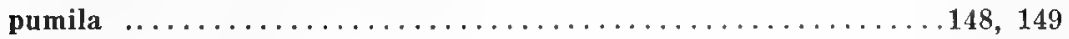

pumila variety Deamii. ....................... 149, 150

Cercis canadensis . . . . . . . . . . . . . . . . . . . 227, 228, 298, 300

Chamacyparis thyoides $\ldots \ldots \ldots \ldots \ldots \ldots \ldots \ldots \ldots \ldots \ldots \ldots \ldots$ 
Page

Cherry, wild $\ldots \ldots \ldots \ldots \ldots \ldots \ldots \ldots \ldots \ldots \ldots \ldots \ldots \ldots \ldots \ldots \ldots$

wild black ............................223, 225, 300

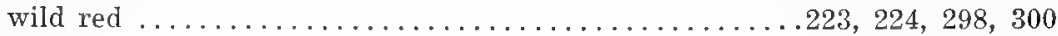

Chestnut ..........................96, 97, 297, 300

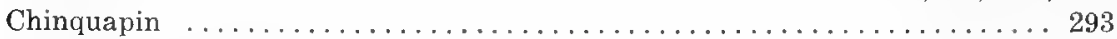

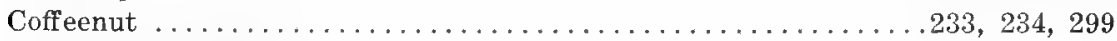

Contents, table of $\ldots \ldots \ldots \ldots \ldots \ldots \ldots \ldots \ldots \ldots \ldots \ldots \ldots \ldots$

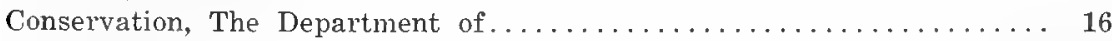

Cornacea ................................... 259

Cornus florida............................ 261, 262, 299

Cottonwood .........................47,49, 297, 300

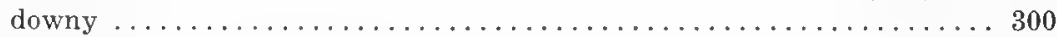

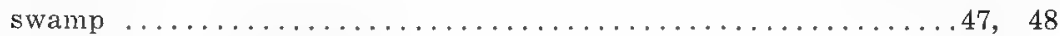

Coulter, Stanley, Commissioner.................... 16, 163, 251

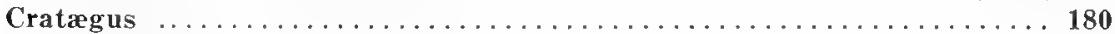

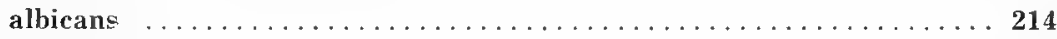

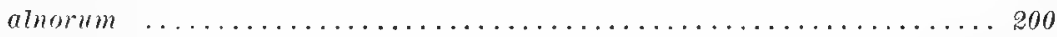

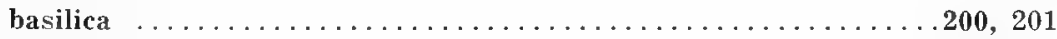

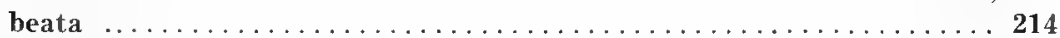

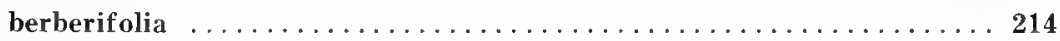

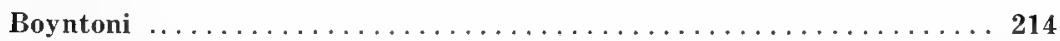

Brainerdi ............................... 214

Calpodendron $\ldots \ldots \ldots \ldots \ldots \ldots \ldots \ldots \ldots \ldots \ldots \ldots \ldots \ldots \ldots \ldots \ldots \ldots \ldots$

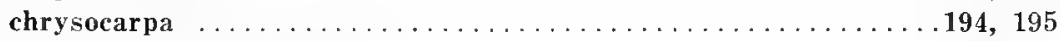

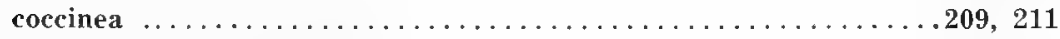

coccinea variety Elwangeriana .................... 212

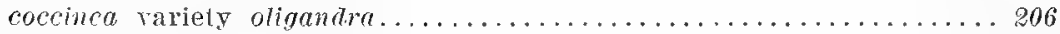

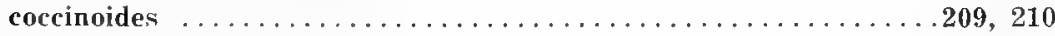

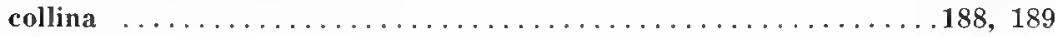

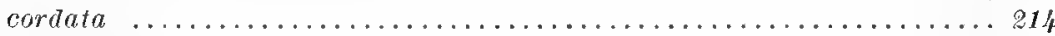

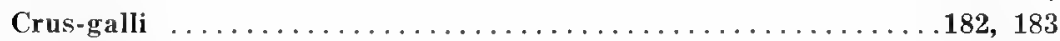

cuneif ormis .................................. 182, 184

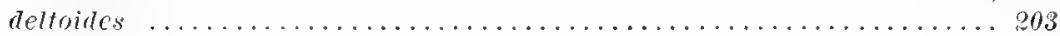

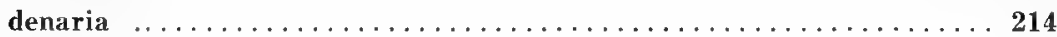

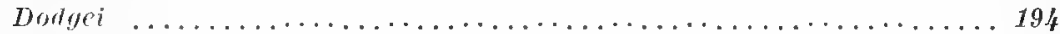

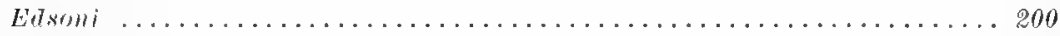

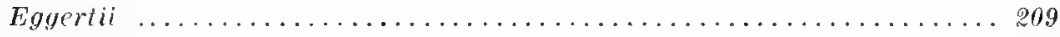

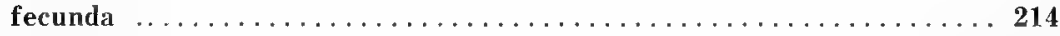

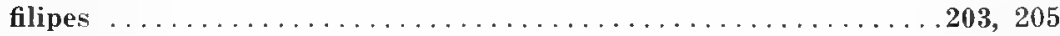

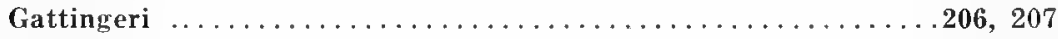

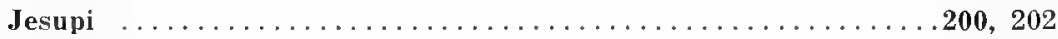

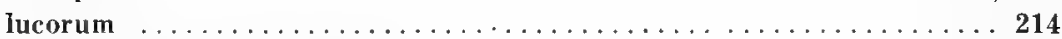

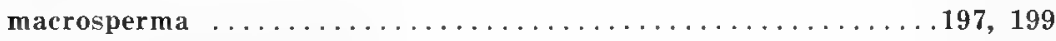

macrosperma variety matura..................... 200

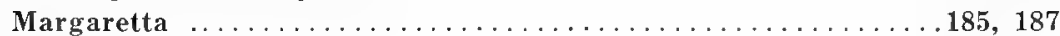

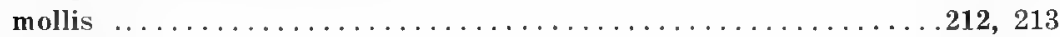

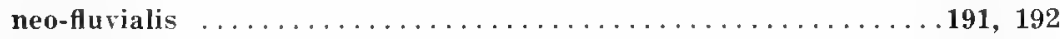

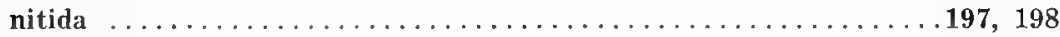

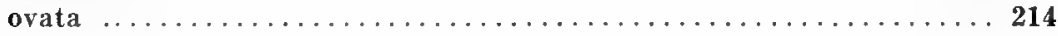


Cratægus_Continued. Page

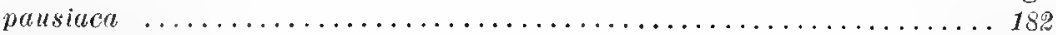

pedicillata $\ldots \ldots \ldots \ldots \ldots \ldots \ldots \ldots \ldots \ldots \ldots \ldots \ldots \ldots \ldots \ldots \ldots$

pedicillata variety Elwangeriana....................212

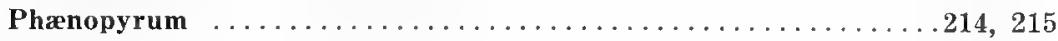

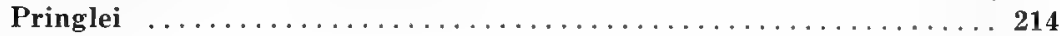

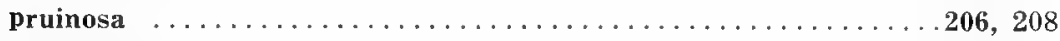

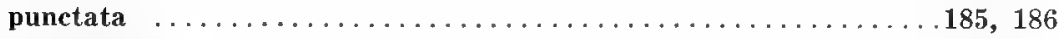

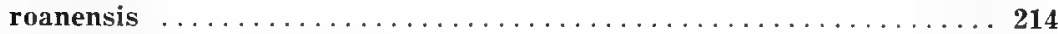

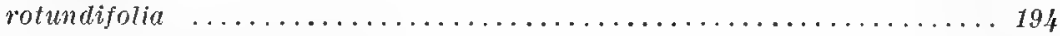

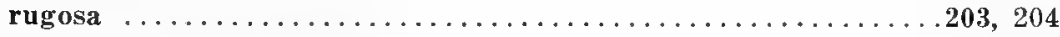

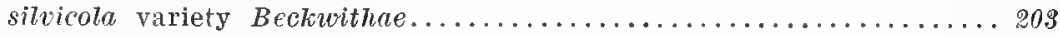

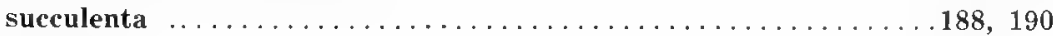

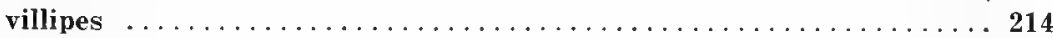

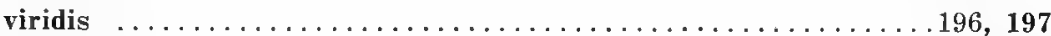

Crooked brush ..............................282, 283

Cucumber tree............................... 157, 158, 300

Cypress, bald .......................28, 31, 297, 300

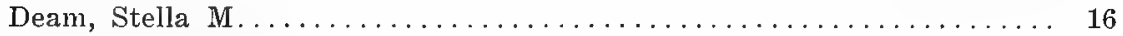

Dietz, Harry F.............................. 15

Diospyros virginiana....................265, 266, 298, 299

Distribution of trees, terms used to define.................. 14

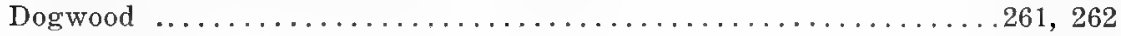

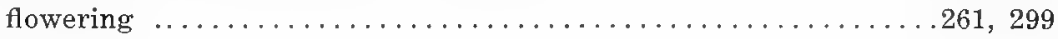

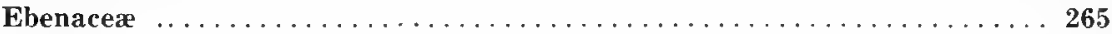

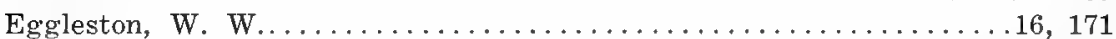

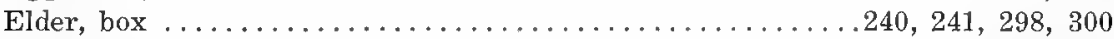

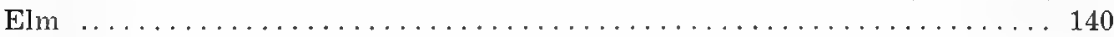

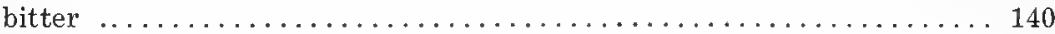

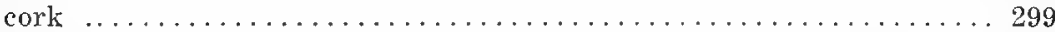

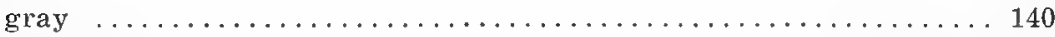

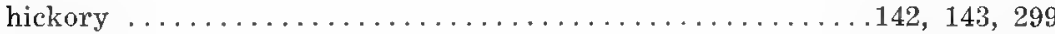

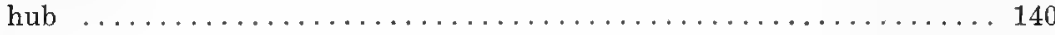

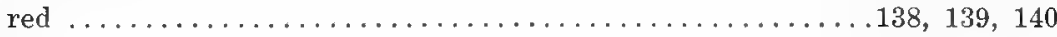

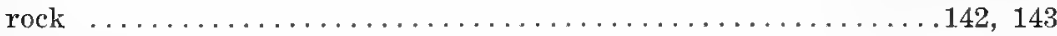

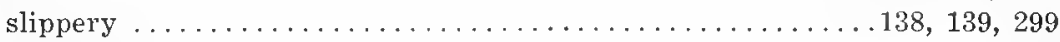

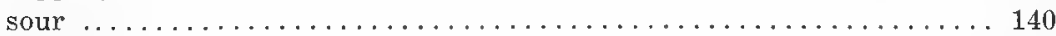

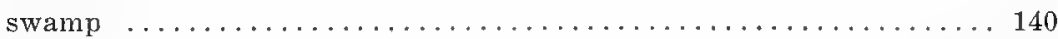

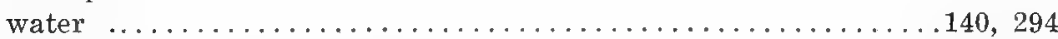

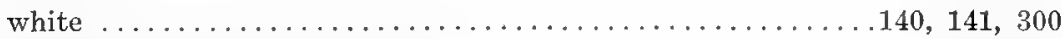

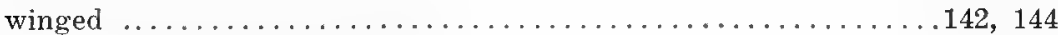

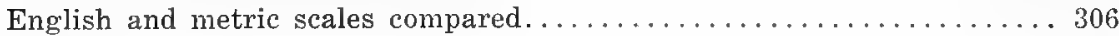

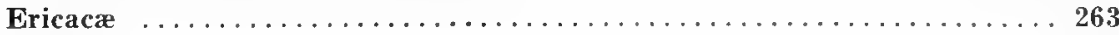

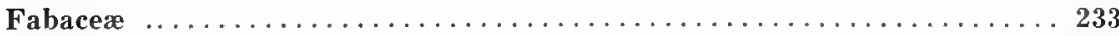

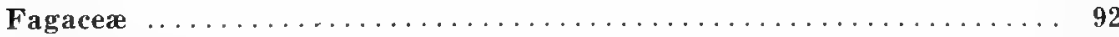

Fagus grandifolia $\ldots \ldots \ldots \ldots \ldots \ldots \ldots \ldots \ldots \ldots \ldots \ldots \ldots \ldots \ldots$. $\ldots \ldots, 95,297,299$

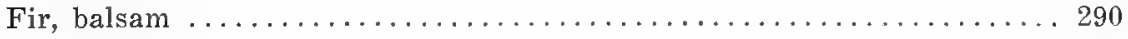


Fraxinus $\ldots \ldots \ldots \ldots \ldots \ldots \ldots \ldots \ldots \ldots \ldots \ldots \ldots \ldots \ldots \ldots$

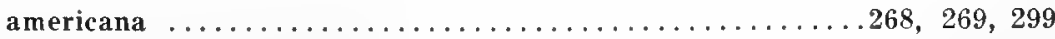

americana forma iodocarpa....................... 270

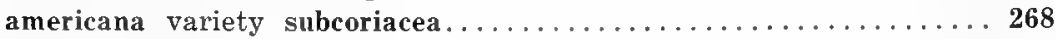

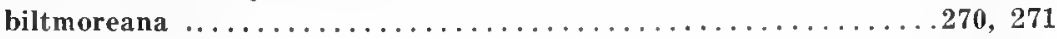

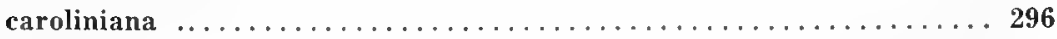

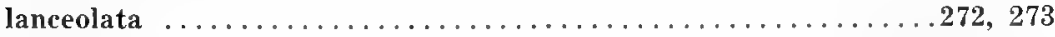

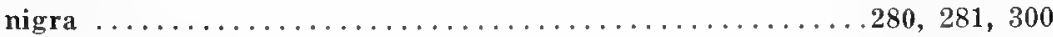

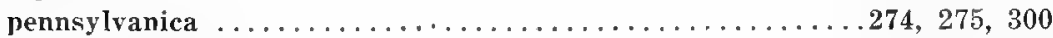

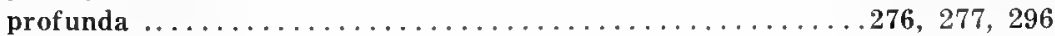

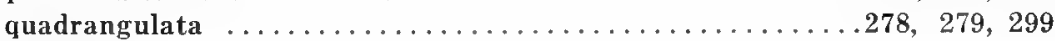

Frontispiece $\ldots \ldots \ldots \ldots \ldots \ldots \ldots \ldots \ldots \ldots \ldots \ldots \ldots \ldots \ldots \ldots$

Gleditsia aquatica........................230, 231, 299

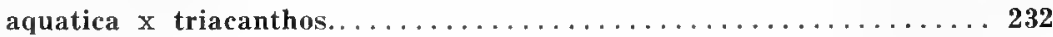

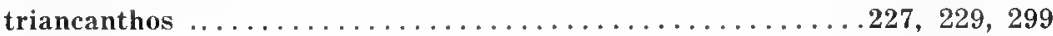

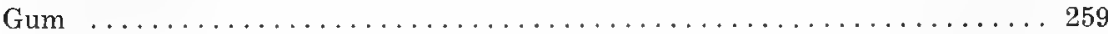

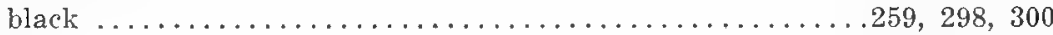

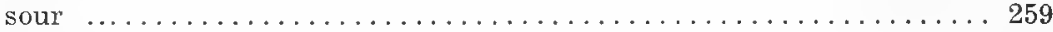

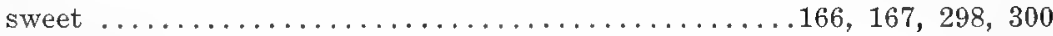

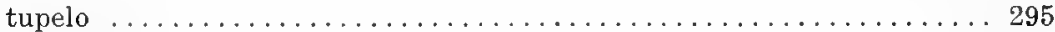

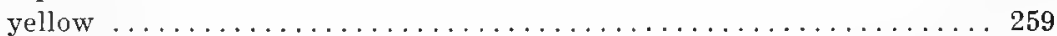

Gymnocladus dioica........................233, 234, 299

Hackberry .........................146, 148, 151, 298, 299

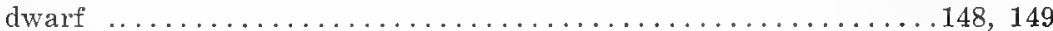

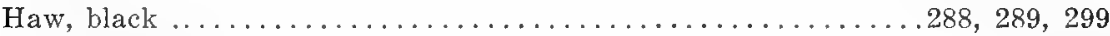

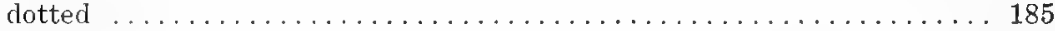

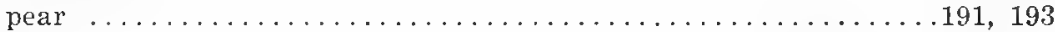

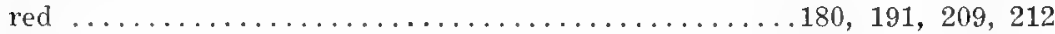

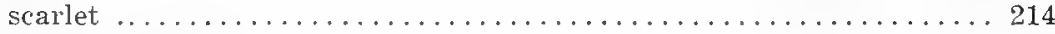

southern black .............................. 289

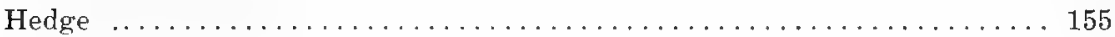

Hemlock ................................. 26, 29, 300

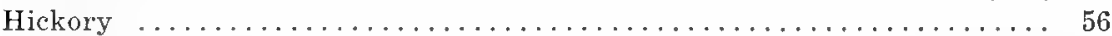

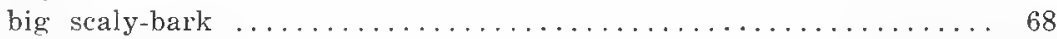

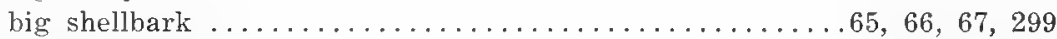

black ........................... 70, 297, 299

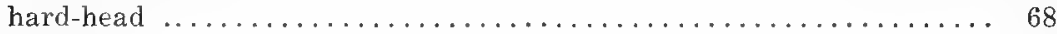

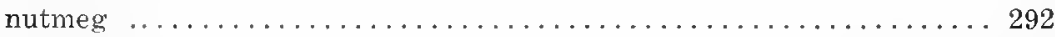

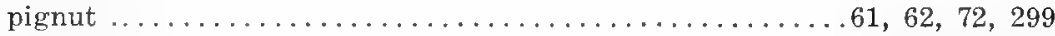

shellbark . . . . . . . . . . . . . . . . . . . 63, 64, 65, 299

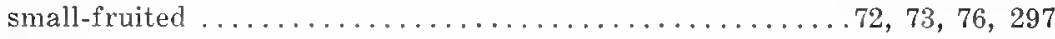

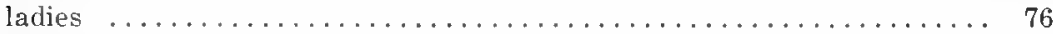

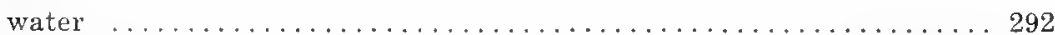

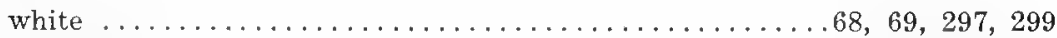

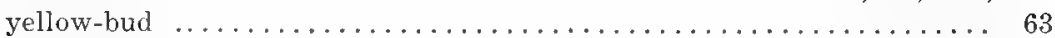

Holly ................................... 295, 298

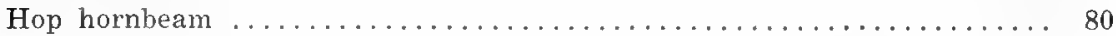

Hough, R. B.......................... 16 
Page

Ilex opaca $\ldots \ldots \ldots \ldots \ldots \ldots \ldots \ldots \ldots \ldots \ldots \ldots \ldots \ldots \ldots \ldots \ldots \ldots \ldots$

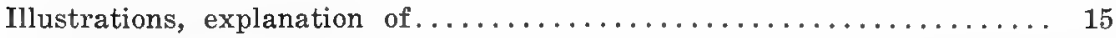

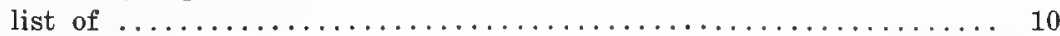

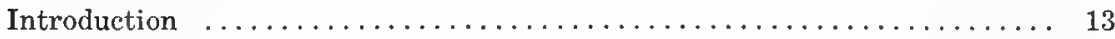

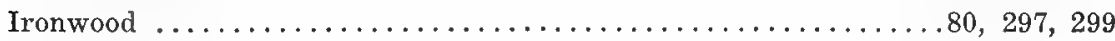

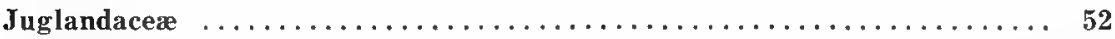

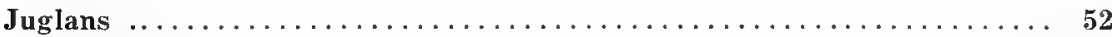

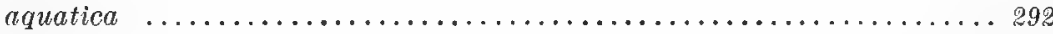

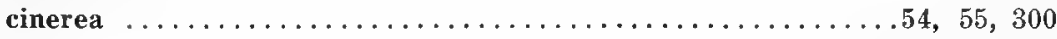

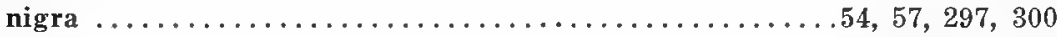

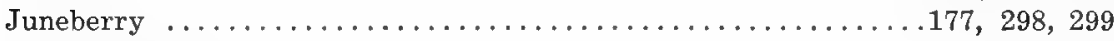

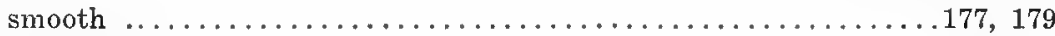

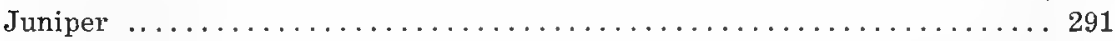

Juniperus communis $\ldots \ldots \ldots \ldots \ldots \ldots \ldots \ldots \ldots \ldots \ldots \ldots \ldots \ldots \ldots$

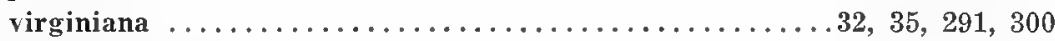

Kalmia latifolia $\ldots \ldots \ldots \ldots \ldots \ldots \ldots \ldots \ldots \ldots \ldots \ldots \ldots \ldots \ldots$

Key to the families of Indiana trees.................... 17

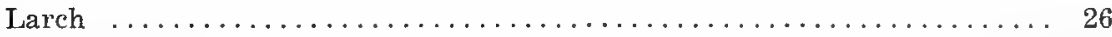

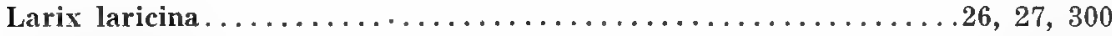

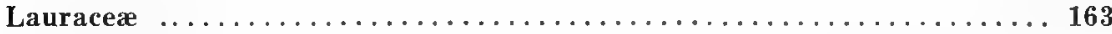

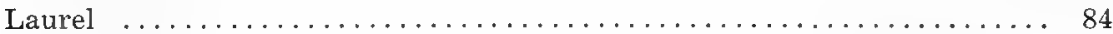

Lieber, Richard $\ldots \ldots \ldots \ldots \ldots \ldots \ldots \ldots \ldots \ldots \ldots \ldots \ldots \ldots \ldots \ldots \ldots$

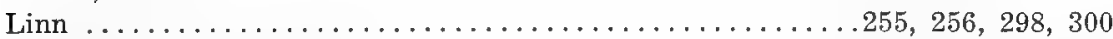

Iiquidambar Styraciflua...................166, 167, 298, 300

Liriodendron Tulipifera . . . . . . . . . . . . . . 159, 160, 298, 300

Locust ..................................... 235

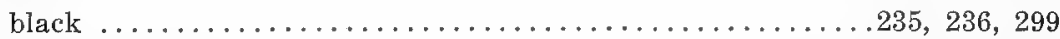

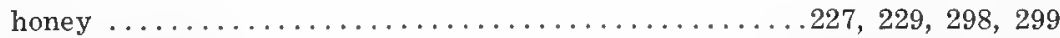

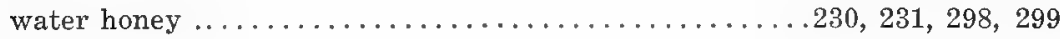

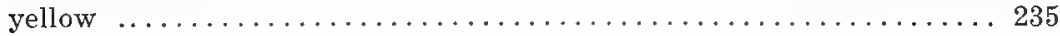

Maclura pomifera $\ldots \ldots \ldots \ldots \ldots \ldots \ldots \ldots \ldots \ldots \ldots \ldots \ldots \ldots \ldots \ldots \ldots$ 155, 156, 299

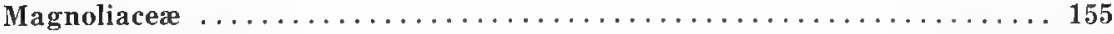

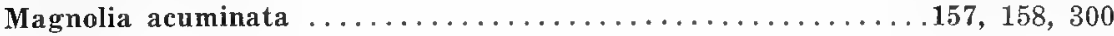

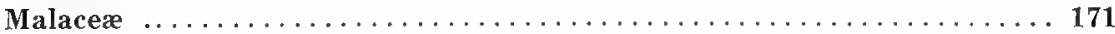

Malus ................................... 171

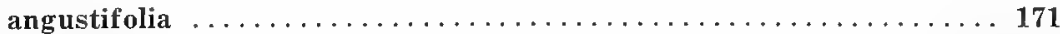

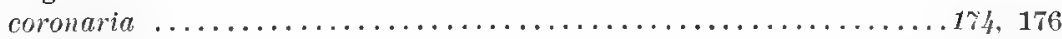

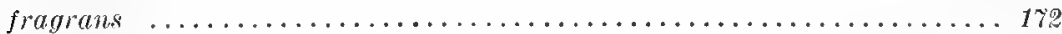

glaucescens. ............................. 172, 173, 299

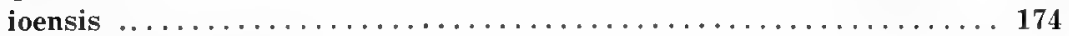

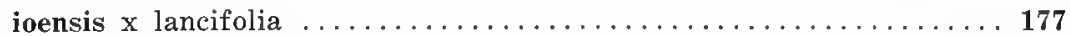

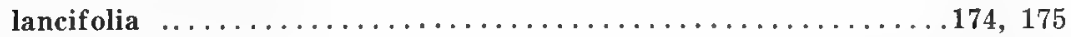

Maple, black ............................246, 247, 299

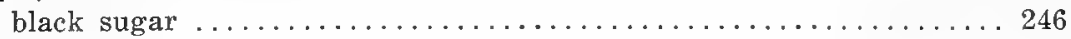

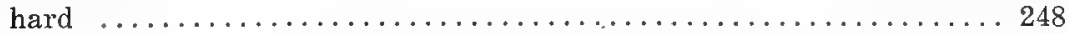


Maple, black-Continued. Page red ............................... 244, 298, 300

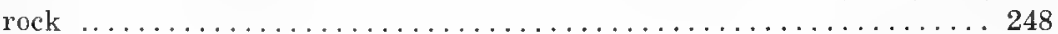

silver ................................242, 243, 300

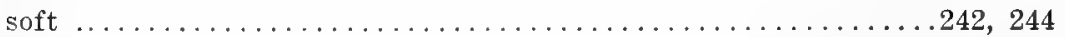

sugar ...........................248, 249, 298, 299

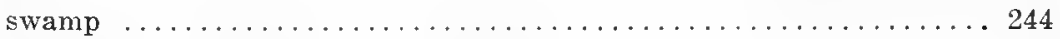

white ....................................... 242

Map of certain forestal areas of Indiana.................... 302

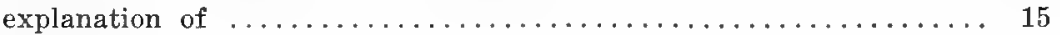

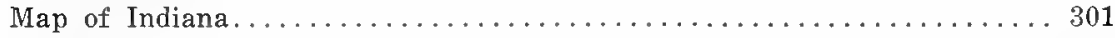

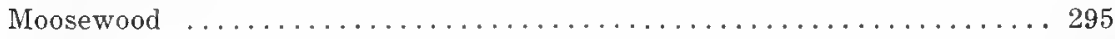

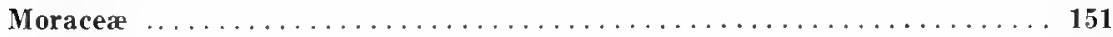

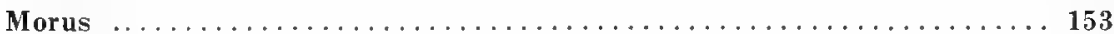

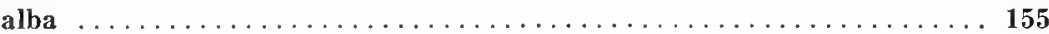

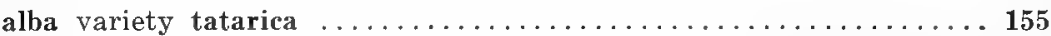

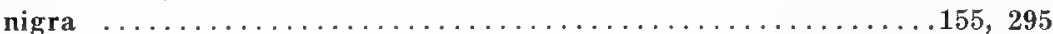

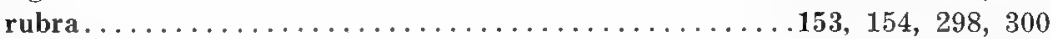

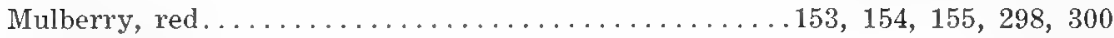

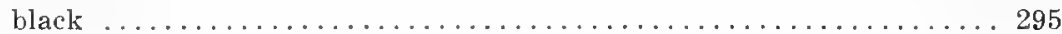

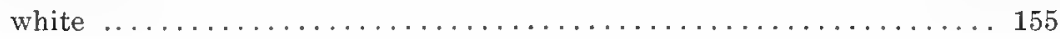

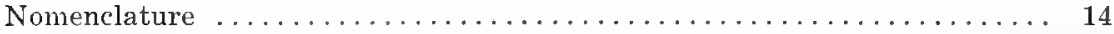

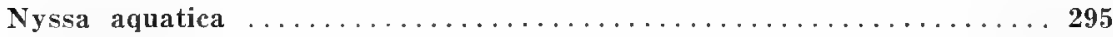

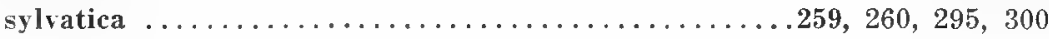

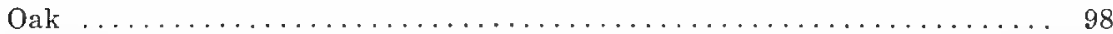

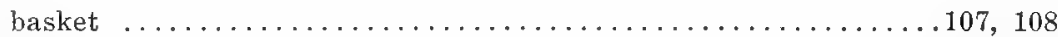

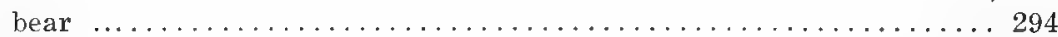

black ....................119, 127, 129, 135, 298, 299

black jack ................................ 135, 299

bur .......................104, 115, 116, 117, 297, 299

chestnut ......................... 104, 110, 111, 299

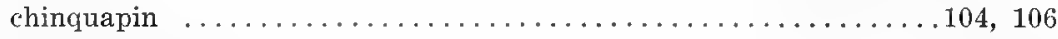

cow ............................. 107, 297, 299

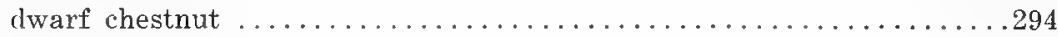

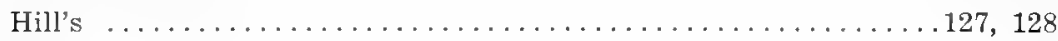

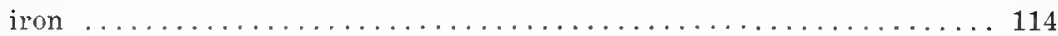

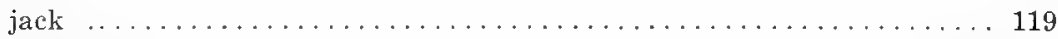

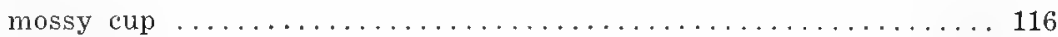

over cup ............................. 118, 299

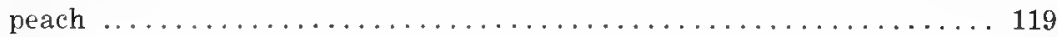

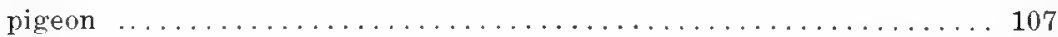

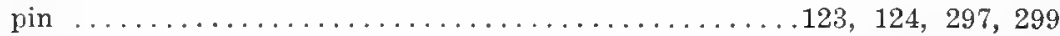

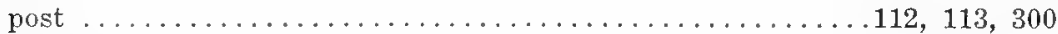

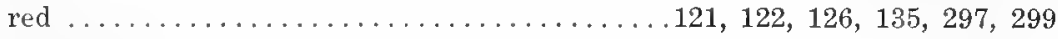

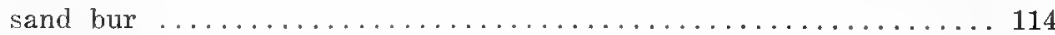

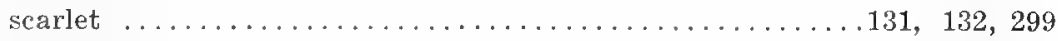

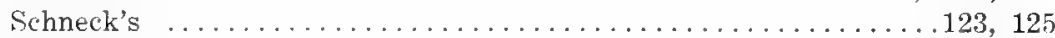

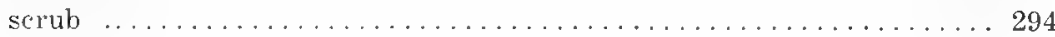


Oak-Continued. Page

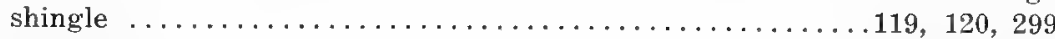

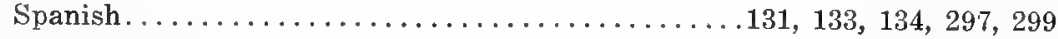

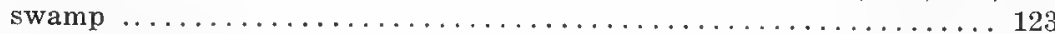

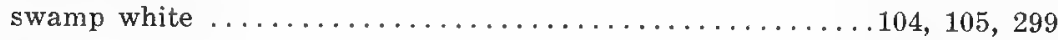

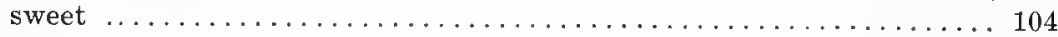

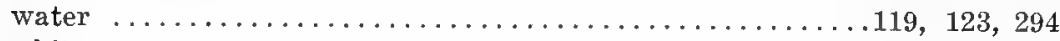

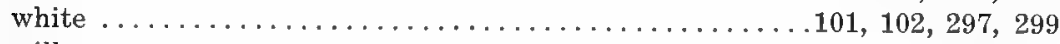

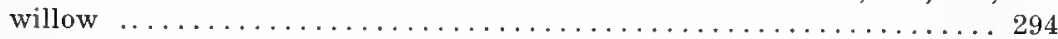

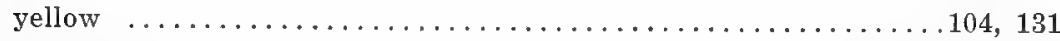

Oleacer $\ldots \ldots \ldots \ldots \ldots \ldots \ldots \ldots \ldots \ldots \ldots \ldots \ldots \ldots \ldots \ldots \ldots \ldots \ldots \ldots \ldots$

Osage Orange ............................ 155, 156, 299

Ostrya virginiana.......................... 80, 81, 299

virginiana variety glandulosa $\ldots \ldots \ldots \ldots \ldots \ldots \ldots \ldots \ldots \ldots$

Oxydendrum arboreum .......................263, 264

Pawpaw . . . . . . . . . . . . . . . . . . . . . . . 161, 162, 298

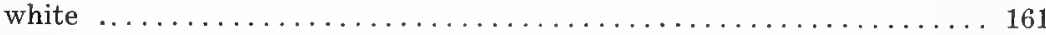

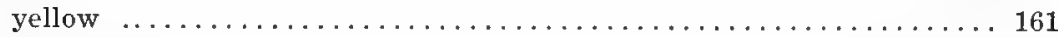

Pecan ............................... 59, 60, 297, 299

McCallister ............................. 60

Pepperidge ................................. 259

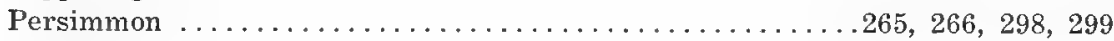

Pinaceæ $\ldots \ldots \ldots \ldots \ldots \ldots \ldots \ldots \ldots \ldots \ldots \ldots \ldots \ldots \ldots \ldots \ldots \ldots \ldots$

Pine $\ldots \ldots \ldots \ldots \ldots \ldots \ldots \ldots \ldots \ldots \ldots \ldots \ldots \ldots \ldots \ldots \ldots \ldots \ldots \ldots$

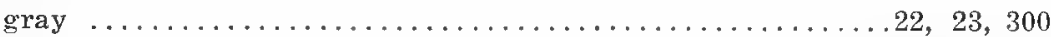

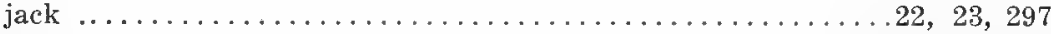

Jersey .............................22, 24, 25, 300

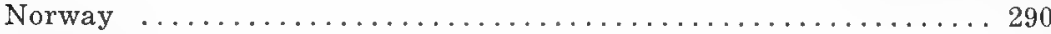

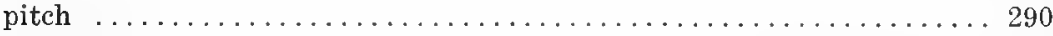

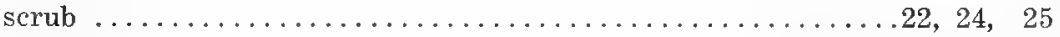

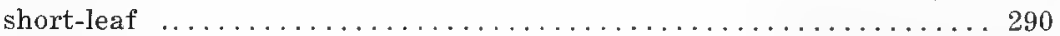

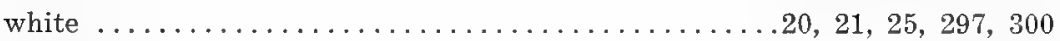

Pinus $\ldots \ldots \ldots \ldots \ldots \ldots \ldots \ldots \ldots \ldots \ldots \ldots \ldots \ldots \ldots \ldots \ldots$

Banksiana .............................22, 23, 300

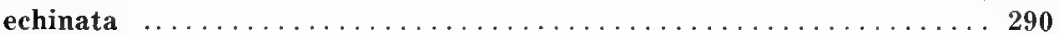

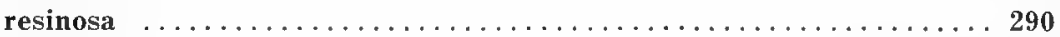

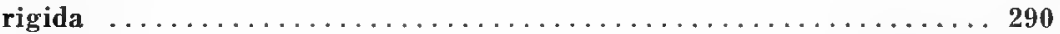

Strobus ........................... 20, 21, 290, 300

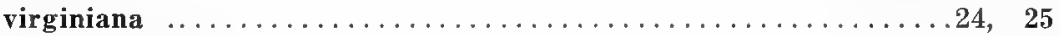

Planera aquatica $\ldots \ldots \ldots \ldots \ldots \ldots \ldots \ldots \ldots \ldots \ldots \ldots \ldots \ldots \ldots$

Planer-tree . . . . . . . . . . . . . . . . . . . . . . . . . . 294

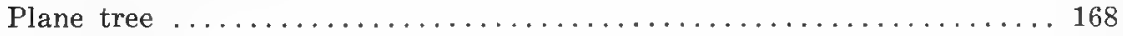

Platanacere $\ldots \ldots \ldots \ldots \ldots \ldots \ldots \ldots \ldots \ldots \ldots \ldots \ldots \ldots \ldots \ldots \ldots \ldots \ldots$

Platanus occidentalis. . . . . . . . . . . . . . . . . . 168, 169, 298, 300

Plum, Canada ...............................218, 220

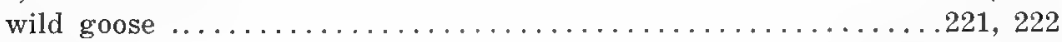

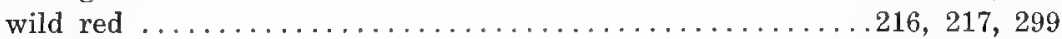

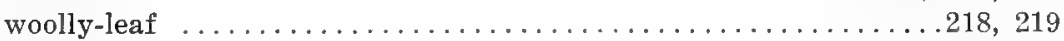

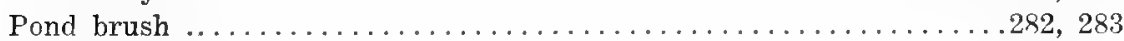


Poplar $\ldots \ldots \ldots \ldots \ldots \ldots \ldots \ldots \ldots \ldots \ldots \ldots \ldots \ldots \ldots \ldots \ldots \ldots \ldots \ldots, 159$

balsam $\ldots \ldots \ldots \ldots \ldots \ldots \ldots \ldots \ldots \ldots \ldots \ldots \ldots \ldots \ldots \ldots \ldots \ldots \ldots \ldots$

blue $\ldots \ldots \ldots \ldots \ldots \ldots \ldots \ldots \ldots \ldots \ldots \ldots \ldots \ldots \ldots \ldots \ldots \ldots \ldots \ldots \ldots \ldots$

Carolina ................................. 479

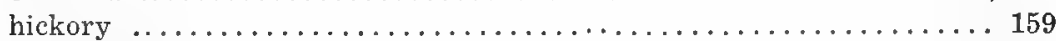

Lombardy ... . . . . . . . . . . . . . . . . . . . . . . . . . . 292

silver-leaf $\ldots \ldots \ldots \ldots \ldots \ldots \ldots \ldots \ldots \ldots \ldots \ldots \ldots \ldots \ldots \ldots \ldots \ldots, 46$

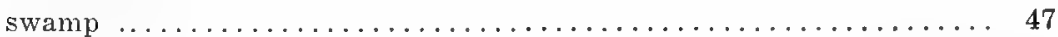

white $\ldots \ldots \ldots \ldots \ldots \ldots \ldots \ldots \ldots \ldots \ldots \ldots \ldots \ldots \ldots \ldots \ldots \ldots \ldots$

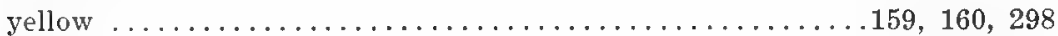

Populus $\ldots \ldots \ldots \ldots \ldots \ldots \ldots \ldots \ldots \ldots \ldots \ldots \ldots \ldots \ldots \ldots \ldots \ldots \ldots \ldots$

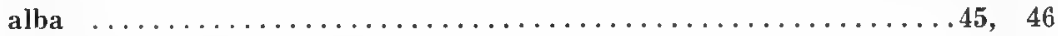

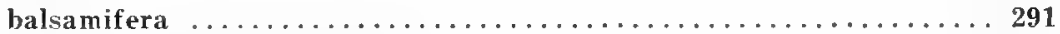

balsamifera variety virginiana....................... 4 .

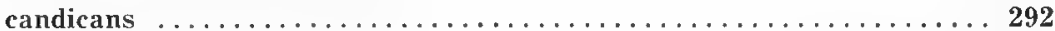

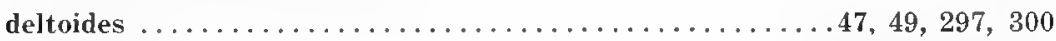

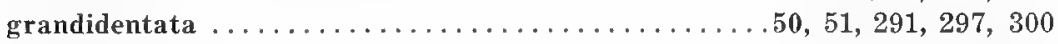

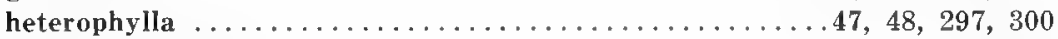

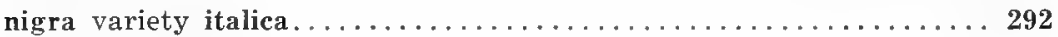

tremuloides .......................52,53, 297, 300

Preface $\ldots \ldots \ldots \ldots \ldots \ldots \ldots \ldots \ldots \ldots \ldots \ldots \ldots \ldots \ldots \ldots \ldots \ldots \ldots$

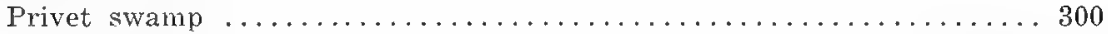

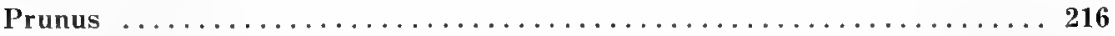

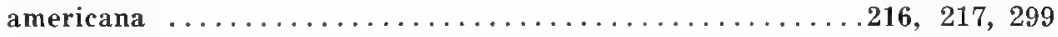

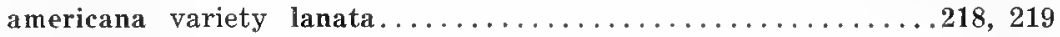

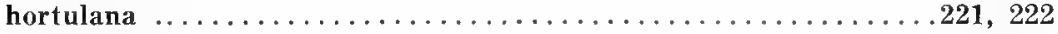

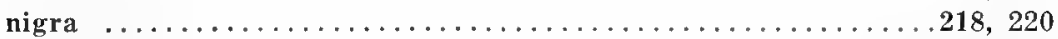

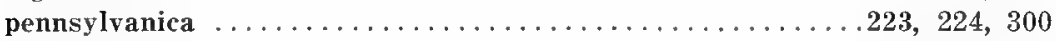

serotina ............................... 223, 225, 300

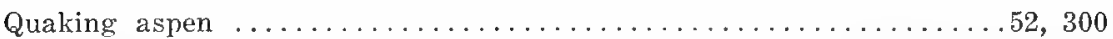

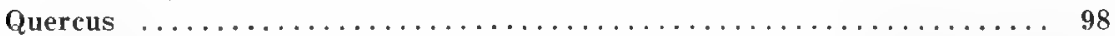

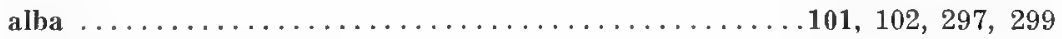

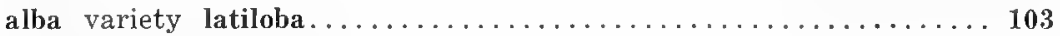

alha $\mathrm{x}$ Michauxii ............................... 110

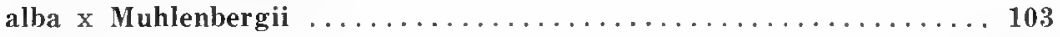

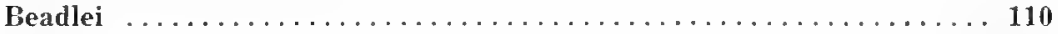

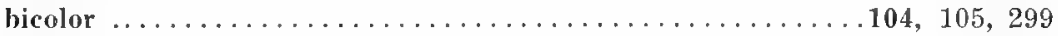

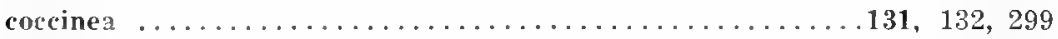

Deami $\ldots \ldots \ldots \ldots \ldots \ldots \ldots \ldots \ldots \ldots \ldots \ldots \ldots \ldots \ldots \ldots \ldots \ldots$

diritutu $\ldots \ldots \ldots \ldots \ldots \ldots \ldots \ldots \ldots \ldots \ldots \ldots \ldots \ldots \ldots \ldots \ldots \ldots \ldots \ldots$

ellipsoidalis ........................... 127, 128

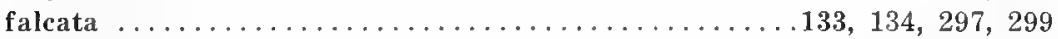

illicifolia $\ldots \ldots \ldots \ldots \ldots \ldots \ldots \ldots \ldots \ldots \ldots \ldots \ldots \ldots \ldots \ldots \ldots \ldots \ldots$

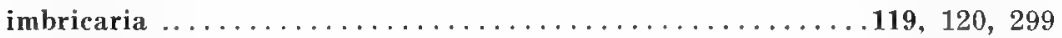

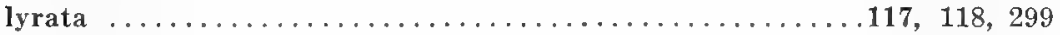

macrocarpa ........................115, 116, 297, 299

macrocarpa variety olivaformis. .................. 116

marilandica $\ldots \ldots \ldots \ldots \ldots \ldots \ldots \ldots \ldots \ldots \ldots \ldots \ldots \ldots \ldots \ldots \ldots \ldots \ldots \ldots$ 135, 136, 294, 299 
Quercus_Continued. Page

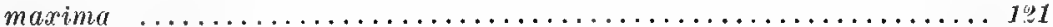

Michauxii ........................107, 108, 297, 299

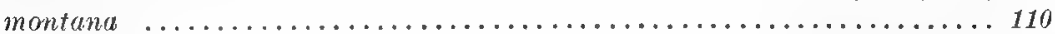

Muhlenbergii ......................104, 106, 109, 112, 293

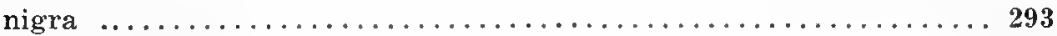

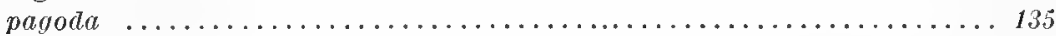

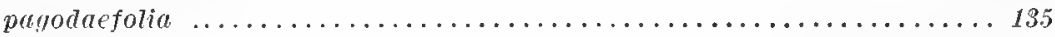

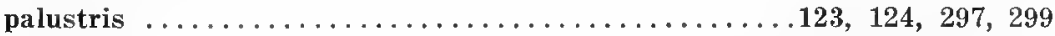

Phellos . ............................... 294

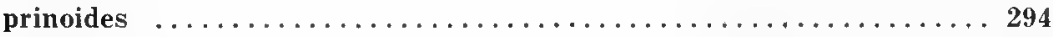

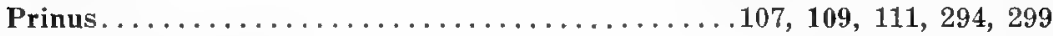

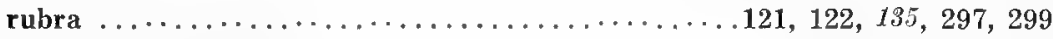

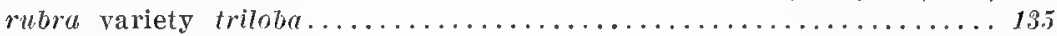

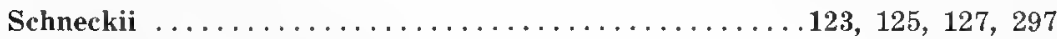

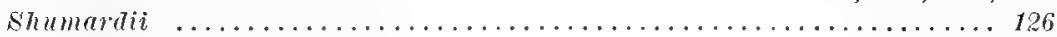

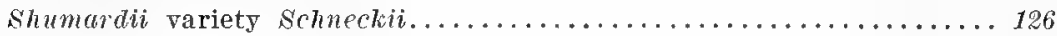

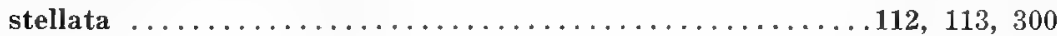

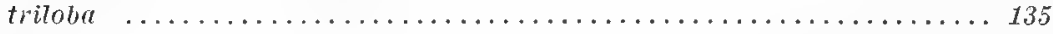

velutina $\ldots \ldots \ldots \ldots \ldots \ldots \ldots \ldots \ldots \ldots \ldots \ldots \ldots \ldots \ldots$ 127, 129, 131, 298, 299

Redbud ...........................227, 228, 298, 300

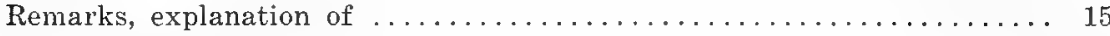

Robinia Pseudo-Acacia ....................... 235, 236, 299

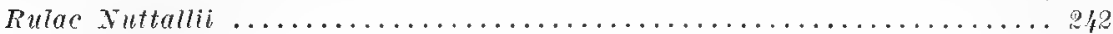

Salicaceæ $\ldots \ldots \ldots \ldots \ldots \ldots \ldots \ldots \ldots \ldots \ldots \ldots \ldots \ldots \ldots \ldots \ldots \ldots \ldots$

Salix $\ldots \ldots \ldots \ldots \ldots \ldots \ldots \ldots \ldots \ldots \ldots \ldots \ldots \ldots \ldots \ldots \ldots \ldots \ldots \ldots$

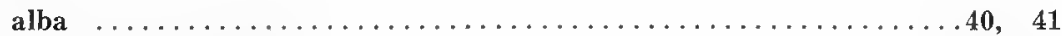

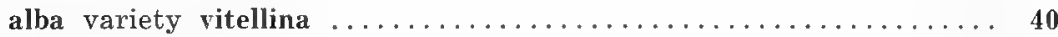

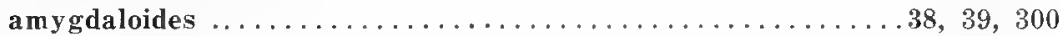

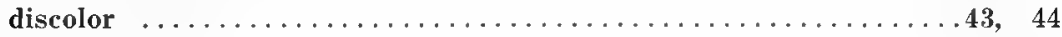

discolor variety eriocephala $\ldots \ldots \ldots \ldots \ldots \ldots \ldots \ldots \ldots \ldots \ldots \ldots \ldots$

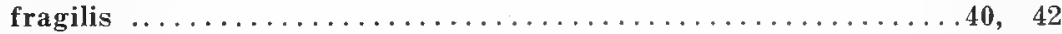

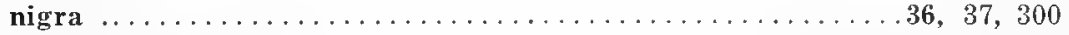

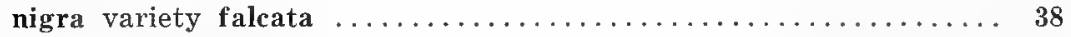

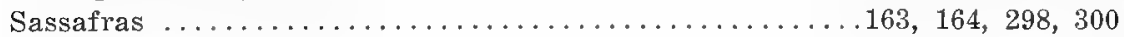

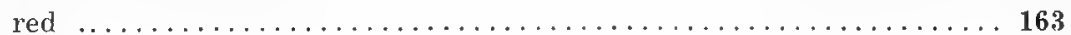

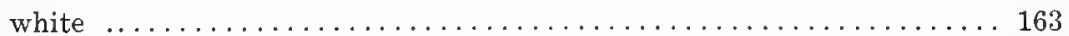

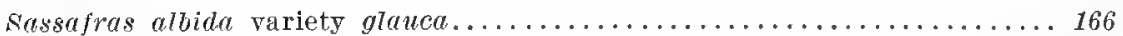

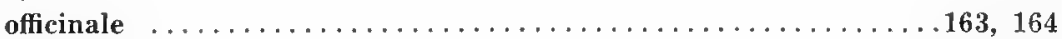

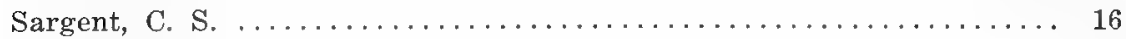

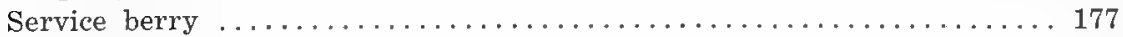

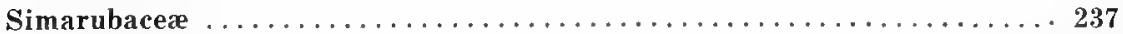

Sorrel tree ................................... 263, 264

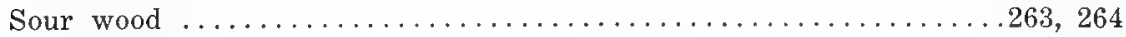

Specific gravity of some of the woods of Indiana................ 299

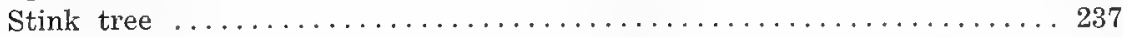

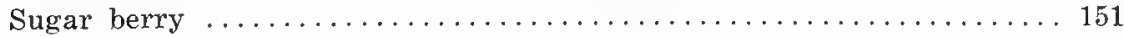


Sugar, black ....................................................

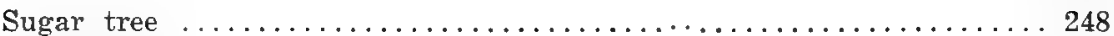

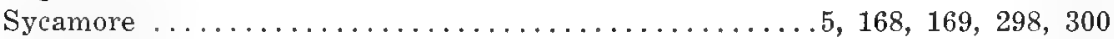

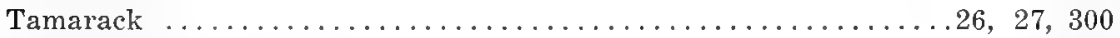

Taxodium distichum...................... 28, 297, 300

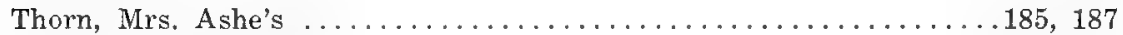

Miss Beckwith's ............................. 203, 205

Judge Brown's ........................... 185, 187

Chapman's Hill ............................. 188, 189

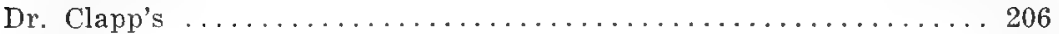

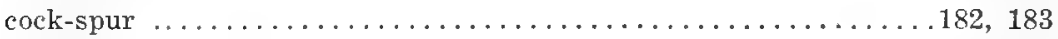

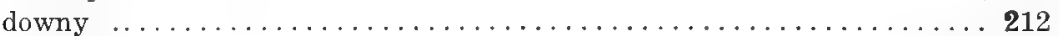

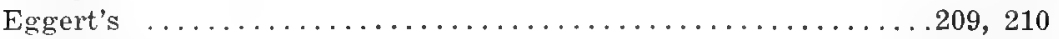

Fretz's ...................................203, 204

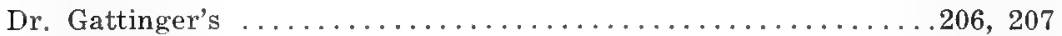

Jesup's .................................200, 202

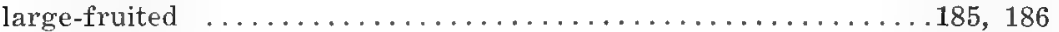

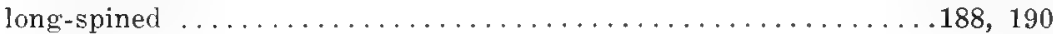

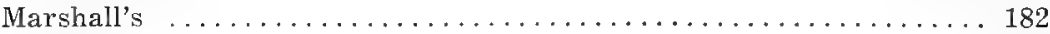

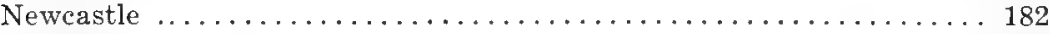

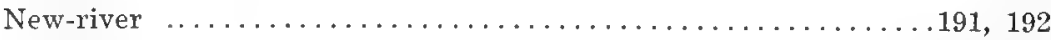

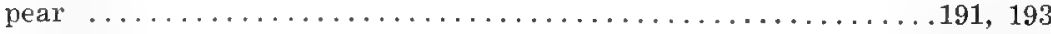

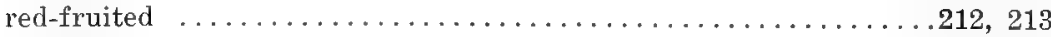

round-leaved ................................. 195

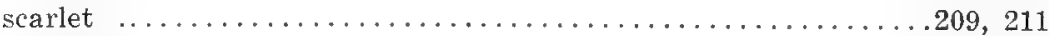

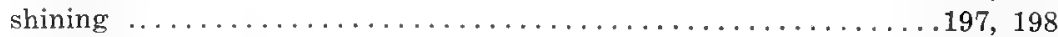

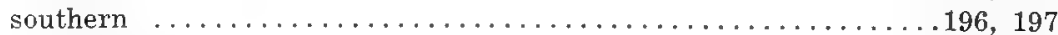

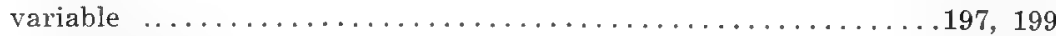

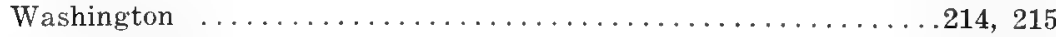

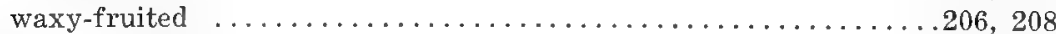

Thuja occidentalis............................... 33, 300

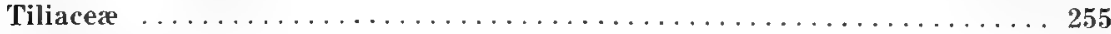

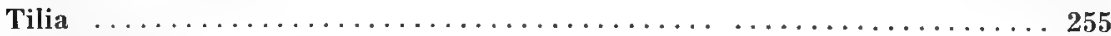

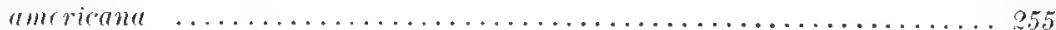

glabra........................ 256, 298, 300

heterophylla....................... 258, 300

heterophylla variety Michauxii.........................259

neglecta ...................................... 259

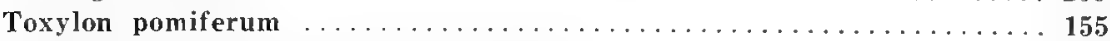

Tree of Heaven.................................... 238

Trees, key to families occurring in Indiana................... 17

species excluded from Indiana flora................... 290

measurement of some of the largest found in Indiana........... 297

terms used to define distribution of ..................... 14

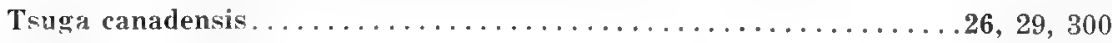

Tulip .......................................... 159, 160

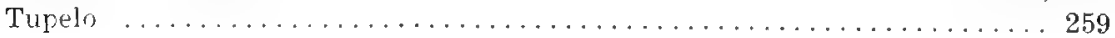


Page

Ulmacea $\ldots \ldots \ldots \ldots \ldots \ldots \ldots \ldots \ldots \ldots \ldots \ldots \ldots \ldots \ldots \ldots \ldots \ldots \ldots$

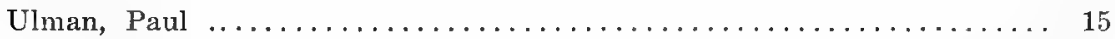

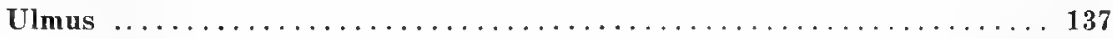

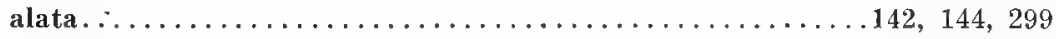

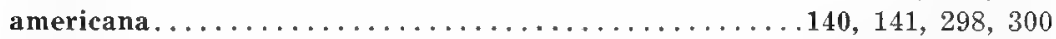

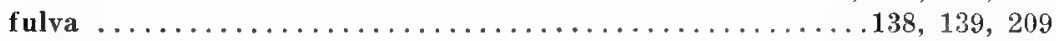

Thomasi . . . . . . . . . . . . . . . . . . . . 142, 143, 299

Viburnum prunifolium..................... 288, 289, 299

rufidulum $\ldots \ldots \ldots \ldots \ldots \ldots \ldots \ldots \ldots \ldots \ldots \ldots \ldots \ldots \ldots \ldots \ldots$

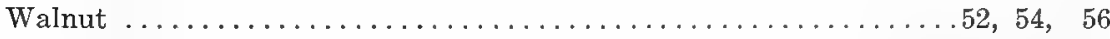

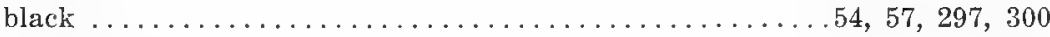

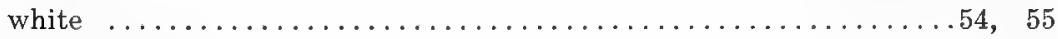

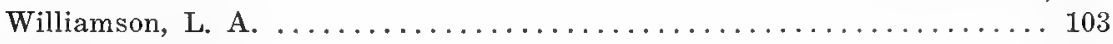

Williamson, E. B. ........................... 103

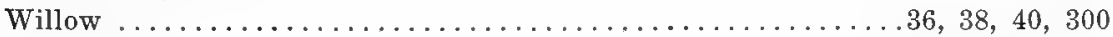

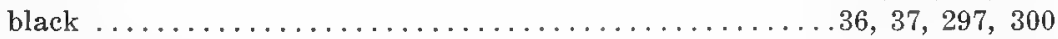

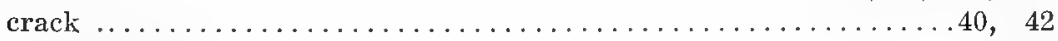

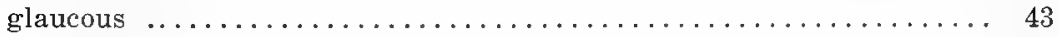

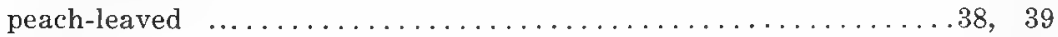

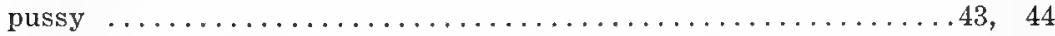

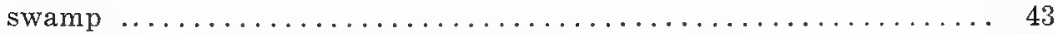

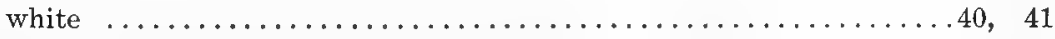

Wood, specific gravity of some species that occur in Indiana. . . . . . . . . 299

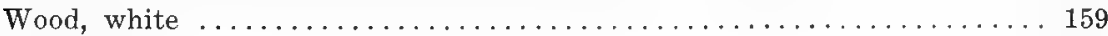

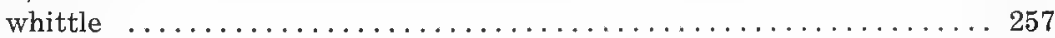








